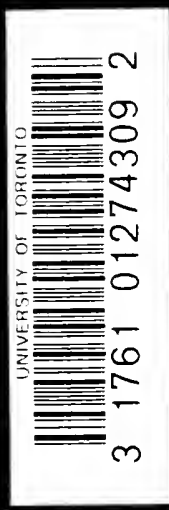

\title{
THE HISTORY OF THE ROYAL SOCIETY OF ARTS
}

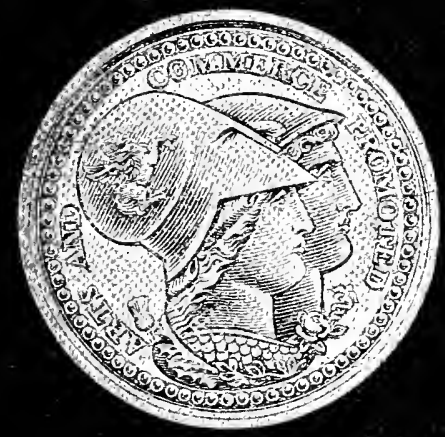







\section{Digitized by the Internet Archive in 2010 with funding from University of Toronto}


A HISTORY OF

THE ROYAL SOCIETY OF ARTS 



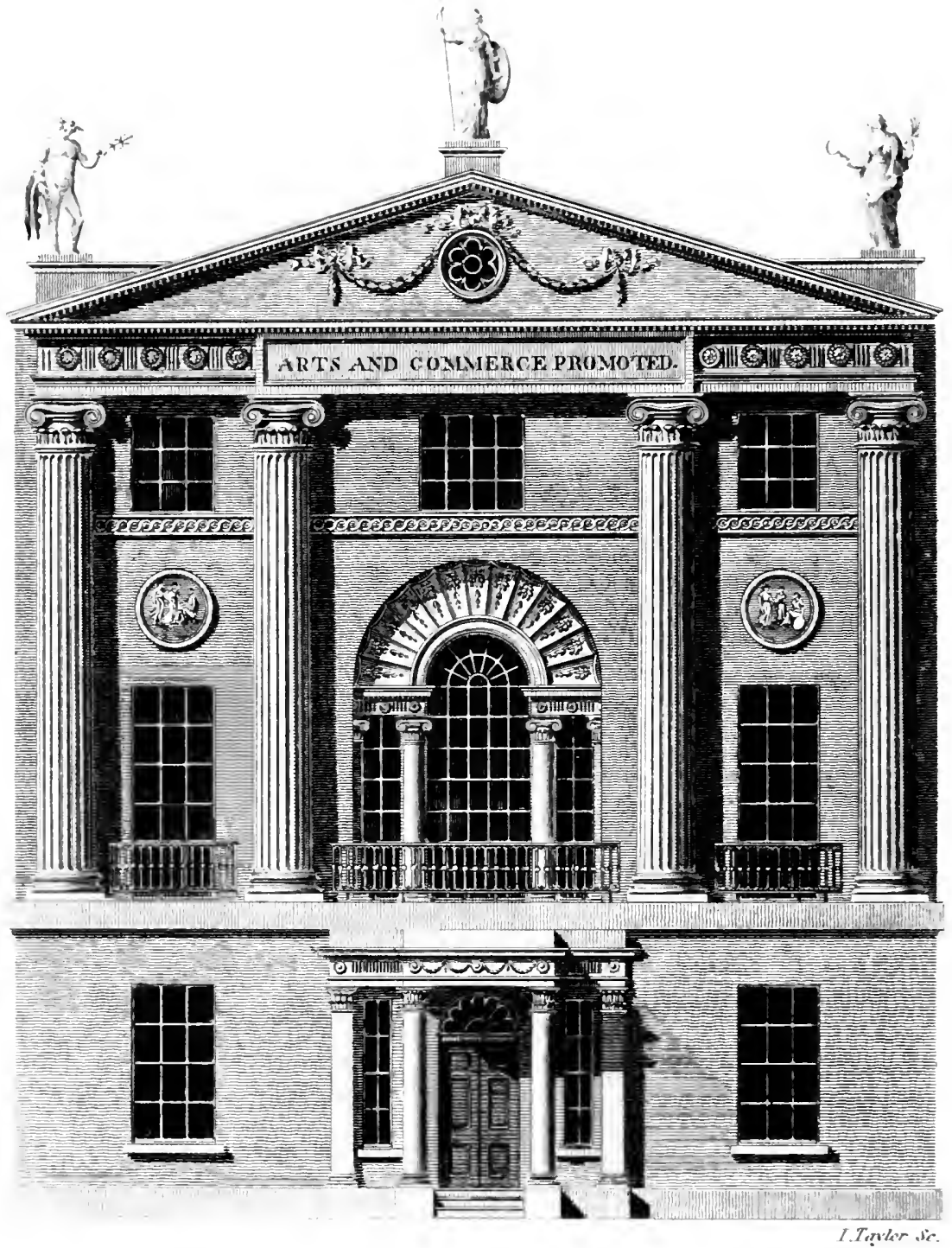

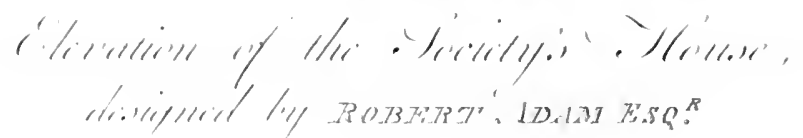




\section{A HISTORY OF}

\section{THE ROYAL SOCIETY OF ARTS}

BY SIR HENRY TRUEMAN WOOD

SECRETARY OF THE SOCIETy

WITH A PREFACE BY

LORD SANDERSON, G.C.B.

Chairman of the Council

WITH ILLUSTRATIONS

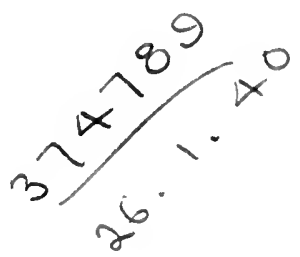

I. ON DON :

JOHN MURRAY, ALBEMARLE STREET, W. 


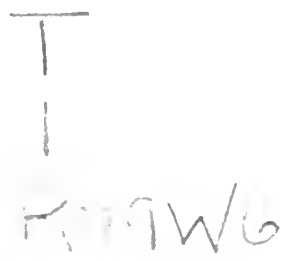

Navigia atque agri culturas moenia leges arma vias vestes et cetera de genere horum, praemia, delicias quoque vitae funditus omnis, carmina picturas, et daedala signa polire, usus et impigrae simul experientia mentis paulatim docuit pedetemtin progredientis. sic unumquicquid paulatim protrahit aetas in medium ratioque in luminis erigit oras. namque alid ex alio clarescere et ordine debet artibus, ad summum donec venere cacumen.

Lucretius, De Rerum Natura, v. I 44 S. 
DEDICATED BY PERMISSION

To

HIS MAJESTY KING GEORGE V.

FOR NINE YEARS PRESIDENT OF THE SOCIETY

AND NOW ITS PATRON 
Ali rights reserved 


\section{PREFACE}

(By Lord Sanderson, G.C.B., K.C.M.G., Chairman of the Council of the Society for the years 191 1-I3)

IT is perhaps at first sight rather remarkable that the Royal Society of Arts should have been approaching the r6oth year of its existence before any attempt was made to write its history. One reason may be assigned for the omission which is of a re-assuring character. Retrospection is the proverbial consolation of old age and declining strength. We may take it as no unhealthy symptom, but rather as an indication that a Society is still in the prime of life, when it is so much absorbed in its actual work as to be content with a very misty knowledge of its origin and early history.

Such certainly was the mental condition of a large proportion of the Members of the Royal Society of Arts (not excepting the Council) before the appearance in the Journal of the series of articles which are now presented in a collected shape. We were fully occupied with the various activities of the Society-its meetings and papers, its examinations, and the distribution of its medals. As regards the past, most of us were conscious that the Society had done much good work under the beneficent presidency of the Prince Consort, and could claim to have taken a leading part in the promotion of the great International Exhibitions of $185 \mathrm{I}$ and $\mathrm{i} 862$. But it came upon us as a revelation that the names of the elder Pitt, Lord North, Lord Rockingham, Lord Bute, and other historic Ministers of the time of George III., were enrolled among its earliest members in somewhat uncongenial company with John Wilkes and Woodfall, the printer of the Letters of Junius; that Dr. Johnson is believed to have made, at 
one of its meetings, the only speech which he is known to have delivered on his legs; that Oliver Goldsmith was anxious to offer himself as a candidate for the post of Secretary, but was deterred by the refusal of Garrick to support lim; and that the Society's efforts to introduce the bread-fruit tree into the IVest Indies led to Captain Bligh's expedition, which terminated in the mutiny of the Bounty and the colonisation of Pitcairn Island.

An illustrious past may, however, be reckoned in the balance-sheet of a Society as an asset of no inconsiderable value, whether it be regarded as establishing a prima facie claim to continued support, or as an incitement to further achievements. In both these respects it may fairly be claimed that the Society's records afford material for stimulating thought, and it was a happy inspiration which prompted its present Secretary to add the preparation of this volume to the many services which he has rendered during more than thirty years of office. It has been a somewhat laborious undertaking, for which the Society owes him a deep debt of gratitude.

From the short note appended to this Preface it will be seen that although materials were not lacking, much research was required to fill up gaps and put the whole into complete shape.

The Society's origin is an instance of evolution, very typical of British methods. Nothing can have been less ostentatious than its entry into the world. The scheme was devised by a drawing-master of no great eminence, and was put into concrete shape at a meeting of eleven persons, of whom the most important in social position were two peers, Viscount Folkestone and Lord Romney, and three members of the Royal Society, Dr. Hales and Mr. Baker, both naturalists, and Mr. Brander, an antiquary and a Director of the Bank of England. Once started, the Society was found to conform to the needs of the time. It waxed and prospered, affording one among many illustrations of the proposition that the permanence of institutions is best assured by a process of steady growth. The doctrine described some years ago in the graphic words that "there is nothing like beginning with a bang " 
may be excellent from a party point of view, but finds little confirmation in history.

The first impression, on a survey of the Society's work, is one of some bewilderment at the multiplicity and diversity of the subjects with which it has dealt in rapid succession or even simultaneously. Nothing seems to have been regarded as too homely for its attention. Side by side with the account of efforts to encourage improved systems of industrial hygiene, of saving life at sea, of the ventilation of mines, of producing coal gas, we find the notice of a gold medal awarded for the invention of the transparent slate which was the delight or torment of our childhood. In $185 \mathrm{I}$, unexhausted by its efforts in connection with the First International Exhibition, the Society was offering a medal for the production of a shilling box of colours. The box which carried off the prize had an unexampled success, and I well remember being myself the happy possessor of one of the eleven millions which were sold. At one moment the Society is endeavouring to further the improvement of labourers' cottages, at another it is proposing a reform in the standard pitch of musical instruments. It encourages with equal energy the planting of osiers for basket-making, the development of the fish supply of London and the introduction of the Dutch system of curing herrings, the use of machines for sweeping chimneys in substitution for boy chimneysweeps, the introduction of artistic designs in household crockery, and the placing of memorial tablets on London houses connected in the past with eminent men.

Such ubiquitous energy presents obvious difficulties to the historian, who finds himself confronted with the task of arranging a patchwork quilt into some kind of ordered pattern. The author has dealt with it by a system partly chronological, but in the main of classification into subjects. This has necessitated some repetitions and numerous cross-references, but it was the only practicable method of making the story clear and consecutive in its various portions.

Another notable feature of the Society's work is the frequency with which it originated, or led the way in, 
movements which were taken up with general favour and gave occasion for the formation of independent associations. Thus in the first half-century or more of its existence it devoted itself largely to endeavours for the development of various branches of agriculture and industry in the Colonies - a work which the Colonial and Imperial Institutes would now regard as their peculiar province. Up to the time of the formation of the Royal Agricultural Society in 1838, the Society of Arts was the prime mover in the development of agriculture in this country also, receiving in this respect much assistance from the advice of the well-known agriculturist, Arthur Young. It seems to have done a good deal towards the adoption of improved methods of cultivation, and we are largely indebted to it for the introduction of the swede turnip and the mangel-wurzel. It offered many prizes for the invention and improvement of agricultural machines, and can claim to have been instrumental in the planting of some fifty millions of forest trees. In I760 it made the first attempt at a public exhibition of the works of artists, and the success of this experiment led to the foundation of the Royal Academy of Arts. By drawing attention to the need for changes in the Patent Laws, it contributed to the passing of the great Patent Law Reform Act of 1852 . In 1852 it held the first exhibition of photographic pictures. In 1858 it took a prominent part in the demand for legislation to protect copyright in works of art. From i 857 onwards it was busy in advocating various Postal reforms, including the purchase of the telegraphs by the State. Between 1867 and 1873 it took a leading part in promoting the establishment of the National Iraining School for Music. It worked strenuously in aid of the formation of Mechanies' Institutes throughout the country, and in i 867 it organised a confercnce on the means of promoting technical education; at the end of 1886 , it started a movement for encouraging drill in schools. Among various other subjects which it took up at different times may be mentioned the production of county maps, the question of our food supplies, sanitation and water supply, cconomy in the consumption of 
coal, increased comfort in the passage across the Channel, improvement of London cabs, and the development of mechanical road traction. The organisation and promotion of the scheme for the International Exhibition of I $85 \mathrm{I}$, with all the results that flowed from it, including the creation of a Government Department of Science and Art, must, however, no doubt be considered the Society's greatest achievement in this field of starting enterprises which have had an independent development.

As regards the efforts of the Society for the advancement of Art pure and simple and their success, ample evidence is given by the distinguished names which will be found in the list of Medallists. It is interesting to notice how many eminent painters, engravers, and sculptors, including several Presidents of the Royal Academy, received in early youth perhaps their first encouragement to persevere in an artistic career by the award of one of the Society's Medals.

Among a host of less well-known names, we find those of Bewick, Hablot Browne, C. W. Cope, Cosway, Cousins, Sir C. Eastlake, Flaxman, Frith, Goodall, Hook, Sir E. Landseer, Sir T. Lawrence, Sir J. Millais, Mulready, Nollekens, Romney, Sir W. Ross, some of whom obtained their first medal at the age of ten or eleven.

The development of Industrial Art and Commercial Industry has, however, naturally been the principal object of the Socicty's attention, and in this field of labour it has shown such a catholicity of interest that the present volume has become a sketch of the whole industrial progress of the country, incomplete, no doubt (for completeness could only have been attained by a work of encyclopædic dimensions), but still eminently suggestive and useful as a starting-point for further research in regard to any particular branch of industry. In this respect Sir Henry Wood has rendered an important service not merely to those who are interested in the Society, but to the much larger class who may wish to study the subjects with which it has dealt.

There is a saying often quoted, though not always with assent, that history repeats itself. Those who 
contest it ignore the qualification added by some sagacious observer, that history repeats itsclf, but always with a difference. The work of the Society follows the general rule. Like many other British institutions, the Society owes its permanence to the power which it has shown of adapting itself to altered conditions and circumstances, it repeats its history with a difference; its objects and principles are in the main the same, though in many respects it has altered its methods. It leaves to other Associations, more recently formed, various branches of work which it was itself the first to undertake; it has changed in character from an Institution offering premiums for specificd inventions and improvements, to one having for its main object the dissemination of information on all branches of Art and Industry, affording facilities for the publication of particulars as to the most recent inventions, and thus making publicity the substitute for encouragement by the award of prizes. For this purpose it has adopted in recent times the practice of holding weekly meetings during a considerable portion of the year for the reading and discussion of papers, and it is provided with the means of arranging for courses of lectures. The proceedings at all these meetings, with much other information, are published in its weekly Joumal. But the Society's medals are still awarded for the more remarkable papers contributed, and occasionally for some special invention in regard to which competition has been invited. Since 1863 it has annually awarded the gold medal instituted in commemoration of the Prince Consort, to some person selected for eminent merit in the promotion of arts, manufactures, and commerce. In another field of work it has during the last half-century instituted a system of examinations, which are now held not only in London, but in all the more important commercial and manufacturing centres in the provinces, and in which the candidates have increased from an initial figure of 62 to a yearly average of 28 ,00o.

It may be claimed for the Society that it is a striking example of the useful work which may be done by a voluntary association, formed for the advancement of 
public objects, dependent on public support, but free to enter upon new fields of work and inquiry, and to make experiments, unhampered by the trammels which beset a Department of State, the restrictions of hard-and-fast rules, and the constant ordeal of Parliamentary questions and criticisms. The Empress Catherine's compassion for the unfortunate savanis who might not say, "I don't know," might be extended to those who must not embark on fresh ventures because under a system of party Government they may not confess to a failure.

The increased share now taken by the State in the active promotion of social progress does not diminish the need for such voluntary associations, though it may in some degree affect the nature of their work. They are still required as the cavalry of intellectual advance, scouting in front, extending its flanks, procuring supplies and information, and performing various indispensable services for which the infantry and heavy artillery of Public Departments are little adapted.

The present volume is a record of change and adaptation from the foundation of the Society in 1754 to 1880 , the year when the Author commenced his duties as Secretary. At that point, for obvious reasons, he has preferred to lay down his pen. Since that date there have been further changes, and we may no doubt look forward to others in the future. But of the spirit which led to the Society's formation, and maintains it in unabated vigour after a century and a half of existence-the spirit which underlies so many British institutions-the desire to give voluntary and unremunerated service for the advancement of the community, to work strenuously for the general increase of knowledge, refined taste, and useful industry-there is no one who will not say Esto perpetua. 
Nothing like a history of the Society has evcr been written. A great deal of information is contained in a lengthy paper read in 1868 (see Journal, vol. xvii. p. 10, et seq.) by S. T. Davenport, who was Financial Officer of the Society from 1853 till his death in 1876 . The best account of the Society is to be found in a series of articles contributed to Engineering in July and August I89I, by H. B. Wheatley (Assistant Secretary, 1879 to 1909). A short but brightly written sketch of the Society is given in Scientific London (B. H. Becker), 1874. The Microcosm of London, published by R. Ackermann in 1811 , gives a good account of the Society as it existed at that date, and contains an interesting picture of the Great Room, showing the arrangement of the room before the modern alterations. Charles Knight's London, vol. v. ( $\left.18_{43}\right)$, also contains an illustrated chapter on the Society. The Penny Cyclopadia (I 842), under the heading "Society of Arts," gives an excellent short history of the Society up to that date. Some other accounts might be mentioned, but on the whole, outside of its own publications, the history of the Society must be sought in the magazines and newspapers of the last two centuries, from the Gentleman's Magazine and the Public Advertiser down to the periodicals and journals of our own time.

H. T. W. 


\section{CONTENTS}

CHAP.

I. THE ORIGIN OF THE SOCIETY

II. The Earliest Lists of Members • . . 26

III. The Society's Offices • $\quad$ • $\quad$ • $\quad$ • 53

IV. The Society and the Colonies • $\quad$ • $\quad .83$

V. The Society and Agriculture (I754-I830) • • I I4

VI. The Society and Forestry (I758-i835) • • I43

VII. The Society and the Fine Arts (I755-I85I) • I5I

VIII. The Fine Art Prize-Winners (I755-I849) • . 162

IX. The Society and the Fine Arts (I755-I85I)-Continued . .

X. The Society's Early Art Exhibitions . . 226

XI. The Premiums (I754-I85I) • • • • 235

XII. The Premiums (I754-I85I)-Continued. • . 257

XIII. The Premiums (I754-I85I)-Concluded. • . 286

XIV. The Society's Medals • • • • • 3 . 34

XV. The Officials. The "Transactions." The Council.

The Charter (I76I-I847) • • • • $32 \mathrm{I}$

XVI. The Presidency of the Prince Consort (i843-i86i) 353

XVII. The I85I Exhibition . . . . . 40I

XVIII. The i 862 Exhibition . . . . . . 4 I6

XIX. The Society's Examinations • • • • . 425

XX. The Presidency of King Edward VII. (I 862-i880) • 442

XXI. The Presid ancy of King Edward VII. (I862-I880)-

Continued-CONCLUSION $\quad$. $\quad . \quad . \quad . \quad 474$

Appendix I. The Society's Officials (I754-i9i3) . . 509

Appendix II. The Albert Medal (I864-igi3) · . 5 I 2

Appendix III. Portraits in the Society's Possession • 5 I8

INDEX $\quad . \quad . \quad . \quad . \quad . \quad . \quad 52 \mathrm{I}$ 



\section{LIST OF ILLUSTRATIONS}

FACING PAGE

Elevation of the Society's House. By Robert Adam

(Original Copper-plate) • • • . Frontispiece

Portrait of William Shipley, the Founder (Original

Copper-plate) $\quad$.

Portrait of Lord Folkestone, the First President (Original

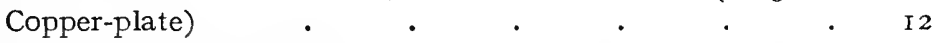

Portrait of Lord Romney, the Second President (Original

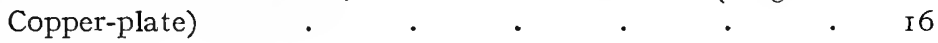

Portrait of Dr. Templeman, Secretary (Original Copper-

plate .

Facsimiles of Signatures of Early Members $\cdot 47,48,49,50$

Reproduction from Old Map, Showing the Society's OfFices opposite Beaufort Bulldings . $\quad$ • $\quad . \quad$. 54

PoRtrait OF ROBERT AdAM . $\quad . \quad$. $\quad . \quad 58$

Photograph from a Medallion by TASsie.

The Society's House IN I9II . . . . . . 60

The Society's Repository in i 843 and an Eariy View of THE ADELPHI

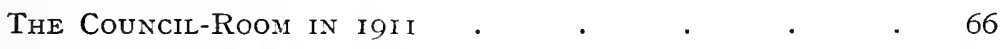

The Society's Meeting-Room in I8O4 . . . 70

Barry's Picture of “The Society" . . . . 76

MaP of the North AMierican Colonies . . . 84

Sherwin's Frontispiece to Vol. I. OF THE "Transactions" I 5 I

The Society's Prize Palette . . . . . . i6o

Commenorative Medals Rewarded by the Society • 220

The Society's Early Medals . . . . . . 3 I4

The Society's Later Medals . . . . . 3 . . 38

The Latest Medals of the Society . • . 320

Portrait of Samuel MIore, Secretary • • • 326

From Sharp's Engraving after the Portrait by West.

Portrait of Arthur Aikin, Secretary . . $\quad 336$

From a Daguerreotype 
The Society's “Honorary Testimonial” (Original Copperplate)

Portrait of Sir Henry Cole, Chairman of Council • 358 From a Photograph by Mrs. CAMERon.

Invitation Card to the Society's First Dinner (Original

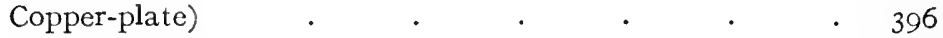

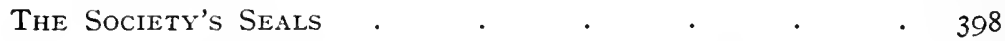

Portrait of Sir Frederick Bramweli, Chairman of Council AND PRESIdent . . . . . . . 4.474 From a Photograph.

A Meeting of the Council in 1900 . $\quad . \quad 500$ From a Picture in The Graphic.

\section{IN THE TEXT}

Plan of Henrietta Street, showing Site of Rawthmell's COFFEe-House

Plan showing Position of the Society's Offices, opposite

Beaufort Buildings

DESIGN BY BARRY FOR A MEDAL

The BREAD-Fruit

EARLY CHAFF-CUTtER

Frontispiece to the Premium List (i 803 )

The Society's Original Book-Plate.

“Arts, Maxufactures, and Commerce," from an Old Die.

StAGHOLD'S GUN-HARPOON

Aliond's LoON .

Sturgeon's Electro-Magnet

Signalling by HaNd (I8O9)

BARry's Design For the Society's Medal • • • 3I7

The Felix Sumierly Tea-Service . . . . . 406

The I85I Exhibition . . . . . . . . 4 . 45

The i862 Exhibition . . . . . . . . 424

The Swiney Cup . . . . . . . . 441

Tablet to Peter the Great . . . . . 470

Johnson's House and Memorial TABlet • • • 473 


\title{
HISTORY OF THE ROYAL SOCIETY OF ARTS
}

\author{
C H A P T E R I
}

The Origin of the Society

Early Technical Societies: Royal Dublin Society-American Philosophical Society-Select Society of Edinburgh-Anti-Gallican Society-Economical Society of St. Petersburg, etc.-Early proposal for a "Chamber of Arts" for London-Shipley publishes proposals for Premiums to promote Arts and Manufactures-Some account of Shipley and his Academy-Mecting at Rawthmell's Coffee-House and Foundation of Society-Names of the FoundersDetermination of Site of Rawthmell's House-Decision to offer Premiums-Further Meetings-First Annual Meeting-Lord Folkestone elected the first President-Four Vice-PresidentsShipley first Secretary-Title, Constitution, and Character of the Society-Finance-Shipley becomes Registrar and Box SecretaryDecision to appoint new Secretary-Templeman elected-Duties of the Officials.

Among the results of the revival of learning in Italy in the fourteenth century was the establishment of Academies-associations of men interested in the cultivation of the humanities or the advancement of natural knowledge, with the purpose of mutual improvement, or the promotion of common objects.

These Institutions, most numerous and most successful in Italy, were soon imitated in other countries. In England the attempts under the earlier Stuart Kings to establish an Academy came to nothing. But after the Restoration, the Royal Society, which had a somewhat precarious existence during the later and troublous days of the Commonwealth, was definitely established under 
the patronage of the second Charles. The Royal Society, though it enjoyed court favour, was, unlike the French Academy, independent of court influence, and this position it has maintained until the present day. Instituted for the general promotion of natural knowledge, it included within its scope all branches of science, both pure and applied, and among its earlier Transactions are many papers dealing with purely technical and industrial subjects.

For more than half a century it had the field to itself, and for more than a century its control of purely scientific matters was undisputed. Towards the end of the eighteenth century the advance of Science led to the establishment of subsidiary Societies devoted to particular branches of knowledge. Their establishment, at first strenuously opposed by the members of the Royal Society, was before long accepted as inevitable, and the Royal Society became the parent of numerous daughter Societies, each devoted to a special branch of natural knowledge, while the main supervision and control of scientific research was still retained in her own hands.

At an earlier date however-a date which we might fix as a little before the middle of the century - the growth of Trade and Industry, and the progress which the industrial arts were already beginning to make, had led to the institution of various technical Societies, the object of which was the promotion of the Arts, Industries, and Commerce of the kingdom. The oldest of these is the Royal Society of Dublin. This was founded in 1731, under the title of the Dublin Society for Improving Husbandry, Manufactures, and other Useful Arts. Previous to this, in I683, a Philosophical Society, on the model of the Royal Society of London, had been formed. This had rather a chequered existence, and seems to have come to an end before the close of the seventeenth century. The second Dublin Society was established mainly by Dr. S. Madden, who himself provided prizes for useful inventions and for proficiency in the Fine Arts.

In 1749 this Society was incorporated under the name of the Royal Dublin Society, in which name it has ever since carried on much valuable work. It had the advantage 
of Government aid, and between 1761 and 1767 it distributed Government grants to the amount of $£ 42,000$ in the promotion of agriculture and manufactures.

The London Society of Arts, therefore, dating as it does from 1754, though the oldest association of the sort in Great Britain, is younger by some twenty-three years than the sister society in Ireland.

Two other technical societies founded in the eighteenth century still survive, the Highland and Agricultural Society of Scotland (I784) and the Bath and West of England Agricultural Society (1 774).

In America, before the foundation of the Society of Arts, Benjamin Franklin had already published ( 1 743) a Proposal for Promoting Useful Knowledge among the British Plantations, and this led to the formation of the American Philosophical Society, which still flourishes, but devotes itself exclusively to pure science. In 1765 , after the establishment of the London Society of Arts, a similar society was formed in New York, and a number of prizes were offered for industrial advances in the Province of New York. The first list of such prizes, which varied in amounts from $£ 30$ to $£ 2$, was sent to the London Society, and is still in existence. Many other societies, some of an industrial character, were started in America later, after the independence of the United States.

All the other technical societies established about this time had but a brief existence, and few of them have left any records behind them. A Society of Improvers in the Knowledge of Agriculture in Scotland was established in 1723. Twenty years later, in 1743, the Select Transactions of this Society were collected and published by Maxwell. In I 754 there was founded the Select Society of Edinburgh for encouraging the Arts and Manufactures of Scotland. The principal promoter of this was Elizabeth, Duchess of Hamilton-one of the beautiful Miss Gunnings. Mrs. Palliser refers to this society in her history of lace, and mentions the award of prizes for Scottish lace for some few years. At one time this institution was in

${ }^{1}$ Lecky, England in the Eighteenth Century, vol. ii. p. 318 (Edition 1909); Encycl. Brit., s.v. "Agriculture." 
correspondence with the Society of Arts in London. It appears to have continued for about eight years, for Sir A. Dick, writing in 1774 , says that "for these twelve years past " there has been no Society of the sort in Scotland. This would give about 1762 as the date when the Scottish Society came to an end. ${ }^{1}$

In 1743 there seems to have existed in Edinburgh a Society for the Promotion of Natural Knowledge, but the only evidence of such existence of which I am aware is to be found in an advertisement in the Caledonian Mercury, 23rd August i743. 'This advertisement asks for information about the discovery of new minerals, and offers to analyse samples of such minerals if they are sent to the offices of the Edinburgh Philosophical Society. We may therefore conclude that it was associated with but distinct from this last-named Society, which was founded in I73I, and afterwards developed into the Royal Society of Edinburgh.

Perhaps the most curious of these institutions was the Anti-Gallican Society, which was established in London in 1750 or $175 \mathrm{I}$, for the protection of native industries and the discouragement of French imports. This Society seems, by reports which appeared from time to time in the Gentleman's Magazine, to have held quarterly meetings up to I 754 or thereabouts, at which meetings small prizes were awarded for English lace, needlework, etc. In i753 a medal was presented to one Captain John Mead, "for having caught the greatest number of whales last season," and another medal to Captain Cockburne "for his gallant behaviour to the commander of the French squadron at Annamobar, on the coast of Guinea." On another occasion the Society made a grant of five guineas to "an honest, industrious old couple," whose cow had died from " the distemper." For some time there is no further available information about their proceedings; but in 1759 they appear

${ }^{1}$ Dossie, Memoirs of Agriculture and other Fconomical Arts, vol. iii. p. 208. This book really constitutes the earliest Transactions of the Society, and numerous references to it will be found in the following pages. An account of the book and its connection with the Society, together with such information as I have been able to collect about Dossie himself, will be found in Chapter XV, p. 330. 
to have taken more strenuous action by starting the " AntiGallican " privateer. This ship captured a French Indiaman in Spanish waters, whence arose considerable difficulty; eventually the prize was declared illegal, and had to be given up. It looks as if this last effort for the promotion of British industries brought this Society to an end, for no further record of their proceedings appears.

There may have been other precursors of the Society of Arts, but research has failed to find evidence of their existence. After the Society was founded it had a certain number of imitators. The Gentleman's Magazine for 1755 , p. 505, contains an account of a society established that year in Breconshire on the model of the Society of Arts, for the encouragement of local agriculture and manufactures by the offer of prizes, and the suggestion is put forward that other like societies might usefully be established in all the counties. After I768, when, as hereafter mentioned, Shipley, the Society's founder, had retired to Maidstone, he founded a local society there which for some years did useful work.

A Society for the Promotion of Industry in the Southern District of the parts of Lindsey in the county of Lincoln, was established in 1783 , and was carried on for at least six years. It is mentioned by Archdeacon Cunningham in his well-known work, ${ }^{1}$ but he gives no further information about it. From an account of the proceedings of this Institution, published in or after 1790 , it appears that it was intended to encourage industry among the poor. For several years it gave small prizes, consisting generally of garments, to women and young people for spinning wool and for knitting. It also made small grants of money to young people on their apprenticeship. It thus appears that there was little in common between this Society and the Society of Arts, except a certain similarity in the titles. ${ }^{2}$ It was really a charitable Society, and its object was rather the reduction of the Rates than the

${ }^{1}$ English Industry and Commerce, vol. ii. p. 993 (Edition 1907).

${ }^{2}$ There is a copy of the book in the London Library. It contains a good deal of curious information about the conditions under which the spinning industry was carried on in the east of England at the time. 
promotion of Industry. Arthur Young mentions an attempt to found a similar Society in Rutlandshire about ten years later. ${ }^{1}$

In the Society's minutes before I 775 there are references to Societies for the promotion of Agriculture in Norfolk, Pembroke, Carmarthen, and Cardigan. Other similar county associations were formed a little later. In i79 I a Society for the Improvement of British Wool was started in Edinburgh. ${ }^{2}$ Sir John Sinclair, afterwards President of the Board of Agriculture, was associated with this Society, and delivered an address at its first meeting. A Society of Arts was established in Barbados in $178 \mathrm{I}$, and continued to publish proceedings till i 784. Its publications are mentioned in Cundall's Supplement to Biographia Jamaicensis.

On the Continent the Society had at least one direct imitator, for it is recorded that the Empress Catharine II. of Russia was so much pleased with the account of the premiums offered by the Society of Arts, that in 1766 she established in her own dominions the Free Economical Society of St. Petersburg, with objects similar to those of the English Society. Arthur Young was elected a member of this Society about i $780 .^{3}$

Later on there were many societies founded, both at home and abroad, with similar objects to those of the Society of Arts, but all these were started after 1800. The closing years of the eighteenth century saw many more scientific, philosophical, and literary institutions founded, but none of these were of the same character as, or had similar aims or objects with, the Society of Arts.

The earliest proposal of which any record exists for the foundation of a Society of Arts in London goes as far back as I72I, when it is said that a pamphlet was published, entitled, Three Lctters concerning the forming of a Society to be called the Chamber of Arts, for the preserving of Opcrative Knowledge, Mechanical Arts, Inven-

${ }^{1}$ Annals of Agriculture, vol. xxii. p. 42 I, 1794.

2 An account of this Society and of its objects is given in The Bee, a weekly magazine started in Edinburgh in $179 \mathrm{I}$ by Dr. James Anderson, vol. i. pp. 116 and 266.

${ }^{3}$ A utobiography (Edition 1898 , by M. Betham Edwards), p. 85 . 
tions and Manufactures. ${ }^{1}$ Probably the time of the South Sea Bubble was not a fortunate one for the exploitation of such schemes; certainly nothing came of the proposal.

In I 753, William Shipley ${ }^{2}$ published in Northampton, where it is said he was established as a drawing-master, certain " proposals for raising by subscription a fund to be distributed in premiums for the promoting of improvements in the liberal arts and sciences, manufactures, etc." This was followed a little later in the same year by "a scheme for putting the proposals into execution," published in London.

Shipley was a portrait and landscape painter of no great merit. According to Redgrave ${ }^{3}$ he was " better known as the founder of the St. Martin's Lane Academy, known as Shipley's School, where the best artists of a whole generation studied." Where Redgrave got his information from is unknown, and he is certainly mistaken.

${ }^{1}$ Short Account of ... the Society, etc., by a member (Edward Bridgen), 1765. A scarce pamphlet, giving an account of the Society of Arts' origin.

Another rather similar pamphlet, A Concise Account... of the Society, was published two years earlier, in i 763 . It also was anonymous, but was written by Thomas Mortimer. The information it contains is rather fuller.

${ }^{2}$ The materials for a life of Shipley are scanty. A certain amount of information is to be found in the Society's minute books and account books. The writer of the Concise Account of the Society, above referred to, states that an account of Shiplcy's proceedings in connection with the foundation of the Society was drawn up, and a copy presented to "the Antiquarian Society," by James Theobald, one of the Society's first Vice-Presidents. No such document, however, either in print or MS., is now to be found in the library of the Society of Antiquaries. The author of the Concise Account, however, extracted a good deal from Theobald's narrative, and it is from this source that most of what we know about Shipley and his efforts to start a society is derived. A short life of Shipley is given in Russell's History of Maidstone (I88I), and this gives some particulars of his later years. This information was reproduced in a short article in the Journal (vol. xxx. p. 933), written by H. B. Wheatley. The account in the Dictionary of National Biography is based on this article, though other references are given. One or two mistakes appear in this account. Shipley was in all probability born in London, not in Maidstone, and he certainly died in Maidstone, and not in Manchester.

${ }^{3}$ Dictionary of Artists of the English School. 
No evidence can be found to prove that Shipley's Academy was in St. Martin's Lane, though the Academy founded by Sir William Thornhill in the Piazza, Covent Garden, was transferred there after his death by his son-in-law, Hogarth. ${ }^{1}$ Later on, in 1763 , we find that special prizes were awarded by the Society to the pupils in this school, and also to the pupils of the school ${ }^{2}$ established by the Duke of Richmond in Whitehall.

There really does not appear to be any satisfactory evidence that Shipley had any Academy in London before I 754, or indeed that he lived in London before that date. At the time of the foundation of the Society he was staying with his friend Messiter the surgeon in Great Pulteney Street, and Messiter's house was given as his address till he moved into Craig's Court. The earliest reference to the Academy that I have been able to find locates it in Castle Court, ${ }^{3}$ whither the Society's offices were moved

1 The St. Martin's Lane Academy was in Peter's Court, between I Io and II I St. Martin's Lane. Hogarth, "thinking that an academy conducted on proper and moderate principles had some use, proposed that a number of artists should enter into a subscription for the hire of a place large enough to admit thirty or forty people to draw after a naked figure" (William Hogarth, by Austin Dobson, I907, p. 48). The room was originally a dancing-school, afterwards the studio of Roubiliac. Later still, the place was rebuilt and turned into a Friend's Meeting-House. Messrs. Chat to \& Windus's premises now occupy the site. The school was extremely successful and flourished for some thirty-four years, till the foundation of the Royal Academy in 1768, when its " anatomical figures, busts, statues, etc." were handed over to it. Hogarth's painting of the Life School was purchased by the Royal Academy and is now in their possession.

${ }^{2}$ A note in the Gentleman's Magazine, March I 758 , p. I4 I, records the opening of this school. A room was supplied with busts and pictures for the use of art students. Wilton and Cipriani were engaged to attend at certain times and examine the students' work. Robert Drummond, Archbishop of York $(1761-76)$, was a patron and supporter of the school.

3 "My late father, Nathaniel Smith, and Joseph Nollekens were playfellows, and both learned drawing together at Shipley's School, then kept in the Strand, at the eastern corner of Castle Court; the house, now No. 229, is at present occupied by Mr. Helps. What renders the building the more interesting is that it was not only in this house that the Society of Arts had its first meetings, but it was subsequently inhabited by Rawle, the antiquary, and friend of Captain Grose" (J. T. Smith, Nollekens and His Times, I 828, vol. i. p. 3). 
in 1756. It may have been started in the house taken by Shipley for the Society in Craig's Court in 1755, and it is possible that when, as hereafter described, the Society moved to the house opposite Beaufort Buildings, Shipley's Academy may have been accommodated in part of the premises.

After this, when Shipley's official connection with the Society had ceased, it appears to be certain that his Academy was moved to the house at the corner of Beaufort Buildings (afterwards No.96 Strand), which later on became Ackerman's Fine Art Repository, and later still Rimmel's well-known perfumery shop. After Shipley left London, the School was carried on for some time by Henry Pars, the brother of William Pars, A.R.A., and its pupils took many of the Society's prizes. ${ }^{1}$ Beaufort Buildings disappeared about 1902-4, when the new Savoy Hotel buildings were erected, and the Strand frontage was set back.

Not very much is really known about Shipley's life. $\mathrm{He}$ is said to have been born in London in $1714^{2}$ His father was Jonathan Shipley, "Citizen and Stationer " of London. He was a native of Leeds, who afterwards lived in Walbrook. William's mother was Martha Davies. Her family owned Twyford House, near Winchester, and the property was inherited by Shipley's brother Jonathan, the Bishop of St. Asaph. He was a liberalminded divine, and a friend of Franklin. It was said, probably without truth, that he might have been appointed

${ }^{1}$ Shipley "erected the Academy in the Strand, opposite Exeter 'Change, where, by his zealous assiduity, and the diligent attention of Mr. Henry Pars, his successor and the present conductor of the School, the greatest number of Contendants for the Rewards of this Institution were formed " (Dossie, Memoirs of Agriculture, vol. iii. p. 394).

${ }^{2}$ This is the date given in all the biographical dictionaries. The same year is given as the date of the birth of his brother Jonathan, and in his case correctly, as is shown by his monument in the churchyard at Twyford, near Winchester. On William's tombstone in All Saints' Churchyard, Maidstone, which was renovated at the Society's cost in $19 \mathrm{I} \mathrm{I}$, it is stated that he died on the 28 th December 1803 , æt. 89 . This is so far vague that it might equally well mean that Shipley was over eighty-nine, or in his eighty-ninth year. It looks as if the correct date of his birth might be I7I5. Probably Jonathan was the elder brother. He inherited his mother's property at Twyford. 
Archbishop of Canterbury but for his strongly-expressed opposition to the American War.

William Shipley appears to have been an activeminded man, full of ideas, and with some capacity for organisation, but perhaps devoid of ambition, for he never seems to have troubled himself to obtain either credit or profit out of the successful realisation of his ideas. According to a Maidstone tradition he was an absent-minded man, so much so, that on his way to church to be married he was led away by the sight of a rare butterfly to start on its pursuit, and consequently he arrived late for the ceremony. At all events, as soon as the Society he suggested was successfully established and flourishing, he retired from its concerns, though for some four years he seems to have devoted himself energetically and without much pecuniary reward to its establishment. For the first year after the Society was formed he acted as secretary without pay. When the Society was formally constituted in 1755 he was appointed secretary, and this post was afterwards, in 1757 , changed to that of registrar.

In October 1760 , at a regular meeting of the Society, a letter from Shipley was read " acquainting the Society of his having lately engaged in business of such importance as to render him incapable of discharging his duty to the Society as their register without very much injuring his own affairs." What this business was does not appear. It may have been the development of his Academy. At all events, his resignation was accepted with thanks for his past services. That his retirement was not due to lack of appreciation of those services may be assumed from the fact that he was made a "perpetual member" of the Society in 1755 , was presented with its gold medal in 1756 , and had his portrait painted for the Society by Cosway, his former pupil. The portrait of Shipley which faces this page is not from Cosway's painting, but from a miniature by IV. Hincks. It is printed from the original copper plate engraved by Hincks for the frontispiece of Volume vi. of the Transactions. The miniature itself is now in the Maidstone Museum, having been presented to 


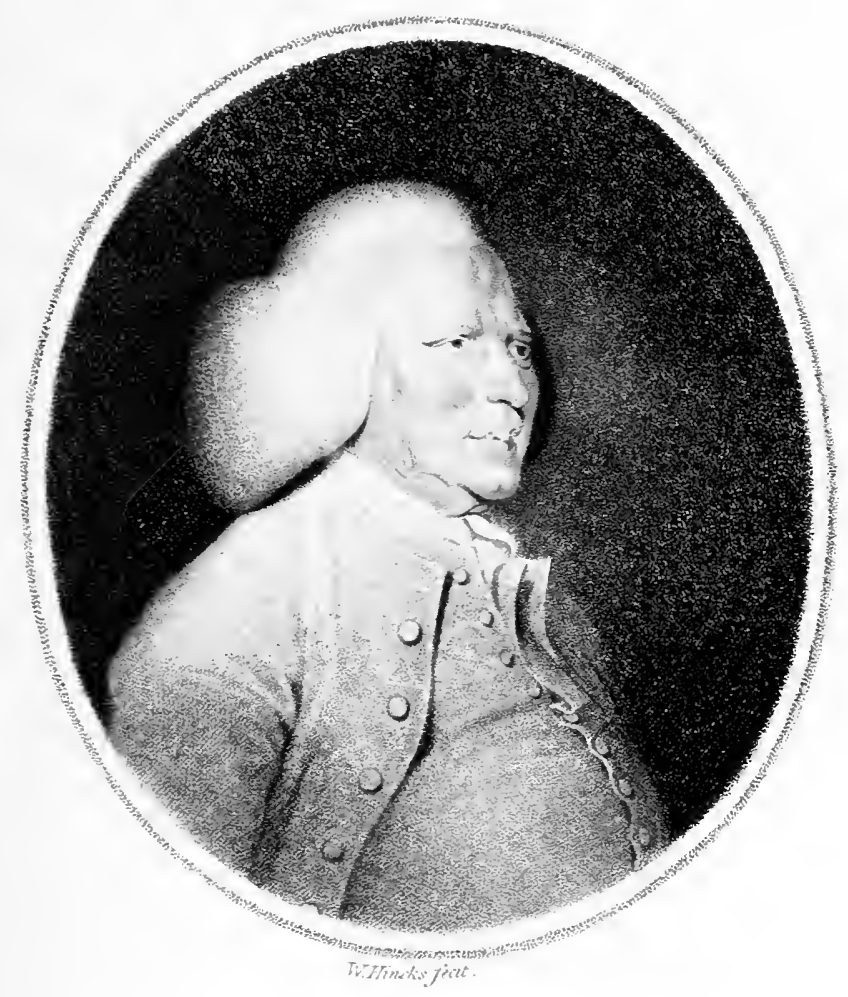

\section{$\mathbb{M} \mathbb{R}$ S}

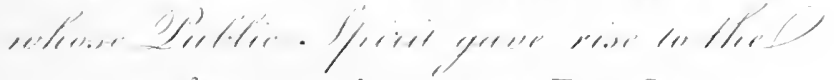
Society Inltituted ant Londond, firi, Illy

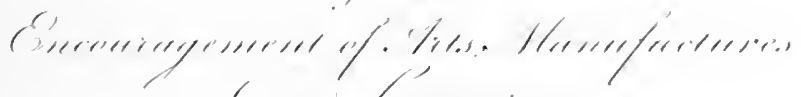

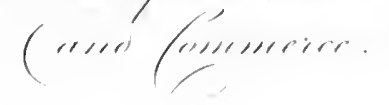




$$
\text { - }
$$


the Museum by the person into whose hands it passed after Shipley's death. How it came into Shipley's possession is not known. ${ }^{1}$

It may be that Shipley's capacity lay rather in the direction of origination than of administration. At all events, we hear little more of him in connection with the Society after 1760 . He occasionally attended meetings of the Society, and of its committees, and in I 776 he was awarded a silver medal for a life-saving appliance of no great merit. ${ }^{2}$ When the date of the Society's jubilee (I 804) was approaching, some suggestions were made that this would be a fitting occasion for doing honour to its founder, but his death in 1803 put a stop to all proposals of the sort. In 1768 he went to live at Maidstone, where he was married, and remained until his death in 1803 . He was buried in the churchyard of All Saints' Church. All that is known of his life at Maidstone is that he established a local Society on the same lines as the Society of Arts, and busied himself in philanthropic work.

Shipley, having published his scheme, set to work to secure the help of influential people, and succeeded in interesting, amongst others, Lord Folkestone and Lord Romney, to whom, with Shipley himself, must be given the credit of founding the Society of Arts. Indeed, it appears that if Shipley originated the idea, Lord Folkestone carried it into execution; and, in all probability, without his practical help and his influence there never would have been a Society of Arts.

On 22nd March I 754 there was held at Rawthmell's Coffee-House, Henrietta Street, Covent Garden, "a meeting of some Noblemen, Clergy, Gentlemen, and

1 "The picture from which this print is taken was painted from the life by Mr. Wm. Hincks, who also engraved the copper-plate, and presented them both to the Society for the purpose of perpetuating the memory, and recording the likeness of Mr. William Shipley" (Transactions, vol. iv. p. xviii, Preface). According to Redgrave, Hincks was an engraver and painter of moderate merit, who exhibited occasionally at the Royal Academy from 1781 to 1797.

2See Chapter XIII, p. 298. 
Merchants in order to form a Society for the Encouragement of Arts, Manufactures, and Commerce in Great Britain." Eleven in all attended : Viscount Folkestone ; ${ }^{1}$ Lord Romney ; ${ }^{2}$ Dr. Stephen Hales, F.R.S. (the eminent physiologist, botanist, and inventor, a friend of Pope); Henry Baker, F.R.S. ${ }^{3}$ (naturalist and author; he married Defoe's youngest daughter); Gustavus Brander, F.R.S. (merchant and antiquary, a director of the Bank of England) ; James Short, F.R.S. (optician and astronomer); John Goodchild (afterwards treasurer to the Society); Nicholas Crisp (watchmaker, of Bow Churchyard); Charles Lawrence; Husband Messiter (a surgeon, then resident in Great Pulteney Street, with whom Shipley was living at the time); William Shipley.

The exact position of the house where the meeting was held was for long a matter of doubt. It was known to have been Rawthmell's Coffee-House in Henrietta Street, Covent Garden; but the precise position in Henrietta Street of the house had never been accurately ascertained, until, at the request of the writer, Sir Laurence Gomme, the Clerk of the London County Council, very kindly caused an inquiry to be made among the records of the Council, and by means of the old sewer-rate books he was able to identify the house as the fourth on the north side of the street, at the western, or Bedford Street, end.

Armed with this information, the writer applied to the

${ }^{1}$ Sir Jacob des Bouveries (afterwards Bouverie) was created Viscount Folkestone in 1747 . His father and grandfather were wellknown Turkey merchants in London. His ancestor, Laurence des Bouveries, a native of Flanders, and a silk-weaver, settled in Canterbury in 1568 , about the time when so many Flemish immigrants came to England to escape the persecutions of Alva. The title was merged in that of Radnor when the second Viscount Folkestone was created Earl of Radnor in 1765 .

2 Robert, Lord Romney, was the second Baron. He was a brotherin-law of Lord Folkestone, who had married his sister, the Hon. Elizabeth Marsham.

${ }^{3} \mathrm{He}$ was the founder of the Royal Society's Bakerian Lecture. He took a very active part in the formation of the Society and in its early work. In Nichols's Literary Anecdotes, vol. v. p. 275, it is stated that he " all along took the minutes, though Mr. Shipley's name appeared as the nominal Secretary of the Society." 


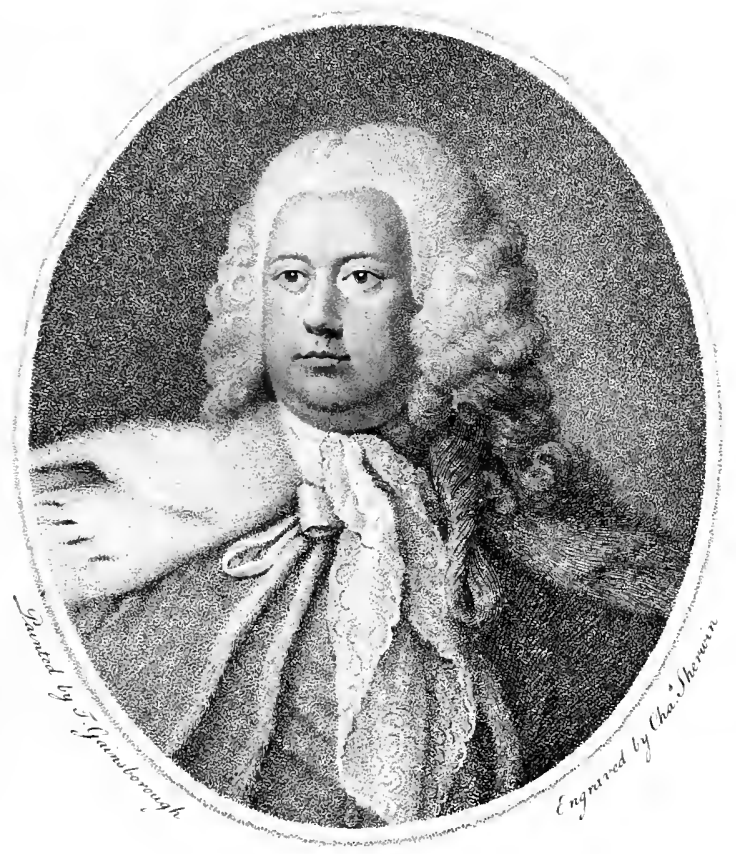

JACOBDVARD VISCOUNT FOLRESTONE,

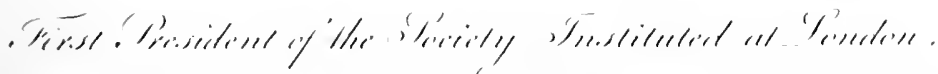

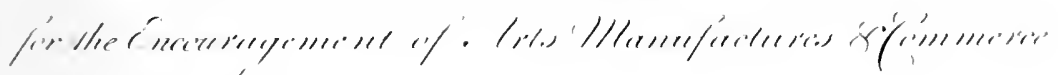

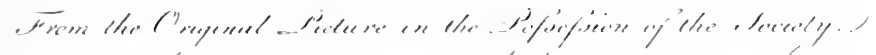


• 
Duke of Bedford's office, ${ }^{1}$ and he was at once supplied with a full history of the premises. It appears that in March I 729 a building lease was granted by the then Duke of Bedford to " John Rawthmell, of the Parish of St. Paul, Covent Garden, in the County of Middlesex, Coffeeman," of a house on the north side of Henrietta Street, the third (or the fourth counting the corner house, which is reckoned in Bedford Street) from the western end of the street. The lease was for sixty-one years from Lady Day i 729, and

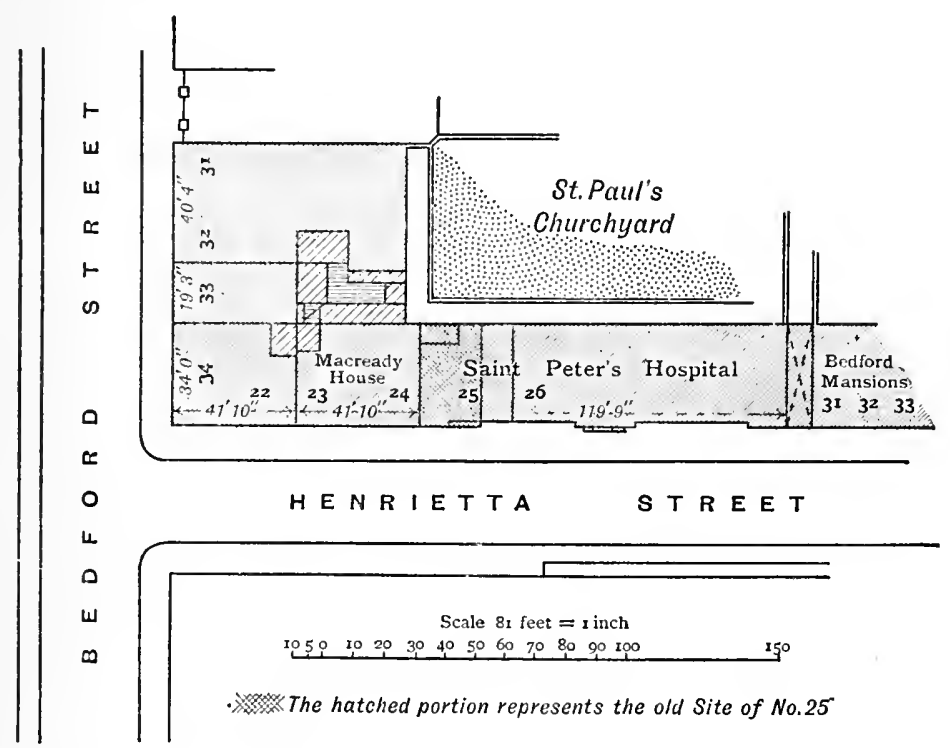

Plan of Henrietta Street, showing site of Rawthmell's Coffee-House.

the rent was $£ 12$ a year. On the expiration of that lease, leases for varying periods, mostly for twenty-one years each, were granted up to i 880 . In that year the whole block of houses on the north side of Henrietta Street, except the westernmost one at the corner of Bedford Street,was pulled down in connection with a local improvement scheme. The original houses had abutted directly on the churchyard of

${ }^{1} \mathrm{He}$ has to express his thanks for the trouble which Mr. Rowland E. Prothero, M.V.O., Mr. Alfred R. O. Stutfield, and Mr. James W. Marchant all took in hunting up detailed particulars about the history of the old house. 
St. Paul's, Covent Garden, with the result that the drainage of the churchyard passed into the basements, and the whole block was in a somewhat insanitary condition.

The new houses constructed on the site do not coincide with the old buildings. The space to the west of the site of the old coffee-house is now occupied by Macready House, the ground floor being in the occupation of The Family Herald newspaper. The actual site of Rawthmell's CoffeeHouse is now occupied by No. 25, the ground floor of which is in the occupation of Messrs. Stuart \& Company, seed merchants, the present house extending some six feet farther east than the old one. This is clearly shown in the accompanying map, the materials for which were supplied by the Duke of Bedford's office. The upper part of No. 25 forms part of St. Peter's Hospital. The block of buildings was erected for the hospital, the ground floors being let off as shops. It will therefore be seen that the site of the old coffee-house has been identified with perfect certainty. Before 1743 the original John Rawthmell must have died, as in that year the house was in the occupation of Sarah Rawthmell, widow.

The coffee-house was one of the favourite resorts of the well-known Dr. Richard Mead, ${ }^{1}$ and amongst the distinguished frequenters of the place were many Fellows of the Royal Society. Daniel Wray, F.R.S., addressed an amusing poem to his friend, Mr. Wollaston, of Charterhouse Square ( 1738 ), in which he refers to his literary and scientific friends, and specially mentions Rawthmell's. John Nichols, who published extracts from this poem in his Literary Illustrations (vol. i., I 817, p. 3I), specially notes that there exists a very scarce satirical portrait of Rawthmell " in the character of Pan, by Vertue, engraved at the expense of some of the members of the Royal Society who frequented the coffee-house."

At the meeting above mentioneda very modest beginning was made by considering a suggestion by Shipley that two prizes should be offered, one for the discovery of cobalt, and

1 Dr. Mead was physician to King George II. and to St. Thomas's Hospital. He was the author of "Suggestions for the Prevention of the Plague," and successfully inoculated seven condemned criminals. 
the other for the growth of madder, ${ }^{1}$ in the kingdom. It was determined to make further inquiries and a decision was postponed. The meeting also resolved "to bestow premiums on a certain number of boys or girls under the age of sixteen who shall produce the best piece of drawing, and show themselves most capable when properly examined," "it being the opinion of all present that the Art of Drawing is absolutely necessary in many employments, trades, and manufactures." This early anticipation of views which in our own time were put forward as novel by the advocates of technical education is interesting. That they were really Shipley's ideas, and that his intention in proposing the formation of the Society was not merely to extend or improve his own "drawing academy" is shown by a letter written a couple of years later by him in the Gentleman's Magazine, ${ }^{2}$ in which he combats vigorously the suggestion that the Society was merely occupied in training young people to become artists, and announces as one of the chief objects of the Society the training of both boys and girls in the industrial arts. Thus it can be truthfullysaid that from its first foundation the Society has taken an active part in the promotion of technical education.

A fortnight after the inaugural meeting a second meeting was held (29th March), and at this further progress was made. A definite decision was arrived at to offer the cobalt and madder premiums, and a subscription list was opened. Lords Folkestone and Romney headed the list with a donation of ten guineas apiece, and also promised to guarantee whatever further sums might be required, so that an announcement might be made of the offer of prizes. The Earl of Shaftesbury also sent ten guineas, and four others gave two guineas each. Funds being thus available,

\footnotetext{
1 Few better selections than madder could have been made. The plant was not grown in England on a commercial scale, though a great deal was imported from the East and from the Low Countries, where its cultivation had been established. The fact that it was grown in large quantities in Flanders was one of the reasons why cloth, made in England, was still sent over there to be dyed. Until the introduction of the coal-tar colours, more than a century later, madder was of course the principal source of all red dyes.

${ }^{2} 28$ th January 1756 , p. 6 I.
} 
an advertisement was inserted in the Daily Advertiser, offering prizes of $£ 30$ each for specified amounts of cobalt and madder, and two sets of prizes amounting each to $£$ I 5 for drawings by boys and girls below fourteen and between fourteen and seventeen. The competitive drawings were to be sent in on 15 th January 1755 , and the prizes were to be awarded a fortnight later. Thus the practical work of the Society was begun.

Six more meetings were held during the year in a circulating library in Crane Court, Fleet Street, in which court was the house then occupied (from I 7 io to i 780 ) by the Royal Society. These were all small meetings, of the nature really of committees, and at them the organisation of the Society was worked out, subjects for premiums discussed, and a general plan of action decided upon. Amongst other things it was decided to have a regular meeting on the second Wednesday in each month, and a committee on each fourth Wednesday.

By the end of the year all preliminaries seem to have been arranged, and it was decided to organise the Society on a more regular basis with a president and officers. This decision was arrived at at a meeting held in January I 755, at Peele's Coffee-House at the corner of Fetter Lane and Fleet Street.

At the same meeting the prizes offered for drawings were adjudged. The only name amongst those of the prizewinners which is still generally known is that of Richard Cosway, who took the first of the five prizes offered for drawings by young people under the age of fourteen. J. T. Smith, in his Life of Nollekens, tells us that Cosway was then employed as a waiting lad at Shipley's Academy, but as the fact is recorded in the Society's minutes that he was brought up to London from Tiverton at the instance of the Society, it must have been at a later date that he was taken into service by Shipley. ${ }^{1} \mathrm{He}$

I Minutes of the meeting of 27 th November 1754. "Specimens of Drawings done by Richard Cosway of Tiverton were produced, it was thought proper his Parents be writ to to know what will be the expence of his coming to Town." At the next meeting ( 8 th December) Shipley reported "that he had wrote about the boy, and he is coming up to 




ROB E R T LORIROAN R Y

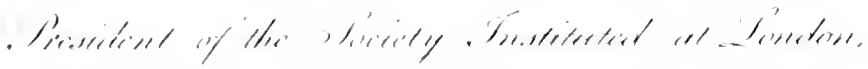

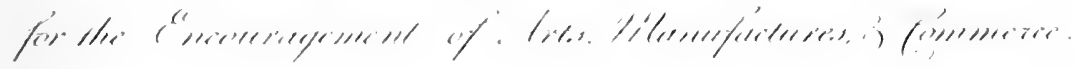

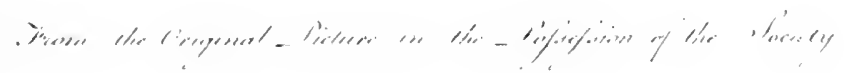



was afterwards a Royal Academician and an eminent portrait painter and miniaturist. John Smart, who took the second prize in the same class as Cosway, afterwards obtained considerable success as a painter of miniatures, and exhibited miniatures and oil portraits at the Royal Academy up to the time of his death in $18 \mathrm{I}$. The third prize went to John Alexander Gresse, afterwards a painter of reputation; and the fourth to Barbara Marsden, who became a flower painter, and married Jeremiah Meyer, R.A. None of the candidates in the senior class appear to have achieved any artistic success in after life. ${ }^{1}$

In the following month ( 5 th February) Viscount Folkestone $^{2}$ was elected the first president, with Lord Romney, Charles Whitworth, James Theobald, and Stephen Hales, vice-presidents. John Goodchild was made treasurer, and William Shipley secretary. At the same meeting Shipley and Henry Baker were elected "perpetual members." The Society was thus formally constituted, and from that date forward meetings were regularly held for the election of new members and the transaction of business.

The title of the Society has always remained that which Shipley suggested in his original scheme, "The Society for the Encouragement of Arts, Manufactures, and Commerce," but this soon proved too long and cumbrous, and very soon after its foundation the shorter name, "Society of Arts," was adopted. In the Gentleman's Magazine of July 1755 , it is so called, and this soon became the name by which it was popularly known. Sometimes it is referred

town." Smith's version of the story (vol. ii. 1829, p. 401) is as follows : "The students, among whom were Nollekens and my father, goodtemperedly gave Dick, for so he was called, instructions in drawing, and also advised him, finding him to have some talent, to try for a prize in the Society of Arts; and in 1755 he obtained a premium of $51.5 \mathrm{~s}$. for a drawing." It is quite clear that our gossipy chronicler's memory was in this case untrustworthy.

${ }^{1}$ The names of all the prize-winners, and such information as has been discovered about their after-careers will be found in the list of the Fine Art Awards, Chapter VIII, p. 162, et seq.

${ }^{2}$ The portrait of Lord Folkestone which faces p. 12 was engraved by Sherwin from the full-length portrait by Gainsborough. It served as the frontispiece for Volume II. of the Transactions, and is from the original copper-plate. 
to as the "Society of Arts and Sciences," 1 and in its own early books of accounts it is called "The Premium Society," though this title does not appear to have been used elsewhere. The earliest known official use of the shorter name appears in the minutes in February I8I I, and from that time onwards it is constantly found. The full title was rather unfortunately adopted in the Charter in 1847 , and the two names have always been used. In 1908 King Edward vir. granted the Society permission to add the word " Royal " to its title.

The constitution of the Society, at first and for very many years, was on a purely democratic basis. ${ }^{2}$ It had no governing body. There were certain standing committees and others appointed from time to time for special purposes, but their duty was merely to prepare the work for the general body of members, by whom all the business was transacted. The "ordinary meetings" were held first on alternate IVednesdays, and afterwards on every Wednesday from November to May, with less frequent meetings from May to November. The ordinary meetings were not competent to alter the "rules and orders." This could only be done at " general meetings," the number of which seems to have varied from time to time. At the ordinary meetings all the regular business of the Society

${ }^{1}$ Boswell sometimes refers to the Society by this name, and Horace Walpole in one of his letters uses the same title. There was at one time some correspondence in the Gentleman's Magazine on the subject.

2 Curiously enough, this characteristic of the Society was commented on by Smollett, who, though never a member, had a great admiration for it, as is shown by the passage from his history quoted on p. 5I. In Humphrey Clinker (published I77I, the year of Smollett's death) he makes Melford, the nephew of old Squire Bramble, write as follows to his friend and constant correspondent, Sir Watkin Phillips. Melford is by way of describing his adventures on his visit to London with his uncle, his aunt Miss Tabitha, and his sister Lydia. His letter bears the date $5^{\text {th }}$ June (Collected Works, I872, vol. vii. p. 161): "We are become members of the Society for the encouragement of the Arts, and have assisted at some of their deliberations, which were conducted with equal spirit and sagacity. My uncle is extremely fond of the Institution, which will certainly be productive of great advantages to the public, if from its democratical form, it does not degenerate into cabal and corruption." As will be seen later on, Smollett's fears were not without justification. 
was transacted, members were proposed, balloted for, and elected, bills were ordered for payment, and expenditure was discussed. Above all, subjects for the award of prizes were considered and voted upon.

It must be borne in mind that the sole object of the Society was to award premiums for meritorious discoveries and inventions, and for advances of any kind in arts, manufactures, and commerce. The mectings had before them descriptions of such advances, reports upon them, suggestions for new premiums, applications from inventors, but all these were merely intended to assist in the selection of suitable subjects for awards. The Society of Arts did not, like the Royal Society, welcome the description of new branches of knowledge (even of practical or applied knowledge); it did not invite its members to contribute essays or read memoirs or give lectures-all that came later. It simply hoped to encourage industry and art by rewarding those who helped in the promotion of art and industry, and to give them either substantial money gifts, or honorary rewards in the nature of medals. Later, when the Society came to publish transactions, it received suitable information readily enough, gave the author a medal, and printed his communication. Eventually the publication became more important than the award; but this was not so at first, or for very many years after the Society's foundation.

It will therefore be seen that the one idea of the founders of the Society was to encourage arts and industries by the offer of prizes. It appeared possible to them that a committee of gentleman, sitting in London, would be able to ascertain what the pressing needs of the public were, to foresee the course which industrial development could most wisely take, to select those inventions which could most usefully be encouraged, and generally to direct, by the judicious apportionment of medals and money prizes, the development of industry and the progress of art. To us, nowadays, the whole scheme seems impracticable, and at the best, utopian, but at the time it was perfectly reasonable, and it commended itself to the shrewdest economists. As a matter of fact, it obtained a very con- 
siderable measure of success, and that it was extremely popular is shown by the support it received from the most influential people of the time.

An attempt has been made by the writer in a previous volume ${ }^{1}$ to indicate the industrial conditions of the era. Here it may suffice to remind the reader that the time was essentially one of industrial change. The old conditions of regulance and support had long since disappeared. The new conditions of competition and the absence of restriction were not yet conceived, let alone formulated. The various young industries, textile, metallurgical, chemical, ceramic, and the rest, all wanted patronage and help. They wanted, too, advertisement and notoriety. All this they got from the newly-formed Society, and it may fairly be said that, having due regard to the then existing conditions, and to the state of public knowledge, it would be very difficult indeed to suggest any scheme better adapted for its purpose than that of Shipley and his patrons.

The annual subscription to the Society was fixed at " not less than" two guineas, and for a long time it was the practice of the more wealthy or more liberal members to pay three guineas. This excellent custom, however, has for many years been abandoned, though the wording of the old rule has been preserved. Peers were expected to pay five guineas, and for the most part did so. In a single instance this practice survived into our own time. The late Marquis of Ripon (who was elected in 1 856 and died in 1909) always subscribed five guineas annually. The composition for life membership was settled at twenty guineas, and has never been altered, though occasionally larger contributions were made. The great Earl of Bute, Prime Minister to George iı., not by reputation a liberal or extravagant donor, gave forty pounds for his " perpetual membership."

The Society has never received any official aid. Less fortunate than the sister institution in Dublin, or than many of the great London societies which have taken over much

${ }^{1}$ Industrial England in the Middle of the Eighteenth Century. Murray, 1910. 
of its original work, it has never been supported or helped in any way by Government. Lecky, in his History of the Eighteenth Century, ${ }^{1}$ says that it received a grant of .500 from the Corporation of London, but a careful search through the early account books has produced no confirmation of this statement. ${ }^{2}$ In 1765 the Society received a donation of $f_{\mathrm{s}} \mathrm{oo}$ from the Corporation of Liverpool, and this appears to have been the only contribution of the sort.

The Society was soon in a very satisfactory financial position. In 1755 , the first year after its formal constitution, its income was $£_{3} 60$. In the following year it was $£ 632$, and in 1757 it was $£ 1203$. In the next six years it mounted steadily, $£_{173} \mathrm{I}$ in $1758, £ 200 \mathrm{I}$ in $1759, £ 3482$ in $1760, £_{3} 656$ in $1761, £ 4533$ in $1762, £ 4614$ in 1763. Then in 1764 there was a drop to $£_{41} \mathrm{II}$.

At first all the Society's cash was in the hands of the treasurer, who was subject only to the control of a finance committee, which audited and reported on his accounts at intervals. The first treasurer was John Goodchild, one of the founders. He was elected in 1755 , and held office until his death at the end of 1756 , when he was succeeded by his son, also John. A year later we find a committee reporting on the treasurer's accounts " that the receipts and disbursements are right, but kept in rather a perplexed method." Probably the younger Goodchild was a bad accountant, for in 1759 he was in difficulties, and had to compound with his creditors, the Society in consequence suffering some small loss. The office of treasurer was thereupon declared vacant, and subsequently abolished. Careful regulations were then laid down as to finance, and it was ordered that all the Society's funds were to be kept in an account at the Bank of England in the names of the President and Vice-Presidents.

In an appendix to the premium list issued by the Society in 1764 , there is a tabular statement of the

${ }^{1}$ Vol. vii. p. 207 (Edition I907).

${ }^{2}$ The books commence with I755, the first entry being dated April of that year. If such a grant had been made in 1754 , it could hardly have escaped notice in the minutes which record all the meetings, from the first at Rawthmell's onward. 
"Receipts and Disbursements " for the nine years 1755 to I763. The total receipts were $£ 22,295$, and the total expenditure was $£_{1} 8,756$. Of this, $£ 8496$ was spent in money prizes and medals, $£ 3507$ on a special grant for a system of land carriage for fish, £29I on the Society's exhibitions, and the balance of $£ 6462$ on general administration, including rent, salaries, advertising, printing, etc. It is clear from this that the affairs of the Society were carefully and economically managed, for the cost of management as compared with the amount of the funds expended is quite reasonable.

A later statement, issued in 1778 in the form of a "Register of the Premiums and Bounties given by the Society" up to the end of 1776 , showed that the total amount given away by the Society was then $£ 24,616$, of which $£ 23,552$ had been money prizes, and $£_{1064}$ the value of the medals awarded. It may be noted that "premiums "were awards to " candidates who claim undier the terms of the annual advertisements of the Society," and that "bounties "were " bestowed on merits that have not been previously called for by the Society, or that do not precisely come within the terms of the annual advertisements." It is added that "these amounts have been distributed all over Great Britain, Europe, and America "a good general statement, which perhaps was not intended to be taken as minutely accurate.

As previously mentioned, during the first year of the Society's existence, Shipley acted as secretary, at first unpaid. When the Society was formally organised in February 1755, Shipley was appointed secretary. $\mathrm{He}$ appears to have had some clerical assistance provided for him, and in January 1756 , George Box was appointed assistant secretary. In March 1757 , Shipley was elected registrar, and Box was made secretary. The registrar was apparently the more important officer of the two, but the secretary did most of the work. It looks as if it had been desired to make his duties a little easier for Shipley, and to find somebody who was more methodical and businesslike to carry on all the routine business. Not very much is recorded of George Box, though it is evident 


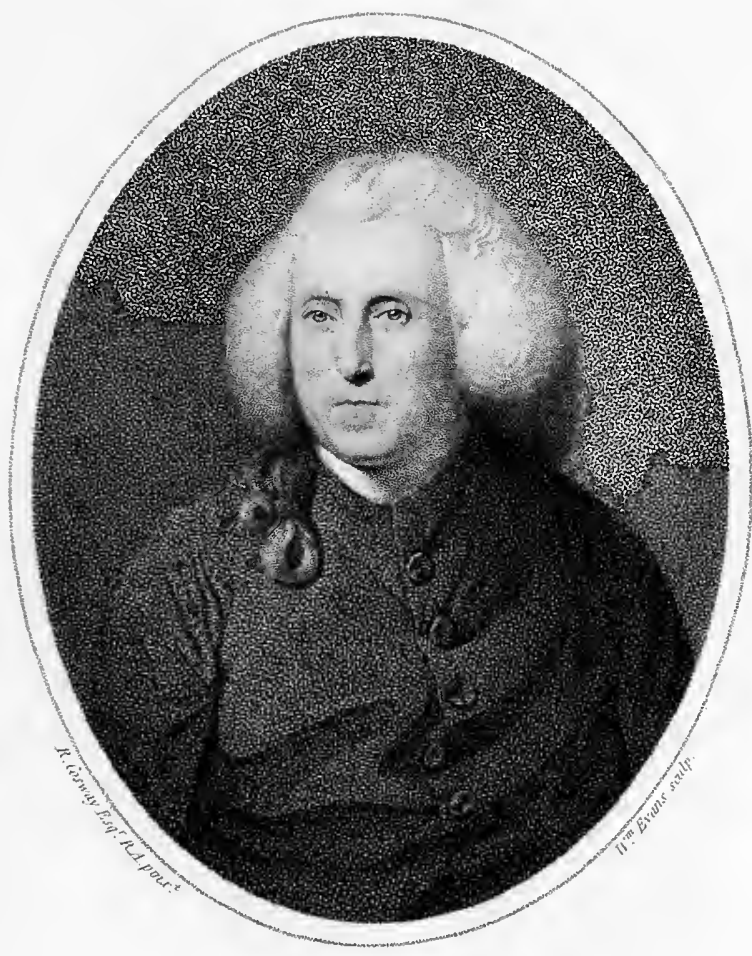

PT:TER TEMTPLEATAN, MID。

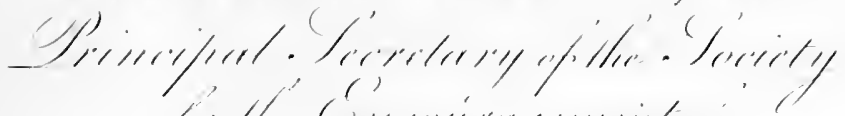

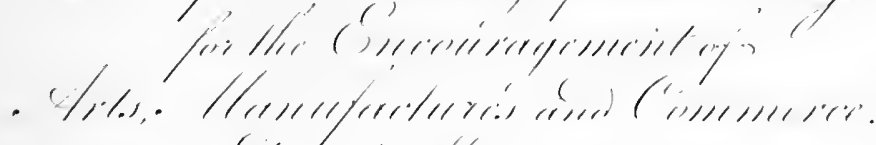

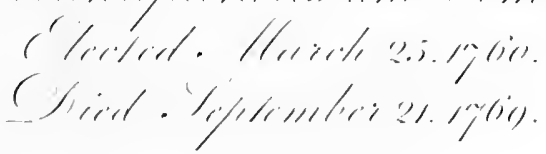



that he was a most efficient and competent official. He served the Society faithfully for twenty-five years, and such records of him as appear from time to time in the minutes show that he was entirely trustworthy and possessed the regard and confidence of the members.

In 1760 , soon after the Society, as will be hereafter related, had established itself in the house opposite Beaufort Buildings in the Strand, where it remained until it moved to the Adelphi, it was decided that a more competent and better-qualified secretary was required. A committee reported in February 1760, that the proper conduct of the Society's work required a man of "general and technical knowledge," able to deal with scientific questions and conversant with foreign languages. "He ought to be a man of character and a man of learning," and such a man the committee thought might well deserve a salary of $£ 200$ a year. The general body of members approved the qualifications, but set a lower estimate on their value, and considered that the required person might be obtained for £ 50 . The committee went on to recommend the appointment of an assistant secretary with a salary of $£ 50$, and a commission of $6 \mathrm{~d}$. in the pound on subscriptions, which at the time must have meant another $€ 75$ a year, so that the pay of the two officials was not very different. It is evident that the committee wished to do the best they could for Box, though they felt that he was not quite qualified for the more important post, since they add that they " take the liberty from the long experience of the diligence and integrity of your present secretary to recommend him to the office of assistant secretary and receiver." Later resolutions decided that the names of both officials were to appear in the Society's lists and other publications.

It was finally decided to appoint Box assistant, and to advertise for a secretary. As regards the office of registrar, the committee considered "the present register a very proper person to be continued in that office, and that he should do the business as usual "; that he should " have the salary and appartments now allowed him," and that he should be " allowed $€$ io a year more for taking care of the rooms, cleaning them and the furniture, and keeping 
all things in proper order for the reception of the Society." This looks as if the Society desired to provide a home and an easy post for Shipley without expecting from him very much useful work.

In response to the advertisement four candidates applied-Dr. Peter Templeman, Dr. Maty, Dr. Mitchell, and Mr. Robert Dossie. It has often been said that Oliver Goldsmith was a candidate, but, as a matter of fact, though he thought of sending in his name, and applied to Garrick for a testimonial, he never actually went so far as to make formal application. The authority for the statement is Thomas Davies, who, in his Life of Garrick, ${ }^{1}$ tells us that Goldsmith asked Garrick to recommend him, but that Garrick had been annoyed by Goldsmith's criticisms, and rather curtly refused. Forster, in his Life of Goldssmith, adopted Davies's story :-

"Thomas Davies tells us that when, somewhere about the time of his connection with the Bee, Goldsmith sought to obtain, what a struggling man of letters was thought to have some claim to, the vacant secretaryship of the Society of Arts, Garrick made answer to a personal application for his vote, that Mr. Goldsmith, having ' taken pains to deprive himself of his assistance by an unprovoked attack upon his management of the theatre in his " Present State of Learning," ' it was 'impossible he could lay claim to any recommendation from him.'

The compiler of this chronicle would like to think that Oliver Goldsmith had been an occupant of the post he now holds, though he realises that the talents of that charming writer were better employed in producing the Vicar of Wakefield, She Stoops to Conquer, and The Deserted Village, than in discharging the routine duties of an office which no doubt was better filled by the successful competitor, Dr. Templeman. Still, the name of Goldsmith on the list of the Society's officials would have added not a little distinction to that list, even if, as would probably have been the case, he had not held an uncongenial office for very long.

Of the four candidates who actually did enter, Temple-

${ }^{1}$ Vol. ii. p. 149.

2 Forster's Life of Goldsmith, vol. i. p. 239. 
man was elected by a considerable majority. Box was appointed assistant secretary, in accordance with the recommendation of the committee. Later in the year Shipley, as previously mentioned, resigned his office of registrar, perhaps not liking the new conditions, or perhaps, as he said, on account of his other occupations.

Templeman was a man thoroughly well qualified for the post of secretary to a young and growing society. $\mathrm{He}$ had had a distinguished career at Cambridge, where he graduated from Trinity in 1731 . He studied medicine in Germany, and in 1737 he obtained the degree of M.D. at the University of Leyden. After this he started practice in London, but being fairly well off he devoted himself to literature rather than to the duties of his profession. In I 758 he was appointed Keeper of the Reading-Room at the newly-established British Museum, and he gave up this post for the secretaryship of the Society. He was the author of numerous medical books, and in 1762 he was elected a Corresponding Member of the Royal Academy of Science of Paris. He was a fine scholar, a good linguist, and an accomplished man, well fitted for the post to which he was elected, and which he held until his death in $1769 .{ }^{1}$ The portrait of Templeman which faces page 22 is from the original plate engraved by Evans after Cosway's portrait, which was published as a frontispiece to Volume xvir. of the Transactions.

The duties of the three principal officers were laid down with great precision in the Society's "Rules and Orders." The secretary was generally responsible for the proper conduct of the Society's business and the due keeping of its records. The assistant secretary had to do all the clerical work, and the registrar had charge of the Society's property, and was required to look after the premises. In addition, there was a collector, who had to collect subscriptions and to pay them into the bank. He was paid by commission and had to give security.

${ }^{1}$ There is a good account of Templeman in the Dictionary of National Biography. It was written by Thompson Cooper, who also contributed a note about him to Notes and Queries, 9th S. I, I2th February I 898 . I have been able to find little further about him, and nothing of any importance. 


\section{CHA PTER I I}

\section{The Earliest Lists of Members}

The Society's original Signature-Book-First List of Members and other Early Lists-Selection from these Lists: (i.) Peers, (ii.) Commoners.

IT was some little time before the ideas started by Shipley and his patrons really got hold of the public. At first no special efforts seem to have been made to obtain subscriptions and attract public support. From the date of the first meeting till the constitution of the Society, nearly a year later, only seventeen members were enlisted. In the first two months after the election of officers in February 1755 , the number was raised to eighty-one, and after that the increase was fairly rapid.

The most interesting record of these early days is an ancient signature-book, which, according to its title-page, was a "List of the Nobility, Clergy, Gentry, Merchants, etc., who have subscribed towards raising a Fund for the Encouragement of Arts, Manufactures, and Commerce, 1754." The signatories of the book bound themselves by the undertaking: "We promise to pay annually during pleasure the several sums to which our names are respectively prefixed."

This seems to have been the original form of the list of members, and as it contains the autographs of a very large proportion of the distinguished persons who from the first supported the young Society, it is really a document of very great value, even though a considerable proportion of the members never signed it at all. Some of the more interesting signatures have been reproduced in facsimile, and a selection from these is given on pages $47-50$. The book remained in use as a signature-book for about ten 
years, but in 1775 a regular register was started, with the names and addresses of members, the amounts of their subscriptions, the dates when they became due, and the dates of their deaths or resignations. The first volume of this register contains the elections from 1755 to 1767 , and it has been continued, almost in the same form, up to the present date. Then, as now, the book lasted for about ten years, and at the end of that time a fresh book had to be opened, the names of surviving members being transferred, and space provided for the receipt of new entries.

The first printed list of members was issued in October I755. It is a mere broadside, and contains i io names. The next list which has been preserved is dated 1758 , in which year the numbers had increased to 708 , and in the next following to 1760 . From that date the lists were produced regularly at short intervals, until their regular annual publication. A careful examination of these lists affords very remarkable evidence of the popularity of the Society, of the way in which it rapidly attracted public support, and of the esteem in which it was held. A very large proportion of the peerage supported the Society with contributions and patronage. Men of distinction in every class of life subscribed, and there is hardly any class or rank without eminent representatives. When it is borne in mind that the whole object of the Society was the promotion of public welfare, and that not the slightest advantage or benefit was offered to individual members, the character of the list seems still more remarkable.

"As the condition of England in the middle of the seventeenth century brought about the foundation of the Royal Society and the popular and widely-spread interest in the investigation of science, so the condition of the country in the middle of the eighteenth century brought about the formation of the Society of Arts for the encouragement of the applications of science for the general good. As Dryden, Waller, Evelyn, and the literary coterie of the Restoration period largely supported the Royal Society, so the circle that surrounded Dr. Johnson took a lively interest in the success of the Society of Arts. The lines upon which the Royal Society was founded were 
not followed by the founders of the Society of Arts. The latter made an entirely new departure and were strictly original in their scheme. Their objects were national, and the members gave their money and their time not for their own private advantage, nor for the increase of their personal knowledge, but in an attempt to raise the productive powers of the nation itself." '

To justify these statements it seems worth while to give a selection of the most eminent names which are to be found in the lists of the Society's members for the first ten years of its existence. The latest list examined is that dated March 1764 .

The following may be taken to be a fairly complete list of the Peers whose names are given in one or other of the lists above mentioned. Many of the Peerages are extinct or have passed to the holders of other titles, and no doubt some may have been overlooked. The holders of courtesy titles have not been included, and it would be too much to hope that some mistakes have not been made in identifying individuals :-

Peregrine Bertie, 3rd Duke of Ancaster. Raised a regiment of foot in the 1745 rebellion. Lord Great Chamberlain of England. The Dukedom became extinct on the death of his brother, the 5 th Duke.

John, 4th Duke of Argyll. He married the beautiful and witty Mary Bellenden.

John, 4th Duke of Bedford. English Minister-Plenipotentiary at negotiations for Peace of Paris, 1763. William, 4th Duke of Devonshire. First Lord of the Treasury, $1756-7$.

Augustus, 3rd Duke of Grafton. He held various offices, and was the nominal head of the Chatham Administration, 1766 .

Evelyn, and Duke of Kingston. He married the notorious Elizabeth Chudleigh, Countess of Bristol, who was afterwards convicted of bigamy.

${ }^{1} \mathrm{H}$. B. Wheatley's account of the Society of Arts, Engineering, $24^{\text {th }}$ July I 89 I. 
George, 4th Duke of Manchester. He was elected in $176 \mathrm{I}$, when he was Viscount Mandeville. He became Duke in 1762 .

George, 4th Duke of Marlborough.

William, 2nd Duke of Portland. When he died in 1762 his successor, William (the 3 rd Duke), became a member. The latter was twice Prime Minister in the reign of George ini.

Charles, 3rd Duke of Queensberry. This was the cousin and predecessor of " Old Q.'

Charles, 3rd Duke of Richmond. Ambassador at Paris, and subsequently Secretary of State in the Cabinet of the younger Pitt. Vice-President of the Society. His portrait appears in Barry's Picture.

James, Marquis of Carnarvon. Eldest son of the and Duke of Chandos. He afterwards became the 3 rd Duke, and the title died with him in 1789 .

Charles, 2nd Marquis of Rockingham. Prime Minister, and head of the Rockingham Administration, of which Fox and Burke formed part.

James, 8th Earl of Abercorn.

Arthur, 7th Earl of Anglesey. His title to the English Peerage was pronounced invalid.

John, 2nd Earl of Ashburnham.

William, 2nd Earl of Bessborough. Postmaster-General, etc.

John, 3rd Earl of Bute. Prime Minister. He paid $£_{40}$ as a " perpetual member."

George, 4th Earl of Cardigan, afterwards (1766) created Duke of Montagu.

Robert, ist Earl of Catherlough.

Philip, 4th Earl of Chesterfield. The celebrated Lord Chesterfield.

Smith, I I th Earl of Clanricarde.

William, 2nd Earl of Dartmouth. John, 2nd Earl of Egmont. 
Charles, 2nd Earl of Egremont.

Brownlow, 9th Earl of Exeter.

Robert, Earl of Farnham. He was the and Baron Farnham, and was created Earl of Farnham in 1763 , but died without male issue, so the earldom lapsed.

Washington, 5th Earl Ferrers, younger brother of the notorious Earl Ferrers, who was executed in 1760 .

John, 7th Earl of Galloway. Elected in 1761 as Lord Garlies.

Charles, ist Earl Grey. General. Commander-in-Chief in America and the West Indies.

George Montagu, 3 rd and last Earl of Halifax, First Lord of the Admiralty, Lord Lieutenant of Ireland, etc.

Simon, ist Earl Harcourt. Ambassador at Paris, and Viceroy of Ireland. His eldest son, George Simon Viscount Nuneham, was also a member. He succeeded his father as 2nd Earl Harcourt in 1777.

Philip, and Earl of Hardwicke. Elected when he was Viscount Royston. Vice-President of the Society.

Wills Hill, Ist Earl of Hillsborough, afterwards (I 789) Marquis of Downshire. Statesman.

Robert, 4th Earl of Holdernesse. Ambassador and Secretary of State.

Francis, Ioth Earl of Huntingdon.

George, 3rd Earl Lichfield. Chancellor of the University of Oxford, i 762. Vice-President of the Society.

Jolin, ist Earl Ligonier. Field-Marshal. He served under Marlborough in Flanders, and received several steps in the Peerage, becoming Earl in 1766. He died in 1770 at the great age of ninety-one and was buried in Westminster Abbey.

Henry, 9th Earl of Lincoln, afterwards 2nd Duke of Newcastle.

George Parker, 2nd Earl of Macclesfield, P.R.S. He took an active part in the introduction of the New Style in $175 \mathrm{I}$. Thomas, the $3 \mathrm{rd}$ Earl, was also a member. He was elected in I 757 as Viscount Parker.

Charles Henry, 7 th Earl of Montrath. James, 8th Earl of Moray. 
Charles, 7 th Earl of Northampton.

Spencer, 8th Earl of Northampton.

Hugh, Earl of Northumberland. Elected under that title in 1757. He was in 1766 created the ist Duke of Northumberland.

Henry Herbert, ioth Earl of Pembroke.

Other, 4th Earl of Plymouth.

George, 2nd Earl of Pomfret.

Henry Arthur, Earl of Powis (Lord Herbert of Cherbury).

The extinct earldom, after the death of his son, was conferred on the eldest son of Lord Clive.

Neil, 3rd Earl of Rosebery.

John, 4th Earl of Sandwich. The famous First Lord of the Admiralty, the inventor of the sandwich, which he ate when too busy for a meal. Known as "Jemmy Twitcher," from the character in the Beggar's Opera, in consequence of his attack upon Wilkes, his former friend and associate at Medmenham Abbey.

Antony, 4th Earl of Shaftesbury. He married a daughter of Lord Folkestone, and was one of the first subscribers, having given ten guineas to the original fund started in 1754 to provide prizes.

William, 2nd Earl of Shelburne. Prime Minister in George iı.'s reign, afterwards ist Marquis of Lansdowne.

Harry, 4th Earl of Stamford.

Philip, 2nd Earl Stanhope, the father of the Earl Stanhope who improved the printing-press.

William Alexander, Earl of Stirling. This was the "Commander-in-Chief of the American forces," who claimed and bore the title after the death of the 5 th Earl in 1739. He died in 1795 .

William, i 8th Earl of Sutherland. His daughter married Earl Gower, afterwards Duke of Sutherland.

Richard, ist Earl Temple, brother of the Prime Minister, George Grenville.

Percy, ist Earl of Thomond.

John, 2nd Earl Tylney. He was the grandson of Sir Josiah Child, the great merchant and economist, chairman and for long absolute ruler of the East India Company. 
Ralph, 2nd Earl Verney, F.R.S. At his death, in I79I, the title became extinct.

James, 2nd Earl Waldegrave. First Lord of the Treasury. Francis Greville, ist Earl of Warwick. He was the 8th Baron, and first Earl Brooke.

Thomas, 8th Earl of Westmorland. His eldest son, John, Lord Burghersh, was also a member. He succeeded his father in 177 I as 9 th Earl of Westmorland.

William, 2nd Viscount Barrington. Chancellor of the Exchequer, etc.

John, 2nd Viscount Bateman.

Frederick, and Viscount Bolingbroke.

James, 3rd Viscount Charlemont, afterwards Earl of Charlemont.

Henry, ist Viscount Conyngham.

William, 2nd Viscount Courtenay. The title became extinct with his son, who, however, had established his title to the Earldom of Devon.

John, 4th Viscount Downe.

John, ist Viscount Dudley.

Lucius, 7 th Viscount Falkland.

Richard, 6th Viscount Fitzwilliam.

Jacob, ist Viscount Folkestone. Founder and First President of the Society. His portrait by Gainsborough is in the possession of the Society, and Barry also included his portrait in his painting of "The Society."

Richard, 4th Viscount Howe. The celebrated Admiral Howe, afterwards Earl Howe.

Charles, 9th Viscount Irvine.

Thomas, 4th Viscount Kenmare.

George, 3rd Viscount Midleton.

Henry, 2nd Viscount Palmerston, father of the wellknown statesman.

Edward, 2nd Viscount Powerscourt.

John, ist Viscount Spencer, afterwards (I765) Earl Spencer. His son was the founder of "the finest 
private library in Europe," and the well-known statesman.

George, Viscount Townshend, the 4th Viscount and Ist Marquis. Field-Marshal, Lord-Lieutenant of Ireland, Brigadier-General under Wolfe in Quebec Expedition. He was elected in 1757 as General Townshend, before his accession to the Peerage.

Thomas, and Viscount Wentworth. His father, the ist Viscount, was elected a member before his promotion, and his name appears in the list as Baron Wentworth. Thomas, 3rd Viscount Weymouth, afterwards (1789) created Marquis of Bath. Secretary of State and Lord-Lieutenant of Ireland.

George, ist Baron Anson. The great Admiral, First Lord of the Admiralty. Celebrated for his voyage round the world. He had no children, so his title died with him.

Frederick, 7 th Baron Baltimore. At his death the title became extinct. The first Lord Baltimore was the coloniser of Maryland in the reign of James 1., and it was from him that the city of Baltimore took its name. Barry heard of Baltimore's charter to the Indians after he had finished the picture in the meeting-room. So in his etching he made Baltimore a prominent figure, and thrust William Penn into the background.

Charles, 3rd Baron Cadogan, afterwards (1 800) created Earl Cadogan.

John, ist Baron Carysfort. Lord of the Admiralty.

Robert, Ist Baron Clive of Plassy. The great Indian statesman and General.

Gabriel, ist Baron Coleraine.

Richard, 2nd Baron Edgcumbe. He died in the year following his election, 176I, when his brother and successor became a member.

George, 3rd Baron Edgcumbe, created Earl of MountEdgcumbe in 1789 .

Thomas, ist Baron Foley. 
George, ist Baron Lyttelton, scholar and author. Thomas, 2nd Baron Montfort.

Frederick, Lord North, afterwards (1790) 2nd Earl of Guilford. The eminent statesman; Prime Minister, I 770 to 1782 .

Francis, ist Baron Orwell, afterwards ( I776) Viscount Orwell and (1 777) Earl of Shipbrook.

John, Ist Baron Pollington, afterwards Earl of Mexborough.

George, ist Baron Rodney, the great Admiral. He was elected in 1757 as Admiral Rodney, and was made a peer in 1782 .

Robert, 2nd Baron Romney. Founder, first Vice-President, and second President of the Society. His portrait by Reynolds is in the possession of the Society.

John, I I th Baron St. John of Bletsoe.

Nathaniel, ist Baron Scarsdale.

Thomas, 3rd Baron Southwell, created Viscount Southwell in 1776 .

John, ist Baron Waltham.

John, 6th Baron Ward, afterwards ( 1763 ) Viscount Dudley and Ward.

Edward, Baron Wentworth, afterwards ( I 762) ist Viscount Wentworth. His son was also a member, and his name is included among the Viscounts.

John, 6th Baron Willoughby de Broke.

Hugh, I 5 th Baron Willoughby de Parham. P.S.A., F.R S., Vice-President of the Society.

Edward, Ist Baron Winterton, afterwards (1766) Earl Winterton.

We may now leave the Peerage, and attempt a selection from the general body of members, dealing as before with the lists previous to, and including that of, i 764. The task of picking out the names of persons eminent at the time or afterwards distinguished has proved rather difficult. Without the help of that admirable work, the Dictionary of National Biography, it would have been hopeless. Wider 
historical knowledge, and a greater familiarity with the records of the time would no doubt have rendered the task easier and the results more complete. In many cases, also, the information given is too slight to render identification certain. The list, therefore, must be taken as representative rather than exhaustive, though probably there are not many names of real eminence that have been overlooked. At all events, the following list is so long that perhaps no apology is needed for not making it longer :-

Robert Adam (elected in 1758), William Adam (elected in I762), and James Adam (elected in 1764), the architects of the Adelphi.

Anthony Addington, M.D., physician to the great Lord Chatham and father of the Prime Minister, who was nicknamed " The Doctor," in allusion to his parentage. Ralph Allen, philanthropist, improver of the Post Office, friend of Pope, Fielding, and others.

William Almack, founder of Almack's Assembly Rooms and of the gaming club in Pall Mall which afterwards changed hands and developed into Brooks's Club.

John Julius Angerstein, whose fine collection of pictures formed the nucleus of the National Gallery.

Thomas Arne, the well-known musician; composer of "Rule Britannia."

Robert Arthur, St. James's Street, proprietor of Arthur's and White's Clubs.

Thomas Astle, antiquary, Keeper of the Records, author of Origin of Writing.

John Astley, portrait painter, and friend of Horace Walpole.

David Erskine Baker, author of Companion to the Playhouse, enlarged to Biographia Dramatica.

Henry Baker, F.R.S., naturalist and author. Defoe's son-in-law. Founder of the Bakerian Lecture of the Royal Society. He took a very active part in the foundation and early organisation of the Society. He was elected a "perpetual member" in 1755 for his services. 
Samuel Baker, founder of Sotheby's Auction Rooms.

Sir Joseph Banks, for forty-one years the autocratic President of the Royal Society.

Sir Francis Baring, founder of Baring Brothers and Chairman of the East India Company.

Robert Barker, the reputed inventor of panoramas.

Sir Edward Barry, physician, medical writer.

John Baskerville, the eminent printer.

Topham Beauclerk, the fashionable friend of Dr. Johnson. William Beckford, Lord Mayor i 762 and i 769 , the staunch supporter of Wilkes.

Jeremiah Bentham, the father of Jeremy Bentham, the great utilitarian philosopher. He was elected in I 755 , when his son Jeremy was sixteen.

James Boswell, elected in I 760 when he was twenty, on his first visit to London and before he knew Dr. Johnson. Alderman John Boydell, the reviver of English engraving by his munificent patronage.

Gustavus Brander, F.R.S., antiquary, director of Bank of England, benefactor to British Museum. One of the Society's founders.

Owen Salusbury Brereton, antiquary, Recorder of Liverpool, Bencher of Lincoln's Inn. Vice-President of the Society. His portrait is in Barry's picture.

Jacob Bryant, classical scholar.

Charles Burney, the well-known author of the History of Music, and the father of Fanny Burney the authoress. He was elected in 1764, when he was living in Poland Street, and before he took the degree of Mus. Doc. His portrait appears in Barry's picture, "The Thames," amongst the sea-nymphs.

William Cadogan, M.D., physician to the Foundling Hospital.

William Caslon, the famous typefounder.

The Hon. Henry Cavendish, the great philosopher and experimentalist.

Sir Robert Chambers, one of the judges in the trial of Nuncomar.

Sir William Chambers, the architect of Somerset House. $\mathrm{He}$ acted as architect to the Society when it 
moved into new premises in Little Denmark Court, I 759 .

Samuel Chandler, D.D., Nonconformist minister and bookseller.

Charles Chauncey, physician and collector.

Sir Henry Cheere, statuary, patron of Roubiliac.

Thomas Chippendale, the famous furniture maker.

Giovanni Cipriani, R.A., historical painter and engraver.

George Colman the elder, dramatist.

Sir Eyre Coote, the famous Indian General and conqueror of Hyder Ali. At the time of his election he was Colonel Coote.

Richard Cosway, R.A., the celebrated miniature and portrait painter. One of the first of the Society's prize-winners.

James, Thomas, and Patrick Coutts. James at the time of his election was already a partner in the great banking firm, then in the "New Exchange," and carrying on business as "Canipbell \& Coutts." Thomas was elected in 1762 , the year after he had been taken into partnership, after the death of Campbell. Patrick was at the time of his election (1767) a partner in the bank in St. Mary Axe, first started by the Coutts brothers.

Sir John Cust, Speaker of the House of Commons, I76I and i 768-70.

George Dance, the elder of the two architects, father and son. He designed the Mansion House.

Sir Francis Dashwood (Baron le Despencer), Chancellor of the Exchequer, and leading member of the Dilettanti Society ; founder of the "Hell Fire Club" at Medmenham.

Captain (afterwards Colonel) Thomas Desaguliers, F.R.S., son of J. T. Desaguliers, author of various books on mechanical and experimental philosophy.

Sir Alexander Dick, president of the Edinburgh College of Physicians and friend of Dr. Johnson.

Robert and James Dodsley, the well-known booksellers.

John Dollond, the eminent optician, Copley Medallist. 
Robert Dossie, the editor of the Memoirs of Agriculture, etc., in which the Society's early Proceedings were recorded. Some record of him will be found in Chapter $\mathrm{XV}, \mathrm{p} .331$. His Memoirs are constantly referred to in these pages.

Robert and John Drummond, the bankers, whose bank was then, as now, at Charing Cross, were both members. The former was elected in 1757 and the latter in 1762 . Robert was the son of Viscount Strathallan, who was killed at Culloden and was attainted, as was also his eldest son. John married a granddaughter of the first Duke of St. Albans (Nell Gwynne's son), and it was through this connection that the Adelphi estate, acquired by the second Duke of St. Albans on his marriage with the daughter of Sir John Werden, whose trustees had purchased it, came into the possession of the Drummond family. The Drummonds have ever since been connected with the Society; and Mr. George James Drummond, the owner of the Adelphi, is now (1913) the Society's landlord. The bank was founded in 1707 by Andrew Drummond, the father of John, above-mentioned.

Sir John Fielding, the magistrate, half-brother to the novelist.

Sir Samuel Fludyer, Lord Mayor in 1 761 . Fludyer Street, Westminster, was called after him.

John Fothergill, M.D., F.R.S., botanist and physician, associated with Franklin.

Benjamin Franklin, the great American philosopher and politician. He was elected a corresponding member in 1756 , but paid the amount of a Life Subscription, and his name afterwards appears among the ordinary members. He kept up a correspondence with the Society, and in I 76I, while in England, he accepted the office of chairman of the Committee of British Colonies and Trade.

David Garrick, the great actor.

Edward Gibbon, the historian.

Thomas Gisborne, M.D., President of the College of Physicians. 
Oliver Goldsmith, whose address when he was elected in I 763 was the Chapter Coffee-House.

Major-General Sir John Griffin, afterwards Field-Marshal, and ( 1784$)$ gth Baron Howard de Walden.

Admiral Thomas Griffin, served in the West Indies and elsewhere, but left an unfortunate reputation for lack of intrepidity and for unpopularity.

Thomas Grignion, the clockmaker, who presented to the Society the clock in the meeting-room.

Francis Grose, antiquary and author.

Stephen Hales, D.D., F.R.S., Copley Medallist, physiologist, botanist, and inventor. One of the Society's founders. His portrait is in Barry's picture of "The Society."

Jonas Hanway, the historian of commerce and the introducer of umbrellas.

Sir Charles Hardy, Admiral, Governor of New York; served in command under Hawke at Brest and Quiberon Bay, M.P. for Portsmouth

The Hon. Thomas Harley, afterwards Lord Mayor ( 1767 ), opponent of Wilkes.

Sir Edward Hawke, the distinguished Admiral, afterwards (1 776) ist Baron Hawke.

John Hawkesworth, LL.D., friend of Dr. Johnson, and his successor as compiler of the Parliamentary reports in the Gentleman's Magazine.

Sir Cæsar Hawkins, the eminent surgeon.

Sir George Hay, lawyer and politician.

Francis Hayman, original R.A.; friend of Hogarth and Garrick.

William Heberden (the elder), physician and scholar; attended Johnson, Cowper, and Warburton. He, like Cæsar, wrote his Commentaries, and a bookseller is said to have recommended one as a substitute for the other.

William Hoare, of Bath, original R.A.; distinguished portrait-painter.

William Hogarth. His signature is crossed out in the signature-book; why, there is no saying. He was duly elected in December I755, and subscribed for 
two years. His namc appears on committees in 1757 . He died in 1764 .

Thomas Hollis, republican and author. Presented portrait of Newton to Trinity College, Cambridge, and portrait of Cromwell to Sidney Sussex College. John Howard, the philanthropist.

Richard Huck, army surgeon and physician of reputation. In 1777 he took the additional name of Saunders.

Dr. William Hunter, the physician, who was as well known in his day as his younger brother John.

Dr. Robert James, the inventor of James's Powder.

Richard Jebb, M.D., afterwards (I 778) baronet. Friend of IVilkes and Churchill.

Soame Jenyns, a great man in his day, but now best known as having had his Nature and Origin of Evil unfavourably reviewed by Dr. Johnson.

Samuel Johnson, LL.D. He took a great deal of interest in the Society, attended its meetings, and took part in its deliberations, though by his own account he was no orator. He told Boswell that he had "several times tried to speak at the Society of Arts and Sciences, but had found that he could not get on." Also he "acknowledged that he rose in that Society to deliver a speech which he had prepared; 'but (said he) all my flowers of oratory forsook me.'" Boswell (Edit. G. Birkbeck Hill, I 887), vol. ii. page I 39 .

Hugh Kelly, a playwright who considered himself a rival of Goldsmith.

Admiral Augustus Keppel, afterwards (1782) created Viscount Keppel.

Gowin Knight, M.D., F.R.S., Principal Librarian of the British Museum.

Sir Charles Knowles, Admiral, Governor of Louisburg and of Jamaica.

Abraham Langford, auctioneer and playwright.

Colonel Stringer Lawrence, called the "father of the Indian Army." He left India in 1759.

Thomas Lawrence, friend and physician of Dr. Johnson.

Sir Wilfrid Lawson, the 8th Baronet. 
Henry Bilson-Legge, financier, Chancellor of the Exchequer, etc.

James M'Ardel, one of the best English mezzotint engravers. Robert Mackreth, the well-known waiter at Arthur's Chocolate-House, known as " Bob," afterwards M.P., and knighted.

Sir Richard Manningham, known as a great "man-midwife."

William Markham, D.D., headmaster of Westminster School ; afterwards ( 1777) Archbishop of York.

Matthew Maty, M.D., F.R.S., secretary R.S., Principal Librarian of the British Museum. He was a candidate for the secretaryship of the Society in I 760, when Dr. Templeman was elected.

Israel Mauduit, F.R.S., political pamphleteer and preacher, Agent in England for Massachusetts.

John Mitchell, F.R.S., botanist, made a map of the British and French Dominions in North America.

Sir Henry Moore, Bart., Governor of Jamaica and of New York.

Robert More, F.R.S., botanist.

Charles Morton, M.D., Principal Librarian of the British Museum.

George Michael Moser, chaser and enameller, first keeper R.A. Engraved George in.'s first Great Seal. Father of Mary Moser, R.A.

Lieut.-General Lord John Murray, M.P. for Perth.

Robert Mylne, F.R.S., constructed Blackfriars Bridge, engineer to the New River Company.

John Newbery, publisher and bookseller. He employed Johnson and Goldsmith.

Frank Nicholls, F.R.S., physician.

Lieut.-General Oglethorpe, M.P., founder of Georgia.

Dr. Johnson offered to write his life. Austin Dobson calls him a "Paladin of Philanthropy."

James Paine, a successful and industrious architect. He built numerous country houses and several in London. He was President of the Society of Artists, 177I. He rebuilt Salisbury Street in 1783 . There is a good account of him in Chancellor's British Architects, 1909. 
Sir Robert Palk, Bart., Governor of Madras. Palk Strait, between Ceylon and India, is called after him.

James Parsons, M.D., F.R.S., physician and antiquary.

Sir Lucas Pepys, Bart., M.D., President of the Royal College of Physicians, physician to George in. Attended the King in his insanity. He was elected in 1764 , when twenty-two years of age.

John Lewis Petit, M.D., F.R.S., physician.

Constantine John Phipps, commanded the Racehorse in expedition of 1773 to discover a north-eastern route to India, and attained a high latitude to north of Spitzbergen. Afterwards 2nd Baron Mulgave, M.P., and Lord of the Admiralty, etc.

Christopher Pinchbeck, son of the inventor of copper and zinc alloy named after him.

Charles Pinfold, Governor of Barbados.

Thomas Pingo, medallist, assistant engraver to the Mint. William Pitcairn, M.D., President of the College of Physicians, $1775-85$. A ward in St. Bartholomew's Hospital is named after him.

George Pitt, afterwards Baron Rivers, author of Letters to a Young Nobleman, etc.

William Pitt, the great statesman, afterwards Earl of Chatham.

Admiral Sir George Pocock. He took Havana in 1762 .

Sir James Porter, F.R.S., Ambassador at Constantinople. Governor Pownall, politician. His work on The Administration of the Colonies went through several editions. He was elected in 1760 , and his name in the List is altered from "Governor" to "Thos., Esq."

Sir Charles Pratt, afterwards created Earl Camden, Lord Chancellor and Chief Justice; decided in the case of John Wilkes that general warrants were illegal, and thereby gained immense popularity.

William, Viscount Pulteney, the son of the well-known politician who was made Earl of Bath by Walpole. He died before his father, and the earldom became extinct.

Sir Thomas Pye, Admiral. "A man of slender ability, thrust into office by the Bathurst influence" (Dict. Nat. Biog.). 
Allan Ramsay, portrait painter to George III., acquaintance of Dr. Johnson.

Sir Joshua Reynolds, first President of the Royal Academy. Elected in 1756 before he was knighted.

General Robert Rich (afterwards 5th Baronet), wounded at Culloden.

Samuel Richardson, the novelist.

Sir Thomas Robinson, Governor of Barbados and Commissioner of Excise.

John Robison, went to Jamaica for the test of Harrison's chronometer.

Francis Louis Roubiliac, the sculptor.

Sir John St. Aubyn, 5th Baronet, M.P., F.R.S.

Lord George Sackville, afterwards Viscount Sackville, of unhappy reputation for his behaviour at the battle of Minden in 1759 .

Paul Sandby, R.A., water-colour painter and engraver.

Sir Charles Saunders, Admiral, served on Newfoundland station, and First Lord of the Admiralty.

Sir George Savile, Bart., M.P., F.R.S., well-known independent politician, and Vice-President of the Society.

Gregory Sharpe, D.D., F.R.S., Master of the Temple.

Peter Shaw, physician and author.

Thomas Sheridan, author and actor (father of Richard Brinsley). Proposed by Garrick.

The Rev. Laurence Sterne, author of Tristram Shandy.

John Stock, painter to His Majesty's dockyards. He died in $178 \mathrm{I}$, leaving the bulk of his property, upwards of $£ 60,000$, to the Painters' Company, with instructions that the interest should be distributed to the aged blind, the poor of the Company, and others. He left $£$ roo to the Society, with the condition that the interest should be applied for the promotion of drawing, sculpture, and architecture.

Sir Robert Strange, the eminent English engraver.

General William Strode. It was he who erected the statue of Queen Charlotte in the centre of Queen's Square, and that of William, Duke of Cumberland, in Cavendish Square. 
James Stuart, author, member of the Dilettanti Society, generally known as "Athenian" Stuart. Designed the Society's first medal (see Chapter XIV, p. 316).

George Stubbs, the well-known animal painter.

Robert Taylor, M.D., F.R.S., a well-known physician.

James Theobald, F.R.S., F.S.A. One of the first Vice-

Presidents of the Society. He took an active part in the movement for obtaining a charter for the Society of Antiquaries, of which Society he became the Secretary in January 1727-8. Afterwards he became a member of its Council and one of its Vice-Presidents, He made many communications to that Society, and there are frequent references to him in its minutes. He died in 1759. He is mentioned several times in Nichols's Literary Anecdotes, but is ignored by the Dict. Nat. Biog.

Sir Noah Thomas, M.D., F.R.S., physician.

Bonnell Thornton, well-known wit and writer, member of the " Nonsense Club," which organised an " Exhibition of the Society of Sign-Painters," in ridicule of the Society of Arts Exhibition (see Dict. Nat. Biog.). He only subscribed for one year, so perhaps the Society's methods did not commend themselves to him.

John Thornton, one of the first of the well-known Clapham family, the great evangelicals.

Henry Thrale, the brewer, Dr. Johnson's friend.

Jacob Tonson, great-nephew of Jacob Tonson, Dryden's first publisher, employed Warburton and Johnson among others.

Rev. James Townley, headmaster of Merchant Taylors' School, author of High Life below Stairs; friend of Hogarth.

Charles Townshend, Chancellor of the Exchequer, etc., and brilliant wit.

Jonathan Tyers, proprietor of Vauxhall Gardens.

Robert Vansittart, Regius Professor of Civil Law, Oxford. Horace Walpole, the great connoisseur and well-known author and collector. Afterwards (I79I) 4th Earl of Orford. 
Joshua Ward, "Spot" Ward, the well-known quack and nostrum-monger, whose statue by Agostino Carlini decorates the Society's Hall. He acquired a fortune by the sale of pills and potions, and a reputation by his introduction of improved methods of making sulphuric acid.

Richard Warren, M.D., a well-known physician.

Sir William Watson, M.D., F.R.S., physician and man of science. Physician to Foundling Hospital.

Philip Carteret Webb, F.R.S., M.P. He was joint solicitor to the Treasury and a leading official in prosecution of John Wilkes.

Alexander Wedderburn, Lincoln's Inn, afterwards Lord Loughborough and Earl of Rosslyn.

Saunders Welch, a magistrate of Westminster, friend of Fielding and Dr. Johnson.

Benjamin West, R.A., the painter. President of the Royal Academy.

Samuel Whitbread, brewer, father of the better-known politician.

Caleb Whitefoord, wit and diplomatist. Friend of Franklin, Johnson, Goldsmith, and Horace Walpole. He was a Vice-President of the Society, and a very active member of it. He was instrumental in obtaining the portraits of Shipley and Templeman. The Society possesses his portrait by an unknown painter.

Charles Whitworth, M.P., Chairman of Ways and Means, 1 774-78. Knighted in 1768. One of the first VicePresidents of the Society.

John Wilkes, the notorious politician, elected I 758 , when thirty-one years of age. He was proposed by his brother, Israel Wilkes, who joined the Society in 1757, and was a very active member, constantly taking the chair at committee meetings.

Sir Edward Wilmot, Bart, M.D., F.R.S., PhysicianGeneral to the Army.

Sir John Eardley-Wilmot, Chief Justice, Common Pleas. Educated with Johnson at Lichfield.

Joseph Wilton, sculptor, foundation member of R.A., associated with Sir William Chambers, the architect. 
Henry Sampson Woodfall, the printer of the Letters of Junius, and conductor of the Public Advertiser.

Sir George Yonge, Bart., Governor of the Cape.

Christian Friedrich Zincke, enamel painter; produced many portraits in enamel.

In addition to the subscribing members, the Society had also a number of corresponding members, men distinguished in various capacities, or who had rendered services to the Society. They were for the most part foreigners or resident abroad. The greatest name on the earlier lists is that of Linnæus, which appears for the first time in the list of 1770 .

Amongst the names which came up for election there were very few rejected, as would naturally be the case when the object of the Society was to collect subscriptions for a certain purpose. However, one was that notorious free-lance, Dr. John Hill, or Sir John Hill, as he called himself after he had been made a knight of the Order of Vasa by the King of Sweden. He was proposed for election, but was unsuccessful, as he also was when he tried to get into the Royal Society, so that he might put F.R.S. after his name in the title-page of one of his books. TheDictionary of National Biography describes Hill as " a versatile man of unscrupulous character, with considerable abilities, great perseverance, and unlimited impudence." He appears to have been at loggerheads with all his contemporaries. He paid out the Royal Society for not admitting him by an attack upon them which certainly found out some of the weak joints in the armour of that distinguished body. He tackled Fielding and got rather the worst of it. When Garrick spoke slightingly of a play written by him, he attacked him also. Garrick retaliated by the well-known epigram :-

"For physic and farces his equal there scarce is, His farces are physic, his physic a farce is."

He does not appear to have been much affected by his 


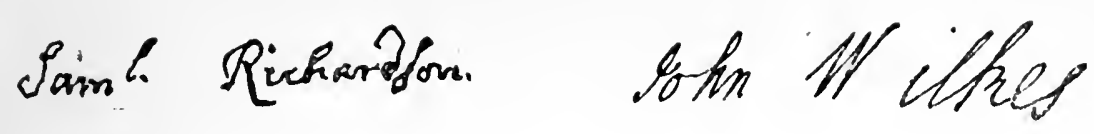
Siancir Itayman foras Hanvars Gohn Belestorough Cadingan shaclesfued

Slimouth lemey romons qithtield Richmont go: Gom detoch sam: Johnfor 
Martborough Tho. OPinge wom Chambers GHancount? George Colman Shastesburs Siglhestow Molt Walpole hominey elimgstone Ioshua Rezhots Sainhope

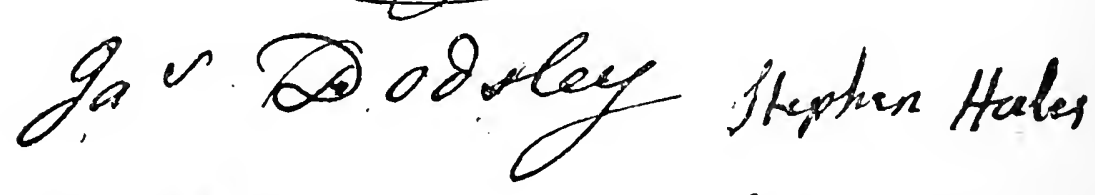
Galtimore Aobutbluve 
Modstiy Hor Anson Qiovam batiun lijerianc Edward Eibbon Gon-Boy dell Allan Ramsay Sorn Fothergile Gomfoclicso Sngeasteon Aulnsbesly stover Execter-

Elurmam Tho: Rorwich 
Camarciak Donfoshe

Sorreano Durtmouth Topham heauclenk Sohn tzashcriville.

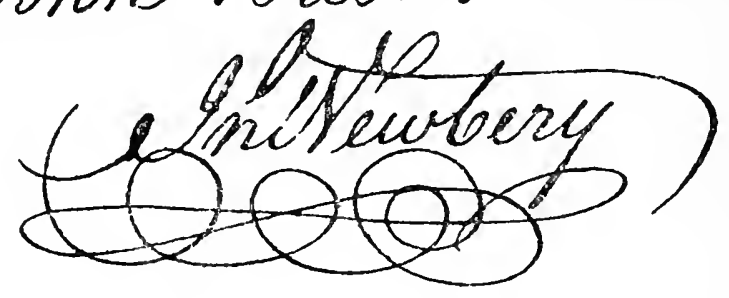

Geo: Dance Qphoorney AobitdamSemple Howialopo Solhu How ard temitury 
rejection by the Society of Arts, though he wrote what was for him a temperate letter of protest.

From the first foundation of the Society ladies have been eligible for membership, and the Lists of Members have always contained a certain number of women's names. The first list of October 1755 contains the names of Miss Elizabeth Vaughan and Lady Betty Germain, daughter of the Earl of Berkeley, and wife of Sir John Germain, who came with William the Third to England and served under him. She inherited a large fortune from her husband, and bequeathed it, in accordance with his desire, to Lord George Sackville, who took the name of Germain. She was a friend of Swift and other literary men. Miss Mary Cook-who, like Miss Vaughan, is now but an unknown name to us-was elected a little later in the same year (1755), and Mrs. Elizabeth Montagu-whose name is spelt Mountague in the list-the earliest " blue stocking" and the well-known authoress and leader of intellectual society, became a member in 1758 . Her portrait appears in Barry's picture of the Society. Later lists include the names of the Countess of Denbigh, the Countess of Macclesfield, the Countess of Northumberland, and Viscountess Falmouth.

There can be no doubt that the list from which the above names have been selected was a very remarkable one, and one which may challenge comparison with that of any other society, however distinguished. Statesmen, philosophers, philanthropists, painters, lawyers, divines, physicians, authors, dramatists, actors, musicians, bankers, soldiers, sailors, architects, historians, mechanicians, merchants, all are to be found, and many of them are the most eminent of the time. Besides these, there is a crowd of peers and wealthy men who seem to have been quite ready to support, with their purses and their influence, a scheme which commended itself as likely to promote the growing industrial and commercial interests of the kingdom.

Other evidence as to the early popularity of the Society, 
and of the public esteem in which it was held, is to be found in contemporary literature. Smollett, in his History, ${ }^{1}$ gives a full and laudatory account of the institution and proceedings of the Society : "The protection, countenance, and gratification secured in other countries by the institution of academies, and the liberalities of Princes, the ingenious in England derived from the generosity of a publick, endued with taste and sensibility, eager for improvement, and proud of patronizing extraordinary merit. . . In a word, the Society is so numerous, the contributions so considerable, the plan so judiciously laid, and executed with such discretion and spirit, as to promise much more effectual and extensive advantage to the publick than ever accrued from all the boasted academies of Christendom."

Anderson, in his History of Commerce, ${ }^{2}$ speaks of the Society as "One of the noblest designs for the improvement of the Commerce of Great Britain which could possibly have been devised." Perhaps in both cases the laudation is a little exaggerated, but the quotations may serve to show the estimation in which the early efforts of the Society were held.

1 Book iii. chap. $x . \S$ iv.

${ }^{2}$ Vol. iii. p. 298. 


\section{H A P T E R I I I}

\section{The. Society's Offices}

First Offices of Society in Craig's Court-Moved to Castle Court Proposal to rent Exeter Change-House taken in Little Denmark Court, opposite Beaufort Buildings-Exhibition Room builtAgreement with the Brothers Adam for Premises in the AdelphiThe Adams and the Adelphi-The Society's House in the AdelphiThe Meeting-Room-Its Decoration-Changes in the BuildingLighting and Warming-Barry's Pictures-Barry and his Aspirations-His History-Devotion to his Ideas-Description of the Pictures-Portraits of Lords Folkestone and Romney-Barry wishes to substitute Portraits of George III. and Queen Charlotte -Portraits of Queen Victoria and Prince Albert.

The first permanent offices of the Society were in Craig's Court, Charing Cross. At a meeting held on igth February 1755, at Peele's Coffee-House, arrangements were finally made with Shipley that he should take a house in Craig's Court, and sublet a portion to the Society. Whether the rest of the house was used by Shipley for his Academy or not, there is nothing in the Minutes to indicate. The rent paid was $£ 20$ a year, including coals and candles. The first meeting at Craig's Court was held on ist March 1 755. Here the Society remained for a year, but the rooms were too small, so they moved to a house at the corner of Castle Court on the east side, "opposite the New Exchange," on 2nd June I 756. For this they paid to John Fielding a rent of thirty-five guineas for the first floor and some other part of the house. Castle Court was a narrow alley leading from the Strand to Chandos Street. It disappeared when the district was rebuilt in the reign of William IV., the date being commemorated by the names of King William Street and Adelaide Street. The ground on which the house containing the Society's offices 
stood now forms part of the site of the British Medical Journal office.

The accommodation, however, soon proved insufficient for the growing needs of the Society. It was increasing rapidly in numbers and in wealth, and it soon seems to have felt the need of more spacious quarters. Two years after it was established in Castle Court we find in the Minutes that inquiries were being made for new premises. Several localities were suggested and rejected. In May 1758 a committee reported favourably on a proposal to acquire Exeter Change. It appeared that a total outlay of $£ 2500$ would have been required for necessary repairs and alterations, and that Lord Exeter was willing to grant a lease for about sixty years at a rent of $£ 200$ a year. As a set-off against this, there was the rent of certain shops forming part of the building, and to be sub-let by the Society. The outlay, however, was considered too great, and the proposal was declined.

Eventually the Society came to terms with Messrs. Williams \& Woodin, who carried on the business of upholsterers and carpenters in premises opposite Beaufort Buildings in the Strand. These premises included the house afterwards No. 380 and $38 \mathrm{I}$ Strand, and a warehouse and yard behind. Messrs. Williams \& Woodin agreed to build a Great Room for the Society on the site of their warehouse, and to let this room, with another goodsized room on the ground floor, together with a certain part of the house, for a payment of $£ 200$ and a rent of $£ 120$ a year for three years, and $£ 100$ afterwards, for a term of fifteen years from Midsummer i 759. The first meeting in the new rooms was held on I 8 th July in that year. The various alterations in, and additions to, the buildings were made under the superintendence of Mr. (afterwards Sir William) Chambers, who acted as the Society's architect. He later achieved a great reputation, his bestknown work being Somerset House.

The house stood on ground which was then part of the property of the Duke of Bedford, and the plan on page 56 has been prepared from records still preserved in the office of the Bedford estate. The area, which, so far as 


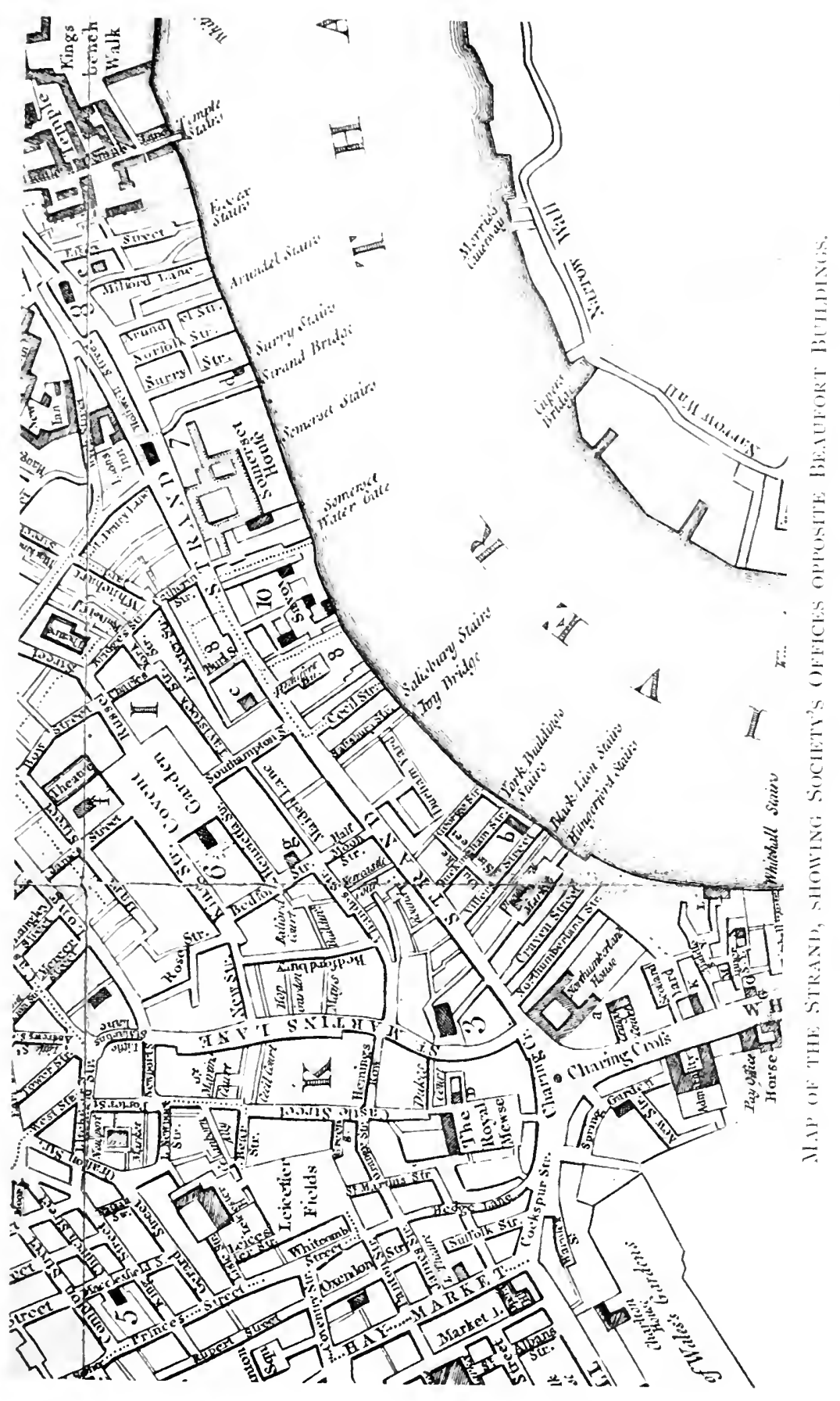


can be made out, was occupied by the Society's premises, is indicated by dark shading. A is the Great Room, B is the smaller room on the ground level, used for the Society's collection of models, and $C$ shows the offices with an entrance to the Strand. D is the house taken a year and a half later, in January $176 \mathrm{I}$, for a residence for Dr. Templeman, the newly appointed secretary. The description in the lease is rather vague, and it is doubtful whether the whole, or only a portion of the shaded part, was included. This house was leased from IVoodin, Williams having died in 1760 , and his interest having been acquired by Woodin. The position of the present Exeter Street is shown in dotted lines on the plan, and it will be seen that nearly the whole of the area occupied by the Society's area is now covered by the modern extension of that street, the rest of it being now occupied by the recently erected building of the Strand Hotel. Exeter Street originally extended only from Catherine Street to Burleigh Street. The L-shaped extension leading southwards into the Strand was a later enlargement of Denmark Court (which, as shown in Horwood's map, circa I 800 , was an extension of Exeter Street) and of Little Denmark Court, which led from the end of Denmark Court, at right angles, down to the Strand. Little Denmark Court was a narrow alley for foot-passengers only, and probably its entrance to the Strand was an archway under the first-floors of the adjacent houses.

It has not been found possible to make out precisely how much of the Strand frontage was occupied by the Society. It certainly had an entrance on the Strand, and perhaps it had the whole or part of the first floor. Or the original house may have been divided into two, and this idea is suggested by a comparison of the entries in the sewer-rate book for 1763 and subsequent years. The earliest entry shows one house, in the occupation of Thos. Wooden [sic]; the entry for 1765 shows the same house as occupied by Geo. Box (in whose name the lease to the Society had been taken out) and formerly by Price, while subsequent entries show two houses. It was certainly for long in the joint occupation of the Society and 
the landlords, for both Williams and Woodin, who were members, have their addresses recorded in the lists as "Society's Offices."

The original house and buildings had been leased by the Duke of Bedford in 1753 to John Price, by whom it

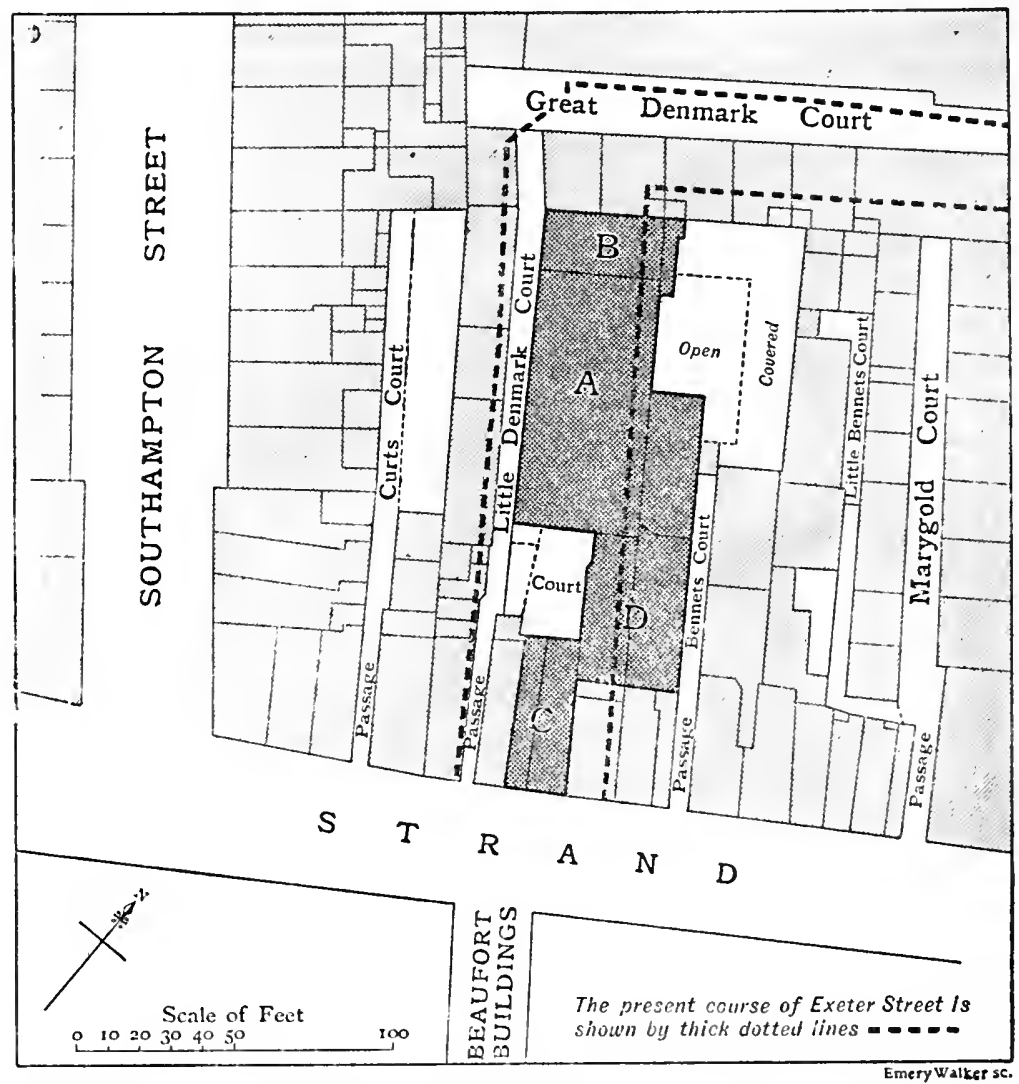

Plan showing position of the Society's Offices, opposite Beaufort Buildings.

was demised to Williams \& Woodin. It was, when let to Price, the Greyhound Tavern, but presumably Price or his successors gave up the tavern and used the premises for other purposes. The district extending a certain way eastwards from Southampton Street is designated in the rent-books of the Bedford estate "Fryers' Pyes," but up to 
the present it has not been found possible to ascertain the meaning of this curious title or to find any explanation of it. ${ }^{1}$

For the information which has enabled the site of the Society's old offices to be identified the writer is entirely indebted to Sir Laurence Gomme, the accomplished Clerk of the London County Council, and to Mr. A. R. O. Stutfield, the steward of the Bedford estate. The writer has much pleasure in acknowledging the valuable and ready help they have given. It has always been known that the Society occupied offices "opposite Beaufort Buildings" from I759 to I774, but it had been assumed that these offices were at the north-east corner of Beaufort Buildings, in the house afterwards No. 96 Strand, long well known as Rimmel's, the perfumer's. The fact that Shipley's Academy was, as previously mentioned, established in this house, probably led to the mistake. The solution of the problem, and the identification of the Society's old premises, had been the cause of considerable gratification to the present writer, because it completes the history of the Society's migrations before it found a permanent home in its present buildings in the Adelphi.

The position of the Society's house is also indicated in the old map of this part of London, a portion of which is reproduced in the plate facing page 54. In the narrow street opposite Beaufort Buildings, which is not named, but is really Little Denmark Court, the square block with the reference letter " c" is, as stated in the margin of the map, "The Society of Arts and Sciences, Strand." The map was published by Thomas Jefferys, and the date on it is 1766 . The copy from which the reproduction was made is in the possession of the Athenæum Club. Jefferys was a wellknown cartographer, and would probably have received a prize from the Society for his map of Yorkshire but for his death in $1771 .^{2}$ It is clear that the building shown on the map is merely the "Great Room" where the

${ }^{1}$ Hare in his Walks in London (vol. i. p. 31, 2nd edition, I894) says that Covent Garden was in 1222 known as Frère Pye Garden.

2 See Chapter XIII, p. 299. 
exhibitions were held, the Society's offices being, as above stated, between this building and the Strand.

All this district was altered under the Act (7 Geo. Iv. cap. 77) passed in 1826 for the widening of the Strand, and in the various improvements carried out Exeter Change itself disappeared. The principal building erected on its site was Exeter Hall, long a well-known concert room, opened in 1831. Now it too has followed its predecessor, and its place is occupied by a big hotel. Beaufort Buildings remained until 1902, when the extension of the Savoy Hotel swallowed it up, and all the old buildings on this part of the south side of the Strand were demolished. The courtyard of the hotel now occupies the ground which was formerly the roadway of Beaufort Buildings.

If the conclusions drawn from an examination of the plans and documents in the Bedford estate offices are correct, the "Great Room " was worthy of its name, being an apartment $80 \mathrm{ft}$. long by $40 \mathrm{ft}$. broad, almost identical in dimensions with the large Gallery of the Royal Academy in Burlington House, which is $82 \mathrm{ft}$. by 42. It was here that the first exhibition of pictures by British artists was held in 1760 . The smaller room on the ground level was $40 \mathrm{ft}$. by $20 \mathrm{ft}$. In this the first exhibition of models and machines was held in 1761 .

A considerable amount was expended in fitting and furnishing the rooms and offices, besides the cost of structural alterations. Among other improvements it was found necessary to make a "crossing" in the Strand, at a cost of three and a half guineas, to facilitate the access to the Society's entrance door.

In 1770 the lease of the Society's premises having nearly expired, and the accommodation being again found insufficient, it was decided to advertise for new premises, and accordingly an announcement was inserted in some of the daily papers inviting any person who had

${ }^{1}$ The Act authorised the widening of the Strand "on the north side thereof opposite Cecil Street in an easterly direction to the East end of Exeter Change." The sewer-rate book for 1830 shows that the demolition had then began. A note in a subsequent rate book states that sixteen houses had been pulled down. Among these were Nos. 380 and $38 \mathrm{I}$. 


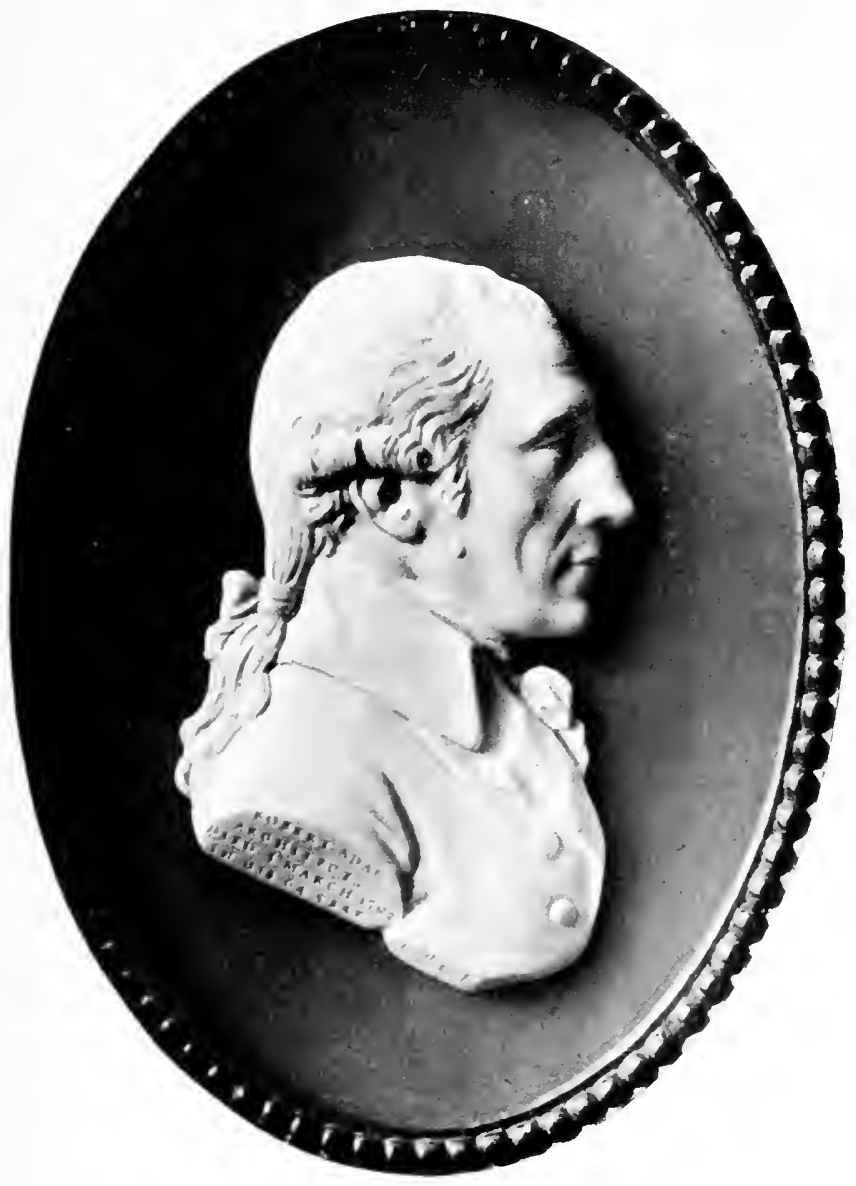

ROBERT ADA.I.

From a Medallion by Tassie. 
proposals to make for the accommodation of the Society to communicate with the secretary.

The result of this advertisement was that the Brothers Adam, ${ }^{1}$ who were then occupied with their scheme for the construction of the Adelphi, offered to include in that scheme a suitable house for the Society's purposes.

The history of the Adelphi has often been written.? The site was long occupied by the historic buildings of Durham House, the residence of the Prince-Bishops of the northern See. The house and grounds originally occupied the area between Adam Street and Buckingham Street, from the Strand to the river. The New Exchange was built in 1608 by Lord Salisbury on the site of the Durham House stables, and extended from George Court to what used to be Durham Yard, but is now Durham House Street. It thus included the site of Coutts's Bank. $^{3}$ It was pulled down in 1737 , when shops and houses were erected along the present line of the Strand. In the space between these buildings and the river, where old Durham House once stood, fronting the river, with its gardens reaching to the Strand, were " a number of small low-lying houses, coal-sheds, and lay-stalls, washed by the muddy waters of the Thames." The ground sloped down from the Strand level to the brink of the river, which must have been, at high water, somewhere about the inner edge of the Embankment Gardens.

On this slope the Brothers Adam (Robert, William, James, and John) proposed to build a great terrace, level with the Strand, the idea being taken from the arched terrace or gallery in the Palace of Diocletian at

${ }^{1}$ The head of Robert Adam, facing page 58 , is a reproduction from a fine medallion by Tassie, now in the collection of the Edinburgh Board of Manufactures.

2 The fullest history of the Adelphi is contained in three articles by Mr. H. B. Wheatley in the Antiquary magazine for June, July, and September 1884 . In these a great deal of information will be found which it has not been thought needful to include here, as it has no special connection with the Society of Arts. Mr. Austin Brereton's Literary History of the Adelphi (1907) is the most recent book on the subject. Mr. Percy Fitzgerald devotes the best part of a chapter of his Picturesque London (1890) to the Adelphi.

${ }^{3}$ The bank was moved in 1904 to the opposite side of the Strand. 
Spalatro, ${ }^{1}$ which Robert Adam studied with great care, and described in a monumental folio. ${ }^{2}$ The ground was in the possession of the spendthrift Duke of St. Albans, or rather of his trustees. By the year $\mathrm{I}_{42} 2$ the estate had finally passed out of the possession of the Bishops of Durham, and under the provisions of an Act of Parliament it became the property of the Earl of Pembroke and Montgomery, a rent-charge only of $£ 200$ a year being reserved to the See of Durham. This rent-charge, it may be interesting to mention, is still paid by the present owner to the Ecclesiastical Commissioners. In 1677 the estate was sold by the Earl of Pembroke to Sir Thomas Monpesson, and in I7 6 it was again sold by the representatives of Sir Thomas Monpesson to the trustees of the will of Sir John IVerden, whose daughter Lucy married Charles, the second Duke of St. Albans. Their son George, the third Duke, brought the estate into settlement, and in 1767 a private Act of Parliament was passed for vesting part of his estates in trustees for the purpose of raising money to pay his debts.

These trustees, Lord Charles Spencer and Sir Philip Musgrove, in 768 granted a lease to the Brothers Adam for ninety-nine years at a rent of $£_{\mathrm{I}} 200$ a year. It has seemed worth while to record these details because they have never been accurately stated in previous accounts of the Adelphi, and it is only by the obliging assistance of Mr. George Drummond, the owner of the Adelphi, and of Messrs. Fladgate, the solicitors to the estate, that it has been possible to trace out the manner in which this historic bit of London passed into the possession of its present owner.

The design proposed by the Brothers Adam was duly carried into effect, the requisite height on the river side being obtained by the construction of tiers of superimposed arches. ${ }^{3}$ Some of these arches formed public

1 Fitzgerald, Picturesque London, p. 39.

${ }^{2}$ Ruins of the Palace of the Emperor Diocletian at Spalatro in Dalmatia, by R. Adam, F.R.S., F.S.A., I 764 .

${ }^{3}$ The view of the Adelphi (facing page 64) shows the terrace with the houses as originally built, and justifies Horace IValpole's criticism (quoted by Mr. Wheatley) that the Adelphi buildings resembled " warehouses laced down the seams, like a soldier's trull in a regimental old 


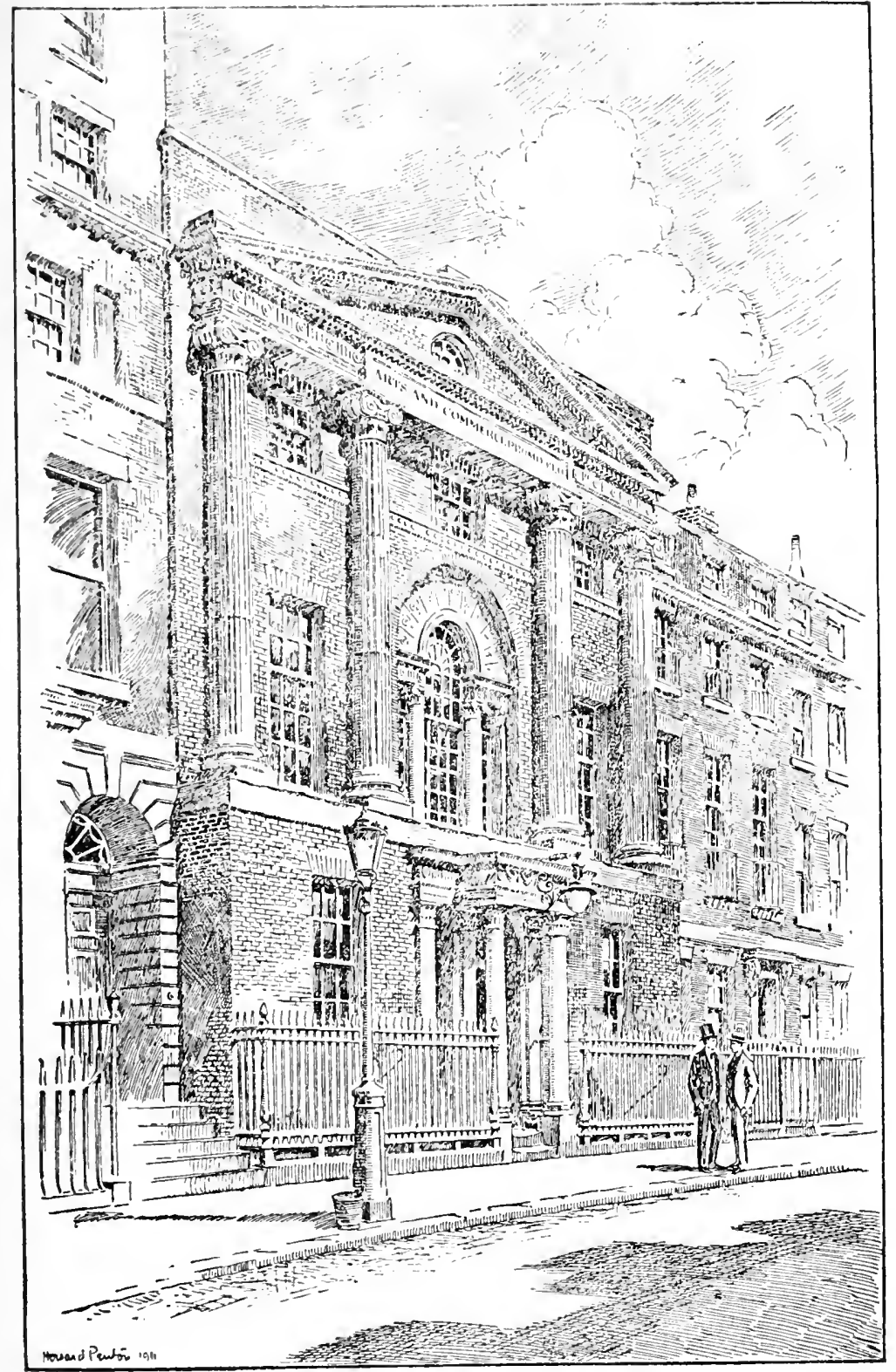

The Society's House in $19 \mathrm{I}$. 

thoroughfares, and later gained an unenviable reputation on account of their nocturnal frequenters. Others were let as storehouses; at one time a number of cows were stabled in some of the arches, and supplied milk to a large part of the West End. Others, again, served as cellars for the houses built on the substructure. The Society's house has two stories of cellars below the south-western part of the building, while the foundations of the northeast corner are in the original ground. The house has undergone a certain amount of repair, but it seems now as sound as when it was first built.1

When the Thames Embankment was made, ${ }^{2}$ the buildings on the south side of the estate, near the river, were affected, and some reconstruction work had to be carried out on the arches, but the ground on which the Society's house stands does not seem to have been at all disturbed.

The work, commenced in July i 768, was practically completed in about six years, but before it was finished the Adams were in financial difficulties. In the course of their operations they encroached on the foreshore of the Thames, and thereby involved themselves in a dispute with the Corporation, their difficulties being increased by the political circumstances of the time, as the Corporation were strongly Wilkesite, while the Adams enjoyed Court favour. Eventually they succeeded in obtaining an Act of Parliament to authorise their proceedings. In this they were assisted by their patron, the Earl of Bute. Their pecuniary difficulties were set right by means of a second Act, which empowered them to organise a lottery, the chief prizes in which were the houses then in course of building on the estate. In many cases the prizewinners sold their rights, and thus the sub-leases became the property of various owners. Their tenures expired

coat." There are still two or three houses in the Adelphi which preserve this old form of decoration-long vertical mouldings extending from the ground to the uppermost story. The illustration is from a contemporary print.

1 The view of the front of the building opposite page 60 is from a drawing by Mr. Howard Penton. It shows no changes since the house was built.

2 The Embankment was commenced in 1862 and opened in 1870 . 
at the termination of the principal lease in 1867 , long before which time (in 1787 ) the property had come into the possession of the Drummond family. George, the third Duke of St. Albans, had no son, and was succeeded as fourth Duke by George Beauclerk, the grandson of Lord William Beauclerk, the second son of the first Duke, who had married (in I 744) Charlotte, the other daughter of Sir John Werden above mentioned. Lord William Beauclerk's daughter Charlotte married John Drummond, the son and successor of the Hon. Andrew Drummond, the founder of Drummond's Bank, and to her the Adelphi estate was devised by her nephew, the fourth Duke. From her son George the estate passed to his son, his grandson, and his great-grandson, George James Drummond, the present owner of the estate and the Society's landlord.

John Drummond and his cousin Robert were among the earliest members of the Society, ${ }^{1}$ and the connection of the family with the Society has since continued.

Negotiations, the progress of which is described, though not very fully, in the old Minute-books of the Society, went on for some time, and eventually the Adams undertook to build a house such as was required for a premium of $€$ I I 70 , and a rent which was finally settled at $£ 200$ a year. The plans, after much discussion, were finally approved, the foundation-stone was laid by Lord Romney in 1772 , and the Society entered into possession in 1774 , though the lease only dates from 1775 . It was for $91 \frac{1}{2}$ years, from Midsummer 1775 , ending at Christmas I 866-a quarter before the end of the landlord's lease.

Such was the origin of the historic building in which the Society has carried on its work for I 39 years. It really consists of two houses, one of which was intended for the private residence of the secretary. There has always been a communication between the houses on the ground and first floors (as well as in the basement), and a few years ago a third one was constructed on the second floor. Otherwise the two houses are separate and distinct. The last secretary to live on the premises was Sir George Grove.

No structural alterations of any importance seem in 1 See Chapter II, p. 38 . 


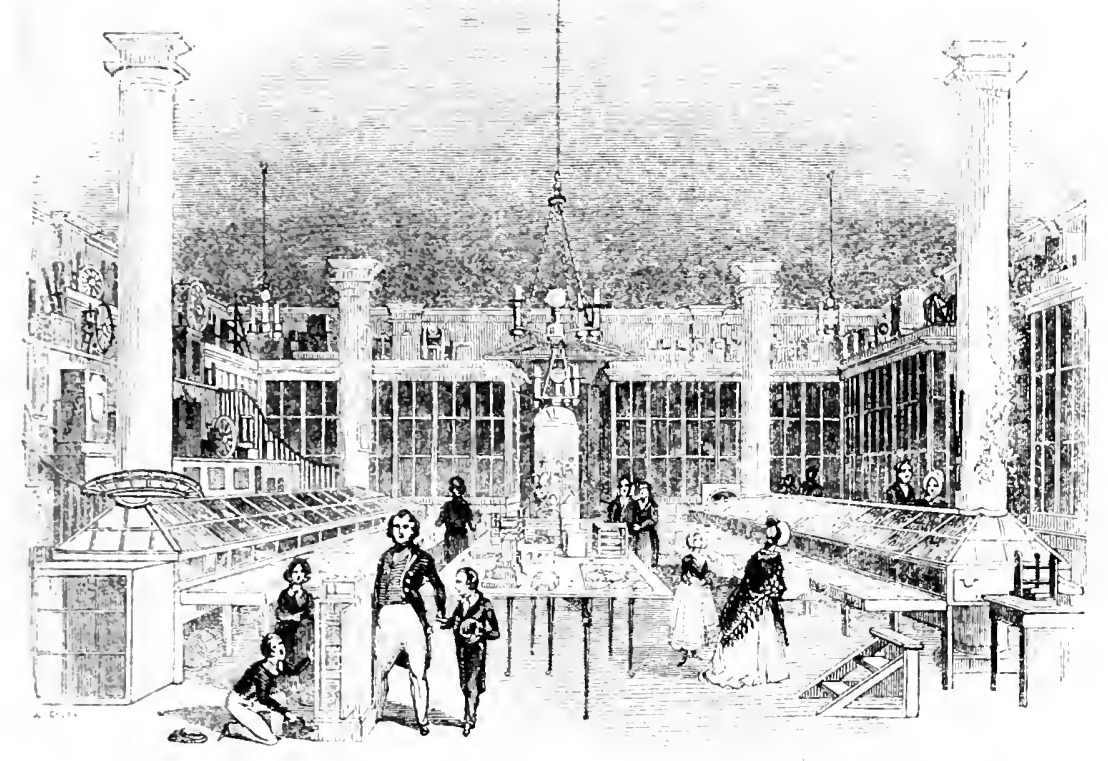

THE SOCIETY"S "REPQSITURY." A.D. 1843.

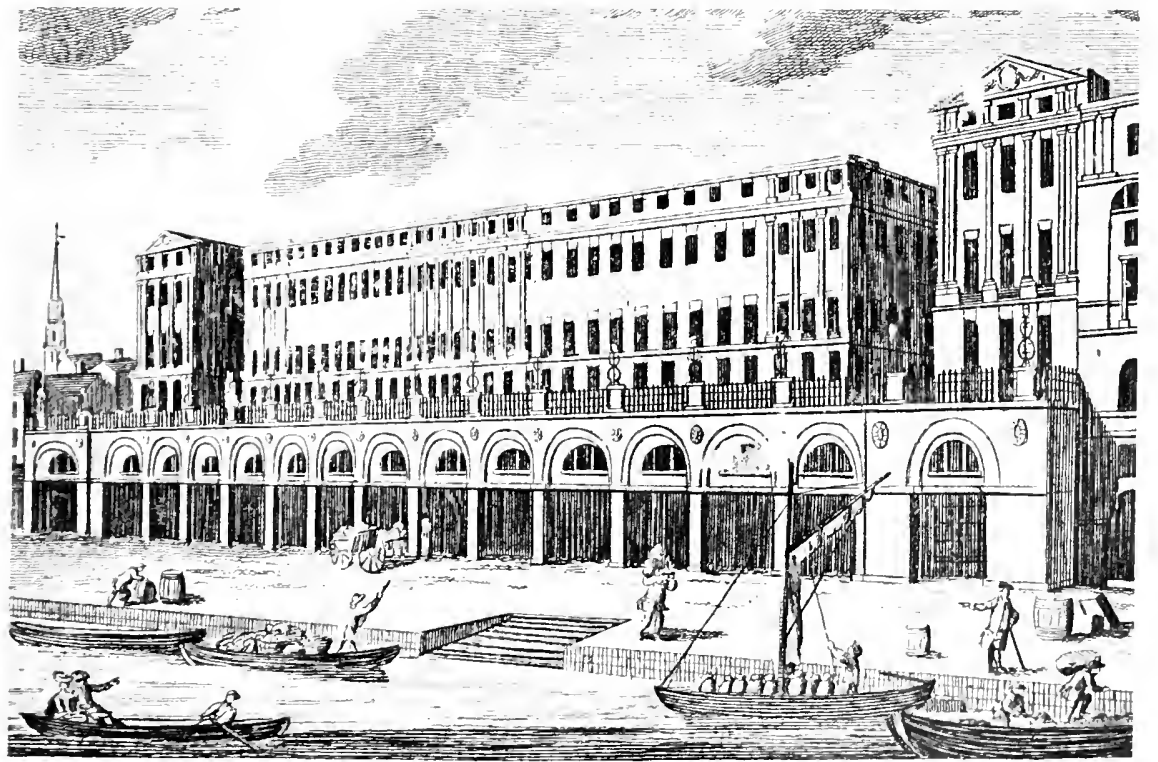

Helplii. Hiritilinen.

THE AIFIPH.

From an olel l'rint. 
ever to have been made in it. Such changes as have been made were for the most part in the meeting-room and in the "Model Room," now the Library. In I 815 the old skylight in the meeting-room was altered, the existing lantern being substituted for the original oval light. In 1846 the room was re-decorated by D. R. Hay of Edinburgh. A full account of his scheme of decoration is given by Hay in a paper he read after the work was completed. ${ }^{1}$ Originally the treatment of the room had been extremely simple, and indeed there had been little attempt at decoration. According to the short description given by Hay in his paper: "The wall terminates in a narrow and lightly enriched cornice surrounded by a plain cove of $8 \mathrm{ft} .4 \mathrm{in}$. wide; this cove is terminated by a narrow border of stucco work, between which and the aperture for the cupola light there is a flat space, also quite plain. The aperture towards the cupola light is thrown into eight panels by a plain narrow moulding, and this completes the architectural decoration." The lower part of the ceiling with the cornice is shown in the picture facing page 70 , and the whole upper part of the room is to be seen in a coloured print in the Microcosm of London. ${ }^{2}$

In place of this Hay introduced a somewhat elaborate scheme of colour. The walls above and below the pictures were covered with purple cloth, in order to set off the effect of the pictures. The cornice was coloured "Etruscan brown or deep terra cotta hue," and the cove and span above it enriched with coloured mosaic. For further details, the reader may be referred to Hay's paper.

When the original lease of the premises had to be renewed, a new lease for thirty years from Lady Day I 867 was obtained. In additional to the renewal fine, which together with other charges amounted to $£_{2} 36 \mathrm{I}$, the Society had to incur an expenditure of $£ 2800$ for repairs. A good deal of work was done in 1863 , and considerable changes were made in the arrangements of the Great Rocm.

The position of the platform and the chairman's seat in the meeting-room was altered. Originally they were

1 Transactions, vol. lvi. (Supplemental volume, I852), p. I3.

${ }^{2}$ Vol. iii. p. 67. 
on the north side of the room, facing the entrance. They are now on the east side. The object of the change was to give greater facility of access from the offices to the officials' seats. The old arrangement was inconvenient in this respect, but in all other respects it was certainly better.' The present decorations of the ceiling, which were designed and executed by Messrs. Crace, are of the same date. At the same time the existing glass cases in the lower room-which was originally designed for the "Repository" of the Society's collection of mechanical inventions-were substituted for the pillars which previously gave apparent support to the ceiling and to the floor of the room above. This change had nothing to recommend it, and should never have been made. The appearance of the room as it was originally designed was much better, and the present cases are at once ugly and useless. ${ }^{2}$

In 1847 the mosaic pavement in the entrance hall was presented by Messrs. Minton (then Minton \& Blashfield); it is interesting as being one of the earliest examples of the application of mechanically produced tesseræ under Prosser's patent, afterwards the foundation of an extensive industry. The glass mosaic on the staircase was laid down in $187+$ by Messrs. Powell. This, again, was one of the first uses of a novel and ingenious method of manufacture, though it had previously been utilised in one of the staircases of the South Kensington Museum.

When the house was first built, the meeting-room was warmed by two large fireplaces, one at each end of the

${ }^{1}$ The illustration opposite page 70 shows the arrangement of the room in I 804. It is copied from a print in the Crace Collection, now in the British Museum.

2 The picture of the "Model Room" or "Repository" (facing page 64) is copied from a print in Knight's London (1843), and shows very well the difference between the room as it now is and as it was originally built. The Act for the establishment of the British Museum (26 Geo. II. cap. 22, 1753) is entituled "An Act for the Purchase of the Museum or Collection of Sir Hans Sloane, and of the Harleian Collection of IIanuscripts, and for providing one general Repository for the better reception and more convenient use of the said Collections," etc. So it would appear that what is now called a Museum was then termed a Repository, while the rord II useum was applied to its contents, 





room. Later a furnace was fitted in the basement, and the heated air from it passed up through gratings into the present library, and thence by other gratings into the Great Room. This arrangement was naturally very inefficient. The existing system of heating by hot-water pipes was introduced in 1877 .

At first the Great Room seems to have been lighted by candles, though I have never been quite able to satisfy myself whether the six chandeliers or "branches " brought from the old house, and placed in the corners and the middle of the room, were for candles or oil. At all events oil lamps were not long afterwards employed, and their use was continued up to the middle of the last century. There were five chandeliers, one in the centre of the room, and one at each corner of the skylight. These were suspended by chains, and were pulled up and down for cleaning and lighting. They seem to have given a great deal of trouble and to have caused a great deal of complaint. The Society had in 1796 a contract with a lamplighter, one George, who was paid $4 \frac{1}{2} \mathrm{~d}$. per lamp per night, and on one occasion when fault was found with the badness of the light, George attributed it to "the villainy of his servant, who defrauded him of the oil." Seven years later the contract price was raised to $6 \mathrm{~d}$. on the ground of the increased cost of oil, and nine years later still, in 18 I 2 , it was raised to $7 \mathrm{~d}$. The annual charge for lighting in the last few years of the eighteenth century, and the first few of the nineteenth, was about $\$ 33$. In 18 ig the lamplighter having again failed in his duties, Miss Cockings, the energetic housekeeper, volunteered to undertake them, and from that time forward the lighting appears to have been both better and cheaper.

The first use of gas by the Society seems to have been about I 8 I 5, when a proposal to have a gas-light over the entrance was approved and apparently carried out. The imperfectly purified gas of that date was not considered fit for indoor lighting, and it was not for some time later that gas was introduced inside the house. In 1835 a proposal to light the meeting-room with gas was considered, but rejected as "inexpedient." In I 847 the stairs were 
lighted by gas at a cost for installation of $£ 7,5 \mathrm{~s}$. In the following year it was introduced into the model-room, and a single central light was fitted in the Great Room. In I 849 it was brought into the Hall and the committee-room. In 1853 the four hanging chandeliers in the meeting-room were ordered to be altered to gas, and in 1854 a central sunlight was fitted in the room.

In I 882 electric light was first installed, the installation being one of the first in London. The current was obtained from a Siemens dynamo driven by a gas-engine, both being placed in one of the cellars. Later a storage battery (E.P.S.) was added. The cost of the installation was met by a subscription from past and present members of the Council. In 1899 this private installation was given up, and the current was taken from the then newly-established street mains.

In 1774 , when the Society was about to move into its new house in the Adelphi, the question of the decoration of the Great Room naturally gave rise to a good deal of discussion. It was determined that it would be desirable to procure " proper historical or allegorical pictures," to be painted by the most eminent artists. Further, it was decided that there ought to be eight historical and two allegorical pictures; that the subjects of the historical pictures should be taken from English history, and that the allegorical pictures should be "emblematick designs relative to the Institution and views of the Society." A proposal was accordingly made to eight artists, that they should paint each a historical picture, and to two others that they should paint allegorical pictures, the conditions being that they should not be paid, but should receive the profits arising from an exhibition of the pictures, to be held for four months. The historical painters were Angelica Kauffmann, Sir Joshua Reynolds, West, Cipriani, Dance, Mortimer, Barry, and Wright; the allegorical painters, Romney and Penny. Valentine Green, the engraver, was requested to communicate with the selected artists, and to report their answer. Unfortunately, the answermainly, it appears, owing to Sir Joshua Reynolds-was a 


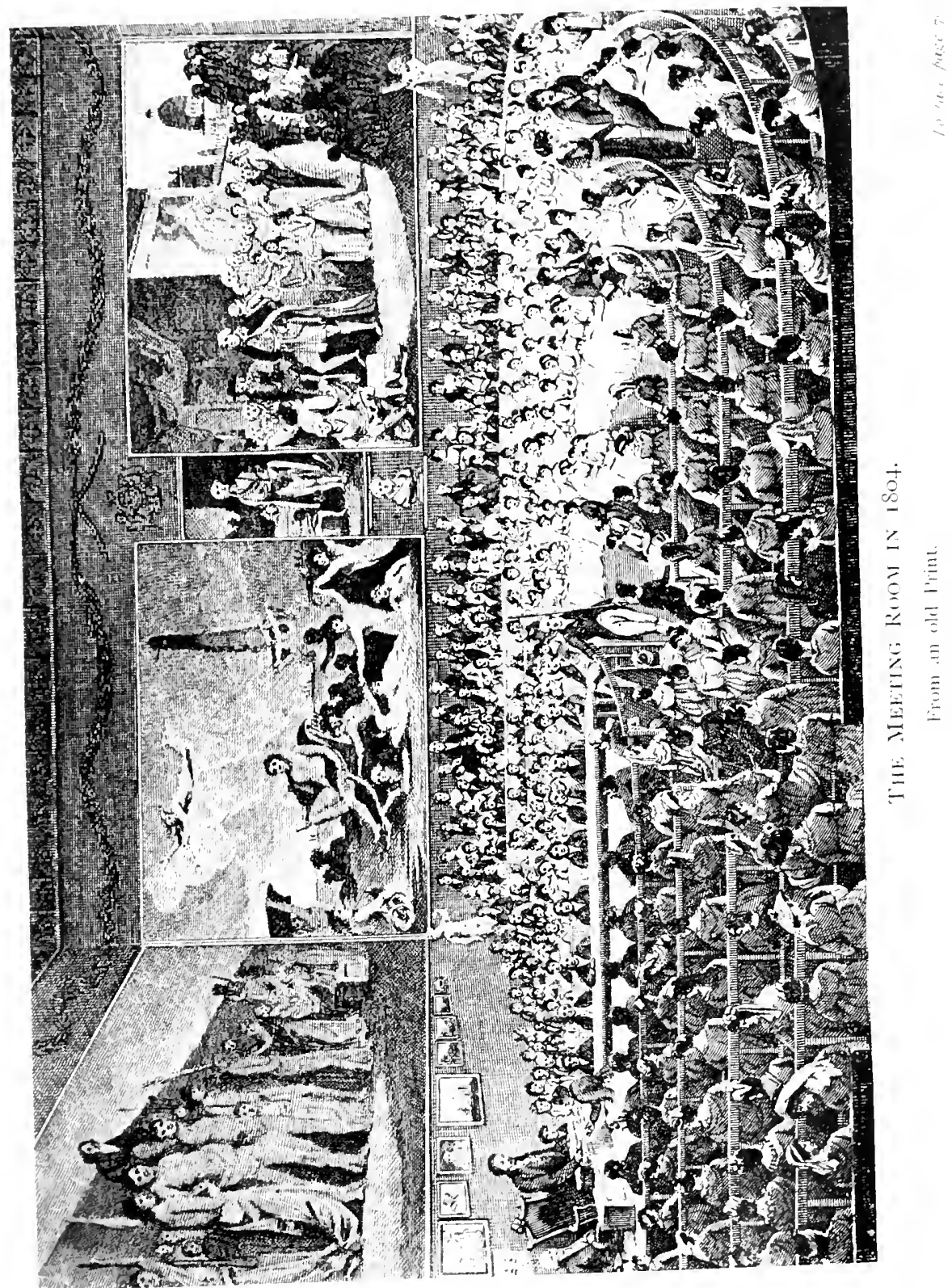



refusal. The portraits of the first two presidents of the Society, Lord Folkestone and Lord Romney-the first by Gainsborough and the second by Sir Joshua-were placed over the two chimney-pieces, and there the matter rested for a while.

Three years afterwards, viz. in 1777 , Barry authorised the same Mr. Green-a member of the Society who took a very active interest in its welfare, and who afterwards received a gold medal on that account-to inform the members that one of the Royal Academicians they had applied to was willing to take the whole work upon himself, and to decorate the Great Room " with a series of pictures analogous to the views of the Institution." It was estimated that the canvas, frames, and colours would cost $£ \mathrm{roO}$, and there was a further expense of $£ 30$ for models, which the artist offered to discharge, but which was eventually paid by the Society. The proposal, made at an ordinary meeting of the Society, was referred to the committee of "Polite Arts." The committee considered and accepted it before it was known who the artist was to be, and thereupon the chairman produced a letter from Barry, stating that the offer was his. Barry was then young and little known, full of confidence in his own powers, and assured that nothing but opportunity was wanting for him to make a reputation. Nor were his objects wholly. personal. He was impressed-as well he might be-with the degraded condition of English Art, " fitted for nothing greater than portraits, and other low matters, from whence no honour could be derived either to the artist or the country," 1 and he believed that the production of " some great work of historical painting " would refute the assertions of those foreign critics who declared English painters to be incapable of any permanent work, and would also serve as an example to his countrymen. Feeling at once the necessity of the work, and the capacity within himself for executing it, he set himself to do it, without,

${ }^{1}$ An Account of a Series of Pictures in the Great Room of the Society of Arts . . By James Barry, R.A., Professor of Painting to the Royal Academy. London: Printed for the Author, by William Adlard, Printer to the Society. . . " $I_{7} S_{3}$ (Introd.). 
as it seems, considering or caring even how he was to live during the years so long a task must occupy.

On the whole, his hopes of fame were realised, for such reputation as Barry now possesses rests entirely on the great pictures he painted for the Society. The man himself was of a strange character, his life was by no means happy. An artist of considerable power, his talents were yet not equal to his own estimation of them; and his life, like that of Haydon, a few years later, was embittered by what he considered a lack of appreciation of his deserts.

He was born at Cork in $174 \mathrm{I}$. The ability he showed in various early pictures gained him the notice of Burke, who assisted him in various ways, and gave him an allowance of $£ 50$ a year to visit Rome. In 1770 he returned to London, and in $177 \mathrm{I}$ he exhibited his first picture at the Royal Academy - the "Adam and Eve " now belonging to the Society. It was in 1777 that he began his great work, the pictures in the Society's meeting-room. In I 782 , after they were completed, he was appointed Professor of Painting to the Royal Academy. His career in this office was by no means happy. He seems to have been afflicted with an irritable, cross-grained temper, and this led him into disputes with everybody with whom he came in contact. He quarrelled with the artists at Rome; with anybody who criticised his pictures; with his pupils; and with many influential friends who tried to assist him. Finally, he quarrelled with the Royal Academy itself, so that he was expelled from it in 1799. He grumbled at the Society, which seems to have treated him with sufficient liberality, for it had either given him, or assisted him to procure by exhibitions, a sum amounting altogether to $£ 700$, while the members of the Society raised $£ 1000$ for him, and purchased an annuity of $£_{\mathrm{I}} 20$; but, unfortunately, only a month before his death.

He died under very miserable conditions. After his expulsion from the Academy he seems to have supported himself mainly by the sale of his etchings from his own works. He was taken ill in an eating-house near his home in Castle Street, Oxford Street ; and, his own house being locked up, he was carried to that of a neighbour, 
where he expired on 22nd February 1806. Even in his death his morose nature was shown, for he locked himself in for forty-eight hours, refusing medical aid ; and this, when it did come, came too late. When his works were sold at Christie's in I 807 , they fetched very fair prices, the "Adam and Eve" being purchased for I oo guineas. One of them, however, the "Pandora," which brought, though unfinished, 230 guineas, when resold in 1846 , to pay the expense of warehouse room, only fetched I I $\frac{1}{2}$ guineas. His body was placed in the Society's Great Room for a day before it was carried to St. Paul's, to be laid beside that of Reynolds. ${ }^{1}$

When Barry began his task he had, it is said, only sixteen shillings in his pocket, and he supported himself while it was in progress by etching. He applied to patrons, principally members of the Society, for a loan to assist him while he was at work, but it does not appear whether his applications were successful or not. The exact date at which the work was commenced is not stated in the Society's Minutes, but the pictures were well advanced by the recess of 1778 , when the key of the Great Room was entrusted to Barry in order that he might work without interruption; and the work was continued until October 1781 . During its progress the Society's meetings were at first held in the Great Room, the pictures being covered up with canvas; but in 1781 the meetings were held in the committee-room-i.e. the present council-room-the Great Room being given up entirely to the artist. In the same year, frames, designed by Barry himself, were procured from Mr. Adrian Maskens, of Compton Street, Soho, at the expense of $f_{100}, 17 \mathrm{~s}$. These frames are those in which the pictures now are, though they have, of course, been regilt since they were first put up. Not much information as to the progress of the pictures is

${ }^{1}$ Further information about Barry's life is given in S. Redgrave's Dictionary of Avtists of the English School. A longer life, written by the late S. T. Davenport, for a Dictionary of Painters, was printed in the Society's Journal, vol. xviii. p. 803 . There is also a life in the Dictionary of National Biography. In 1880, Mr. J. Comyns Carr read a paper before the Society on "The Influence of Barry upon English Art" (Joumal, vol. xxix. p. 20). 
given in the Society's Minutes. There are occasional references to the work, and payments on account of expenses incurred are authorised from time to time.

A suggestion made by the painter, that some portraits of members of the Society should be introduced, gave rise to considerable discussion, and seems to have exercised the minds of the committee of "Polite Arts" for some time, but eventually a selection was made. As soon as the work was finished, a public exhibition of the pictures was held for the painter's benefit. They were shown for two months during 1783 , and for the same time during I784. The cost of these two exhibitions was defrayed by the Society, and amounted to $£_{174}$. About 6500 persons attended the first exhibition, and about 3500 the second, among them being Jonas Hanway - the introducer of umbrellas - who was so pleased with the pictures that he showed his gratification by the very practical step of changing the shilling he had paid for a guinea as he left. The exhibitions produced $£ 503$, I 25 . Congratulations poured in upon the artist, accompanied in some few cases at least by subscriptions or orders for paintings. But the measure of praise his pictures received was by no means equal to the artist's estimate of their deserts. In a letter, dated October i 784 , to the president and members of the Society, we find him complaining bitterly of this want of taste on the part of the public. Sixteen or eighteen thousand pounds had, he says, been squandered that year at Westminster upon a "Jubilee of hackney'd German musick," "an empty hubbub of hundreds of fiddles and drums, which was dissipated in the air as soon as performed." This, too, had been attended by "well-dressed people of the first rank and condition, great Lords and Ladies with white wands, blue ribbans, and medals." Meanwhile his pictures, which were to have revolutionised English art, were being neglected in the Adelphi.

A full account of the pictures is given in Barry's own work, above referred to. A shorter account was printed in the third volume of the Society's Transactions (1785), and this has been since republished in the Joumal, with 
alterations (vol. xvi. p. 604). Various other descriptions have been printed at different times, but they all seem to be derived, either directly or at second hand, from Barry's book. The whole series of pictures was intended "to illustrate this great maxim or moral truth, viz. that the obtaining happiness, as well individual as public, depends on cultivating the human faculties. To prove the truth of this doctrine, the first picture exhibits mankind in a savage state, full of imperfection, inconvenience, and misery. The second represents a Harvest Home, or Thanksgiving to Ceres and Bacchus. The third, The Victors at Olympia. The fourth, Navigation, or the Triumph of the Thames. The fifth, the Distribution of Rewards by the Society. And the sixth, Elysium, or the State of Final Retribution. Three of these subjects are truly poetical, the others historical." 1

The height of all the pictures is the same, I I ft. Io ins. The first, second, fourth and fifth, being those at the ends of the room, are each I $5 \mathrm{ft} .2$ ins. long; the third and sixth, which occupy the north and south sides of the room, are each $42 \mathrm{ft}$. long. They take up all the upper portion of the wall, leaving a space beneath them of ro $\mathrm{ft}$. 6 ins. down to the ground.

The description of the pictures is too long for repetition, though its quaintly serious style makes it worth consultation. It may, however, be desirable to try to give a very brief explanation of the meaning of the pictures, for the use of those who care to follow out the story they are meant to tell. The first picture, the "Orpheus," is on the left-hand side of a person entering the room, and occupies the southern half of the west wall. It is intended to represent a savage people, living in a wild and desert country, while Orpheus is explaining to them the advantages of culture.

In the second picture, "A Grecian Harvest Home," we have the second, or agricultural, stage of civilisation.

The third picture, "The Victors at Olympia," which faces the visitor as he enters, is typical of the most advanced

1 Transactions, vol. iii. p. I 10. 
culture. At the right ${ }^{1}$ of the picture the conquerors in the games are receiving the prizes at the hands of the judges. Two of the athletes are carrying their father, Diagoras, a former victor. Near this group is another, the chief person in which is Pericles, who has borrowed the face of the Earl of Chatham. The personage in the chariot is Hiero of Syracuse; the leader of the chorus is supposed to be Pindar; the statue at the right end of the picture is Minerva; that at the other end is Hercules. The figure seated at the base of the statue of Hercules represents Barry himself.

The fourth picture, "The Thames," is emblematical of the triumphs of modern commerce. The central figure represents Father Thames sitting in a triumphal car, steering with one hand, and holding in the other the mariner's compass. The car is borne along by Sir Francis Drake, Sir Walter Raleigh, Sebastian Cabot, and "the late Captain Cook, of amiable memory." In the front of the car are four figures, representing Europe, Asia, Africa, and America. Mercury, "the emblem of commerce," is represented at the top of the picture as summoning the nations, and the Nereids following the car carry several articles of the principal manufactures of Great Britain. "The sportive appearance of some of these Nereids gives a variety to the picture, and is intended to show that an extensive commerce is sometimes found subversive of the foundation of virtue." In order to introduce the personification of music into "this scene of triumph and joy," the artist has placed amongst the seanymphs " his friend Dr. Burney, whose abilities in that line are universally acknowledged." "This," remarks a writer in the Microcosm of London (I 809), was "a whim equally absurd and incomprehensible which no raillery or good counsel could induce him to dismiss from his canvas."

The fifth picture, "The Society," 2 represents a dis-

${ }^{1}$ In every case right and left mean right and left of the spectator.

2 The illustration is taken from Barry's etching, not from the painting, and the two vary considerably. The description in the text corresponds with the painting. 


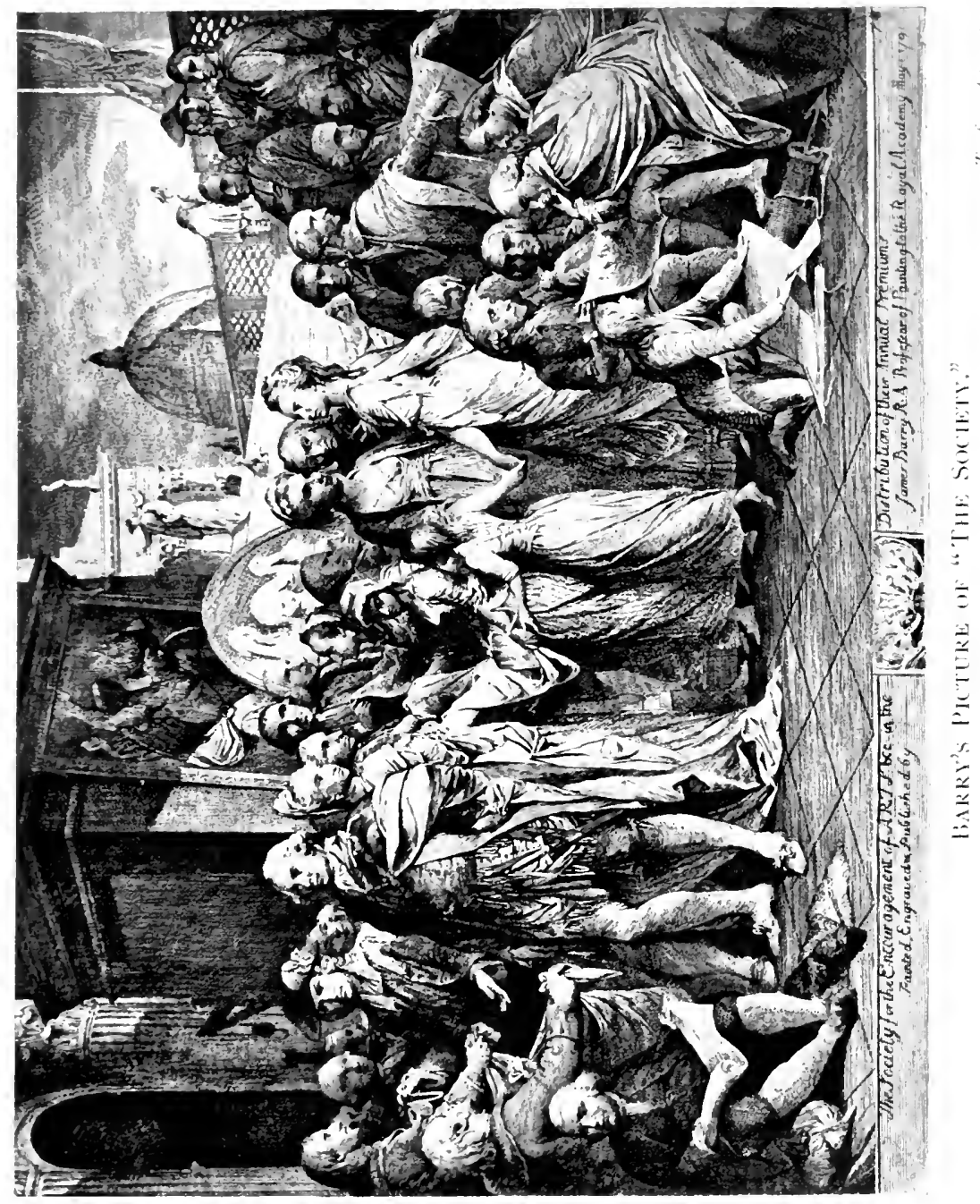



tribution of the rewards in the Society. The figure near the left in nobleman's robes is Lord Romney, who was president when the picture was painted; near him is the Prince of Wales (George IV.) ; sitting at the corner of the picture, with a manuscript in his hand, is William Shipley, the originator of the Society ; one of the farmers carrying specimens of grain is Arthur Young; the figure near him, holding a pen, is Mr. More, the then secretary. On the right of Lord Romney is the Hon. Charles Marsham, one of the Society's vice-presidents ; on the left is another vice-president, Mr. Owen Salusbury Brereton. About the centre of the picture is "that distinguished example of female excellence, Mrs. Montague, who long honoured the Society with her name and subscription." Near her are the Duchess of Northumberland, Earl Percy, Joshua Steele, Sir George Savile, Dr. Hurd, Bishop of Worcester, Soame Jenyns, James Harris, and the two Duchesses of Rutland and Devonshire. Between these ladies " the late Dr. Samuel Johnson seems pointing out this example of Mrs. Montague to their graces' attention and imitation." Further to the left is the Duke of Richmond, and near him Edmund Burke ; still nearer the right side of the picture are Edward Hooper and Keane Fitzgerald. The Duke of Northumberland, the Earl of Radnor (the second Earl), William Locke, and Dr. Hunter are examining some drawings by a youth. Near the right side of the picture are Lord Folkestone, first president of the Society, his son, the first Earl of Radnor, and Dr. Stephen Hales. The introduction of Somerset House and St. Paul's Cathedral is intended to show that the Society is in London ; the picture (Barry's "Fall of Satan ") and the medallion represent the arts of Painting and Sculpture.

The sixth picture represents " Elysium, or the State of Final Retribution." In it are "brought together those great and good men of all ages and nations, who have acted as the cultivators of mankind."

According to the account in the Transactions, the first group on the left consists of Roger Bacon, Archimedes, Descartes, and Thales; behind them stand Sir Francis Bacon, Copernicus, Galileo, and Sir Isaac Newton; near 
these is Columbus with a chart of his voyage; and close to him, Epaminondas with his shield, Socrates, Cato the younger, the elder Brutus, and Sir Thomas More. Behind Brutus is William Molyneux, holding " his book of the Case of Ireland " ; near Columbus are Lord Shaftesbury, John Locke, Zeno, Aristotle, and Plato ; and in the opening between this group and the next are Dr. William Harvey, the discoverer of the circulation of the blood, and Robert Boyle. King Alfred is leaning on the shoulder of IVilliam Penn, who is showing his code of laws to Lycurgus; standing round them are Minos, Trajan, Antoninus, Peter the Great of Russia, Edward the Black Prince, Henry the Fourth of France, and Andrea Doria of Genoa. Then come patrons of genius, Lorenzo de Medici, Louis the Fourteenth, Alexander the Great, Charles the First, Colbert, Leo the Tenth, Francis the First, the Earl of Arundel, and " the illustrious Monk Cassiodorus " ; behind the archangel are Pascal and Bishop Butler, behind whom again is Bossuet, his hand resting on the shoulder of Origen. Behind Francis the First and Lord Arundel are Hugo Grotius, Father Paul, and Pope Adrian.

"Near the centre, towards the top of the picture, sits Homer, on his right hand Milton, next him Shakespeare, Spenser, Chaucer, and Sappho; behind her sits Alcæus, who is talking with Ossian; near him are Menander, Molière, Congreve, Brahma, Confucius, Mango Capac, etc. Next Homer, on the other side, is the Arch Bishop of Cambray, with Virgil leaning on his shoulder; and near them Tasso, Ariosto, and Dante. Behind Dante, Petrarch, Laura, Giovanni, and Boccaccio. In the second range of figures, over Edward the Black Prince and Peter the Great, are Swift, Erasmus, and Cervantes; near them Pope, Dryden, Addison, and Richardson. Behind Dryden and Pope are Sterne, Gray, Goldsmith, Thompson, and Fielding; and near Richardson, Inigo Jones, Sir Christopher Wren, and Vandyck. Next Vandyck is Rubens, with his hand on the shoulder of Le Sueur; behind him is Le Brun ; next are Giulio Romano, Domenichino, and Annibale Carracci, who are in conversation with Phidias, 
behind whom is Giles Hussey. Nicolas Poussin and the Sicyonian maid are near them, with Callimachus and Pamphilus; near Apelles is Correggio; behind Raphael stand Michael Angelo and Leonardo da Vinci ; and behind them Ghiberti, Donatello, Masaccio, Brunelleschi, Albert Durer, Giotto, Cimabue, and Hogarth. In the other corner of the picture the artist has represented Tartarus, where, among cataracts of fire and clouds of smoke, two large hands are seen ; one of them holding a fire-fork, the other pulling down a number of figures bound together by serpents, representing War, Gluttony, Extravagance, Detraction, Parsimony, and Ambition ; and floating down the fiery gulph are Tyranny, Hypocrisy, and Cruelty, with their proper attributes." 1

It is stated in the Transactions, vol. xxiii. p. i 8 , that on the death of Lord Nelson in I 805 " the Society proposed to commemorate that hero by introducing his portrait in one of the pictures which decorate the Great Room," and Barry undertook to execute the work, but his death prevented the design from being carried into execution.

The six pictures did not occupy the whole wall of the room, the spaces over the chimney-pieces at either end being filled by the portraits of Lords Folkestone and Romney, before referred to. It does not appear that Barry's original design included pictures for these spaces, but we find him, in I 801 , expressing a wish that these two portraits should be placed in some other room of the Society, and that he should be allowed to execute pictures which might fill the vacant places. This he was willing to do without charge, and without interruption to the business of the Society. The cost of them would not, he said, exceed $£ 10$ for canvas and stretchers. It may be supposed, and indeed it appears from the style of the letter, that he was at that time perfectly well satisfied with the treatment he had received from the Society, for

${ }^{1}$ Transactions, vol. iii. p. I28. I have ventured to rectify the spelling of some of the names. Brahma appears in the Transactions as Bruma, which I take to be a misprint for Brama, the name given in one edition of Barry's book. 
he expresses himself as being "both gratified and flattered with the publick reputation of the pictures." Permission was given to Barry to carry out his scheme, and it may be presumed that it was upon the receipt of such permission that he prepared the two designs which are still preserved amongst his etchings, representing George in. and Queen Charlotte. But, although the proposal was at first readily accepted, it seems to have given rise to some difference of opinion, for the then president, the Duke of Norfolk, notified his intention of moving to rescind the resolution of the Society for the removal of the portraits. Under these circumstances Barry at once withdrew his offer, at the same time disclaiming any intention to show disrespect to the memory of the first two presidents of the Society. He urges very fairly that another position might be found for the pictures, which would be in no way injured, and that his design could then be harmoniously completed. Coming from a man of his temper, it must be allowed that his second letter is most dignified, and in excellent taste. The portraits consequently remained in their places until I864, when they were removed to make way for the portraits of the Prince Consort and Queen Victoria, by J. C. Horsley, R.A., and C. W. Cope, R.A. These, with the bust of Prince Albert now standing in the ante-room, form the memorial which was provided in I 863 by subscriptions from members of the Society in memory of their President. ${ }^{1}$

It is needless to say that Barry'scelebrated pictures have always been an object of great care to the Society. Looking through the Minutes since the commencement of the last century, we find constant references to the attention bestowed upon them. In one place, instructions are given to the housekeeper that they should be carefully wiped down every year ; in another we find West, and later on Mulready, reporting on their condition. The frames were regilt several times, and so on. The pictures have been cleaned at various times; about 1834 it is said that a thick coat of olive oil, which had been applied to them under some mistaken notion of preserving them, was 1 Chapter XVI, p. 400, and Appendix III. 
removed. In 1846 , when the room was redecorated by Hay, of Edinburgh, the way in which the pictures had been treated called forth a good deal of adverse criticism, and it was then that Mulready was called in to report upon them. His report was that they were in excellent condition, and that nothing appeared to have been done to them which had inflicted the slightest injury. This opinion was confirmed by the opinion of Seguier, the picture restorer. "The Orpheus " had, either then or at some previous time, been badly varnished, and stains from this treatment are still perceptible. In 1861 (Sir) John Robinson ' was asked to report upon them, and this he did at some length." In accordance with his advice they were relined and stretched upon new frames by Merritt, a well-known picture cleaner, at a cost of $£ 220$. This work was completed in 1863 . In 1880 they had got to be extremely dirty, and they again underwent a thorough cleaning. Since that date they have been cleaned every year.

Besides the pictures in the Great Room, the Socicty possesses the plates of a number of etchings by Barry, most of which were presented to the Society in $185 \mathrm{I}$ by Miss Barnett. Some of these may have been done while he was at work upon the pictures, but most of them probably during his later years. Six of them represent the six pictures. They were etched after the completion of the pictures, and were copied from the originals by the artist himself, yet, curiously enough, they differ in many of the details from the paintings. It is true that some slight alterations were made by Barry in the pictures after they were first painted, but this does not seem sufficient to account for all the variations. The other etchings are nearly all from pictures of the artist, most of which are no longer extant. The Society also possesses Barry's "Adam and Eve," one of his more important works, which, as above mentioned, was sold after Barry's death at Christie's. It was presented to them by $\mathrm{Mr}$.

${ }^{1}$ Sir J. C. Robinson was superintendent of the Art Collections of South Kensington Museum, and surveyor of Pictures to Queen Victoria. He died in April of the present year (1913).

${ }^{2}$ Council Minutes, 27 tli November i 861 . 
R. H. Solly. This picture has been for some years on loan at the Victoria and Albert Museum. There is also a portrait of Barry, painted by himself, which is hung up in the ante-room, and an oil painting which is said, it is not known on what authority, to be a portrait by him of his mother. The former was presented to the Society by Mr. W. Moffat. There seems to be no record in the Society's Minutes of the way in which the latter picture came into the Society's possession, and there is some doubt as to its authenticity.

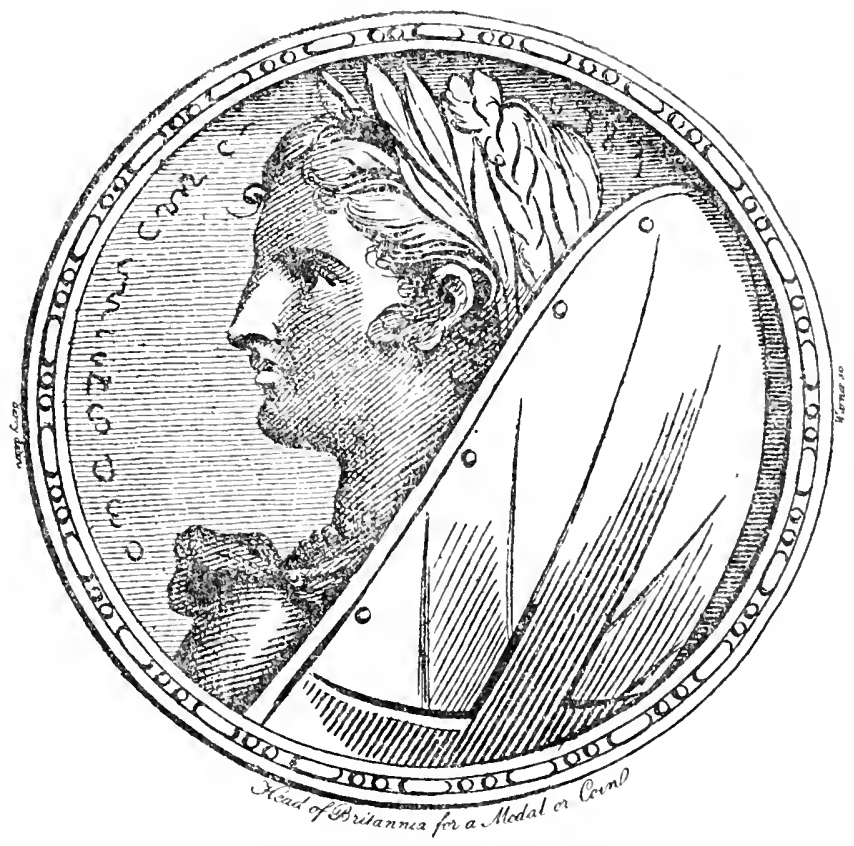

Design by Barry for a Medal. 


\section{H A P T E R IV}

\section{The Society and the Colonies}

\section{(1 754-1 847)}

The Colonics in I754-The North Anerican Colonies-Silk in Georgia-Benjamin Franklin-Wine--Potash-Saltpetre-IronHemp-Sturgeon - Isinglass-Myrtle Wax-Pipc-Staves-Sawmills-The West INDIES-Introduction of Economic Plants from the East-Cochineal-Brcad-Fruit-Mango-Cinnamon-Indigo -Cotton-Logwood-Botanic Gardens in St. Vincent and Jamaica - Results of Society's Work in the West Indies-INDIA and the EAST-The East India Company-Tin, Cotton, Cinnamon, etc.Roxburgh and the Calcutta Botanic Gardens-Caoutchouc-Ramic -Gutta Percha-Tea-Dr. Wallich and his Collection of Woods - Similar Collection by Captain Baker-CEylow-Machine for Decorticating Rice-CANADA-Hemp-Mackenzie and his Explorations-Survey of Canada-Australia - Wool-Wine Tanning Materials--Other Australian Products-New ZEALANDPhominm tenax-Minorca-Silk-Mauritius-Silk-CaPe-Wine.

IT is proposed in this chapter to deal with the efforts which, during the first century of its existence-from its foundation in 1754 to the grant of its Royal Charter in 1847 -the Society made to encourage and develop the resources of the British colonies.

During that long period our colonial empire underwent many and great changes, both of restriction and of expansion. At its commencement "His Majesty's Colonies and Plantations abroad" meant, with some insignificant exceptions, only the North American colonies ${ }^{1}$ and the West Indies. Before its close the American colonies had

1 The original from which the map facing page $S_{4}$ is reproduced is contained in Jefferys' American Atlas, London, I776. It is in the possession of the Royal Geographical Society. In the original the Mississippi is marked as indicating the western limit of the British possessions. 
developed into the United States, Canada had become British, Australia had been partly explored and settled, the Cape and Ceylon had been taken from the Dutch, and many other additions, in many parts of the world, had been made to the British possessions. India alsofor the earlier associations of the Society with India must be included in our review-had during this period definitely become a part of the Empire, which it assuredly was not in 1754 .

It was in America, and before the Declaration of Independence, that during the first twenty years of its existence the most important part of the Society's colonial work was done. The only reference to the West African settlements that has been noticed in the Society's Minutes or Transactions about this time relates to the offer of a gold medal for the importation of cotton from Africa, and though the Society was ready to extend its efforts to the East Indies, and occasionally did so, its proposals do not appear to have been welcomed by the East India Company, which had distinctly monopolistic views as regarded its possessions. For example, in 1758 it was proposed that a prize should be offered for the production of cinnamon in " our own Territories in the Island of Sumatra," but the court of directors of the Company were " under apprehensions that if so valuable an article should be produced in the island, the Dutch will use their best endeavours to get possession of it." So the proposal was dropped, as was also a similar one for the encouragement of the production of cochineal.

At one of the first meetings of the Society after it had moved into its rooms in Craig's Court, in April I 755, Lord Romney informed the members that 300 lbs. weight of raw silk had lately been brought to England from Georgia, and that the silk was of very excellent quality, equal to the best Piedmont. He therefore suggested that the Society, by way of encouraging the production of silk in the colony, should offer a prize for planting mulberry trees, and it was thereupon resolved that a premium "of fio sterling money" should be offered to the person "who shall plant, and properly fence, the greatest number 


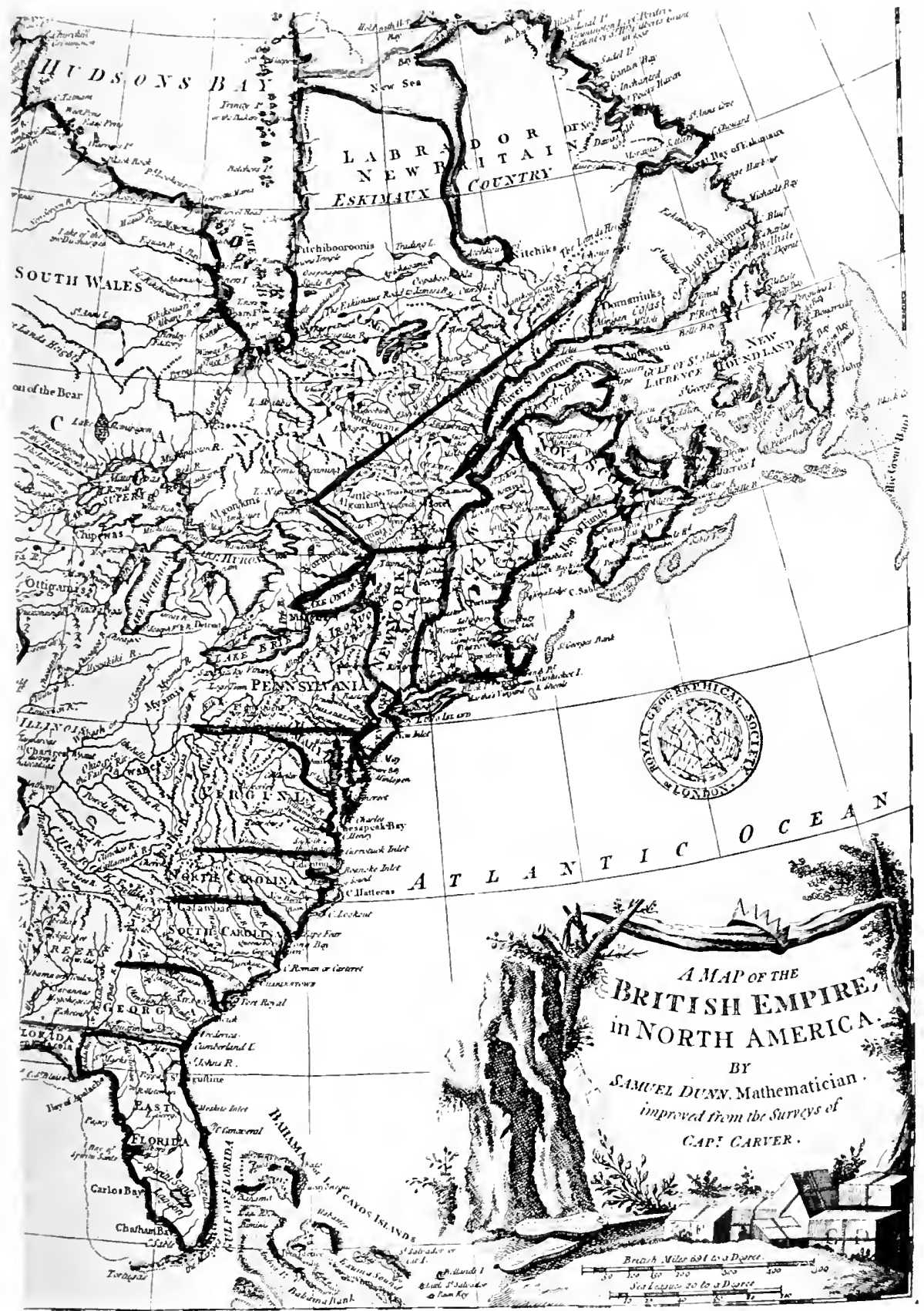

MAP OF THE NORTH AUERICAN COLONIE 

of white mulberry trees on his own plantation in the province of Georgia before the first day of March I 756 ." Prizes of $£ 5$ and $£ 3$ were added for the second and third largest number. An announcement of this prize appears in the earliest list of premiums, dated April 1756 , the date being extended to March 1757 .

In 1758 the nature of the offer was modified, and a payment of threepence a pound was offered for cocoons raised in Georgia, and two shillings and sixpence a pound for merchantable raw silk produced in Connecticut, Pennsylvania or North Carolina, with another shilling per pound for silk imported into England. Franklin was interested in the development of the silk industry, and acted as one of the Society's referees for distributing the awards. Certain of the colonial governors also helped by their influence and interest. The British Government gave encouragement and a bounty, and a public filature was established in Georgia. The offer of premiums was continued up to I 763 , by which time a sum of over $£$ i I had been expended. Although at one time the promoters of the scheme seem to have been sanguine about success, the industry was never established. The absence of cheap and abundant labour may have been one reason for this, but the outbreak of the War of Independence put an end to this attempt to nurse into existence what was really not a very suitable industry. ${ }^{1}$

Much the same fate attended the efforts made to start wine-making in some of the colonies, though it, too, promised well for a time, and vineyards stocked from European sources were actually established in Virginia and elsewhere. The first offer of a prize for wine appears in the 1758 list, in which the amount of $£ 100$ is promised for five tuns of good wine made at a plantation in any colony, provided that one tun was imported to London. In 1763, Mr. Charles Carter sent a dozen bottles of two

${ }^{1} \mathrm{James}$ I. had long before endeavoured to introduce the silkworm into his American Colonies, and had urged the colonists to devote their attention to the mulberry tree instead of to "that pernicious and offensive weed," tobacco. Much information about his Majesty's proposals will be found in Porter's Treatise on the Silk Manufacture (1831), p. 32. 
kinds of wine from grapes which grew in vineyards of his own planting in Virginia. One of these samples was the product of vines brought from Europe, and the other of American wild vines. The gold medal was awarded to Mr. Carter " as the first who had made a spirited attempt towards the accomplishment of their views respecting wine in America." 1 Amongst other awards for wine produced in the North American colonies, £200 was given to Mr. Edward Antill in 1768, for vines planted for making wine near Brunswick, North America; the Earl of Stirling 2 received a gold medal in 1769 , for planting 2100 sets for wine; and Mr. Christopher Sherb got $£ 50$ in $\mathrm{I} 77 \mathrm{I}$, for planting and cultivating vines in South Carolina, and producing wine from them.

Much greater success attended the Society's efforts to encourage the production of potash and pearlash (a rather less impure form of potassium carbonate than the crude form of the salt then sold as potash). By the prizes offered, and still more by the information supplied as to the best means of manufacture, an important industry was set up, and one very suitable for a country abounding in forests. This prize was offered in 1758 , the amount being $£_{\mathrm{I}} \mathrm{OO}$ for fifty tons of potash.

There was a large and growing industrial demand for alkali, especially for use in glass-making, soap-making, and dyeing. Until the great discovery by which carbonate of soda was manufactured from common salt, the foundation of modern chemical industry (it is interesting to note that the Society's premium list for 1783 includes an offer of a gold medal for the production of "Fixt Alkaline Salts" from common salt), this demand could only be supplied by alkali procured from the ashes of plants, and to a smaller extent by imported natural saltpetre. When such ashes are treated with water the salts of potash are dissolved, and on the evaporation of the solution they are recovered. Certain plants give much larger proportions

1 Dossie, Memoirs of Agriculture, vol. i. p. 242.

${ }^{2}$ This was William Alexander, "Commander-in-Chief of the American forces," who claimed and bore the title after the death of the 5 th Earl in 1739. He was a member of the Society, and died in 1795 . 
of alkaline salts than others. Plants of the genus Salicornia, or glasswort (the Eastern name of which, "kali," was the origin of the term " alkali "), give the best material, and it was known as barilla. In England large amounts of alkali were obtained by burning kelp, and this was an important industry on the Scotch and Irish coasts. All plants, however, contain more or less potash, and therefore the raw material for the manufacture was abundant in America. There were some difficulties at first in the production and purification of the salts, but these were eventually overcome by the full and detailed instructions sent out by the Society at the request of the colonial authorities.

It is interesting to note that in 1766 , Robert Dossie, the able and accomplished editor of what was practically the first series of the Society's Transactions, was presented with a gold medal for " effectually aiding to establish the manufacture of potash in North America."

The result of the attempt to encourage the production of saltpetre in America was less satisfactory. It seems that the prize was really offered (in I 764) in the hope that it might lead to the discovery of natural sources of supply of nitrate of potash or soda, though Dossie tells us that the Society was also encouraged by reports of some new method of manufacturing the salt having been discovered in America. The old system of obtaining nitre from " nitre-heaps," mixtures of animal excreta with woodashes and lime, was obviously not well suited for a sparsely populated country like America, and it was not to be expected that there would be any artificial nitre produced in excess of the requirements for home consumption.

But the hope of discovering natural sources of supply of natron, ${ }^{1}$ the neutral carbonate of soda $\left(\mathrm{Na}_{2} \mathrm{O} \cdot \mathrm{CO}_{2} \cdot 1 \mathrm{O}\right.$ Aq.),

1 The word natron, never common, is now practically obsolete, though Murray's Dictionary gives an authority as late as 1876 . It is, perhaps, derived from the Arabic natrûn, the Greek equivalent being

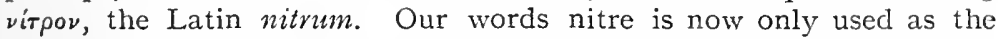
equivalent of saltpetre (potassium carbonate), but it was originally employed as identical with natron. Skeat suggests that the sense of the word has been changed, but it is probable that it is merely a case of a word, originally used in a general sense, having its application reduced, as chemical technology became more accurate, to a specific substance. 
was perfectly reasonable. The salt existed in various forms, sometimes as an efflorescence on ground or rocks, sometimes in mineral springs or lakes, and sometimes as solid deposits in " pits," in many countries. The " soda lakes" in the Libyan desert and in Upper Egypt were known from remote antiquity. Herodotus (ii. 86) describes the use of the nitron obtained from them in embalming. The natron pits of Khaipur in Sind have long been a source of revenue to their owners, and there were numerous other places in the Old World whence the material was brought to England before the secret of making " artificial saltpetre " was purchased from the German Honrick by Queen Elizabeth. There was, therefore, every reason to believe that similar deposits might be found in the New World. Indeed, in our own days, the anticipations of the Society have been justified by the discovery of the vast nitrate fields of Chile, from which nearly all the world's supplies of nitrate of soda are now derived.

However, the hopes were not realised at the time, and as no response was made to the offer, it was withdrawn after a few years, though at a later date it was renewed, and in 7 7 86 a silver medal was actually awarded to $\mathrm{H}$. Scott, a surgeon in the East India Company's service in Bombay, for a sample of "native Indian fossil alkali." This was "a brown earth brought from Sindy." It was stated that large amounts of the earth were available, and on analysis it proved very rich in alkali. Very probably this was the first introduction to England of soda carbonate from the natron pits of Sind above mentioned, though it may indeed have been imported without its source of origin being known.

The only connection between the Society and the manufacture of iron in America seems to have been that a prize was offered for making iron from "black sand" (magnetic oxide of iron). The offer was a reasonable one, but the solution of the problem was far beyond the metallurgical knowledge of the time, and indeed, until lately, it has never been possible to treat this ore successfully. Still a certain amount of success was attained, for a gold medal was given in $7_{7} \sigma_{3}$ to Jared Eliott for malleable iron 
from American black sand. According to Scrivenor, ${ }^{1}$ iron was first made in America in 17 15, and the amount made steadily increased, until about i 776 some 4000 tons were exported. Ten years later the amount produced in England and Wales was only I3,000 tons, the production having fallen off in consequence of the diminished supply of wood, the only fuel by the aid of which iron could at that time be produced.

With its enormous forests, America might well have supplied the English market for iron, and from time to time provisions were grudgingly introduced into Acts of Parliament with the view of encouraging the industry, but when any encouragement was given it was either so set round with limitations as to be useless, or was soon taken away at the appeal of the English iron-makers, in spite of the demands urged by those who wanted iron but were not makers. An account of the legislation from I 79 to 1769 is given by Scrivenor, and it is as little creditable to the British Government as were most of the dealings of this country with its American colonies.

The Colonial Manufactures Prohibition Act, I750, so far encouraged the production of raw iron that it removed the duties on bar or pig iron, but it not only forbade the working up of such iron, but prohibited the establishment in America of furnaces, tilt-hammers, or slitting-mills for the purpose. England at this time was always ready to help the colonies, provided only they did not compete with her own manufacturers. Raw materials to any extent they were encouraged to provide, but manufactured articles of any sort they were not permitted to export, or even, in most cases, to produce.

A considerable amount of hemp has alvays been grown in England, but large quantities were imported from abroad, especially from the Baltic ports. It was thought that the North American colonies might become sources of supply, and a prize was therefore offered for American imported hemp. Soon, however, it was realised that, as there was a great local demand for hemp for rope-

${ }^{1}$ History of the Iron Trade (1854), p. 69. 
making, and the price was consequently higher in America than in England, it was not likely that the fibre would be sent over here, and the conditions of the offer were changed, so that it might serve to encourage the actual production of the fibre without calling for its export. The scarcity of labour, however, again proved an obstacle, and though some hemp was grown, there were difficulties in obtaining labour to treat the stalks for the production of the fibre.

As regards one important application of hemp at the time, the manufacture of sail-cloth, it soon found a rival in the native American fibre, cotton, which was extensively applied to sail-making in America, before its use was ever adopted for the purpose on this side of the Atlantic. Later on, as will be seen, when Canada became a British possession, the cultivation of hemp in that country was successfully established by the Society's efforts.

The Society expended a good deal of money in the attempt to organise a supply of pickled sturgeon from the North American colonies. It appears that there was a considerable import of this fish from Russia, and that which was brought over from the colonies was nearly as good. The attempt seems to have been moderately successful, but the demand was not very large, and no doubt the trade was a small one. The premium was first offered in 1760 , and was continued for some time, various sums of $£ 50$ and less having been paid for importations on a commercial scale of the preserved fish.

The offer, made in 1768 , of a reward for American isinglass, might seem more likely to have had good results, but it was dropped on an appeal from the owner of a patent $^{1}$ for making isinglass in England, who hoped to obtain abundant material for the manufacture from the Newfoundland cod fisheries. Dossie ${ }^{2}$ tells us that these hopes were not realised, though the Society was led to abandon its offer.

The sturgeon of the American Great Lakes and rivers (Acipenser rubicundus) is a different species from the

${ }^{1}$ An cxamination of the lists of patent grants about this date has not afforded any clue to this patent.

${ }^{2}$ Vol. i. p. 276. 
Russian sturgeon (A. stellatus), and is less abundant. Economically, however, it is equally valuable, and it is now the subject of a considerable industry. The flesh is pickled, while caviar and oil are also obtained from the fish. The offer, therefore, of the Society, though fruitless at the time, was reasonable enough, for it only anticipated by a century or so the establishment of an important industry.

Another object on which a good deal of trouble and some money was spent, was an attempt to import myrtle wax, or, as it is now commonly called, myrtleberry wax, from North America. This is a well-known vegetable wax, the produce of Myrica cerifera and other species of Myrica, which are found in North and South America, Africa, and elsewhere. The plant is not a myrtle at all, but is allied to the willow tribe. ' The British representative of the genus is Myrica gale, gale, or Scotch or Dutch myrtle, also " bayberry tallow," common in moist heathy grounds. A kind of wax can be obtained from this plant when it is boiled. Some foreign species supply wax in greater abundance, the succulent fruit being covered with a waxy secretion. The product of the American species, known as bay myrtle, or candleberry bush, had long been used, in combination with beeswax, for the manufacture of wax candles, and at the time when there was a great demand for materials for candle-making, it was thought that the importation of such a material would be valuable, if on a sufficiently large scale. Accordingly, a prize of $£ 20$ was offered in 1759 for the importation of the material in commercial quantities. Prizes were awarded in 1760 , but after that they were dropped, as it was not considered that a sufficient amount of the wax was likely to be imported; in fact, as Dossie said, the only applica-

${ }^{1}$ The myrica of Virgil (and Pliny) is not the same plant at all, but a tamarisk. When in his Eclogues (viii. 54) Virgil includes in his list of portents the production of amber by the tamarisk-

"Pinguia corticibus sudent electra myricæ,"

he was perhaps influenced by the knowledge that the tamarisk really does produce a secretion, so-called manna, the result of the action of a coccus inhabiting the tree. Hence the botanical name of one species, Tamarix mannifera. 
tion of the material was the "sophistication of plasters in the manufacture of them by some wholesale dealers in medicinal preparations."

In 1776 an application was made to the Society by certain coopers to give assistance in promoting the importation of pipe staves from America in place of those brought from Germany. ${ }^{1}$ The committee which was appointed to consider this matter, found that at least £ IOO,000 was annually paid for staves imported from Germany, and that Quebec oak made into staves would answer all the purposes of the German ; but whether any practical result came of the suggestion does not appear.

Such were the more important or interesting colonial products, the growth or importation of which the Society strove to promote. Amongst others of minor value may be mentioned olives, raisins, logwood, cochineal, scammony, opium, safflower, persimmon, aloes, and sarsaparilla.

Besides encouraging the production of new commodities in the colonies, the Society rendered valuable service on occasion by sending out machinery. As will be mentioned in a future chapter, ${ }^{2}$ the Society succeeded in establishing a saw-mill in England, and the result of this was an inquiry from America, where there would be much greater scope for the use of such machinery.

Accordingly the Society paid Stansfield, the original constructor (he cannot well be called the inventor, for the machinery had long been in use in Holland and Germany), $£ 60$ for a model of his apparatus, and sent it out to America. It appears to have been useful, for " the good effects of it have been acknowledged in the strongest terms by the governor of one of the colonies and some other principal persons." 3 As Dossie remarks that from this model the colonists were able to make great improvements in their saw-mills, it is evident that such mills were in use in America before they had been established in England.

${ }^{1}$ Pipe stave, a "stave used for making pipes or casks." - Murray, Engl. Dict.

${ }^{2}$ Chapter XI, p. 247.

${ }^{3}$ Dossie, vol. i. p. 126. 
A gold medal was awarded in 1766 to Sam Brown, of Georgia, "For his useful observations in China, and industrious application of them in Georgia." No record has yet been found of these observations, so it is not known what they were. ${ }^{1}$

The Declaration of Independence in 1774 , and the resulting separation of the United States from the Mother Country, of course put an end to the attempts of the Society to develop the resources of the North American colonies, and from that date till the end of the century the attention of the Society was practically confined to the West Indies. Here a considerable amount of useful work was done. Sometimes the offer of prizes produced immediate practical results, sometimes the suggestions originated experiments and inquiry, so that ultimately useful industries were started, and valuable imports obtained.

Among the vegetable products, for the growth of which in the West Indies prizes were specially offered, may be mentioned mango, bread-fruit, olive, opium, cinnamon, nutmeg, sarsaparilla, aloe, safflower, indigo, cotton, anatta, vanilla, clove, pepper, mace, camphor, quinine, various tinctorial plants, and ornamental woods. For several of these rewards were claimed and awarded, but in other cases the offers produced no practical result.

The main idea which directed the efforts of those who were trying to develop the West Indies was the introduction of the known and tested products of the ancient civilisation of the East into the new lands of the West. Those who in the eighteenth century were working with this object were only following the lead of the earliest colonisers of America. The Spaniards introduced the sugar-cane into San Domingo before the end of the fifteenth century, and it flourished as it had never done in the Eastern lands where it was indigenous. It is said to have been first

${ }^{1}$ According to a letter in the Museum Rusticum, vol. i. p. 442 (1764), tea was introduced into South Carolina by a Dutchman who had lived in China. It is said that this man died before there was any practical result from his work, except that the tea tree was cultivated as a garden plant. The letter is signed "Americanus." 
cultivated in Jamaica by Sir Thomas Modyford in $1660 .{ }^{1}$ Coffee was introduced by the French into either Cayenne or Martinique about 1722 , and it soon spread to the other islands.2 By I 770 or thereabouts it was a staple product of Jamaica. The insurrection of the blacks in Haiti at the close of the eighteenth century drove a number of coffee-planters and their loyal slaves from Haiti to Jamaica and Cuba, and this gave an impulse to coffee-growing in both those islands. The Oriental bamboo is believed to have been artificially planted in Hispaniola, whence it spread to Jamaica and the other islands. Cotton was indigenous in the Western Hemisphere, though the species was different from the cotton of the East known to Herodotus, Theophrastus, and Pliny, the wild tree bearing fleeces from which the Indians made cloth. The cotton grown in the islands was no doubt brought from the mainland. The orange is believed to have been introduced by the Spaniards into the West Indies, and to have been transplanted thence to Florida. Long, in his History of Jamaica (1774), speaks of it as growing wild in that island, but not being properly cultivated, as it was in South Carolina. The mango is said to have been first introduced from the East Indies into Brazil by the Portuguese, and to have been transplanted thence to the islands, but of this more hereafter.

In continuation of these importations, the English colonists and their associates at home hoped to transplant to the tropical western islands the economic flora of India and the spice islands, especially the latter, while they were also not unmindful of the resources placed at their disposal by the recent discovery of the islands of the South Seas.

1 Hortus Jamaicensis, vol. ii. p. 205, quoted in an article in the Jamaica Handbook for I 899 on "Public Gardens and Plantations," which contains a great deal of information about the introduction of numerous economic plants in to the West Indies.

${ }^{2}$ In a little History of Coffee, by W. Law, of Edinburgh, "coffee merchant to the Queen "( 1850 ), it is stated that the coffee plant was introduced by the French into Cayenne from Surinam in 1722 , and five years later into Martinique. According to another account it was sent to Martinique direct from France, a coffee tree having been presented to Louis Xrv. by the magistrates of Amsterdam. 
The first mention of the West Indies occurs in the Premium List for 1760 , which contains a special offer of floo for cochineal from Jamaica, though in the previous lists various prizes were included which were open to the West Indian in common with the other colonies.

The story of the introduction of the bread-fruit (Artocarpus incisus), with its incidents of the mutiny of the Bounty in 1789, the abandonment of Captain Bligh, and the colonisation of Pitcairn Island by the mutineers, is well known.

The first suggestion that the bread-fruit might be introduced into the West Indies is said ${ }^{1}$ to have come from Valentine Morris, the Captain-General of St. Vincent, who wrote in 1772 on the subject to Sir Joseph Banks, and it was no doubt as the result of this letter that a prize was offered in 1777 by the Society. In I 786, Sir Joseph, urged by Mr. Hinton East, of Kingston, Jamaica, ${ }^{2}$ who was then in London, brought the matter before George iII., and the result was that the expedition of which Captain Bligh was the commander, was sent to the South Seas in the Bounty to collect bread-fruit trees and to transport them to the West Indies. The fullest instructions were drawn up by Banks, the ship reached Otaheite, and a number of plants were collected. All went well until the return voyage from Otaheite, when the mutiny took place, and Bligh was sent adrift in the ship's launch. A second expedition was more successful, and in 1793 a cargo of bread-fruit trees was safely conveyed to the West Indies by Captain Bligh in H.M.S. Providence. On his return, Captain Bligh sent in a full report to the Society, ${ }^{3}$ from which it appeared that over 300 bread-fruit plants had been successfully landed in St. Vincent, and a like number in Jamaica, besides a large number of other plants from the Pacific Islands. Most of these are only described by their native names, but the

${ }^{1}$ E. Smith, Life of Sir Joseph Banks (I9I I), p. I23.

${ }^{2}$ Hinton East was Receiver-General of the Colony and member of the Assembly for Kingston. His botanical garden is referred to later on.

${ }^{3}$ Transactions, vol. xii. p. 305 . 
list includes mango, pomegranate, coco-nut, coffee, almond, and plaintain. The gold medal was, on this report, awarded to Captain Bligh.

From reports made to the Society in 1795 by General Melville (St. Vincent) and by Dr. Dancer (Jamaica) in I 796, ${ }^{1}$ it appears that the trees grew and flourished in the islands, and a little later further information was received from St. Vincent. Dr. Alexander Anderson, the superintendent of the Botanic Gardens in that island, reported fully in 1798 on the condition of the trees there, and stated that they were well established and were producing an ample supply of the fruit. ${ }^{2}$ Later reports in 1802 and 1803 were equally satisfactory, and in 1807 he writes that though it is one of the most valuable productions sent to the West Indies, it is not appreciated at its proper value. $\mathrm{He}$ adds that it was said that the negroes did not like it, but that he did not believe this. Its want of popularity he attributes to the apathy of the planters. It may be added that in 1799 a gold medal was awarded to S. Mure for a plantation of bread-fruit trees in Jamaica, and two gold medals were given in 1802 and in 1803 to the Hon. Joseph Robley, the Governor of Tobago, for his plantation of bread-fruit trees in that island.

In 1760 a gold medal was offered for the introduction of the mango into the VVest Indies, but after three years the offer was dropped. Twenty years after this, in 1784 , Walter Maynard, of Nevis, wrote to the Society that in I 770 he had brought some young mango plants from the Island of Bourbon to St. Vincent, that they had fruited there, " and are now propagated in almost all the West India islands." The statement was supported by evidence, and it was said that one of the plants had been given to Dr. Young, the superintendent of the Botanic Gardens at St. Vincent. ${ }^{3}$ It appeared, however, that this was not the

1 Transactions, rol. xii. p. xriii., and rol. xiv. p. xv.

2 Ibid., vol. xvi. pp. xii. and 327.

${ }^{3}$ In his report on the Botanic Gardens, referred to on p. 99, Young mentions the "East India mangoe" as having been introduced into St. Vincent. This was in 1773 . 
first introduction of the mango, for on inquiry being made of Mr. Joshua Steele, a member of the Society, and the President of the Barbados Society of Arts, that gentleman sent the Secretary an account of an ancient mango tree then existing in a plantation in Barbados, called "The Guinea." 1 This tree had, it was believed, been imported and planted by Edwin Lascelles in 1742 or 1743 , but it bore no fruit till 1761 . It is very likely that this was the tree mentioned by Dossie ${ }^{2}$ as having been brought from the Brazils, where the mango was said to have been introduced from the East Indies by the Portuguese missionaries. From this tree others had been propagated, and were growing in different parts of the island. It is clear, therefore, that the mango was well established in the West Indies in 1784 . It has been said that Lord Rodney introduced the fruit in 1782 , but this is not quite correct. One of Lord Rodney's captains (Captain Marshall, of the Flora frigate) certainly captured a French ship carrying some economic plants from Bourbon to Hispaniola, and these plants were sent to Jamaica. According to Bryan Edwards, ${ }^{3}$ some mangoes included in the cargo were planted in Hinton East's Botanic Garden. The mango is now one of the commonest trees in the island. It is also possible, and by no means unlikely, that the French may have introduced the mango into Martinique, with other plants they sent there, before it was established in any of the British islands.

Among the plants whose destination was thus altered, were some young cinnamon trees, and this appears to have been the first introduction of the Eastern cinnamon to Jamaica, for which the Society had offered a prize as far back as 1760 , though the Guadaloupe cinnamon is mentioned by Dr. Young. Dr. Dancer, the superintendent of the Jamaica Botanic Gardens, writing in 1789 to the Society, gives an account of the condition of the cinnamon trees then growing in the island, and describes them as flourishing, but not very numerous.4

1 Transactions, vol. iv. p. 2 I9.

2 Vol. i. p. 286.

${ }^{3}$ History of the British West Indies, 4 th ed. (1807) vol. i. p. 257.

- Transactions, vol. viii. pp. viii. and 207. See also vol. iv. p. 229. 
Indigo was at one time largely cultivated in Jamaica, but heavy import duties imposed by Parliament ${ }^{1}$ destroyed the industry, the revival of which seems to have been stimulated by the Society, not only in Jamaica, but in the other islands; for in 1778 a gold medal was awarded to John Robley for growing and manufacturing indigo in Tobago. The account given in the Transactions ${ }^{2}$ states that in one year as much as 10,00o lbs. of good indigo was raised on a plantation formerly devoted to sugar-planting. The indigo was presumably the indigenous Mexican and Guatemalan variety, I. disperma, not the East Indian sort, I. tinctoria. Four years previously, in I774, a gold medal had been awarded for the production of indigo in East Florida.

A gold medal was offered in 1768 , and the offer was continued till 1777 , for the best specimen of cotton equal to " the best Brazilian," produced in any of the American colonies, but it appears not to have attracted any claimants till I778, when it was awarded to Andrew Bennet, of Tobago, for cotton grown in that island.

A prize offered for logwood from British colonies was abandoned, because it was found that the wood produced in Jamaica was inferior to native Honduras and Campeachy logwood, and besides that the cultivation of logwood in the sugar islands was unnecessary and undesirable, since its luxuriant growth sometimes interfered with the cultivation of the sugar-cane. Perhaps this conclusion was reached on insufficient evidence. Certainly logwood was for long a valuable product of Jamaica.

A great deal of valuable work was done in the West Indies by the establishment of Botanic Gardens, and they were aided in various ways by the Society. In one of the earliest Premium Lists, that for 1760 , it is suggested that land should be allotted in the colonies for "gardens or nurseries for the making experiments in raising such rare and useful plants as are not the spontaneous growth of the kingdom or of the said colonies," and it is added

\footnotetext{
${ }^{1}$ Long, History of Jamaica (1774), vol. iii. p. 68o. $\quad{ }^{2}$ Vol. ii. p. 233.
} 
that if the colonial legislatures, or "other incorporate bodies," would help to establish such gardens, the Society would provide "proper premiums" for plants raised in them. This undertaking was liberally and fully carried out. The suggestion soon bore fruit. The first of these gardens was started in St. Vincent in 1765 by General Melville, the Governor-General of the "Southern Caribbee " or Windward Islands, a member of the Society whose attention was attracted by the notice. ${ }^{1}$

Dr. George Young, an army surgeon in the island, took charge of the gardens. He was acting as superintendent of them in 1774 , and in that year sent the Society a full report ${ }^{2}$ on the gardens, for which he received a gold medal. For a time the island was in possession of the French, but the garden was kept up. In 1784, St. Vincent was restored to Great Britain, and Dr. Alexander Anderson took charge of the garden. In 1798 he received a silver medal from the Society for an account of the plants cultivated in it, and in $\mathrm{I} 8 \mathrm{O} 2$ he was awarded a gold medal for the "culture of cloves and cinnamon." $\mathrm{He}$ was a corresponding member of the Society, and a constant contributor to the Transactions. He died in I 8 I I.$^{3}$

The first Botanic Garden in Jamaica was, according to a letter written by Dr. Hope (the Professor of Botany at Edinburgh) to Sir Joseph Banks, ${ }^{4}$ founded in 1775 . This may have been the garden of Hinton East at Liguanea ${ }^{5}$ (Gordon's Town) which was purchased in $1792-3$ by the Government. James Wiles, who had sailed with Captain Bligh, was made superintendent about twenty years later. In 18 10 the garden was sold, and the site is now private property.

${ }^{1}$ Dossie, vol. iii. p. 460 .

${ }^{2}$ Dossie, vol. iii. p. 196.

${ }^{3}$ In 1825 the Rev. Lansdown Guilding published at Glasgow an account of the St. Vincent Garden from its establishment to I 825 . The book contains a good deal of information about Anderson and his work. A copy is in the Society's library.

${ }^{4}$ E. Smith, Life of Sir Joseph Banks (I9I I), p. 122.

'Bryan Edwards' History, before quoted, gives as an appendix a catalogue, "Hortus Eastensis," of the plants in the garden at the time of East's death. 
In 1777 , Dr. Thomas Clarke, " Practitioner in Physic and Surgery," went to the island at the request of Sir Basil Keith, and became superintendent of a second garden established at Bath. Both the gardens were of the greatest service to the island. Clarke introduced the camphor tree, and the sago palm.

Later, Dr. Dancer had charge of this garden. He received the Society's silver medal in 1790 for his account of the cinnamon tree in Jamaica above referred to. $\mathrm{He}$ was a valued corresponding member, and, like Anderson, a frequent contributor to the Transactions.

In the year 1793 the Society offered 100 guineas for the establishment of a Botanic Garden in the Bahamas. This offer was repeated annually up to 1802 , but no response having been made, it was then withdrawn.

The Society does not seem to have had any association with the Botanic Garden in Trinidad, but in 1831 , David Lockhart, "Botanical Gardener to the Government of Trinidad," received a gold medal for the successful culture of nutmegs and mace in that island.

In the case of the West Indies, as with the North American colonies, useful service was rendered by the transmission of seeds, samples, etc., the provision of machinery and models, and the supply of information.

A good deal of correspondence has been preserved in the old guard-books of the Society, showing the anxiety of the colonial officials and others to obtain information, and the readiness of the Society to collect and supply it. It appears quite certain that the aid thus rendered was fully appreciated. That the Society was so successful in this branch of its work was due to the fact that it was in constant communication with the officials on the spot, and with those colonial residents who took an interest in the economic progress of the islands, and could supply information as to local requirements. On the other hand, it had the command of the best advice from scientific men at home who could provide the requisite botanical and chemical knowledge (so far as such knowledge existed at the time), and from manufacturers and traders who knew what products would best find a market in Europe. 
The staple products of the islands were not considered to need encouragement or help, and so we read little in the Society's colonial records about sugar or tobacco. The object was to discover new sources of revenue, to introduce fresh industries and new economic plants, and there is no great reason for surprise if we find that many of the suggestions bore little or no fruit. On the whole, the efforts of the Society to aid colonial progress during the first fifty years or so of its existence were well applied, and had very considerable practical results. ${ }^{1}$

In the early years of the new century the interest which had been taken in the West Indies, so far as relates to the introduction of new economic plants, grew less. This may have been partly due to the death of those men in the islands who had devoted themselves to the work; for when Young, Dancer, and Anderson had all passed away, the Society lost its most important correspondents, and there were none to take their place. But beyond much doubt the real cause was the dislike of the planters to anything which interfered with the cultivation of the sugar-cane. Sugar was firmly established as the staple industry of the islands; it was successful and profitable, and the planters not only did not desire, but were inclined to oppose, the introduction of any other crop which might interfere with its cultivation. In one of the letters which Anderson wrote to the Society in I 807 , he refers to this feeling. The result was that the efforts of those on this side who had tried to encourage the introduction of new economic plants were relaxed, and though the special offers of prizes for the growth of West Indian products remained in the Society's lists, the awards became fewer, though some were occasionally claimed. For instance, in 1824 a sum of fifty guineas was presented to Francis Le Cadre for his plantation of clove trees in Trinidad.

${ }^{1}$ From the account published in 1783 of the amounts awarded in premiums up to that date, it appears that $£ 2785,13$ s. $8 \mathrm{~d}$. had been expended, and fourteen gold medals awarded by the Society as rewards in the colonies. Of this amount, $£$ I 75 was spent for importing ear th nuts, myrtle wax, sturgeon, and zebra wood; $£ 50$ for making indigo, iron, and saltpetre; $£$ r666 for planting vines and mulberry trees, and producing silk and cotton; and $£ 895$ for the manufacture of potash and pearlash 
As before stated, the Society in its early years had but little connection with India and the East, though on occasion it was consulted by the East India Company, and information was supplied to it by the Company. A few, but not many, prizes were offered for the productions of the British possessions in the East Indies, and only a small proportion of these were claimed. The award of a gold medal in I 792 to George Unwin " for reviving the trade of tin from this country to India and China," was intended as an encouragement to British rather than to colonial or Indian industry, but it is curious, because it was after the importation of Eastern tin to Europe had begun. It was about 1787 that the first samples of tin from Banca, in Sumatra, were brought over, and a source of supply of the metal made known which soon interfered with the monopoly possessed by the Cornish mines. Before many more years the course of trade was in the other direction, and large amounts of tin were being brought from Banca to England.

From I 800 to I 82 I a prize was open for the importation of "Bhaugulpore cotton "-_ from which clothes are made in imitation of nankeen, without dyeing "-but without any effect. This offer was at first confined to the "British Settlements in the East Indies," but it was afterwards extended to the other colonies. In I 792 a silver medal was presented to Mrs. Anstey, of Madras, for the introduction of cinnamon in $178 \mathrm{I}$. In I80I, Andrew Stephens, of Calcutta, had a silver medal for " Lake from stick lack." The award of a prize for Sind natron in 1786 has been mentioned previously on page 88. About the end of the century, however, a greater interest seems to have been aroused in Indian matters on the part of the Society, and perhaps the Company were more ready to avail themselves of such advantages in the way of technical advice and publicity as the Society was able to supply.

It is probable, too, that the new interest in East Indian matters was to a large extent due to Dr. William Roxburgh, the great Indian botanist, who was superintendent of the Calcutta Botanic Gardens from I793 to I8I3. Roxburgh became a corresponding member of the Society 
in 1797 , and from that date until the time of his death in I 815 he was constantly forwarding communications, most of them of considerable interest and value, to the Society. In 1798 he sent the first specimen of Malayan rubber to the Society, having discovered the source of the rubber in the tree which he described and named Ficus elastica. Caoutchouc had been known since the middle of the eighteenth century, but only as a curiosity, and as useful for rubbing out pencil marks. Priestley, in his book on Perspective (1770), refers to this use, and mentions that the price of a block half a cubic inch in size was three shillings. The sources of rubber in Para, and the method of collecting it, were well known; samples frequently reached Europe, and the gum was described to the Paris Academy of Sciences by La Condamine, who had been sent out by the Academy in 1736 to make certain observations near Quito, with a view to the determination of the figure of the earth. Its properties were afterwards investigated by Fresnau, who submitted a memoir on the subject to the French Academy in $175 \mathrm{I}$. It may be added that at a later period rewards were offered by the Society for caoutchouc from Africa, the West Indies, and elsewhere, but without any result.

Roxburgh was also the first to introduce to Europe the important fibre ramie (now classified as Boehmeria Nivea, var. tenacissima, but named by him Urtica tenacissima). He reports ${ }^{1}$ that he had plants growing in 1804 in the Botanic Gardens, Calcutta, from Malay seed. Nine years later, in 18 I 5 , a silver medal was awarded to Captain Cotton for growing ramie (which is termed "calooee hemp ") in Bengal, apparently from plants or seed obtained from Sumatra by Dr. Roxburgh. Captain Cotton's communication to the Society is probably the first account of the plant and its treatment. ${ }^{2}$ From that date up to the present the development of ramie has formed a constant topic of discussion at the Society of Arts. In I 860, Dr. Forbes Watson prophesied that the fibre from this and other plants of the nettle species would occupy a place second only to that of Flax. Dr. Watson's prophecy has

1 Transactions, vol. xxiv. p. 148 .

${ }^{2}$ Ibid. vol. xxxiii. p. I82. 
perhaps not yet been quite realised, but it is certainly on the way to realisation, as the various difficulties of manufacture are being overcome.

Various other communications were made by Dr. Roxburgh to the Society, but none of them have quite the same present interest as the two above referred to. He received a gold medal in 1805 , and another in 1814 for his communications on East Indian products, and on many other occasions he was formally thanked by the Society for the valuable information he supplied to its Transactions. A portrait of Dr. Roxburgh forms the frontispiece to Vol. xxxiii. of the Transactions, and the same volume contains a memoir of him.

In the year 1843 , Dr. William Montgomerie, of Singapore, sent to the Society some samples of gutta-percha, and in the same year Dr. José D'Almeida presented some specimens to the Royal Asiatic Society. Nothing was done with D'Almeida's specimens, but those of Montgomerie were examined by the Joint Committee of Chemistry, Colonies, and Trade, which resolved " that this substance appears to be a very valuable article, and might be employed with great advantage in many of the arts and manufactures of the country." This resolution was passed at a meeting on $23 \mathrm{rd}$ January 1845 . At the ordinary weekly meeting on 19th March, the Secretary, Francis Whishaw, described the specimens and showed a piece of pipe and a lathe-band made by him, which were afterwards exhibited at the Great Exhibition of I 851 . He also produced some good impressions of medals. It was at this meeting that (Sir) William Siemens became acquainted with the new material, and obtained a sample which was subsequently sent to his brother Werner in Berlin, to try whether it was suitable for insulating telegraph wires. In June of the same year the gold medal was awarded to Dr. Montgomerie for his discovery. He had previously (in 1842 ) received a gold medal from the Society for the cultivation of nutmegs in Singapore.

Nothingwas said or apparently known about D'Almeida, on whose behalf a claim was made many years later, in 
I 858 , by his son, whose letter will be found in the Journal. ${ }^{1}$ Such evidence as there is appears to show that in point of time Montgomerie was the first to realise the value of the gum, because in March i 843 he had already submitted samples of gutta-percha to the Bengal Medical Board before sending the samples to London. But whichever of the two claimants may have been first to suggest the practical value of gutta-percha, there is no doubt that it was Montgomerie's action which first introduced it to public knowledge, and rendered its practical applications available.

The subject had been very thoroughly worked out by the late Dr. Eugene Obach in his Cantor Lectures on "Gutta-percha." Many further details will be found in the report of his first lecture, ${ }^{2}$ and there is much other information about the early history of the gum in the appendixes which were added by Dr. Obach when the lectures were republished.

As far back as i 788, Sir Joseph Banks suggested to the court of directors of the East India Company the practicability of cultivating the tea plant in British India; but nothing came of the suggestion, probably because the H.E.I.C. then had the monopoly of the China tea trade, and saw no advantage in starting a competition. In the year I 822 a gold medal was offered by the Society to the person who should communicate, from information obtained in China, the best and most authentic account of the culture of the plant or plants, the leaves of which furnish the different kinds of tea, together with the method of gathering, drying, and otherwise preparing the leaves. This offer was supplemented in the following year by one of a gold medal or fifty guineas to the person who should grow and prepare the greatest quantity of China tea of good quality, not being less than $20 \mathrm{lbs}$. weight, in the island of Jamaica, or in any other British West Indian colony, and should import the same into Great Britain. The same premium was offered for the colonies of the Cape of Good Hope, Mauritius, and New South Wales. These

$$
{ }^{2} \text { Vol. vii. p. } 20 .
$$$$
\text { 'Journal, vol. xlvi. p. } 98 .
$$ 
offers, opportune as they certainly were, seem to have been in advance of their time, for they produced no response.

Twelve years later, in 1834 , when the East India Company's monopoly had expired, and there was no longer any objection to a rival to the China trade, it was realised that it was not safe or desirable that England should be dependent on China for its supplies of tea, and steps were taken to ascertain the possibilities of raising tea in India. A committee was appointed by the Governor-General, Lord William Bentinck, with Dr. N. Wallich, the successor to Dr. Roxburgh as superintendent of the Calcutta Botanic Gardens, as its secretary. The existence of wild tea in Assam had been discovered " perhaps originally by Major Bruce, subsequently in Manipur by Mr. Scott" (Watt) between I 821 and I 826 , but no attention had been paid to the discovery, and China plants were imported. In the meantime the Assam tea tree had been rediscovered by Captain Charlton and Captain Jenkins. The general belief is that the introduction of the Chinese plant was a mistake, and that the hybrids which were produced were inferior to the native Indian shrub. Eventually tea plantations were established in Assam, and in $1836 \mathrm{Mr}$. C. A. Bruce was appointed superintendent. Samples of the tea were sent to England in 1838 , and were presented by the H.E.I.C. to the Society. In 1839 a Committee of the House of Commons on the subject reported favourably on Mr. Bruce's work, and in consequence of this the gold medal offered seventeen years before was awarded to him in the session 1839-40, "for his meritorious services in discovering the indigenous tea tracts and cultivating and preparing tea in Assam." There seems no doubt that Mr. Bruce's work was well deserving recognition, but it seems equally certain that he was in no sense the discoverer of the tea plant or " the indigenous tea tracts." 1

In $183 \mathrm{I}, \mathrm{Dr}$. Wallich, the superintendent of the Calcutta Botanic Gardens, presented through the court of directors

1 Watt, Commercial Products of India, s.v. Camellia Thea; Berry White, "Indian Tea Industry," Journal, vol. xxxv. p. 734 ; Transactions, vol. lii. p. 200 ; vol. liii. p. 30. 
of the East India Company a very fine collection of Indian woods, containing 456 specimens, ${ }^{1}$ and for this in the following year he was presented with a gold medal. Dr. Wallich, who was a corresponding member of the Society, had previously sent some valuable communications on Indian economic plants, which appeared in the Society's Transactions. In 1834 another collection of Indian and other woods (comprising 452 specimens) was presented by Captain H. C. Baker of the Bengal Artillery.2

Ceylon was not a British colony till 1802 , when it was ceded to Great Britain by the Treaty of Amiens. It seems to have received but a small share of the Society's attention. In I 8 I $_{5}$ a silver medal was awarded to Thomas Hoblyn for the introduction of coco-nut oil from the island, and in the following year he received a gold medal for inventing and introducing into Ceylon a machine for decorticating rice. This machine, as well as a press for the production of the coco-nut oil, is described in the Transactions. ${ }^{3}$ The decorticating machine appears to be the first of its kind, at least the earliest patent for such apparatus is dated 1819 ; it anticipates in many of its details the principles on which later machines for the purpose were based, especially the application of adjustable mill-stones for husking the rice. Before this invention the operation was carried out with a pestle and mortar, the result being that the grains were, to a large extent, broken and rendered useless.

For Canada it cannot be said that very much was done by the Society. When the Society began its colonial work, Canada was still French; it was only partly explored and quite undeveloped, and for some time after it passed under the British flag there were few industries of value except the exportation of furs. Yet, as time went on, and the country was settled, the Society endeavoured to do its duty to what was then the greatest colony, or group of

${ }^{1}$ A catalogue is printed in the Transactions, vol. xlviii. p. 44I.

${ }^{2}$ Transactions, vol. l. part ii. p. 173 .

${ }^{3}$ Ibid. vol. xxxiii. p. 60 ; vol. xxxiv. p. 250 . The press was constructed by Bramah, and the decorticating apparatus by Maudsley. 
colonies, belonging to Great Britain, and much of interest about Canada is to be found in the Transactions. In the early part of the nineteenth century a strong effort was made, and with a good deal of success, to encourage the growth of hemp, a fibre then in great demand for naval purposes, as it was practically the only material available, not only for ropes, but also for sails. In 1801 various medals and prizes were offered for the growth of hemp in the two Canadas, Nova Scotia and New Brunswick, and these were continued for thirty years. Many of these were awarded. In 1804 a gold medal was awarded to J. W. Clarke, a similar medal and oo guineas to Jacob Schneider, and a silver medal to Daniel Mosher. In I 806 silver medals were awarded to Philemon Wright, Frederick Arnold, and Joshua Cornwall, also a prize of twenty dollars to G. Ward. In 1809 a silver medal " set in a broad gold border "was given to C. F. Grece, and a silver medal to $\mathrm{Mr}$. Durand. All the above were Canadians. It is stated in the Transactions that, as a result of the attention which had been drawn to the subject by the Society's announcements, a considerable trade in hemp had been set up, and a large amount of fibre imported.

The offer of a prize for the growth of hemp was a little later extended to the other colonies, and there was added a reward for the discovery of a good substitute. In announcing this award in 1823 a note was added, drawing special attention to the Phorminm tenax, or New Zealand flax, of which specimens had lately been brought to England. The importation of the fibre rapidly extended, and between 1828 and 1832 no less than $£ 50,000$ worth was shipped to Sydney alone. ${ }^{1}$ The present annual value of the export from New Zealand is $£ 307,000$.

It does not appear what prompted the offer in 1792 of a gold medal for the discovery of a " North-West Passage by land from Canada to the South Sea." It is possible that the disputes between Spain and England about Nootka (now St. George's) Sound (on the west coast of Vancouver) and the adjacent regions, which nearly led

${ }^{1}$ Morris's Cantor Lectures on Commercial Fibres (I 895). Journal, vol. xliii. p. 923. 
to war but were settled by the Treaty of the Escurial in I 790, may have directed public attention to those littleknown lands. More probably it was reported that attempts were being made to explore the north-west of Canada, and the Society wished to encourage them, and to identify itself with them. However, soon after the offer was made, Alexander Mackenzie completed the adventurous journey which brought him to the shores of the Pacific near the present boundary between Alaska and British Columbia. After exploring much of the north-west, and discovering the great river which now bears his name, he started in 1789 from Lake Athabasca to make a passage to the coast, which he reached in June I 793..$^{1}$ The richly-deserved gold medal was awarded to him in 1800 , a rare, if not a unique, instance of a reward made by the Society for exploration alone. About this time Mackenzie came to England, and in 1802 he was knighted by George iाı. He died in 1820 .

In 1807 a silver medal was awarded to William Bond for a communication printed in the Transactions ${ }^{2}$ containing information about Canadian industries and resources.

In I 8 i 6, Lieutenant-Colonel Joseph Bouchette, Government Surveyor to the Commission for settling the boundaries between the British colonies in North America and the United States, presented an extensive survey or map of Canada to the Society, for which he received the gold medal.

Mr. William Green, secretary of the Literary and Historical Society of Quebec, communicated to that society in 1827 a paper on colouring materials produced in Canada. The paper and a box of colours prepared from these materials were sent to the Society of Arts at the instance of the Earl of Dalhousie, Governor of Canada, and the Society in 1828 awarded a gold medal to Mr. Green for the pigments, which consisted of certain ochres and lakes, with some colours of vegetable origin. They were pronounced by the authorities to whom they were referred

1 A brief and singularly modest report of his journey by Mackenzic himself appears in the Transactions, vol. xviii. p. 289.

2 Vol. Xxv. p. 147. 
for examination to be good, though perhaps the influence of the Governor-General had as much to do with the award as the importance of the products.

The first reference which has been discovered in the Transactions to the Australian colonies occurs in the volume containing the list of premiums for 1820 , when two gold medals were offered, one for the greatest quantity of fine wool imported from New South Wales, and one for the finest sample of wool from the same colony. It is probable that the offer was prompted by the knowledge that Australian wool was being shipped to England, for in 1822 both medals were claimed by John M'Arthur, the "Father of New South Wales," and the founder of the Australian wool trade. M'Arthur had imported merino sheep from the Cape in 1795 , and from that time he had devoted himself to the growth of wool on land near Sydney, which had been granted to him for the purpose by the Government. Whether this was his first consignment to London does not appear from the account of his labours given in the Transactions, but it amounted to over i 5,000 lbs., and so complied with the conditions of the Society's offer. It is clear that the importation was in no sense the result of the offer, but the award of the medals, the report made by the Society on the high character of the wool, and the publicity gained by the account contained in the Transactions, appear to have helped considerably in making known the new and important source of supply thus opened up. At the instance of the Society, some cloth was made from the wool, and a silver medal was given to the manufacturers, Starkey, Buckley \& Co., of Huddersfield. ${ }^{1}$

In the same year, I 821 , a silver medal was given to John Raine for the importation of wool from Van Diemen's Land.

In 1824 a second gold medal was awarded to John $\mathrm{M}^{\prime}$ Arthur, and 'also a silver medal to Hannibal M'Arthur, a nephew of Johin, for the importation of the next greatest quantity of fine wool. Besides these, there were some prizes

${ }^{1}$ Transactions, vol. xl. pp. xxxix. and 230. 
to manufacturers for cloth made from the wool, and after this the offer of rewards was dropped, the trade in Australian wool being established on a firm basis.

In 1822 a gold medal was offered for the importation of " the finest wine, not less than twenty gallons, of good marketable quality, made from the produce of vineyards in New South Wales." For some years this produced no response, but in 1833 a silver medal was presented to Mr. Gregory Blaxland for wine the produce of his vineyard at Paramatta. "On examination by the Committee, it appeared to be a light but sound wine, with much of the odour and flavour of ordinary claret, ... though the present sample, from the inexpertness of the manufacture and the youth of the vine, is by no means of a superior quality, yet it affords a reasonable ground of expectation that by care and time it may become a valuable article of export."

From a memorial to Governor Macquarrie from Mr. Blaxland, in October i 8 i 8 , printed in the Transactions, ${ }^{1}$ it appears that he was preparing his land for a vineyard in September 1816 . He had really been anticipated by $\mathrm{M}^{\prime}$ Arthur, who had started a vineyard, and had also planted olive-trees some years before.

In 1828 a second medal, this time a gold one, was presented to Mr. Blaxland for a pipe of wine the produce of his vineyard in 1827 . "On tasting the samples, it was the general opinion that both of them are decidedly better than the wine for which, in I $823, \mathrm{Mr}$. Blaxland obtained the large silver medal of the Society, and that they were wholly free from the earthy flavour which unhappily characterises most of the Cape wines."

Many years after this, in 1856 , a silver medal was awarded to James King for wine from New South Wales.

In 1824 the sum of thirty guineas was given to Mr. T. Kent, for preparing and importing from New South Wales extract of mimosa bark for the use of tanners, and in the following year (1825) a gold medal was awarded to Messrs. Petchey \& Wood for similar material from Van Diemen's Land. In 1824 the thanks of the Society 1 Vol. xli. p. 286. 
were accorded to Mr. R. W. Horton, M.P., UnderSecretary for the Colonies and Vice-President of the Society, for sundry articles from New South Wales which he had presented.

There were a few, but not very many, other prizes to Australia. In 1830 a gold medal was voted to Sir John Jamison, President of the Agricultural Society of New South Wales, for his method of extirpating the stumps of trees in order to clear forest land for cultivation; in I 834 a silver medal was awarded to James King, of Sydney, for his discovery of a sand in New South Wales, which was reported upon by Apsley Pellatt as being eminently fitted for the manufacture of the finer kinds of glass; and in 1845 a silver medal was given to Mrs. Allom for the "Introduction of Bees to New Zealand."

The award in 1775 of a small prize (first offered in 1773) to a resident in Minorca for growing silk in that island is of interest, as reminding us that at various times, including a period from 1769 to $1782,{ }^{1}$ Minorca was subject to this country, and was therefore included in the list of British colonies. After Malta was taken in 1800 , it also became eligible for the Society's awards, and so in i 81 i a prize of a gold medal or fifty guineas was offered for Maltese silk. The offer was extended in 1819 to the "Isle of France "(Mauritius), which had been taken in I810, possession being confirmed to England by the Treaty of Paris in 1814 . The medal for Mauritius was taken in 1824 by M. de Chayal, who had been entrusted in 18 I 5 with some silkworms' eggs obtained from Bengal by the Governor of the island, Sir R. T. Farquhar. The silk sent to London was reported on as ibeing of good quality, but not first-class. In the Session of $1825-6$ a gold medal was awarded to M. Barbé, of Mauritius, for the importation of coco-nut oil.

In 1822 an attempt was made to foster the growth of the vine at the Cape, which had then been definitely British about eight years, and a gold medal was offered

1 Minorca was assigned to England by the Peace of Utrecht, I7 I3; after changing hands more than once, it was finally ceded to Spain by the Peace of Amiens in 1803 . 
to the person who should import the finest wine made from the produce of vineyards at the Cape of Good Hope, or the parts adjacent. It was announced that this premium was not offered for the sweet or Constantia wine, but to encourage the improvement of the vineyards more recently established. Viticulture had been introduced by the Dutch settlers in 1653, and developed by the Huguenot refugees in 1688 . The premium was awarded in 1827 to Francis Collison, who stated that about three hundred pipes of the same quality had been sent by him for sale in the London market. "The wine was examined at the Committee by dealers and other competent judges, and was considered by them to be far superior to the Cape wines in general. It is free from the unpleasant, earthy flavour by which such wines are usually characterised, and was considered to bear a near resemblance to that made at Teneriffe." 1

${ }^{1}$ For an account of the later colonial work of the Society, and the formation of the Colonial Section, reference may be made to Chapter XX, p. 453 .

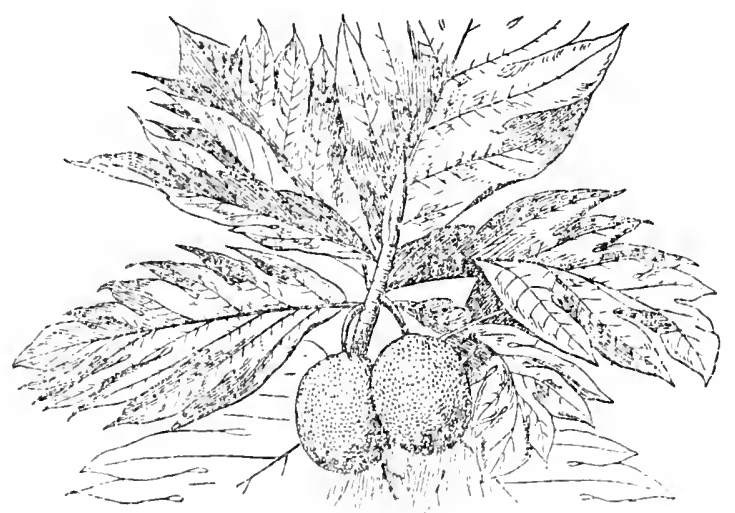

The Bread-fruit (see p. 95). 


\section{CHA P TER V}

\section{The Society And Agriculture}

$$
\text { ( } 1754-1830)
$$

Condition of Agriculture in 1754-Work of the Society's Committee on Agriculture-Value of the Society's operations-Arthur Young's Opinion of them-Publication of Agricultural Information-Food for Stock-Winter Fodder-Introduction of the Turnip-Kohl-rabi -Swede-Mangel-wurzel-Agricultural Implements, Ploughs, Drills, Horse-hoes-Reaping Machines, The Origin of the Reaping Machine, Common's Early Machine, Bell's Reaper-Threshing Machines-Chaff-Cutters-Root-Cutters-Manures-Raising and Fattening Stock-Land Reclamation-The Board of Agriculture -The Royal Agricultural Society.

WhEN the Society of Arts first included agriculture among its objects, but little real advance had been made on mediæval methods. Yet new ideas were in the air, and as far back as the very beginning of the eighteenth century the commencement of the change can be discerned which was soon to abolish the old order of things, and to modify in the course of a comparatively short period the ancient system which had sufficed for so many generations. The time was favourable for improvement, and some central authority was badly needed to co-ordinate and direct the scattered efforts which were being made in England, Scotland, and Ireland to bring about an improved system of husbandry. As a matter of fact, side by side with the industrial revolution, an agricultural revolution was in progress, and the two great movements had their reciprocal influences upon each other. The development of the factory system was at once drawing the agricultural population into the towns, and was depriving them of their ancient means of livelihood by the destruction of domestic industry, 
while the growth of the urban population demanded more abundant food supplies and thus necessitated improved systems of cultivation, by which alone those supplies could be provided. The old open-field system had by no means come to an end by the middle of the century, but the system of enclosure and the division of previously common land had made sufficient progress to render possible the existence of those large farms on which alone any attempt at scientific agriculture could be made. While the arable land of a village was divided up afresh every year among the commoners to whom it belonged, none of its temporary owners could do much, if anything, for its permanent improvement, or even for its systematic cultivation to the best advantage. Again, it was only on farms of considerable size that experiments in new methods of cultivation could be made, and there were many ready to try such experiments, for scientific agriculture had already made some advance. The system of a proper rotation of crops had been invented, and was being rapidly extended. New crops had been introduced, which alone made rotation possible. Of these, the most important was the turnip, but clover and lucerne had also not long before been added to the list. The new ideas promulgated by Jethro Tull, of the highest practical value, if based on erroneous theory, were attracting attention. Bakewell had just commenced his experiments in stock-breeding by the help of careful and judicious selection. Such were some of the main elements of the agrarian revolution in the successful development of which the Society of Arts was certainly one of the main factors.

In the original scheme of the Society agriculture was not included, and when the suggestion was made to Shipley that it should be so included, he met it with the not very conclusive objection that all the awards would be taken in those districts of the country in which the greatest progress had been made. Indeed, in the first list of premiums, that of 1756 , there is no prize offered for any agricultural subject, unless, indeed, madder be considered as such. But this was soon altered. In the next list $(1758)$ there are a number of prizes offered for 
agricultural improvements, and from that date onwards for the next fifty years agriculture occupied an important, indeed the most important, part in the lists of premiums.

In fact, the Society was for long mainly an agricultural society, and by far the most important one in the kingdom. There were some provincial societies in existence when it was founded, and others were soon formed, but it was in communication with all of them, and it was the centre to which information was sent, and from which it was dis. tributed to the various parts of the country.

In agriculture, as in the other divisions of its work, the fundamental idea which directed the Society's efforts was the offering of rewards, either pecuniary or honorary, for the successful carrying out of its objects. These rewards varied greatly in value, and they were carried on from year to year until the end sought for appeared to have been attained, and the new industry or method of tillage, or crop, or whatever it might be, was so firmly established as not to require further assistance or protection. The scope of the prizes offered under the direction of the Committee on Agriculture was very wide. It included the successful rearing of all sorts of crops, even of such well-known crops as wheat, barley, oats, and rye; the introduction of new forage plants and of roots for cattlefeeding; the suggestion of new methods of husbandry, their discussion and the supply of information about them; the invention of new implements or appliances and the improvement of old ones; information on the use and value of manures; suggestions on soil analysis; the treatment of cattle and sheep, and in fact any advance or improvement calculated to aid the progress of agricultural knowledge and practice. An annual list of suggested subjects was published, but the rewards were by no means confined to these lists, and the Society was quite as ready to consider and reward any useful proposal submitted to it from outside, as it was to award the prizes enumerated in its own catalogues.

The lists were prepared with great care, and modified from year to year, though we find the same offer repeated time after time, sometimes over a long period, even though 
large amounts had already been paid away among successful competitors, for it is to be remembered that the premiums were not, as a rule, in the nature of prizes to be taken once for all, but rather as grants-in-aid, to be repeated as long as there seemed to be any need for such assistance.

The value of the help thus rendered to agricultural progress is made evident by much contemporary testimony. In such a matter there is no higher authority than Arthur Young, and he, in his Farmers' Letters, ${ }^{1}$ speaks in terms of high commendation of the Society's work, and comments on the premiums offered for i766. Arthur Young was a member of the Society from 1769 till his death in 1820 , and in 1774 he became Chairman of the Committee on Agriculture. He was therefore thoroughly well acquainted with the Society's work, and he was also a very outspolien person, and very candid in the expression of his opinions, so that any laudatory expressions from him are likely to be well justified. But, while on the whole he appreciated the Society's action, he thought that it might be improved upon, if, instead of merely offering prizes for successful agricultural experiments, it would undertake the direction of such experiments by selecting a number of intelligent farmers who could be trusted to carry out the work, and itself would subsidise them, giving them also additional premiums in proportion to the manner in which the work was carried out.

There cannot be much doubt that a great deal of useful information might have been accumulated by following out Young's suggestions, though it might have been difficult to carry them into effect without more expense in the way of supervision than he contemplated. If the Society could have secured Young's services and got him to undertake the supervision of a scheme such as he suggested, the

${ }^{1}$ Letter VI. vol. i. p. 214. The edition to which reference is made is the third, published in $177 \mathrm{I}$. The first edition was published in 1768 , the second in 1769 . Some sixteen years later, in his Annals of Agriculture, vol. i. (1784) p. 65, Young comments in extremely laudatory terms on the work of the Society of $\Lambda$ rts and its members. "It is probable," he says, "that the kingdom has been benefited a thousand pounds for every guinea these men have expended." 
difficulties might have been overcome, but in the absence of a thoroughly competent expert to control the whole working of such experiments, it is difficult to see how they could have succeeded. In Mr. Wynn Baker the Dublin Society had such an expert, and they wisely placed considerable funds at his disposal, with very satisfactory results. It may, however, be observed that during the many years while Young was Secretary to the Board of Agriculture after I793, he never seems to have made any attempt to carry out the excellent suggestions he proffered for the benefit of the Society of Arts.

But while the distribution of rewards for successful experiment or invention was the principal device by which the Society endeavoured to attain its objects, it must not be thought that it was the only one. The diffusion of information by means of its publications was one almost equally important method, though its value was not recognised for some time. At first in the publications in which its proceedings were reported, to begin with in the Museum Rusticum, afterwards in Dossie's Memoirs of Agriculture, ${ }^{1}$ and eventually in its regular Transactions, it recorded and disseminated a vast deal of agricultural information, and in this way aided most effectually the progress of agricultural science and practice. Another important agency was its " Repository of Inventions," which, during the first half century of its existence, contained an excellent collection of models of agricultural implements. This was opened freely to the public, and by its means an opportunity of examining the latest implements and appliances was afforded to all who cared to profit by it. On occasion also the Society purchased machines and models in foreign countries, and obtained from abroad plants and seeds, which were distributed to the members.

When the Society began its agricultural operations one of the greatest difficulties which pressed upon the farmer was the need for a supply of winter fodder. He was then entirely dependent upon a meagre provision of hay, and

${ }^{1}$ Musenm Rusticum et Commerciale (6 vols. 8vo, i764-66); Memoirs of Agriculture and other Economical Arts, by Robert Dossie (3 vols. Svo, i $768-82$ ). 
that not of the best quality. The use of turnips for cattle food was only gradually making way, for although Arthur Young, ${ }^{1}$ writing about I 769 , speaks of "vast fields " of turnips in Norfolk, it is probable that the epithet was only used in comparison with the scanty crops grown in other counties, and, indeed, the remark was made by way of drawing attention to the small amount of the root which was actually being cultivated. The use of oil-cake for cattle food was hardly thought of. The editor of the Museum Rusticum, ${ }^{2}$ in a note on a correspondent's article on feeding cattle, says that in Flanders the refuse from oilmills had been given to cattle of all kinds, and in another similar note in the same volume, ${ }^{3}$ he adds that oil-cake from which the oil has been expressed, had been tried with success in England as well as in Flanders. It had not really come into use, however, by that time, for in the first volume of the Society's Transactions (1783), in connection with the offer of a prize for oil from cotton-seed, it was suggested that the seed, after the extraction of the oil, might form a useful food for cattle. Ten years later its use must have become fairly general, for in 1794 we find Arthur Young in his Annals of Agriculture referring to cattle being fed on oil-cake as an ordinary thing. ${ }^{4}$

One of the first things taken up by the Society was the production of grass seed, and Arthur Young thought this a matter of the highest importance. Previously the only grass seed used was the sweepings of the hay-lofts, in which all sorts of seeds were mixed together, with a large proportion of seeds of undesirable weeds. The Society offered in 1762 several prizes for clean grass seed, giving instructions as to the way in which grass should be specially cultivated for seed, and promising also to find a market in London for any parcels of seed of a suitable character. Prizes were also offered for hand-picked grass seed, provided the seed was all of the same species.

${ }^{1}$ Tour through the Southern Counties (2nd edition, 1769), p. 25.

${ }^{2}$ Vol. iv. (1765), p. 378 .

3 Vol. iv. (1765), p. 398.

${ }^{4} \mathrm{Mr}$. R. E. Prothero in his Pioneers of British Farming (1888) attributes the introduction of oil-cake as cattle-food to Coke of Holkham (p. 8o), but does not suggest any precise date. 
Awards were also offered and conferred for the growth of crops considered to be suitable for winter or early spring food, including burnet, borecole, sainfoin, lucerne, winter clover, buck-wheat, cabbages, beans, vetches, etc. These crops were then little known and sparsely cultivated.

The ordinary field turnip had been known for less than a century; it had been introduced some time-it is not really known by whom-near the end of the seventeenth century. Arthur Young gives the credit of its introduction to Jethro Tull (1674-I74I), the father of scientific agriculture in England, but in this he was certainly mistaken. Both sheep and cattle were folded upon turnips, which were used to a very limited extent for winter food. Carrots and also parsnips were grown for cattle food, but their growth had hardly got beyond the experimental stage. Potatoes were only to be found in gardens, and were not used for cattle ${ }^{1}$ until some time in the early part of the century. In I779, Arthur Young received a gold medal for an account of the "Clustered Potatoe." This was one of the two medals ${ }^{2}$ he had from the Society. For the cultivation of all these roots and for information as to the best methods of cultivating them, the Society offered many rewards, extending over a long series of years. The list also, at a later date (I 805 ), included beet, on account of its use for cattle food, not for its sugar-producing qualities, which were a much later discovery.

All agricultural authorities are agreed as to the great

1 Although the potato was introduced into Ireland by John Hawkins in 1565 , and into England by Sir Francis Drake in 1585 , it had attracted so little attention that in 1663 the Royal Society urged such of its Fellows as possessed land to plant potatoes, and to persuade their friends to do the same, in order to alleviate the distress that would accompany a scarcity of food. Nothing, however, seems to have come of this recommendation, and so little was thought of the potato for some years after that Bradley (Historia Plantanum Succulentarum, 1716-27) speaks of it as of little note, and in the Complete Gardener of London and Wise ( 17 I9) it is not mentioned at all.

$2 \mathrm{He}$ also received two small prizes in 1765 and 1767 for growing maddor. 
part played by the introduction of the turnip into British agriculture. Without it any proper rotation of crops would have been impossible, and, until it was available for the purpose of feeding stock through the winter, farmers and graziers were in bad seasons forced to kill their stock cattle and salt the meat down for winter use. Hence for centuries the only meat generally available in the winter was salt meat. The extended cultivation of the turnip rendered possible the supply of butchers' meat in winter time to the rapidly increasing population, and so this modest vegetable was not only a prime factor in the agrarian revolution, but a valuable if overlooked agent in the progress of industrial development, and, indeed, of civilisation.

In encouraging the cultivation of the turnip the Society did its full share. Many pages in many volumes of the Transactions are devoted to the discussion of the best methods of growing it, and to dissertations upon the comparative advantages of drill and broadcast husbandry.

But besides encouraging the growth of crops already known, if not extensively cultivated, the Society was directly the means of introducing into England two roots which are now as important as the turnip itself--the swede and the mangel-wurzel.

Among the forage plants which had been introduced into England about this time was the turnip-cabbage (Brassica olcracea caulorapa), or chou-rave, now known under its German name of Kohl-rabi. This plant, according to Young, was brought into England from Carniola in 1749 by the Rev. Mr. Haste, Canon of Windsor, well known at the time as the author of Essays on Husbandry. It had attracted a good deal of attention, and was to some extent being cultivated. It was the subject of two long articles in the Museum Rusticum in $1766,{ }^{1}$ which gives two good illustrations of the plant. It appeared to the Society that this little-known plant was well worth further attention, and amongst the premiums for 1867 was one for its cultivation. The offer attracted the notice of John Reynolds, a farmer of Kent, and he, being unable to obtain

1 Vol. vi. pp. 46, 220. 
a supply of the seed in England, sent to Holland for some. The plants grown from this seed proved to be quite different from what he expected, and turned out to have large roots resembling that of the turnip, instead of the succulent stem of the Kohl-rabi.

As a matter of fact he had been supplied with seeds of the Swedish turnip (Brassica campestris rutabaga); and this was the first introduction of the now well-known swede, then cultivated to some extent in Sweden, Russia, and Northern Germany, but absolutely unknown in England. This unknown plant he christened "the turniprooted cabbage," a not very suitable title, for though both it and the field turnip (Brassica rapa) are members of the cabbage family (Brassicacea) the swede is not a bit more like a cabbage than is the ordinary turnip. He grew a small crop of it and sent specimens to the Society. The value of the introduction was at once recognised, and a grant was made to Reynolds of 650 . Seed from his plants was also distributed among the members for trial, and the new crop was recommended for its hardy nature and its capacity for withstanding frost.

A full account of his experiments is given by Dossie, ${ }^{1}$ and this is supplemented by some further observations on the nature and character of the plant, apparently written by Dossie himself. The full information on the subject first published by the Society attracted a good deal of attention, and for many years the Society continued to offer and present rewards for persons growing the "turnip-rooted cabbage" and for those who supplied information as to the best methods of securing large crops of it. The similarity of the two names evidently caused confusion, for appended to the offer of one of the prizes in 1769 is a note: "The plant here called the Turneprooted cabbage is not the same with the Turnep Cabbage, but that kind newly introduced into this country." For a long time it is only mentioned under this name in the Premium lists and Transactions (though it is said also to have been known as " Reynolds's Turnip "), but eventually the title seems to have been dropped, and the now well-

1 Vol. i. p. 42 I. 
known name of swede, ${ }^{1}$ applied to the plant from the country of its origin, came into use.

The introduction of the mangel-wurzel came a little later. In 1786 some seeds of the Racine de disette, or "root of scarcity," were given by Sir Richard Jebb² - a very well-known physician at the time, who died in the following year-to the Secretary of the Society, Dr. More, by whom they were distributed to some of the members. This " root of scarcity"--soon better known by its German name " mangold-wurzel "3-according to a statement made by Jebb's executor, Granville Sharpe, had been discovered by a French cultivator in search of a new forage plant. It was suggested that both the leaves and the roots might serve as a table vegetable.

Amongst the members who received samples of the seed was J. C. Lettsom. He grew the seeds, and tried the leaves cooked like a cabbage and also the root, but does not seem to have greatly appreciated their flavour, though he thought that, as its name implied, the vegetable might be useful in times of scarcity. He was much interested in the new plant, which he considered much more suitable

${ }^{1}$ In Les Plantes Potagères (Vilmorin-Andrieux et Cie, Paris, I883, p. I4I) the authors, under the heading of "Choux-Navets," give as synonyms: Chou-rave en terre, chou turnep. Noms étrangers:Anglais : Turnip-rooted cabbage, swede, Swedish turnip; Allemand: Kohlräbe, etc.

The Vegetable Garden-a translation (1905) by W. Robinson of the above-(p. I66), under the heading "Turnip-rooted cabbage (Swedish turnip); French, chou-navet ; German, Kohlrabi," etc., says: "The varieties of turnip-rooted cabbages differ from the Kohlrabi (chou-rave) in that, instead of having the stem swollen overground, they producc partially buried in the soil, a thick root which is about as long as it is broad, resembling a huge turnip, and of which the flesh is yellow in the Swedish turnips and white in the other kinds. The characters of the leaves and flowers of these plants indicate plainly that they are true cabbages. ... The Swedish or turnip-rooted cabbage is an excellent vegetable."

In vol. xv. of the Transactions (I/97) it is mentioned that Lord Romney had presented the Society with "a quantity of Swedish Turnep-Seed."

${ }^{2}$ The seeds were sent to Jebb from Metz by T. B. Parkyns. See his letter in the Transactions, vol, v. p. 52.

${ }^{2}$ Mangel-wurzel is a beet, its botanical name being Beta hybrida. On its introduction it was known as Beta vulgaris macrorhiza. 
as a fored for cattale than for human beings, and translated at ereatises on it by the Abtes Commerell, which was pub-

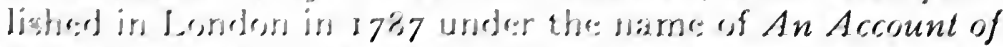
Mangel-yinurel. The particulars hore stated are taken from the profesces to thest beok. The value of the plant

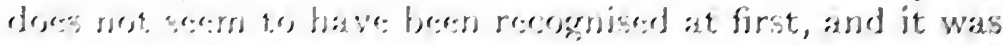
sorsur: tirsor: forfore: it recosved the attention it deserved.

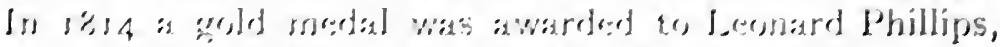

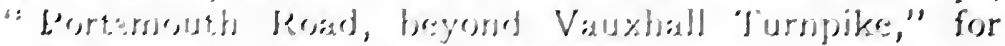

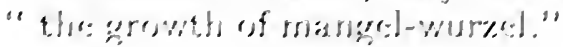

'The: implements thern availathe for the farmer's use were very frow and of a very inforior sort. For tillage thore was the plowsh, varying in charsetw in different distriets of fingland, and the Harrow. The horse-hoe'

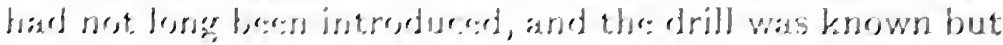

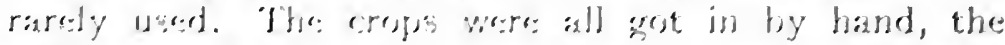

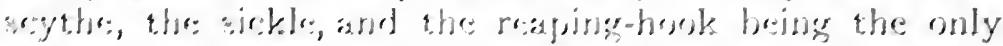

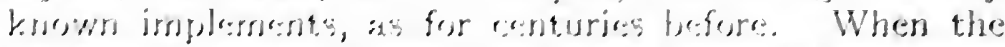
cern was hareseted the conly rrowas for separating the grain fress the stran was boy the lase es the flail.

This stides of thiness, forwever, was very soon to be alteresed. In all industrial precesses the substitution of

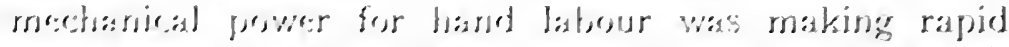

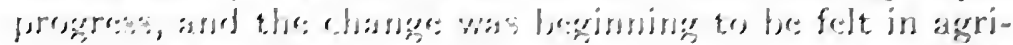

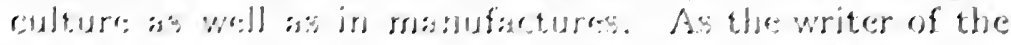

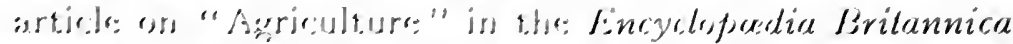
put: it: "The quarter of a cerstury immediately following 176,0 jo rnesnerabule in our agrieultural annals for the intro-

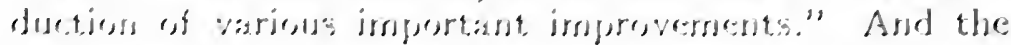
interestuetion of these imprevements was mainly due to the efferts ef the Serejety of Arts. As evidence of this


Cyaloferedia (editions of s\%se) the writer of the correspond-

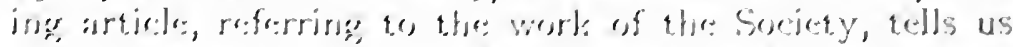

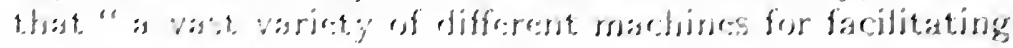

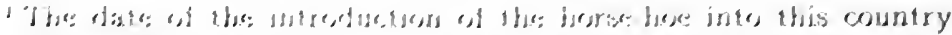

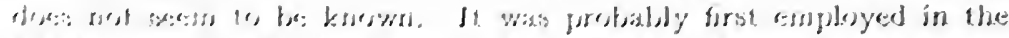

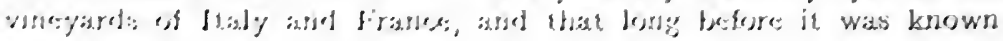
heses.
} 
the practice of agriculture have been invented and presented to the public, in consequence of the large premiums and bounties which have been offered " by it.

To trace in detail the history of all the improvements in agricultural implentents and machinery which were due, in whole or in part, to the rewards paid by the Suciety, to the suggestions it put forward or to the information it collected, would be a long and difficult task and the result would not be either interesting or valuable, but it may safely be asserted that of all the implements new and old used by the farmer during the fifty or sixty years from I 760 onwards (not including, of course, ordinary hand tools), there was not one which was not either introduced or improved in consequence of the Society's exertions and influence.

Even the ordinary plough underwent a larger amount of development during this period than in the century or more preceding, not so much in consequence of any. direct offer of premiums for improrements, as because the Society was always ready to take up and reward any ingenious adrance in this or any other implement. Such changes as were effected were mainly in detail. The frame was made lighter and better balanced; iron was substituted for wood in many parts of the frame, etc.; the shape of the share, coulter, mould-board, and other details were improved; the draught was lessened, and-a very important matter-the price was lowered, so that, as a general result, many of the ploughs commended and rewarded by the Society became popular, and are said to have sold well. All these improvements, however, were the result of rule-of-thumb experiment, and it was nor until 1 39, when the question was taken up by the Royal Agricultural Society, that any scientific investigation was really made into the principles which should govern the construction of ploughs. In that year Mr. Philip Pusey published, in the first volume of the R.A.S. Tournal (p. 219), the results of an experimental inquiry on draught in ploughing made by him, and the dynamometrical tests which he conducted upon the different sorts of ploughs had an immediate effect in improving plough construction. 
The Society also, besides improving the character of the ordinary plough, did much to introduce ploughs of special types, applicable for trenching, draining and subsoiling, paring and scarifying, etc.

The drill had been invented by the enthusiastic and eccentric Jethro Tull in 1707 , and its use advocated in his remarkable book, Horse hoeing Husbandry, in 1731, but it had not really come into use except to a very limited extent. Dossie ${ }^{1}$ is responsible for the statement that Tull " only started the notion. The practice was very little pursued till the Society awakened the public attention to it by their premiums." That this statement was correct seems indisputable. The offer of a gold medal in I 762 for the best set of experiments and observations on the comparative merits of drill and broadcast husbandry produced a series of communications from Sir Digby Legard, extending from i $76_{3}$ to I $_{768} 6$, and giving the result of a very careful series of tests carried on during those and previous years in Yorkshire, and also one from the Rev. Mr. Lowther, giving an account of similar experiments in Cumberland in or before 1763 . Both these gentlemen received a gold medal, and their papers were the first of a long series of communications on the subject, which eventually established the value of the then novel system.

Tull himself, in the various editions of his well-known book, ${ }^{2}$ describes his drill in full detail and with abundant illustration. It must have been an excellent piece of apparatus, well suited for its work, and in its mechanical details considerably in advance of most contemporary machinery. Very probably its actual construction may have been deficient, and it was less effective in operation than appears on paper, for in those days the means of accurate machine construction were sadly lacking. But

1 Vol. i. p. 73 .

2 The book was first issued in an incomplete form in 1731 . The first complete edition appeared in 1733. A further edition, with additions, was published in 1739. After Tull's death in 1740, other editions were issued, $175 \mathrm{I}$, etc. Cobbett published an edition, with much of the original omitted, in 1822 . An interesting account of Tull and his work, by the late Earl Cathcart, appears in the Journal of the Royal Agricultural Society, I89r, 3rd series, vol. ii. p. I. 
by all accounts it was a good practical implement, and quite effective in operation.

Sir Digby Legard speaks favourably of the original machine, though he suggests certain additions and seems to have made some. Still it was not considered satisfactory, and prizes were therefore offered in $176 \mathrm{I}$ for "drill ploughs which should cut several furrows, deposit the seed, and cover the seed with earth at one operation." The earliest award under this head was to the Rev. H. Gainsborough, a brother of the great painter, in 1766. He received $£ 30$ for a "drill plough." Other prizes followed in $1770,1771,1775$, and for many years later. ${ }^{1}$ The earliest patents for drills are those granted to Proud (in I78I) and to Cooke (in I783). After this date the patents are numerous; there were about ten others in the next eight years.

Cooke's patent drill was submitted to the Society in I 787 , and was commended, not-as the subject of a patent-being eligible for reward. Two reports, speaking well of the apparatus, were printed in the Transactions. ${ }^{2}$

Still, though the advantages of the drill were recognised, and the machine itself became well known, it was very many years before its use became general. As late as I $839, \mathrm{Mr}$. Pusey, in his inaugural address to the then newlyfounded Royal Agricultural Society, addressing an assembly of farmers, thought it necessary to describe the drill as a machine "by which the seed is laid in regular rows," and mentioned that "it was not very much used, although it had lately become frequent."

Another implement which, though not invented by Jethro Tull, was the subject of his earnest advocacy, was the horse-hoe. A clumsy-looking implement is figured and described in the Museum Rusticum, ${ }^{3}$ and various prizes for horse-hoes were awarded at different

1 The best, among the early inventions, seem to have been those of Gale and Craik, both Scotchmen, to whom gold medals were awarded in $\mathrm{I} 77 \mathrm{r}$.

${ }^{2}$ Vol. v. p. 7 I et seq. A description, with a drawing, will be found in the patent specification.

${ }^{3}$ Vol. vi. (1766), p. 402 . 
times by the Society. The earliest of these was a gold medal to the Rev. Mr. Hewett in $177 \mathrm{I}$.

Numerous awards were also made for harrows and for rollers, including a "spiky roller" in I $766 . .^{1}$ In I 80 I a silver medal was awarded to W. Lester for an implement " named by him a cultivator." The implement, as described and figured in the Transactions, is typical of the older form of cultivator before its modern improvements and alterations. It has vertical tines, slightly curved at the points. As is well known, the modern cultivator has various forms, is applied to many purposes, and is called by several names. It had, as originally designed, vertical coulters or tines, and was used for breaking up unreclaimed or fallow land. Probably the first description of it is that contained in Lester's communication to the Transactions. ${ }^{2}$

In its efforts to encourage the invention of a reaping machine, the Society was certainly much less successful, and this chapter of the Society's history is decidedly less satisfactory to its historian than those which deal with other agricultural implements.

In the premium list for I774 appears the first offer of a reward for a machine capable of reaping corn, and this offer was continued with certain variations up to I 820 , a period of forty-six years. During all this long period not a single award appears to have been made, and this is really inexplicable, because a number of inventions were brought out during this period, and several were at different times submitted to the Society. Most of these were impracticable and useless, but there was certainly one which was beyond much question the origin of the modern reaper. In the year i 8 i 2, Earl Percy sent to the Society a model of a machine made by John Common of Denwick, Northumberland, together with a certificate from John Thew and Thomas Appleby that the machine

1 Museum Rusticum, vol. vi. p. $37 \mathrm{I}$.

2 Vol. xix. p. 142. This, however, is not the first use of the term, for in the list of implements in the Society's Repertory in 1783 , a "cultivator " is mentioned. Murray's Dictionary gives a still carlier use in a translation of Duhamel's Husbandry, 1762. 
had successfully cut a patch of ripe oats. The apparatus is described, not very fully, in the committee minutes of I 5 th April; but the description is sufficient to show that the principal feature of the machine was a set of angular knives mounted on a horizontal bar, to which reciprocating motion was given by a crank, the corn being guided to the cutters by means of spikes or "fingers." This is precisely the mechanism of all existing reapers. Previous inventions, and some of a later date, used reciprocating blades or revolving scythes, but none of these gave the shearing or drawing cut which alone answers for cutting corn. The verdict of the committee was that the invention was incomplete, and they did not recommend it for an award-a verdict which simply shows that the committee as then constituted was unfortunately incapable of appreciating a most important invention, the very novelty of which was probably too great for them to realise its value.

The history of the invention is given in full detail in an article and some letters contained in the Journal of the Society for i 878..$^{1}$ From these it appears that Common co-operated with Ogle, who was the inventor of an unsuccessful reaping machine of the rotating scythe class, and that he employed one Brown to make certain castings for him, the patterns for which Brown in I 830 took to America. There he either constructed a machine, and disposed of it to McCormick, or gave the patterns to McCormick, and provided him with information from which McCormick was able to construct a machine. At all events there seems no doubt whatever that Common's reaper was the original of the machine brought out by McCormick, and exhibited by him in the American section of the I85 I Exhibition as his own. In consequence McCormick had for long the credit of being the inventor of the modern harvester until the true facts were brought out, and the invention attributed to its real author, John Common. At the same time it should not be forgotten

${ }^{2}$ Vol. xxvi. pp. 369,419 , and 479 . The information contained in these papers, with some further additions, was republished in a little book in 1907 by R. F. J. Common, the grandson of the inventor. 
that while the evidence seems to disprove McCormick's claim to be an original inventor, it does not in any way diminish the value of his public services in the introduction of the reaping machine. It often needs two men to make a success of an invention, one to invent and one to publish. Generally the second man gets the profit, and it is not always certain that he may not deserve it; he does not generally get the credit, though there seems no reason why he should not fairly claim a share of it. John Common's first machine appears to have been made about the year 1803 , and to have grown out of a suggestion made by Ogle. Two other machines were made by him-one about I8II, and the third in 1812 .

It makes it the more remarkable that Common's reaping machine was never rewarded by the Society, that later, in 1818 , he received a gold medal for a turnip drill, and later still, in $\mathrm{I} 844$, a silver medal for a plan of putting new roots to old trees, neither of them comparable with his really great invention of the reaping machine. John Common was living in 1860 , and a letter of his of that date is published in one of the Journals above quoted. John Thew, one of the witnesses of the trial above mentioned, was living in 1878 , and was able at that date to confirm his former statements.

Nor was the Society more successful with another inventor of an original reaper, the Rev. Patrick Bell, whose machine was submitted to the Society in 1830, but was not rewarded on the ground that the description of the machine, which was an excellent one, had brought it sufficiently before the public, and that it did not therefore require the Society's aid to bring it into notice. Bell, who was then a young man studying for the ministry at the University of St. Andrews, invented his reaper in I 827, and it was tried the following year on a farm in Perthshire belonging to his brother, George Bell. He appears only to have constructed one machine, which worked regularly from about i 828 to 1868 , when it was purchased for the Museum of the Patent Office. It is now in the Mechanical Engineering collection of the 
Victoria and Albert Museum. ${ }^{1}$ A full account of his invention was given by Dr. Bell at the meeting of the British Association at Dundee in I 867, but unfortunately only a brief report of the paper appears in the Proceedings of the Association. Bell's machine was never patented, but later on, after attention had been drawn to McCormick's machine in the 185 I Exhibition, many machines were made after his model, and came into extensive use. ${ }^{2}$

Unlike most of the new agricultural implements, the reaping machine, when once attention had been drawn to it, came rapidly into use. Morton, in his Cyclopadia of Agriculture, writing in I85 , refers briefly in his article on "Harvesting Machines," to Bell and McCormick, and says: "Notwithstanding all the ingenuity, however, that has hitherto been applied to the subject, reaping has been, and no doubt for many years, as we have said, will continue to be, a manual operation." In the same work, in a later article on "Reaping Machines," which must have been written in or before 1855 , he recants his views of four years before and describes at considerable length, with illustrations, an improved form of Bell's machine, and also those made by Hussey and by McCormick.

The earliest reference to a threshing machine must certainly be contained in the grant of Letters Patent in $16_{3} 6$ to Sir John Christopher Berg, for an "invencion to be agitated by winde, water or horses for the cleane threshing of corne," but about this no further information exists, and the first machine which is known to have been used for

1 The excellent catalogue of this collection contains (Part ii. p. 227, edition 1908) a brief historical note on harvesting machines and (p. 232, Nos. 1515 and 1516 ) a description of Bell's machine (No. 1515 is the original machine somewhat altered, and No. 1516 is a model of the original). There are also models and descriptions (pp. 232 and 233, Nos. 1517,1518 , and 1519) of McCormick's reaper. No reference is made to Common, and it is to be hoped that the omission may be rectified in any future reprints.

${ }^{2}$ Much information about the carliest attempts to make reaping machines will be found in the Appendix to the Specifications of English Patents for Reaping Machines, by B. Woodcroft, published by the Patent Office. This work is now scldom to be met with. 
the purpose of threshing corn was that patented by Michael Menzies in 1734. No specification was filed, and the only information afforded by the terms of the grant is that the machine "threshes with common swipples." 1 A description, however, is given by Maxwell in the Transactions of the old Scottish Society of Improvers in the Knowledge of Agriculture, which he published in 1743 . This machine appears to have consisted of a number of flails, probably mounted on a central shaft or drum, which was either operated by hand or " by means of a great water-wheel and triddles." Though Maxwell recommends it, it does not appear that Menzies' machine was ever much used, and the first practical threshing machine was that of Andrew Meikle, patented in I788, and stated to have been working in 1798 in Clackmannanshire. From the description in the patent specification it is evident that this machine may be regarded as the precursor of the modern threshing machines, since the principle on which it was constructed is really that which has been elaborated in the modern machine-a revolving drum with what he called "scutchers" working under a curved shield. This apparatus soon came into practical use, and it was later largely improved upon, until it developed into the apparatus now in common use. ${ }^{2}$

The first award made by the Society for a threshing machine was in 1761 , when $£ 15$ was given to John Lloyd. No description of this appears to be extant. A machine "for threshing and winnowing corn," for which fifty guineas was awarded in 1769 to John Evers, is highly commended by Dossie, ${ }^{3}$ but it appears to have been rather a clumsy apparatus, and must have absorbed a

${ }^{1}$ Swipple is a north-country name for a flail, or the head of a flail.

2 Young, in his Annals of Agriculture, vol. xxii. p. 426, states that Meikle's (or Mickle's) machine was an adaptation of one which F. Kinlock had brought to Meikle's father's mill that its capacity for being driven by water power might be tested. Young gives a few details about the apparatus, and says that in 1794 the use of threshing machines was becoming general in Northumberland, where they had been introduced twenty years before (i.e. about 1774) from Scotland by Edward Gregson.

${ }^{3}$ Vol. i. p. 86. 
great deal of power. The corn was spread on a revolving floor, and thus brought under the action of "a row of a kind of flails." This anticipated Meikle's by some twenty years, but was certainly inferior and worked on a very different principle.

Four years before this, in 1765 , a bounty of $£ 15$ had been awarded to a Mr. Harvey for a threshing machine "used in Connecticut." From the note upon it in the manuscript minutes of the Committee on Agriculture, it consisted of a cone with longitudinal ribs revolving from a fixed centre over a floor on which the corn was laid. Nothing more is known of the apparatus.

After this the subject was neglected till I801, when a gold medal was offered for a threshing machine which should be an improvement on any then used. This was awarded in 1810 to $H$. P. Lee. His machine consisted of four vanes or beaters on a central shaft working in a concave. Motion was given by a horse-gear through spur gearing to the shaft. A special merit of the apparatus seems to have been the high speed at which it could be driven.

The earliest suggestion of the use of apparatus for cutting or chopping straw for fodder is probably contained in the first volume of the Museum Rusticum (176I), p. 258 , and further details are given in the volumes for 1765 and 1766.1 In the first of these a "cutting-box " for fodder is described as a novelty, and in the second a fuller account with illustrations is given of a machine devised by Thomas Comber. It is simply the old form of chaff-cutter, common enough fifty years ago, in which the straw or straw and hay is pushed along a trough by hand, and cut by a hinged blade working across the end of the trough, the straw, etc., being held down, while the cut is being made, by a presser worked by the foot or otherwise. The machine is spoken of as something quite new and useful, and from the description it appears that the idea of using chopped straw for the food of cattle and horses was previously unknown.

This machine does not seem to have been submitted to the Society. The first award for a chaff-cutter was one of twenty guineas in 1768 made to J. Edgill. This

1 Vol. v. p. 208, and vol. vi. p. 8. 
is interesting because the machine, which is described in Bailey's Mechanical Machines (vol. i. p. 42), ${ }^{1}$ contains in principle all the elements of the modern chaff-cutter. A single blade, curved so as to give a slicing cut, is mounted on a horizontal axle fitted by the side of a trough. A winch handle, also on the end of the axle, gives a rotary motion to the knife, which works across the mouth of the trough, in which the straw to be cut is placed. The straw is fed through the trough by means of a block carrying prongs, which is mounted to slide to and fro in the upper part of the trough. An intermittent motion is given to this block by means of a tappet on the axle, which engages with a pin rack sliding by a wheel at the side of the trough, and connected with the block. When the block had reached the front of the trough it was lifted and moved back by hand. There is also a weight to keep the straw down. It will be seen that this machine therefore anticipates all the movements of a modern chaff-cutter.

Two years later, in 1770 , a William Bailey received twenty guineas for an improved straw-cutter, but of this no description seems to be extant. In 1774 Stephen Smith received twenty guineas and a gold medal for a machine rather resembling Edgill's, but having a double-bladed knife, so that there were two cuts in each revolution. The feed mechanism, as figured and described by Bailey, seems to be of a somewhat complicated character; but an intermittent motion appears to be given to a sliding board on the bottom of the trough by worm gearing on a shaft mounted on the side of the trough. Bailey's drawings are all in perspective, and therefore, though they are extremely good, it is sometimes difficult to follow the action of the mechanism.

The next award was in I786, when twenty guineas were given to James Pike, a watchmaker of Newton Abbot, for a machine in which the chief improvement appears to be that the feed was effected by means of rollers operated by a worm and spur wheels from the main axle. So far

${ }^{1} \mathrm{~W}$. Bailey was registrar to the Søciety. Some information about him and his book will be found in Chapter XI, p. 239, and in Chapter XV. p. 329. 
as can be judged from the illustration in the Transactions ${ }^{\mathrm{I}}$ the feed in this way was continuous, the rollers being simply driven by spur wheels gearing with a worm on the main shaft. He also mounted his knife (he only used a single blade) on a fly-wheel, instead of using one or two blades fitted radially on a shaft, and this was an obvious economy of power.

In 1797 the final improvement was introduced by Robert Salmon, ${ }^{2}$ the ingenious land agent of the Duke of Bedford, who made the feed intermittent by driving the feed rollers through the intervention of a ratchet wheel operated by a connecting rod from the main shaft. Salmon's machine, however, was in other respects inferior. His cutters were carried by two wheels mounted on an axle which was at right angles to the trough and some little distance in front of it, so that as the wheels revolved the cutters were brought successively across the mouth of the trough. It is evident that in this machine the power was employed at much less advantage than in those in which, as in the modern machine, the wheel and cutters revolved across the line of the trough.

It will thus be seen that the whole evolution of the modern chaff-cutter may be traced in these early implements to which prizes were awarded by the Society.

A little later on great improvements in the mechanism were effected. The first patent for a chaff-cutter, taken out by James Cook in 1794 , was of the same character as Edgill's and Pike's, but he fitted three knives on his fly-

1 Vol. v. p. 62.

2 Robert Salmon was a most ingenious inventor. He received numerous medals and prizes from the Society for the most diverse machines and appliances, including surgical apparatus, a man trap, a canal lock, and a method of transferring pictures from the surfaces on which they were painted. He took out eleven patents, the first in 1796 and the last in 1821 , three of which were for surgical appliances. He invented one of the earliest reaping machines (1807), but, so far as I have been able to ascertain, he did not submit it to the Society. A short account of him is given in the Journal of the Royal Agricultural Society, vol. ii. (3rd series), p. I32. He was a member of the Society, and his name appears on the lists from 1816 to 1820 . He died in 1821 , at the age of eighty-nine. 
wheel, a great but obvious improvement. He also added a fixed blade, against which the revolving blades acted. Later inventors made the feed intermittent by means of a worm of varying pitch, or by driving the gearing through a wheel with only one tooth on each side, and improved the construction generally, but the chaff-cutter now universally known is only an improved version of those of Edgill and Pike.

The offer of a prize in 1766 for a machine for slicing turnips was condemned by Arthur Young ${ }^{1}$ as rather trivial, but the apparatus sent in in answer to the offer was the first of a long series of inventions upon which a vast amount of ingenuity has been spent. The turnipcutter of the present day is the result of the best part of a century's work, and it is not very long since the apparatus has been brought to perfection, so that it will not only slice the roots but will cut them into "fingers" of a convenient size and shape for the food of cattle. In the following year, 1767 , two rewards were given, £20 to James Edgill, and ten guineas to William Bailey. Dossie, who speaks well of Edgill's machine, does not describe its action, but Bailey gives some figures of it. A circular tub is mounted to revolve on a central vertical spindle. The tub has no bottom, but it has four cutting blades mounted radially in place of its bottom. The tub is supported by friction rollers on a base which is perforated at intervals to allow the cut roots to pass through. Rotary motion is given to the tub by cross handles. The tub being filled with roots, and motion being given to it, the roots are sliced by the knives - the size of the slices being determined by the space between the knives and the base, which is adjustable.

The implement would no doubt work perfectly well, as Dossie said it did. But it would certainly require a good deal of power, and the whole idea, though ingenious, is a little clumsy. Bailey states that two men could work the machine with ease and facility, and that it would slice twelve bushels of turnips in five minutes. The award to Bailey was for improvements on Edgill's machine.

2 Farmers' Lethers, vol. i. (2nd edition, I77 I), p. 234. 
According to a statement made by Lovell Edgeworth in his autobiography, a machine of his was tested in competition with Edgill's. From his own account it appears to have been inferior to the apparatus above described, though he himself did not think so. In view of the fact that nothing seems to be known of these early attempts to construct what eventually proved to be a very valuable agricultural implement, it is worth while to quote Edgeworth's own account. ${ }^{1}$

"I sent also to the Society of Arts a machine for cutting turnips, which consisted simply of a circular trough with a dropping knife moving on a pin in the centre, so that the person who worked it had nothing to do but walk round the circle, and to lift the cutter up and down, as a turner works his paring knife. This was put in competition with the machine for cutting turnips which is now in common use, and for which the Society adjudged to Mr. Edgehill the premium. Very little difference was perceived in the performance of our machines, and I still employ my own because it can be made anywhere, of any coarse timber, has but one knife, which can be easily kept from rust and readily sharpened; in short, it performs nearly as much work as Mr. Edgehill's turnip-cutter, and does not cost one-fourth part as much. The machine which I use is a trough on three legs, about five feet long, a foot wide, and a segment of a circle of six feet diameter."

In succeeding years other machines were commended or rewarded by the Society, but to judge by the records of the Patent Office it was very long before attention was really directed to this class of apparatus. The earliest patent for a turnip-cutter was granted in 1803 , and it was not till 1834 that Gardner's machine, which afterwards came largely into use, was invented. After this there were numerous improvements, but Gardner's machine in its modified and modern form is still considered the best. ${ }^{2}$

The use of manures was very limited, and, indeed,

1 Memoirs of R. L. Edgeworth (Edition I $82 \mathrm{I}$ ), vol. i. p. I67.

2 R. P. Wright's Cyclopadia of Agriculture, 1910, s.v. " Root-cutter," vol. x. p. I 39. The writer of the note says that "it has practically been unimproved since its introduction," seventy years ago. 
manure could hardly be applied with much effect so long as the open-field system endured. The practice of applying marl had been lately revived in Norfolk, ${ }^{1}$ and a writer in the Muscum Rusticum (vol. ii. p. 132) states that the Suffolk farmers were in the habit of using " cragg " containing " remains of marine shells." Farmyard manure was, of course, available, and the manuring of fields by folding sheep and cattle upon them was also practised. Lime was used to a very limited extent, and so were ashes. On the sea-coast, seaweed seems to have been utilised. Town nightsoil was employed in some localities where it was available, and the system of paring the surface and burning it was also found serviceable. Young, writing about i 769 , mentions that oil-cake was imported from Holland for use as a manure at a cost of ${ }_{15} \mathrm{~s}$. an acre. Its value as a cattle food was not then generally known, though, as previously mentioned, such application had been proposed, and indeed tried.

In 1758 a prize was offered for a dissertation on "The Nature and Operation of Manures," the following being specified: "Soot, coal-ashes, wood-ashes, lime, and nightsoil." The offer was continued in the same terms for very many years, "bones " being added to the list in 1817 , and "salt" in i 825. After this date the prize was discontinued. During its continuance a good many awards were made, and various papers, none, perhaps, of very great value, were published in the Transactions.

${ }^{1}$ Elton, in his Origins of English History, p. I 16, edit. I 890 , tells us that the Gaulish immigrants into Britain before Cæsar's invasion were familiar with the agricultural applications of marl and chalk. They were good farmers and had large fields. There were among them no traces of the co-operative system of farming. Elton doubtless got his information on this point from Pliny, who (Hist. Nat., xvii. 4) treats at some length on the employment of marl (marga) and refers to its use in Gallia and Britannia. A writer in the Museum Rusticum (vol. ii. p. 376), who signs his letter " X. Y. Z.." a Member of the Society of Arts, and who was very likely Arthur Young, relates his own experience, and gives instructions for the use of marl. Young, in his Annals of Agriculture, gives a good deal of information about marl, and (vol. xxii. p. 547) refers to the above-cited passage of Pliny. A Charter of Henry III. of I 225 gave every man a right to sink a marl-pit on his own ground. 
The same list (that of 1758 ) which contains the first reference to manures, includes also a premium for a dissertation on "Soils and their Natures." This was afterwards developed into an offer of a gold medal for " ascertaining the component parts of arable land," by a series of experiments. Detailed instructions were laid down as to the nature of the analysis of the soil, and practical proof was demanded of the improvement of sterile soil, by the addition of such "components" as appeared to be lacking, and the absence of which might be assumed to be the cause of the sterility. A good deal of information was supplied to the Society from time to time, and published in the Transactions, but it does not appear that the exhaustive series of experiments laid down by the Society were ever carried out in their entirety. The proposal, however, is not without interest, as marking the commencement of agricultural chemistry, which may be said to have first taken definite form in England when Sir Humphry Davy, after delivering a course of lectures in I 803 on the "Connection of Chemistry with Vegetable Physiology" for the Board of Agriculture, was appointed by the Board Professor of Chemical Agriculture, with the duty-besides that of delivering annual courses of lectures-of analysing soils and manures at fixed fees for those who required such work. Davy had been preceded by Duhamel in France, where science-especially chemical science-was ahead of English knowledge ; but the work of Davy soon surpassed that of his foreign rivals. ${ }^{1}$

The question of stock-raising never seems to have received any attention at all from the Society, and this is rather remarkable, because the successful experiments of Bakewell-commenced just about the time the Society was established-had attracted a great deal of attention, and had been followed up by numerous breeders of stock, cattle as well as sheep, all over the country. He was the first to indicate and to emphasise the necessity for proper selection in breeding, and the principles he laid down had

${ }^{1}$ See a "Life of Davy," by H. B. Wheatley, Journal of the Royal Agricultural Society, vol. lxv. I904. p. I ; also Humphry Davy, by Sir Edward Thorpe, I 896, pp. 94-99. 
the greatest possible effect in improving the character of British stock. George 111. was an enthusiastic farmer and breeder, and many of the great landowners were devoting themselves to what was really the scientific raising of new breeds of sheep and cattle. All this, however, seems to have been regarded as outside the Society's province. There are occasional papers in the Transactions on feeding cattle, horses, and sheep, on treating their various illnesses, etc. Arthur Young had a gold medal in 1769 (his first medal from the Society) for his system of fattening hogs, and from time to time a few unimportant premiums of a like nature were offered and bestowed; but, on the whole, the Society appears to have left this important subject severcly alone.

Very many other objects were suggested in the Society's lists, or received premiums when submitted to the Society's notice. One of the most important of these was the reclamation of land from the sea, and there is a long list of those who received medals for such additions to the cultivable area in many places on the coast. The cultivation and improvement of waste land, the proper rotation of crops on different soils, irrigation, the destruction of insect pests, methods of marking sheep so as to avoid the use of tar, harvesting crops in wet weather, the draining of land, were all matters to which attention was directed, and on which, from 1760 till about 1830 , considerable amounts of money were expended. Bee culture was at one time (from 1760 to 1770 ) one of the minor industries that was warmly supported, and a large number of small prizes were given for keeping bees, and for producing wax and honey. Beeswax was then a more important article than it is now, as it was practically the only material available for the best candles.

$\mathrm{By}$ the end of the second decade of the nineteenth century the value and importance of the Society's agricultural work had greatly fallen off. In the Preface to the volume of Transactions for is 89 (Vol. xxxvir.) we find a suggestion that "The object of the Society in the early and enlightened liberality with which they fostered the most important of the practical arts, agriculture, has for 
the most part been accomplished." The fact probably was that while the prosperity of the Society was at this time waning, the attention of its most active supporters was directed to other subjects than agriculture, and it did not appeal specially to them. At all events, from this time forward the Society was content for the most part to leave to other agencies the direction of agricultural progress. After this date, though occasional rewards were given for agricultural implements, they were neither numerous nor important. A few years later (in 1827), in place of the various detailed descriptions of apparatus which were required, the premium list contains only a general offer of rewards for " machines for performing any agricultural operations," and eventually the prizes seem to lapse altogether. The work had indeed been taken up by another agency. The "Board of Agriculture" had been established in 1793 , and had carried on a not very valuable life till i 822. It was not really a Government department, but a sort of independent commission, enjoying a subsidy of $£ 3000$ a year from the State. It had the good fortune to secure Arthur Young as its secretary, and if he had had a free hand it might have effected more useful work ; but for the first part of his tenure of office he was hampered by the proceedings of the chairman, Sir John Sinclair, whose influence had obtained from Pitt the Treasury grant by which the Board was established, and after i 808 Young was incapacitated by blindness and old age. The Board produced one valuable piece of work in the Statistical Surveys of the counties of England, and it did good service when, as above mentioned, it appointed Davy its professor. It followed the example of the Society by offering premiums, when the time for such offers had passed away, and beyond this it really did very little. It is probable that the fact of the Board's existence diminished the Society's interest in agriculture, and made its agricultural work less necessary. ${ }^{1}$

Soon after the Board was abolished, a very different institution for the promotion of agricultural science came

${ }^{1}$ An account of the Board of Agriculture, by Sir Ernest Clarke, will be found in the Journal of the Royal Agricultural Society, vol, ix. (3rd series), p. I. 
into being, for the Royal Agricultural Society was founded in 1838. From its first start it secured the support of all interested in the subject, and was at once recognised as the fit representative of British agriculture. From that date there was nothing more for the Society of Arts to do. But until the interests of this great industry passed into its competent hands it can be truly said that they were well looked after by the older Society. Amongst all its multifarious objects there were none more zealously pursued than those associated with agriculture. "Nor," in the words of the writer of the above-quoted prefaceprobably Arthur Aikin-" is it unjust to suppose that the unexampled rapidity with which the art of cultivation has advanced to its present state is in no small degree owing to the protection originally conferred by this institution."

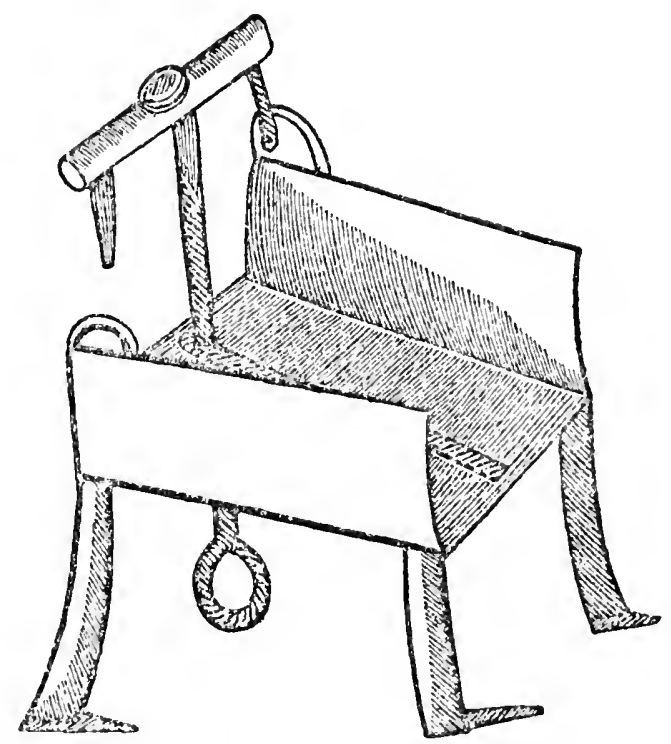

Early Chaff-Cutter (see p. I33). 


\section{H A P T E R V I}

\section{The Society and Forestry}

$$
\text { (I758-1835) }
$$

Need of Timber for Fuel and Shipbuilding-Evelyn's Sylva-Proposal to Encourage Tree-planting-First Offer of Prizes-Names of some of the Recipients-Summary of the Results of the Awards.

From a very early date in English History we find recurrent complaints of the lack of timber. Wood was almost the only fuel. It was one of the principal materials for construction on land, and the only one available for naval purposes. The forests which once covered the country had been cut down, and the timber used for a thousand purposes, of which the most important were shipbuilding and ironfounding. The places where the iron manufacture was located were decided, not as now by the existence of coal, but by the neighbourhood of forests. Sussex and the Forest of Dean were the chief centres of the iron trade, not so much because of the abundance of iron ore, as because of the abundance of wood. Sheffield became the chief seat of the cutlery business because it was surrounded by forests; and as the wood was used or burnt no efforts were made to replace it.

Even in Tudor times we find attempts by legislation to provide a remedy by limiting the destruction of woods and coppices, and by preventing waste of timber. The demand for fuel in London and the need of timber for shipbuilding led to a statute of Henry vir. for the preservation of woods, and there were several Acts of Elizabeth to the same effect. ${ }^{1}$ At the time of the

${ }^{1} 35$ Henry vir. c. I7 ; I Elizabeth c. I 5 ; 23 Elizabeth c. $5 ; 27$ Elizabeth c. I9. Cunningham, in his English Industry, vol. i. (edit. I907), pp. 64, 525, and elsewhere, refers to these and other Acts, and discusses the subject fully. 
Restoration the need of timber for shipbuilding had grown urgent.

In or about 1662 the Navy Office, alarmed at the increasing lack of timber for naval purposes, applied for advice to the Royal Society, who passed on to John Evelyn the questions they had been asked. The result of his investigations was the well-known book, Sylva, or a Discoutrse of Forest Trees and the Propagation of Timber in His Majesty's Dominions. ${ }^{1}$ In it Evelyn appealed to the landowners to improve their forests and woods, and provided them with the fullest information as to how they should set about the work. "To you princes, dukes, earls, lords, knights, and gentlemen, noble patriots (as most concerned), I speak to encourage and animate a work so glorious, so necessary." It is, however, doubtful whether this remarkable book, which has become an English classic, had any very great practical or permanent effect, though the author was able to boast that "many millions of timber trees have been propagated and planted at the instigation and by the sole direction of this work."

At all events, things were no better a century after Evelyn's time, though the use of "sea-coal" for fuel had increased, and it was applied for various manufacturing purposes. Iron, however, still had to be made with charcoal, since it was only about 1730 or 1735 that Abraham Darby first succeeded in employing coke for the purpose, and about $175^{\circ}$ that he had established the manufacture on a commercial basis. For many other manufacturing purposes, coal, with its sulphurous fumes, was not considered suitable, and nearly all over the country wood was still the only domestic fuel. Not only were the trees cut down, but they were either pollarded or stripped of their branches. Arthur Young, in his Farmers' Letters, says that in many parts of the country the result of this practice had been to convert the trees into "May-poles."

Attempts had been made by legislation to limit the use of wood for fuel, but apparently there had been no serious efforts to replace the stock of timber by acting

1 The "discourse "was "delivered" to the Royal Society on I 5 th October I662, and the complete book was first published in I664. 
on the principles laid down by Evelyn, until the Society of Arts took up the question.

The first suggestion came from Mr. Henry Baker, who, according to the minutes of the meeting of 26th March 1755 , presented to the Society from the author, Mr. Edward Wade, " a quarto pamphlet published by him to promote the planting of timber trees in the common and waste ground all over the kingdom for the supply of the Navy, the employment and advantage of the poor as well as the ornamenting the nation." This led to the inclusion in the 1758 prize-list of three premiums for treeplanting. A gold medal and two silver medals were offered for sowing the greatest quantity of land with acorns (five acres at least), four bushels to the acre. Similar premiums were also offered for planting Spanish chestnuts, elm, and Scotch fir. In I 759 the same prizes were offered, with the addition of similar awards for Weymouth pine, " "being the properest sort for masts." As time went on various additions were made to the list, and the conditions were varied, but not very widely. Eventually the list included besides oaks, which were to be planted as well as raised from acorns, and the trees above mentioned, red Virginia cedar, spruce fir, silver fir, larch, Norfolk willow, alder, red willow, ash, Lombardy poplar, elm, and walnut. At one time, about 1795, a special prize was offered for oak trees in "compass forms" for shipbuilding, but this elicited no response, and the offer was dropped.

The first award was in 1758 , when a gold medal was given to the Duke of Beaufort for sowing twenty-three acres in Hawksbury, Gloucestershire, with acorns. ${ }^{2}$ In I 76I the Duke of Bedford received a silver medal for sowing eleven acres with acorns at Woburn, and in 1763

1 The "white pine of the United States, Pinus strobus, first brought from the St. Lawrence in 1705 , and planted in Wiltshire by Lord Weymouth" (Lankester).

2 The entries up to 1783 are taken from four sources: The Register of Premiums, 1778; Dossie's Memoirs of Agriculture, etc., vol. iii. 1782 ; the list in Vol. II. of the Transactions, 1784 ; and a list in Vol. xum. of the Transactions, part ii. p. I. These lists do not always agree. From I 784 on we have the annual prize-lists in each volume of the Transactions. 
a second similar medal for 16,000 Scotch firs planted at Millbrook, Bedfordshire. In I76I, Earl Winterton had a gold medal for sowing twenty acres near Plaistow with acorns. Lord Winterton also received another gold medal in 1767 for planting 2000 elms in Ash Park, Sussex, and two more in 1776 -one for sowing acorns and the other for planting Lombardy poplars. In 1763 the Earl of Portsmouth had a gold medal for planting 6100 smallleaved or English chms. After this clate the prizes become more numerous, and the following awards were made to various noblemen for plantations on their estates; i 766 , silver medal to Lord Scarsdale for planting Scotch firs; I776, aold medal to Viscount Turnour for Spanish chestnuts, gold medal to the Earl of Moray for planting 7,646,000 oaks, firs, and other trees; I779, gold medal to Lord Paget for sowing acorns, silver medal to the Earl of Donegal for planting oaks; 1784 , gold medal to the Earl of Upper Ossory for his plantations (not specified); 1788 , sold medal to the Earl of Fife for his plantations in Scotland. The same nobleman got a second gold medal in I 803 for planting forest trees. In I 797 a gold medal was given to Lord Brownlow for planting osiers, but this was a special offer, quite apart from the prizes for raising timber. ${ }^{1}$ Two years before, Lord Brownlow had a grant of $£ 20$ for the same thing, which was a very unusual thing in the case of noblemen, since members of the peerage were only considered entitled to honorary rewards. In 1800 the Marquis of Titchfield had a gold medal for sowing acorns; in ISO3 Viscount Newark received a gold medal for planting oaks ; in 1805 the Earl of Breadalbane had a silver medal for firs. In i 808 the Earl of Mansfield had a gold medal for oaks. A gold medal was presented to the Duchess of Rutland in 1816 , but this was for ascertaining the best method of raising oaks, and was not a prize for planting. In 1820 the Duke of Devonshire received a gold medal for planting forest trees. The last award for plantations to a nobleman was the gold medal given to Lord Newborough in 1828 for planting forest trees.

${ }^{1}$ Sec Chapter XIII, p. 306. 
Richard Watson, who was Bishop of Llandaff from 1782 to 1816 , received three gold medals from the Society ; in 1788 for larch, in 1789 for ash, and in 1808 for larch. All his plantations were on an estate which he inherited in 1789 .

The awards to other landowners are too numerous to set out in detail, but some may be mentioned, on account of their comparative importance, or because of the personality of the recipient.

In 1759 a gold medal was awarded to Dennis Rolle, of Hudscot, Southmolton, for sowing about twenty-five acres with acorns, and three silver medals were given to Philip Carteret Webb, John Berney, and T. Drew, for sowing smaller areas. Dennis Rolle received a second gold medal in 1761 for planting over 100,000 Scotch firs. In i 763, four gold medals in all and two silver were awarded for elms, chestnuts, and fir.

In i 764, Robert Fenwick, of Lemington, Northumberland, had a gold medal for 104,000 Scotch firs. In 1765 he had a second for another 102,000 , and in 1766 a third for yet another $100,000-306,000$ in all.

William Beckford, the author of Vathek, in 1769 received a gold medal for planting 61,800 Scotch firs at Fonthill, the celebrated estate where he ruined himself by his lavish expenditure on fantastic decoration.

Richard Muilman Trench Chiswell, of Debden Hall, Essex, had a gold medal in 1776 for planting Lombardy poplars, and two gold medals, in 1777 and 1778 , for planting elms. His name was originally Muilman, and he changed it on succeeding to the Debden Hall estate. He was an antiquary, and wrote on the history of Essex.

Thomas White, of West Retford, Notts, received six gold medals in 1778 for his plantation of poplar, larch, Scotch fir, occidental plane tree, spruce fir, and silver fir. $\mathrm{He}$ also received two gold medals in 1779 for Norfolk willow and ash, one in 1785 for elm, one in 1786 for alders, and a silver medal in 1788 for oaks, making in all ten gold medals and one silver medal.

In 1778 a gold medal was awarded to William Mellish, of Blythe, Notts, for planting ror,600 spruce firs, and in I 780 a second medal for 475,000 larches. 
Richard Slater Milnes of Fryston Hall, Yorks, the grandfather of Richard Monkton Milnes, the first Lord Houghton, had three gold medals, one in 1789 for planting 200,000 larch, a second in 1700 for 20,000 elms, and a third, also in $\mathrm{I} 790$, for 38,400 timber trees.

Lewis Majendie, of Hedingham Castle, Essex, received four gold medals for planting oaks, chestnuts, and ash (two) in I 792, I 794, and I 797 .

The most extensive plantations were those made by Colonel Thomas Johnes, of Hafod, Cardiganshire, a man of considerable reputation in his time. He was LordLieutenant of Cardiganshire, and from 1774 to 1816 he represented a Welsh constituency. He was well known as a book collector and as the translator of Froissart, Monstrelet, and other chroniclers. Between I 795 and I 80 I he planted 2,065,000 trees, of which number I,200,000 were larches. Besides this, fifty-five acres of land were sown with acorns or planted with oaks, and it was subsequently stated that he had raised 922,00o oaks. He received altogether six gold medals from the Society, in 1800 , I 80 I, I 802 , I 805, I 810 , and I8I3. A special account of his plantations is given in the Preface to Vol. xiv. of the Transactions (p. x).

John Christian Curwen, M.P., of Workington Hall, Cumberland, received four gold medals, in I 797, 1 802, I 804, and 1809 , for sowing acorns and for planting larch (two) and timber trees. In $180 \mathrm{I}$ and $\mathrm{I} 802$ he planted 814,000 trees. He was a member of the Society from 1798 to I 827, and a Vice-President from I809. Besides these awards for planting, he received seven gold medals and one silver for cultivating wheat, beans, carrots, cabbages, and potatoes, for draining and improving land, and for feeding cattle. In all he received eleven gold medals from the Society, which must certainly be the largest number presented to any single individual. He contributed numerous papers to the Transactions, and also published a good deal on agricultural matters, and on the condition of the labouring classes. According to a statement made by himself, it was due to the Society that he first took up farming. 
An award of a silver medal in 1806 to Robert Salmon may be mentioned, though it was not for planting, but for a paper on pruning fir trees. ${ }^{1}$

Dr. IVilliam Makepeace Thackeray, of Chester, received a gold medal in 1809 for extensive plantations of ash, beech, chestnut, elm, and other forest trees, and another one in 1819 for planting 188 acres with forest trees. He was a first cousin of Richmond Thackeray, the father of the novelist. The plantations, according to the account he gave of his work in the Transactions, were made on property in Denbigh and Merioneth, belonging to his stepson, J. M. Jones, for whom he was trustee.

Dr. Henry Ainslie received a silver medal in 1803 for planting timber trees, and a gold medal in 1812 for the same. He was a distinguished physician, Senior Wrangler, and a Fellow of Pembroke.

Charles Fyshe Palmer, M.P., of Oakingham, Berks, received two gold medals for forest trees $(893,000)$ and oaks, and a silver one for sowing acorns-all in 1821 . Before this, in 1819 , he had a silver medal for planting I 5 acres with forest trees.

The last award for tree-planting was in 1835, when a gold medal was given to Edward Rogers of Stanage Park, Radnor, for plantations carried on from 1799 to 183 I by Mr. Rogers and his father. The number of trees planted was about $700,000 .^{2}$

In all, i 27 gold medals and forty silver medals, besides certain pecuniary grants amounting to about $£ 200$, were given by the Society for arboriculture. Nearly all these were awarded in the period from 1758 to 1821 . After 182 I there were very few awards, only seven in all. The offer of prizes was continued down to 1846 , but was not renewed after that year.

It is impossible to state with exactitude the number of trees planted which these awards represent, for although in some cases the particulars are given in the records of

${ }^{1}$ Transactions, vol. xxiv. p. 68. In the previous chapter, p. 135 , reference has been made to this ingenious inventor, and to the awards he received from the Society.

${ }^{2}$ Transactions, vol. l. part ii. p. I. 
the Society with extraordinary precision, in others such phrases as "extensive plantations" are used; but at the very lowest estimate this number must have considerably exceeded fifty millions, of which some twenty millions were firs and larches, and some fifteen million oaks.

On the whole, it may certainly be said that the attempt was extremely successful, thousands of acres were planted, and, as a practical result, the supply of timber was, to a certain extent, renewed. Nany of the woods throughout the country owe their present existence to the initiative of the Society of Arts. ${ }^{1}$

${ }_{1}$ Dr. Alexander Hunter, F.R.S. (1729-1809), who produced several additions of the Sylva, in one of his notes (Introduction to the I812 Edition, p. 2) says, "The Society of Arts, etc., established in London in the year 1754 , have greatly contributed, by their honorary and pecuniary premiums, to restore the spirit for Planting." 



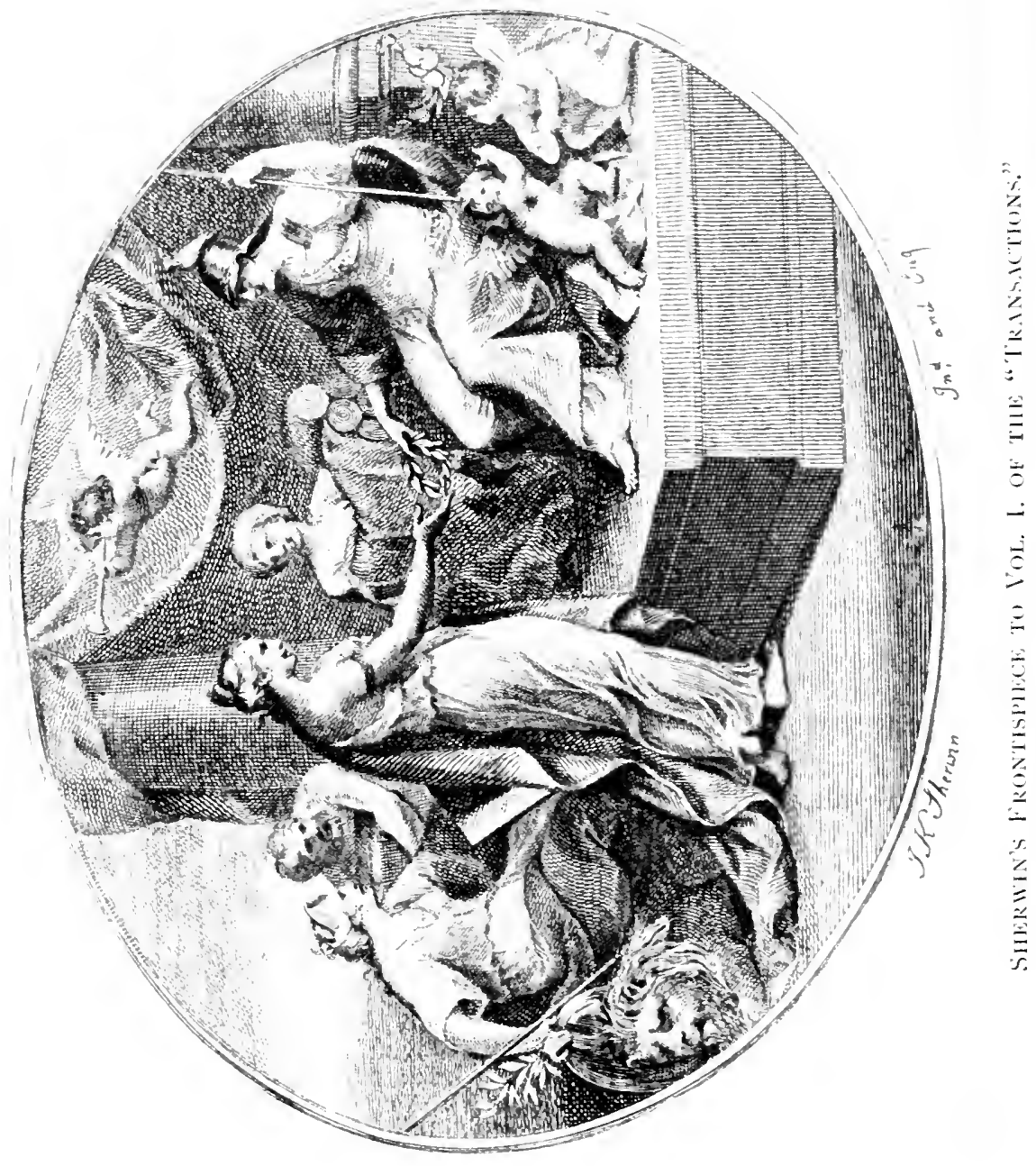




\section{CHAPTER V I I}

The Society and the Fine Arts

$$
\text { (I } 755-\text { I } 851)
$$

The First Fine Art Prizes-Early encouragement of Industrial ArtChange of system and establishment of Prizes for ArtistsDevelopment of the system-The Fine Art Premiums gradually become the most popular part of the Society's work-'Their value and the results they produced-The Prize-winners-The specific Prizes offered.

IT has sometimes been suggested that the early offer of prizes to young artists was due to the fact that Shipley was a drawing-master, and that his principal object was to establish a society for the encouragement of painting and drawing, thereby serving his own professional interests. There is, however, no vestige of evidence of this in any of the Society's records. As before mentioned, ${ }^{1}$ it was quite clearly stated that the reason for the offer was the belief of the founders of the Society that "the Art of Drawing is absolutely necessary in many employments, trades, and manufactures." It will also be remembered that Shipley himself controverted in the Gentleman's Magazine, in 1756 , the idea that the intention of the Society was to train young people as artists, and declared that its main object was to fit them for the pursuit of the Industrial Arts.

The history of the origin of the Society's Fine Art prizes has already been told in the first chapter. ${ }^{2}$ It was there recorded how, out of the limited funds subscribed for the purpose of offering prizes, a certain portion was devoted to rewards for young people of both sexes in drawing, and how the first prizes were taken by Cosway

${ }^{1}$ See Chapter I, P. I5. 
the painter, Smart the engraver, Gresse the painter, and Barbara Marsden, the clever girl who afterwards married Meyer, one of the original members of the Royal Academy.

From this modest beginning there soon developed a well-organised system for the encouragement of Pictorial Art, which lasted for nearly a hundred years, and had very real influence on the growth of English Art.

The prizes were at first intended to encourage Industrial Art, Art applied to manufactures, but it is not difficult to trace the changes in the Society's plans, which ended in the development of a scheme for encouraging young artists pure and simple.

In the first list of premiums, a list published as an advertisement in the newspapers, but only preserved by the Society in MS., prizes are offered to boys and girls under the age of seventeen, for "the most ingenious and best fancied designs, composed of Flowers, Fruit, Foliage, and Birds, proper for Weavers, Embroiderers, or Callico Printers."

In the oldest printed list of premiums, that issued in 1758 , the objects of the Society in including "Premiums for improving Arts, etc.," are very clearly set out. "Fancy, Design, and Taste being greatly assisted by the Art of Drawing, and absolutely necessary to all persons concerned in Building, Furniture, Dress, Toys, ${ }^{1}$ or any other Matters where Elegance and Ornament are required," it is " judged proper " to offer certain prizes to young persons, according to a schedule carefully drawn out, for drawings of the Human Figure, Landscapes, Casts, etc. Some of these are confined to students in "The Academy for Painting, etc., in St. Martin's Lane" "2 others are open to candidates who had studied in the Duke of Richmond's gallery, ${ }^{3}$ and others were quite open.

In the same list, besides these prizes for drawing, etc.,

${ }^{1}$ Toys, - trinkets, wares made of polished stcel or iron, buckles, brooches, braces, watch-chains, sword hilts, purse mounts, châtelaines, etc. (Timmins, Birmingham and the Midland Hardware District, p. 216). The term is still used in the trade. It was with this meaning of the word in his mind that Burke called Birmingham the "Toy-shop of Europe."

2 See Chapter I, p. 8.

${ }^{3}$ Sce Chapter I, p. 8. 
we find special offers for designs for weavers and calicoprinters, cabinetmakers and coachmakers, as well as for manufacturers of iron, brass, china, earthenware, or " any other Mechanic Trade that requires Taste." All these were for young people. There was also a prize for a copper medal, open to candidates a little older, but still under twenty-five. ${ }^{1}$ All this goes to show that the founders of the Society were anxious to encourage the application of Art to industry, and were fully conscious of the need existing at the time for such encouragement.

During the next few years the list was extended by the addition of engraving, mezzotint, etching, woodengraving (with which is included engraving on type-metal), gem-engraving, cameo-cutting, modelling in pastes (cameos),bronze-casting, mechanical drawing, architectural design, furniture design, etc. Many prizes were awarded under these various heads (Bewick got a prize of seven guineas in 1775 ), but, on the whole, the response was hardly satisfactory. The number of entries in the purely artistic classes was far more numerous, and the result was that by 1778 all the technical subjects had been practically dropped out, and the list confined to the artistic classes alone-including, of course, all the methods of reproduction-engraving, modelling, carving, casting, etc., but omitting the industrial applications. No doubt the Society moved in the direction of least resistance, and endeavoured to supply what the public demanded; but it is impossible to suppress a feeling of regret that the work so well begun was not continued, and that a further effort was not made to improve the artistic quality of the various industrial products then being manufactured in rapidly increasing amounts in England.

However, the Committee of Polite Arts evidently took greater interest in Art pure and simple than in its industrial applications, though some of them must have seen the importance of encouraging the "Lower branches of the Polite Arts, such as drawings for Patterns for Silkweavers and Callico-printers," for in the observations appended in the list of Fine Art awards in the "Register

1 See Chapter IX, p. 2 Ig. 
of Premiums," etc., published in 1778 , credit is claimed for the work done by the Society in the promotion of the application of Art to textile manufactures.

"The elegance of pattern adopted by them [weavers and calico-printers] may with justice be attributed in a great degree to the rewards and attention bestowed upon them by the Society."

Nevertheless, the Society stopped its rewards and turned its attention elsewhere, practically abandoning the whole field of industrial Art. Now and again prizes were offered for designs. In I SO I "chints" patterns were asked for, and copper-plate patterns for calicoprinters, but both offers were dropped after a few years, and it may be said with truth that very little was done to advance industrial Art until Prince Albert told a deputation from the then newly-formed Council of the Society, that "The department most likely to prove immediately beneficial to the public would be that which encourages most efficiently the application of the Fine Arts to our Manufactures." The result of this advice was that the Council arranged a special list of prizes for artistic manufactures; among which was one for "A plain and cheap Earthenware Tea Service in one colour, consisting of Teapot, Basin, Milk-jug, Cup and Saucer, and Plate." This prize was taken by "Felix Summerly, of I 2 Old Bond Street," the pseudonym or trade-name adopted by Henry Cole ; and as will be hereafter related this particular award had really a close association with the origination of the I 85 I Exhibition. ${ }^{1}$ Of this more will be said hereafter, for Colc's connection with and services to the Society belong to a much later chapter of its history.

The foundation of the Royal Academy in 1 768 might scem to have left nothing for the Society of Arts to do, so far as the Fine Arts were concerned, and it is evident that those who were responsible for the direction of the Society's work were anxious to avoid any rivalry with the new Academy. They did not carry out the intention, which at one time appears to have been favoured, of confining the Society's work to the encouragement of

$$
{ }^{1} \text { See Chapter XVII, p. } 406 .
$$


industrial Art, and in all probability the suggestion was not very popular, and doubtless at the time appeared impracticable; but they did definitely restrict the artistic awards to young students-either young people who " are intended hereafter to become artists," as the Transactions rather quaintly put it, or to young folk of the upper class who were studying Art as amateurs.

It appears to have been thought that the Society's work in encouraging Art might gradually be dropped, and that it would be taken over by the Royal Academy; but things worked out differently. The Academy wisely confined itself to the instruction of the best class of Art students, and insisted on a high standard in those whom it admitted to its instruction, while the Society continued to offer rewards to all who cared to enter for its competitions. The value of its work was soon realised. The rewards of the Society were evidently highly appreciated, and it became clear that there was a keen competition among the younger Art students for the Society's prizes, and that they provided a valuable incentive to such students, both professional and amateur.

At first only boys and girls were allowed to compete ; then classes of prizes for rather older candidates were formed, and there were some special classes without limitation of age. But the general idea evidently was that the Society would be wise to confine its competitions to young people, so this was for the most part done; and at all events so far as drawing, painting, and sculpture were concerned, the prizes were restricted to youthful candidates of both sexes. There were various classes, with various limitations of age, and from time to time the rules were modified. Sometimes special subjects were set; sometimes the young artists were allowed to choose their own. When they were permitted to send in works of their own choice they had to execute sketches of a similar character in the presence of examiners, to prove their capacity. The tests seem to have been quite fair, and the correctness of the adjudicators' judgment is sufficiently proved by the long list of distinguished artists who won their earliest successes in the Society's competitions. 


\section{I56 THE SOCIETY AND THE FINE ARTS}

At first nearly all the prizes were in money, but "In order to encourage a love of the Polite Arts, and excite an Emulation among Persons of Rank and Condition," there was included in the 1758 list an offer of a gold and a silver medal for drawings by "Young Gentlemen or Ladies under the age of Twenty," and a similar offer to those under sixteen. The same prizes were offered in the following year,

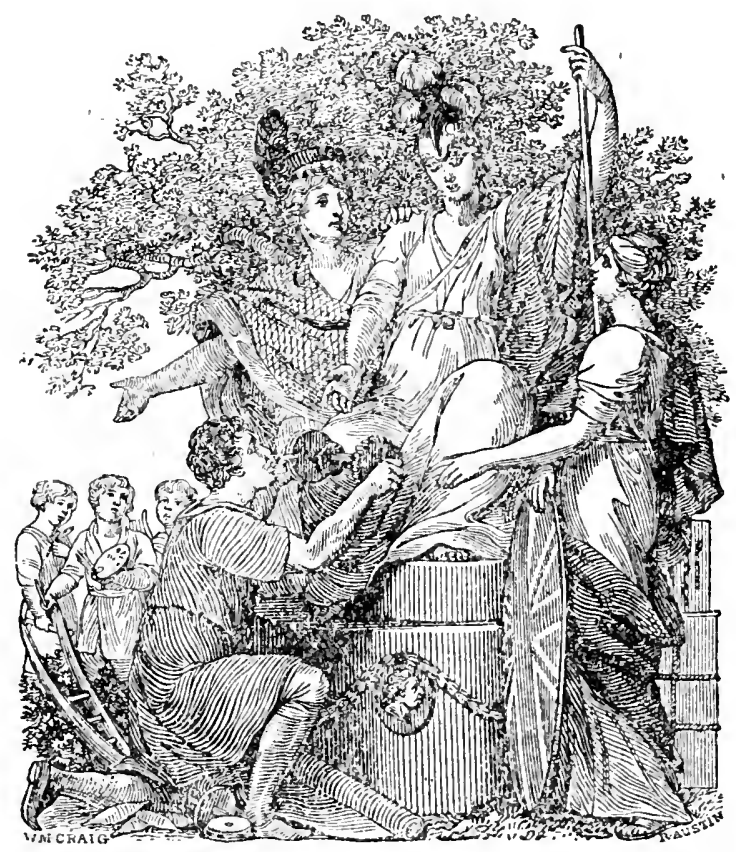

Austin's design used as a Frontispiece for the Premium List of $180_{3}$ (see p. I63).

but were not continued after that. In 1762 , however, a still more exclusive class was introduced-perhaps the definition of "rank and condition" was found difficultfor gold and silver medals were offered for drawings by sons and daughters of peers or peeresses. This queer distinction was carried on almost, but not quite, continuously for many years, with the addition of another generation, grandchildren of the nobility being included. A good many awards were made under this regulation to youthful aristocrats. 
In or before $I_{7} \delta_{3}$ a class was added for " young gentlemen " or " young ladies," and it was added that it was intended for those who " may hereafter become Patrons or Patronesses of the Arts." It was not, therefore, open to professional artists or their children. The rules were varied from time to time, but the distinction of rank was kept up till is39, after which the privileges of the nobility disappeared, and the only distinction drawn was between amateurs and professionals.

In the closing years of the eighteenth century the interest in this department of the Society's work evidently flagged. The number of premiums offered was not very large, and the list of awards was a short one. It seems likely that this was mainly due to the feeling before referred to, that the Royal Academy was the proper authority for controlling all Art education, and that the Society ought to relinquish to it the work it had initiated. However, it was soon found that there was a public demand for artistic education of a more elementary character than was provided by the Academy, and that the Society's prizes indirectly supplied this demand. The result was that the Society was influenced to provide what was demanded, and that the natural popularity of the Society's prizes led to a great increase in the number of the awards. Whatever the cause, it is certain that by the end of the first quarter of the nineteenth century the section of "Polite Arts" had evidently grown to be the most popular part of the Society's work. As before mentioned, industrial Art, the application of Art to industry, received but scant attention. No doubt the Society was influenced by the general state of public opinion; but all branches of artistic industry were encouraged, so far as the award of prizes could encourage them. As regards drawing, painting, and sculpture, the prizes were still confined to young people only; but in the case of such Arts as die-sinking, gem-engraving, cameo-cutting, casting in metals, wood-engraving, and even line or mezzotint engraving and etching, there were, as a rule, no limitations of age, and many of the best 


\section{${ }_{1} 58$ THE SOCIETY AND THE FINE ARTS}

workers of the time looked for their recognition to the medals or premiums of the Society.

In the classes for drawing and painting, the limitations of age (with a few rare exceptions in earlier years) were always preserved, the limit being generally twenty-five, though in some of the classes it was lower. By far the largest proportion of the prizes was taken by these young candidates, and contemporary press descriptions of the Society's prize distributions refer almost exclusively (when speaking of the Art awards) to the young people who came up to receive them from the President. So long as the system of premiums was continued, the award of prizes to young artists was an essential part of it. Even when it was being revised in the years before the $185 \mathrm{I}$ Exhibition, with the avowed object of substituting the application of Art to industry for the cultivation of pictorial Art, the prizes for painting and drawing were not discontinued, and the names of numerous recipients of such prizes are to be found in the lists down to that of I 849. There was no prize distribution of any sort in 1851 ; at the last distribution in 1853 only one solitary medal was given in the class of Fine Arts. ${ }^{1}$

On the whole, the result of the Society's efforts for the promotion of Art during the first century of its existence must be regarded as distinctly valuable. The same causes which gradually rendered less and less effective the general offer of prizes for inventions and discoveries, by no means applied in the case of Art. If the medals and money prizes of the Society had obviously no direct educational influence, they had without any question a very genuine value as a means of discovering hidden talent, as an incentive and stimulant to youthful effort, and as a much-appreciated reward for success. Hundreds of young artists received from the Society the first recognition of their powers, and were thus encouraged to persevere in careers which in many cases led to reputation and success-in some to fame and fortune. And the prizes given were often of large amount, so as to afford substantial assistance to young artists. Prizes of ten,

$$
{ }^{1} \text { Journal, vol. i. p. } 365 \text {. }
$$


fifteen, and twenty guineas were common, and when they recognised cases of unusual merit the Committee did not hesitate to grant sums of fifty or a hundred pounds.

The best evidence of the value of the Society's Fine Art awards is to be found in the list given in the following chapter, a list selected from the very much longer catalogues of prize-winners. In it an attempt has been made to pick out those who afterwards became professional artists, and attained some amount of success in their profession. Some other names of persons who attained eminence or reputation have also been included. It will be seen that the list contains a great number of Royal Academicians and Associates, amongst them three Presidents-Sir Thomas Lawrence, Sir Charles Eastlake, and Sir John Millais ; many of the best-known English engravers; several celebrated sculptors; numerous architects of eminence; a large proportion of our best-known medallists and gem-engravers ; and besides these a very large number of artists of distinction in all classes. There are also many of reputation in their day, but now forgotten, and some who showed promise in their youth not fulfilled in after years. The 450 or so names printed have been collected out of a list of about 3000 awards, extending over a period of ninety-five years, 1755 to 1849 . In the mass this represents a very considerable amount of volunteer labour, carried out by a committee of artists and amateurs, and it may certainly be regarded as reflecting very great credit on the institution by whose members it was faithfully undertaken.

The task of selection has been one of some difficulty, and has involved a certain amount of labour. Though pains have been taken to ensure accuracy, it is certain that there must be many crrors and inaccuracies in the list. Completeness was not to be expected, and it can only be hoped that not many names of importance have been overlooked. In many cases identification was not found to be possible, and no doubt in others awards may have been attributed to the wrong persons. 
The accounts of the subsequent careers of the prizewinners are mainly based on Redgrave's and Bryan's well-known dictionaries. The notes about some of the medallists and gem-engravers are taken from Forrer's Dictionary of Medallists. ${ }^{1}$ The Dictionary of National Biography has, of course, been invaluable, though only a small proportion of the candidates attained its standard of distinction. Graves's Dictionary of Exhibitors has supplied numerous references. Dossie's list of the Society's awards down to 1775 contains a certain amount of biographical information, but the notes are unfortunately very brief.

The Society's rewards in the class of "Polite Arts," as in all the other classes, were at first always pecuniary. In 1756 it was determined to provide also "Honorary Premiums" in the form of gold and silver medals, but this decision was not carried into effect until 1758 , by which time, after a good deal of discussion, a design for the medal had been approved and a die cut. The first medals were awarded in December of that year, and amongst them was a gold medal to Lady Louisa Augusta Greville for a landscape drawing in Indian ink. This was the only medal awarded in the Art class in 1758 , but after that year the awards of medals became numerous, at first only to amateurs, but later to professional artists also. The "Honorary Palette" was devised in I766. An illustration of the Palette is given on the opposite page. A description of it will be found in Chapter XIV, p. 318 . It was in two sizes, in gold and silver, sometimes in silver-gilt.

The awards (other than money prizes) given by the Society in the class of Fine Arts were : The Society's Medal (often called the "Large Medal"), in gold and silver; the Isis Medal (sometimes called the "Small Medal "), in gold and silver; the Palette, in two sizes and in both metals, also rarely in silver gilt. On a very few occasions the silver medal was "set in a gold border." There was

${ }^{1}$ When the list was drawn up this Dictionary had not yet reached letter R, but Mr. Forrer very kindly supplied some information eollected for the later volumes. 


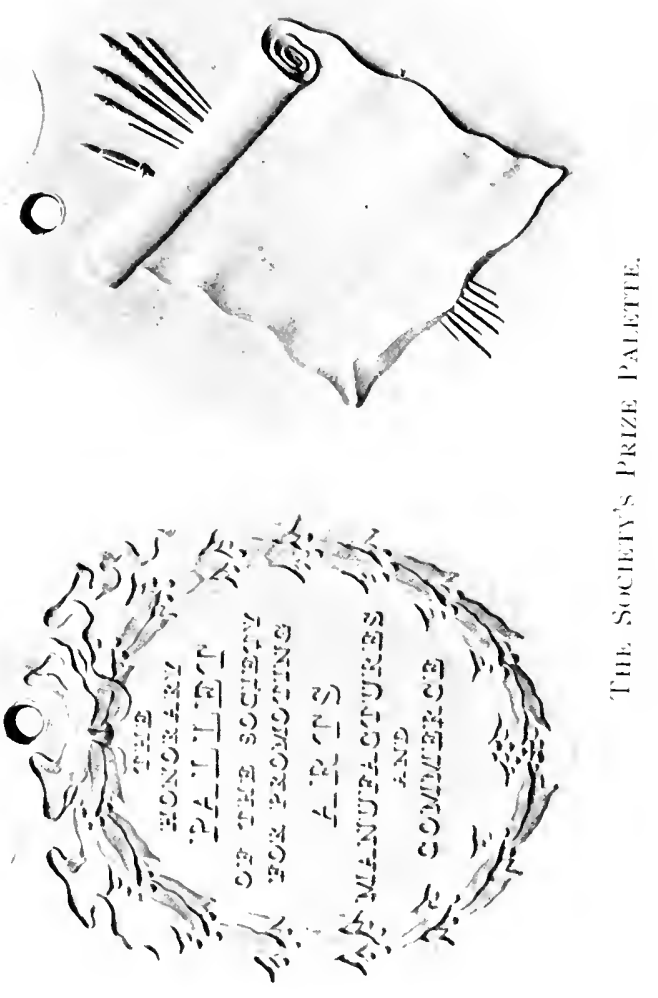


also the Stock Medallion, ${ }^{1}$ nearly always given for Architecture, but occasionally for Sculpture."

The "Premiums" mentioned in the list are all money prizes. They vary in amount from $£ 150$ to a few pounds, when a given amount had to be divided in shares amongst a number of candidates. It has not been considered necessary, except in some special cases, to state in the list the value of the prizes. Sometimes a medal and a money prize were both given.

1 This was awarded under the bequest of John Stock, "Painter to His Majesty's Dockyards," who in I78 I left £Ioo to the Society, with the condition that the interest should be applied for the promotion of Drawing, Sculpture, and Architecture. See also Chapter XIV, p. 319.

2 A fuller account of the Society's various medals will be found in Chapter XIV, p. 3 I 4 .

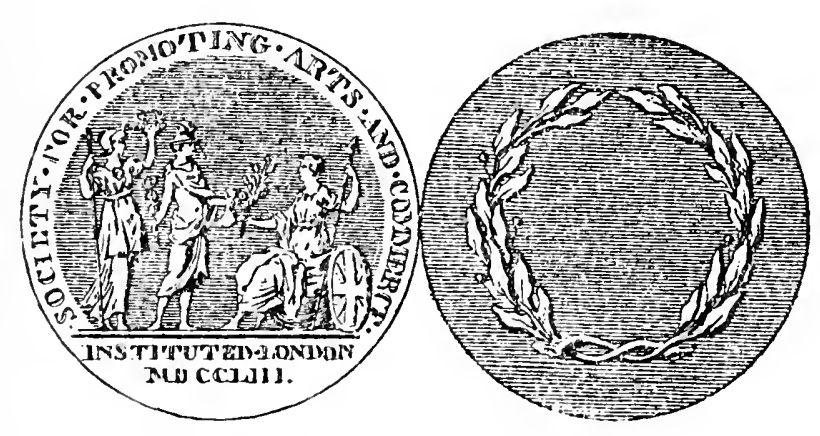

The Society's Original Book-Plate. 


\section{H A P T E R V I I I}

\section{The Fine Art Prize-IVinners}

$$
\text { (1755-1 849) }
$$

Artists and others who received the Society's Medals and PrizesA Selection from the Premium Lists.

Absolon, John. Silver Palette in 1832 for a Portrait in Chalk. Water-colour painter. Treasurer N.W.C.S. Died 1895 .

Adams, Francis. Premium in 1760 for a Drawing. Portrait painter and engraver. "Did not attain any excellence" (Redgrave).

Agar, John Samuel. Silver Palette in 1793 for Historical Drawing. Portrait painter and engraver.

Aglio, Augustine. Silver Medal in I83 I for a Bust. An Italian artist, who came to England in 1803 to assist William Wilkins, R.A., the architect of the National Gallery. Died 1857.

Alcock, J. Rutherford. Gold Medals in 1825 and 1826 for Anatomical Models in Wax (coloured). Sir Rutherford Alcock, K.C.B., Consul in China; the first British Envoy and Consul-General in Japan; afterwards British Envoy at Pekin. He gave up medicine for diplomacy in 1837 . He was for long a member of the Society, and from I 880 to 1883 one of its Vice-Presidents. In 1882 he read an important paper on the Opium Trade. Died 1897.

Aliamet, Francis Germain. Premiums in 1764 and 1765 for Engravings. Engraver. Brother of the celebrated French engraver. Worked for Boydell and others. Died I 790. 
Allason, Thomas. Gold Medallion in 18 io for a Design for an Academy of Arts. Architect. Alliance Fire Office in Bartholomew Lane said to be his chief work (Redgrave).

Andras, Catherine. Silver Palette in I80 I for Models of Princess Charlotte and of Lord Nelson. Medallist. Modeller in wax to Queen Charlotte. Produced Portrait Medallions in the enamelled paste of Tassie (q.v.), under whom she probably studied. Exhibited at Royal Academy I 799-1824.

Artaud, William. Silver Palette in 1776 , I777, and 1782 for Drawings. Painter of portraits and historical pictures. Exhibited at Royal Academy up to 1822 .

Austin, Richard. Silver Medal in 1802 , Silver Medal (and Io guineas) in I803, and Silver Palette in 1804 for Wood Engraving. The 1803 medal was for a wood-cut (reproduced on page 156), "England, Scotland, and Ireland receiving the offerings of Genius, alluding to the rewards of this Society," used as a frontispiece to the Premium List for the year ( 1803 ), and printed in Vol. xxi. of the Transactions (facing page 1 ). Wood engraver. Pupil of Bewick. "He was a clever artist, and much employed by the booksellers, but he did nothing to promote the art" (Redgrave). Exhibited at Royal Academy I 803 and I 806 .

Bacon, John. Premium in I 759 (aged eighteen) for a figure of Peace; subsequent awards were made to him in $1760,1761,1764$ (two), I $765,1772,1774,1776$, I777, and I778, all for Casts or Models. In 1778 he was also presented with a Gold Medal in recognition of his gift to the Society of the statues of Mars and Venus. An engraving of his Mars, by Bartolozzi, is prefixed to Vol. V. of the Transactions, and one of his Venus to Vol. vir. Sculptor. R.A. Eminent and popular in his own day. Carried out many important works and monuments. The Mars and Venus are now in the Victoria and Albert Museum. Died I 799 . 
Baillie, Edward. Silver Medals in 1833 and 1837 for Enamel Painting. Glass painter. Exhibited in I 85 I Exhibition. Died I 856.

Baily, E. Hodges. Silver Medal in 1808 for a Plaster Cast of the Laocoon. A pupil of Flaxman. Sculptor. R.A. Retired I 863 and died I 867.

Ballantyne, John. Silver Medal in I 833 for a Drawing from an Antique Statue. Copyist and portrait painter. R.S.A. Died 1897.

Banks, Charles. Premiums in $1764,1765,1767$, and 1768 (two) for Bas-reliefs. Sculptor. Brother of Thomas Banks, R.A. Gold Medallist R.A. I774. Exhibited at Royal Academy I 775-1 792.

Banks, Thomas. Premiums in 1763 , I 765, and 1766 for Basreliefs ; Premiums in 1769 for a Cast and for a Design for Furniture. Sculptor. R.A. Monuments in St. Paul's and in Westminster Abbey. "Takes high rank among England's sculptors" (Redgrave). Died 1805. Barney, Joseph. Silver Palette in 1774 for a Drawing of Flowers; Gold Palette in I78I for Historical Drawings. Fruit and flower painter. Exhibited at Royal Academy I786-1827. Drawing Master at Royal Military Academy.

Barralet, John James. Gold Palette in 1774 for a Landscape. Water-colour painter. Exhibited at Royal Academy from 1770. Died in America about i 81 2.

Barret, George. Premium in $1764(£ 50)$ for a Landscape Painting. Landscape painter. R.A. One of the founders of the English school of water-colour painting. A painter who "enjoyed great reputation in his lifetime, which his works have not since maintained " (Redgrave). Died I 784 .

Barret, Joseph. Gold Palette in 1775 for an Ornamental Design. Gold Palette in I 777 for Landscape Drawing. Landscape painter. Son of George Barret, R.A. Exhibited at Royal Academy 1785-1800.

Barron, Hugh. Premiums in 1759, 1761, I 765, and I 766 for Drawings. Portrait painter. Exhibited at Royal Academy I $782-1786$. "The first amateur violinist of his day" (Redgrave). Died I 79I. 
Barron, William Augustus. Premium in I 766 for a Chalk Drawing; Silver Palette in 1774 and Gold Palette in I 775 for Landscapes. Landscape painter. Brother of Hugh Barron, and like him a musician. Exhibited at Royal Academy i 774-I 777 .

Barry, James, R.A. Gold Medal and 200 guineas in 1798 , "In testimony of his public zeal and eminent abilities, manifested in the series of Pictures in the Great Room of the Society."

Bassett, Henry. Gold Medal in 1823 for a Design for British Museum ; Gold Medallion in I 825 for a Design for a Church. Architect. Exhibited at Royal Academy down to i 844 .

Beauvais, John. Premium in 1765 for a Drawing. Miniature painter. A native of France. "Practised with success as a miniature painter at Bath" (Redgrave).

Behnes, William. Silver Medal in 18 44 for an Outline of the Gladiator Repellens; Gold Medal in I8I9 for the invention of an Instrument for Transferring Points to Marble. Sculptor. He was originally a portrait painter, but afterwards obtained considerable fame as a sculptor, and was specially successful with his busts. Exhibited at Royal Academy I 815-1863. Died I 864 .

Bellingham, John. Premiums in 1758 and 1759 for Ornamental Designs; in I760, 1761, and 1763 for Drawings. Draughtsman and drawing-master.

Bentley, Charles. Silver Medal in 1826 for Landscape in Water-colour. Water-colour painter. Member WaterColour Society and constant exhibitor. Died i 854 .

Benwell, Sarah. Silver Palette in 1806 for a Drawing. Mentioned by Peter Pindar. Redgrave thinks the poet really referred to her sister, Mary Benwell, a better-known artist.

Berridge, John. Premiums in 1766 and 1767 for Drawings. Portrait painter. Pupil of Sir Joshua Reynolds. Exhibited at Royal Academy I 785 .

Bewick, Thomas. Premium in I 775 (seven guineas) for an allegorical Vignette on Wood. The great wood- 
engraver must have been just out of his apprenticeship, as he was born in 1753 . Died i 828 .

Biffin, Sarah. Silver Medal in 1821 for an Historical Miniature. Miss Biffin, although born without hands or feet, succeeded in making a name for herself as a miniaturist.

Billings, Robert William. Silver Medal in 1833 for a Drawing; Silver Medal in 1835 for an Engraving; Silver Medal in 1836 for a Water-colour Drawing; Silver Medal in 1838 for an Oil Painting; Gold Medal in I 837 for an Etching; Gold Medallion in i 839 for " an Analysis of the great east window of Carlisle Cathedral." Architect. Writer on architecture and archæology. Died I 874.

Birch, William. Silver Palette in 1784 for Pictures in Enamel. Enamel painter and engraver. Went to America and died in Philadelphia. Painted miniature of Washington.

Blackmore, John. Silver Palette in 1772 for a Drawing. Mezzotint engraver. Engraved some of Sir Joshua Reynolds's portraits. Died about i 780 .

Blore, Edward. Silver Medal in 1809 for a Drawing of Fotheringham Church. Architect. F.R.S. Built Sir Walter Scott's house at Abbotsford. Architect to King William Iv. and to Queen Victoria. Designed the front of Buckingham Palace. Died 1879.

Bond, John Daniel. Premiums in 1764 and 1765 for Landscapes. Landscape painter. "Resided chiefly at Birmingham, where he conducted the decorative branch of some large manufactory" (Redgrave). Died I 803 .

Bonner, Thomas. Premium in 1763 for an Etching of a Landscape. Topographical draughtsman and engraver. Illustrated several topographical works. Exhibited at Royal Academy in $\mathrm{I} 807$.

Bonomi, Joseph. Silver Medal in 18 is for a Bas-relief. Sculptor. Son of Joseph Bonomi, A.R.A. Exhibited at Royal Academy i 809-i 838. The well-known Egyptologist. Curator of Sir John Soane's Museum. Died 1878 . 
Bouvier, Augustus Jules. Silver Medal in $184 \mathrm{I}$ for a Chalk Drawing. Water-colour painter. Died I88I. Boydell, John. Gold Medal in I 773 for Encouraging the Art of Engraving. Engraver and publisher. Published celebrated " Shakespeare Gallery." Lord Mayor I 790. Died I 804.

Brandenburgh, Anspach, and Bareith, etc., The Margravine of (previously Lady Craven). Silver Medal in I 806 for a Model in Bas-relief of the late Margrave.

Branston, Allen Robert. Silver Palette in I 806 and Silver Medal in I807, both for Wood-engraving. Wood-engraver. Died 1827 .

Branwhite, Charles. Silver Medal in 1837 for a Figure in Bas-relief. Landscape painter. Died i 880.

Brigstocke, Thomas. Silver Medal in 1826 for a Chalk Drawing; Silver Medal in 1827 for an Oil Painting. Portrait painter. Exhibited at Royal Academy from I 842. Died 188I.

Brockedon, William. Silver Medal in 1823 for a Rest for painters engaged in minute work. Subject and history painter. He was an F.R.S. and made various inventions, some of which were patented. He received another Medal for a Surgical Apparatus in 1825 . He was Chairman of the Committee of Polite Arts from I 824 to I $83 \mathrm{I}$. "He displayed no ordinary talent in the various departments of painting - historical, landscape, and portrait " (Bryan). His portrait by himself is in the Uffizzi Gallery at Florence. Died 1854 .

Bromley, James. Silver Palette in $182 \mathrm{I}$ for an Etching. Mezzotint engraver. Engraved many well-known portraits. Died I 838 .

Bromley, John Charles. Two Silver Palettes and a Silver Medal in I 808, i 809, and i 8 io for Etchings. Mczzotint engraver. He was born in $\mathrm{I} 795$, so that he cannot have been more than fourteen when he took his first prize. Died I 839 .

Bromley, William, A.R.A. Gold Medal i 82 I for an Historical Engraving. This was not an award to a student, for Bromley had been an Associate Engraver 
of the Royal Academy since i 8 I9. He was the father of J. C. Bromley and of James Bromley. Died 1842 . Browne, Hablot Knight. Silver Medal in I 832 for a Group of Figures in Pencil ; Silver Medal in 1833 for a "Free Etching of historical composition." Two years before he gained his first medal (at the age of seventeen) he began the association with Dickens on which his reputation was founded. Under the well-known signature of "Phiz" he illustrated the latter part of Pickwick, Nicholas Nickleby, Martin Chuzzlewit, Dombey, Copperfield, Bleak House, Little Dorrit, and A Tale of Two Cities (Bryan). Died i 882.

Browne, John. Premium in I 763 for a Drawing. Engraver. A.R.A. Apprenticed to Tinney the printseller, and to Woollett. Exhibited at Royal Academy I 771-I783. Died i 801.

Bryer, Henry. Premium in 1762 for an Etching. Premiums in 1763 and 1764 for Engravings. Engraver. Engraved some of Angelica Kauffmann's pictures. Pupil and partner of W. W. Ryland. Died I799 according to Redgrave and Bryan, but Dossie in the list published in 1783 speaks of him as dead.

Bunning, James Bunstone. Silver Medal in 1822 for a Drawing of Bow Church. Architect. Surveyor to Foundling Hospital, architect to Corporation of London. Amongst his chief works were Billingsgate Market, Coal Exchange, Islington Cattle Market. Died i 863 .

Burch, Edward. Premiums in 1762 , I 763 , and 1765 for Gem Engraving. Sculptor and medallist. R.A. "As a gem engraver he was unrivalled in his day" (Redgrave). Died i 8 i 4 .

Burgess, Thomas. Silver Palette in I77I and I773 for Drawings. Portrait painter and teacher. "Mr. Burgess's Academy in Maiden Lane produced many able claimants for the Society's awards" (Dossie). Exhibited at Royal Academy i 778-1 786.

Burgess, William. Premium in $176 \mathrm{I}$ for a Drawing. Portrait painter and teacher. He was connected with Thomas Burgess's Academy in Maiden Lane, and 
was probably related to him. Exhibited at Royal Academy I 774-I 799. Died I 8 I 2.

Burt, Albin R. Silver Medal in 1830 for a Portable Easel. Engraver and portrait painter. Produced a print of Emma, Lady Hamilton. Died i 842 .

Buss, Robert William. Silver Medal in I 826 for a Portrait in Oil. Portrait and subject painter. Illustrated numerous books. Exhibited at Royal Academy I 826-I 859. He was employed to make illustrations for Pickwick after the death of Seymour, and before Hablot K. Browne ("Phiz") took up the work, but his engravings were not used. Died i 874 .

Byrne, William. Premium in 1765 for an Engraving. Landscape engraver. Engraved Hearne's (q.v.) drawings for the Antiquities of Great Britain. "May be justly ranked among our eminent engravers of landscape" (Bryan). Died I 805.

Calvert, Frederick. Silver Medal in I 833 for an Oil Painting. Topographic draughtsman. Published various series of views, etc.

Carr, Johnson. Premiums in 1757, I 758, I 759, and I 764 for Drawings of Figures; Premiums in I760, I76 I (two), I 762 , and 1763 for Landscape Drawings. Pupil of Richard Wilson, R.A. He died young, at the age of twenty-two. "This promising young man, at the early period of twenty-one years, executed drawings equal to those of the ablest masters then in this country. He died, much regretted, in 1764" (Dossie).

Carter, James. Silver Medal in I8 I9 for Architectural Drawing. Engraver. Engraved for the Annuals and for the Art Union. Died I 855 .

Casali, Andrea. Premiums (1 00 and 50 guineas) in 1760 , I761, I762, and I766 for Historical Oil Paintings. Historical painter. Casali was an Italian who came to England before 1748 , and returned to Italy about I766. He painted an altar-piece for the Foundling Chapel, some pictures for St. Margaret's, Westminster, some ceilings at Fonthill, etc. 
Chalon, Maria Ann. Silver Palette in I 8 I 3 for a Drawing ; Silver Medal in 1818 for a Painting. Miniature painter. Daughter of H. B. Chalon, the animal painter. She was miniature painter to the Duke of York. Exhibited at Royal Academy 1819-1866. Married H. Moseley. Died I 867.

Chamberlin, Mason. Premium (50 guineas) in 1764 for an Historical Oil Painting. Portrait painter. R.A. His portrait of Dr. Hunter is in the Royal Academy, and his portrait of Dr. Chandler at the Royal Society. Died I 787 .

Cheesman, Thomas. Silver Palette in I78 I for a Drawing; Gold Medal in I8I4 for an Engraving. Engraver and draughtsman. One of Bartolozzi's best pupils. Exhibited drawings and portraits at Royal Academy I 802-I820. Engraved Hogarth's “ Lady's Last Stake."

Clack, Richard Augustus. Silver Medal in 1825 for a Landscape; Silver Medal in 1826 for a Portrait. Portrait painter. Exhibited at Royal Academy I830I 857 .

Clennell, Luke. Gold Palette in I 806, and Gold Medal in I 809, both for Wood Engraving. Wood engraver and subject painter. He was apprenticed to Bewick, and succeeded as a wood-engraver, but abandoned that art for painting. Exhibited at Royal Academy i 8I2-i8i6. Became insane in I8I7. Died 1840 .

Clevely, John, Premium in 1765 for a Sea Painting in Oil. Silver Palette in I 774 for a view of a Castle in the Isle of Wight. Marine painter. Exhibited at Royal Academy i770-1786. Draughtsman to Captain Phipp's Arctic Expedition, and illustrated the Journal of the voyage. Died i 786.

Clint, George. Gold Medal in 18 I 9 for an Historical Engraving. Portrait painter and engraver. A.R.A. Died I 854 .

Clint, Raphael. Gold Medal in 1825 for an Intaglio of a Head. Gem engraver. Son of George Clint, A.R.A. "Possessed considerable talent" (Bryan).

Clint, Scipio. Gold Medals in 1824 and 1826 for Medal 
Dies. Mcdallist. Son of George Clint, A.R.A. Medallist to the King. Died I839 at the age of thirty-four.

Coleman, William. Premiums in 1775 , I776, and 1777 for Engraving on Wood. Wood engraver. Died 1807 .

Collyer, Joseph. Premium in i76r for a Drawing. Engraver. A.R.A. Engraved some of Sir Joshua Reynold's portraits, also for Boydell. He was about thirteen when he took the prize. Died i 827.

Cook, Richard. Gold Palette in $\mathrm{I} 802$ for a Drawing of Mucius Scævola. History painter. R.A. Died I 857 .

Cook, Thomas. Premium in 176 I for a Drawing; Silver Palette in 1770 for a Drawing. Engraver. "Rose to the very top of his profession" (Redgrave). Worked for Boydell. Died I818.

Cooley, Thomas. Premiums in 1763,1764 , and 1765 for Architectural Designs. Architect. Built the Royal Exchange in Dublin, and other buildings in Ireland. Died I 784 .

Cope, Charles West. Silver Medal in 1828 for a Finished Drawing from a Statue; Silver Medal in 1829 for an Oil Painting. Historical painter. R.A. The portrait of Prince Albert in the Society's meeting-room was painted by Cope. Died I 890 .

Corbaux, Fanny. Silver Medal in 1827, and Gold Medal in 1830 for Miniatures; Silver Medal in 1829 for a Water-colour. Water-colour painter. Exhibited numerous pictures at Royal Academy, and also at the New Water-Colour Society. Writer on Oriental subjects and Biblical exegesis. Died 1883 .

Corbaux, Louisa. Silver Medal in 1828 for a Drawing; Silver Medal in 1829 for a Water-colour. Watercolour painter. Sister of Fanny Corbaux. Exhibited at Royal Academy, but more frequently at New Water-Colour Society.

Corbould, George. Silver Palette in 1806 for a Drawing.

Engraver. Brother of H. Corbould. Died I 846 . Corbould, Henry. Gold Palettes in 1804 and 1805 , both 
for Historical Drawings. Historical painter and draughtsman. He prepared the drawings of the Elgin Marbles. Died i 844.

Cosway, Richard. Premium in 1755 for a Drawing in Chalk, the First Prize in the Society's first competition; Premium in 1757 for an Ornamental Design; Premiums in 1758,1759 , and 1760 for Drawings. Miniature and portrait painter. R.A. A pupil of Shipley. The Society possesses two portraits by him, Shipley and Templeman. Died I 82 I .

Cotman, John Sell. Silver Palette in I 800 for a Drawing. Landscape and marine painter. Worked both in oil and water-colour. Exhibited at Royal Academy. Lived some time in Norfolk, and much of his work was done in that county. Died I 842 .

Cousins, Samuel. Silver Palette in 1813 , and Silver Medal in I 814, both for drawings. His first award was obtained when he was eleven years old. Engraver. R.A. "His cuvre consists in all of about 200 plates" (Bryan). An apprentice and assistant of S. W. Reynolds, the engraver, he lived to engrave Millais's " Cherry Ripe." Died I 887.

Crellin, Henry Pickersgill. Premium in I 820 for a Drawing. Nephew of H. W. Pickersgill, R.A. Did not follow artistic pursuits, but practised as a medical man. Brother of H. N. Crellin. Died about i 843 .

Crellin, Horatio Nelson. Premium in 18 I 9 for a Drawing. Engraver. Gave up the pursuit of Art and became a medical man. Died about i 88I.

Cross, Richard. Premium in I 758 for a Drawing. Miniature painter. Exhibited at Royal Academy I770I 795. Died I 8 Io.

Dall, Nicholas Thomas. Premium in 1768 for a Landscape. Landscape painter. A.R.A. He was a Dane, and settled in London about I760. Was a scene painter at Covent Garden Theatre before his election into the Royal Academy. Died I 777.

Daniell, Thomas. Premium in 1780 for Landscape Painting. Landscape painter. R.A. Painted in India 
for ten years, and made his reputation by Indian views. Died i 840 .

Davis, John Scarlett. Silver Palettes in 1816 for an

Engraving, and in $182 \mathrm{I}$ for a Head in Pen-and-Ink.

Subject painter. Successful as a painter of interiors.

Exhibited at Royal Academy i 825-1841. Died i841. Dean, Hugh Primrose. Premium in 1765 for a Landscape. Landscape painter. Exhibited at Royal Academy 1779-1780. Died about I 784 .

Deare, Joseph. Silver Medal in 1823 for a Plaster Model. Two Silver Medals in 1824 for a Bas-relief and for a Copy of a Group. Sculptor. Exhibited at Royal Academy I 825-I 832 .

De la Motte, William. Silver Medal in 182 I for an Etching. Water-colour painter. Pupil of West. Exhibited at Royal Academy i 796-i 848. Drawing-master at Royal Military Academy. Died 1863.

Denman, J. Flaxman. Silver Palette in 1822 for a Drawing in Indian Ink. Subject painter. Exhibited at Royal Academy in i 839. Presumably a relation of Mrs. Flaxman.

Denman, Maria. Silver Medal in 1807 for her Drawing of Flaxman's Design for the Society's Medal, printed as the Frontispiece to Vol. xxv. of the Transactions; Silver Medal, also in 1807 , for " a Beautiful Plaster Model of a Cupid's Head." She was the sister of Flaxman's wife, and his adopted daughter. She founded the Flaxman Gallery at University College, London.

Denman, Thomas. Silver Palette in 1807 for a Plaster Model. Sculptor. Exhibited at Royal Academy and elsewhere i 8 I 5-1 837. Possibly Mrs. Flaxman's brother. Derby, Louisa. Silver Medal in I 828 for a Pencil Drawing of a Landscape by Claude. She afterwards married Henry Room, a portrait painter of some reputation. Their eldest son, Howard Henry Room, was a valued official of the Society from 186I-1900.

Devis, Antony. Premium in 1763 for a Landscape. Landscape painter. Exhibited at Royal Academy I 772 and 1781 . Died I8I7. 
Dickinson, William. Premium in 1767 for a Mezzotint of R. E. Pine's Portrait of King George II. Engraver. Engraved after West, Morland, Stubbs, Reynolds, etc. Died I 823 .

Dighton, Denis. Silver Medals and Palettes in 1807 , I 808, I 810 , and I 81 I for Drawings and an Oil Painting (Battle of Agincourt). Battle painter. Exhibited at Royal Academy i 81 I--1825. Son of Robert Dighton. Died I 827.

Dighton, Robert. Silver Palette in 1768 for a Fancy Head in Pen-and-Ink after Worledge. Portrait painter and drawing master. Exhibited at Royal Academy 1775-I777. Died I 814.

Dobson, William Charles Thomas. Silver Medal in I84 I for an Oil Painting, "The Prodigal Son." Painter in oil and water-colour. R.A. Died 1898.

Donaldson, John. Premium in 1764 for an Historical Painting; two Premiums in I 768 for Enamels. Miniature painter. Apparently a man of varied accomplishments, but unsettled and wanting in application. He seems to have failed in life, and died in poverty $\mathrm{I} 80 \mathrm{I}$.

Donaldson, Thomas Leverton. Silver Medal in I 8 I 5 for an Original Architectural Design. Architect. P.R.I.B.A. Author of works on architecture. Died i 885 .

Downman, John. Premium in 1779 for an Historical Painting. Portraitand subject painter. A.R.A. Died 1824 .

Drummond, Eliza Anne. Gold Medal in I 822 for " an original portrait," no doubt the portrait of Ann Cockings, the Society's Housekeeper, now in the Society's possession (see page 343 and Appendix III.). Silver Medal in 1823 for an "Historical composition." Exhibited at Royal Academy and elsewhere.

Dubourg, Richard. Premium in 1755 , at the first of the Society's competitions, at the age of fourteen, for a Drawing. Dossie says that he devoted himself to the reproduction of examples of ancient Italian architecture, and had some sort of exhibition of 
reproductions in cork of "Venerable Remains of Antiquity." His name does not appear in Redgrave or Bryan.

Dunkarton, Robert. Premiums in $1761,1762,1763$, 1764,1765 , and 1766 for Drawings of various sorts ; Premium in 1767 for an Engraving of Chamberlin's Portrait of Dr. Chandler, the antiquary and traveller (now in the possession of the Royal Society). Mezzotint engraver. Exhibited portraits at Royal Academy I 774-I779. "As a mezzotintist . . . he was rarely surpassed " (Redgrave). Engraved portraits by Reynolds, West, and others. After I8I I "there is no trace of him" (Bryan).

Durant, Susan. Silver Medal in 1847 for an Original Plaster Bust. Sculptor. Exhibited at Royal Academy 1 $847^{-1873}$. The Princess Louise was her pupil. Died I 873 .

Durnford, Elias. Premium in 1755 for a Drawing of Flowers (third prize in the class between fourteen and seventeen); Premium in 1757 for an Ornamental Design. Went to America, and became Lieut.-Governor of Pensacola (Dossie).

Durno, James. Premiums in 1762 and 1765 for Drawings; Premiums in 1766, I 770, and I 773 (100 guineas) for Oil Paintings. Historical painter. Died in 1795 in Rome, where he lived from I 774.

Earlom, Richard. Premiums in I 757 (under fourteen years of age), 1758, I 759, I 760, I 761, I 762, 1 763, 1764 , and 1765 for Drawings in various classes; Premium in 1766 for an Etching. Engraver. A pupil of Cipriani, and afterwards one of the most distinguished of English engravers. "His 'Liber Veritatis,' comprising mezzotint engravings after 200 drawings by Claude, published in 1777 , is well known " (Redgrave). Died 1822.

Eastlake, Charles Locke. Silver Medal in isıo for a drawing of Cupid and Psyche. Historical painter. Sir Charles Eastlake, P.R.A. Director of the National Gallery. He acted as Chairman of the Society's 
Committee which procured the passing of the Art Copyright Act, I 862. Died I 865.

Eckstein, John. Premiums in 1761 and 1764 (50 guineas) for Bas-reliefs. Modeller and portrait painter. Exhibited wax models and portraits at Royal Academy I $770-1798$.

Eddis, Eden Upton. Silver Medal in I 828 for a Drawing. Portrait painter. Gold Medallist R.A. I837. Exhibited at Royal Academy I834-1881. Popular and successful artist. His portrait of Theodore Hook is in the National Portrait Gallery. Died rgor.

Edwards, Edward. Premium in 1762 for a Drawing; Premiums in 1764 and 1765 for Historical Pictures; Gold Medal in 1770 for an Historical Painting; Premium in I78I for a Landscape. Portrait and subject painter. A.R.A. Teacher of perspective at Royal Academy. Published Anecdotes of Painters, a supplement to Walpole's work. Died i 806.

Edwards, John. Premiums in 1757 for a Drawing; in I 760 for an Ornamental Design ; in I 760 for a Landscape Drawing; in $1761,1762,1763$, and 1767 for Drawings of Flowers; in I764 for an Historical Drawing; Gold Palettes in I 769 for a Figure Drawing, and in I 77 I for a Drawing of Flowers. Historical and flower painter. Pupil of Maberley. Exhibited at Society of Artists, etc., up to I 81 2.

Eggbrecht, John E. Silver Medal in I82 I for a Chalk Drawing; Silver Medal in I 824 for an Oil Painting. Painter of still life. Exhibited at Society of British Artists I 826-I 828 .

Engleheart, Thomas. Premium in I 777 for a Model of a Human Figure. Sculptor and modeller in wax. Exhibited at Royal Academy i773-1786. Gold Medallist R.A. I772.

Engleheart, Timothy Stansfeld. Silver Palette in I 82 I for a Chalk Drawing. Line engraver. Engraved for the Annuals. Son of William Francis. Died I 879.

Engleheart, William Francis. Silver Palette in 1798 for an Outline Drawing. Engraver. Engraved after Stothard, Cook, and Smirke. Died I 849. 
Ensom, William. Silver Medals in 1815 and 1816 for

Pen-and-Ink Drawings. Engraver. Died I 832 .

Fairland, Thomas. Silver Medals in I 822 and 1823 for Drawings. Engraver, lithographer, and portrait painter.

Died 1852 .

Falconet, Peter. Premium in I 766 for an Historical Painting; Premium in I768 for an Oil Painting. Portrait painter. Exhibited at Royal Academy in I 773 .

Farey, Joseph. Silver Palette in I 809 for an "Original Drawing of a Steam Engine"; Silver Palette in I 809 for a "Perspective Drawing of London Bridge Water-Works." Engineer and dranghtsman. He was the son of John Farey, geologist and consulting surveyor, and the brother of John Farey, jun., a civil engineer of eminence, who received a Gold Medal from the Society for his ellipsograph. As a young man, John Farey supplied mechanical drawings to various works, and some of the illustrations in Vols. xxvi. to xxxi. of the Transactions are by him. It is possible that some may also be by Joseph, as the initials of the brothers are the same. Joseph Farey later on took over part of his brother's work. He died about I 829 .

Farington, George. Silver Palette in 1770 and 1771 for Landscapes; Silver Palette in $177 \mathrm{I}$ for a Drawing. History painter. Brother of Joseph Farington, R.A. Pupil of West. Gold Medallist R.A. I780. Exhibited at Royal Academy in 1773 and 1783 . Died I 788 .

Farington, Joseph. Premiums in 1764,1765 , and 1766 for Landscape Drawings. Landscape painter. R.A. Illustrated Boydell's great work on the History of the Thames. Died i 821 .

Faulkner, B. Premiums in I819, 1820, and 1822 for Die Engraving. Medallist. Forrer mentions several of his medals, all produced in or before 1826 . He suggests that he may have been identical with B. R. Faulkner, a portrait painter of reputation who 
exhibited at the Royal Academy 1821-1849, but this is improbable, for the Faulkner (or Faulkener) who took the prizes lived in Birmingham, whereas B. R. Faulkner was at the time living in Newman Street, London.

Feary, John. Premiums in 1766 for a Drawing and in 1776 for a Landscape. Landscape painter. Exhibited at Royal Academy 1772-1788. Painted views of gentlemen's seats and parks.

Fennell, John G. Silver Medal in I 827 for a Chalk Drawing. Engraver. Pupil of Henry Sass. Superintended the Findens's establishment.

Finden, Edward. Silver Palette in 1810 for an Outline of the Laocoon. Engraver. Younger brother of William Finden. Died i 857 .

Finden, William. Silver Palette in 1807 and Silver Medal in 1808 for Drawings; Gold Medal in 1813 for an Engraving. Engraver. The two Findens, Edward and William, worked together. They engraved some of Landseer's and Wilkie's works, and produced many illustrations for books. Died I 852 .

Finlayson, John. Premium in 1764 for an Enamel Painting; Gold Palette (and 30 guineas) in 1773 for his Mezzotint of Sir Joshua Reynolds's Portrait of Lord Romney. Mezzotint engraver. Engraved portraits after Hone, Coates, Zoffany, and Reynolds. Died about 1776 .

Flaxman, John. Premium in 1766 (at the age of eleven) for Modelling in Clay ; Premiums (two) in I 769 for the same; Gold Palette in I 770 for Modelling a Statue of Garrick ; Gold Medal in I 807 for Designing the Society's Medal and presenting it to the Society. In the latter year a Silver Medal was awarded to his sister-in-law, Miss Maria Denman (q.v.), for a Drawing of the Medal, which forms the Frontispiece to Vol. xxv. of the Transactions (1807). Sculptor. R.A. Died 1826.

Fox, Charles. Silver Medal in I 847 for an original Composition in Plaster. Modeller. Died 1854.

Freebairn, Alfred Robert. Silver Palette in 1810 for a 
Drawing. Engraver. "Chicfly known by his engraving of Flaxman's 'Shield of Achilles '" (Bryan). Died i 846 .

Frith, William Powell. Silver Medal in 1836 for Drawing in Chalk from a Bust; Silver Medal in 1837 for a finished Drawing from a Cast. Subject painter. R.A. Painter of the celebrated and popular pictures, "The Derby Day," "The Railway Station," "Margate Sands," etc. Frith was born in 1819, so he must have been about seventeen when he received his first award. Died 1909.

Frost, William Edward. Silver Medals in 1829 , I 830 , and 1831 for Drawings; Silver Medal in 1832 for Composition in Oil in Still Life; Gold Medal in 1834 for a Portrait in Oil. Subject painter. R.A. Died I 877 .

Gahagan, Sebastian. Premium in 1777 for a Model. Sculptor. Assistant to Nollekens. Exhibited at Royal Academy I802-1835. The Duke of Kent's statue at the top of Portland Place is by him.

Gandon, James. Premiums in 1757 for a Drawing; in 1758 for a Design for Weaving; in 1759 for a Landscape; in 1762, 1763, and 1764 for Architectural Designs. Architect. Gold Medallist R.A. I769. Exhibited at Royal Academy I774-I780. Carried out important works in Dublin. Died 1823.

Gardner, Rev. John. Premium in 1767 for a Landscape in Oils. Amateur. Vicar of Battersea. Died 1808.

Garvey, Edmund. Premiums in 1769 and $177 \mathrm{I}$ for Landscapes. Landscape painter. R.A. Died I813.

Geddes, Margaret. Silver Medal in I 8 I 2 ; Gold Medals in 1813 and 1814 for Oil Paintings. Portrait painter, "who secured great reputation" (Bryan). She married IV. H. Carpenter, Keeper of Prints and Drawings in the British Museum. Three of her portraits are in the National Portrait Gallery. Died I 872 .

Godby, James. Silver Palette in 1787 for an Outline Drawing. Engraver. Illustrated Fine Arts of the English School, 1812 , etc. 
Goldicutt, John. Silver Medallion in 1815 for an Architectural Design. Architect. Secretary R.I.B.A. Published an account of the Pompeian paintings, etc. Died i 842 .

Gooch, Thomas. Silver Palette in I 778 for Drawings of Animals. Animal painter. Exhibited at Royal Academy $1781-1802$, principally portraits of horses and dogs.

Goodall, Edward. Silver Medal in 1837 for a Watercolour Painting. Water-colour painter. Brother of F. Goodall, R.A.

Goodall, Frederick. Silver Medal in 1837 for Watercolour Drawing; Silver Medal in 1838 for Oil Painting, "Interior of Thames Tunnel." He was not sixteen when this, his first oil painting, was produced. It led to a friendship with Sir Isambard Brunel and to a visit to Normandy, where he found the materials for his first Royal Academy picture, "French Soldiers Playing at Cards," exhibited 1839. From that date his career was one of successful and deserved popularity. Subject painter. R.A. Died 1904.

Gott, Joseph. Silver Palette in 1808 for Original Plaster Cast. Sculptor. Gold Medallist R.A. I819. Exhibited at Royal Academy i 820-1 848 .

Graham, George. Silver Palette in 1780 for a Drawing. Engraver. Produced book illustrations, etc.

Grant, William. Silver Palette in I837 for a Pencil Drawing. Historical painter. Exhibited at Royal Academy i 847-1 866. Died I 866.

Green, Benjamin Robert. Silver Palette in 1824 for a Chalk Drawing; Silver Medal in 1825 for an Outline Drawing ; Silver Medal in 1827 for a Portrait in Oil. Water-colour painter. Died 1876.

Gresse, John Alexander. Premium in 1755 (aged twelve) for a Drawing; Premiums in 1756, 1757, 1758, 1759 (three), 1761 , and 1762 for Drawings; Premium in I 769 for a Landscape in Oils. Water-colour painter. Fashionable drawing-master. Taught the daughters of George III. Died I 794.

Greville, Lady Louisa Augusta. Gold Medals in I758, 
I 759, and I 760 for Drawings. She was the first to take one of the honorary awards offered to amateurs. Gold Medal in 1759 for an Etching. She was a daughter of the eighth Earl of Warwick, and an amateur of considerable skill who produced some good etchings.

Grignion, Charles. Premium in 1765 for a Drawing ; Silver Palette in 1768 for a Drawing. Portrait and history painter. Son of Thomas Grignion, the clockmaker. Gold Medallist R.A. I 776. Painted Nelson's portrait. Exhibited at Royal Academy r770-I784. Died I 804.

Grignion, Thomas. Premium in $176 \mathrm{I}$ for a Drawing. This was the son and successor of Thomas Grignion, one of the earliest members of the Society, an eminent clock-maker, and the donor of the clock now in the meeting-room. Thomas Grignion the younger was also a well-known clock-maker.

Gwilt, George. Silver Palette in 18 I 8 for a Drawing. Architect. Best known by his restoration of St. Saviour's Church, Southwark (I 822-25). Died I 856 .

Habershon, Matthew. Silver Medallion in I813 for a Design for a Palace. Architect. Built several churches, public buildings, and country houses in Derbyshire, Yorkshire, Worcestershire, etc. Exhibited at Royal Academy I807-I 827. Published Ancient Half-Timbered Houses of England, 1836. Died I 852 .

Hakewill, John. Premiums in I759, I 760, I761, I762, 1763 , and 1764 for Drawings in Various Classes; Silver Palette in 1772 for a Landscape. Landscape and portrait painter. Died $\mathrm{r} 79 \mathrm{I}$.

Hall, John. Premium in 1756 for a Drawing ; Premium in $176 \mathrm{I}$ for an Engraving. Engraver. Engraved after West, Reynolds, Gainsborough, Hoare, and Dance. "Ranks among our best historical engravers " (Redgrave). Died I 797 .

Hamilton, Hugh Douglas. Premiums in 1764,1765 , and I 769 for Historical Picture and Oil Paintings. Portrait painter. R.H.A. Died I 806. 
Handasyde, Charles. Premiums in 1765 and 1768 for Enamel Paintings. Miniature and enamel painter. Exhibited at Royal Academy in 1776.

Harding, James Duffield. Silver Medal in 18I5 for a Drawing; Silver Medal in 1818 for an Original Landscape. Water-colour painter. Died I 863.

Hardwick, Philip. Gold Medallion in I 809 for Original Drawing of an Academy of Arts. Architect. R.A. Amongst his principal works were Euston Square Station, the Goldsmiths' Company's Hall, and Lincoln's Inn Hall and Library. Died i 870.

Hart, Solomon Alexander. Silver Medal in 1826 for a Finished Drawing from a Statue. Subject painter. R.A. Exhibited from I 826-1880. Librarian of the Royal Academy for some years. He was about twenty when he gained the medal. Died i 88 I.

Hassell, Edward. Silver Medal in 1828 for an Oil Painting of the Altar-piece of St. Margaret's ; Silver Medal in 1829 for Painting of Interior of Edward the Confessor's Chapel. Landscape painter. Secretary to Society of British Artists. Most of his exhibits were interiors of Gothic cathedrals. Died about i 852 .

Hassell, John. Silver Medal in 18 Io for Improvements in Aquatint. Draughtsman and engraver. Worked in aquatint. Published Illustrated Guide to Bath, and some other works.

Hayter, George. Silver Medal in 1821 for an Etching from a picture by Titian. Sir George Hayter. Portrait and historical painter. He was appointed portrait and history painter to Queen Victoria on her accession. Died I 87 I.

Head, Guy. Silver Palettes in 178 I and 1782 for Historical and Landscape Drawings. Portrait painter. Resided many years in Rome. "Best known as a copyist" (Redgrave). Died I 800.

Hearne, Thomas. Premiums in 1763 for a Drawing, in I 764 for a Drawing of a Horse, in I 765 for an Etching, in 1767 for a Landscape; Gold Palette in 1776 for a Landscape in Oils. Water-colour painter. Worked first as an engraver. Exhibited at Royal Academy 
up to I 802 . His drawings for the Antiquities of Great Britain were engraved by W. Byrne (q.v.). Died I 8 I 7 .

Hebert, William. Prenium in 1760 for a Flower Picture. Engraver. Published some landscapes.

Henderson, John. Premium in i 762 for a Drawing. Engraver. Pupil of Shipley. Abandoned his art and became a successful actor. Died i 785 .

Henning, John. Silver Medal in 1816 for a Plaster Cast. Modeller. Copied some of the Elgin Marbles. Died I $85 \mathrm{I}$.

Hilditch, George. Gold Medal in 1823 for an Original Landscape in Oil ; Silver Medal in 1824 for a Copy in Oil ; Silver Medal in 1825 for an Original Picture (still life) in Oil. Landscape painter. Exhibited at Royal Academy i 823-1 856 . Died i 857 .

Hoare, Prince. Premium in 1772 for a Flower Picture. Portrait and historical painter. Exhibited at Royal Academy I78I-I8I5. Son of William Hoare, R.A. Wrote several books on Art. Foreign Corresponding Secretary to Royal Academy. Died I 834.

Hodges, William. Premium in 1759 for Modelling in Clay ; Premiums in 1762,1763 , and 1764 for River Views. Landscape painter. R.A. Errand-boy in Shipley's School. Appointed in 1772 draughtsman to Captain Cook's second expedition. Died 1797.

Hodgson, Thomas. Premium in 1775 for Wood Engraving. Wood engraver. Employed by Bewick, and practised on his own account.

Hole, Henry. Gold Palette in 1804 for Wood Engraving. Wood engraver. Pupil of Bewick.

Hollis, Thomas. Gold Medal in 1837 for a Water-colour. Draughtsman. Son of George Hollis, engraver, and worked with him. Died I 843 .

Hook, James Clark. Silver Medals in 1837 and 1838 for Drawings in Chalk; Silver Medal in 1840 for Two Portraits in Oil. Marine painter. R.A. Died 1907. Hopwood, James. Silver Palette in 1803 for an Outline Drawing. Engraver. "Designed and engraved some clever book illustrations " (Redgrave). 
Horsley, John Callcott. Silver Medal in 1830 for a Chalk Drawing from a Bust; Silver Medal in I83 I for a Finished Drawing from a Statue. Subject painter. R.A. He painted the portrait of "Queen Victoria and her Children" in the Society's meeting-room. As Horsley was born in 1817 his first award was taken when he was thirteen. Died 1903.

Horwell, Charles. Silver Palette in 1787 for a Figure of Psyche. Sculptor. Gold Medallist R.A. I788.

Exhibited at Royal Academy i 787-1807.

Howard, Frank. Silver Palette in I 822 for a Chalk

Drawing. Designer and draughtsman. Son of Henry Howard, R.A. Exhibited at Royal Academy i 825I 846. Published various works, mostly manuals of instruction in Art. Died i 866.

Hughes, Edward. Silver Palette in I846 and Silver Medal in 1847 for Drawings. Portrait painter. Exhibited at Royal Academy I 855-1884. Painted portraits of Queen Mary, Queen Alexandra, and other members of the Royal family. Died 1908.

Hullmandel, Charles Joseph. Silver Medal in I819 for Specimens of Lithography. This same year a Gold Medal was awarded to Senefelder for the invention of lithography. Hullmandel, who was an artist, took up lithography in i 818 . From that time he devoted himself to it, and with great success. He introduced many improvements, and was associated with the production of many important works. Died 1850 .

Humphreys, William. Premium in 1764 for a Drawing ; Premiums in 1765 and 1766 for Mezzotints. Engraver. "His mezzotints . . possess very high merit, and were esteemed among the best of the time" (Redgrave.)

Hurlstone, Frederick Yeates. Silver Palette in I 812 for a Drawing ; Silver Medals in I8I 3 and I 814 for Drawings ; Silver Medals in 1816 and 182 f for Oil Paintings. Portrait and history painter. Exhibited at Royal Academy I82I-I 845. Took Gold Medal at Paris Exhibition 1855. President of the Society of British Artists. Died I 869 . 
Hurlstone, Richard. Premiums in 1763 and 1764 for Drawings. Portrait painter. Exhibited at Royal Academy I77I-1773. Died about I 774 .

Inwood, Henry William. Silver Medal in 18 I 6 for Original Architectural Drawing. Architect. Joint architect with his father of St. Pancras' Church. Exhibited at Royal Academy 1809-1838. Died 1843 .

Ireland, Samuel. Premium in 1760 for a Drawing. Engraver. Exhibited at Royal Academy in I 782 . Published several works. His son, William Henry Ireland, was the author of the famous Shakespearean forgeries. Died I 800 .

Jeffereys, James. Gold Palette in I 774 for an Historical Drawing. Marine painter. Gold Medallist R.A. 1773. Exhibited at Royal Academy in 1783. Died 1784 .

Jones, George. Silver Palettes in I 802, I 804, and I 805 for Drawings. Battle and subject painter. R.A. He was supposed to resemble the great Duke of Wellington, and acted the part. Died 1869.

Jones, Thomas. Premiums in 1764 and 1765 for Drawings; Premiums in 1767 and 1768 for Landscapes. Landscape painter. Exhibited at Royal Academy I 784-I 798 .

Jukes, Francis. Premium in 1778 for a "Map of Boston in Aqua Tinta." Painter and engraver. "Successful in aquatint, principally sea-pieces and landscapes" (Redgrave). Died I812.

Keith, Elizabeth. Premium in 1755 for a Drawing. She obtained the second prize in the class between fourteen and seventeen in the Society's first competition. According to Dossie, she died young.

Kelsey, Charles Samuel. Silver Medal in I 846 for a " design for a ticket of admission to the Society's Rooms "; Silver Medal in I 847 for a figure. Sculptor. Exhibited at Royal Academy i 840-1877.

Kelsey, Richard. Silver Medal in 18 i 9 for a Design for a Mansion; Silver Medallion in 1820 for a Design 
for a National Museum. Architect. Gold Medallist R.A. I 82 I .

Kendrick, Emma Eleonora. Silver Palette in 18 I 1 for a

Drawing; Silver Medal in 1812 for a Miniature;

Gold Medals in 1814 , I 815, I 816 , and 18 I 7 for Miniatures. Miniature painter. Daughter of Josephus

Kendrick. Exhibited at Royal Academy i 8I I-I 840.

Miniature painter to William IV. Died I 87 I.

Kendrick, Josephus. Silver Medal in I8 I f for a Plaster

Cast. Sculptor. Gold Medallist R.A. I8I3. Exhibited at Royal Academy i 8 I 3-I 829.

Keyse, Thomas. Premium in I 764 for a Method of Fixing

Crayon Drawings. Painter of still life. Keeper of Bermondsey Spa. Died i 800.

Kirby, Sarah. Premiums in 1757 and I 758 for Ornamental Designs. Daughter of Joshua Kirby, F.R.S., architect and writer on perspective. Afterwards Mrs. Trimmer, the once popular educational writer. Kirby, William. Premiums in 1760 for an Etching, and in $176 \mathrm{I}$ for a Landscape Drawing. Son of Joshua Kirby, F.R.S. Died I 77 I.

Kirk, John. Premiums in 1759,1762 , and 1763 for Die Engraving. The 1762 premium (30 guineas) was for " the Seal for the Society's letters, after a design of Cipriani." Medallist. Died 1 776.

Kirk, Thomas. Silver Palette in 1785 for Historical Drawing. Painter and engraver. Exhibited at Royal Academy 1785-I794. "An eminent artist," who "passed like a meteor through the region of art" (Dayes, quoted by Redgrave). Died I 797 .

Kitchingman, John. Premiums in $1762,1763,1764,1765$, and 1766 , and Gold Palette in 1770 for Drawings in various classes. Miniature painter. Pupil of Shipley. Exhibited at Royal Academy I770-I78I. Died I78I.

Lambert, James. Premium in I770 for a Landscape. Landscape painter. Exhibited at Royal Academy I 774-I 778. A well-known scene-painter and a friend of Hogarth. He was the first President of the Incorporated Society of Artists. Died I 779. 
Landseer, Charles. Silver Palette in I8 5 for a Drawing of the Laocoon. Subject painter. R.A. Brother of Sir Edwin Landseer. Died I 879.

Landseer, Edwin. Silver Palette in 1813 for Drawing of Animals from Life; Silver Medal in 1814 for a Drawing of a Horse; Silver Medal in 1815 for a Painting of a Dog; Silver Medal in 1816 for an original Painting, "The Stable Guardian." As he was born in March i 802 he was only eleven when he received his first award. The eminent and popular Animal painter, Sir Edwin Landseer, R.A. Died I 873 .

Landseer, George. Silver Medal in I841 for "Watercolour Drawings of Birds and Beasts from Nature" ; Silver Palette in I 842 for an "Oil Painting of a Lion from Nature." Portrait and landscape painter. Only son of Thomas Landseer, A.R.A. Was in India from about I 844 to I 870 . Died I 878 .

Landseer, Miss. Silver Palette in 1813 for an Original Landscape. This was probably Jessica, daughter of John Landseer, R.A. (and sister of Edwin), who " used the painter's brush and the etching-needle," and "etched a few designs after her brother Edwin" (Bryan). Exhibited at Royal Academy 1816 and afterwards. Her younger sister Emma (Mrs. Mackenzie) did not begin to exhibit until 1838 .

Landseer, Thomas. Silver Palette in i 8 i o for an " Etching of Sheep and Goats"; Silver Medal in 1813 for an "Etching of Animals"; Silver Medal in I8I4 for a Painting of a Horse. Engraver. A.R.A. Eldest brother of Sir Edwin Landseer, many of whose pictures he engraved. Died I 880.

Lane, John Bryant. Silver Palette in 1806 and Gold Medal in 1807 for Historical Drawings. Historical painter. Exhibited sacred and classical subjects at Royal Academy i 808-18I3. Then went to Rome and devoted fourteen years to the production of what he hoped would be a masterpiece, but proved a failure, "The Vision of Joseph." Afterwards he showed some portraits at the Royal Academy I 83 I-1 834 . 
Lawranson, William. Premiums in 1760, I761, 1762, I 763, 1764, I765, and I766 for Drawings. Portrait painter. Exhibited at Royal Academy 1774I 780 .

Lawrence, Thomas. Silver Gilt Palette and Five Guineas in I 784 for a Copy of the "Transfiguration " of Raphael. The committee found that the drawing had not been executed within the limit of time specified, and therefore that it was disqualified, and they consequently withheld the Gold Medal offered. Subsequently they decided to make the above-named award, " as a token of the Society's approbation of his abilities." The award, therefore, does not appear in the printed list. The only record of it is in the Society's minutes and the committee minutes (Committee of Polite Arts, 9th and 3oth March 1784). The candidate was afterward Sir Thomas Lawrence, P.R.A. He was not fourteen years of age when the award was made, as he was born in May i 769. Died I 830 .

Lawrie (or Laurie), Robert. Premium in 1770 for a Drawing ; Premiums in I 773,1775 , and I 776 for Ornamental Designs; Silver Palette in 1773 for a Study of Flowers ; Bounty of 30 guineas in 1776 for Improvement in Mezzotint Colour Printing. Engraver. Besides producing a large number of engravings, he carried on the business of a publisher of prints, maps, etc. Died I 836 .

Leake, Henry. Premium in 1760 for a Drawing. Portrait painter. Pupil of W. Hoare, R.A.

Legrew, James. Silver Palette in 1822 for a Plaster Model. Sculptor. Pupil of Chantrey. Gold Medallist R.A. I 829. Produced many groups of merit. Died I 857 .

Le Jeune, Henry. Silver Palette in I 834 for a Copy of a Figure in Indian Ink. Historical painter. A.R.A. Gold Medallist R.A. I 84I. Died I904.

Liart, Matthew. Premiums in 1764 and 1765 for Drawings. Premium in 1766 for an Engraving. Engraver. Died about 1782 . 
Lines, Samuel. Silver Medal in I825 for Pencil Drawing. Painter and drawing-master. One of the founders of the Birmingham School of Art. Died I 863 .

Linwood, Mary. Silver Medal in 1 786 "for submitting to the inspection of the Society, as examples of works of art, and of useful and elegant employment, three pieces of needlework, representing a hare, still life, and a head of King Lear." Miss Linwood opened her celebrated exhibition of embroidered pictures at the Hanover Square Rooms in 1798 , and afterwards removed to Leicester Square, where her exhibition was considered one of the chief sights of London. Died i 845 .

Loat, Samuel. Silver Medal in 1825 and Gold Medal in 1827 for Architectural Designs. Architect. Gold Medallist R.A. I827. Exhibited a design in I83I, "after which there are no traces of his art" (Redgrave).

Lochée, John Charles. Premium in 1775 (30 guineas) for a Statue; Premium in 1776 (50 guineas) for a Statue; Silver Medallion in 1790 for a Bust of the Prince of Wales (afterwards George IV.). An engraving of this bust forms the Frontispiece to Vol. x. of the Transactions. Sculptor. Exhibited at Royal Academy I776-I790. Some portrait medallions by him were reproduced by Wedgwood and by Tassie.

Long, J. St. John. Silver Medal in 1825 for a Landscape. Brought up as engraver, but did not follow the profession. Not successful as an artist he set up as a quack doctor. Died 1834 .

Lucy, Charles. Silver Medal in 1834 for an Oil Painting. Historical painter. Exhibited at Royal Academy 1838-1873. Most of his works related to the history of England, and were meritorious but not very successful.

Lupton, Thomas Goff. Gold Medal in 1822 for a Mezzotint on Soft Steel. He introduced the use of soft steel for mezzotint (see his paper, Transactions, Vol.xi. 
p. 4I ). ${ }^{1}$ He worked both on steel and on copper, and produced many fine plates after Turner. Died 1873 .

Malton, Thomas. Premium in I 774 for a Drawing of a Tide-Mill. Architectural draughtsman. Gold Medallist R.A. I782. Published several topographical works and views. Died i 804.

Malton, William. Premiums in 1775 and 1777 for Drawings of Machines. Architecturaldraughtsman. Brother of Thomas Malton.

Manning, Samuel. Silver Medals in I 83 I, i 832, and I 838 for Busts; Gold Medal in I 833 for a Model of a Figure; Silver Medal in 1840 for a Group. Sculptor. Son of Samuel Manning, also a sculptor. There is some confusion in the books between father and son. According to the account in the Dictionary of National Biography, which seems the most correct, the "Prometheus," for which the I 833 award was made, was shown in marble at the Royal Academy in 1845 . Died I 865 .

Marchant, Nathaniel. Premiums in I761, 1762, I763, I 764 (two), and I 765 for Engraved Gems. Gem engraver and medallist. R.A. Pupil of E. Burch, R.A. Engraver to the Mint. Designed some coins and medals. "Chief of English gem engravers of the eighteenth century" (King, quoted by Forrer). Died I 8 I 6.

Marsden, Barbara. Premiums in 1755 and 1756 for Drawings; Premiums in 1757 and 1758 for Ornamental Designs. She married Jeremiah Meyer, R.A. (q.v.). The 1758 award was in a class limited to candidates under fourteen, so she cannot have been twelve years old when she took the prize in 1755 .

${ }^{1}$ The credit of having produced the first mezzotint on steel has always been given to William Say, the mezzotint engraver, and it would appear with justice, since there is a mezzotint print by him, dated ISI7, which is said to be from a steel plate. See Chapter IX, p. 2 I6. The two inventors were probably working independently. There is nothing in Lupton's paper to suggest that his work was not original, and probably it was. 
Martin, David. Premiums in 1759,1760 , and 1761 for Chalk Drawings. Portrait painter and engraver. Died I 798.

Martin, William. Gold Palette in 1776 for an Historical Drawing ; Premium in I 780 for a Landscape. History painter. Pupil of Cipriani. Exhibited at Royal Academy 1775-1816. History painter to George III. Mason, William. Silver Medal in 1776 for a Drawing of a Horse. Animal painter.

Masquerier, John James. Silver Palettes in 1794, 1795, and I796; Silver Medal in 1799, all for Drawings. Portrait painter. Born at Chelsea of French parents. Studied in Paris. Pupil of Vernet. Exhibited at Royal Academy I796-I838. Painted Napoleon's portrait. Died I 855 .

Mayor, Barnaby. Premium in 1765 for a Landscape Etching. Engraver and painter. Died I 774 .

Medland, Thomas. Silver Palettes in 1777, I779, and I 780 for Drawings. Engraver. Illustrated numerous books. Exhibited at Royal Academy I 777-1822. Metz, Conrad Martin. Gold Palette in 1783 for an Historical Drawing. A German artist who came to London.

Meyer, Jeremiah. Gold Medal in $176 \mathrm{I}$ for Profile Likeness of George iII. from memory, intended to be, but not actually, used in cutting a die for the coinage. Miniature painter to the king. Miniature painter. R.A. Enameller to King George III. and miniature painter to Queen Charlotte. Married Barbara Marsden (q.v.), who took several of the Society's prizes. Died 1789.

Milbourn, John. Premiums in 1763,1764 , and 1765 for Drawings. Portrait painter. Exhibited at Royal Academy 1773 and 1774 .

Millais, John Everett. Silver medals in I 839 for Drawing in Chalk from a Bust; in I 840 for an Historical Composition in Pencil; in 1841 for an Historical Composition in Sepia ; Gold Medal in 1846 for an Original Historical Painting; Gold Medallion in 1847 for an Original Composition in Oil. Subject, landscape, 
and portrait painter. Sir John Everett Millais, Bart., P.R.A. As Sir John Millais was born in 1829, his first award was obtained when he was only ten. Died I 896.

Miller, John. Premiums in 1764 for a Flower Picture ; and in 1766 for an Engraving. Flower painter and engraver. Published an illustrated botanical work, $1770-77$.

Mills, George. Gold Medals in 1817 and 18 i 8 for Medal Dies, and in 1823 for presenting the Society with a new Die for the Vulcan Medal. Medallist. Produced medals of General Moore, Watt, West, George Iv., and Sir F. Chantrey. Exhibited at Royal Academy 1816-1823. Died 1824.

Mitchell, Thomas. Premium in 1766 for a Sea-piece. Marine painter. Exhibited at Royal Academy 1774I789. Had appointments in the dockyards, and worked as an amateur.

Moore, Francis John. Premium in 1766 for an Allegorical Bas-relief; Silver Palette in 1769 for a Statue. Sculptor. Died 1809.

More, Samuel. Premiums in 1763 and 1764 for two sets of Impressions of Pastes resembling Antique Cameos and Intaglios. Afterwards Secretary of the Society.

Moring, Thomas. Gold Medal in i 845 for " an Engraving on White Cornelian." Seal engraver. Practised as a professional seal engraver and medallist. Died I 884 .

Mortimer, John Hamilton. Premiums in 1759 (two), 1760,1761 , and 1762 ; Premium in 1763 (50 guineas) for an Oil Painting "Edward the Confessor taking his Mother's Treasures" ; Premium in 1764 (100 guineas) for "St. Paul Preaching to the Britons." The last picture was placed as an altar-piece in the church of High Wycombe, Bucks, where the painter is buried. History painter. A.R.A. Died I 779 .

Moser, George Michael. Premium in 1758 for "A Model, chased in gold, of an Honorary Medal proposed by him to the Society ... afterwards engraved by John Kirk" (Dossie). Enameller and modeller. R.A. 
One of the founders of the Royal Academy, and its first Keeper. "Had high merits as an artist, excelling not only as a chaser, but as a medallist, and he painted in enamel with great beauty and taste" (Redgrave).

Moser, Joseph. Premiums in I762, I 763 , and 1765 for Modelling in Wax. Enameller. Nephew of G. M. Moser, R.A. Exhibited at Royal Academy I774I 787. Afterwards a London Police Magistrate.

Moser, Mary. Premium in 1758 for an Ornamental Design ; Premium and Silver Medal in 1759 for a Flower Picture. The Silver Medal was a special and additional award "presented to her as a further Reward for her extraordinary merit." Flower painter. R.A. Daughter of G. M. Moser, R.A. Original member of Royal Academy, and one of the two woman Academicians (the other being Angelica Kauffmann). Married Captain Hugh Lloyd. Died I 8 I 9 .

Moses, Henry. Silver Palettes in I800 and I80 I for Drawings. Engraver. Produced plates after Barry, Northcote, Opie, and others. Died I 870.

Mulready, William. Silver Palette in I 801 for a Drawing. Subject painter. R.A. Mulready was born in I786, so he was only fourteen at the date of the award. In I 848 a collection of Mulready's works was exhibited in the Society's house. Died I 863.

Nesbitt, Charlton. Silver Palette in I798, and Silver Medal in 1802 , for Wood Engraving. Wood engraver. A pupil of Bewick. Successful illustrator of numerous books. Died I 838 .

Netherclift, Joseph. Premium in I 829 for Lithographic Transfer Paper. Lithographer and printer. This was the first practical transfer paper, for though the earliest lithographs made were transfers, the diffculties attending the process were so great that the work was all executed direct on the stone until a suitable paper was produced. Died I 863.

Nollekens, Joseph. Premium in I759, at the age of 
eighteen, for a Drawing; Premiums in 1759,1760 , I76I (two), and I 762 for Bas-reliefs. Sculptor. R.A. One of Shipley's pupils. This celebrated sculptor amassed a large fortune by his work. His peculiarities are well known from the Life by Smith, Nollekens and His Times. Died I 823 .

Norton, Christopher. Premium in 1760 for a Drawing. Engraver.

Okey, Samuel. Premiums in 1765 and 1767 for Mezzotints. Engraver. Engraved after Sir J. Reynolds, Pine, and others.

Pain, George Richard. Gold Medal in 1812 for a Design for a Church ; Silver Medal in I 8 I 3 for a Design for a Palace. Architect. Apprenticed to Nash. Went to Ireland about 1817 , and practised there. Died I 838 .

Papworth, Edgar George. Silver Medal in 1825 for a Pencil Drawing; Silver Palette in I 827 for a Basrelief. Sculptor. Died I 866.

Papworth, John Woody. Silver Medal in i 838, Gold Medal in 1840 , and Gold Medallion in 1845 for Architectural Designs. Architect and heraldic painter. Designed for glass, pottery, and textiles. Brother of Wyatt Papworth. Died I870.

Papworth, Wyatt. Silver Medal in 1836 , and Silver Palette in 1838 for Architectural Drawings. Architect. Editor of the Dictionary of Architecture. Curator of Soane Museum. Died I 894 .

Parke, Henry. Silver Medals in I807, I 808, I810, I8I I, I 812 ; and Gold Medal in 18 I 4 for Sea-pieces. Architect. Pupil of Sir John Soane. Made many drawings of monuments of Italy and Egypt, and, according to Redgrave, "Some naval drawings of much ability." A collection of his drawings is preserved by the R.I.B.A. Died 1835 .

Parker, John. Premiums in 1762 and 1763 (two in each year) for Drawings in different classes. Landscape painter. Exhibited at Royal Academy I 770-I 778. 
Parry, William. Premiums in $1760,1761,1762,1763$, 1764 , and 1766 for Drawings in various classes. Portrait painter. A.R.A. Died I 791 .

Pars, Albert. Premiums in 1759, I 764 , and 1765 for Modelling in IVax; Premium in 1767 for a Bronze Cast. Modeller. Brother of William Pars, A.R.A. "Successful modeller in wax" (Redgrave).

Pars, Anne. Premiums in I 764, I 765, and I 766 for Drawings. Sister of William Pars, A.R.A. Exhibited at Royal Academy in I 786.

Pars, William. Thirteen Premiums from 1756 to 1764 in various classes, including Drawings of Landscapes, Animals, Still Life, and Ornamental Design, Wax Modelling, and an Oil Painting. In 1757 he was admitted to the class under fourteen, so he cannot have been thirteen when he took his first award. Portrait painter. A.R.A. Produced also views of temples in Greece and in Asia Minor, and some Swiss views. Brother of Henry Pars, Shipley's successor as the Master of the Academy in the Strand. Died 1782.

Parsons, William. Premiums in 1757,1758 , and 1760 for Drawings. Portrait painter (amateur). Died 1795.

Patmore, Coventry. Silver Palette in I 838 for a Pencil Drawing. The well-known poet. He contributed to the Germ, and was a friend of the first pre-Raphaelites, but does not appear to have continued his artistic studies or work. Died I 896.

Patten, George. Silver Palette in 1816 for a Miniature. Portrait and history painter. A.R.A. Exhibited at Royal Academy I 819 to about i 865 . Portrait painter in ordinary to Prince Albert. Died 1865.

Pearson, Mrs. C. Silver Palette in 1816 , Silver Medal in 1817, Gold Medal in 1819 for Oil Paintings. Portrait painter. Exhibited at Royal Academy I 82I-I 842. Her maiden name was Dutton, and the first two awards were gained before her marriage. Died 1871 .

Peart, Charles. Silver Medallion in 1783 for Modelling from the Life. Sculptor. Gold Medallist R.A. I782. Exhibited at Royal Academy i 778-i 798. 
Peters, Matthew William. Two Premiums in I759 for Drawings. Portrait" and history painter. R.A. Became a clergyman and abandoned painting, except as an amateur. Died 1814.

Pether, William. Premiums in 1756 for a Drawing and for an Ornamental Design; in 1760 and 1767 for Mezzotints. Mezzotint engraver. Exhibited miniatures at Royal Academy I78I to I 794, but " his true art was mezzotint," in which he "gained great distinction "(Redgrave). Died about I 794 .

Physick, Edward Gustavus. Silver Medals in 1823 and I 824 ; Gold Medal in I 826 for Plaster Models. Sculptor. Exhibited at Royal Academy and elsewhere r822I 868.

Physick, E. J. Silver Medal in I 846 for a Plaster Cast; Silver Medal in I 847 for a Modelled Figure. Sculptor. Pinches, Thomas R. Silver Medals in 1836 and 1837 for Medal Dies. Medallist. One of the well-known family of London die-sinkers and medallists. "Cut many military, academical, and private medals" (Forrer). Amongst them was a memorial medal of the Duke of Wellington, i 852 .

Pine, Robert Edge. Premium in 1760 (100 guineas) for an Oil Painting, "The Surrender of Calais" ; Premium (Ioo guineas) in 1763 for " Canute Rebuking his Courtiers." History and portrait painter. Exhibited at Royal Academy and elsewhere 1760-1784. Went to America. Died at Philadelphia 1790.

Pingo, Benjamin. Premiums in 1765 . I 766, and 1769 for Drawings. Youngest son of Thomas Pingo.

Pingo, Henry. Premiums in 1756,1758 , I 759,1760 , and I 76 I for Ornamental Designs. Second son of Thomas

Pingo. Exhibited flower pictures at Free Society of Artists, I 772 and 1773 .

Pingo, John. Premiums in 1759 , I760, I762, I763, and I 765 for Die Engraving. Medallist. Assistant Engraver to the Mint. Eldest son of Thomas Pingo.

Pingo, Lewis. Premiums in 1756 and 1759 for Drawings ; Premiums in 1759 and 1760 for Medallions ; Premiums in 1757,1758 , 1760, and 1761 for Ornamental Designs; 
Premiums in 1761 , I 763 , and 1 764 for Die Engraving ; Premium in 1763 for Gem Engraving; Gilt Palette in 1770 , Gold Palettes in 1771 and 1772 for Medallions. Medallist. Third son of Thomas Pingo. Engraver to the Mint. Died i 830 .

Pingo, Mary. Premiums in 1758 and 1759 for Ornamental Designs; in 1761 and 1762 for Drawings of Flowers. Daughter of Thomas Pingo.

Pingo, Thomas. Paid 80 guineas in 1758 for making the dies for the Society's First Medal from a design by James Stuart, the Architect, "Athenian Stuart." Medallist. Engraver to the Mint. Died I 776.

Pitts, William. Gold Medal in 1812 for a Wax Model. Sculptor. Exhibited at Royal Academy i 823-I 839. Produced much successful work. Died I 840 .

Pocock, William Fuller. Silver Medallion in 1807 for an Architectural Design. Architect. Exhibited at Royal Academy I 799-I 84I.

Porter, John Ashwood. Premium in 1755 for a Pen-andInk Drawing. He was the last of the five candidates who took the first prizes offered by the Society for young people under fourteen. "He was the son of a drawing-master in Wapping" (Dossie), but nothing more seems to be known about him.

Porter, Robert Ker. Silver Palette in I 793 for an Historical Drawing. History painter. Sir Robert Porter, brother of Anne and Jane Porter, the novelists. "He was by turns, during his adventurous career, artist, soldier, author, and diplomatist" (Redgrave). Died I 842 .

Poynter, Ambrose. Silver Medallion in 1818 for an Architectural Design. Architect. Father of Sir Edward Poynter, P.R.A. Exhibited at Royal Academy I817-1852. Foundation Member of R.I.B.A., and its Secretary 1840 , etc. Took important part in establishment of Schools of Design. "Had considerable practice as an architect" (Dictionary of National Biography). Died I 886.

Proctor, Thomas. Gold Palette in 1787 for an Historical Drawing. Sculptor and history painter. A brilliant 
but unfortunate genius. Gold Medallist R.A. I784. Exhibited at Royal Academy 1785-1794. Died in misery and want 1794 .

Pugh, Hubert. Premium in 1765 for a Landscape in Oil.

Landscape painter. "There is a work of his in the Lock Hospital " (Redgrave). Died after 1788.

Pye, Charles. Silver Palette in 1791 for a Drawing. Engraver.

Radclyffe, George Edward. Silver Medal in I 824 for an Etching. Silver Palette in 1826 for an Engraving. Engraver. Worked for the Annuals and Art Journal. Died 1863 .

Raimbach, Abraham. Gold Palette in I 806 for Wood

Engraving. Engraver. Exhibited miniatures at Royal Academy I797-1805, but afterwards devoted himself to engraving. Engraved many of Wilkie's pictures. Died I 843 .

Ranson, Thomas Frazer. Silver Medal in I814; Gold Medals in 1821 and 1822 for Engraving. Engraver. $\mathrm{He}$ was interested in the question of preventing the forgery of bank-notes, and barely escaped conviction for having a forged note in his possession.

Ravenet, François Simon. Premiums in 1761,1762 , and I 764 for Engravings. Engraver. A.R.A. Native of France. Came to England about I 750. Worked for Hogarth and Boydell. Engraved the "Mariage à la Mode." Died I 774 .

Read, Nicholas. Premiums in 1762 ( 100 guineas) and in I 764 (140 guineas) for Statues. Sculptor. Pupil of Roubiliac, and his successor. Some monuments by him are in Westminster Abbey. Died I 787 .

Read, Richard. Silver Palette in I77 I for a Drawing. Engraver. Worked chiefly in mezzotint.

Reinagle, Philip. Premium in I767 for a Drawing. Animal and landscape painter. R.A. "His hunting pieces, sporting dogs, and dead game were excellent" (Redgrave). Died 1833 .

Revel, Richard. Premium in 1755 for a Chalk Drawing of a Horse. This was the fifth prize in the class 
between fourteen and seventeen in the Society's first competition. "Nothing seems to be known of his after career" (Dossie).

Richardson, George. Premium in 1765 for an Architectural Drawing. Architect. Author of the New

Vitruvius Britannicus and other works on architecture. Rigaud, Stephen Francis. Silver Palette in 1794; Gold Palette in I 799 for Drawings. Water-colour painter. Exhibited at Royal Academy 1797-I815.

Roberts, James. Premium in 1766 for a Drawing. Portrait painter. Exhibited at Royal Academy I 773-1799.

Robertson, George. Premiums in 1760 and 1761 (three) for Drawings. Landscape painter. Pupil of Shipley. Went to Jamaica and painted views of the island, which were exhibited in London and engraved. Died I 788 .

Rochard, Frederick. Silver Medal in 1823 for a Watercolour Portrait. Miniature painter. Exhibited at Royal Academy from i 819 . Died 1858.

Rogers, Philip Hutchins. Silver Medal in 1808 and Gold Medal in 18 I 1 for Oil Paintings. Marine and landscape painter. Exhibited at Royal Academy and elsewhere I 808-1851. Died I 853 .

Rolls, Charles. Silver Medal in 1818 for a Drawing. Engraver and draughtsman. Assisted the Findens in their Gallery of British Art.

Romney, George. Premium in I763 (20 guineas) for an Oil Painting of the Death of General Wolfe ; Premium in 1765 (50 guineas) for Oil Painting of the Death of Edward the First. The celebrated Portrait painter. Died I 802 .

Romney, John. Silver Palette in I 806 for Outline Drawing. Engraver and draughtsman. Engraved some of Smirke's illustrations to Shakespeare, etc. Died I 863 .

Rooker, Michael Angelo. Premiums in 1759 for a Drawing (age under fourteen), and in 1760 for a Landscape. Water-colour painter and engraver. A.R.A. Died 1801 . 
Ross, William. Silver Palette in I 807 for a Drawing (at the age of twelve) ; Silver Medal in 1808 for a Drawing; Silver Palette in 1809 for a Miniature; Silver Medals in 18 I 0 and 18 I I for Drawings; Silver Palette in 1 8 I 3 for a Drawing; Gold Medal in 18 I 6 for a Portrait of the Duke of Norfolk; Gold Medal in 18 I 7 for an Historical Painting. Sir William Ross, R.A., the well-known Miniature painter. He was Chairman of the Committee of Fine Arts I 845-6, and a Member of the first Council 1845 and 1846. An exhibition of his works was held by the Society in 1860. Died I 860 .

Rossi, Charles. Premium in I 794 (50 guineas) for a Group of Statuary. Sculptor. R.A. Sculptor to George iv. and to William IV. Executed several monuments in St. Paul's Cathedral. Died 1839.

Rossi, Henry. Silver Medal in I8 I5 for Copy of Plaster Cast. Sculptor. Designed terra-cotta ornaments for interior of St. Pancras' Church.

Russell, John. Premiums in 1759 and 1760 for Drawings. Portrait painter. R.A. His best work was in crayons, and he published a book on Painting with Crayons. Died i 806.

Ryder, Thomas. Premium in I 766 for a Drawing ; Gold Medal in 1803 for a Line Engraving. Engraver and draughisman. "One of the best engravers of his time" (Redgrave). Executed eight plates for Boydell's Shakespeare Gallery. Died i 810.

Ryley, Charles Reuben. Premium in 1770 for a Drawing. History painter. Gold Medallist R.A. I778. Exhibited at Royal Academy i 780-I 798. Died I 798.

Samuel, George. Silver Medallion in I 784 for a View of the Front of the Society's House. Landscape painter. Exhibited at Royal Academy i 786-I 823 .

Samuel, Richard. Premium in 1773 for a Tool for Laying Mezzotint Grounds; Gold Palettes in 1777 and 1779 for Drawings. Portrait and historical painter. Exhibited at Royal Academy I 772-1779.

Sass, Henry. Silver Medal in 1807 for an Outline of the 
Laocoon. Portrait painter and teacher. According to Redgrave he was more successful in the latter capacity than in the first. Exhibited at Royal Academy isos-1838. Died I 844 .

Savage, William. Silver Medal in 1825 for " Block Printing in Colours in Imitation of Drawings." Painter and engraver. Experimented in printing in colour from wood blocks, and published a book on the subject in I 822. Died i 843 .

Say, Frederick Richard. Silver Palette in I8I7 for a Drawing ; Silver Medal in I 8 I 9 for a Chalk Drawing ; Silver Medal in 820 for Crayon Drawings. Portrait painter. Exhibited at Royal Academy from 1825. Died probably about i 860 .

Scharf, George. Silver Palette in I 835 and Silver Medal in 1836 for Drawings. Sir George Scharf, K.C.B., Keeper of the National Portrait Gallery. Died 1895.

Scheemakers, Thomas. Premiums in 1 765 for Modelling in Clay, and in 1766 for a Bas-relief. Sculptor. Son of Peter Scheemakers, a Belgian sculptor who settled in London. Exhibited at Royal Academy 1765I 804 . Died I 808.

Schiavonetti, Lewis. Silver Medal in 1807 for Engraving of the British Troops in the Bay of Aboukir. Engraver. Pupil of Bartolozzi. Died i 8 Io.

Scott, John. Gold Medal in I 8 i i for two Original Engravings of Fox-Hunting. Engraver. Successful as an engraver of animals. Died 1828 .

Scoular, James. Premium in 1755 for a Drawing (at age of fourteen). Miniature painter. Exhibited at Royal Academy $176 \mathrm{I}-\mathrm{I} 787$.

Scoular, William. Silver Medals in 1816 and 1819 ; Gold Medal in 1820 ; all for Models. Sculptor. Gold Medallist R.A. I8I7. Exhibited at Royal Academy I 8 I 5-I 846 .

Scriven, Edward. Gold Medal in 1813 for an Engraving after Gerard Douw ; Gold Medal in I 8 I 5 for Engravings after West. Engraver. Worked for Dilettani Society, Shakespeare Gallery, etc., and was much employed by publishers. Died I $84 \mathrm{I}$. 
Seddon, Thomas. Silver Medal in I 848 for Drawings of an Original Design for an Ornamental Carved Sideboard. He was the son of a cabinetmaker. Landscape painter. Exhibited at Royal Academy i 852-i 856. A collection of his works was shown at the Society in 1857 , when an address was delivered by John Ruskin (Joumal, vol. v. p. 360). Died 1856. Senefelder, Aloys. Gold Medal in 18 i 9 for the Invention of Lithography. The process had been perfected in 1798 , and lithographs had been published in England in I80I, but in I8 8 Senefelder published his book on the subject.

Setchel, Sarah. Silver Palette in 1829 for a Pencil Drawing. Water-colour painter. Exhibited at Royal Academy and elsewhere I83I-I867. Gained great popularity by her picture, "The Momentous Question." Died I 894 .

Sharp, William. Premium in 1760 for a Drawing; Premiums in 1761,1763 , and 1764 for Designs. Engraver. "One of the most celebrated of English line engravers" (Bryan). Engraved West's portrait of Samuel More, the Society's Secretary. Died I824. Shelley, Samuel. Silver Palette in I 770 for a Figure Drawing. Miniature painter. Exhibited at Royal Academy I 773-I 808 . Died I 808 .

Shenton, Henry Chawner. Silver Medal in i 844 for a Clay Model of Sabina. Sculptor. Son of the engraver of the same name. Died i 846 .

Sherlock, William. Premium in 759 for a Figure Drawing; Premium in 1760 for an Engraving. Portrait painter and engraver. Exhibited at Royal Academy I 802-1806. Engraved portrait heads for Smollett's History of England.

Sherwin, John Keyse. Silver Palette in I 769 for a Drawing; Premium in 1772 (50 guineas) for a Drawing; Premium in 1774 for an Engraving; Premium in I 775 for an Engraving; Gold Medal in I778 for "Excellence in Engraving." The engraving (reproduced in the plate facing page 157) for which the I 774 Premium was awarded was used for a vignette 
on the title-page of the Register of Premiums and Bounties issued in 1778 , and was reprinted as a frontispiece to the first volume of the Transactions. Engraved the portraits of Lord Folkestone (p. 12) and Lord Romney (p. I6). Engraver and history painter. Worked under Bartolozzi. Gold Medallist R.A. I 772 (for a Painting). "It is as an engraver that he will rank high among our artists" (Redgrave). Engraver to George IrI. Died I 790.

Sievier, Robert William. Silver Medal in I812 for a Pen-and-Ink Drawing. Engraver and sculptor. After practising as an engraver for some years he devoted himself to sculpture. A man of varied accomplishments and of scientific tastes, he became an F.R.S. Died i 865 .

Simmons, William Henry. Silver Medal in 1833 for an Engraving. Engraver. "For many years perhaps the chief of English workers in his own line "(Bryan). Engraved after Landseer, Millais, Faed, Holman Hunt, Frith, Rosa Bonheur, and Hook. Died I 882.

Simpson, Philip. Silver Medal in 1822 for a Copy of a Portrait ; Gold Medal in I 823 for a Portrait. Portrait and subject painter. Exhibited at the Royal Academy up to 1836 .

Skelton, William. Silver Palettes in 1778 and 1779 for Drawings. Engraver. Published series of portraits of the family of George III. Died I 848 .

Smart, John. Premiums in 1755 and 1756 (aged twelve) for Drawings; Premium in 1757 for a Portrait in Chalks of Shipley ; Premium in 1758 for a Drawing. Miniaturist. Exhibited at Royal Academy I770-I8II. Spent some years in India. Died I8I I. Smirke, Robert. Silver Medallion in 1797 for Drawing of the Water-Gate at York Buildings. Sir Robert Smirke. Architect. R.A. Died I 867.

Smith, Emma. Silver Palette in 1803 for an Historical Drawing. Water-colour painter. Exhibited at Royal Academy in I 805. She was a granddaughter of "Smith of Derby."

Smith, George. Premiums in 1760,1761 , and 1763 (50 
guineas each) for Landscapes in Oil. Landscape painter. Known as "Smith of Chichester." "In his day they [his works] were lauded beyond their merits" (Redgrave), and he acquired considerable reputation and popularity. Died I 776.

Smith, Joachim. Premium in 1758 for a Medallion Model in Wax; Premium in 1761 for a Composition for Modelling Portraits in Miniature. Modeller. Dossie says that he practised his invention successfully for some years. Some of his models were reproduced by Wedgwood and by Tassie.

Smith, John. Premiums in 1760 and 1761 (25 guineas each) ; Premium in 1762 (50 guineas) for Landscapes in Oil. Landscape painter. Younger brother of George Smith, and not so good a painter. Died i 764 . Smith, J. Catterson. Silver Medal in 1825 for an Oil Painting. Portrait painter. President of the Royal Hibernian Academy. Died I 872 .

Smith, Nathaniel. Premiums in I758, 1761, and 1762 for Modelling Figures in Clay; Premiums in 1759 (two) for Drawings; Premium in 1760 for a Basrelief. Modeller. Pupil of Roubiliac. Assistant to Nollekens.

Smith, Thomas. Premium in 1760 for an Engraved Gem. Seal engraver. No record of any later work of his has been found.

Solomon, Abraham. Silver Medal in $18{ }_{3} 8$ for a Chalk Drawing from a Statue. Subject painter. Exhibited at Royal Academy i 843-i 862. Died 1862.

Spang, Michael Henry. Premium in 1758 (30 guineas) for Modelling the "Seal of the Society used for Letters" designed by Cipriani and engraved by Kirk. Modeller. Carved the decorations on the Admiralty Screen, and the figures on the pediment of Spencer House. Died about i 767.

Spicer, Nehemiah. Premiums in 1762,1763 , and 1764 , and a Gilt Palette in 1768 for Gem Engraving. No further record of his work has been found.

Spiller, John. Silver Palettes in 1778 and 1780 for Outline Drawings. Sculptor. Exhibited at Royal 
Academy 1778-1792. "The statue of King Charles, which stood in the centre of the piazza of the Royal Exchange, before the fire in 1838 , was his work" (Redgrave). Died in 1794.

Spilsbury, John. Premiums in 1761, 1762, and 1763 for Mezzotints. Mezzotint engraver. Engraved some of Reynolds's portraits. Drawing-master at Harrow about i 782 .

Stannard, Mrs. Joseph. Gold Medal in 1828 for an Oil Painting. Wife of Joseph Stannard, a wellknown landscape and marine painter of Norwich. Some members of the Stannard family designed for the Lowestoft Pottery Works.

Staples, Robert. Premiums in I763, I 764, I765, and i 766 for Gem Engraving. He was a jeweller in Harp

Court, Fleet Street. Nothing more seems to be known of his work.

Stevens, Edward. Premiums in 1762 and 1763 for Architectural Designs. Architect. A.R.A. Pupil of Sir

William Chambers. Died 1775 .

Strange, Mary Bruce. Premiums in 1764 and 1765 for Drawings. Daughter of Sir Robert Strange, the eminent engraver.

Stubbs, James Henry Phillipson. Silver Medal in 1826 for an Etching ; Silver Palette in 1828 for a Pen-andInk Drawing. Engraver. Pupil of the Findens. Produced book illustrations and some sporting plates. Died i 864 .

Swaine, Francis. Premium in 1764 for a Sea-piece. Marine painter. "Two small paintings by him are at Hampton Court" (Redgrave). Died i 782 . Swaine, John Barak. Silver Palette in I831 for a Chalk Drawing; Silver Medal in 1833 for an Etching. Redgrave, under John Swaine, the father of J. B. Swaine, says he died in 1828 , and Bryan follows him, but this seems to be a mistake. A John Barak Swaine exhibited in 1837 at the B.I.

Tallmache, William. Silver Medal in 1813 for a Bronze Cast. Sculptor. Gold Medallist R.A. I 805 . "He 
does not appear to have followed up this success" (Redgrave).

Tassie, James. Premium in 1767 for " Figures, Heads, and Portraits of his composition resembling antique onyx." Gem engraver. Exhibited at Royal Academy 1769-1791. Successful in reproduction of ancient engraved gems, and produced many fine originals. Died r 799.

Taylor, Isaac. Gold Palette (and 25 guineas) in I79I for an Engraving of Opie's " Death of Rizzio." Engraver. Pupil of Bartolozzi. "Known chiefly by his works for Boydell's Shakespeare Gallery " (Redgrave). Died I 829 .

Taylor, John. Premiums in I76I and 1762 (two) for Drawings. Portrait and subject painter. Exhibited at Royal Academy i 779-I 800. Died i 838.

Taylor, John. Premiums in 1763 and 1764 for Designs for Medals. Jeweller at Bath (Dossie).

Taylor, Simon. Premiums for Drawings in 1756, 1757, 1758 , and 1759 ; Premiums in 1759 and 1761 for Pictures of Flowers; Premium in 1759 for an Etching. Botanical draughtsman. Pupil of Shipley. Employed by Lord Bute and by Dr. Fothergill. Died about I 798 . Theed, William. Silver Palette in I 820 and Silver Medal in 1822 for Copies of Statues. Sculptor. Son of W. Theed, R.A. Exhibited at Royal Academy i 825I 885. Produced many statues and busts. His most important work is the group of "Africa " in the Prince Consort's memorial. The bust of the Prince Consort in the possession of the Society is his work. Died 1891. Tomkins, Charles. Silver Palette in 1776 for a View of Millbank. Painter and engraver. Son of William Tomkins, A.R.A. Exhibited at Royal Academy I 773-1 779 .

Tomkins, Peltro William. Silver Palette in 1780 for Landscape Drawing; Gold Medal in I 8 I 3 for Method of refining Ox-Gall for artistic purposes. Engraver. Son of William Tomkins, A.R.A. Published various works, original and after other artists. Engraver to Queen Charlotte. Died I 840 . 
Tomkins, William. Premium in 1762 for a Landscape. Landscape painter. A.R.A. Also painted some pictures of dead game. Died I792.

Toussaint, Auguste. Premium in 1766 and Silver Palette in 1768 for Drawings. Miniature painter. Exhibited at Royal Academy 1775-1788.

Towne, Francis. Premium in 1759 for a Design. Landscape painter. Exhibited at Royal Academy I775I 8 Io. Died I 8 I6.

Towne, Joseph. Silver Medal in 1826 for a Model of a Skeleton; Gold Medal in 1827 for a Wax Model of the Brain. The skeleton is now in the museum of Guy's Hospital. He was seventeen when he constructed it, and it served as an introduction to Sir Astley Cooper, who at once put Towne in the way of obtaining employment. Anatomical modeller. Though selftaught, he was soon "engaged continuously in the practice of the art which he originated and brought to perfection, though it died with him " (D'Arcy Power, in the Dictionary of National Biography). $\mathrm{He}$ made over a thousand wax models of anatomical preparations, remarkable both for their verisimilitude and for their artistic qualities. Towne was also a capable sculptor. Died 1879.

Turner, William. Silver Palette in 1793 for a Landscape Drawing. This may have been "Turner of Oxford," who exhibited as a water-colour landscape painter at Royal Academy, etc., for fifty-four years (Bryan), and died i 862 .

Turnerelli, Edward Tracy. Silver Medal in 1833 for a Drawing. Son of Peter Turnerelli, a sculptor of reputation. Studied at Royal Academy. Achieved notoriety by collecting money for a gold laurel wreath for the Earl of Beaconsfield, which Lord Beaconsfield refused. Died 1890.

Twining, Elizabeth. Silver Medal in 1824 for a Watercolour Painting of Flowers. Amateur painter. Philanthropist and botanist. Daughter of Richard Twining. One of the founders of Bedford College. Died I 889 . 
Tytler, George. Silver Medal in 1825 for a Lithographic Drawing. Lithographer. Published some views of Italian scenery. Died i 859.

Underwood, Thomas. Silver Palette in 1828 for a Pencil Drawing of a Landscape. Engraver and writer on art and archoeology. Lived in Birmingham. Died I 882 .

Vacher, Charles. Silver Medal in I 837 for a Lithograph. Water-colour painter. Died I $88_{3}$.

Van Rymsdyk, Andries. Premiums in I 765 (at the age of eleven), I 766 , and I 767 for Drawings ; Premium in i 767 for a Mezzotint. Son of John van Rymsdyk, history painter.

Vendramini, Caroline. Silver Medal in I 82 I for a Drawing. Daughter of Giovanni Vendramini.

Vendramini, Giovanni. Gold Medals in I 819 and I 829 for Engravings. Engraver. His reputation rested chiefly on his reproductions of the Old Masters. Died I 839 .

Vendramini, R. Silver Palette in 1829; Silver Medals in 1830 and I 833 for Drawings. Daughter of Giovanni Vendramini. It is uncertain to which of the two sisters the i 829 and i 830 awards were made.

Vickers, Alfred Gomersal. Gold Medal in 1828 for a Marine Painting. Marine, subject, and landscape painter. Exhibited at Royal Academy and elsewhere i 827-1 837. Died I 837 .

Vivares, Mary. Premiums in I 759 and I 76 I for Drawings ; Premium in 1763 for an Engraving. Daughter of Francis Vivares, the engraver.

Vivares, Thomas. Premiums in 1758 for an Ornamental Design; in 1760 for an Etching; in i76 I for a Drawing; in 1762 for an Etching; in 1763 for a Landscape; in I764 and I765 for Engravings; in I 766 for an Etching. Engraver. Son of Francis Vivares, the well-known engraver. Exhibited at Royal Academy i 783-I 787 .

Vulliamy, Benjamin. Premium in 1758 for a Drawing. He was a son of Justin Vulliamy and the father of Benjamin (the second) and Lewis Vulliamy. Justin 
and the two Benjamins were cminent clock-makers. Benjamin the elder was favoured and consulted by George III. in connection with Kew Observatory, which was a hobby of the King. Died i 810.

Vulliamy, Lewis. Silver Medal in 1813 for an Architectural Design. Architect. Gold Medallist R.A. I813. Exhibited at Royal Academy 1822-1838. Son of Benjamin Vulliamy the elder. Architect of many public buildings in London, and of numerous mansions, including Dorchester House, Park Lane. Died I 87 .

Ward, Edward Matthew. Silver Palette in 1831 for "a copy in Indian ink of figures." Historical painter. R.A. From 1839, when he first exhibited at Royal Academy, his work was popular and successful. Painted several of the pictures in the corridor of the House of Commons. Died i 879.

Ward, Francis Swaine. Premium in 1765 for a Sea-piece. Landscape painter. Entered the service of the H.E.I.C. and went to Calcutta. Made numerous drawings of Indian temples, etc. Died about 1805 .

Ward, John Raphael. Silver Medal in 1823 for a Watercolour Portrait (copy). Engraver and copyist. Produced miniature copies of some of Sir Thomas Lawrence's portraits. Son of James Ward, R.A. His daughter married E. M. Ward, R.A. Died I879.

Ward, William. Silver Palette in 1805 for a Drawing of Ewell Church. Mezzotint engraver. A.R.A. Engraved many of the pictures of George Morland, whose sister he married. Died 1826 .

Ward, William James. Silver Medals in 1813,1814, and I815 for Drawings. Mezzotint engraver. Son of William Ward, A.R.A. Engraver to the Duke of Clarence, afterwards William IV. Died I 840.

Waring, John B. Silver Medal in 1843 for an Architectural Design. Architect. Superintendent at 1862 Exhibition. Author of the three volumes on the Industrial Art and Sculpture of the Exhibition, and of other works on Art. Died i 875 . 
Warner, William. Gold Medal in 1827 for an Intaglio. Seal engraver. Started a business in London, which is still carried on by his son. Engraved seals for Queen Victoria. Died i 872.

Warren, Charles. Gold Medal in 1823 for Improvements in the Art of Engraving on Steel. Engraver. He had been employed in engraving for calico printing. Came to London in 1802 and was successful in book illustration. Chairman of Committee of Polite Arts, 1822. Died i 823 .

Watson, John Burgess. Gold Medal in I 824 for a Design for a House ; Silver Medal same year for a Drawing of a Crane. Architect. Died I 847.

Webber, Henry. Silver Palette in 1783 for an Historical Drawing. Gold Medallist R.A. in 1779 for a Group. As his address was " Etruria," he was presumably employed by Wedgwood.

Westall, William. Silver Palettes in I 798 for a Drawing; and in 800 for a Landscape. Landscape painter. He was draughtsman to Captain Flinders's voyage of Australian discovery, was wrecked, and had many adventures. Died i 850 .

Wheatley, Francis. Premiums in 1762 and 1763 for Drawings; and in 1767 for a Landscape. Landscape and subject painter. R.A. Pupil of Shipley. Died i 80 I.

Wickstead, Philip. Premiums in 1763,1764 , and 1765 for Drawings. Portrait painter. Pupil of Zoffany. Went to Jamaica. Died before 1790.

Wilkins, Robert. Premiums in 1765 and 1766 for Seapieces. Marine painter. Exhibited at Royal Academy 1772-1788. Died about 1790 .

Williams, Penry. Silver Medal in 1820 for a Landscape in Water-colour; Silver Medal in $182 \mathrm{I}$ for a Chalk Drawing. Landscape painter. Exhibited at Royal Academy 1827-1869. Died 1885.

Williams, William. Premium in 1758 for a Drawing. Subject and portrait painter. Exhibited at Royal Academy 1770-1 792 .

Wilson, Andrew. Gold Medal in 1810 for Stereotype 
Printing. Some examples of his work are given in Vol. xxviri. of the Transactions, p. 3 I 7.

Winkles, H. Silver Medal in I 820 for Pen-and-Ink Drawing of St. Mary's Abbey, York. Architect. Joint author (with B. Winkles) of works on the English and French Cathedrals.

Woollett, William. Premium in 1759 for a Drawing. Engraver. His "were the first English engravings that gained notice on the Continent." "His works gave a high character to the English school" (Redgrave). Died 1785 .

Woolner, Thomas. Silver Medal in 1845 for "original modelled design, entitled 'Affection.'" Sculptor. R.A. Died i 892 .

Wright, Richard. Premiums in I 766 and 1768 for Seapieces. Marine painter. His best-known work is his " British Fishery," engraved by Woollett. Died about I 775 .

Wyatt, Henry. Silver Medal in 1812 , and Silver Palette in 1813 for Drawings. Portrait and subject painter. Exhibited at Royal Academy after 1825. Died I 840 .

Wyon, Anne. Silver Medal in I82 I for Modelling Wax Flowers. She was the wife of Thomas Wyon the elder, and the mother of Benjamin.

Wyon, Benjamin. Gold Medals in 1819 and 1821 for Medal Dies. Seal engraver. Chief engraver of seals. Son of Thomas Wyon the elder. Died i 858.

Wyon, James. Silver Medal in 1820 for a "Head in Miniature." Die engraver. Engraver at the Mint. Son of George Wyon, brother of Thomas Wyon the elder.

Wyon, Thomas, junr. Gold Medals in 1810 and 181 I for Die Engraving. The award in 18 Io was for a head of Isis, adopted for the Society's Isis Medal. Medallist. Son of Thomas Wyon the elder. Chief engraver to the Mint. Died i 8 I 7 .

Wyon, William. Gold Medals in I8I3, I814, and 1820 for Medal Dies. Medallist, R.A. Chief engraver to the Mint. Nephew of Thomas Wyon the elder. 
The Medal in 1813 was for engraving the head of Ceres for the Society's Medal; that of I 820 was for designing and executing the dies for the " new large Medal of the Society," which he presented (see Transactions, Vol. xxxvin. p. xxxiii). Died I 85 I.

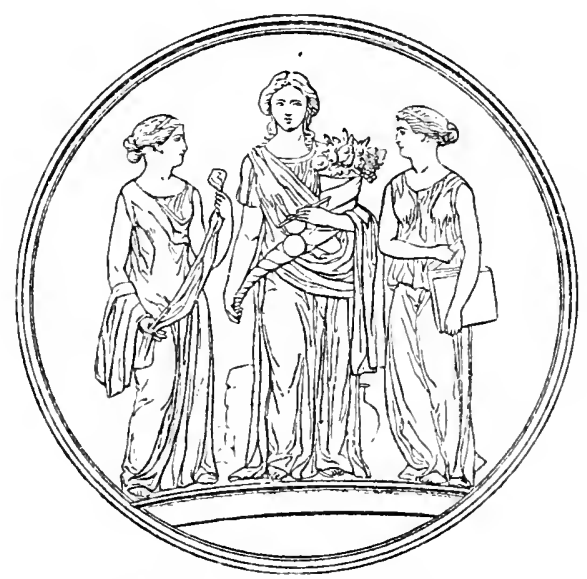

"Arts, Manufactures, and Commerce." From an old Die in the Society's possession. 


\section{HAPTER IX}

The Society and the Fine Arts-(Continued)

$$
\text { (1755-185r) }
$$

Prizes for Artists' Instruments and Materials, Crayons, Colours, Pencils, Paper, Etching Fluids, etc.-The Society's Shilling Colour-BoxSteel Engraving-Acierage - Aquatint - Colour Printing-DieSinking, Medals, and Medallists-Gem-engraving-Pastes for Cameos-Tassie and his Medallions.

Besides the prizes given to artists as encouragement for technical skill or in appreciation of genius, there were also a certain number for inventions and improvements connected with the Arts. A good many of these are trivial, but there are others of interest and some of importance in the history of the technics of Art.

A few prizes were at various times offered and awarded for artists' instruments and materials. In I 764 a premium of thirty guineas was given to Thomas Keyse for a method of fixing crayon drawings. Keyse was a still-life painter of some repute. He was also the keeper of Bermondsey Spa, where he had a gallery of his own works. The masterpiece was the interior of a butcher's shop, and over it certain of the wits of the time made merry.

In 1772 twenty guineas were given to Joseph Pache for preparing crayons, and "establishing a manufactory thereof in England." In I78 I the greater silver palette was awarded to Thomas and William Reeves for improved water-colours. In 1794 the palette and twenty guineas were awarded to George Blackman for his method of making oil-colour cakes. These were reported on favourably by Cosway and by Stothard, and the method of their preparation is described in the Transactions. ${ }^{1}$ In 1803 a

${ }^{1}$ Transactions, vol. xii. p. $27 \mathrm{I}$. 
silver medal and ten guineas were given to James Harris for a syringe for preserving oil-colours. The syringe was of the ordinary sort, when it was filled with colour the piston was inserted and secured by screwing on the head. It was certainly an improvement on the then existing method of supplying artists' oil-colours in bladders, and received the approval of Sir Thomas Lawrence, P.R.A.

An award to William Brockedon in 1823 for a rest for painters engaged in minute work, may be noticed on account of the inventor's personality, rather than because of its intrinsic importance. Brockedon was a versatile genius, an excellent painter, a man of science (he was an F.R.S.), and an ingenious inventor. He was Chairman of the Committee of Polite Arts 1824-1831.

Besides these there were rewards for various drawing instruments and appliances, sculptors' instruments, etching fluids, drawing tablets, pencils, paper for copper-plate printing, etc. Reference to some of these will be found in Chapter XIII, which also records the award to Senefelder for the invention of lithography. ${ }^{1}$

One of the most popular things the Society ever did was its offer of a medal for a shilling colour-box, and mention may be made of it here, though we are anticipating by some half a century at least the proper course of the Society's history. This offer was made in $185 \mathrm{I}$, and in the following year the medal was awarded to $\mathrm{J}$. Rogers, of I 33 Bunhill Row, E.C. The box has long since been obsolete, or rather has been superseded by better appliances of the same sort; but it was a very great advance on anything which existed at the time, and its enormous popularity was sufficient evidence of its value.

The proposal was put forward by Henry Cole, and was carried out with the promptitude that characterised all that remarkable man's ideas. The offer was advertised in September 1851 . The competing boxes were received on ist December, and the award was published on I 4 th January 1852 . The medal was presented at the distribution of awards held by Prince Albert in 1853. According to

${ }^{1}$ See Chapter XIII, p. 305. 
a statement made by Sir Henry Cole, ${ }^{1}$ the maker reported to him in I 870 that eleven millions of these boxes had then been sold.

At the same time a medal was offered for a cheap set of drawing instruments, to contain a pair of compasses, a drawing square, and a graduated ruler. This was awarded to J. \& H. Cronmire, of Cottage Lane, Commercial Road, for two sets of instruments, one to be sold at $2 \mathrm{~s}$. 6d., and one of a superior character at 6s. A good many of these were sold, but the drawing instruments never attained the popularity of the shilling colour-box.

Two prizes awarded in 1822 and 1823 mark an important though temporary modification in the technique of the engraver, the substitution of steel for copper plates. Although steel had been employed for etched plates by Albert Dürer in I 5 Io, it had never really come into use, and until the middle of the nineteenth century copper was in practice always used by engravers. It had the advantage of being easily worked upon, and the disadvantage of only giving a small number of impressions. The precise date of the invention of the modern steel plate seems uncertain, and the name of the inventor (if any single person can claim the credit) is also doubtful. S. T. Davenport ${ }^{2}$ attributes the invention to Jacob Perkins, whose " siderographic" process for printing bank-notes will be described later. ${ }^{\mathbf{3}}$ In the volume of the Transactions for 1820 , in which the process is fully described, Perkins states that his method had been "in successful operation many years in America," and it certainly involved the use of engraved steel plates, but he makes no claim to having been the first to engrave on steel. He merely refers to such plates as if they were in ordinary use. ${ }^{4}$ In the specification of his patent, taken out in October I 8 I9, Perkins describes a method of " decarbonat-

${ }^{1}$ Fifty Years of Public Work, vol. i. p. 385.

2 "Engraving and other Reproductive Art Processes," Joumal, vol. xiii. p. I 34 .

${ }^{3}$ See Chapter XIII, p. 303.

${ }^{4} \mathrm{E}$. Turrell, in a communication (Transactions, vol. xlii. p. 43), says that Perkins first used steel plates "in his bank-note manufactcry in the United States." 
ing " and "reconverting" steel plates for engraving, and refers to the use of steel plates as a thing commonly known.

Early in the century Abraham Raimbach, the engraver, made some unsuccessful experiments with steel, but it seems to have been considered that the difficulties of engraving on the metal, even in a soft state, and of afterwards hardening it, were practically insuperable.

Raimbach, in his Memoirs, ${ }^{1}$ does not refer to his experiments, and he only alludes to steel-plate engraving as a cause of the deterioration of the art from the numbers of plates produced to comply with the popular demand, and the consequent inferiority of the work.

In I 822, T. G. Lupton was awarded a gold medal for introducing the use of soft steel for mezzotint. In a communication on the subject, ${ }^{2}$ he says that the method of working is precisely the same as for copper plates, except that greater strength has to be used in laying the ground, and the plate has to be gone over with the tool a greater number of times.

The medal was evidently given to Lupton under the idea that he was the first to employ steel, at all events for mezzotint, and in his paper he appears to claim this credit for himself. As a matter of fact, however, he seems to have been anticipated by William Say, since there is in the collection of the British Museum a mezzotint by the latter engraver, which is dated 1817 , and this is said to have been printed from a steel plate. It is from a portrait by G. Dawe, R.A., of the Princess Charlotte, the daughter of George IV., who died in I8I7. This has always been believed to be the first mezzotint on steel, and inasmuch as Lupton's plate, submitted to the Society in I822, appears from his paper to have been his first success, there is no reason to question Say's claim to priority. ${ }^{3}$

In 1823 a gold medal was given to Charles Warren for " Improvements in the art of engraving on steel." These improvements consisted in substituting a plate of soft steel for the ordinary copper plate. His process is described

1 Memoirs of Abraham Raimbach, I 843.

${ }^{3}$ See also Chapter VIII, p. I90 $n$.

${ }^{2}$ Transactions, vol. xl. p. 4 I. 
in the Transactions, ${ }^{1}$ and it appears that he was led to experiment in the use of steel from early training in engraving for calico printers, and from observation of methods used in ornamenting articles of cast steel. He began by decarbonising steel plates, and, after engraving on the softened steel (or iron), re-hardening it, but he found that plates of sufficient thinness for the purpose werc apt to warp in the hardening, while there were other difficulties in using thicker plates. He was then led to try printing from the plates in their soft state, and found no difficulty in producing large numbers of impressions. The details of the method of softening the plates were improved, and it was found that editions of 4000 and 5000 prints could be produced without the plates showing signs of deterioration. Warren died suddenly, after the award of the medal, and before its presentation, so the account of his process in the Transactions is contained in a report by the committee, not in a communication from himself. So far as can be judged, the method is principally intended for etching, though available also for line engraving.

Probably the truth about the invention of steel-plate engraving is that many engravers tried to employ steel. Perkins was successful with the small plates that served his purpose, and probably those who tried to use larger plates found difficulties in the processes of softening and hardening the steel. Very likely, therefore, it was not till Say (possibly) and Lupton and Warren (certainly) found that steel plates could be employed without the necessity for hardening them, that such plates came into extensive use. That they did come into such use, and very rapidly, is, of course, well known. The facilities they afforded for printing large editions enabled publishers to produce the flood of "Annuals " which were popular in the thirties and forties of the last century, and served to popularise Art, if they did little to elevate it.

The copper plate came to its own again when it was found possible to deposit upon its surface a thin film of steel, or rather iron, and thus to give it a hard "face"

${ }^{1}$ Transactions, vol. xli. p. 88. 
which would stand the wear of printing. The process was termed " acierage," and was, as all the evidence goes to show, the invention, about 1858 or a little earlier, of Henry Garnier, a Paris engraver, with whom F. Joubert, also an engraver, co-operated. Joubert brought the process over to London, and in November i 858 he read a very full description of it before a meeting of the Society. ${ }^{1}$ The process was patented in England, 29th March 1858, by E. A. Jacquin, as a " communication" from Henry Garnier. The process, which was merely a method of electro-deposition, came rapidly into use, and for a time was associated with Joubert's name. It proved to be of the utmost value, and has ever since been extensively applied to copper plates of every description, including those produced by photographic methods. ${ }^{2}$

When steel was first used for etching, a difficulty was found in discovering a suitable etching fluid. Nitric acid acted too violently, and Warren recommended a solution of copper nitrate, acidified with nitric acid. In the following year (1824) Edmund Turrell ${ }^{3}$ received a gold medal for his etching fluid, composed of pyroligneous acid, nitric acid, and alcohol, and this fluid, with some modifications and the omission of the spirit, seems to have been largely used for some years for etching steel.

A few other awards in connection with plate-printing may be mentioned. In I773, Richard Samuel received fifteen guineas for a tool for laying mezzotint grounds. Samuel was a portrait painter of no great merit, according to Redgrave. In 1776 , Robert Lawrie (or Laurie), an engraver, who took several of the Society's prizes, received a "Bounty" of thirty guineas for an invention which facilitated the printing of mezzotint plates in colours.

In 18 io a silver medal and thirty guineas were given to John Hassell for improvements in the aquatint process. ${ }^{4}$ His invention consisted in drawing direct on the plate

1 Journal, vol. vii. p. I 5 .

${ }^{2} \mathrm{~S}$. T. Davenport, in his paper above mentioned, quotes a letter froin Joubert, in which it is stated that the process was patented in in 18.48 by $M$. Jacquin ; but this is merely an unfortunate misprint.

${ }^{3}$ See his paper in Vol. xiri. of the Transactions above referred to.

${ }^{4}$ Transactions, vol, xxviii. p. 97. 
with a specially prepared ink, which, when removed from the varnished plate, left the lines clear for etching. Such devices were at a later date known to and employed by aquatint workers, but the method may have been new at the date of the award.

The idea of producing prints from wood blocks in various colours is very old, and the method of colour printing for which William Savage obtained a silver medal and fifteen guineas in 1825 really involved no novel principle. He used different blocks for the different colours, and employed various devices for ensuring accurate register. Savage produced some excellent work, and devoted much attention to the subject, on which he wrote a book.

The work done by the Society in encouraging the art of die-sinking during the latter part of the eighteenth century deserves special note. In the 1758 prize-list is an announcement that "The Medallic Art being capable of great Improvement in this Nation," a prize of twenty guineas will be given for a copper medal, " after a model first produced by the candidate, and approved by the Society," the competition being limited to persons under the age of twenty-five. The offer was continued for several years, the terms being slightly varied. The age limit was raised to forty, and a second prize was offered for younger candidates.

The effort to improve the character of British medals was successful, for the result was that a number of admirable medals were produced. In some cases the candidates were allowed to choose their own subjects, in others the subjects were specified by the Society. Most of the selected subjects were British victories, of which there were, fortunately, about that time a sufficient number to provide ample choice. Several of the prizes were taken by members of the Pingo family, and, according to a statement by Dossie, ${ }^{2}$ the designs from which the dies were cut were prepared by their father, Thomas Pingo, the engraver to the Mint.

${ }^{1}$ Practical Thoughts on Decorative Printing, 1822.

${ }^{2}$ Vol. iii. p. 428 . 
Thomas Pingo himself did not enter for any of the competitions, but he was paid eighty guineas for cutting the dies for the Society's first medal. His two sons, John and Lewis, carried off a number of the awards for medals, and his other children, Benjamin, Henry, and Mary, took numerous prizes in other classes. Thomas Pingo was an Italian who came to England, and was appointed Engraver to the Mint, an office afterwards filled in succession by his sons, John and Lewis. In October 1758, John Pingo produced a model for a medal with a head of Britannia on the obverse, with the legend, "O fair Britannia, hail!" taken from Akenside's "Ode on leaving Holland." On the reverse was the figure of Victory standing on the prow of a ship, with the inscription, "Louisburg taken, MDCCLVIII." This referred to the taking of Louisburg and Cape Breton by the English, under Amherst and Boscawen, in July i758. The model was accepted, but before the year was out the small island of Goree, on the west coast of Africa, was captured from the French by Admiral Keppel, and the glory of this achievement was supposed to eclipse that of the taking of Louisburg. Pingo was therefore directed to make a new die for the reverse of his medal, and to cause the words "Goree taken " to replace "Louisburg taken." Hawkins in his book on Medals ${ }^{1}$ tells us that this and other medals rewarded by the Society were produced under the direction of Thomas Hollis, the republican writer, and that he presented copies of the Goree medal to Pitt, Keppel, and Akenside.

Three other medals were produced in connection with the conquest of Canada, one by John Pingo (1759) with the inscription "Quebec taken"; a second by Lewis Pingo (1761), "Canada subdued"; and a third by John Kirk (1763), "Conquest of Canada completed." In 1762 a prize was given to John Kirk for a medal in commemoration of the brilliant exploit of Admiral Hawke off Belleisle, on 2oth November I759, usually called the "Battle of Quiberon." Hawkins did not know

${ }^{1}$ Medallic Illustrations of the History of Great Britain and Ireland. Edward Hawkins. I 885. 


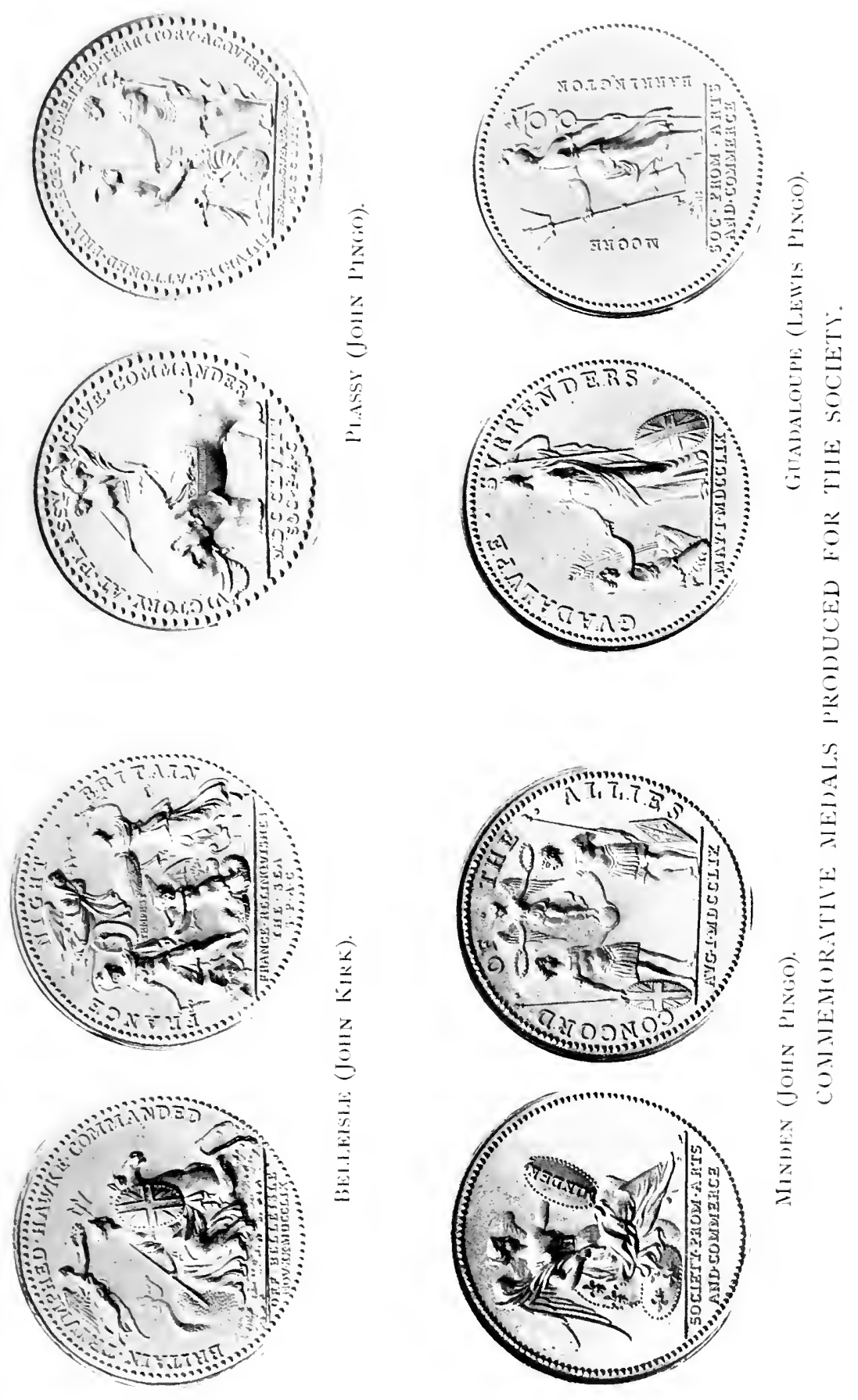



the real name of the artist, and says that the medal was "probably by Thomas Pingo." Kirk had been a pupil of J. A. Dassier, who had been engraver to the Mint about 1750 . He died young in I776. In I763, John Pingo received a prize for a medal, the subject of which was the Battle of Minden, fought in August I759, and in 1765 one for a medal commemorating the Battle of Plassy, 23rd June I 759 .

Lewis Pingo also received, in 1764,1771 , and 1772 , three other premiums for medals commemorating victories, the capture of Guadaloupe in 1759 ; the naval victory at Lagos in 1759 ; the capture of Havana in $1762 .^{1}$

Besides these, John Pingo received an award in 1762 for an allegorical group of the Arts-c" Painting, Sculpture, and Architecture" ; and Lewis Pingo two awards, one in 1759 for a medal representing the granting of Magna Charta, and a second for a portrait medal of King George iII. John Kirk also received a premium in 1762 for engraving a seal for the Society from a design by Cipriani, modelled by Spang, and Spang was rewarded for his model. ${ }^{2}$ This seal was used for many years, and when the Society was incorporated it was adopted as the corporate seal until it was abandoned for the vastly inferior design now employed. It also served as a book-plate for the books purchased under the bequest left in 1797 by W. B. Earle.

There were also a few other awards for medals about this time. One was to G. M. Moser (the first Keeper of the Royal Academy) for a medal for the Society, which does not seem to have ever been adopted; two to his nephew, Joseph Moser, in I 762 and 1763 ; and two to John Taylor, afterwards a jeweller at Bath, for allegorical designs.

After the date when these prizes were awarded, the subject of die-engraving dropped out of the Society's lists. Indeed, the last offer of a prize for medals appears in the list for 1765 ; though prizes for wax models for medallions were continued to I770. It was one of these

1 The four medals for Belleisle, Minden, Guadaloupe, and Plassy are in the possession of the Society. Illustrations of them are given in the plate facing p. 220.

2 See the plate facing p. 398. 
that Lewis Pingo obtained in 1772 , and it was many years before attention was again given to the art of the medallist. Indeed, it is not until 1807 that an offer of a premium for medal die-engraving again appears, and then it does not seem to have attracted much attention. In I 8 I7, George Mills, a medallist of repute at the time, received a gold medal for a medal die, and he followed up this success by obtaining similar awards in 18 I 8 and in I 828, the last prize being for a new die for the Society's Vulcan medal. From I 813 to 1820 a number of gold medals were taken by members of the Wyon family, several of them were for medals for the Society. Of these a fuller account will be given later on. ${ }^{1}$ The name of Pinches appears in the list for the years 1836 and I 837 , when silver medals were awarded to T. R. Pinches for medal dies, and Scipio Clint, the son of George Clint, A.R.A., the engraver, received gold medals for dies in 1824 and 1825 .

It seems not unreasonable to assume that the revival of gem-engraving, which occurred in the latter part of the eighteenth century, was due to a large extent, and perhaps entirely, to the Society of Arts. In I 759 a prize of ten guineas was offered for an intaglio on red cornelian, and it is stated that the prize was offered because, although " the Art of Engraving in Gems is a very ancient, useful, and curious Art, and has always been esteemed, yet [it] is but little practised in this nation." The age of the candidates was limited to twenty-six. The prize was taken in 1760 by Thomas Smith, jun., for an engraving of the statue of Meleager in the Vatican Gallery. In the following year the age of the candidates was reduced to twenty-four, and the prize was taken (I76I) by Nathaniel Marchant, then a young man of twenty-one.

In the list of prizes offered in 1761 the age was again raised to twenty-six. This prize was taken by Edward Burch. Both Marchant and Burch became Royal Academicians, and were undoubtedly the finest gemengravers of their day. Mr. Cecil Thomas, a most competent authority, expresses a preference for the work of

'See Chapter XIV, pp. 319 and 320 ; also Chapter VIII, p. 2 II. 
the younger artist. "Marchant was easily the foremost, many of his figure-subjects being admirable and delicate examples of intaglio engraving."

The offer of prizes was continued down to about 1770 , the conditions being varied from time to time, and separate prizes being added for cameo-cutting. In the 1762 list there is no age limit. During the ten years or so for which prizes were offered Marchant took six, Burch three, Nehemiah Spicer four, Robert Staples four, John Fruin two, and Lewis Pingo one.

Cordial testimony to the value of the help given by the Society in the encouragement of gem-engraving is borne by Burch himself, who says in his catalogue of engraved gems :-

"The first step of lifting the arts from obscurity may justly be ascribed to that truly laudable and patriotic Society for the Promotion and Encouragement of Arts: Manufactures, and Commerce; the Duke of Richmond's Gallery; with a valuable collection of gesses from the most admired figures and busts of the antique; and the Artists Subscription Academy for studying after Nature : if we take these collectively, we shall there find an ample field for encouragement and improvement. First, the above honourable society who gave (with a liberal hand) premiums for history paintings, large and small models for sculpture likewise, and engravings on gems; and it is with thankfulness that I acknowledge the share I had in these honors and emoluments. Premiums were also given for engravings on copper plate, drawings in various branches: in short, what was most for the fame and opulence of their native country was generously undertaken by them, and carried on with a spirit which must do honor to any institution." 2

In the same year ( 1759 ) in which the prize for gemengraving was first offered, a prize was also proposed for

1 "Gem Engraving," Journal, vol. 1x. p. 366.

${ }^{2}$ From the Introduction to A Catalogue of One Hundred Proofs from Gems Engraved in England, by E. Burch, R.A., Engraver to His Majesty, for Medals and Gems; and to His Royal Highness the Duke of York. London : 1795. Printed for the author. (Pp. ix, x.) 
" casts or impressions in glass, commonly called pastes," " nearest in excellence to antique pastes, as well cameos as intaglios." The offer was continued in successive lists up to 1764 , and after this occasionally prizes were offered for cameos and intaglios. It did not produce very much result. Two awards of twenty guineas each were made to Samuel More, afterwards Secretary to the Society and then a member, in 1763 and 1764 for two collections of such impressions, and in 1765 premiums of ten and five guineas were given to Edward Carter, a jeweller, and to Robert Fruin, a gem-engraver. No information about More's imitation cameos seems to be available.

Of more interest and importance is the award of ten guineas in 1767 to James Tassie for "Figures, heads, and portraits of his composition resembling antique onyx." Tassie soon acquired a considerable reputation, both for his copies of ancient gems and for portrait cameos modelled by himself. The paste was, according to an analysis by Professor Crum-Brown, "a very easily fusible glass, essentially a lead potash glass," and as it was reduced by a very moderate heat to a pasty consistency, it was admirably suited for taking casts from moulds of plaster or other material. ${ }^{1}$ Tassie was not only a competent chemist, but a skilful modeller, and he eventually established a considerable business, which, after his death in 1799 , was carried on by his nephew William. His portrait medallions and reproductions were highly appreciated, and Mr. Gray, in his memoir, quotes a letter from Shelley to Thomas Love Peacock in I 822 , asking Peacock "to get me two pounds' worth of Tassie's gems, in Leicester Square, the prettiest, according to your taste." At the present time his works are of value. There is a collection of them in the possession of the Edinburgh Board of Manufactures. Miss Catherine Andras, who received a silver palette in I 80 I for her portrait-models in wax of the Princess Charlotte and Lord Nelson, is thought by Mr. Gray to have been connected with the Tassies, as some of her models were cast in their paste by them.

1 James and William Tassie, by John M. Gray. I894. Mr. Gray died in the year in which his book was published. 
During a long interval the subject of gem-engraving was quite neglected by the Society, so far as the offer of prizes was concerned. The subject reappears in the premium list for 1823 , and from that date on prizes were occasionally given. In 1828 a gold medal was presented to C. Durham for an intaglio, and a silver medal to J. S. Phillips for a cameo. F. F. Cuisset took silver medals for intaglios in I 830 and 1832. Nothing more has been discovered about these artists' work, and their names do not appear in Forrer's Dictionary.

A gold medal was awarded in 1827 to William Warner for an intaglio of a group (Mare and Foal) which has been preserved, and is a nice piece of work. He was a seal engraver established in London, who afterwards cut some seals for Queen Victoria and the Prince Consort, as well as some medallion portraits of Napoleon 111. and the Duke of Wellington. The last award which requires mention is a gold medal in 1845 to $T$. Moring, for an engraving on white cornelian. This is still in existence, and the writer has an impression of it.

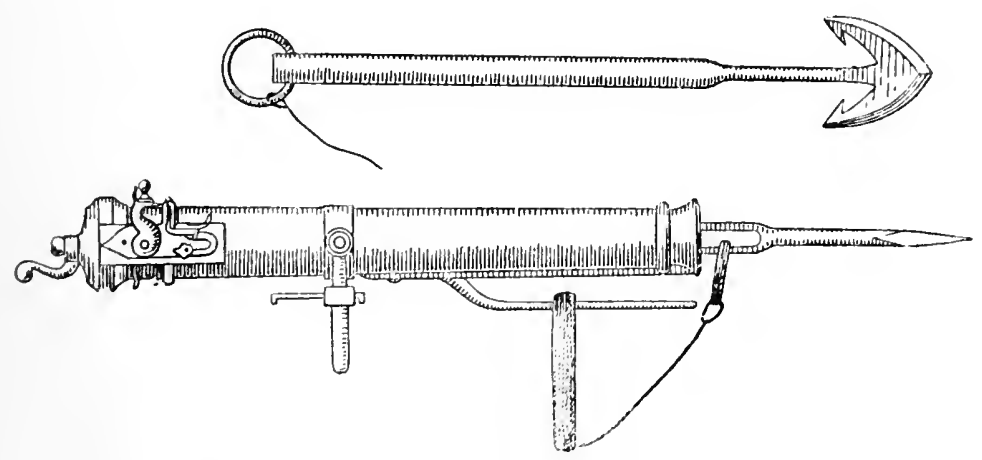

Atraham Staghold's Gun-Harpoon (see p. 249). 


\section{H A P T E R X}

\section{The Society's Early Art Exhibitions}

The Society originates Exhibitions of Artists' Works-The French Salon -The Foundling Collection-The first Picture Exhibition in London-Its Successors, the Free Society of Artists and the Incorporated Society of Artists-First Suggestions for an Academy of Arts-The Royal Academy.

A VERY important service rendered by the Society to the promotion of the Fine Arts in England was the establishment of periodical exhibitions of the works of contemporary artists, since it was directly as a consequence of those exhibitions that the Royal Academy was founded. The Society, therefore, may legitimately claim to have been not only the precursor of the Academy, but the original source from which that great institution was developed.

That English artists should never before have adopted this method of making their works known to the public is the more extraordinary, because it had long been well known and popular in Paris. Exhibitions of contemporary pictures had been held regularly in France a century before the idea was started in this country. As a French writer on the subject says : "C'est à la France que revient l'honneur d'avoir institué les expositions périodiques des artists vivants." On the advice of Colbert, Louis XIV. suggested to his Academy of Painting and Sculpture that its members should hold an annual exhibition of their works. The proposal was accepted in I663, though it was not till 1667 that the first Salon des Beaux Arts was opened. By the advice of Colbert the exhibition was made biennial instead of annual, and from that time it has been continued, with certain short intervals and occasional irregularities, at first biennially 
and afterwards annually, down to the present day. There is no need to follow the history of these exhibitions. Those who wish to do so will find an excellent account, succinct, but with full detail, in Larousse's well-known Dictionary, ${ }^{1}$ from which source the above particulars aretaken. Mention may, however, be made of Diderot's studies on the Salons, from 1759 to $178 \mathrm{I}$, collected and published in 1796 , and afterwards included in a more complete form in the edition of Diderot's works, edited by Mons. Assèzat. ${ }^{2}$ It does not look as if many English artists contributed to any of these Salons. The only English name mentioned by Diderot is that of Strange, the engraver.

There seems reason to believe that the idea of holding an exhibition of pictures in London was suggested by the popularity attained by the collection of pictures at the Foundling Hospital. This collection was formed by the liberality of various artists, who contributed pictures for the decoration of the walls of the new building of the hospital, Hogarth being a principal donor, and the most eminent among the contributors. According to the statement in Austin Dobson's Life of Hogarth, which is corroborated by information in Brownlow's account of the Foundling, the collection was formed about i 746. It soon became a popular resort, and the artists who had given the pictures found a good deal of benefit from the advertisement, though there was no actual profit, as nothing was charged for admission.

The very moderate publicity thus given to the pictures of a few artists seems to have suggested the idea that an exhibition on a larger scale would be highly profitable, by attracting the attention of the public and giving artists generally an opportunity of making their works known. At any rate, it is certain that, whether in consequence of the Foundling collection or not, a committee of artists was formed in I 759 or I 760 , at the "St. Martin's Lane Academy" - the well-known painting school previously referred to ${ }^{3}$-with the object of promoting the

'Grand Dictionnaire Universel du XIXe Siècle, art. "Salon," vol. xiv. p. 136 (1875).

${ }^{2}$ Euvres complètes de Diderot. Par J. Assèzat, I 876.

${ }^{3}$ See Chapter I, p. 8. 
formation of a regular exhibition of paintings. Of this committee, Mr. Francis Hayman, an active member of the Society of Arts, and afterwards an original Royal Academician, was chairman.

The Society had moved into its new premises opposite Beaufort Buildings in $1759,{ }^{1}$ and one of the reasons for its move was the acquisition of a "Great Room," in which could be exhibited the pictures and other works of Art to which its premiums had been awarded. It had, therefore, facilities for holding an exhibition on a large scale (the Great Room was $80 \mathrm{ft}$. by $40 \mathrm{ft}$.), and had already held exhibitions of a less important character. Hayman, therefore, very naturally appealed to the Society for its aid.

This he did by making a formal application, since it appears from the minutes of the Society of Arts that on 27 th February i 760 , "A letter from Mr. Francis Hayman, Chairman of the Committee of Artists, was read, desiring the use of the Society's room for exhibiting paintings, etc." The letter was referred to a large and important committee, including among its members, Israel Wilkes, R. E. Pine, Sir George Savile, Lord IVard, P. Carteret Webb, Mr. Chambers, Lord Midleton, Sir Thomas Robinson, Thomas Hollis, Dr. Knight, and Henry Baker. The committee reported on 5th March that "they are of opinion that the Society may allow a Public Exhibition of Productions in the Polite Arts for one fortnight this year under such regulations and restrictions as the Society shall hereafter prescribe." 2

Regulations were accordingly prepared, under which all pictures sent in by the committee of artists were to be accepted, all other pictures being selected by a committee of the Society. The Society's committee was to be the hanging committee, and to "appoint the places where all the productions may be hung or exhibited, in case any dispute shall arise among the artists about

${ }^{1}$ See Chapter III, p. 54 .

2 Much of this account of the Society's early Exhibitions of pictures has been taken from the article by Mr. H. B. Wheatley in the Journal, 6th September 1895 . 
placing them." No charge was to be made for admission.

It is quite clear that, although the Society accepted the proposition of the artists for an exhibition, its committee took care to reserve to themselves all the arrangements-so that it was, in fact, the Society's exhibition. All the costs and charges were borne by the Society, and it appears from the account books that though they paid all the expenses, they received nothing whatever in return. More than this, the Society's committee were responsible for all the details of the arrangements, the printing of the tickets, the preparation of the catalogue, etc. Pictures sent in by the committee of artists were accepted, but that was all they had to do with the management of the exhibition.

In the exhibition there were 130 pictures by sixtynine painters. The best artists were well represented. Reynolds had four portraits, Richard Wilson three landscapes, Hayman his well-known picture of Garrick as Richard III., and Cosway the portrait of Shipley. Among other important exhibitors may be mentioned Highmore, Morland, Pine, Sandby, Carlini, Moser, Pingo, Roubiliac, Wilton, MacArdell, Gwynn, Rooker, Strange, and Woollett.

The exhibition was a success, but, unfortunately, a success which led to disaster, for a disagreement arose among the exhibitors as to the use to be made of the money received at the door in payment for catalogues. This amounted to one hundred pounds, and the money was, apparently, left to the disposal of the contributors. The Society certainly never had or asked for any of it. It appears to have been invested, and was probably added to the fund devoted, as is mentioned later, to charitable purposes. In consequence of the dispute there were two rival exhibitions in $176 \mathrm{I}$. The chief artists seceded, and formed themselves into the Society of Artists of Great Britain, which exhibited in Spring Gardens, and the Society of Arts continued its patronage to the others, who subsequently styled themselves the Free Society of Artists. Each body took credit for the exhibition of 
I760, and counted its own exhibition of 1761 as the second. ${ }^{1}$

The Society's exhibitions were continued for four more years-176I to 1764 -and they were principally supported by those artists who eventually became the Free Society of Artists. These exhibitions all seem to have been well supported. But the artists who contributed, although distinguished, were neither so numerous nor so important as those who contributed to the rival exhibition of the Society of Artists of Great Britain.

It was definitely decided, and notices were printed on the catalogues, that the money arising from the sale of the catalogues, which formed the only profits of the exhibition, was to be given " by the artists immediately after the exhibition to some public charity." There seems to have been a certain amount of trouble in consequence of the numbers of visitors, as no admission fee was charged, and it was found necessary to employ a number of constables to control the crowd.

After 1764 the Society decided to discontinue the exhibitions, but the artists held exhibitions in 1765 and 1766 in " Mr. Moreing's Great Room in Maiden Lane, Covent Garden." In I 767 the Free Society of Artists was definitely formed, and they held annual exhibitions up to I 783-first in "the two new Great Exhibition Rooms in the Pall Mall, near the bottom of Hay Market," then in "Mr. Christie's new Great Room, next Cumberland House, Pall Mall," 2 and after this, in rooms in or near the Haymarket.

"The Society of Artists of Great Britain," on leaving

${ }_{1}$ Dr. Johnson, writing in June 1761 to Baretti, who was then in Milan, speaks of this second exhibition: "The artists have instituted a yearly exhibition of pictures and statues, in imitation, as I am told, of foreign academies. . . They please themselves much with the multitude of spectators, and imagine that the English School will rise in reputation. . . Surely life, if it be not long, is tedious, since we are forced to call in the assistance of so many trifles to rid us of our time, of that time which never can return."-Boswell's Life, edited by G. Birkbeck Hill, vol. i. p. 363 .

${ }^{2}$ Cumberland House was afterwards part of the War Office, and was pulled down when the Automobile Club was built in rgro. 
the Society of Arts, went to " the Great Room in Spring Garden, Charing Cross." It is not quite certain where this room was situated, but it is supposed to be now incorporated in the offices of the London County Council. As previously stated, the chief cause of the split among the artists was a dispute as to the use to be made of the money obtained from the sale of the catalogues; but it is evident that the ruling of the Society of Arts, that no charge should be made for admission, had much to do with the decision of the chief artists to go elsewhere, for in the preface of the catalogue of the Society of Artists for 1762 , which was written by Dr. Johnson, we read :-

"Of the price put upon this exhibition some account may be demanded. Whosoever sets his work to be shown naturally desires a multitude of spectators, but his desire defeats its own end when spectators assemble in such numbers as to obstruct one another. Though we are far from wishing to diminish the pleasures or depreciate the sentiments of any class of the community, we know, however, what every one knows, that all cannot be judges or purchasers of works of art, yet we have already found by experience that all are desirous to see an exhibition. When the terms of admission were low, our room was throng'd with such multitudes as made access dangerous, and frightened away those whose approbation was most desired."

The exhibition of the Society of Artists of Great Britain for $176 \mathrm{I}$ is styled on the catalogue "the second year," but no explanation of the secession from the exhibition of the Society of Arts is given. This catalogue contains a frontispiece by Hogarth, representing Britannia as watering the roots of three trees, labelled respectively painting, sculpture, and architecture, from a fountain surmounted by a bust of George iII. Hogarth himself exhibited no less than seven pictures, among which were his celebrated "Sigismunda," the "Gate of Calais," "Picquet, or Virtue in Danger," and "The Election." Gainsborough sent a portrait, Reynolds five portraits, Richard Wilson six landscapes, and Francis Hayman a picture of "Sir John Falstaff." The receipts from this exhibition were $£ 650$. 


\section{THE SOCIETY'S EARLY ART EXHIBITIONS}

The Society of Artists of Great Britain obtained a charter and a coat of arms in 1765, and became known as the Incorporated Society of Artists. George Lambert was appointed the first president, Francis Hayman the first vice-president, and F. M. Newton the first secretary. The Incorporated Society seemed to be on the high road to prosperity, but, in spite of complaints, it did nothing for teaching, and formed no school, so that many of the leading artists became disgusted, and again there was a secession. The seceders applied for a charter for an academy, which was granted, and the Royal Academy was founded in 1768 . From that date the Incorporated Society steadily declined, although for a time some of the Royal Academicians continued to send to its exhibitions.

The exhibitions of the Incorporated Society continued to be held in Spring Gardens until 1 771. In the following year the Society removed to their " new room near Exeter Exchange," which was on the site of the present Lyceum Theatre. In I 777 the Society went to Piccadilly, near Air Street; in 1780 to Spring Gardens, and in 1783 to Exeter Change again. No exhibition was held between 1783 and 1790 , when a final exhibition was held, and after this the Incorporated Society came to an end.

For at least fourteen years previously various proposals had been made in different quarters for the formation of an Academy of Arts. Soon after the Society of Arts had been established, a suggestion was considered that the Society itself should apply for a charter for an Academy of Painting, Sculpture, etc. The principal advocate of the scheme was Henry Cheere (afterwards Sir Henry Cheere), and he was warmly supported by Dr. Madden. The full text of his proposal, with the draft of a charter for a Royal Academy, is preserved in Dr. Templeman's MS. volume of Transactions hereinafter referred to. ${ }^{1}$ The proposal, however, was not approved, and the Society even refused to offer one of its prizes for a scheme for such an Academy.

Even before the establishment of the Society a definite

${ }^{1}$ See Chapter XV, p. 328. 
proposal for an Academy of Fine Arts had been put forward. In 1753, a number of artists, under the chairmanship of Francis Hayman, actually held a meeting to discuss the project. The official notification of the meeting, held on I 3 th November, is as follows :-

"There is a scheme on foot for creating a public Academy for the improvement of painting, sculpture, and architecture, and it is thought necessary to have a certain number of professors with proper authority in order to making regulations, taking subscriptions, etc., erecting a building, instructing the students, and concerting all such measures as shall be afterwards thought necessary. Your company is desired at the Turk's Head, in Gerard Street, Soho, on the I 3 th November, at five in the evening, to proceed to the election of thirteen painters, three sculptors, one chaser, two engravers, and two architects, in all twenty-four, for the purpose aforesaid.

(Signed) Francis Milner Newton, Secretary." 1

No agreement was come to at the meeting, and the projectors were satirised by their fellow-artists, and became the objects of several caricatures.

The reason why those proposals all failed, and why the Royal Academy succeeded, was, as has been pointed out by Messrs. Hodgson and Eaton in their History of the Royal Academy, that its projectors had realised that there was a source of revenue in the holding of exhibitions of pictures. The hundred pounds taken at the Society's first exhibition proved that, and further confirmation was provided by the larger receipts at those exhibitions when a charge was made for admission. The founders of the Royal Academy made good use of their experience, and from their day to our own the Academy has earned much money by its exhibitions, and has applied that money wisely and well to the education of artists.

It is interesting to note that while the constitution of the Academy, as defined in the "Instrument " or charter, granted by George III., is entirely different from that

${ }^{1}$ Rimbault's Soho (1895), pp. 194, 195, quoted by Mr. H. B. Wheatley. 


\section{THE SOCIETY'S EARLY ART EXHIBITIONS}

proposed in the scheme for an Academy of Painting submitted to the Society in 1755 by Sir Henry Cheere, its objects, and the methods of attaining them, are identical with those set forth in the original proposal. Those who drafted the older scheme evidently had in their minds the establishment of an institution similar to the Royal Society, and consisting of an unlimited number of Fellows with a president and a council, whereas the founders of the Royal Academy took for their model the French Academy of Louis XIV. with its forty members, the governing body being a council of eight, on which all Academicians served in rotation. When, however, they came to details, they practically adopted the scheme set out in Cheere's draft charter, which proposed an annual exhibition, the appointof professors (anatomy, geometry, perspective, architecture, antiquity, and "other studies"), and a drawing-master, the establishment of a school with models, the provision of medals, etc. Practically the same establishment is provided in the "Instrument," which, though obsolete in some particulars and modified in others, is still the fundamental charter of the Academy.

Had the original proposal been carried out, there can be little doubt that the Society of Arts would have been merged in the Academy, which would almost certainly have developed on its present lines. It is therefore probable that much of the useful work carried out by the Society in the first half century of its existence would never have been accomplished, and it is highly unlikely that any improvement would have been effected in the methods of the Academy. Probably the net result would have been that Art would not have benefited, while agriculture, invention, industry, and commerce would, for a time at least, have suffered. So while the Society of Arts may take a legitimate pride in the share it had in preparing the way for the establishment of the Royal Academy, it may also congratulate itself on the fact that the attempt to concentrate in the hands of a single institution the work of supervising and promoting all the arts and industries of the country did not succeed. 


\title{
CHAPTER XI
}

\author{
The Premiums
}

(1754-1851)

Object of the Premiums-Committees of Award-Method of Adjudication-The Premium Lists-Character of the Premiums offered -General Results of the System of Prize-giving, its Good and Bad Points-Exclusion of Patented Inventions-Motive Power before the Steam Engine-Its Applications, Weaving, Sawmills, etc.-Lovell Edgeworth's Inventions-The Screw-jack-The Gunharpoon-Mechanical Telegraphs-Mining, Pumps, Ventilation, Safety Lamps-Civil Engineering, the first Iron Bridge-Naval Construction-Various Mechanical Appliances.

As previously mentioned, the sole original object of the Society was to promote art, industry, commerce, and invention, by granting rewards and premiums for meritorious discoveries and inventions, for success in the various branches of the fine arts, for increasing the economic resources of the kingdom by the import of new or little known materials of industry, or for developing those resources by novel or improved methods.

We have seen what the Society did to aid the progress of the fine arts, by the award of prizes and in other ways. We have also considered what it did for agriculture before the foundation of the Royal Agricultural Society, and for forestry, which may be looked upon almost as a branch of agriculture. An account has also been given of its early relations with the Colonies, and of its share in the development of Colonial resources. It now remains to consider the manifold and miscellaneous work it did in the promotion of invention, and to give some account of the objects for which it offered and 
awarded prizes in every branch of industry and every class of technical science.

The Society took infinite pains to prepare a list of suitable objects for its premiums. Each year the list was carefully revised. Some items were omitted, either because the offered award had been made, or because it had elicited no response. Fresh entries were constantly added, and changes made in the terms of those which were not dropped. And besides the specified articles in the list, the Society was ever ready to consider any suitable application, so that it constantly made grants for things entirely outside its own proposals, so long only as the object was deemed worthy.

The classes under which the awards were arranged varied from time to time, but eventually they were distributed among six committees :-

1. Polite Arts. 2. Agriculture. 3. Manufactures.

4. Mechanics. 5. Chemistry. 6. Colonies and Trade.

The subject-matter with which the different committees dealt is sufficiently indicated by their titles. "Polite Arts " included painting, drawing, sculpture, die-sinking, designs for manufactures, and also, to a certain extent, literature. Agriculture included forestry. Mechanics and Manufactureswere at one time dealt with byone committee, but were afterwards divided. Chemistry was industrial chemistry only, but comprehended also other branches of applied science. The work of the committee on Colonies and Trade was practically restricted to colonial matters. There were at various times other committees, such as those on Correspondence, on Miscellaneous Matters, etc., but these were not concerned in the adjudication of the premiums. ${ }^{1}$

At first a number of members were appointed on each of these committees. At a later period this practice was abandoned, two chairmen were elected at the annual meeting for each committee, and it was left to those members who thought fit to attend.

${ }^{1}$ As in the case of the classes already dealt with, the awards consisted of money prizes and medals. A full account of the Society's medals and their history will be found in Chapter XIV, p. 314. 
The practice seems to have been that a general notice was sent round to those who were in the habit of attending the committees, and also to other persons, who were not necessarily members of the Society, known to be interested in, or conversant with, the subjects which were to come before the meeting. The whole proceedings were conducted with a good deal of formality. Any communication which was received was referred by the Secretary to the committee to which it scemed appropriate-the committee consisting, as above shown, of a certain number of persons who might be considered as more or less experts, and of any members of the Society who liked to attend. The candidate for the premium was also invited to be present to give such an account of his invention as he thought proper. After he had given his own version, and had replied to any questions which were addressed to him, the subject was discussed, first in his presence, and then after his withdrawal. Formal resolutions were then put as to the award to be made, and these recommendations were submitted to the next ordinary Wednesday meeting of the Society, when they were generally confirmed, but in some cases disapproved. If any award was made, the paper was generally referred to the Committee on Papers, with a view to its being inserted in the next volume of Transactions, if suitable.

It is thus evident that a great deal of trouble was taken to ensure a fair adjudication of the premiums. But it must often have happened-and, indeed, from the records it is evident that it did, at all events, sometimes happenthat the committee were by no means competent to deal with the invention, especially if it was of a new and original character. The committee must also, in the nature of things, have generally been composed of amateurs, who, however well-meaning and hard-working they might be, were sometimes incapable, and, in all cases, naturally biased by their own opinions. On the whole, however, it may be said that no one who makes a careful investigation of the awards made-and probably there are not very many who would care to undertake such a task-can fail to be of opinion that a genuine effort was made to do 
justice, and that in a great majority of cases fair justice was done. As a matter of fact, it is quite certain that most of the awards leaned to the side of generosity. But while a great many undeserving inventions were rewarded, there are not a great many which were rejected and afterwards proved themselves of any value. ${ }^{1}$

The first actual premium list issued was that of 1756 , and this only exists in manuscript. The first printed list is the second issued, and that is dated 1758. From that date the lists were issued annually. Till the publication of the first volume of Transactions, in 1783 , the lists were issued separately; from 1783 they were included in each volume of the Transactions, besides being printed separately. The Society's set of lists before 1782 is, unfortunately, not complete, a volume in which the lists from 1763 to 1767 inclusive were bound up, having apparently at some time been lost. A separate copy, however, of the list for 1764 has been preserved. A partial list for 1765 and the complete list for I 766 are printed in the Museum Rusticum.2 The British Museum set is complete from I 758 to 178 I inclusive.

After I 829 many changes were introduced in the lists. The importance of the Society's prizes was much diminished, and the character of its work was changing. The lists were shortened. Sometimes the offers of prizes were in general terms instead of being made for specific objects. From I 843 to 1847 the list was only issued in alternate years. With the grant of the Charter in I 847 the Society's system of prize-giving practically came to an end. Special prizes were offered and awarded from time to time, but the practice of issuing a general list of subjects for awards, though it was not formally abandoned, was really obsolete. A sort of attempt to renew it was made in $1863,{ }^{3}$ when a list of the old character was published in the Journal.

${ }^{1} \mathrm{~A}$ full and detailed account of the method adopted in making the awards will be found in the address delivered by Arthur Aikin, at the distribution of awards by the Duke of Sussex, as President, in 1817 . Transactions, vol. xxxv. p. 209.

${ }^{2}$ Vol. v. p. 90 ; vol. vi. p. 339.

${ }^{3}$ Journal, vol. xii. p. 9. 
The last such list appeared in $1873,{ }^{1}$ but hardly any awards were made upon it, and in practice the whole system had been defunct for at least a quarter of a century.

The first lists of awards made by the Society are contained in Dossie's Memoirs of Agriculture, in which they were published by the Society's authority. The list down to the end of 1767 (exclusive of "Polite Arts ") is given in the first ( 1768 ) of Dossie's three volumes (page 3 ). The complete list of the awards in "Polite Arts," to the end of 1776 , and the other awards, from 1768 to 1776 inclusive, appear in his third (1 782) volume (page 447).

The same list was also published by the Society in $1778,{ }^{2}$ and in a few cases where the two lists differ it may be assumed that the Society's list is accurate. There are very few discrepancies. There is yet another list, down to 1770 , given in the Descriptions of the . . Machines - . in the Repository of the Society, etc., published by William Bailey, the Registrar of the Society, in $1772 .^{3}$

In the second volume of the Transactions (1784) a list is given of the awards from 1775 to 1782 inclusive. This list is by way of being a continuation of Dossie's lists, though, as a matter of fact, the two overlap as regards the years 1775 and 1776 . From this date onwards the awards are given year by year in the annual volumes of the Transactions, down to what is really the last volume of the series, that for the session 1843-4, Vol. LV. In the interval between the cessation of the regular Transactions and the commencement of the Journal, lists for the years 1845 to 1850 were issued, and all of these are extant, that for 1847 being in MS. only. In $185 \mathrm{I}$, the year of the Great Exhibition, there was no distribution of prizes, on account of the exhibition, and consequently no list. In 1853 there was a meeting for the distribution of prizes, and a list was printed in the Journal. ${ }^{4}$

1 It was issued as the "Premium List for the Sessions I 873-4-5."

${ }^{2}$ Register of Premiums and Bounties, I754-1776.

${ }^{3}$ This is a quarto volume with a collection of fine illustrations in folio. In 1782 another edition was issued by A. M. Bailey, who succeeded his father as Registrar in 1773. It is in two volumes, folio. See also Chapter XV, p. 329.

4 Vol. i. p. 365 . 
The premium lists were advertised and circulated as widely as possible. At one time the Society received a little official help in obtaining publicity for its work, for in 1775 the Postmaster-General sent a copy of the list to the local post offices, with instructions to the postmasters to let all persons coming to their offices have an opportunity of reading it.

An examination of the old prize-lists, especially those between 1760 and 1800 , affords an interesting indication of the state of scientific and industrial knowledge at the time. Naturally, we now possess a great number of the things for which the Society then offered prizes. Some of these offers produced good results, some were abandoned as utopian, though the machines or articles asked for are now commonplaces of industry and manufacture. Some of the proposals show what our modern conceit may regard as lamentable ignorance, others afford evidence of considerable shrewdness; others, again, indicate a quite natural incapacity to realise the direction of future progress.

That in the lists so many familiar names are missing is certainly disappointing. One would like to have found the names of Watt, Hargreaves, Crompton, Roebuck, Arkwright, and Cort, amongst those whose inventions were recognised and rewarded by the Society of Arts. But in the early records none of these names appear. Why is this? The best reason that can be suggested is that all these men were in advance of their time. Like all great inventors, they had to wait for recognition until they had overborne the opposition of ignorance and of rival interests. When recognition came, it was too late for the prize or contribution which would have eased the early struggles. A committee which could anticipate the direction in which industry or science would progress would have to be composed of men with prescience beyond their fellows, and they would not have received the acquiescence or approval of their contemporaries.

It has always been so throughout the history of invention. The great inventor must, of necessity, be a man with ideas ahead of his contemporaries. He has never had 
their sympathy or their appreciation. On the contrary, he has always had to struggle against their active opposition. If his invention, as has generally been the case, has for its prime object the substitution of mechanism for human labour, he incurs the violent hatred of those who can only realise that their livelihood is being taken away from them.

The history of the introduction of textile machinery, by which millions of operatives now make their living, is a record of the attempts of the progenitors of these operatives to wreck the new machinery, and, if possible, to murder the man who designed it. As long ago as 1710 the Spitalfields weavers rose in riot and smashed their frames in protest against the introduction of improvements. A hundred years later, in 1816 , the Luddite riots-after the wholesale destruction of factories and machinery in the Nottingham district-were only suppressed by the stern expedient of hanging a number of the ringleaders.

In the first half of the nineteenth century the hatred of new machinery was combined with strikes, often justifiable enough, for better pay, but certainly for nearly three centuries-since James Lee invented his stocking frame in 1589 -the workers of the textile trades have done their very best to prevent any improvement in the tools of those trades. If the spinners and weavers had had their own way, all yarr, would now be spun by the spinning-wheel and woven on the hand-loom. The artisan fought for the ancient system of economic organisation, for domestic industry and handiwork. Forces were too strong for him. The growth of capital and its systematic industrial application conquered in the end, but only after a long struggle against excusable ignorance and natural incapacity to appreciate the inevitable.

And the opposition did not come from workmen alone. Manufacturers a hundred and fifty or two hundred years ago were no more anxious to change all their methods and scrap all their machines than they are now. When an invention had proved its value, and had been taken up by the more enterprising manufacturers, the rest had perforce to follow suit, but in the meantime the original 
inventor had had but a poor time of it, and in all probability had died a pauper.

Nor did the inventor as a rule get much sympathy from the general public, or even from those members of the public who might have been expected to know better. After some centuries of mechanical and scientific progress we have perhaps learnt the lesson. Nowadays we are so accustomed to the rapid multiplication of scientific inventions that we readily accept any marvel, however marvellous. Yet there can be hardly any great invention which has not been condemned or depreciated by a competent and well-qualified authority. The working of the same spirit may be traced from the beginning of the industrial revolution down to our own day. When Dr. Lardner demonstrated beyond cavil that no steamship could carry coal sufficient to take her under her own steam to America, the statement was accepted as the opinion of one of the best authorities of the time. The heads of the Admiralty declined to consider the use of the electric telegraph because the excellent and efficient semaphore arrangement fulfilled all their needs. We might have had mechanical transport on roads fifty years before it was accomplished, but for the oppositionpartly interested and partly ignorant-to the early constructors of road locomotives. A year or two before the incandescent filament lamp was perfected the best authorities were agreed that the "subdivision of the electric light" was impossible. The internal-combustion engine found but small favour amongst the older mechanical engineers (there was one brilliant exception). The idea of a "rotary steam-engine" was regarded with derision before the steam-turbine was perfected. The members of the old Aeronautical Society were for years looked upon as harmless visionaries. When the first paper on the basic process of steel-making was offered to the Iron and Steel Institute, the council of that body, a competent tribunal if ever there was one, declined to accept it.

Other instances might be cited, but these may serve to show the value of contemporary opinion on new dis- 
coveries, and the extreme difficulty of forming a sound judgment as to the direction which future progress in the application of science to industry is likely to take.

What can we expect if we go back a hundred and more years into a non-scientific age, when men were beginning dimly to realise the value of machines, and to recognise that processes which had for centuries been wrought by human hands alone might possibly be aided by inanimate mechanism if it were only possible to devise it? What wonder, then, if those who were most anxious to improve the manufactures and industries of their country, could imagine no better means than to reward small improvements in the crude existing appliances, if they could not imagine a development which astonished their successors, or foresee an advance which we, a century later, regard with wonder and admiration?

Another reason which prevented the Society from taking cognisance of many important inventions was the regulation which excluded patented articles. In one of the earliest lists of Rules and Orders-that for 1765-it was expressly laid down that " No person will be admitted a candidate for any premium offered by the Society who has obtained a patent for the exclusive right of making or performing anything for which such premium is offered." This rule continued in force until 1844 or 1845 , when it was finally abolished. The first suggestion for its abolition appears to have been made in a report of a Committee of which Thomas Webster was chairman, presented in I 841. Several resolutions were passed in I 843, I 844, and I 845 , all apparently rescinding the old rule. In Vol. LIV. of the Transactions (184I-3), the disqualification is for the first time omitted in the Regulations, and in the Preface to Vol. LV. attention is drawn to the fact that Patented Inventions are no longer disqualified from competition. At all events, from 1845 onwards they were eligible for awards.

So strong was this feeling of opposition to patents that it was at one time proposed to require every prizewinner to agree not to take out a patent, but this proposal was negatived. In later years, when patents 
became more numerous, the restrictive effect of this rule became much more injurious than in 1765 (in which year only fourteen patents were granted), but even at that time it shut out many valuable improvements. However, the motion that the grant of a patent was an injurious restriction on industry, only to be condoned if the public could not get the benefit of a useful invention unless it bribed the inventor with a monopoly, survived long after the end of the eighteenth century. Indeed, it was only in our own generation that the value of protection by patent was fully realised, and that - to quote once more an often-quoted saying of the late Sir William Siemensif an invention were found lying in the gutter, it would be worth while to assign it to an owner who would have an interest in looking after it. Of course, this general statement, like all such statements, has its exceptions. Some inventions do not need a foster-mother. A case in point is that of the safety-lamp, for which Sir Humphry Davy refused to take out a patent. The need was so urgent, its fulfilment so complete, that no advocacy or advertisement was wanted. But the invention of the safety-lamp was exceptional, not only in this respect.

On the whole, we should admire the amount of useful work done by the Society's premiums rather than cavil because it did not accomplish more. What it really did effect may be judged from the following selection of the more interesting or more important of the subjects to which its energies were devoted. The task of selection has been by no means easy. Its successful accomplishment would demand an amount of technical and expert knowledge to which the present writer can make no claim. The examples chosen out of a century's work may, however, show how much was really accomplished, and how much those earnest industrial pioneers effected who worked in the name and on behalf of the Society of Arts.

The period covered is just a hundred years, from the foundation of the Society to the 185 I Exhibition. Of this period the first half was by far the more fruitful, and it is really to this half that our attention must principally be directed. By the expiration of the eighteenth century 
the system of prize-giving had practically fulfilled its work. It gradually became less and less effective till at last it died out. The work of the Society tended in other directions. For some years the Society languished; indeed, it nearly collapsed, to be revived again in the middle of the nineteenth century. The record of these changes is, however, a matter for future consideration. For the present we are concerned only with the history of the useful work effected by the Society during that first prosperous portion of its career, when its sole aim and object was the awarding of premiums for the promotion of Art and Industry, and the discovery of suitable objects for its awards.

Of all the inventions upon which, at the time when the Society commenced its work, the advance of industrial progress principally depended, the most important were certainly those dealing with the generation and application of motive power, and yet it was not to these inventions that most attention was directed. If those who devoted themselves to this department of the Society's work were unconscious of the change shortly about to be effected by the substitution of mechanical for animal power in every branch of industry, it is not to be wondered at. The modern steam-engine and the Society of Arts were almost absolutely contemporaneous. James Watt began his scientific career in the year in which the Society was founded, though it was eleven years later that he conceived the idea of the separate condenser, and four years later still (in I 769) that he took out his first patent.

In 1754 the need for some agency which could drive heavier machinery than could be worked by a man or a team of horses was hardly existent, and almost wholly unrealised. Yet it must, to some small extent, have been in men's minds, and we may find evidence for this in the desire to improve those elementary methods for utilising the known natural forces, wind and water, which showed itself in the work of the earliest engineers-millwrights, as they were called-and in the technical literature, such as it was, of the time. Amongst other places, we find it in the Society's premium list. The list for 1759 contains 
two offers of $t 50$ each, one for a tide-mill, and one for an improved wind-mill which should more effectively utilise the force of the wind than previously existing forms, and should also, with varying wind-velocity, communicate a uniform motion to the mill-shaft. As a result of these offers, several rewards were paid, one for a tide-mill going to the Rev. Humphry Gainsborough, 1 a brother of the painter, who seems to have been an inventor of considerable ingenuity. These and similar offers were repeated from time to time during the next fifty years, and various sums of money were paid for improvements in windmills and also in water-wheels. Dr. Erasmus Darwin corresponded with the Society at one time about his idea of a horizontal windmill, but no award was made to him.

It is some time before the steam-engine makes its appearance in the list. In I 780 we find a gold medal offered for an engine for "working at one time, the greatest number of looms, not fewer than three." The offer was continued for some time, but there is no record of a prize ever being awarded. As a matter of fact, the first recorded use of the steam-engine in a factory is in I786. Cartwright's power-loom was brought out in 1785 , and was driven by steam in 1790 . John Austin, of Glasgow, also claims, in a communication to the Society, ${ }^{2}$ to have constructed a power-loom in 1789 , and to have had one running in 1798 at Pollokshaws, near Glasgow. He adds that, after this, a building was constructed to hold two hundred of his looms at the same mills. He received a gold medal from the Society in I So6. It is probable that the first to invent a power-loom was John Kay, whose patent of I 745, taken out jointly with Joseph Stell, included, as Kay himself says, "tape lomes to weave by water." 3 No description, however, of Kay's loom is extant. Kay was, at all events, indirectly

${ }^{1} \mathrm{He}$ was a friend of R. L. Edgeworth's, who says that he had never known "a man of a more inventive genius" (Edgeworth's Memoirs, I82 I, and ed. vol. i. p. I 53).

2 Transactions, vol. xxiv. p. 93. See also Chapter XII, p. 263.

${ }^{3}$ Journal, 8th December I9I I, p. 8 I. 
the inventor of the power-loom, because it was his flyshuttle that enabled a mechanical movement to be substituted for the action of the human hand.

Up to the end of the century references to the steamengine are rare. A vague offer of a reward for " increasing the force or quantity of steam " in steam-engines was published in 1783 , and long kept its place on the list, but it elicited no response. Would a modern triple-expansion engine or a turbine be eligible for the prize? They utilise the energy, but cannot be said to increase it .

The first substitution of mechanical power for handwork in the timber trade in England is certainly due to the Society. A premium for a saw-mill was awarded to James Stansfield in $176 \mathrm{r}$, and sums amounting in all to over $£ 300$ were given to him to help him in improving and working his mill. By the instrumentality of the Society Stansfield was also introduced to one Charles Dingley, who found the capital for setting up a mill at Limehouse which was driven by wind-power. This mill, after working a short time, suffered the usual fate of all mechanical improvements, and was destroyed by a mob, but the owner was compensated, the rioters punished, and the mill reinstated. ${ }^{1}$ For his services in the matter, a gold medal was awarded to Dingley. The backward state of English industry is shown by the fact that saw-mills worked by water and by wind had previously been in existence on the Continent, and even in America, though there seems reason to believe that Stansfield's was an improvement on the older types.

That eccentric mechanical genius, Richard Lovell Edgeworth, received several rewards. The most important of these was a gold medal awarded in 1769 for various inventions communicated to the Society. What these were, it is not very easy to say. It is just possible that one of them was a proposal for a steam carriage, which seems to have arisen out of a suggestion by Dr. Erasmus Darwin, who was a friend of Edgeworth. ${ }^{2}$

This, however, is not mentioned by Edgeworth himself,

\footnotetext{
${ }^{1}$ Dossie, vol. i. p. 123. Transactions, vol. i. p. 4 I.

2 Thurston, History of the Steam Engine (1879), p. I 50.
} 
who, in his Memoirs, ${ }^{1}$ enumerates only a carriage with springs and a new form of frame, a waggon "divided into two parts," 2 a cover for haystacks, and a turnip-cutter . He also says that he afterwards submitted a dynamometer, and from a letter of his it appears that he suggested a new form of camera-obscura.

For his "Perambulator, or instrument for easily measuring land," he had a separate silver medal in 1767. The idea of using a wheel for the purpose was not novel. Such an apparatus was known in the seventeenth century, and was called by the same name. Edgeworth's machine consisted of a wheel, or rather a framework of spokes without a tyre, to the axle of which was fitted a long screw projecting horizontally. A nut loosely fitted on this screw was prevented from revolving with it, when the wheel was run over the ground, by a suspended weight, so that the motion of the wheel caused the nut to travel along the screw, one thread for each revolution, and the distance traversed was thus indicated. The apparatus would, no doubt, be effective, but it must have been clumsy, and rather inconvenient to work. The circumference of the wheel was to be one pole $\left(5 \frac{1}{2} \text { yards }\right)^{3}$ In

${ }^{1}$ Vol. i. p. I67.

2 This was the invention for which Edgeworth took out a patent in 1770 , his only patent. It was really a "portable railway." Neither the specification of the patent (there is no drawing) nor Edgeworth's own account of the invention is very clear. It is possible that the railway was an endless or continuous one, but I am inclined to think that it consisted of a number of separate platforms, laid down before the carriage wheels, and picked up after they had passed, by some sort of lever arrangement. It is the first of a long series of patented inventions of a similar kind, none of which have come into general use, though I believe supporting rails or platforms carried on endless chains travelling over wheels have been successfully applied to traction engines and other implements for use in heavy soil, where even wide wheels are liable to sink in. Edgeworth's idea was, as he himself says, anticipated by the carriage with wheels travelling on an endless chain of rollers described in vol. iii. p. 7 of the Machines Approuvées par l'Académie Royale des Sciences (1713). There is a note on this in the abridgments of specifications relating to Aids to Locomotion, published by the Patent Office in I 858 .

${ }^{3}$ There is an illustration of the apparatus in Bailey's Machines, etc., vol. i. p. 59 (edition of 1782 ). 
the Memoirs he states (vol. i. p. I 7 I) that the instrument worked with great accuracy, having run over a measured mile twice with a difference of only one inch between the two results. Edgeworth's eldest son Richard also received a silver medal in I 778, " for early mechanical genius shown in the constructing several models and machines." As he was born in 1765 , he must have been about thirteen years old at the time. This reward seems to have remained unique.

The award of a gold medal in 1770 to Abraham Staghold for a screw-jack is of peculiar interest, because the jack, which is figured and described by Bailey, ${ }^{1}$ is identical with the well-known modern implement, which, many years after Staghold's invention, was the subject of a patent. The vertical screw is operated by a worm-wheel working thereon as a nut, which worm-wheel gears with a horizontal worm driven by a winch-handle. The screwjack, however, was known before this date. Murray in his English Dictionary gives a reference to it in 1703 , and readers of Robinson Crusoe (the first edition of which was published in 1719) may remember that "a great screw jack" was one of the things that Crusoe brought ashore from the wreck. Without placing too implicit reliance on the accuracy of Defoe's narrative, we may accept his statement as proof that he was aware of the existence of the implement. Abraham Staghold was a blacksmith of Maldon, in Essex, and appears to have been a man of considerable inventive ingenuity, for he was also the inventor of the gun-harpoon, for which he received a grant of twenty guineas in I 770. His inventions, however, do not appear to have brought him a fortune, for in $\mathrm{I} 774$ he sent in a petition to the Society, " desiring relief in his state of distress." The Committee on Correspondence were unable to recommend the Society to devote its funds to a charitable purpose, so the unlucky inventor got nothing by his application.

This first award for a gun-harpoon was followed by several others. For many years the Society continued

1 Bailey's Machines, etc., vol. i. p. I68 (edition of 1782). 
to offer prizes for improved forms of the apparatus, and they also spent over $£ \mathrm{IOO}$ in experiments and tests. ${ }^{1}$

As soon as a satisfactory weapon had been obtainedand this involved the improvement of many details both in the gun and in the harpoon-they continued to offer rewards for whales taken by its use. One of the recipients of these grants, Captain Humphrey Foord, of Hull, wrote an interesting account of his experiences with the new weapon, and made several pertinent suggestions for its improvement. He concludes his letter with a quite unnecessary apology for "the blunders of an illiterate tar, who is unacquainted with writing to the great."

Up to I 792 something like $£ 400$ had been expended, but after this the number of claimants diminished, and though the offer was not discontinued till I82I, the awards made in later years were few and the amounts paid inconsiderable.

Scoresby, in his history of the northern whale fishery, ${ }^{2}$ gives an account of the Society's efforts to introduce the use of the gun-harpoon. He says that the weapon was invented in I $73 \mathrm{I}$, and was used with some success. "Being, however, difficult and somewhat dangerous in its application, it was laid aside for many years. In I 77 I or 1772 a new one was produced to the Society of Arts, which differed so materially from the instrument before in use that it was received as an original invention." On the whole, Scoresby says, in spite of the great improvements resulting from the Society's premiums, "on account of the difficulty and address requisite in the management of it, and the loss of fish which, in unskilful hands, it has been the means of occasioning, together with some accidents which have resulted from its use, it has not been so generally adopted as might have been expected." Later on, still further improvements mere made, and at the date of Scoresby's writing (1820) it was coming to a certain extent into use. At the present date, under the different conditions of the whale fishery, the gun

1 A picture of Staghold's harpoon is given on p. 225.

${ }^{2}$ The Arctic Regions, by W. Scoresby (1820), vol. ii. p. 227. 
is always employed to the practical exclusion of the old hand weapon. ${ }^{1}$

Just about the end of the eighteenth century a great deal of attention was paid to the subject of mechanical telegraphs. ${ }^{2}$ The first suggestion for such a method of conveying intelligence was made by Robert Hooke, who described, in a paper before the Royal Society in 1684 , a method of exhibiting signals to be observed through a telescope, which, though rather complicated, might have been perfectly efficient had it ever been put into practice. The credit of making the first practical telegraph may be assigned to R. L. Edgeworth, who, as has been already mentioned, received several prizes from the Society. There is, however, no evidence to show that he submitted his telegraphic system to the Society. He says in his Memoirs that his attention was first drawn to the subject by a bet that he could report in London the result of a race at Newmarket before it could be brought by mounted messengers. Later on he described his method in the Transactions of the Royal Irish Academy (Vol. vi. I 795). In his system it was proposed to use four triangular pointers, each pivoted to the top of a mast, and representing units, tens, hundreds, and thousands, the precise figure being indicated by the position of the pointer. These numbers corresponded with words or sentences in a vocabulary.

The mechanical telegraph, however, was first introduced by a Frenchman-Monsieur Chappe-about I 794 . Several lines of his telegraph were set up, and it was regularly used for military purposes. According to his system, six discs were mounted side by side in a frame in such a way that either or all of them could be turned edgeways, so as to be practically invisible, or vertical, so

1 The latest information on the subject will be found in a paper read before the Society by T. E. Salvesen in March I9r2. Journal, vol. 1x. p. 5 I 5 .

${ }^{2}$ Rees's Cyclopadia, vol. xxxv. I 819, has a very full and excellent account of mechanical telegraphs. Most of the Society's awards are mentioned. 
as to be seen. By various combinations of these discs a great number of signals could be sent. For use at night, lamps were substituted for discs. A practically similar arrangement was submitted in $\mathrm{I}_{\mathrm{SO}} \mathrm{S}_{5}$ to the Society by $\mathrm{J}$. Davis, and he received a silver medal for it. Two other awards were made by the Society in 1808 - a silver medal to Major Le Hardy for a rather ingenious device for indicating numbers by means of index discs capable of being set in different positions on a polygonal frame, and a silver medal to Chevalier Edelcrantz, a Swede, for a telegraph composed of vanes or shutters capable of being turned edgeways.

Two awards made in I 809 are also worthy of notice, because they refer to methods of hand-signalling. In one of the communications Lieutenant James Spratt, who was wounded at Trafalgar, describes a method of signalling by a handkerchief held in different positions; and in the second, Knight Spencer submitted what he termed an " anthropo telegraph "-a method of signalling by different positions of the arms. This idea has been developed, and is now in common use in the Navy and the Army.

The device, however, which superseded all of these was that invented by Admiral Sir Home Popham, which received a gold medal from the Society in 1816 . This was a semaphore arrangement, in which two masts were employed, eacl with an arm capable of being set at any desired angle to the vertical. It was by this apparatus that information was transmitted from Portsmouth and elsewhere to the Admiralty, until it was at length superseded by the electric telegraph. This was the apparatus with which Barrow (not yet Sir John) was so well satisfied, that when Ronalds in I816 offered to the Admiralty his pith-ball telegraph, which was really the first practical electric telegraph, Barrow, then Secretary to the Admiralty, wrote, with his compliments to the inventor, "that telegraphs of any kind are wholly unnecessary, and that no other than the one now in use would be adopted." This historic communication is dated 5th August 1816.1

${ }^{1}$ History of Electric Telegraphy, J. J. Faliie (I 884), p. I 36. 
Popham applied his apparatus to ships, and it was for long used in the Navy, chiefly from the bridges of ships and from positions comparatively low down in the vessels. Within quite recent years the practice arose of fitting masthead semaphores so as to signal over longer distances during the day. Difficulties, however, arose in carrying the heavy weights of the semaphores at the mastheads, and the practice was abandoned. The introduction of wireless telegraphy has of course rendered such apparatus obsolete.

The list of awards connected with mining is not a very long one. There were a few inventions for raising water from mines, the most important of these being William Westgarth's hydraulic engine, for which a gold medal was awarded in i 769. Nearly twenty years later, in 1787 , a silver medal was presented to Smeaton, the great engineer, for a description of the apparatus which he communicated (after the inventor's death) to the Society." Smeaton had a very high opinion of the value of the apparatus, which, he said, was much appreciated in the Cornish tin-mines. Various methods of raising minerals were also rewarded by the Society, and described in the Transactions. All of these became obsolete when the steam-engine was applied to that purpose.

In I 8 I 6 a gold medal and 100 guineas were presented to James Ryan for his system of mine ventilation. Galloway ${ }^{2}$ speaks in terms of high commendation of Ryan's system, which was to drain off the gas by " passages or gas drifts so arranged as to collect and draw off the gas at the highest level." It was largely introduced into Staffordshire, where it suited the character of the coal measures, but in the northern districts, where it was not so useful, it met with less approval and was not adopted.

The first person to provide miners with a fairly good and safe light was Dr. Clanny, of Bishop Wearmouth. He devised various forms of lamps into which air was forced by a bellows, its exit being controlled by valves of various

${ }^{1}$ Transactions, vol. v. (1787), p. I 81 .

${ }^{2}$ History of Coal Mining (1882), p. I 35. 
device. After working for some time at the subject, he described one form of his lamp to the Royal Society in I 813 . In I 815 he submitted an improved form to the Society of Arts, and received a silver medal, while in 1816 he was awarded a gold medal for a steam safety-lamp. These various devices were undoubtedly valuable and of practical utility, but they never came into general use. They were soon quite superseded by the safety-lamps of Davy and Stephenson, both of which were invented independently in 1815 .

Civil engineering also hardly received its due meed of attention from the Society. The Duke of Bridgewater in 1800 received a gold medal in recognition of the great system of canals which he constructed, a well-deserved award, though perhaps it might have been more fittingly bestowed upon Brindley, the great engineer, whose genius was so wisely utilised by the Duke.

In 1788 a gold medal was given to Abraham Darby for the iron bridge he built over the Severn, near Coalbrookdale. This was the first iron bridge ever constructed. The beautiful model which Darby presented to the Society is now in the Victoria and Albert Museum.

The award in 1762 of fifty guineas to G. Weldon for a machine for planing cast-iron is of interest, because it seems likely that this is the earliest true planer of which there is any record. No picture or description of the machine has been discovered in the Society's records, but Dossie ${ }^{1}$ says that " it planed large iron plates as effectually as a common plane does boards ; making curled shavings, and completely smoothing the surface of the plates."

As might naturally be expected, a good deal of attention was paid by the Society at the end of the eighteenth and the beginning of the nineteenth century to questions of naval construction. The old records of the Society show that it was frequently consulted by the naval authorities on questions of timber for use in building the King's

1 Vol. i. p. I6I. A note on early planing machines, and some references to authorities, will be found in Industrial England in the Middle of the Eighteenth Century, p. 27. 
ships, and such information as the Society could furnish was readily supplied. Some important awards were made by the Society in the class of naval architecture. In I 759 a prize offered for " Ships' Blocks," that is to say, models of ships of new construction, was awarded to Joseph Aldridge, and in 1804 a gold medal was voted to Robert Seppings (afterwards Sir Robert, and Surveyor of the Navy), for his invention of suspending instead of lifting ships in dock. ${ }^{1}$ For this Seppings was granted $£ 1000$ by the Admiralty. It was the first of many important inventions which gained him the reputation of being the greatest naval architect of his time. It was he who first introduced the extensive use of iron in the construction of ships, which, by the additional strength provided by his diagonal braces and trusses, prevented the arching of their keels, technically called " hogging," which always occurred when ships were laid by. Although in the use of iron for shipbuilding he had been partly anticipated by T. Roberts (Assistant Surveyor to the Navy)-who in $\mathbf{1} 808$ received the Society's silver medal for " attaching the end of the beams of ships to their sides by iron instead of wooden knees "-it was Seppings who really revolutionised the art of shipbuilding by the extended use of iron framing. The Howe, launched in I 8 I 5 , was the first ship built entirely on Seppings's method, although the system had been partially applied before that date.

As may be supposed, a great variety of mechanical and engineering inventions besides the few mentioned above received awards from the Society. In the first half-century of its existence these included corn and other mills, canal locks, dredgers, cranes, pile-driving machines, carriages of many sorts, a packing press, tools of many descriptions, mechanical movements, locks, clocks and watches, etc.

Later on, in the early years of the nineteenth century, most of the mechanical inventions submitted to, and rewarded by, the Society, were of a minor character,

${ }^{1}$ Transactions, vol. xxii. (1804), p. 275. See also Seppings's Life in the Dictionary of National Biography. 
though many of them were valuable. The offer of a prize for an original screw brought out several methods for obtaining one, but not of the accuracy required for astronomical and other scientific purposes. There were many awards for improvements in clocks and watches, devices for cutting wheels for watches, watch-springs, etc. The prizes connected with lathes and turning were also numerous, including chucks, self-centring and other. Various mechanical appliances and devices now well known and familiar were brought out by the Society's awards, and descriptions of them will be found in the pages of the Transactions.

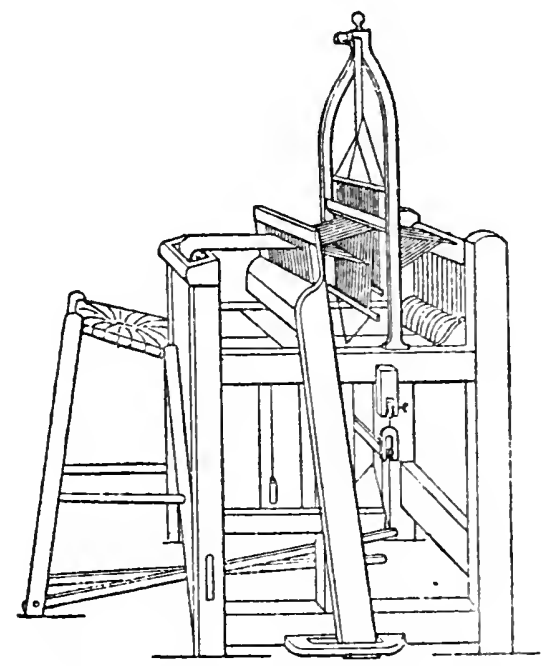

Almond's Loom, i 77 I (see p. 263). 


\title{
CHAPTER XII
}

\author{
The Premiums-(Continued)
}

$$
\text { (1754-1851) }
$$

Textile Machinery-Invention of Spinning Machinery-SpinningWheels-John Kay and his Relations with the Society, his Carding Engine and the Drop-box of Robert Kay-Looms and Stockingframes-The Drawboy-Sill Manufacture, and the Production of Silk in England-Lace- "Quilting in the Loom"-CarpetsBrocade-weaving-Manufacture of Fishing-nets by MachineryIndustrial Hygiene-Fire-gilding-Apparatus for Protection from Noxious Vapours and Dust-Leadless Glazes-Chimney Sweeping and Climbing Boys-Industrial Chemistry, Saltpetre, Natron, Verdigris, Cobalt, Ultramarine, etc.-Dyes and Dye-stuffsMadder, Orchil, etc.-Substitute for White Lead-Pigments and Varnishes-MLarsh's Test for Arsenic_-Illuminating Oils-Medicinal Plants, Rhubarb, Opiun.

Is the first twenty years or so of its existence, down to I 776, the Society expended a little over $£$ I 500 in premiums connected with the manufacture of textiles-part in establishing, or attempting to establish, new branches of the industry, part in endeavouring to improve textile machinery. With regard to the latter part of the work, it is easy to see, after a century's experience, that they were working on wrong lines; but that is merely to say that the members of the Society who directed its proceedings were no wiser (or not much wiser) than their contemporaries. They took immense pains to improve existing apparatus, instead of-as, if they had been gifted with sufficient prophetic insight, they might have doneanticipating the slow course of inventive progress, by encouraging the production of new methods. It is reasonable to wish they had been more enterprising; it is unI8 
reasonable to blame them for their lack of non-existent knowledge. Ex post facto criticism of the sort is as foolish as it is easy.

The Society's treatment of the important question of spinning mechanism is a good case in point, and it is very clearly stated by Dossie. ${ }^{1}$ At the time when he was writing ( 1768 ) a certain amount of progress had been made in the construction of spinning machinery. Just thirty years before (I 738) Paul and Wyatt's machine for "spinning by rollers" had been patented, and soon after the patent was granted the apparatus was in successful operation. ${ }^{2}$ Yet Dossie, with full knowledge of the facts, gives his deliberate and reasoned opinion in favour of improving the ordinary spinning-wheel.

"I am authorised," he says, " to give this judgment on the principle of spinning by mechanism instead of the hand, from my own observations, as well as those of two other very judicious members of the Society, who were best acquainted with that matter, in the spinning machine invented by the late Mr. Paul, which carried this application of mechanics to the greatest extent it is perhaps capable of. By a very great expense, and the assistance of the most ingenious theoretic, as well as practical, mechanicians of our time, he attained to the construction of a machine that, being moved by water, horses, or any other power, would spin, in the most perfect manner, any number of threads, without other assistance of the hand, than to supply the carded cotton, take away the finished roll of thread, and rectify any accidental disorders of the operation. But the delicacy of the work of the machine, equal almost to that of clocks, which subjected it to be easily disordered, and at the same time so expensive to be repaired, and the peculiar manner of carding, which was likewise very expensive, have occasioned this machine to be wholly laid aside as unprofitable, after sixty or seventy thousand pounds have been spent in various attempts to establish its use."

Now these remarks are perfectly sensible, and it was in

${ }^{1}$ Vol. i. p. 93 .

'Industrial England in the Middle of the Eighteenth Century', p. 53. 
consequence of the ideas and opinions that they embody that the attention of the Society was devoted to the improvement of the spinning-wheel. Various prizes were offered, and certain small improvements were duly rewarded. None of them, however, were of any great value, and, as we fully recognise now, the efforts of the Society were quite futile, and its energy was entirely misdirected. Hargreaves had already ( I 764) invented his " Jenny," and Arkwright had patented ( I 769) his " water-frame," while a little later ( 1780 or thereabouts) Crompton brought out his "mule." One wishes that those three names were to be found in the Society's lists, instead of three of the improvers of the venerable spinning-wheel, who were duly rewarded.

The name of a greater inventor than any of these, if, as must surely be the case, the value of a man's discovery is to be estimated by the effect it has upon an industry, does appear in the Society's records, that of John Kay, who, though he lived neglected and died a pauper, revolutionised the whole textile industry by his invention of the fly-shuttle.

Kay was a prolific inventor. He began by devising wire "reeds" for looms, and by the sale of these he made his living. ${ }^{1}$ His greatest invention was the fly-shuttle, which doubled the output of the hand-loom, while improving the quality of its product, and rendered possible the construction of the power-loom. He has a fair claim, as previously mentioned, to be considered the inventor of the power-loom, but this claim can now never be substantiated.

Also he constructed a machine, or rather a pair of machines, for making wire cards for carding wool. ${ }^{2}$ These

${ }^{1}$ Thin strips of cane or reed (whence the name). They may be regarded as the teeth of the comb or grating, in the interstices of which the threads of the warp pass, so that by the swinging of the frame in which the reeds are set, each successive thread of the weft is pressed into its place between the warp threads, and the whole fabric rendered close and compact.

${ }^{2}$ The preparation of wool for spinning was at the time all done by hand, as it is even now to a very limited extent in the domestic production of genuine homespun goods.

The hand cards used may be described as stiff wire brushes. The wires are fixed in a tough leather backing, which is supported by a further backing of wood. Two of them are cmployed in the process of 
are his more important inventions; none of his others appear to have been of much practical value.

The story of Kay's relations with the Society is rather curious and interesting. It has long been known that Kay had applied to the Society, but it was not known which of his inventions he submitted. It was generally believed that he exhibited his fly-shuttle to a committee of the Society, and the Society has been blamed for not recognising the value of so important an invention. This, however, is very far from the truth. The facts have only recently been discovered; they show that the invention submitted was not his fly-shuttle, and that Kay was quite fairly treated by the Society's committee, but also that the committee had no true idea of the merits of the man or of the value of his ideas. They give us a rather pathetic picture of the inventor in his old age, poor, unknown, and rather hopeless, yet still full of faith in the value of his earlier inventions, and confident also as to the merits of certain newer ideas which he puts forward-though with the fuller knowledge now available, it is easy to see that these later notions are of no particular value, the sort of ideas which are always the output of an active and inventive mind. It is the weakness of the born inventor that he must be always inventing, and a large proportion of his inventions are worthless. Very often he himself is not the best judge of the value of his own work. ${ }^{1}$

carding, the lock of wool being laid upon one and combed out with the other. The result is to straighten out the fibres-a process required in all materials used for the manufacture of textiles, except silk, which is produced as a natural thread. The sliver produced by the action of carding is ready for the spinner, who spins it into a thread.

${ }^{1}$ In I9I I was fortunate enough to find in one of the Society's old guard-books several original letters of Kay and some other papers relating to his inventions, and as these seemed to me of very great interest, both from the fresh information they gave about this great but unfortunate inventor, and because no specimen of his handwriting was known to be in existence, I published in the Society's Journal (vol. 1x. p. 73) a long article, in which all the letters and papers were reprinted with extracts from the Committee Minutes and facsimiles of some of Kay's signatures. To this, all who are interested in the subject may be referred. Kay was born in $\mathrm{I}^{\mathrm{O}} 4$, and it is clear from the evidence in these documents that he died somewhere about 1770 . 
It was his apparatus for making wire cards that brought Kay to the Society.

In November I 765 he wrote that he had devised "two engines" for making wire cards, and in January of the following year he attended a committee and demonstrated the working of his machines. The committee reported favourably, and advanced Kay two guineas that he might get six pairs of cards made from "wires crooked and leaves pricked" by his machines, but there is no record of his having done so and no further minute on the subject. Of course, the committee missed an opportunity of doing credit to the Society, but there is no fault to be found with them for that. The apparatus was not of the highest order of importance, and it is quite clear that it received full attention. If Kay had done what he was asked to do, he would certainly have got a reward. It may seem remarkable that the name of a man who is now recognised as one of our greatest industrial pioneers should have been quite unknown to his contemporaries, but so it was. It is evident that the name of the inventor of the fly-shuttle meant nothing at all to a committee of mechanical experts just thirty years after the invention was patented, though we know that it came largely into use in the wool-working districts soon after it was first invented. Probably the committee did not know that the John Kay who showed them his " engines " for making cards had ever invented a shuttle.

Nine years later, November ı 774, William Kay, John's youngest son, attended a committee which had before them another wire-card making machine, and he told the committee that he had " used a machine upwards of ten years for this purpose invented by his father." At a later meeting of the committee William Kay stated that he had improved his father's apparatus and had made cards for sale by his improved machine, which his father had never done. Eventually a bounty of 50 guineas was awarded to William Kay. The award was recorded in the Register of Premiums issued in 1778. Unluckily, Dossie ${ }^{1}$ printed the name Ray in his list of awards, and

1 Memoirs of Agriculture, vol. iii. p. 458. 
this is probably the reason that no mention, so far as I can find, has ever been made of an award being given by the Society for Kay's machine for making wire cards.

A few years before William Kay brought before the Society his improved form of his father's card-making machine, his brother Robert, the eldest son of John Kay, submitted his own improvements on the "wheel-shuttle" (the name by which the fly-shuttle, as it is now called, was then generally known).

This application was made in 1764 (the original patent for the fly-shuttle is dated I733) and was considered at two meetings of the Committees of Mechanics and Manufacturers. Nobody familiar with the working of the apparatus could be found in London, and Robert Kay suggested that it might be tested in Bolton or Manchester and a report made to the Society. This, however, was apparently not done, and there is no further record of any proceedings in the matter. ${ }^{1}$

In the article in the Journal of the Society mentioned above, I discussed at some length the question as to what the invention really was which Robert Kay brought under the Society's notice, and I believe I succeeded in showing that it was in all probability his own invention of the "drop-box," a device by which a weaver could bring into use any one of three different shuttles, each containing a different coloured weft. This drop-box of Robert's (first brought out about i 760) is always stated to be the first device for weaving cross-striped fabrics conveniently, without stopping the loom to change the shuttle, or to re-charge it with different coloured weft. On the whole it appears fairly certain that Robert Kay's "Improvements on the Wheel-Shuttle" consisted of the addition of his own drop-box to his father's fly-shuttle, and that this is the only theory which satisfies all the statements made in the papers brought before the Society's Committee, and published in the Journal of the Society in I9I I.

${ }^{1}$ Along with Robert Kay's papers are two letters from John Kay referring to various inventions of his, and probably of the same date as Robert's application, 1764 . The letters were reprinted in full in the number of the Journal above referred to. 
A good many rewards for improvements in the loom were made at different times by the Society. In i 764 a prize of $£ \mathrm{r} O 0$ was offered for improvements in the stockingframe, and in the minutes of 1765 is an interesting description of the competition, for which a large number of frames were entered. These were set up in the " machine room," and a number of expert workmen were employed to test them. After a careful examination a prize of $£ 80$ was awarded to Samuel Unwin; but in the following year (1766) a still better frame was submitted by John Whyman, and to this the full prize of $£ 100$ was given. The grant was also supplemented by an amount subscribed by a number of manufacturers. This encouragement to British stocking weavers was of special value, because the manufacture was in a depressed condition at the time, and suffering severely from competition with the better productions of French looms.

In 1771 a prize of 650 was awarded to John Almond for a hand-loom, which is interesting because it resembles in many respects the form eventually adopted for the power-loom. ${ }^{1}$ In 1798 , according to a statement by him in the Transactions, ${ }^{2}$ John Austin erected a number of power-looms for a Mr. Monteith, a Glasgow manufacturer, and these, according to Mr. Hooper (Cantor lecture above quoted), were extremely like Almond's hand-loom. A model of one of Austin's looms was for some time in the possession of the Society. He received a Gold Medal in I 806, as well as a Silver Medal in the previous year for his improvements in the loom.

The premium lists contain mention of occasional awards down to the year 1830, and amongst these were some for improvements of considerable value. Porter, writing in $183 \mathrm{I},{ }^{3}$ refers to the improvements in silk weaving rewarded by the Society, which he says, "has done more for the encouragement of ingenious artisans in this branch of industry than has been, or than could be, effected by

'Luther Hooper, "Cantor Lectures on Hand-loom Weaving," Journal (1912), vol. lx. p. 995.

${ }^{2}$ Vol. xxiv. (I 806) p. 93.

${ }^{3}$ Silk Manufacture (Lardner's Cabinet Cyclopædia), p. 35. 
the patent laws under the present system." Amongst these may be noted the improvements in the "drawboy," for which a prize was awarded in 1807 to A. Duff. The mechanical drawboy was invented by Joseph Mason, to whom, in 1687 , a patent was granted for " weaveing such stuffes as the greatest trade in Norwich now doth depend upon, without the helpe of a draught-boy." Before his invention the cords of the loom, which had to be drawn in a prearranged succession in order to produce the pattern, had to be pulled down by a boy who stood at the side of the loom and used a large fork and lever for the purpose. When a mechanical device was substituted for the boy who acted as the weaver's assistant, the apparatus took its name from the original worker whom it replaced.

The actual invention of the drawboy has erroneously been attributed to Duff, but what he did was to introduce very considerable improvements. He himself, in his paper in the Transactions, disclaims novelty for his invention, which he describes as an improvement on methods previously known. Three years later, in i 810 , J. Sholl was rewarded for further improvements on Duff's apparatus. ${ }^{1}$ A little later still came the great invention of Jacquard, on which various improvements in details were made by English inventors. Some of these were rewarded by the Society, the most important being the invention of $W$. Jennings, a weaver or loom-maker of Bethnal Green, who reduced the great height of the Jacquard apparatus, and thereby rendered it available for use in the rooms in which the silk weavers then generally worked. ${ }^{2}$

The manufacture of silk in England had been firmly established by the two great immigrations of Flemish weavers in the sixteenth century and of Huguenots in the seventeenth. Mills for "throwing" silk had also been set up in the eightcenth century. But the various attempts which had been made to produce silk in this country had all failed. The success of Louis xiv.'s great minister, Colbert, in establishing the production of silk

1 Transactions, vol. xxr. p. 5 I (I 807 ), and xxviii. p. I 23 (I810).

2 Porter, Silk Mamfacture, p. 253. Transactions, vol. xlviii. p. I75. 
in France aroused emulation over here, but without practical result. James I., whose efforts to encourage English manufactures perhaps deserve more credit than they have received, tried to acclimatise the silkworm, and for this purpose he had mulberry trees planted in St. James's Park on the site of the present Buckingham Palace. The experiment was continued for some time, since it is recorded that in 1628 , Charles 1 . appointed Lord Aston keeper of "His Majesty's mulberry garden at St. James's, and of the silkworms and houses thereunto appertaining " ; but the garden, as far as its original object was concerned, proved a failure, and was eventually turned into a place of public entertainment.

A scheme started in 17 i 8 had no better success. Large plantations were laid out in Chelsea, but after a short trial the project collapsed. Dossie, in two letters which he wrote (under the signature of "Agricola") to the Museum Rusticum in $1766,{ }^{1}$ relates how a person, whose name is not given, sent some specimens of English-grown silk to the Society in that year, and how the Society, not considering his silk deserving any serious reward, yet encouraged him by the gift of a reel and basin such as were used by the silk-growers of Piedmont. ${ }^{2}$ This seems to have been one of several attempts to grow silk in this country at the time, for some small prizes were awarded in 1763 and in 1778 for raising and winding silk.

The Society seems to have held the view that the production of silk in England was not practicable, and while, as previously recorded, ${ }^{3}$ it took a good deal of trouble to promote silk-growing in the American colonies, it did nothing at first to encourage it in Great Britain. The specimens, however, above-mentioned drew fresh attention to the matter, and Dossie rather vigorously combated the received opinion, urging that further experiments should be made. Accordingly, in 1 768, a prize for English-raised silk

1 Museum Rusticum, vol. vi. pp. 89 and 24 I.

2 It appears from the minutes that the correspondent wrote under an assumed name, "Rusticus," but it seems, from a note by Dr. Templeman on one of his letters, that he was really John Delamare, a member of the Society and a silk manufacturer of Spitalfields.

${ }^{3}$ See Chapter IV, p. 84 . 
was offered, and from time to time after this date efforts were made to encourage the planting of mulberry trees and the raising of silkworms. The Hon. Daines Barrington contributed a paper to the second volume of the Transactions on the subject, and in it he also urged the advantage of silk-growing in England, and gave some information as to the practice in the East and on the Continent. The Society continued to offer rewards for the plantation of mulberry trees, and for the production of silk, with the result that from time to time small quantities of cocoons were produced, but the matter never got beyond the experimental stage, where indeed it now remains.

Many years later, in 1825 , a vigorous attempt was made to raise silk here on a commercial scale, and a company with a large capital was started. It, however, was unsuccessful, and though even later proposals have been put forward for the plantation of mulberry trees and the raising of silkworms, they have never led to any practical result. In 1840 , W. Felkin, of Nottingham, sent the Society some samples of British-grown silk, and was formally thanked for them, and in 1873 , Sir Daniel Cooper produced some similar experimental specimens.

The latest communication on the subject to the Society is a paper read in 1877 by $\mathrm{Mr}$. Francis Cobb, in which the writer recommended the raising in England of silkworm "grain," or eggs, for exportation abroad. The reason generally put forward for the failure has been the lack of cheap labour, but whatever the cause, the fact remains that while it has been shown that perfectly good silk can be produced in this country, nobody has ever succeeded in obtaining it in profitable quantities.

At various times attempts were made to encourage the production of lace in England. The first award was taken in I 762 by Dorothy Holt, who made the ruffles worn by George III. at his coronation. Several other small prizes were given about the same time, but the matter dropped, and though some years later the offer of prizes was renewed, nothing very much came of it. Lace-making was one of the very few domestic industries which survived, 
and perhaps it neither needed nor profited by artificial stimulation.

Between the years 1761 and 1765 the amount of $£ 410$ was expended in rewards for what was known as " quilting in the loom "- that is to say, weaving fabrics having a diagonal pattern like a quilt. Such fabrics were imported from the East, and "Indian quilting " was much admired, as appears from occasional references in contemporary literature. Some, perhaps all, of the material was handmade. It was not, however, produced in England till the Society, in 1761 , offered a prize for " a quantity of quilting, made in a loom in imitation of, and nearest in goodness to, the Marseilles or India quilting." In successive years samples of a gradually improving character were produced in silk, cotton, linen, and wool, until in I 765 the Committee on Manufactures reported that " the manufacture appears to be sufficiently established," and the prizes were discontinued.

The writer of the "Observations on the Effects of Rewards " in the class of manufactures, appended to the list of awards published in 1778 , writes in a very jubilant strain about the result of these particular prizes, for he says :-

"The manufacture is now so thoroughly established and so extensive, being wrought in all the different materials of Linen, Woollen, Cotton and Silk, that there are few persons of any rank, condition, or sex in the kingdom (and we may add within the extent of British commerce, so greatly is it exported) who do not use it in some part of their clothing; so that we may safely say, if the whole fund and revenue of the Society had been given to obtain this one article of trade, the national gain in return should be considered as very cheaply purchased."

In the first half of the eighteenth century a number of factories had been started in England by Walloon, Flemish, and French weavers for the manufacture of tapestry and pile carpets, apparently with but moderate success. ${ }^{1}$ The subject was one to which a good deal of

${ }^{1}$ A good summary account of these is given in the latest (eleventh) edition of the Encyclopedia Britannica, in the article on "Carpets," by Mr. Alan Cole. The history in the carlier editions is neither full nor accurate. 
attention was paid by the Society, and premiums were given in 1757 to Moore, of Chiswell Street, and to Whitty, of Axminster; in 1758 to Passavent, of Exeter; and in 1759 to Jeffer, of Frome. It seems probable that Passavent's factory was the one founded about three years earlier, and mentioned by Johnson's friend, Baretti, two years later ( 760 ).

By these awards, it is stated," the manufacture of carpets " is now established in different parts of the kingdom, and brought to a degree of elegance and beauty which the Turkey carpets never attained."

The drugget, for the manufacture of which a prize was offered in 1758 , was not the floorcloth now known by that name, but a " sort of stuff very thin and narrow, usually all wool and sometimes half-wool and half-silk." 2 It was used as a material for clothing, and as late as i 832 Bulwer Lytton describes one of the characters in his Eugene Aram as wearing a "spencer of light brown drugget." There was a great demand for it in the Lisbon market, and this market was mainly supplied from France, so it was thought that there was a good opening for British trade. Various awards were made during the next four years, and satisfactory samples were produced, but " owing to exterior circumstances attending the course of our trade with Portugal," the importation to Lisbon was never established. Dossie, who reports the matter, comforts himself with the philosophical reflection that if such a branch of the woollen manufacture had been established it would only have come into competition with branches already existing.

In 1809 the Society awarded a " silver medal set in a broad gold border" to "The Patrons and Committee of the Flag Association, for a matchless specimen of double brocade-weaving in a flag now executing in Spital-fields."

A full account of this flag is given in a curious and rather interesting pamphlet which has been preserved in the Guildhall Library. ${ }^{3}$ It appears that one Samuel Sholl

1 Transactions, vol. i. (I783), p. 28. ${ }^{2}$ Chambers's Cyclopadia, I75I.

${ }^{3}$ Short Historical Account of the Silk Manufacture in England. By Samuel Sholl (1811). 
and some other journeymen weavers formed a committee to produce a piece of work which would afford proof of the capacity of British workmen to manufacture something as good as any foreign production. With this object they collected subscriptions to defray the cost of weaving a very elaborate flag. They collected over $£ 570$, but when the flag was finished they found themselves in debt for $£ 380$ more. The flag was exhibited at the Society's distribution of prizes in I $81 \mathrm{I}$, when the medal was presented, the flag being then finished. It seems by the description to have been a very remarkable piece of work, and from the terms of the award it was evidently highly approved by the committee. Its after history is not known, Sholl's work having been published in 18 I I .

About the end of the eighteenth century the idea of making fishing-nets by machinery seems to have attracted some attention both in France and in England. The Société pour l'Encouragement de l'Industrie Nationale (founded in ISOI) offered a prize of 10,000 francs, a part of which (according to the Encyclopedia Britannica) was awarded to Jacquard. In 177 I the Society of Arts offered a prize of twenty guineas for a similar object. Awards were made in 1776,1796 , and 1806 , and the two machines (by Boswell, of Barnstable, and Robertson, of Edinburgh), for which the last two awards were made, look from the descriptions as if they would have worked well enough, but the above-quoted authority states that the first efficient machine was by Paterson, of Musselburgh (the date of which was about i 820). The devices of some of these net-making machines were afterwards embodied in some of the later lace-making machines. ${ }^{1}$

Amongst the first subjects to which attention was given was what is now termed "Industrial Hygiene "- that is to say, methods of preventing injury to workmen engaged in dangerous or unhealthy occupations, or proposals for the substitution of innocuous substances for those in the

1 Felkin's History of the Machine-Wrought Hosiery and Lace Manufacture (1 867), p. I 56 . 
preparation or use of which there was risk of injury to life or health.

The late Mr. Benjamin Shaw, therefore, when in 1876 he founded a prize for inventions devised to minimise the risks incidental to industrial occupations, was only carrying out a very old tradition of the Society.

The first prize of the sort was offered in $177 \mathrm{I}$, for any means of lessening the injurious effects of the process of fire-gilding or water-gilding, as it was sometimes called. In this process a coating of an amalgam of gold and mercury is applied to the metallic surface to be gilt. The mercury is volatilised by heat, and the gold is left as a thin adherent film. The process has now been to a large extent superseded by electro-plating; but it is still used for fine work, as it gives a very good solid deposit. The mercurial vapours given off are, however, extremely injurious to the operator, and before proper appliances were devised to carry them away, the early workers suffered severely from them. The offer produced an apparatus intended to remedy the objections, and in 1774 a prize of twenty guineas was awarded to its inventor ( $\mathrm{J}$. Hills), who kept a curiosity shop in Berwick Street. According to the description of Dossie, ${ }^{1}$ who (like the present writer) found Hill's own description unintelligible, the apparatus consisted of a funnel fixed in front of the furnace and over the article under treatment. This funnel was connected by a pipe to the furnace chimney, and a draught produced by a bellows drew up the fumes and discharged them into the flue. If necessary, glass screens could be added, with openings through which the workman could pass his hands, enclosed in leather gauntlets. After inspecting a model, the Society's committee ordered a full-sized apparatus to be constructed and set up. A "Mr. Platts, a workman in the water-gilding way," was engaged to work it. "A day being fixed, several members of the Society went to see its effect, and reported that they had not felt any of the so-called sweet vapour during the operation." Having thus assured themselves, by personal immunity from mercury poisoning, of the value of the apparatus, they

${ }^{1}$ Dossie, vol, iii. p. 370. 
decided to award Mr. Hills the offered prize. A little later Platts wrote that he had made use of the apparatus " ever since the trial." He added, "I . . . wish I had been so happy as to have had the use of such an invention twenty years ago ; I make no doubt but that I should have been free from the disorder I have so long laboured under."

The actual process of fire-gilding is practically identical now with that seen by the Society's committee in I774, and a certain amount of risk is still run by the workman. But he works under very much better sanitary conditions, and he has the advantage of various appliances, such as india-rubber gloves, unknown to his predecessors of a hundred and fifty years ago.

Forty years later we find the same grievances existing, and a fresh attempt made to remedy them. In I8I I a prize of twenty guineas was awarded to Richard Bridgen for " a method to prevent the inhalation of noxious vapours in gilding metals." This time it was a mask to be fitted over the workman's nose and mouth, and connected to a tube, which was led to the back of the head, so that the air breathed was not charged with the fumes immediately proceeding from the heated metal. If preferred, the tube might be lengthened and led to a window, so as to provide communication with the external air. That the device was quite practical and effective, though decidedly inconvenient, may be admitted as certain. That it is still regarded in some quarters as a novelty is shown by the fact that when, ten years ago, in 1903, a special prize was offered by the Society for a dust-arresting respirator, several masks, identical in principle with Bridgen's, were submitted in competition.

A considerable further advance was made by John Roberts, who in 1825 received a silver medal and fifty guineas for " apparatus to enable persons to breathe in thick smoke, or in air loaded with suffocating vapours." This apparatus would appear to be the original of the various modern devices, firemen's helmets, respirators, and the like, used-or proposed-for enabling persons to breathe in smoke or noxious atmospheres. It consisted of a leather helmet, padded so as to fit airtight to the 
wearer's neck and shoulders, and fitted with glass or mica eye-pieces. From the front of the helmet was suspended a flexible leather tube, with a helical wire inside, and terminating in a trumpet-shaped mouth. The object of this was to draw the air for respiration from near the floor level, where there was less smoke. The trumpet was filled with moist sponge covered with coarse cloth. For convenience, the pipe was strapped to the wearer's thigh. If the cloth was sufficiently porous, this must have been a very efficient and practical appliance. It is evident that the pipe was an unnecessary detail, and might have been dispensed with. Roberts's apparatus was carefully tested by the Society's committee, and was found to work very well, according to the account given in the Transactions. ${ }^{1}$ He himself was a working collier of St. Helens.

Considerable public attention was drawn a little later still (in 1830) to the Chevalier Aldini's ${ }^{2}$ wire-gauze mask ${ }^{3}$ or screen for the use of firemen, and the Society gave him a gold medal, with the remark: "Something is still wanting to give to his ingenuity all the practical utility of which it is capable; and it is in the hope of this being effected that the Society again call it to the public atten tion." 4

The dangers to health from any dusty trades, in which the harm is done by mechanical particles breathed by the workman, was not overlooked, and in 1805 a gold medal was offered for "obviating the prejudicial effects that attend the operation of pointing needles by grinding them dry, during which the particles of grindstone dust and steel, being thrown into the air, and received with it into the lungs, occasion asthma, consumption, and other painful disorders." The offer was afterwards extended to include other processes of dry grinding, and was con-

1 Transactions, vol. xliii. p. 25.

? Giovanni Aldini (1762-I834) was an Italian physicist of some distinction, and Professor of Physics at Bologna.

In 1827 a reward of five guineas had been paid to J. Callaghan for a wire-gauze "face-guard for smelters." This was intended merely to protect the face from heat, but it might have been applied to other purposes (Transactions, rol. xlv. p. I 52 ).

'Transactions, vol, xlviii. p. I4I. 
tinued for twenty years. In ordinary grinding work with a wet stone, the stone cuts more quickly, because the water washes away the metallic particles and fine dust, so that the grain of the stone is not, as the grinders say, " choked," but the dry stone, though it cuts more slowly, leaves a finer surface, and therefore has always been used for needle-pointing and for similar work. ${ }^{1}$

Of the various appliances submitted, some of which received rewards, the best was that of J. H. Abraham, of Sheffield, to whom, in 1822 , the Society awarded its gold medal for a magnetic guard to protect persons employed in dry grinding. The apparatus is described in the Transactions. ${ }^{2}$ The stone is enclosed in a wooden casing, so that only a portion is exposed, and the current of air generated by its revolution carries the dust into a tube, by which it is led away. The invention also includes a respirator to cover the mouth and nose. This respirator was fitted with magnets, for the purpose of arresting the fine particles of steel thrown off in the process of pointing needles, and in other processes of dry grinding. Although the invention was greatly appreciated at the time, and was actually brought into practical use, it never became popular, the main objection to it having been raised by the workpeople themselves, who feared that the lessened risk attached to their employment would lower their wages. Similar considerations have always stood in the way of the introduction of various appliances intended to limit the risks associated with all trades in which the workpeople breathe a dusty atmosphere.

The question of producing a leadless glaze for pottery, which would be effective without injuring the health of those employed in the manufacture, is a very old and a very important one, and one that has not yet been solved. At a very early date it came before the Society, and in 1793 a prize of a gold medal was offered for "glazing earthenware without lead."

As is well known, the glaze on earthenware is merely

${ }^{1}$ Holtzapffel, Mechanical Manipulation, vol. iii. (1850), p. I I I .

2 Vol. XL. (I822), p. 135. 
a thin coating of glass, or silicate of soda. On many of the coarser forms of pottery the glaze may consist of pure silicate of soda, and may be obtained by the use of common salt. But such a glaze is only applicable to clay bodies, which will stand a very high temperaturea class which includes a very large number of the roughest sorts of pottery, and also what is known as stoncware. By the use of lead a very much more fusible glaze is obtained, and this is available for all the more delicate kinds of porcelain and other more easily fusible ware.

The offer, in 1793, induced an application from one Law, who submitted specimens of an "East Indian material called by him 'She Kaw.'" Samples were submitted to Thomas Wedgwood for report, and he reported adversely on the material, which proved to be some sort of selenite.

For many years the offer was continued without any result, until 1820 , when a claim was made by John Rose, of Coalport. "The principal ingredient of my glaze," he wrote, " is felspar of a somewhat compact texture, and a pale flesh-red colour, which forms veins in a slaty rock adjoining to the town of Welsh Pool, in Montgomeryshire. This material, being freed from all adhering pieces of slate and of quartz, is ground to a fine powder, and being thus prepared, I mix with 27 parts of felspar, 18 of borax, 4 of Lynn sand, 3 of nitre, 3 of soda, and 3 of Cornwall china clay. This mixture is to be melted to a frit, and is then to be ground to a fine powder, 3 parts of calcined borax being added previously to the grinding." This was perhaps the first of the many felspathic glazes which have been suggested as substitutes for lead glaze. It was no doubt an excellent glaze, and probably well deserved the gold medal which was awarded to Mr. Rose for his invention. Two years later, in 1822 , another premium was awarded to J. Meigh, of Shelton, Staffordshire, for another felspathic glaze.

The offer of the prize was continued for another two years, and in the meantime arsenic had been added to 
the prohibited ingredients. But after 1823 the premium was discontinued.

As is well known, the problem has not yet been satisfactorily solved. As late as 1910 a Departmental Committee reported on the dangers attendant on the use of lead in the manufacture of earthenware and china, and this report contains the fullest and latest information on the subject of leadless glazes. Many such glazes have been added to that of John Rose, but none of them are so effective as, and all of them are more expensive than, a glaze in which lead forms a part. Very great improvements have naturally been made in the manufacture, and to a very large extent the desired end has been attained by the method of preparing the lead glaze, which is now made of a much less soluble character than of old, so that the processes of manufacture are much less dangerous to the workmen. By such means, and by insisting upon proper sanitary precautions, the death-rate has been so largely reduced that practically the object sought for is believed to have been attained without the necessity for prohibiting certain methods of earthenware-making. It is to be hoped that this belief is well-founded, since the proposed legislation, whatever might be its result upon the health of the workers, would only, in the opinion of those best qualified to judge, have the result of driving the manufacture of high-class ware out of this country, and placing it in the hands of foreigners.

Until quite the end of the eighteenth century, chimneys were always swept by climbing-boys, and nobody seemed to see any hardship in this occupation for children. Even so kindly a soul as Charles Lamb, in his essay on chimneysweeps, ignores the enormous amount of brutality and cruelty which fell to the lot of "those tender novices, blooming through their first nigritude." Mrs. Montagu, the celebrated "blue-stocking," gave the climbing-boys an annual dinner, and so, if Elia is to be believed, did his old school-fellow, James White. But the first to make a serious effort to improve their condition appears to 
have been Jonas Hanway, who was instrumental in introducing into Parliament the Bill which was passed in 1788 . This Act (28 George III. c. 48) imposed certain restrictions on the business, but, on the whole, was ineffective.

In 1796 the Society offered a prize for an apparatus for " obviating the necessity of children being employed within flues." A note to this announcement refers to the great hardships endured by, and to the frequent fatal accidents occurring to, the children employed. The prize offered was a gold medal or forty guineas, and the offer was renewed at intervals up to 1803 . Various proposals were submitted, including a machine by G. M. Smart, but no awards were made before I805, when Smart sent in an improved machine, and to this the prize was awarded. This apparatus was practically the same as that which is now used-namely, a number of rods connected together, and carrying a brush at the top. In Smart's apparatus the rods were hollow; they fitted one into the other by means of sockets or screws, and were all held together by a cord running through them. This machine was afterwards known as the "scandiscope," and soon came into general use. ${ }^{1}$ According to a note in the Transactions, Smart had given up his own profitable business from philanthropic motives, and devoted himself to the invention and popularisation of chimney-sweeping apparatus.

In the year 1800 the Society for Improving the Condition of the Poor took up the subject, and in $\mathrm{I} 8 \mathrm{O} 3$ a special society was formed for superseding climbing-boys. The treasurer of this society at one time was William Tooke, a vice-president of the Society of Arts, who many years later, on the death of the Prince Consort in 1862, held the presidency of the Society for a year until the election of the then Prince of Wales (King Edward

${ }^{1}$ A great deal of information about the climbing-boys and the reform which led to their suppression will be found in Mayhew's London Labour and the London Poor (edition of I86I), vol. ii. p. 399. Hone, in his Everyday Book, vol. ii. p. 5 I 8 , also gives many curious and interesting details, including a quaint adverisement of the scandiscope. 
vir.). It was due to the exertions of Mr. Tooke, and to the appeal of $\mathrm{Mr}$. J. J. Angerstein, the well-known philanthropist, that the Society of Arts associated itself with the newly formed society, and renewed its offer of prizes for machines for sweeping chimneys. In 1817 a Parliamentary inquiry was held, at which Tooke, Smart, and others gave evidence, and this led to the passing of a second Act in 1834 (4 \& 5 Will. IV. c. 35). Eventually a third Act (3\& 4 Vict. c. 85 ) was passed in 1840 . This came into force in $\mathrm{I} 842$, and at last put an end to the use of climbing-boys.

After the award to Smart various other prizes were given for other chimney-sweeping machines, including some in which the brush was dragged through the flues by means of a rope. But none of these seem to have come into general use in this country, although the rope machine is extensively employed in France, and the flues in the high buildings erected of recent years are usually swept by means of what is known as a "ball and line," the ordinary sweep's broom not being capable of the necessary extension.

Considering that the foundations on which the science of chemistry was eventually built were only laid in the last years of the eighteenth century, it is obvious that such industries of a chemical nature as existed could only be of a purely empirical character, and were not really conducted on scientific principles at all. Some progress, it is true, had been made in technical chemistry abroad,"2 but in England there had been but little advance. Indeed, it was the discovery by Leblanc, in I792, of the method of making carbonate of soda from common salt that really formed the basis of modern industrial chemistry, since it provided a cheap source of alkali, previously only obtainable from vegetable ashes as an impure carbonate of potash and soda, or in the form of saltpetre (nitrate of potash), either native or artificial. In an early premium

1 See Chapter XX, p. 444.

2 Sir Edward Thorpc, in his History of Chemistry (1909), gives the names of Gahn, Marggraf, Duhamel, Réaumur, Macquer, Kunkel, and Hellot as the pioneer technical chemists of the eightecnth century. 
list ( 1770 ) is included a prize for barilla," " made from Spanish kali raised in Great Britain." The offer was continued for thirty years, but produced no results, nor was a similar offer for barilla grown in any British possession more effective, though the barilla industry was an important one in India, and Dr. Roxburgh, the great Indian botanist, who died in 18 I5, reported that one species of Salicomia, abundant on the Coromandel coast, might yield barilla sufficient to make soap and glass for the whole world. No better result was obtained by a similar prize offered for British-grown kelp richer in alkali than the ordinary sort.

Later on ( 1783 ) the true way of supplying the demand for alkali was suggested in the offer of a prize for obtaining soda from sea-salt, a problem which, after exercising the minds of many chemists and inventors (among the most notable of these was Roebuck, the friend of Watt and Priestley, who ruined himself in the attempt), was eventually solved by Leblanc, in response to a prize offered, not by the Society of Arts or any other society, but by the Emperor Napoleon.

The Society's efforts to increase the supplies of saltpetre, or "fossil fixt alkali," have already been referred to in the chapter dealing with the Colonies." An attempt was also made to establish works for the production of saltpetre in England, but the only result of these efforts was to demonstrate the impracticability of manufacturing it on a commercial scale at a price which would compete with that of imported saltpetre, and, after a few years, the attempt was abandoned.

Rewards were also offered for the production in Great Britain of borax, sal-ammoniac, bismuth, and some other materials, but naturally without result. Somewhat better fortune attended an effort to establish in England the manufacture of verdigris (basic acetate of copper), used as a pigment and a dye, and then imported from France, where it was made by treating copper plates with wine-lees. ${ }^{3}$

1 Barilla was the ash of plants of the genus Salicornia or glasswort. It contained only about a fourth of its weight of carbonate of soda.

${ }^{2}$ See Chapter IV, p. 87.

${ }^{3}$ The chief seat of the manufacture is still Montpellier, in France. 
In this country the necessary vegetable acid was obtained by using the pulp of apples from cider-presses, and other fruit-juice. By the offer of liberal and continued grants, the industry was actually started, and a considerable amount of the material was produced, but no regular manufacture was established.

One of the first two prizes offered by the Society was for English cobalt, the object being the production of smalt and zaffre, both silicates of cobalt associated with silicate of potash, and made by melting the oxide of cobalt with sand and potassium carbonate. The glasses thus obtained form useful blue colouring matters. The first offer ( 1754 ) produced some samples, and an award of $£ 50$ was paid for cobalt from a Cornish mine in 1755. Nine years later, a similar sum was granted to Nicholas Crisp, the watchmaker, one of the founders of the Society, for making zaffre and smalt. Again, in 1810, the attempt was renewed, but without practical result.

In I 80 I a gold medal was offered for the production of artificial ultramarine. The offer was continued for a good many years, and in the list for i 8 i 2 a note was added that "it appears from the analysis of lapis lazuli by Klaproth, and the experiments of Guyton (related in the Amnales de Chimie), that ultramarine is a blue sulphuret of iron, and that a blue substance much resembling it is constantly found amongst the scoriæ of blast furnaces where iron is reduced." Nobody was found, however, to act on the suggestion. Foreign chemists were more enterprising, for after Tassaer in 1814 observed the spontaneous formation of a blue compound in the soda furnaces at St. Gobain, the Société pour l'Encouragement offered a prize for an artificial ultramarine. Ultimately the problem was solved by Guimet and by Gmelin, the latter of whom was then at Tübingen, and an industry was started which still flourishes in Germany. The material is a silicate of alumina and iron, together with iron sulphide. The manufacture has never been established in this country.

Among the earliest objects to which attention was directed was the improvement of methods of dyeing textiles, 
wool, silk, and cotton, and the encouragement of the domestic production of the materials (mainly vegetable) which were then employed. England was much behind other countries in its methods of dyeing and calicoprinting (as it was in most other industrial processes) when the Society was founded, and much of the cloth woven here had to be sent abroad to be dyed, as much of the linen had to be sent abroad to be bleached. The very first prize offered by the Society was for a dyeing material, madder, and this was followed by others for dyeing cloth, silk, linen, and cotton, sometimes of specified colours, and sometimes by improved or cheaper methods, or by materials not previously used. The Society worked hard for twenty years to establish the cultivation of madder in England, and by 1775 it had expended a sum of $£_{1} 5_{16}$ in the effort. After the first two or three years it paid a definite amount of $£ 5$ per acre of madder grown annually, and these payments varied from $£ 5$ for a single acre up to, in one exceptional case, $£ \mathrm{I} 45$. After 1775 the rewards were discontinued, the Society's object having so far been attained that the price of imported madder was reduced, and its quality improved, by the competition of the home-grown product. It is also recorded that the Society was instrumental in obtaining an Act of Parliament, which modified the amount of tithe levied on land used for the growth of madder. ${ }^{1}$

Numerous rewards were offered for the importation of new or little known dye-stuffs from the colonies, and some rather unavailing efforts were made to start in England the growth of tinctorial plants better suited for other climates. Such, for instance, were the orchella weed (Rocella tinctoria), a lichen native to many parts of the world and producing the colouring matter archil, or orchil, long used for dyeing red and purple ; and, even a less reasonable proposal, indigo. A premium for growing

${ }^{1}$ Dossie, vol. i. p. 42. The Act was 3I Geo. II. I755, c. 12, "An Act to encourage the growth and cultivation of madder in that part of Great Britain called England by ascertaining the Tithe thereof there." The Act was for fourteen years, and was continued for a second fourteen by 5 Geo. III. c. I8 (Gents. Mag. vol. lxvi. pt. I. February 1796, p. I I 5). 
the former in Great Britain was offered in 1763 , and a similar offer was published in 18 I 7 with reference to indigo. A suggestion in 1763 as to the employment of Prussian blue (sesqui-ferrocyanide of iron) may be noted. The material was known at the time, but appears not to have been used as a dye.

Besides thus endeavouring to add to the list of materials available for the dyer, the Society included in its premium list the production of new or improved colouring matters for use as pigments. Amongst these perhaps the most important was a substitute for white lead. For over fifty years from I788, when it was first offered, a prize for a "substance for the basis of paint" "equally proper for the purpose as the white lead now employed," appeared in the premium list. The value of the prize was at first $£ 30$, but it was afterwards raised to roo guineas. That the prize was never awarded is not perhaps very remarkable, since it is only of quite recent years that even a partial substitute for white lead (a basic carbonate of lead) has been found in zinc-white (zinc oxide), and even this, though it is non-poisonous and is unaffected by atmospheric influences, does not combine with the oil of the paint as effectively as the lead, while the paint has less " covering power," and is more costly. ${ }^{1}$

In the first printed list of premiums is a prize for improved varnish, and from time to time prizes were offered for varnishes, materials for varnish-making, methods of bleaching lac, etc. Although some small rewards were given, the offers appear to have had no practical result until 1833 , when a gold medal was presented to $\mathrm{J}$. Wilson Neil for a paper on the art of making copal and spirit varnishes. Until the publication of this memoir, varnishmaking had always been professedly a trade secret, and the methods of its manufacture were jealously concealed. Mr. Neil, however, who was a varnish-maker of great experience and of considerable reputation, put an end to this state of things by giving full and copious details of

${ }^{1}$ The subject of white lead substitutes has recently been discussed with much ability in a paper read before the Society in March 1913 by Mr. Noel Heaton (Journal, vol. Ixi. 1). 458). 
all the methods and materials employed. His paper ${ }^{1}$ was for long the principal, if not the sole, source of information on the subject, and though its contents have often been republished, it remains to the present day a valuable treatise on the manufacture, and may still be consulted with advantage.

In $182 \mathrm{I}$ a gold medal was offered for a test for arsenic, and the offer was continued for six years without result. Fifteen years later, however, it produced a communication from James Marsh, the well-known chemist of Woolwich Arsenal, and to him the medal was awarded in 1836, for the test since known by his name. Marsh's test for arsenic is described in all chemical text-books, and is familiar to all chemists. It is only necessary to say that the description given in the Transactions ${ }^{2}$ holds good to-day. The test is one of extraordinary delicacy, and the cautions given by the inventor as to the need for special care in securing the purity of the reagents employed are as necessary now as when they were written.

At a time when oil was the chief source of illumination, and vegetable oils were scarce and expensive, many attempts were made to get rid of the fœetid smell of the train oil, which was for many purposes, on account of its cheapness, the only sort available. A very early prize was offered by the Society (in 1757) for the "edulcoration" of oil. According to Dossie, ${ }^{3}$ the result can hardly be considered to have been satisfactory, for when samples of the "edulcorated" oil were compared with some of the same oil before treatment, "it was difficult to say which was the worst. For the operation had added an empyreumatic smell to the putrid fotor, which was very little diminished." Dossie, however, can hardly be considered an impartial critic, for he afterwards (1761) produced a process of his own, for which the Society gave him $f$ Ioo. His process consisted in treating the oil with chalk or lime, and adding

\footnotetext{
1 It occupies fifty-five pages in Vol. XLIX. of the Transactions (I \& 2 T-2). pp. $33-87$.

2 Transactions, vol. li. p. 67 .

${ }^{3}$ Vol. i. p. I 88.
} 
either common salt or potash. It was said to have been very successful. ${ }^{1}$

A good example of the results of the efforts of the Society to introduce new medicinal plants is afforded by the introduction of rhubarb (Rheum palmatum) into Great Britain. In 1763 the Society appointed a committee "to pursue the requisite measures for introducing the culture of the true rhubarb," and eventually a gold medal was offered.

The committee obtained specimens of the plants and roots from various sources, but were doubtful if they had got hold of the genuine rhubarb, until they found that Dr. Mounsey, an English physician settled in Russia, had, at the suggestion of Sir Alexander Dick, President of the Royal College of Physicians of Edinburgh, sent over some seeds of the plant, which had been planted by various persons in England and Scotland. Dr. Hope, the Professor of Botany at Edinburgh, had raised some plants, and others, it is stated, had been " raised in the garden of the Museum in London." 2 Accordingly, in 1769, gold medals were awarded to Dr. Mounsey for " having introduced the seed of the true rhubarb some years before," and to James Inglish ${ }^{3}$ for raising plants from it. ${ }^{4}$ Seven years later (1776) Sir A. Dick was awarded a gold medal,

${ }^{1}$ Dossie's paper was published in full, some time after the author's death, in the Transactions, vol. xx. (I 802), p. 209.

${ }^{2}$ There cannot, I think, be any doubt that by this is meant the Chelsea Physic Garden, since some of the first rhubarb seeds ( $R$. Rhabarbarum, not the true medicinal rhubarb) were sown in that garden by the curator, Isaac Rand, about 1732 (Rees's Cyclopedia, edit. I819, s.v. Rhubarb). Rhabarbarum was first named by Linnæus, who afterwards found that Palmatum was a different species, and named it also (Species Plantarum, 2nd edit. 1762). Hope described the plants he had raised in a communication to the Royal Society, $24^{\text {th }}$ Sept. 1765 (Phil. Trans., vol. lv. No. xxxii.). In that paper he gives the date of his receiving the seeds from Mounsey as 1763 .

${ }^{2}$ The name is thus given in the prize-lists, and in the MS. Commit tee Minutes, but Dossie spells it "English."

${ }^{4}$ A full account of the history of the introduction of rhubarb is given in Dossie, vol. ii. p. 258 ; and in vol. iii. p. 208 , there is a very interesting letter from Sir A. Dick. 
and Mr. Callendar, of Newcastle, a silver one. The Society still continued its rewards in order to secure the growth of the plant on a commercial scale, and during the following twenty years various medals were given, amongst others a silver medal, in 1789 , and a gold one, in 1794 , to William Hayward, of Banbury, which town became, and still remains, the principal seat of the industry in England.

Another medicinal plant, the growth of which it was attempted to encourage, was opium. In I796, John Ball, of Williton, Somerset, sent to the Society some samples of home-grown opium, and, as on examination the drug proved to be of good character, a "bounty" of fifty guineas was presented to him. Full details of his method of growing the poppies and of obtaining the extract were supplied by Mr. Ball," who wrote enthusiastically about the prospects of his crop, and said that he expected to be able to dispose of all that he could grow to a London druggist at the price which foreign opium then fetched, viz. twenty-two shillings a pound.

In the premium list for the following year, 1797 , gold and silver medals were offered for specified amounts of British-grown opium, and this offer was continued for some time, though without much response. In i 800 the larger prize was awarded to Thomas Jones, who for some years had grown opium at Enfield and elsewhere. ${ }^{2}$ Though he says he found more difficulties than Mr. Ball had reported, and had suffered in some years from unfavourable weather, he had produced considerable amounts of saleable opium, which was reported upon as equal to the best Turkey. It was concluded that the possibility of producing the drug commercially in England had been demonstrated.

After an interval of nearly twenty years, yet another gold medal was awarded, in I8I9, to John Young, an Edinburgh surgeon, who had successfully grown opium in Scotland. He, like his two predecessors, contributed a very full and interesting paper to the Transactions, ${ }^{3}$ and he writes as if he had had some experience of Indian opiumgrowing. He states that he had obtained $56 \mathrm{lb}$. of opium

1 Transactions, vol. xiv. p. 253.

2 Ibial. vol. xviii. p. I6I.

${ }^{3}$ Ibid. vol. xxxvii. p. 23. 
from an acre of ground, which, at 36s. per pound (the London price at that time), would bring in a little over fioo. The total net profits per acre are estimated at $£$ I I0, 7s. 6d. It was therefore demonstrated that opium, as rich in morphia as the Eastern product, could be grown in Great Britain, but it is one of those crops which requires an abundance of cheap labour, and probably for that reason its cultivation has never been permanently established here.

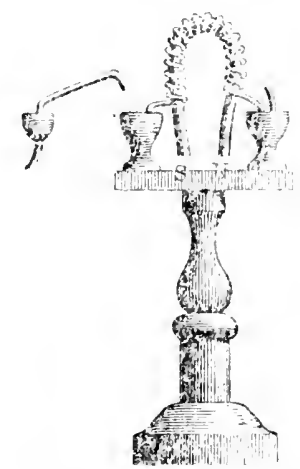

Sturgeon's Electro-Magnet, I 825 (sec p. 292). 


\section{H A P'T E R X I I}

\section{The Premiums-(Concluded)}

$$
(1754-1851)
$$

()ptical Glass-Microscopes-Standards of Weights and MeasuresSaccharometer - Hydrometers - Tachometer - Counters - Sturgcon's Electro-magnet-Smee's Battery-Plumbago for Electrodeposition - Drawing Instruments, Surveying Instruments, Surgical Apparatus, and Philosophical Instruments-Gas-makingResidual Products-Gas-holders and other Apparatus-The Lifeboat-I.ife-saving Apparatus-County Maps-William Smith's Geological Map-Horwood's Map of London-Steel EngravingPaper-making-Printing-Lithography-Basket-making and the Supply of Osiers-Straw-plaiting-William Cobbett-Leather Manufacture-Saving Life from Fire-Uninflammable FabricsFish Supply-Curing Herrings-Miscellancous Awards.

DOLLOND's invention of the achromatic telescope in 1758 (for even if he was anticipated by Moor Hall, Dollond was an original inventor) rendered necessary the production of glass, especially flint glass, of great purity, perfectly homogeneous and free from striæ. Not only was improvement in the quality of the glass required, but large discs were wanted for astronomical refractors. With this object the Society offered prizes for optical glass in 1768. Two such prizes were proposed-one of $£ 60$ for a sample of optical glass not less than 20 lb. in weight, " fit for those purposes for which flint glass is used in achromatic telescopes," and a second of $€ 20$, for glass " suitable for the general purposes of opticians." The minutes of the committee at which the proposal was discussed do not give any further particulars, nor has any record been found to show with whom the proposal originated. It is possible that the committee hoped to obtain glasses which in com- 
bination would prove achromatic for all the colours in different parts of the spectrum, and so to get rid of the " secondary spectrum " or " residual dispersion," which can never be entirely abolished by the use of two kinds of glass only, though the Jena factory has recently produced glasses which go near the attainment of this end. It is also evident, from the stipulated weight of the specimen, that the committee had in view the production of larger discs than could at the time be manufactured. At all events, the committee wisely drafted their proposal in very general terms, so as to cover any possible improvements in the manufacture.

Two prizes were awarded- $£ 30$ to Abraham Pelling in 1770 , and $£ 40$ to Richard Russell in 1771 -but no practical result followed, and the offer of prizes was not continued after 1779 .

It was indeed many years before the need was supplied. The French Academy also offered prizes for perfect discs of optical glass, but without any better success than the Society of Arts. The first to produce such discs was Pierre Louis Guimand, a Swiss watchmaker, about I 790 . He was afterwards ( 1805 ) associated with Fraunhofer, and on his discoveries are based all the great modern improvements in the production of large discs for refracting telescopes. For any serious improvement in the character of the glass itself we have had to wait till our own times, since it is only within the last twenty years that the Jena laboratory has furnished the makers of optical instruments with glasses in which high refractive power is combined with low dispersion, and high dispersive power with lower refractivity.

Henry Baker, the microscopist, was one of the founders of the Society, but this does not seem to have led him to propose any premiums for improvements in the microscope. Nor, indeed, had any such offers been made, could they have had much practical result, since it was not until the achromatic object-glass had been perfected that the modern microscope came into existence. Fraunhofer seems to have been the first to make an achromatic 
objective of any practical use (about i 816 ), and this was very imperfect, for five years later ( 182 I) M. Biot expressed the opinion that "opticians regarded as impossible the construction of a good achromatic microscope." 1 Dr. Wollaston also thought that "the compound microscope would never rival the single." However, in 1824 satisfactory objectives were independently produced by Chevalier, in Paris, and by Tulley, in London, and the development of the microscope went on apace. The use of high powers necessitated the provision of rigid stands, and gradually led to the invention of the various mechanical devices for accurate focussing, and for imparting minute movements to the object, as well as all the other details of construction, which have brought the instrument to its present perfection. In the third and fourth decades of the nineteenth century, prizes for various improvements in the microscope were awarded to Varley (I 83 I), Powell (I 835 and I 841), Goadby (I835), and Ross (1837). ${ }^{2}$ The Transactions about the same time contain other communications on the subject. Hogg, in his book above referred to, attributes the Society's action to the influence of Edward Solly," who, he says, "has been the means of making its Transactions, since 1831, the vehicle through which nearly all the improvements in the construction of telescopes and microscopes have been made known to the world."

In I 782 a gold medal was offered for " a cheap and portable transit instrument which may easily be converted into a zenith sector, capable of being accurately and expeditiously adjusted for the purpose of finding the latitudes and longitudes of places." This prize was continued till 1819 , but without any result. The transit instrument was invented in 1690 by Olaus Römer, the great Danish astronomer, who was the first to measure

1 The Microscope, Jabez Hogg (I 855), p. S.

${ }^{2}$ For the prize offered later for a cheap microscope, sec Chapter XVI, p. 390.

${ }^{3}$ It was really R. H. Solly, F.R.S., not Edward Solly, to whom this credit was due. See Cornelius Varley's paper on the Microscope, Transactions, vol. xlviii. p. 400. 
the velocity of light by observing the eclipses of Jupiter's satellites. The first transit instrument was set up at Greenwich in I72I. It is not very obvious why this prize should have been offered, except that the great improvements in accurate timekeepers, resulting from the work of Harrison, Arnold, and the other skilful chronometermakers of the time, rendered possible the use of more accurate astronomical instruments, and thus created a demand for them.

In I774 a gold medal was offered for an invariable standard of weights and measures, and it was pointed out in the notice of the offer that previous suggestions for the determination of a standard by means of the pendulum had not been successful. The first of these suggestions was made by Picard in $167 \mathrm{I}$, who proposed that a pendulum beating seconds should be employed, and that one-third of its length should be adopted as the standard foot. Nevertheless, the only two candidates who received any awards both proposed to use the pendulum, and both submitted devices which could only give results of moderately approximate accuracy. One of them, Hatton, a watchmaker, who received thirty guineas in 1779 , speaks of his apparatus as correct to the twentieth of an inch, though he proposes to employ an adjusting screw to ensure even greater accuracy! Fifteen years later, in I794, Dr. More, the secretary, submitted a communication to the Society, ${ }^{1}$ in which he very sensibly deprecates a reference to natural constants for the construction of a standard, and proposes the accurate copying of the then existing pound, preserved at the Exchequer. It seems likely that More was led to publish his paper by the attempts then being made by the French National Assembly to fix on a theoretical standard. In I 790 they passed a decree adopting a system of measures based on the seconds pendulum, but in the following year they abandoned the pendulum, and decided to base their standards on a quadrant of the meridian. When the Republic was proclaimed this proposal was confirmed, and the one ten-

${ }^{1}$ Transactions, vol. xii. p. 292. 
millionth part of the arc of the meridian from the Pole to the Equator, was, as is well known, declared to be the metre or standard of length for France.

Dr. More really anticipated the course of our own legislation on weights and measures, which has simply ordained the accurate copying of certain ancient examples, and has declared that these copies are the actual standard weights and measures of the country. Practically the French Government have had to do the same thing, for the metre is not a fractional part of the earth's meridian, but the length of a certain platinum bar, preserved in Paris, just as our yard is the length of a certain bar (or rather the distance between certain marks on that bar) preserved in London.

The premium was only continued for a very few years. It is exceptional, inasmuch as it was open to " persons residing in any country whatever." Had the prize been continued for another 120 years or so, it would therefore have been available for the very beautiful suggestion, made about twenty years ago by Professor A. A. Michelsen, that the length of the metre might be stated in terms of the wave-lengths of red light. ${ }^{1}$

In 1777 a gold medal was offered for a method of measuring "the degrees of sweetness in saccharine substances." This does not seem to have meant a saccharometer, but some means of establishing a standard of sweetness. Nothing came of this offer, which was continued for some time, and then abandoned, nor is it conceivable that such a standard could be set up. It was soon after this, in 1784, that the brewer's saccharometer was first introduced by Richardson, of Hull. It was a form of Martin's hydrometer, which indeed had been used in brewing in 1768 . It had a scale adapted for the use of brewers, and was indeed merely a hydrometer which indicated the difference between water and wort, water containing a percentage of saccharine matter.

1 Valeur du mêtre en longueurs d'ondes lumineuses. Paris (1894). Chaney's Weights and Measures (I 897), p. 23. 
Richardson's calculations are said not to have been quite correct, but sufficiently so for practical purposes.

The hydrometer in its modern form was described by Robert Boyle in the Phil. Trans. 1675. It remains the same in principle, but has been improved in details, and has been fitted with weights and various scales to adapt it to liquids of different specific gravities. In I77I a prize was offered for an instrument to measure the strength of spirit, and in $178 \mathrm{I}$ a silver medal was awarded to Matthew Quin for his hydrometer. In 1790 a second silver medal and twenty guineas were given him for an improved instrument, the principal feature of which was a sliding scale to adapt it to different temperatures. Other awards were made, the latest in I 820 , but Quin's appears to have been the most important instrument recognised by the Society.

Two gold medals were at different times awarded to the eminent mechanical engineer, Bryan Donkin ; one, in 1810 , for his tachometer, and one, in 1819 , for his counting machine. Mr. Donkin was for long a Vice-President of the Society and Chairman of its Committee on Mechanics. He was the leading mechanician of his time, and was best known for his share in the completion and construction of Fourdrinier's paper-making machine. It can hardly be doubted that he would have received some recognition for this also from the Society, if the machine had not been the subject of a patent.

The tachometer was so named by himself, and was intended, in his own words, "for indicating the velocity of machines." According to the description in the Transactions, ${ }^{1}$ it was meant to indicate the varying velocity of machines rather than to measure their speed. This it did by means of a rotating cup filled with mercury, to which motion was given from some part of the machine. The spinning of the cup caused the level of the mercury to sink at the centre and to rise at the rim. The variations of level were indicated by the rise and fall of a column of spirit in a glass tube, the lower end of which was immersed in the mercury.

${ }^{1}$ Transactions, vol. xxviii. p. 185. 
The counter would appear to be the original form of the now well-known device in which a train of wheelwork indicates on a series of dials for units, tens, etc., the revolutions of any spindle. Two arrangements are shown, both working by ratchet-gear, and indicating by clockhands on a single dial. ${ }^{1}$

The award in 1825 of a silver medal and thirty guineas to W. Sturgeon, for "Improved Electro-Magnetic Apparatus," is of extreme interest, because the account of his apparatus contributed by Sturgeon to the Transactions, ${ }^{2}$ proves him to have been the inventor of the electro-magnet. The whole subject has been very carefully worked out by Professor Silvanus Thompson, ${ }^{3}$ who quotes a letter from Dr. Joule to Mr. Angus Smith, in which that great philosopher says: "I have sifted Mr. Sturgeon's claims to the utmost. I have examined all the periodicals likely to throw light on the history of electro-magnetism, and find that Mr. Sturgeon is, without doubt, the originator of the electro-magnet, as well as the author of the improved electro-magnetic machine. The electro-magnet described by Mr. Sturgeon in the "Transactions of the Society of Arts for I 825' is the first piece of apparatus to which the name could with propriety be applied. . . . To Mr. Sturgeon belongs the merit of producing the first electro-magnet constructed of soft iron."

Dr. Joule also states that Sturgeon was "without doubt the constructor of the first rotary electro-magnetic machine," the inventor of the commutator, and the first to use amalgamated zinc plates in batteries.

Professor Thompson reproduces the pictures of Sturgeon's electro-magnets from the Transactions, and expresses the regret, which all interested in the subject must share, that the actual instruments given by the inventor to the Society's museum have not been preserved. He also, in an appendix, gives a very full account of Sturgeon's life and researches. Like so many other

1 Transactions, vol. xxxvii. p. I I6.

2 Vol. xliii. p. 37.

${ }^{3}$ The Electromagnet, by Silvanus Thompson, F.R.S. (2nd Edition, I892), pp. 2 -9 , and Appendix A, p. 4I 2 . 
inventors, Sturgeon never received in his lifetime either the recognition or the reward he deserved. After his death his discoveries were utilised and developed by his successors, whose increased knowledge enabled them to realise the value of researches which his contemporaries were not sufficiently well informed to appreciate.

Two years previously, in 1823 , a similar award had been made to James Marsh, the chemist, whose discovery of the well-known test for arsenic has been noticed in the preceding chapter, ${ }^{1}$ and with whom Sturgeon had been for some time associated. In the note appended to Sturgeon's communication to the Transactions, attention is drawn to several points in which Sturgeon's apparatus is considered superior to that of Marsh.

The award of a gold medal in 1840 to Alfred Smee for his galvanic battery was certainly well deserved. A convenient source of electrical energy was then much wanted, and Smee's cell was a great advance on all its predecessors. It was fairly constant, moderately cheap, of high electro-motive force, free from fumes, and readily put in and out of action without loss or waste.

The negative element was a thin sheet of platinised silver, the platinum being deposited as a fine adherent powder on the surface of the silver, which had previously been slightly roughened. This plate was supported in a light wooden frame between two zinc plates which formed the positive element. The exciting fluid was diluted sulphuric acid.

Smee's battery came into very general use for experimental work, and was for long used and greatly appreciated. A well-known and popular writer on electrical matters said, in 1875 , after the battery had been in use for over thirty years, that it was "one of the most valuable gifts ever made to electrical science." 2

The now universally used method of obtaining a conducting surface for electro-deposition by means of plumbago was the discovery of Robert Murray, and for it he received a silver medal and ten pounds in 1841 . In his

I Chapter XII, p. 282.

2 J. T. Sprague, Electricity (1875), p. 9 I. 
paper in the Transactions, ${ }^{1}$ he says that Edward Solly was the first to obtain a conducting surface on a non-conducting material by the use of nitrate of silver, and he goes on to describe his own process, which is identical with that now used. In fact, the instructions he gives describe in every detail the present method.

In the later volumes of the Transactions are to be found descriptions of a great variety of instruments which received rewards of different value from the Society. Many of these are obsolete, many contain the germs of appliances since improved and perfected, some are now familiar. Drawing instruments, " perspectographs," etc., are numerous. Amongst these may be mentioned the ordinary child's " transparent slate," which now common toy received a gold medal in 18 I 4 , as a valuable means of teaching writing. There are several ellipsographs (including those devised by Farey, Cubitt, Clement, and Hicks), Ross's first spherometer (I84I), with a central axial sliding rod, mounted in a truly-turned supporting ring, afterwards perfected by the substitution for the ring of a frame with three supporting points. Surveying instruments, sextants, and their predecessors, quadrants and octants, appear in the lists. Surgical and dental instruments are also fairly numerous. The list is a very long one. As to the value of its contents, only an expert in each class could speak with confidence, but its immense variety, at all events, bears testimony to the catholicity of the Society's objects and operations in the first half of the nineteenth century.

After the application of gas for illuminating purposes by Murdock in I792, we find a few prizes offered and awarded for improvements connected with gas-lighting.

In 1797 a prize was offered for a " substitute for tar," but though the offer remained open for many years, it does not seem to have attracted any competitors. This is remarkable, because the production of tar from coal had been known and practised for a considerable period.

1 Vol. liii. part ii. p. 10. 
In I68 I letters patent had been granted to John Joachin Becher and Henry Serle for "a new way of makeing pitch and tarre out of pit coale." These inventors were followed by several others, amongst them the Earl of Dundonald, who had a patent for obtaining tar and other products from coal.

In $\mathrm{I} 8 \mathrm{ro}, \mathrm{B}$. Cook, of Birmingham, described a process for the distillation and utilisation of gas-tar, which he said was at the time a waste product, though considerable amounts were made in the production of gas, and the coking of coal. ${ }^{1}$ The tar, Cook stated, was superior to the "common tar" for paying ships' timbers. The more important part of the communication related to a method of distilling the tar, from which a "liquor or volatile oil " (light oil) was obtained, and a "residuum " (pitch) " equal to the best asphaltum." He had varnish made from the pitch and the light oil, and sent in a sample of work treated with the varnish. For this paper, which was certainly among the early practical proposals for the utilisation of the by-products of gas-manufacture, Cook received the very inadequate reward of a silver medal.

Cook, however, had been anticipated by Winsor, whose patent specification of 1804 refers to the production and utilisation of various by-products from gas-making. Still, Cook's paper is full of interest, as he appears to have been an original worker and to have achieved a considerable measure of practical success.

In 1808 a silver medal was given to Samuel Clegg " for his apparatus for making carbonated hydrogen gas from pit coal, and lighting factories therewith." The apparatus included a gasholder of the form now generally employed, of which Clegg was apparently the inventor. $\mathrm{He}$ was apprenticed to Boulton and Watt, and was in business in Manchester as a builder of steam-engines. He was the inventor of the gas-meter, which he patented in 18I5, but (probably because it was the subject of a patent) he did not submit it to the Society. In I8I9 a gold medal was given to John Malam for improvements on Clegg's original meter.

${ }^{1}$ Transactions, vol. xxviii. (I 8 10), p. 73. 
It is worth mention that the well-known telescopic gas-lamp, or chandelier, which is in common use up to the present date, was invented by William Caslon, who received a silver medal for it in 1817 . Caslon was one of the well-known family of type-founders, being the grandson of the original William Caslon who started the business. He sold his share of the type-founding business and started another in Sheffield in I819. The drawings in the Transactions ${ }^{1}$ show a chandelier identical with the most modern form, with sliding tubes, water-slide and counter-balance weights.

In the year 1802 a gold medal and a grant of fifty guineas were given to Henry Greathead, of South Shields, for the invention of the lifeboat. There seems very little doubt that Greathead was the builder of the first practical lifeboat, but it is uncertain how far the actual invention was due to him. The subject has been very carefully and exhaustively worked out by Sir John Lamb in a paper on the lifeboat, which he read before the Society in 1910.2 Sir John Lamb considers that Lionel Lukin, of Long Acre, not Greathead, should have the credit of having made the first lifeboat, and that the prizes and rewards should have been given to him. In i 785 , Lukin took out a patent for an "unimmergible boat." Nothing very much seems to have come of Lukin's invention, though in the year that he took out his patent he converted a coble into a safety-boat, which was afterwards employed at Bamburgh, Northumberland, in saving life from shipwreck. Lukin's boat was fitted with a cork gunwale and airtight cases at the end. Another inventor was William Wouldhave, of South Shields.

In April I 789 , the Brethren of the Newcastle Trinity House had before them a proposal to station a boat permanently at the mouth of the Tyne for the saving of shipwrecked persons. A committee was appointed to con-

1 Vol. xxxy. p. I62.

2 Journal, vol. lviii. p. 354. The paper, with some additions and many fresh illustrations, was republished in I9I I under the title of The Lifeboat and its Work. 
sider suggestions for the construction of a suitable boat, and to this committee both Wouldhave and Greathead submitted models. Neither was adopted, but Greathead, who was a skilled boatbuilder, was instructed to build a boat, which he seems to have done, partly carrying out his own ideas and partly those of some of the members of the committee.

The various claims of the three inventors have long been the subject of discussion, and are never likely to be settled. But it is clear that Greathead's was the first practical lifeboat, and the credit of its construction has generally been allotted to him. Besides the awards from the Society, Greathead received a grant of $£ 1200$ from Parliament, and 100 guineas each from the Trinity House and from Lloyd's, besides various other rewards.

A little earlier than this, attention had been directed to means of saving life from shipwreck by methods for effecting a communication between stranded ships and the shore. In 1792 the Society had given a "bounty" of fifty guineas to John Bell (then a sergeant, but afterwards a lieutenant in the Artillery), for a method of throwing a rope from the ship to the shore. ${ }^{1}$ But a great improvement upon this was brought before the Society sixteen years later, when Captain Manby received a gold medal $^{2}$ for his device for establishing communication from the shore to a stranded ship by the use of a mortar by which a line was thrown. The apparatus itself was devised in 1807 , and was successfully used in the following year at the wreck of the brig Elizabeth. It was reported upon favourably by the Board of Ordnance, and before many years were over it was in extensive use

1 Transactions, vol. x. p. 203 ; vol. xxv. p. 135 . It is interesting to note that among the most recent improvements in devices of this sort is a proposal for sending a line from the ship to the shore by the usual rocket apparatus. As ships are usually wrecked on a lee shore there are obvious advantages in starting the communication down-wind from the vessel, instead of from the shore in the teeth of the gale. Bell's mortar apparatus was too heavy and clumsy to be carried on board ship, but this objection would not seem to apply to modern rocket apparatus.

${ }^{2}$ Ibid. vol. xxvi. p. 209. 
all round the coast. After some twelve years' experience, the invention had been used so successfully, and had saved so many lives, that a Committee of the House of Commons recommended a payment to Manby of $£ 2000$. The invention is still widely used in this and in other countries, but for many years past rockets have been substituted for the original mortar.

Other inventions of the same character were also rewarded by the Society about the same time, but none of them have stood the test of experience in the same way as Manby's well-known apparatus.

In 1776 a silver medal was given to Shipley, the originator of the Society, for a lighted buoy for saving life at sea. As the invention does not seem to be either specially valuable or remarkably original, it may, perhaps, be assumed that a certain friendliness of feeling dictated the award, as respect for his memory may have led to the publication of a description of the apparatus in the Transactions $^{1}$ a few years after the inventor's death. A similar feeling may justify its mention now.

In the last half of the eighteenth century a great number of county maps were published. Their issue may without much doubt be traced to the offer by the Society of a prize of $£ \mathrm{I}$ oo for the map of any county on the scale of an inch to the mile. In justification of this statement it may be said that, of the county maps mentioned by Gough in his great work on "British Topography," published in 1780 , as being issued or in hand at that date, nearly all appear to be of a later date than 1762 ; and the same may be said of a list of such maps, which has been most obligingly placed at the disposal of the writer by Sir H. George Fordham, the great authority on this subject. Speaking of the survey of Yorkshire, which

1 Vol. xxv. ( 1807 ), p. 94. This life-saving device was evidently an old hobby of Shipley's, for in the minutes of one of the earliest meetings, $27_{\text {th }}$ November I754, it is recorded that_-" A model of a Float was produced by Mr. Shipley, contrived by himself, to preserve the Lives of them that fall overboard at Sca, it was ordered that Enquiries be made of Persons skilled in Sca Affairs." 
was carried out by Thomas Jefferys, the well-known cartographer, Gough says: "Jefferys undertook this, and other such surveys, in consequence of a premium of $£ 100$ offered by the Society of Arts for a county map." Jefferys died in 1771 ; and this may account for his never having received a premium. After his decease the map was purchased and published by Robert Sayer.

This prize of $£_{100^{1}}$ was first offered in 1759 , though it was not included in the regular premium list before I 762. To avoid needless competition, a special announcement was made that the Society would accept an offer for the production of each map, and would afterwards pay the premium when the map was completed to its satisfaction. The first offer accepted was for a map of Dorset by Isaac Taylor. This was published in 1765 , and is described by Gough as a capital survey of the county, but he adds: "This, though the most particular, is very faulty in the place names." Whether on this account or for other reasons, no award was made to Taylor. There was some correspondence with him, and the last entry is in December 1765 , when the consideration of his map was "postponed." The first actual award was to Benjamin Donn, who in 1765 received $£$ ioo for his map of Devonshire. This was engraved by Jefferys.

The offer of prizes was continued in various terms up to I8OI, after which it does not appear in the premium list, though awards were made as late as i 809 . Smaller amounts than the original sum of $£ \mathrm{I}$ oo were sometimes paid, and in some cases medals were given instead of money prizes. In all, an amount of $£ 460$ was expended, besides four gold medals, three silver medals, and a

${ }^{1}$ It was, however, but a small contribution to the actual expenditure on the production of such maps, if we are to rely upon the statement contained in Gough's notes on Sussex, in which a projected map of that county on a scale of two inches to a mile, in eight large sheets, is referred to as estimated to have cost more than $£ 2400$ for surveying, drawing, and engraving, and to have taken six years in execution, four hundred subscribers at six guineas for the whole map being asked for. 
silver palette. Maps were obtained of the following counties and districts :-

Devonshire ( 1765 ).

Dorsetshire (1 765 ).

Derbyshire ( 1767 ).

Northumberland ( 1773 ).

Leicestershire ( 1778 ).

Somersetshire (1783).

Suffolk ( 1784 ).
Lancashire ( 1787 ).

Hampshire (1 793).

Sussex ( I 796).

Oxfordshire (1 797).

North Wales (1 802).

Cardiganshire (1 804).

Shropshire ( 1 809).

Many of these are mentioned by Gough.

For the map of Derbyshire P. P. Burdett received $£_{\mathrm{I}} \mathrm{oo}$. This map was said to have been produced under the direction of the Rev. John Prior, of Ashby-de-la-Zouch, who himself received a silver medal and twenty guineas in 1778 for a map of Leicestershire, which was really made by $\mathrm{J}$. Whyman, an assistant of Burdett, and was published in 1777. Burdett also produced maps of Cheshire and Lancashire.

William Faden, who received $£ 50$ for a map of Hampshire in I793, and a gold medal for one of Sussex in 1796 , was a well-known map-maker. He afterwards presented to the Society a number of county maps which he had produced.

John Cary (whose name is given as Carey in the list) received a gold medal in 1804 for his map of Cardiganshire. This engraver and map-seller is best known as the publisher of the New Itinerary, a road-book which ran through eleven editions, I 798 to i 828 , but he and his successors, G. and J. Cary, engraved and published between I 769 and 1850 a very large number of maps, atlases, and topographical works. ${ }^{1}$

The map of Northumberland, for which, in I 773, Lieutenant Armstrong received fifty guineas, is said to have been a capital map. It was engraved by Kitchin in I769. Lieutenant (afterwards Captain) Armstrong was

1 See John Cary, Engraver and Map-seller, a paper by Sir H. G. Fordham, read in 1909 (6th December) to a meeting of the Cambridge Antiquarian Society, and published in pamphlet form. Cambridge, 1910, 8vo. 
a son of an earlier map-maker of repute, also Captain Armstrong.

Besides the Society's prize maps, a good many other county maps were issued. The Transactions for $\mathrm{I}^{801}{ }^{1}$ give a list of twenty-six such maps of English counties in the possession of the Society, and some were afterwards added. In all, about fifty seem to have been produced, besides the great series issued by the Greenwoods (1 829-34).

In 1802 the Society offered three gold medals for mineralogical maps of England, Ireland, and Scotland. Each map was to be on a scale of not less than ten miles to the inch, "containing an account of the situation of the different mines therein, and describing the kinds of minerals thence produced."

It is not reported that any of these medals were awarded ; but the offer had the important result of assisting William Smith to publish his great geological map of England and Wales.2

William Smith is known as the father of British geology. As Canon Bonney says of him, in his life in the Dictionary of National Biography, "he found the key to stratigraphy -viz., the identification of strata by their fossil contents." Though a well-known and successful canal engineer (he received a medal from the Society in 1805 for draining Prisley Bog), he was a poor man, and had great difficulties in publishing his map. He was assisted by the Society with $£ 50$, and his map of England and Wales and part of Scotland-in fifteen sheets, measuring $8 \mathrm{ft} .9$ in. high by $6 \mathrm{ft} .2$ in. wide, and on a scale of five miles to the inch, with geological colouring-was engraved and published by John Cary on ist August I 8 I 5 , with a dedication to Sir Joseph Banks, P.R.S. It was accompanied by a memoir to the map (London, I 8 I 5, 4to), also published by Cary, who, in addition to stratigraphical tables issued in I 8 I6 and I 8I 7 , published a series of six detailed geological sections across various parts of England (1817-19), and also,

1 Vol. xix. p. 43.

"An "explanation" of the map and some most interesting "observations" by Smith, are given in the Transactions, vol. xxxiii. (18 I 5), p. 5 I. 
between I 819 and I 824, twenty-one out of the full number of the county maps in his large folio atlas (Cary's New English Atlas, I809), with Smith's geological colouring and marginal notes on the strata.

In the same year (1802) as that in which the prizes for mineralogical maps were offered, the Society also offered a gold medal for a Natural History of any English or Welsh county. This was to be really an account of the natural resources of the county, "so that the public may be enabled to judge what arts or manufactures are most likely to succeed in such county." This information was more effectively provided by the "Statistical Surveys " of the counties, published by the Board of Agriculture. The first of these is dated 1793 , so the offer of the Society seems rather superfluous.

In 1803 the Society gave fifty guineas to R. Horwood for his map of London. Some sheets of the map had previously been submitted, in I79I, but the Society declined to make any award to the work in its incomplete state, though it passed a vote of thanks to the author. There had been a number of maps of London published since Ralph Aggas issued what is believed to be the first map of the sort somewhere about i 560. Horwood's map was certainly a considerable advance on those of his predecessors, and more elaborate than any of them. It was one of the few maps of London made from an actual survey, carried out, as he says, by Horwood himself. All the houses are numbered, and it is stated that the publication of Horwood's map led to the general adoption of numbering, which had previously only been applied to a few streets. This statement, however, does not seem to rest on any very good authority. Not a great deal is known about Horwood. He was surveyor to the Phœnix Fire Office. It is said he produced his map for the use of that office, but he makes no reference to this in the letter from him printed in the Transactions.

Although no actual award, beyond the thanks of the Society, was made to Messrs. Perkins \& Co. for their

\footnotetext{
I Vol. xxi. (1803), p. 3 I r.
} 
description in the Transactions ${ }^{1}$ of their process of steelengraving for bank-notes, it is too interesting to be passed over. This absence of any award is doubtless due to the fact that the process was in use in America and by private English banks. ${ }^{2}$ It was afterwards applied to the production of postage stamps, when the introduction of the Penny Post in 1840 caused a demand for a large number of identical stamps. ${ }^{3}$ Jacob Perkins, the principal of the firm, was a very ingenious inventor, and received several gold and silver medals from the Society. An American by birth, he passed much of his life in England. He was a pioneer in the use of high-pressure steam, and in this he was followed by his son, Angier March Perkins, and his grandson, Loftus Perkins, the last-named of whom built several of the first high-pressure steam-engines, and suffered the usual fate of those who are in advance of contemporary ideas.

In the "siderographic process," as it was termed, a soft steel roller was rolled to and fro over the surface of an engraved steel plate, until the design was transferred to the roller, which was then hardened, and used to produce other steel or copper plates. From these, impressions could be taken on paper in the usual way. As any number of these duplicate plates could be obtained, it was possible to produce as many identical paper prints as might be required. In the case of bank-notes, it was proposed that several artists of repute should be employed, each to produce a small vignette. All these vignettes were to be transferred to a single plate, on which also engine-turned patterns might be engraved. Thus prints, both artistic and complicated, would be produced, which certainly it would be beyond the power of any forger to copy, before the invention of photography.

From the commencement of the eighteenth century the paper industry had been developing, but it was chiefly concerned with the production of low-class papers. In

${ }^{1}$ Vol. xxxviii. (1820), p. $47 . \quad{ }^{2}$ See also Chapter IX, p. 215.

${ }^{3}$ Sir Rowland Hill and the History of Penny Postage, by G. Birkbeck Hill (1880), vol. i. p. 407. 
the finer qualities English manufacturers could not compete with the productions of French and Italian mills, until about 1775 Whatman succeeded in manufacturing paper not only equal but superior to that made abroad. As Mr. Rhys Jenkins puts it, the " export of paper in 1775 by Whatman seems to mark a turning-point in English papermaking." The same writer goes on to remark: "Between 1754 and I 782 the Society of Arts was endeavouring to promote the manufacture of high-class paper in this country by the award of premiums and medals for the production of paper for copper-plate printing. The manufacture of silk-rag paper and of embossed and marbled paper also engaged its attention." 1

As Mr. Rhys Jenkins says, many prizes were offered at different times for paper and paper-making materials, and these were continued for many years after the date he mentions. The first was the prize offered in 1757 for paper for copper-plate printing, and one of the latest that proposed, in 1830 , for methods for manufacturing paper equal to China paper. At an early date an earnest attempt was made to obtain materials for paper other than rags, and a prize was offered in 1790 for paper from raw vegetable substances. In the announcement of this it was stated that the Society already possessed specimens of paper made from "thistles, potatoe haum, poplar, hop binds, etc." This offer was continued for thirty years without any addition being made to the list of materials, but it possesses a good deal of interest, because it was an intelligent anticipation of the course of future progress. Now, of course, practically all paper is made from " raw vegetable substances," that is to say, from cellulose which has not already been made up into some textile material. The volume of Transactions for 1823-4 (Vol. Xlir.) was printed upon paper which, it is stated in a note, was made from "pure flax." The paper is good and is in excellent condition now, which is more than can be said for the paper of many of the volumes.

It was really not until about 1860 that paper materials

1 See article on " Paper-making in England (17 14-1788)," by Rhys Jenkins ; Lib. Assoc. Record, vol. iv. pt. I. (1902) pp. I 35 and ${ }_{13} 6$. 
other than rags were generally used. About that time esparto began to be employed to a considerable extent. In I 856 fifty tons of esparto were imported, and perhaps this may be taken as the beginning of its application to the extensive manufacture of paper. ${ }^{1}$

It is rather remarkable that so little was done by the Society for printing, in connection with which there are practically no awards of any importance. Perhaps the most interesting entry in this class is that of the gold medal awarded in I 819 to Aloys Senefelder as the inventor of lithography. The Society was a little behindhand in this award, for the process had been perfected by the inventor in $1798 .^{2}$

The justification for the medal being given at this time was no doubt the fact that in the year I 8 1 8 , Senefelder published his Lehrbuch der Steindruckerey, and that it was this book that really drew attention to the new art, though before that date lithography had been applied to artistic purposes. The first dated English lithograph is a reproduction of a pen drawing by Benjamin West, P.R.A. It bears the date I $80 \mathrm{I}$, and was published with other similar plates by Fuseli, Barry, and others in $1803 .^{3}$

Senefelder was much gratified with the award, and he sent to the Society, through Mr. Ackerman, one of his lithographic presses. In the same year that Senefelder was thus honoured, a silver medal was awarded to C. Hullmandel "for a lithographic drawing," and in 1829 Joseph Netherclift received $£_{20}$ " for his improved methods of making lithographic transfers." 4

In I793 an application was made to the Society by some of the principal London basket-makers, who stated

${ }^{1}$ See paper by Robert Johnston. Journal, vol. xx. (1871), p. 96.

2 See the introduction (by E. F. Strange) to the catalogue of the collection of lithographs exhibited at the South Kensington Museum, I 898-9. This collection was organised and shown by the Science and Art Department, in response to an application from the Society of Arts, suggesting the commemoration of the centenary of Senefelder's invention by an exhibition of lithographs.

${ }^{3}$ See Chapter VIII, p. 202, and Chapter IX, p. 2 I4.

${ }_{4}$ See Chapter VIII, p. I93. 
that their business was almost at a standstill for want of osiers, because "great quantities of these twigs had annually been imported from France, and all intercourse with that country being stopped, a sufficient quantity, the growth of England, could not be obtained." As a consequence of this a great number of the workmen had been thrown out of employment. A number of prizes for planting osiers were offered, and the result was very satisfactory. Many landowners started osier plantations, and numerous prizes were awarded, including a gold medal in 1797 to Lord Brownlow, so that in 1806 the Society was able to announce that its object had been accomplished, and a sufficient supply of English osiers provided. The offer of prizes was consequently discontinued. ${ }^{1}$

It does not appear to be known with any certainty when the straw-plaiting industry was first introduced into England; but it was certainly established at Luton and Dunstable by the middle of the eighteenth century. A little later the Society did a good deal to encourage it. In 1762 and the three following years a number of small premiums were given for " chip hats like the Italian," and at the same time prizes were offered for straw hats like those made at Leghorn; but without any result. ${ }^{2}$ In I 805 a gold medal was awarded to William Corston for making straw-plait similar to the Leghorn plait from rye straw grown in Norfolk. ${ }^{3}$ Again, in 1822, a silver medal was given to John Parry for the manufacture of

${ }^{1}$ Transactions, vol. xi. (1793) p. 262 ; vol. xii. (1794) p. xiii ; vol. xiii. (I795) p. X; vol. Xv. (1797) p. I3I; vol. xxiv. (I806) p. vii. In one place there is a mistake in the date, I 774 being printed for 1773 .

2 The superiority of the foreign production is shown by a curious illustration. In I810, Capt. Thomas Borrow, the father of George Borrow, was in charge of the large prison at Norman Cross, Huntingdonshire, where 6000 French prisoners were confined. These prisoners used to make and sell straw-plait, but as the quality was superior to that made in England, the practice was forbidden, and the soldiers were ordered to destroy all the straw-plait they found (A. Jenkins, Life of George Borrow, 1912, p. I3).

${ }^{3}$ Transactions, vol, xxiii. p. 223 ; vol. xxviii. p. I 30. 
Leghorn plait from straw imported from Italy. In the same year a silver medal was given to Miss Sophia Woodhouse, of Connecticut, U.S.A., for a new material for straw-plait, which turned out to be the Poa pratensis. Through the agency of the Society seeds of the grass were imported, and grown here.

William Cobbett thought he saw an opportunity of encouraging a useful industry in England, and printed an account of what had been done in his Register. An importer of Italian straw then applied to Cobbett to know whether he could not get some of the American straw. The result of this was that Cobbett set to work in his usual energetic manner ${ }^{1}$ to see if English grasses might not be used for the same purpose, and he was successful in utilising various native straws and grasses. In appreciation of his efforts, the Society gave him a silver medal. Cobbett not being by any means a popular character at the time, the award did not meet with general approval. Edward Smith, Cobbett's biographer, says that the newspapers announced the award with the heading, "The Society of Arts humbugged at last." The award was of course perfectly well deserved, and apparently the real objection was to Cobbett's political views, not to the useful work he had promoted. However, the Society continued to encourage the industry, which it hoped might occupy numbers of the unemployed, and for three or four years it continued to give a number of small rewards, varying in value from fifteen to two guineas for the manufacture of hats and bonnets made of English straw. ${ }^{2}$

${ }^{1}$ Cobbett, than whom "no sturdier cudgel player had stepped into the literary ring, since his master had published The Drapier's Letters" (Leslie Stephen). "No man ever fought in a nobler cause, or with more sincerity, with more persuasiveness, with more courage" (Lewis Melville in the Fortnightly Review, April 1912).

${ }^{2}$ A very full account of the development of the straw-plait trade is to be found in a paper read by Mr. A. J. Tansley on 19 th December I 860, and printed in the Journal of the 2ist of that month (vol. ix. p. 69). In the discussion, the secretary (Peter Le Neve Foster) gave a full list of the awards made by the Society from 1805 down to 1825 . 
The manufacture of leather received less encouragement from the Society than might have been expected, considering that the industry had one of its most important seats close to London, in Bermondsey. In the year after the Society's formation (1755) a prize was offered for buff leather, then principally imported. The prize was duly awarded, and the manufacture started, with a certain amount of success. "The Kentish Militia and some other corps had their accoutrements made of it." 1 It does not, however, appear that the production of such leather was continued.

The story of the introduction of the method of " Dying leather red and yellow as practised in the East for that kind called Turkey Leather " is rather a curious one. Dossie ${ }^{2}$ tells us that one Phillippo, "an Asiatic" who was in England, was induced by two members of the Society to "try, on his return to the East, to make himself master of this and some other arts not known here, in order to communicate them, by means of the Society, in case lie should come again to England." The Society agreed to pay him $£$ Ioo if he succeeded, and on his return to this country with the secrets of the process, the money was paid him, with the additional complimentary gift of a gold medal.

The tanning industry was a long-established and flourishing one in this country, but it was hampered by protective legislation. Only certain materials, of which oak-bark was the principal, were allowed to be used. This provision was not apparently for the benefit of the tanners, but to secure the use of proper materials, and, perhaps, to encourage the growth of timber. As a matter of fact, not only was the bark of timber trees used, but oaks were grown in coppices, which were cut for the sake of the bark alone. The Act in which this provision was included was held to prevent the use of oak saw-dust, and therefore a method, said to be successful, of utilising this material could not be employed. The Society gave the inventor $£ 100$, and protested against the clause in the Act-with what effect is not recorded. Prizes were offered, and a few

1 Dossie, vol. i. p. 170.

${ }^{2}$ Vol. i. p. 230. 
awarded, for new tanning materials and methods, but the list is not a long one.

A great many inventions for saving life from fire and for extinguishing fires were rewarded by the Society. Among the latter was an invention of Ambrose Godfrey for extinguishing fires, which was brought under the notice of the Society in I760 by the inventor's son. To test the device, a building was erected in Marylebone Fields. On 2 Ist May i 76I, the building was set on fire, and when it was in full blaze Godfrey's shells were thrown into the house. According to a contemporary description, "their explosion immediately extinguished the fire, and even the smoke soon disappeared." This demonstration was carried out in the presence of the Duke of York, Prince William, afterwards William Iv., Prince Henry, afterwards Duke of Gloucester, and a numerous crowd, which was kept in order by a guard of two hundred men.

There were also a good many fire-escapes. One of these, for which fifty guineas were voted in 18 1o to John Davis, is practically identical with the modern fire-escape with its telescopic ladder and carriage. In his description of his apparatus, the inventor says that his attention was drawn to the subject by the death of a woman at Chelmsford, who had fallen off a "parish ladder" when trying to escape from a burning house.

In 1805 a prize was offered for a method of rendering muslin uninflammable without injuring the quality or appearance of the fabric, but though the offer was continued for many years, it met with no response.

The proposal was a very old one. As early as i735 a patent was granted to Obadiah Wilde, who added a mixture of alum, borax, and vitriol to paper pulp, with the view of producing incombustible paper. In the early part of the nineteenth century the subject attracted the attention of many chemists, amongst others of Gay-Lussac, who in I 830 proposed the treatment of fabrics with the carbonates of potash and soda. Fuchs suggested water-glass. In I 859 an elaborate paper was read to the British Association by Versmann and Oppenheim, who gave a full account of 
their own researches. An abstract of this paper, and an account of the valuable investigations by Sir Frederick Abel carried on from I 855 to I $88 \mathrm{I}$, will be found in a report of a committee of the Society on fire prevention, published in $1883 . .^{1}$ This gives a fairly complete history of the various attempts to render fabrics and other materials uninflammable, down to the date of its issue.

The supply of fish to London had always been a difficulty, and though many attempts had been made to bring fish by land, none of them had succeeded. ${ }^{2}$ In I76I a scheme for the supply of the markets of London and Westminster-a new fish-market had been started in Broadway, Westminster, in I752-with fish brought up from the coast by land was laid before the Society by John Blake. The Society took up the proposal very warmly, and agreed to give Blake $£ 500$ for the purpose of carrying it out. Eventually no less than $£ 3500$ was spent on this scheme. The proposal was taken up with a great deal of enthusiasm. According to a statement in the first volume of the Transactions, Parliament also made Blake a grant of $£ 2000$, and by the energy of the Society an Act of Parliament was obtained by which the tolls on fish carriage were reduced, and other facilities granted for breaking down the monopoly in the London fish supply which then existed.

At first the Society were very much gratified with the result of their efforts, and they awarded Blake a gold medal with the inscription, "Fish Monopoly Restrained." But the practical results of the procedure do not seem to have been very satisfactory, for in the article above mentioned ${ }^{3}$ it is stated that the "plan has not in every degree answered the sanguine expectations of the Society." Still, it is stated that a good deal of fish had been brought up by land, and the fish-supply of London increased. It also appears that the Society were not quite satisfied

${ }^{1}$ Journal, vol. xxxi. (1883) p. 687.

2 Some information about this subject will be found in Industrial England in the Middle of the Eighteenth Century, p. 165.

${ }^{3}$ Transactions, vol. i. p. 57 . 
with Blake himself, because there is evidence in the minutes of disputes having arisen about his accounts.

A later attempt to develop British fisheries was more successful. In 1805 a reward was offered for " curing herrings by the Dutch method." For some years this does not seem to have had much result, but in 1819 and 1820 two rewards of fifty guineas and $£ 50$ respectively were paid to J. F. Denovan, of Leith, for his success in the "curing of British herrings," and for introducing them into the market. Two communications in the Transactions ${ }^{1}$ give an interesting account of the way in which, after many unsuccessful attempts to get hold of the secrets of the business in Holland, he secured the assistance of six experienced Dutch fish-curers, and with their help started to catch and cure herrings on the west coast of Scotland. After a good deal of trouble and various misadventures, he was quite successful in his enterprise, and succeeded in sending to Edinburgh and London cargoes of herrings equal to the best Dutch. The method employed, then as now, is merely, after gutting and cleaning the fish, to pack them in barrels with salt or brine. Many other awards followed, and this was the beginning of the Scotch cured herring trade, which developed into an important business, and has, of quite recent years, spread to the East Anglian fishing ports. At the present time it is a thriving industry at Lowestoft.

In 1783 the Society proposed to deal with the question of general education, and the following announcement was made in the first volume of the Transactions : ${ }^{2}$ "The Society, desirous to improve the present mode of education, hereby offer the gold medal to the master of any academy or school for boys situated within or not more than thirty miles distant from London, who shall within three years from the date of this advertisement teach the greatest number of scholars, not less than four, to write and to speak Latin in common conversation correctly and fluently. Also the gold medal for teaching

${ }^{1}$ Vol. xxxvii. (1819) p. 183 ; vol. xxxviii. (1820) p. I86.

${ }^{2}$ Vol. i. (1783) p. 194. 
in like manner each of the following languages, viz. the German, the Spanish, and the Italian, being commercial languages, not usually taught at schools in England."

In December I786, Dr. Egan, the master of the Royal Park Academy, Greenwich, brought up five of his pupils, whose ages were between eleven and fifteen, and they, after being duly examined by the committee, were each awarded a silver medal, the gold medal being given to Dr. Egan. ${ }^{1}$

In its earlier years the Society offered various prizes of a miscellaneous sort, prizes which may be taken as evidence of the catholic nature of its objects from its very foundation. Such, for instance, was the gold medal for a treatise on the "Arts of Peace " offered in 1759 , a time when the arts of peace must have been less in men's minds than those of war, since the country was engaged in fighting in Europe, Asia, and America.

Among social and economical questions the question of female employment crops up again and again from I768 onwards. Sometimes a reward is offered to those who employ the greatest number of women and girls in specified industries. Then more general offers are maderequests for suggestions, and so on. The general question of want of employment also comes up, and proposals are requested for providing employment for the poor, and for workhouse paupers especially.

It might be thought that the question of housing the agricultural labourer is a fairly modern one. It is certainly an object of discussion at the present moment. In 1799 the Society offered a gold medal to the landowner who should build in that year the greatest number of cottages with an allotment of two acres apiece, and another gold medal to the landlord who should apportion allotments of two acres to existing cottages on his estate. The offer

${ }^{1}$ An account of this examination is given in a letter from John Symonds to Arthur Young, printed in Young's Autobiography (Edition I 898 , by M. Betham-Edwards, p. I 47). 


\section{LABOURERS' COTTAGES}

does not appear to have attracted any response, and, after a few years, it was discontinued.

Many years later the subject was again taken up, and with rather more success, as will be related later on. ${ }^{1}$

${ }^{1}$ Sec Chapter XVI, p. 392, and Chapter XXI, p. 491.
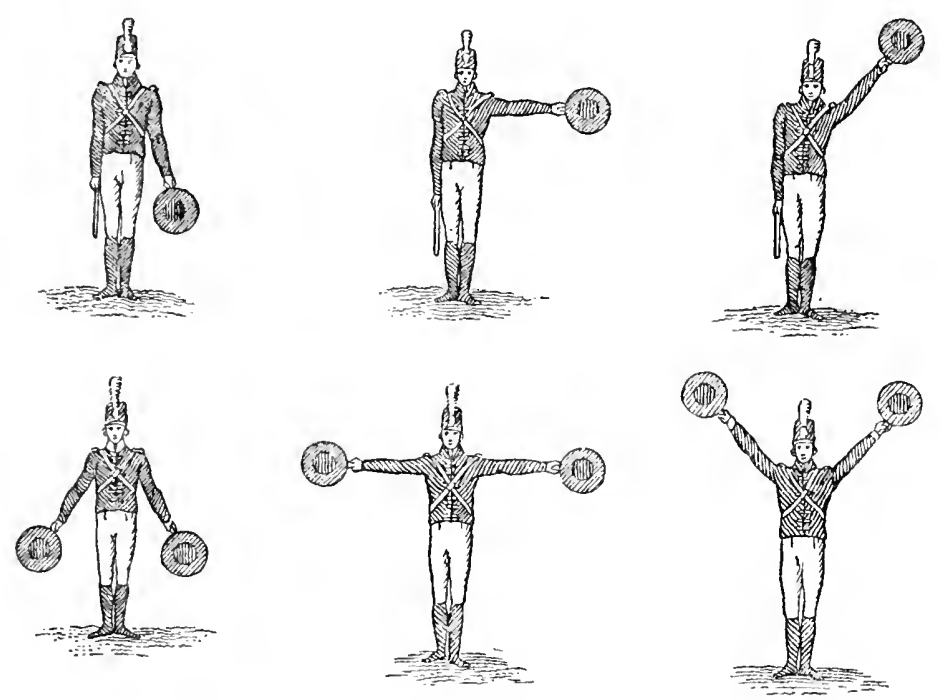

Signalling by Hand, 1809 (see p. 252). 


\section{CHAPTER XIV}

\section{The Society's Medals}

First proposal to offer Medals-The First Medal, Stuart's designBarry's suggestions-Flaxman's Medal-Smaller Medals, Isis, Ceres, and Vulcan-The Palette-IVyon's large Medal-President's Head adopted for Medal--W. Wyon's Head of Prince Albert-King Edward's Head, by L. C. Wyon-The same, by Emil Fuchs-King George's Head, by Bertram Mackennal-The Albert Medal, Prince Consort's Head, by L. C. Wyon.

THE first prizes offered were all in money, but the Society was hardly a year old before the proposal was made to substitute medals for cash in some of the awards. At the meeting held at its rooms in Craig's Court on 3 oth April

\section{I $755:-$}

"Some discourse arose concerning the Society's bestowing Medals on some Occasions instead of Money, but as nothing of that kind can take place this year, the further consideration of it was deferred to another Time."

The idea evidently was that some "Honorary Premium" was desirable in cases for which a money award was unsuitable, and this idea was formally submitted to the Society by Henry Baker on 24th March I756. Baker's paper does not appear in the Minutes, but it has been preserved in one of the old guard-books. The sentiments by which he was actuated may perhaps best be indicated by quoting his own expression of them :-

"Whoever would lead Mankind, even to their own Good, must take Advantage of their Passions, amongst which the Desire of Gain, and the Desire of Esteem, are two of the most prevailing. This Society, as far as is at present in its Power, with due Caution and great Judgment, applies itself to the former ; nor has it been 




Society's ORIGINAL MeMAl. 1757.

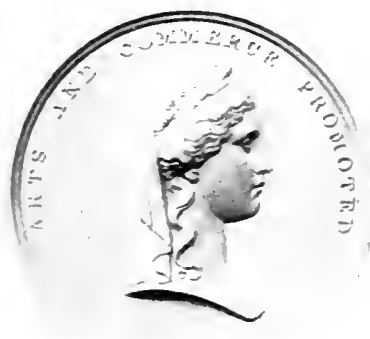

CERE MEJAI.

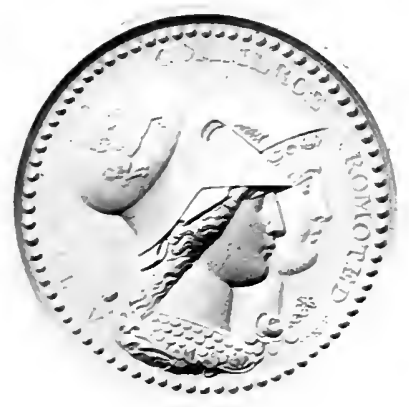

THE SOCIETY'S LARGE MEMAI. (FIAXMAN).

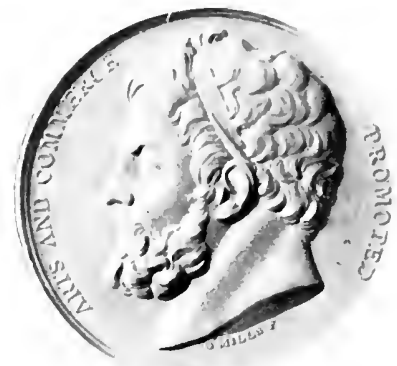

VUICAN MEIJA.

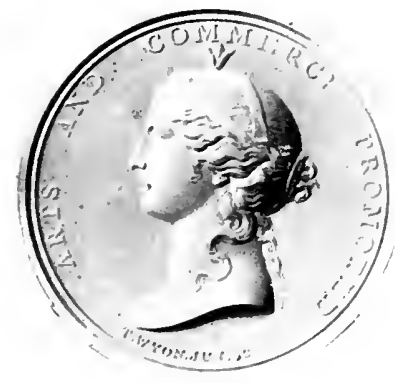

ISIS MEJAI.

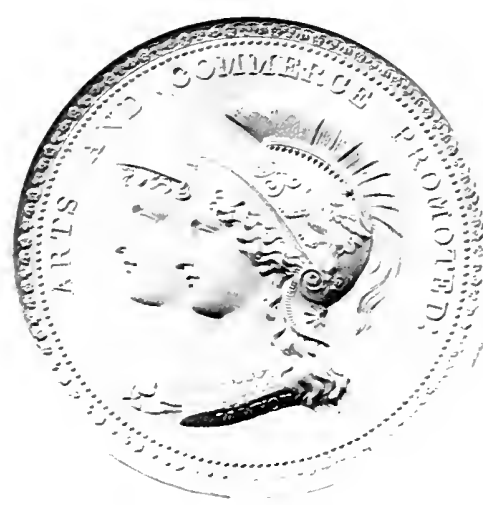

THF SOCHET S I.ARTI MEDAI. (ITON).

THE SUCIETY'S EARLY MEDALS. 

altogether forgetful of the latter ; but, with all submission, may not your extensive and noble Views be greatly forwarded by adverting to it a little more?

"The Desire of Reputation and Esteem is strongest in the most ingenious and most ingenuous Minds, and can set those Heads and Hands to work which the Hopes of Gain can give no Motion to. Undoubtedly your Premiums in Money are, in general, the best Encouragement to the Mechanic, the Manufacturer, and the Planter, and to all the Multitude in whom the Desire of Gain prevails ; but may we not suppose that some honorary Token of Esteem would more effectually bring to your Assistance the Scholar, the Philosopher, and the Gentleman of Estate? By many Others too it would perhaps be preferred to Money.

"It is therefore proposed that a dye be made for striking Medals of Gold, Silver, and Copper (with proper Devices), to be occasionally bestowed by the Society as a Token of Honour and Esteem on such as shall practice or produce some new Manufacture or Discovery that may employ many Hands, some considerable Improvement of Public Utility, or some valuable Branch of Commerce (in one or the other Metal), according to the Nature and Consequence of the Improvement or Discovery ; which Medals in Gold shall be of 56 Value, and proportionately in Silver and Copper; tho', in all of them, the Honour of being thus distinguished is the principal Object of Regard."

This paper was referred to a committee, which reported that they were of opinion that the giving of medals would be of utility, and that a special committee should be appointed to consider a proper device. This committee, of which Baker, Nicholas Crisp, Hogarth, Henry Cheere, and Nicholas Highmore were members, agreed upon a design, but after it had been chased upon gold plates, and the order given for the dies to be cut, a difficulty arose. It had been decided that the value of the medal should not exceed ten guineas, but when specimens of the selected design were produced it was found that not less than fifteen guineas' worth of gold was required. 'This was 
considered too much, and the report of the committee was referred back to them, with instructions to obtain a new device which should only need gold to the amount of five guineas. This, however, was not found to be possible, and after a good deal of discussion, the committee refused to make any report. Thereupon James Stuart, the painter and architect, well known as" Athenian Stuart "from his studies in Greek Architecture, came to the rescue with a design of his own, which after being executed by Thomas Pingo, the engraver to the Mint, was adopted. Pingo made the necessary dies and medals were struck from them in 1757 .

The design of the medal, as shown in the illustration facing page 314 , represented Britannia receiving awards from Minerva and Mercury, "the classical tutelary deities of Arts, Manufactures, and Commerce."

There was much discussion as to the inscription, but eventually it was decided that the legend should be "Arts and Commerce Promoted." At first the date of institution was given as 1753 , but afterwards it was changed to 1754 .

Curiously enough the earlier and incorrect date was preserved for many years when the design was adopted for the Society's book-plate. ${ }^{1}$

The Medal was used for nearly half a century, until the die was worn. In I801, James Barry, while approving the idea symbolised in the medal, criticised the execution and proposed "to substitute instead of the little entire figures of Minerva and Mercury, only two large heads of those deities, and he would omit the head of Britannia altogether, and by a wreath of the shamrock, rose, and thistle, totally rising round the edge of the medal, playing in and out in a graceful gustoso manner, he would represent the present happily United Kingdom of Great Britain and Ireland, with a felicity at least equal to the owl, the horse's head, or the dolphin on the Athenian, Punice, or Sicilian coins." 2

Barry's design is here reproduced from the engraving in his account of the pictures in the Meeting-

1 See figure, p. 16 I.

2 Transactions, vol. xix. pp. xxxvi-xxxix. 
Room. ${ }^{1} \quad$ It is a fine vigorous sketch, evidently the work of an artist accustomed to express himself by the strength of his lines, rather than of a medallist.

His suggestions do not seem to have commended themselves to the Society, and the Committee of Polite Arts asked Nathaniel Marchand, the well-known medallist, to prepare a design in accordance with their suggestions, one of which was to have the President's head on the

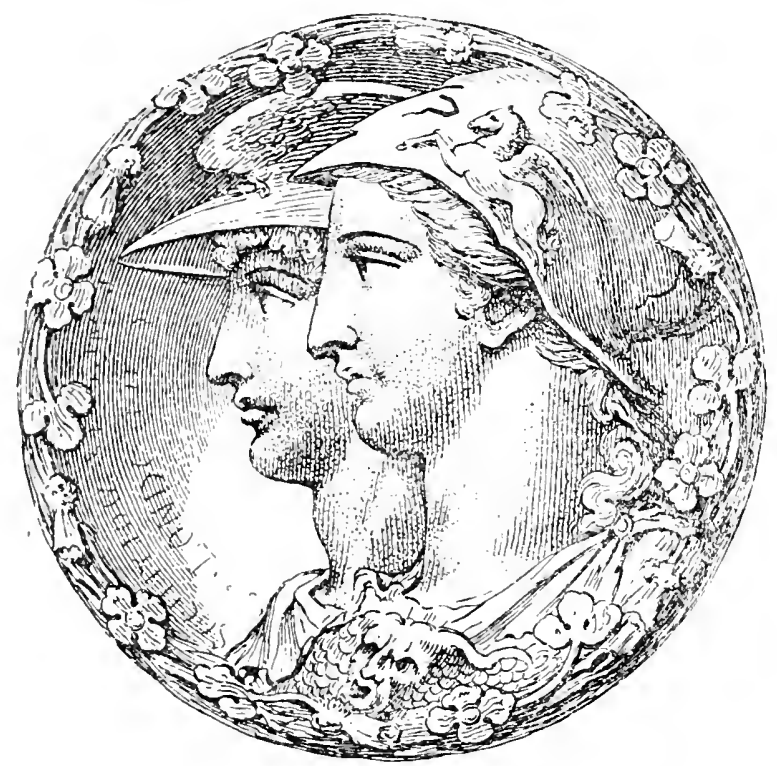

Barry's design for the Society's Medal.

obverse, and a symbolical Society, with statues of the "tutelary deities" on the reverse. Either Marchand did not care for the suggestions, or he was dilatory; but for whatever reason, nothing came of the proposals. Then in 1805 , Flaxman was asked to furnish a design, and he produced the very beautiful medal shown in the plate facing page $3 \mathrm{I}_{4}$.

This, as will be seen, embodies Barry's ideas, and, it may be added, justifies them. Nevertheless, the design

${ }^{1}$ See Chapter III, p. 7 I. 
was not adopted without some opposition from Barry's friends, who wished that the preparation of the medal should be entrusted to him. But Barry's death in 1806 put an end to any proposals of the sort, and no further objections were raised to Flaxman's work. The dies were cut by Pidgeon, ${ }^{1}$ entirely to Flaxman's satisfaction, and from 1806 onwards this medal served as the chief of the Society's awards. A very beautiful engraving of the medal forms the frontispiece to Vol. $\mathrm{xxv}$. of the Transactions. $^{2}$ It was drawn by Maria Denman, Flaxman's sister-in-law, and engraved by Anker Smith.

Besicles this large medal, three smaller medals were afterwards used, the Isis Medal, designed by Thomas Wyon the younger in isio, the Ceres medal by William Wyon, a nephew of the elder Thomas, in 1813 , and the Vulcan medal by George Mills in 1818. These were given respectively for Fine Arts, Agriculture, and Mechanics, and were often designated the smaller Society's medal, while Flaxman's was called the larger medal. They were struck in gold and silver.

The weight and value of the different medals is given in a note in the Committee Minutes ${ }^{3}$ for 1843 :-

Large Gold, weight 3 oz., value $£_{1} 3$, I 5 s.

Small Gold, weight i oz. 8 dwts., value $t 6$, I 4 s. 6 d.

Large Silver, weight 2 oz. $8 \mathrm{dwts}$, value $£ \mathrm{I}, 4 \mathrm{~s}$. $6 \mathrm{~d}$.

Small Silver, weight I oz. 8 dwts, value I9s.

In addition to the medals there was in the class of Fine Arts the palette, an illustration of which is given in the plate facing page 160 . Reference to it has already been made in the chapter on the Fine Art prizes. ${ }^{4}$ It was a miniature copy of an artist's palette, bearing on the obverse the Society's title, and on the reverse a scroll with the recipient's name. It was struck in two sizes $\left(2 \frac{1}{2} \mathrm{in}\right.$. and $2 \mathrm{in}$. long respectively), and was generally silver, sometimes gold, and

1 Probably G. F. Pidgeon, a medallist who worked at the Soho Mint under Matthew Boulton. $\mathrm{He}$ is mentioned and some of his work described in Forrer's Dictionary of Medallists, but it is said that "no particulars of his life appear to be known."

${ }^{2}$ See plate opposite p. 354. $\quad{ }^{3}$ Miscellaneous Minutes, I 843, p. 76. See Chapter VII, p. I60. 

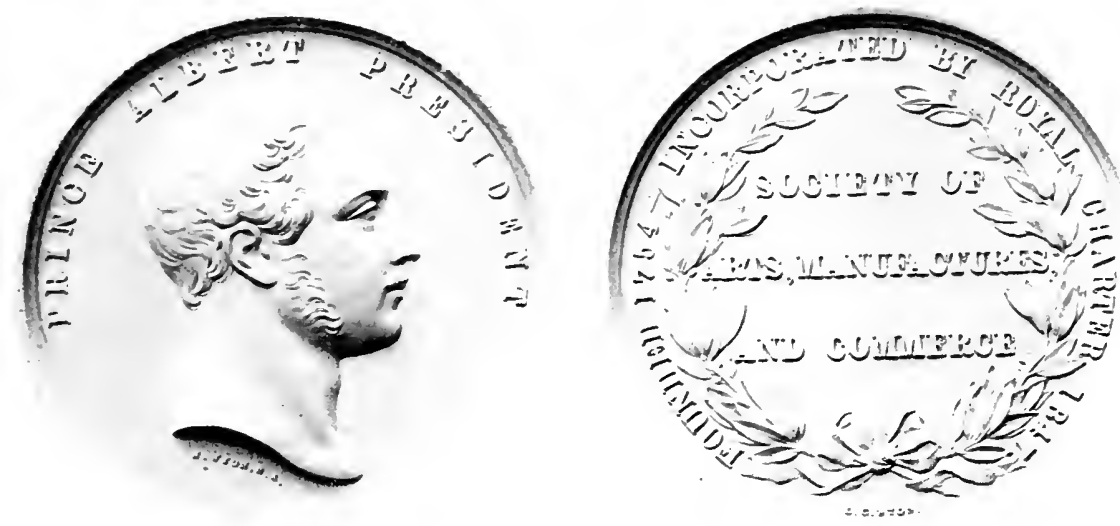

SOCHTY" MEDAI, ISt9-ISGI

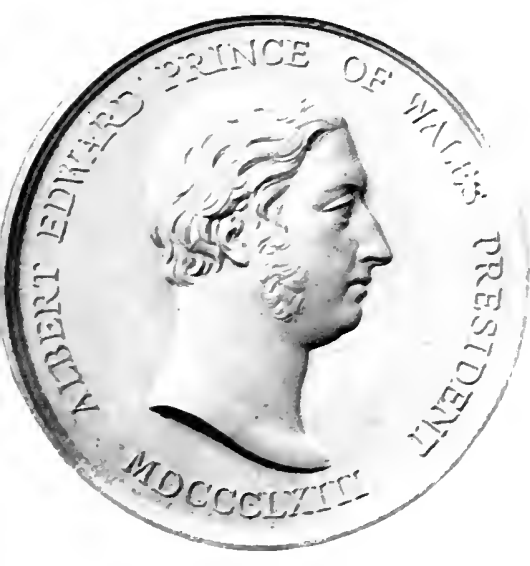

SOCIETY'S MEDAI, $1863-1900$.

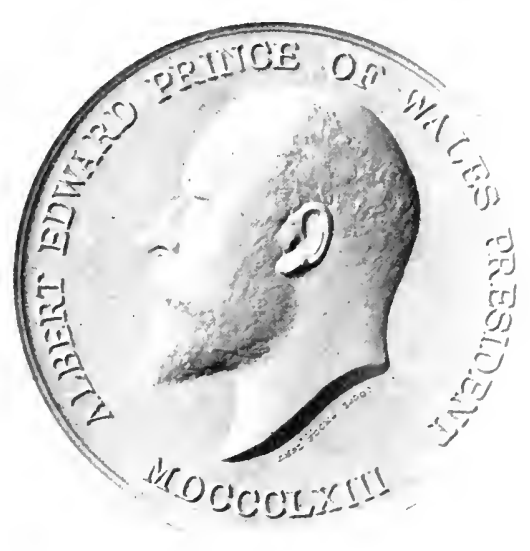

SOCIETY'S MELAI, 1900.

THE SOCIETY'S LATER MEIALS. 

occasionally silver gilt. It was devised in $\mathrm{I} 760$, as a special sort of prize to be given instead of medals or money to youthful candidates. Later on, the restriction to young persons was not always observed. ${ }^{1}$

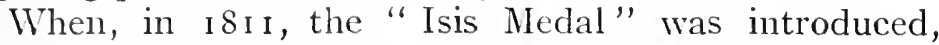
it was intended to substitute this for the palette, but this idea was not carried out. Both medals and palettes were awarded for many years-in fact, as long as any Fine Art prizes were given; but it is not very easy to say what was their precise relative value. At the first institution of the medal, the two were of equal value, and the candidate was given the option of selection. The last award of a palette was in I 847. The Isis Medal was awarded in the last two distributions of awards in 1850 and I $853 .^{2}$

In 1820 a new die was designed and executed by William Wyon to replace the one made from Flaxman's design, which was worn out. It is a design of much beauty, and of exquisite workmanship, but, in the opinion of competent critics, not equal to Flaxman's. This die was used for about thirty years, but in 1849 it was found to be wearing out, and at the suggestion of Henry Cole a new design was adopted, with the head of the President, Prince Albert, upon it. The die for this was also prepared by William Wyon, and must have been one of his latest pieces of work, for he died in $185 \mathrm{I}$. Probably in consequence of Wyon's death there was some delay in the preparation of the new medal, and the old die was certainly used for striking some, if not all the medals presented in I 853 , but from that date onwards the new medal was always used, until the death of the Prince Consort.

1 There was also the "John Stock Medallion," awarded, as stated in Chapter VII, p. I6I, for Architecture, Sculpture, and Drawing. When, in I782, arrangements were under consideration for the award of the prize founded by the testator, it was at first proposed to strike a special medal for the purpose, but afterwards this idea was abandoned and it was "ordered that the medallion ... be composed of the Greater Silver Pallet, hung on a swivel within an oval frame of the same metal."-Minutes of Committee of Polite Arts, 22nd March 1782, 3rd April I782, 22nd January I 783 .

2 In 1850 there were no Fine Art prizes, but the Isis Medal was given for some of the awards in Industrial Art, In I 853 it was given for some purely technical inventions. 
At the election of the Prince of Wales (King Edward viI.) to the Presidentship in I863, his head was placed upon the obverse of the medal. At the same time the reverse was re-engraved; the wreath and inscription remained the same, but the engraving was bolder. The die for this medal was the work of Leonard Wyon, the successor of William.

No further change was made till 1900, when, the need again arising for a fresh die, a new design was prepared by Mr. Emil Fuchs, whose portrait of the Prince was preferred by His Royal Highness. When, in the following year, King Edward came to the throne, he authorised the continued use of his head on the Society's medal, his title being changed, and the word "Patron " being substituted for "President" in the inscription.

On the accession of King George V. in 1910, when he resigned the Presidency and became Patron, he was asked by the Council if he would allow his head to be engraved on the medal. His Majesty consented, and expressed his wish that the work should be executed by Mr. Bertram Mackennal, A.R.A. An excellent likeness of the King was modelled by Mr. Mackennal, and from it a die was engraved by Mr. Allan Wyon, the present representative of the firm.

Since 1853 the medal with the President's head upon it has been the only one employed by the Society for all its ordinary awards. It is struck in gold, silver, and bronze; gold for special prizes, silver for the medals for papers, for examination awards, and for other purposes, bronze for examination prizes, and occasionally for other minor awards.

In addition to this the Society possesses the Albert Medal, founded, as hereinafter stated, in I863, to commemorate the Presidency of Prince Albert.' The designs for both obverse and reverse of this were by Leonard Wyon, the head being intended as a likeness of the Prince during the later years of his life, and the reverse symbolical of Arts, Manufactures, and Commerce.

${ }^{1}$ See Chapter XVI, p. 400 . 




SOCIETY'S MELAI, I $901-19$ I I.
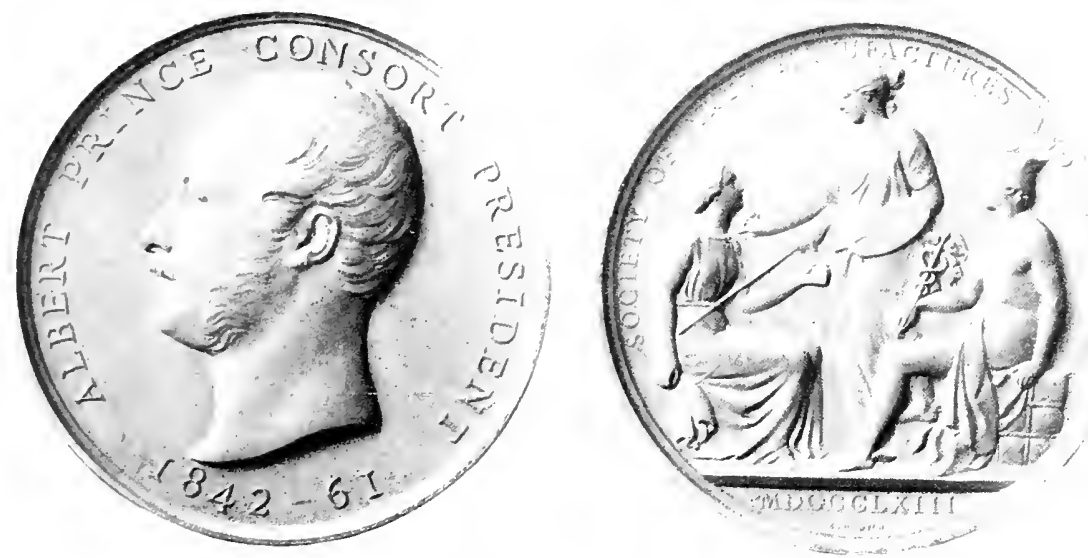

ALPERT MEIAL OF THE SOCAFTY.

THE SOCIETY'S LATEST MEINAS. 



\section{H A P TER X V}

The Official.s. The "Transactions." The Council. The Charter

$$
\text { ( } 176 \mathrm{I}-\mathrm{I} 847)
$$

Presidencies of Lord Romney, the Duke of Norfolk, and the Duke of Sussex-Annual Prize Distributions-The Prince Consort elected President-The Vice-Presidents-The Committees-The Secretaryship of More-The Transactions-The Museum RusticumDossie and his Memoirs of Agriculture-Charles Taylor succeeds More, and is succeeded by Arthur Aikin-Aikin and his services to the Society-His Lectures and his Suggestions for the reading and discussion of Papers-His Resignation and his Successor, W. A. Graham-The Assistant Secretaries, Box, Thomas Taylor the "Platonist," Thomas Woodfall-The Registrars, Shipley, Tuckwell, W. Bailey, E. M. Bailey, George Cockings, Ann Cockings-The Society's decadence-Attempts at Reform by Thomas Webster and others-Their eventual Success-Whishaw, Secretary, succeeded by Scott Russell-Formation of a CouncilThe Charter.

WE have now considered the proceedings of the Society during the first century of its existence, and the methods it adopted, by the distribution of its awards, to encourage the progress of Agriculture, Fine Arts, Industry and Commerce in the Kingdom and the Colonies. We may now devote a chapter to the personnel of the Society, its officials and the principal members of its staff, its general history, and the changes which were gradually effected in its character and its methods.

On the death of Lord Folkestone in I 761, Lord Romney was elected President, and he held the office till his own death in I793. From its foundation he had always taken the greatest interest in the Society, and during his presid- 
ency he continued to attend regularly. There is no doubt that the Society owed a great deal of its early success to its first two presidents.

Lord Romney's portrait,facing page 16 , is the head from the full-length picture by Sir Joshua Reynolds, painted for the Society in I770. It was engraved by Sherwin for the frontispiece to Vol. III. of the Transactions, and is now reprinted from the original copper-plate.

During Lord Romney's presidency a proposal was made that the Prince of Wales should be elected patron, and His Royal Highness seems to have agreed. At the meeting of the Society on 14 th December I 785 , a letter was read from Caleb Whitefoord, ${ }^{1}$ saying that the Prince would become patron, and the proposal was approved. However, at the meeting of the following week (2 Ist December) other counsels prevailed, and the consideration of the question was " postponed," not to be revived. The reasons for this action are veiled in what was perhaps a judicious reticence.

Lord Romney died in November I793, and was succeeded in the following year by the Duke of Norfolk. The Duke had been elected a member of the Society in May i 769, as Charles Howard, jun., his father, also Charles Howard, having become a member in 1758 . The elder Howard became tenth Duke of Norfolk in 1777 , when his son became Earl of Surrey. The tenth Duke died in

${ }^{1}$ Caleb Whitefoord was for long a prominent member of the Society. He was a friend of Franklin, being his neighbour in Craven Street, and was proposed by him in January I762. He continued a member till his death in I810. He was then a Vice-President, having been elected in I 800 , and for many years, from 1786 onwards, he served as Chairman of the Committee of Polite Arts. He was Secretary to the Commission which concluded peace with America in $178 \mathrm{I}$, but had a greater reputation as a wit than as a diplomatist. Burke described him as nothing more than a diseur de bons nots, but he was well known and popular in Socicty. He was a friend of Johnson, Goldsmith, Garrick, and Foote. The Society possesses a portrait of him painted by an unknown artist, and another portrait, engraved by Holl from a painting by Stuart, forms the frontispiece of Vol. xxix. of the Transactions. He presented Templeman's portrait to the Society, and was also instrumental in obtaining the portrait of Shipley. A short memoir of him is included in the preface to the volume of the Transactions above mentioned. 
I 786, when he was succeeded by his son as eleventh Duke. He was made a Vice-President in 1791 , and was elected President at the election of officers in 1794.

He was a man of considerable natural ability and of independent character. He was distinctly eccentric, and was a frequent subject for Gilray's caricatures. Slovenly in his habits and dress, and too much addicted to conviviality, he was yet a liberal patron of literature and the arts, a ready speaker, and endowed with plenty of common sense. He was extremely popular, especially in Cumberland, and in the borough of Carlisle, which he represented for some time in Parliament. But he lacked selfcontrol, and allowed himself a licence in speech and behaviour for which only his great rank procured toleration. He insulted the King, and was deprived of certain of his commissions. At one time he was intimate with the Prince of Wales, but they quarrelled. Their reconciliation was celebrated by the disgraceful practical joke played upon the Duke in his old age by the Prince, and described in scathing language by Thackeray in the Four Georges. The Duke, himself a sufficiently seasoned toper, was invited from Arundel to the Pavilion at Brighton, and there made most disgracefully drunk. Readers of Thackeray's brilliant but very one-sided essays will remember the sorry story well enough.

He certainly did not take the same keen personal interest in the Society's welfare as did his two predecessors, but he made a good and attentive President, and at all events performed efficiently the ceremonial functions of his office. He attended regularly at the annual distribution of prizes, and occasionally at other meetings when important business had to be transacted. It was owing to the Duke's objection to the proposal that the resolution giving permission to Barry in 1801 to substitute portraits of King George in. and Queen Caroline for those of Lords Folkestone and Romney, then in the Great Room, was rescinded. ${ }^{3}$

The Duke of Norfolk died in December I 8 I5, and his death was formally reported at the ordinary meeting ${ }^{1}$ See Chapter III, p. 80. 
of the Society on the 2oth of that month. At the next meeting, on Ioth January 1816 , it was proposed that the Duke of Sussex should be nominated in his stead. The Duke was a member of some four years' standing, having been elected in April I8I I, when he paid the usual life membership fee of $£ 21$. An extraordinary meeting was called for ist February, and His Royal Highness was elected by 180 votes to 24 over the Earl of Liverpool, who had also been proposed. At the same meeting a deputation was appointed to wait on the Duke and to invite him to accept the presidency. The deputation was received at Kensington Palace on the twelfth of the same month. The Duke made a very courteous and complimentary reply to the elaborate address presented by the deputation, and accepted the office, apparently with some gratification. He attended the next meeting of the Society two days later (I $4_{\text {th }}$ February i 8 I6), was duly inducted into the chair, and conducted the regular business of the meeting.

The sixth son of George III., the Duke of Sussex was a man of liberal sentiments, genial manners, and intellectual tastes. He took a genuine interest in art and in science, and was well qualified for such a post as the presidency. He liked the work, and did it well, and enjoyed acting as figure-head on all ceremonial occasions. Afterwards (from I 830 to I 839) he acted as President of the Royal Society, and in both offices he made himself popular. That he should take any active share in the management of either society was not to be expected, but he was always ready to attend any functions which required his presence, and discharged the duties required on such occasions with unvarying amiability and dignity.

So far as the Society of Arts was concerned, the most important functions for its President were the annual dinner and the annual distribution of premiums. The latter ceremonial was for many years held in the Society's own room, but the attendance grew too large for the limited accommodation, and after a good deal of consideration, when it became clear, after several years' experience of inconvenient crowding, that the meeting- 
room was too small for the numbers attending, a move was made in 1816 to Freemasons' Hall. In 1820 the distribution was held in the Argyll Rooms, ${ }^{1}$ and in 1822, as the crowds still grew, Drury Lane Theatre was hired for the occasion. It is clear that the event had become an important social function. There was a military band, a body of stewards was organised, and a staff of policemen was engaged. Altogether it was a very important ceremonial, requiring not a little fuss and organisation. The secretary was required to deliver an appropriate address-two of Aikin's are printed in the Transactions. ${ }^{2}$

For some years these celebrations were continued at Drury Lane or at the King's Theatre, ${ }^{3}$ but in 1829 , either the attractions of the ceremony had diminished, or the decreasing funds of the Society rendered economy desirable, and it was decided to return to the more modest arrangement of a prize distribution in the Society's Great Room. In that year two separate meetings were arranged, one for the prizes in Polite Arts, and the second a month later for the other awards. In the following year a single meeting only was held and all the prizes were presented on the same day. This arrangement, however, was not popular, and in I 83 I Exeter Hall was engaged. The same plan was followed for the next four years. Then for three years ( 1836 to 1838 ) the Society went to the Hanover Square Rooms, and in 1839 , again hampered by failing resources, it came back to the Adelphi and had its annual distribution in its own meeting-room.

In June I 840 , the Duke of Sussex proposed Prince Albert for membership of the Society, and he was at once elected. The Duke of Northumberland and Lord Radnor were his other sponsors. His Royal Highness qualified as a life member. His marriage with Queen Victoria had taken

1 These Rooms were on the east side of Regent Street, at the corner of Little Argyll Street. They were built by Nash in I 818, and must not be confounded with the Argyll Rooms in Windmill Street, which, as Mr. Wheatley says in London Past and Present, acquired an "unsavoury reputation" and had no history.

2 Transactions, vol. xxxv. p. 209 (1817), and vol. xxxvi. p. I79 (18 18).

${ }^{3}$ The King's Theatre or Haymarket Opera-House, later known as Her Majesty's Theatre. 
place in the previous February, when an address was presented by the Society to Her Majesty.

Three years later, in April 1843, the Duke died, and it was at once determined to invite Prince Albert to succeed him. A deputation of three of the most distinguished Vice-Presidents-the Duke of Buccleuch, the Duke of Sutherland, and the Marquis of Northampton-was appointed to invite H.R.H. to accept the presidency. The Prince at once acceded, and was elected President on 26th May of the same year. He entered on his duties by presicling at the annual distribution of awards in June.

The number of Vice-Presidents varied from time to time. There were twelve at the end of the eighteenth century, nearly all great noblemen, with a few distinguished men, who took a more active share in the Society's proceedings. The numbers were afterwards increased to about twenty, most of the additions being of the latter class, more or less active workers, and in 1843 a distinction was actually drawn between the "Honorary" and the "Acting" Vice-Presidents. There were also eighteen Chairmen of Committees, two for each of the nine Committees, which remained unchanged for very many years. These were the six Premium Committees-Arts, Agriculture, Manufactures, Mechanics, Chemistry, Colonies and Trade, with three others-Accounts, Correspondence and Papers, and Miscellaneous Matters.

The paid officials were the Secretary, AssistantSecretary, Registrar and Collector. These, with the President, Vice-Presidents, and Chairmen of Committees, were all elected at the annual meeting.

Dr. Templeman ${ }^{1}$ was succeeded as secretary by Samuel More, who had indeed discharged most of the duties of the office during the long illness which preceded Templeman's death. He held the post for over thirty years, for he was elected in January 1769 (Templeman died in the preceding October), and died in October I799, at the age of seventy-four. He was evidently a capable and efficient secretary, keenly interested in the Society's work.

$$
{ }^{1} \text { See Chapter I, p. } 25 .
$$




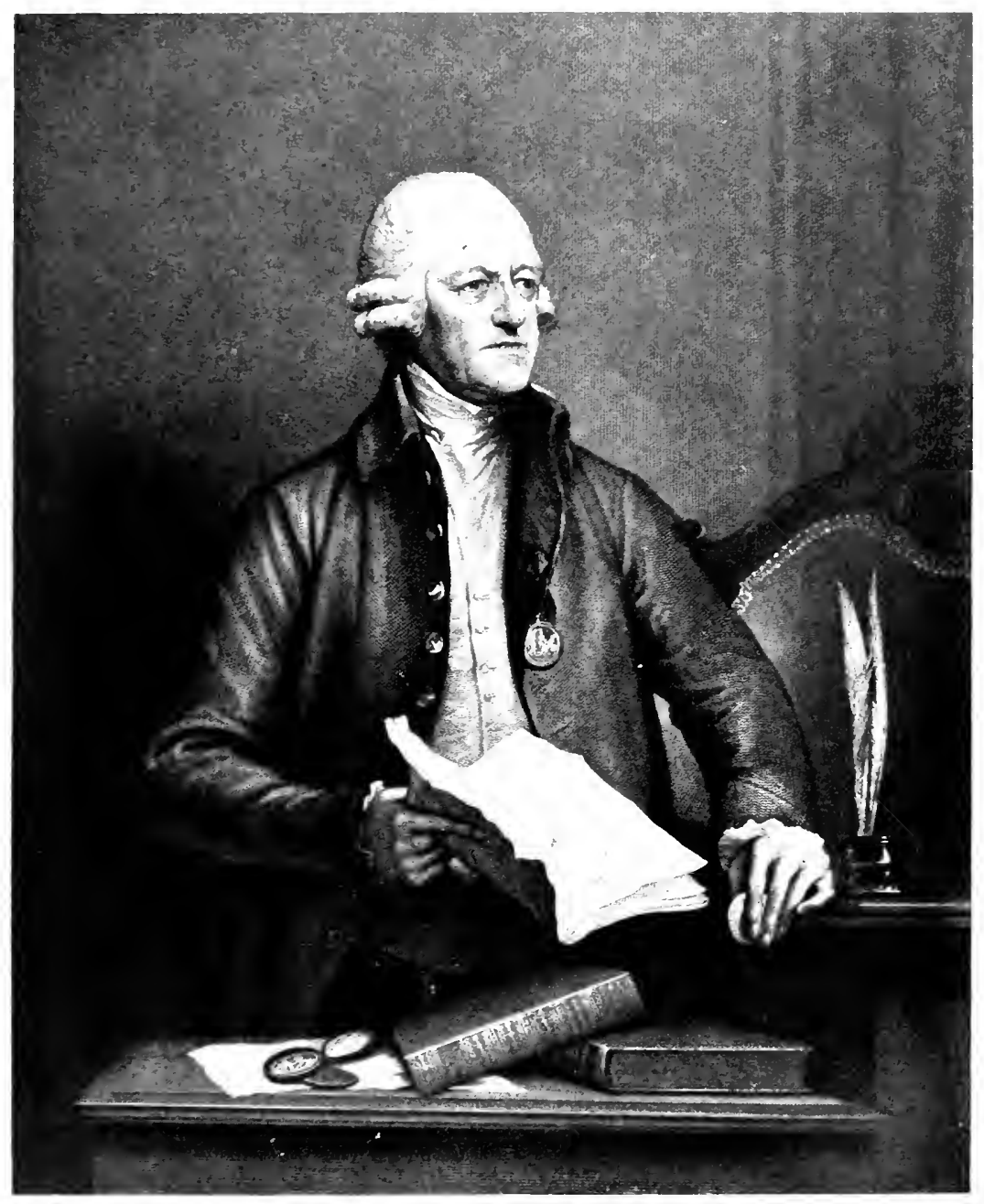

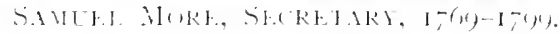

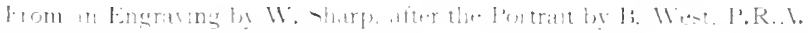



He had been an active member for some ten years before he became secretary, and seems to have been both respected and popular. Of his private life not very much is recorded. A short paragraph in the Gentleman's Magazine reports his death, and in the Preface to Vol. xviri. of the Transactions there are some laudatory comments on his work. No biographical information is given, "because it is expected that a full account of him will be prefixed to the publication of some valuable papers which it is said he has bequeathed to the world." This intention, however, does not appear to have been carried out, as no trace of such a publication can be found.

The estimation in which he was held by the members is shown by the fact that he was presented with a gold medal in 1794 "For eminent services," and also by the inclusion of his portrait in Barry's picture, "The Society." His portrait was also painted for the Society by Benjamin West, P.R.A., in I 796. A fine engraving of the picture was made by W. Sharp, ${ }^{1}$ and this is reproduced in the plate facing page 326 . He contributed two papers to the Philosophical Transactions, ${ }^{2}$ and one, on standards for weights and measures, to the Society's Transactions, ${ }^{3}$ besides his unsigned contributions.

$\mathrm{He}$ seems to have been interested in gem-engraving and die-sinking. Before he was Secretary he received two premiums for collections of "Impressions of Pastes resembling Antique Cameos and Intaglios," and it is stated in Forrer's Dictionary of Medallists that he made some designs "for the coinage and medals which were engraved by Hancock." Forrer gives a cut of a pattern halfpenny, which is also described in Crowther's English Pattern Coins, p. 45, and in Montagu's Copper Coinage, etc., I 885, p. 63. The name is misspelt Moore, but it is stated that the designer was the Secretary of the Society of Arts.

1 William Sharp (I 749-1 824), " One of the most celebrated of English line engravers" (Bryan).

2 "Some Scoriæ from Iron Works," Philosophical Transactions $A b r$. vol. xv. p. 182 (1782); "Account of an Earthquake felt in the Northern Part of England," ibid. vol. xvi. p. 176 (1787).

${ }^{3}$ Transactions, vol, xii. p. 292. 
It was during More's secretaryship that the Transactions were commenced. The need of some permanent record of the Society's proceedings was recognised at a very early date. It was obviously of little use to stimulate invention or to reward progress, unless full information of the results obtained could be made public. The Society soon became possessed of a good deal of valuable information contributed by the competitors for the awards, and this it was at first proposed to publish in an Historical Register, arrangements for the preparation of which, it appears from the minutes, were on several occasions discussed. Instructions were given to Templeman to prepare such a Register, and two MS. volumes are in existence, apparently bound at a later date, and entitled Dr. Templeman's Transactions. These, however, consist merely of extracts and compilations from the minutes, a copy of the 1759 premium list, the Rules and Orders, a list of members elected from April 1755, to April 1758, and similar matter. There are only two documents of any importance. One is a manuscript copy of the pamphlet published in 1721 , containing a proposal for the formation of a London "Chamber of Arts," referred to in the first chapter.' As no copy of this pamphlet, so far as the present writer is aware, has been preserved, Dr. Templeman's MS. copy is of interest. The scheme suggested is so much like that of the Society, that it looks as if Shipley, or some one of the founders, was familiar with the proposal. There is also a copy of a draft charter for an Academy of Arts without any date. This was no doubt the draft submitted to the Society in 1755 by Sir Henry Cheere, but not approved. It is very full and complete, but the scheme was one for an Academy of Arts, not for an industrial Society, such as was really in the minds of the founders of the Society of Arts.

On the whole, it is fairly evident from the contents of these volumes that if Dr. Templeman had been able to complete and publish his Historical Register, it would not have added very much to the information available about the Society's early years.

' See Chapter I, p. 6. 
According to a statement by Arthur Young, ${ }^{1}$ a good many of the communications made to the Society were published as pamphlets, in the book De Re Rustica, ${ }^{2}$ in the Gentlcman's Magazine, or in other periodicals. Descriptions of some of the machines rewarded by the Society are to be found in an illustrated work entitled The Advancement of Art, Manufactures, and Commerce, or Descriptions of the Useful Machines and Models contained in the Repository of the Society, published in 1772, by William Bailey, who was then Registrar to the Society. Various references to this book have already been made. It is a quarto volume with a collection of fine illustrations in folio. In 1782 another edition was issued by A. M. Bailey, who succeeded his father as Registrar in 1773 . It is in two volumes, folio. The book is of some value, as it contains accounts of several pieces of apparatus not elsewhere described, and the illustrations, mostly drawn by A. M. Bailey and W. Bailey, jun., are very good. William Bailey received a bounty of 50 guineas in 1769 for this work. ${ }^{3}$

The first publication, however, which regularly published a selection from the proceedings of the Society was the Museum Rusticum et Commerciale, a monthly journal, of which six volumes were issued, each containing six of the monthly parts. This commenced in I 764 and came to an end in 1766 . It had no official connection with the Society, but it provided a means of publication for some, at all events, of the more important and interesting matters which were brought before it, though it was by no means restricted to the Society's proceedings. ${ }^{4}$

This casual and unofficial method of publication

1 Farmer's Letters (2nd ed. I77 I), vol. i. p. 256.

'De Re Rustica, or the Repository for Select Papers in Agriculture, Arts and Manufactures. London : 2 vols. 8 vo. I77r.

${ }^{3}$ Some further information about the book is given in Ch. XI, p. 239.

4 Two of the chief contributors to the Museum were Arthur Young and Robert Dossie. Young states in his Autobiography (edition of I 898 by M. Betham-Edwards, p. 33) that the Farmer's Letters consisted of his scattered papers in the Museum Rusticum, which, at the suggestion of the Rev. Walter Harte, he republished, with additions, in a volume. Dossie contributed several articles signed "Agricola," and possibly other papers. 
proved unsatisfactory, and its failure suggested to Robert Dossie, an active member of the Society, the production of a similar work which should contain such memoirs as the Society desired to publish, together with other contributions, and also selections from the published proceedings of foreign societies devoted to the Arts and Sciences. An arrangement was entered into between Dossie and the Society, under which he undertook to publish, and they to provide, such communications as seemed suitable to both parties. With this understanding, Dossie started his Memoirs of Agriculture and other Economical Arts, the first volume of which was published in 1768 , and contains a resolution, passed by the Society in June 1767 , to the effect that they "will occasionally publish in this Work such Pieces as they shall think proper to lay before the Public." It is entirely made up of the Society's proceedings, and begins with a list of all the awards, other than those in Polite Arts, up to the end of I 767; next follows a brief statement of the Society's receipts and expenditure to the same date; and after this is a well-written and cxcellent account of the Society's proceedings, presumably prepared by Dossie himself. This occupies the greater part of the book, and it is in these pages that the whole early history of the Society is to be found. The last hundred pages contain seven articles, all but one devoted to agricultural subjects, the one exception being an account of the methods for dyeing Turkey leather, for disclosing which a reward had been granted to one Phillippo.' This first volume was followed by two others, Vol. II. in I771, and Vol. III. in I782. The later volumes contain a few articles besides those contributed by the Society, and are for the most part devoted to agricultural subjects. Vol. III. continues the list of awards down to the year 1776 , and also gives a complete list of the premiums in Polite Arts down to the same year, with some useful biographical notes about the prizewinners. Dossie's intention of continuing the general history of the Society was, unfortunately, never fulfilled, and, indeed, it is probable that it was interrupted by his

${ }^{1}$ See Chapter XIII, p. 308. 
death, which happened certainly not later than 1783 . The catalogue of the Advocates' Library gives 1777 as the date, but this can hardly be correct. In Vol. II. of the Society's Transactions (published in 1784) he is referred to as "the late Mr. Dossie," and the preface to Vol. III. of the Memoirs of Agriculture (1782) is signed by him.

Not very much is known of Robert Dossie, who was certainly a skilful chemist and an accomplished writer. He was a friend of Dr. Johnson's, and almost the only reference to him which appears in contemporary literature is to be found in Boswell :-

"Johnson was well acquainted with Mr. Dossie, author of a treatise on agriculture, and said of him, 'Sir, of the objects which the Society of Arts have chiefly in view, the chymical effects of bodies operating upon other bodies, he knows more than almost any man.' Johnson, in order to give Mr. Dossie his vote to be a member of the Society, paid up an arrear which had run on for two years." 1

There is a short and inaccurate notice of him in Donaldson's Agricultural Biographies, and beyond this there seems nothing beyond scattered references in the Society's records, and his own books. He was the author of several works on chemistry, and he was connected, as a contributor, if in no other way, with the Museum Rusticum. He received a gold medal from the Society in I 766 for " aiding to establish the manufacture of potash in North America," 2 and before this, in $176 \mathrm{I}$, he had received a grant of $€$ Ioo for his method of purifying oil. ${ }^{3}$ As he was a member at the time this would appear to have been irregular, as members were not eligible for money prizes, but the grant was made in consideration of the expenses to which he had been put in experimenting, and no doubt this was considered sufficient justification. He was a candidate for the office of secretary in 1760 ,

${ }^{1}$ Boswell's Life of Johnson, Birkbeck Hill's Edition, I 887, vol. iv.

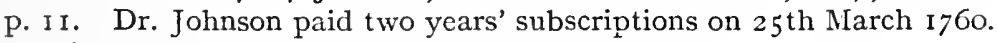
Dossie was elected on 2nd April of the same year.

2 See Chapter IV, p. 87.

${ }^{3}$ See Chapter XII, p. 282. 
when Dr. Templeman was elected, and it was after his failure to secure this office that he became a member, He was an active and useful member of the Society, and a frequent attendant at its committees.

It may have been Dossie's death, and the consequent discontinuance of the Memoirs of Agriculture, that brought to a head the proposals for a regular series of Transactions. Valentine Green claimed the credit for carrying the proposal through, and from the minutes it appears that the final decision to publish transactions was due to his efforts, but Arthur Young, apparently with justice, claims to have originated the idea. In his Autobiography he says, ${ }^{1}$ under the date 1772: "This year I attended very much the meetings of the Society for the encouragement of Arts, Manufactures, and Commerce, as well as the Committee of Agriculture, of which I was chairman. In a letter from Mr. Butterworth Bayley, he lamented the want of a respectable publication by the Society of Arts, and called on me to think of some means of remedying the misery. When I became chairman of the Committee of Agriculture, I was the first to propose that annual publication which afterwards took place. This proposition was at once acceded to, and Valentine Green, the engraver, had the impudence to assert that it originated with him."

In this Young probably refers to his remarks above referred to in the Farmer's Letters of $177 \mathrm{I}$, in which he dwells very earnestly and with much force on the necessity of the Society publishing Transactions, and points out that the value of the premiums, though in some cases they are "truly munificent," is greatly lessened by the absence of any published record. When the Transactions began to appear Young spoke of them very favourably in his Annals, and took the opportunity of praising the Society's work generally, as he very often did. ${ }^{2}$

The first volume of the Transactions was published

${ }^{1}$ Autobiography of Arthur Young (ed. by M. Betham-Edwards), I 898, p. 59.

${ }^{2}$ Annals of Agriculture, vol. ii. p. 323. 
in 1783.1 It compares rather unfavourably with Dossie's skilful compilation. The original papers are neither numerous nor important, and the bulk of the volume is made up of mere official records, necessary but insufficient by themselves. Subsequent volumes show a marked improvement, and the records of the Society's proceedings bear a more reasonable proportion to the purely official matter. The series was continued to 1844 , when it ceased with Vol. Lv. ${ }^{2}$ Up to I 830 an annual volume was published, but from that date to i 843 (Vols. Xlviri. to LIV.) each volume consisted of two annual parts. Vol. Lv. contains only the proceedings of a single session, that of $1843-4$. In 1848 , a few years later, an attempt was made to start a new series, and a volume was published purporting to contain the proceedings for the sessions I 846-7 and I847-8. It is a handsome quarto volume, containing some good illustrations, a selection of papers read before the Society, and the Charter. This was eventually treated as Vol. LVI., though on the title-page (which bears the date 1852 ) it is called a "Supplemental Volume." In December i 851 a volume called Vol. Lvir. was published, containing the proceedings for the session I $850-1$. It corresponds in form with the original series, and is in no sense a continuation of Vol. LVI. After this no further Transactions were published.

In 1845 there was commenced the issue of a publication called the Abstract of Proceedings. This was published weekly during the session while meetings were being held. At first it consisted only of a few octavo pages of notices and general information about the Society, but from i 848 onwards it contained abstracts of the papers read. A little later it was entitled Weekly Proceedings, and in this form it continued till the end of the session for $185 \mathrm{I}-2$,

1 Vol. III. was printed by John Walter at the "Logographic Press." He applied for the contract for Vol. Iv. but did not get it. The Minutes record rather fully the negotiations with Walter, who replied to a question as to whether he considered he had any claim to another order, that he would show no "bad temper" if he did not get it.

${ }^{2}$ A general index to the contents of previous volumes of the Transactions is given in Vols. XxVI. (1808), XL. (1823), and L. (1836). At the end of Vol. vill. there is a Catalogue of the Library. 
the last number being dated I 7 th July i 852 . The number for 12 th June contains a note stating that the Council were considering the publication of " a stamped weekly Journal," and with the new session the Journal of the Society of Arts was started. The first number of the Journal was published on 26 th November i 852.1

After the death of More in October I799, the usual steps were taken for the election of a new secretary. Amongst the candidates who applied, besides Charles Taylor, who was successful, were included the Rev. Edmund Cartwright, the inventor of the power-loom, and Valentine Green.' Valentine Green had for very many years taken a leading part in the Society's affairs, but he had been involved in a very serious loss by the failure of his scheme for publishing a collection of prints from the pictures in the Dusseldorf Gallery. It was no doubt this which made him apply for the secretaryship, as it afterwards led him, on the foundation of the British Institution in 1805 , to accept the office of its Keeper. The committee, which subjected all the candidates to a severe catechising, rejected Green but recommended as qualified Taylor, Cartwright, and another.

Cartwright submitted a special memorial of his qualifications, which was afterwards published ${ }^{3}$ in a volume together with some further information relating to his improvements in the steam engine, and his mechanical inventions. Much of the matter it contains was incorporated in the memoir of his life afterwards published by his daughter, Mary Strickland. His qualifications were con-

${ }^{1}$ For some account of the origin of the Joumul, see Chapter XVI, p. 373 .

2 Valentine Green (1739-1813), the well-known mezzotint engraver, was a member of the Society from 1772 till his death. He was one of the most regular attendants and took an active share in its proceedings. He was Chairman of the Committee of Polite Arts from I 780 to 1786 , and Chairman of the Committee of Correspondence and Papers from 1787 to 1797 . In 1773 he received a gold medal "For repeated services."

"A Mcmorial read to the Society of Arts . . With an Appendix." I 800 . 
siderable, for his experience not only of textile machinery but also of agriculture, was very great. He received three medals from the Society, a silver medal in 1803 for a plough, a gold medal in 1816 for a horse gear, and a gold medal in I 8 I 7 for experiments on manures. Shortly before the date of the election, Cartwright withdrew, and this left the field practically open for Taylor, who was elected by a large majority in February 1800.

Taylor was a competent chemist, and, according to his statement to the committee, he was known to almost all the chemists in Europe. He informed the committee that he was the inventor of a method of calico printing "by wooden cylinders and sliding metallic cylinders." $\mathrm{He}$ also claimed to have furnished the Government with valuable information on indigo, which had led in the eight years from i 789 to 1797 to an increase in the value of the export of indigo from the East Indies from $£_{1}$ IO,, 00 to $£ 558$,ooo. Taylor was for some time engaged in the cotton manufacture in Manchester, but, as the short notice which appeared in the Transactions after his death states, "the opulence which flowed so exuberantly to many of his fellow-townsmen did not find its way to him." He was also among the first to utilise Berthollet's discovery of the applicability of chlorine for bleaching, and was said to be "the first to produce for sale in the Manchester market an entire piece of calico bleached by oxy-muriatic acid." His death took place in I8 86 , after sixteen years' service. He appears to have devoted himself energetically to his duties, and to have made an efficient secretary, without being a man of scientific eminence.

Arthur Aikin, who succeeded Taylor in the secretaryship, had, even when he was elected in February 18 I 7 , though he was then only about thirty-four years of age, acquired a much greater scientific reputation than his predecessor. He had already been one of the founders of the Geological Society, which was established in 1807 , and had published, in connection with his brother Charles, a dictionary of chemistry and mineralogy and some other works. From I 8I I he had been honorary secretary of the Geological

1 Transactions, vol. xxxv. (1818) p. 8. 
Society. He was an accomplished chemist, and was familiar with several branches of industrial chemistry. He told the committee, on his examination for the post of secretary, that he was then occupied in drawing up patents, and in advising on scientific matters. He had also a very considerable knowledge of metallurgy, and was a good botanist. He was the eldest son of John Aikin, M.D., a brother of Lucy Aikin, and a nephew of Mrs. Barbauld. His father was a friend of Priestley, and it was his association with that distinguished philosopher that led Arthur Aikin to the study of science. He was first intended for the Unitarian ministry, but he abandoned this idea in early life, and devoted himself entirely to science. He held the office of secretary for twenty-three years, and after his resignation in 1839 he became chairman of the Committee on Chemistry. He also became the first treasurer of the Chemical Society, which was founded in 1841 at a meeting held in the Society's room, and afterwards (184345) its President. ${ }^{1}$ He was never married, and died in I 854 .

To Aikin was certainly due the initiative of a change in the Society's methods, which ultimately had the result of turning the Society from a purely premium-giving body into one whose main object became the dissemination of information about the industrial arts and sciences, and the publication of new discoveries and inventions of an industrial character. The change was not effected during Aikin's secretaryship, but it was certainly completed before his death, though that completion was effected by other hands than his. The foundation was laid by his proposal that courses of lectures on manufactures should be organised, and arrangements made for the reading and discussion of papers at the evening meetings.

So far as the lectures were concerned Aikin not only suggested that they should be given, but gave them himself. From 1829, when the scheme was first started, to

1 The first regular meeting of the Chemical Society was held on 3oth March 184I. After this, for some time, its meetings were held fortnightly at the Society of Arts' House. See Gentleman's Magazine (N.S.), vol. xv. pt. i. p. 527 . 


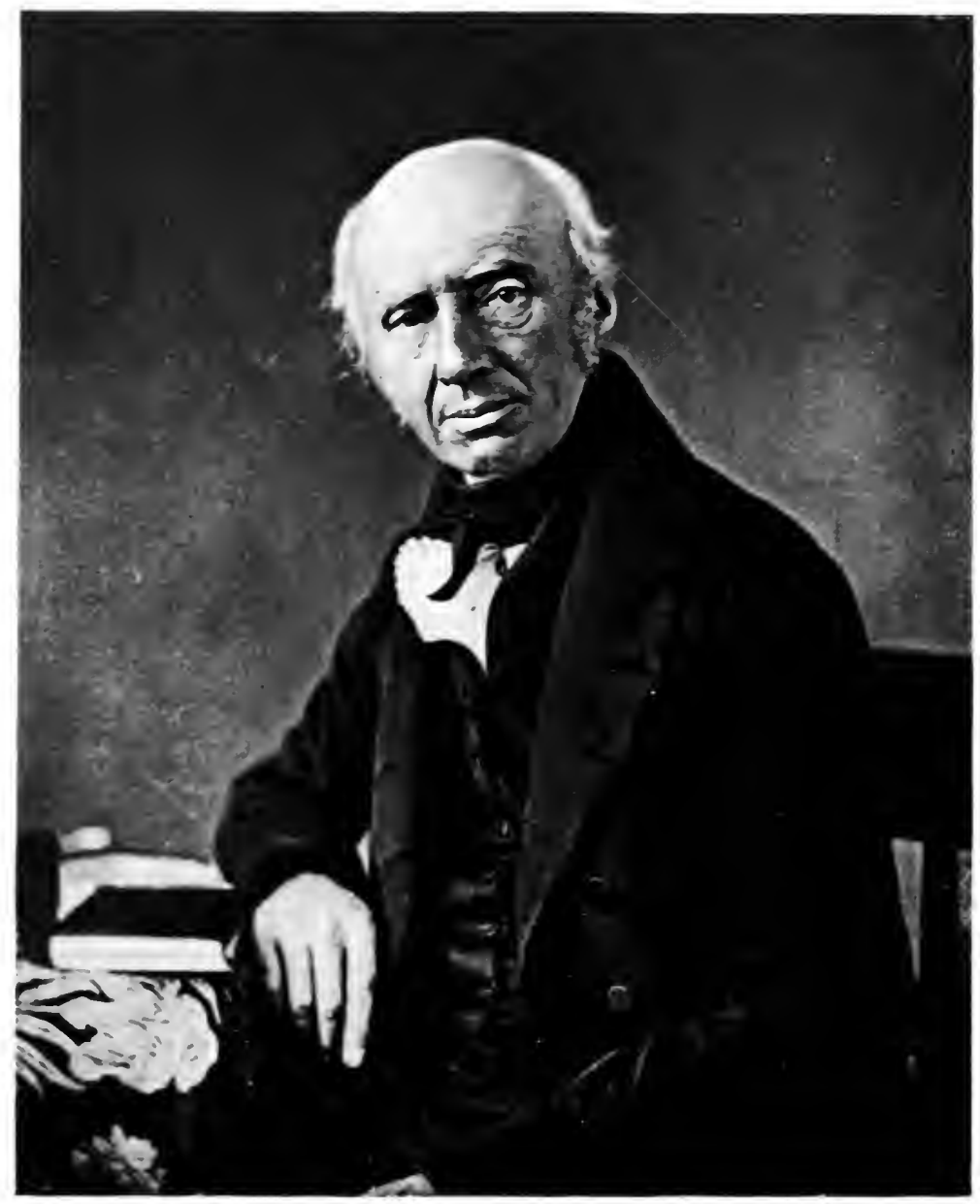

ARTHIR VIRI, SECRFTART, ISI7-IS30.

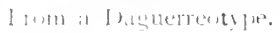



1842 , after he had resigned the secretaryship, he continued to deliver, year after year, excellent and well-illustrated courses on various branches of manufacture. The subjects were very varied. They included glass, pottery, papermaking, furs, tanning, silk, sugar, artificial lighting, timber, horn and tortoiseshell, and other equally divergent topics. At first practically the whole of the work was carried out, and very efficiently carried out, by the secretary, though after two or three years Aikin only gave annually one or two of the "illustrations," and the bulk of the work was taken over by others. The lectures were much appreciated, and did something to keep up the waning popularity and reputation of the Society. Aikin received no payment for the work, and a proposal in I83 I to present him with a gold medal was not carried, though the award was fully merited, and might well have been given. There is nothing in the minutes to show why the proposal was not adopted, but it appears that Aikin himself declined it, on the ground that he was an officer of the Society. At all events, a vote of thanks was substituted, couched in very warm and complimentary terms. Before he resigned his office, however, a testimonial was presented to him, in the form of a valuable microscope, with an inscription testifying to the esteem in which he was held, and to the value at which his services to the Society were rated. The instrument is now in the possession of his grand-nephew. Moreover, he got his gold medal eventually, for when he retired in 1839 it was voted to him unanimously, and he was also made a life member. Few compliments could have been better deserved, for during his twenty-two years' service he devoted himself earnestly to the Society, and it was certainly no fault of his that his single-minded efforts were not entirely successful. In after years his labours bore fruit, and he lived long enough to see their results.

Even more important as regards its permanent effects was the substitution of papers and discussionsat the ordinary meetings for the mere consideration of inventions competing for prizes. There is no definite evidence in the records to prove that this change was Aikin's doing, but there is 
not much doubt that it was due to his initiative. Among the suggestions made in 1828 for rendering the meetings more attractive was one that, instead of confining the discussions to inventions submitted for awards, a notice should be issued that the Society would welcome communications of interest on suitable subjects for reading and consideration only. Such papers had indeed always been received, and, if considered worthy, printed in the Transactions. As far back as 1784, Daines Barrington made two interesting communications to the Society, one on silk and one on tobacco, and both were published in the second volume of the Transactions. But such papers were rare, and it was considered to be contrary to the spirit of the Society to invite them, because it looked like holding out an offer of a prize and so prejudging the decision of the members. It was, however, realised that publication was often more important than the grant of a medal, and that many inventors and students would welcome the chance of publishing their ideas who would not care to enter in competition for a prize, or might, for various reasons, not be eligible if they did. Accordingly a notice was issued in the Transactions for I 829, that papers would be received for reading and publication only. The proposal proved popular, and before long such papers were found to be among the most important contributions to the annual volume. The system gradually developed, until in another ten years we find that the reading of such papers came to be the most important business of the meetings, as eventually it became the most important business of the Society. And when, as we shall see later, the whole proceedings of the Society were reformed, a special committee was appointed to secure suitable papers. At first they were only printed in abstract, but even in this form they are interesting, and among them are many communications of importance.

It was in May 1839 that Aikin sent in his resignation, but he did not actually retire till the beginning of the new session in the autumn. In December, W. A. Graham was elected as his successor, but he only held office for three years, for he resigned in December i 842 
During the period covered by the secretaryships of Templeman, More, Taylor, and Aikin, there were many changes in the staff of the Society. As previously stated, ${ }^{1}$ Box became assistant secretary on the appointment of Templeman as secretary. He held the office till I779, when he retired from failing health, having served the Society in various capacities for twenty-three years. Till I 77 I he also acted as collector, but he then gave up that part of his duties, no doubt in consequence of his health, which, it appears, was but feeble for some years before he actually resigned. $\mathrm{He}$ was succeeded as collector by Abraham Brockelbank, the man who was first appointed (Thomas Dawson) being discharged after a few months, because he was unable to find the necessary security. As assistant secretary Box was followed by Richard Samuel, who was elected in May i 779. He died in the summer of 1787 , and was succeeded by John Samuel, presumably a relation, who was first appointed temporarily to do the work, and was formally elected in November i 787. He served for a little over ten years, and died just before the annual election of officers in March I 798, when the post of assistant secretary was left vacant. Bowman, the collector, was engaged to fill the vacancy, pending the regular appointment of a new assistant secretary, and in April I 798 Thomas Taylor was elected.

Taylor, known as the "Platonist," was distinctly an eccentric character. He was an ardent student of the Greek philosophers and of mathematical philosophy, though he was absolutely unqualified either by aptitude or education to appreciate either branch of knowledge. He was the son of a London stay-maker, and was born in $\mathbf{I} 758$. Though he was at St. Paul's School for three years, he does not seem to have profited much by the teaching he got there. After serving as an usher in a Paddington school he obtained a clerkship in Lubbock's Bank, and appears to have eked out his moderate financial resources by literary hackwork. Being lucky enough to have an annuity of $£$ Ioo left to him, he gave up his clerkship, and applied for the assistant secretaryship. He held the post for seven

${ }^{1}$ See Chapter I, p. 23. 
years, till November I 805 , when he resigned on the ground of ill-health. He wrote in a very desponding tone about his health, but recovered, and lived for another thirty years, devoting himself assiduously to the work of translating and expounding the writings of the ancient philosophers. "His equipment for this enterprise left much to be desired. Critical faculty he had none. No doubt of the historic personality of Orpheus or the authenticity of the hymns ascribed to him ever crossed his mind; the mystical neo-Pythagorean mathematics he esteemed the true science, which the Arabians and their European successors had corrupted.... But with an ardour which neither neglect nor contempt could damp, he plodded laboriously on until he had achieved a work never so much as contemplated in its entirety by any of his predecessors." " This is rather a hard saying, but it appears to be justified. Still, Taylor seems to have been a kindly and amiable character. Although he was, and probably always will be, regarded as a half-crazy enthusiast, he had many friends, and appears to have been much liked. The list of his translations and dissertations occupies nearly three columns of the Dictionary of National Biography, so he was a most laborious and industrious author. The best, perhaps, that can be said of his writings is that they were voluminous. They were certainly but little appreciated when they were written, and the lapse of time has added neither interest nor value. He died in 1835 .

When Taylor resigned, his post was temporarily filled by John Taylor, who was apparently a relation, perhaps his son, as he is spoken of as "Mr. Taylor, jun.," and in February 1806, Charles Combe was appointed. $\mathrm{He}$ held the post for less than a year, for he resigned in January $\mathrm{I} 807$, and in the following March Thomas Woodfall was appointed. He was a son of William Woodfall, a brother of Henry Sampson Woodfall, the publisher of Junius's Letters, and the conductor of the Public Advertiser. William was a journalist and reporter, endowed with an extraordinary memory, on which he relied for his reports.

${ }^{1}$ Life of Taylor, by J. M. Rigg, in the Dictionary of National Biography. 
Thomas Woodfall had a printing business, which he was allowed to retain after he became assistant secretary, and he seems to have done some of the Society's printing. He continued in the Society's service till I 842.1

When, in October 1760 , Shipley resigned the office of Registrar (the title is always spelt " register "), he was succeeded by E. G. Tuckwell, who continued in office till 1766. On his resignation William Bailey was appointed. His excellent account of the machines and models in the Society's collection has already been mentioned. ${ }^{2}$ He died in January 1773 , and the post was given to his son, Alexander Mabyn Bailey. He held it for six years, but resigned in March 1779 to avoid discharge. He seems not to have given satisfaction, and the Society, for some reason, disapproved of his action in bringing out a second edition of his father's book, or, at all events, in soliciting subscriptions for it. This second edition was, however, duly brought out, and, so far as the work itself goes, it is a credit to the Society.

-He was succeeded by a man whose name was associated with the Society for nearly eighty years. George Cockings was appointed porter in November 1765 , in place of a man discharged for accepting a gratuity of $£ 5$ from a candidate for a premium. In 1777 , when Brockelbank died, he succeeded him as collector, and when A. M. Bailey resigned, he was appointed registrar. He had wished to offer himself for the post in 1766 , but this had not been permitted. His election as registrar took place in May I 779, at the meeting when Richard Samuel was elected assistant secretary.

Before he entered the Society's service, Cockings had held some small Government appointment in Boston, North America. He is noticed in various biographical dictionaries (including the Dictionary of National Biography) on the ground of his having produced certain inferior poems and dramas. Of most of these the present writer is not in a position to offer any opinion, as he has not felt it his duty to study them, but one particular epic, "Arts, Manufactures, and Commerce," written in 1766 , no doubt in the first flush of satisfaction at being ap-

${ }^{1}$ See p. 349. $\quad{ }^{2}$ See Chapter XI, p. 239, and Chapter XV, p. 329. 
pointed porter, he has sampled, and he can only express a regretful belief that the very contemptuous opinions of the critics of his other works are probably fully justified. ${ }^{1}$ But Cockings was a better official than he was a poet. $\mathrm{He}$ worked himself up from a very humble post to a responsible position. In one capacity or another he served the Society well for thirty-seven years, and he evidently gained the esteem and approval of his employers long before his death in February 1802 .

For some years previous to his death he had been assisted in his work by his daughter, Ann Birch Cockings, and she was appointed his successor, with the title of housekeeper, but practically with the same duties as her father. This office she held for forty-two years, till her death in February i 844 . She was evidently a very remarkable woman, endowed with great force of character, and it is quite clear that during the later years of her life she practically ruled the Society. Tradition records that she had a

${ }^{1}$ It may be but reasonable to give readers an opportunity of judging for themselves. The following extracts are fair specimens, and are selected because of the courage they show in compelling the muse to treat subjects generally held to be beyond her competence :-

"On Principles of Skill (well understood,)

With plain intelligible Aptitude,

To polish Glass, a new Machine comes forth,

(Whose future Trials may proclaim its Worth;)

'Tis work'd by windy Pow'r, or watry Force,

Or by a circumambulating Horse :

Two diff'rent Ways the Crank, the Runner guides,

As o'er a subject Plate it gently glides;

By other Cranks, some Polishers are made

At first $t^{\prime}$ advance, and then turn retrograde;

And as they o'er the Spheres, and Basons pass,

Polish the convex, and the concave Glass."

And again :-

"Efford contrives a Rod, by Rules of Art,

For Mensuration of th' internal Part

Of any Cask, which gives th' exact Contents,

Better than any other Instruments :

Inserted thro' the Bung, compactly shut,

And thro' the Liquid perpendic'lar put,

By an expanding Pow'r, 'tis open thrown,

Both Bung, and Length, at once are truly shown." 
bitter tongue as well as a strong will, and she was apparently a lady of some humour. She is said to have retorted to an importunate applicant who wanted to interview the secretary, that " one old woman ought to do as well as another." The story may serve to show the view she took of her own duties, and of her relation to the other officials of the Society. She became eventually, in name as well as in fact, registrar and librarian, as well as housekeeper, and if she never assumed the title of secretary, she probably did her share even of the secretary's work. Apparently a truculent and masterful old lady, she was an earnest and devoted servant, who was appreciated and esteemed by the masters whom she ruled. When she died, they subscribed for a monument in Kensal Green " in grateful remembrance of the perfect integrity and the constant and zealous diligence with which she performed the duties of her office." 1 The Society possesses her portrait, a work of moderate merit, by Miss E. A. Drummond. ${ }^{2}$

Aikin was certainly the most accomplished secretary the Society had had since the death of Templeman, but this did not prevent the Society's decline during the term of his office. This is not to say that he was in any way to blame for the result. Indeed it appears from what has been said above that he realised that the time had come for a change in the Society's methods, and he did his best to initiate such a change. There is good authority for believing that he in later life stated to his brother and his nephew that he could never get his ideas properly supported by the influential members of the Society, and the history of the years immediately following his resignation renders the accuracy of such a statement not only probable but obvious. It is very likely that he was not specially endowed with those qualities which go to make a good man of business, but he was a man of refined and cultivated intelligence, who had also the gift of making himself liked by those with whom he had

1 Transactions, vol. lv. (I845) p. xvi.

2 See Chapter VIII, p. I74, and Appendix III. 
to work. Still the fact remains that at the end of his secretaryship the influence and reputation of the Society had reached a very low point. Its resources had fallen off and the number of its supporters had seriously diminished.

As a matter of fact, the Society's revenues had been for some years decreasing. Its period of greatest prosperity had been in the first ten years of its existence. The largest amount subscribed in any one year was in I 763 , when a sum of $£ 4614$ was collected. In succeeding years we find a gradual falling off, till at the end of the century the average income was about $£ 2000$. In 1804 a careful examination was made into the Society's financial condition, and an analysis of receipts and expenditure for the seven years ending with 1803 is given in one of the volumes of committee minutes. From this it appears that the annual receipts just balanced the annual expenditure, there being a trifling surplus, about $£ 150$, on the results of the seven years' work. At this date about $£ 50,000$ had been expended in premiums since the Society's foundation. For the next quarter of a century the income fluctuated about this same figure of $£ 2000$, with a tendency to decline, and then it began to drop, till we find that the balance-sheet for the year ending June I 837 shows a total revenue of only $£ I 235$, and a debt of nearly $£ 300$. After this things went from bad to worse, until, as we shall see later on, the Society was reorganised, and its affairs again put on a prosperous and satisfactory footing.

The causes for this unfortunate condition of an institution which had for long been so prosperous and so popular were no doubt various. The political and economic state of the country may have contributed. For long after the end of the Napoleonic wars there was serious industrial depression, and this must have reacted on a Society whose main objects were industrial. Also it had to contend with the competition of many similar institutions. By the end of the first half of the nineteenth century there had been founded the Royal Academy, the Linnean, Geological, Chemical, Agricultural, and Geographical Societies, the Royal Institution and the London Institution, the Institutions of Civil Engineers and of 
British Architects-all occupying ground once left to the Royal Society and the Society of Arts. But it is certain that the main factor was the obsolete character alike of the Society's objects and of the manner in which they were carried into effect. Its constitution badly needed reform, and until that reform was effected, as it was a few years later, the Society remained incapable of useful work, and was consequently not likely to receive public support.

The idea of encouraging industrial progress by the award of prizes, useful at a time when practical applications of science were unknown, and invention required all the artificial stimulus it could get, was out of date. As the distribution of such prizes was obviously ineffective, people were less ready to provide money for them, and so the whole scheme came near collapse. Besides, had the scheme been sound, the manner of its administration was ineffective. The whole business of the Society was carried on in open meetings, which all members had a right to attend, and at which consequently the attendance was always varying. The natural result was that the less work there was to do, the greater was the expenditure of time and talk.

Much time was occupied in discussing the proper way of transacting business, and in making elaborate regulations to that end. The story goes that Lord Brougham, on one occasion attending a meeting of the Society, went off with an outspoken declaration as to what he hoped might be his final fate if he ever wasted his time with a Society that spent all its time in discussing " rules and orders." Thus was lost to the Society the energy afterwards expended in promoting the Society for the Diffusion of Useful Knowledge and the Social Science Association, two institutions which owed much to Lord Brougham's exertions.

To such a serious condition had the Society's affairs come, that at the first meeting of the session $184 \mathrm{I}-42$, the Committee of Accounts reported that it had practically used up all its available resources, that its revenue was insufficient to meet its expenditure, and that of its accumu- 
lated funds only some $£ 400$ was available to meet future deficiencies. A special committee was at once appointed to consider the position of the Society and to suggest " means by which the Society can be rendered more efficient, both as regards its objects, management, and constitution." The chairman of the committeewas Thomas Webster, ${ }^{1}$ and its appointment was the beginning of the much-needed reforms which he, and a small party of which he was the leader, eventually succeeded in bringing about. This committee, which was only appointed on $17^{\text {th }}$ November, produced at the meeting of i 5 th December an excellent and exhaustive report, one characteristic of which was its extreme candour, and another the clear insight it showed into the causes of the Society's decay. Two passages are worth quotation :-

"Among the causes which have contributed to the present state of the Society the most prominent appears to be the want of an efficient governing body to direct the general proceedings and the internal regulations, upon the proper control of which the success of every society so much depends.

"From the period when the Society was established to the present time, the system pursued has differed from that of all other societies instituted for the promotion of science and art, in which a council or committee of general management has always been considered essential.

"The want of a superintending council was not for many years perceived or felt. But with the rapidly spreading taste for useful knowledge and scientific pursuits, other societies arose of a popular character, and the consequences soon became apparent in the diminished

${ }^{1}$ Thomas Webster (1810-75), afterwards Q.C., and an eminent patent lawyer. At this time he had only lately been called to the Bar, after acting for two years (I837-39) as Secretary of the Institution of Civil Engineers. Associated with him in the reform of the Society were Edward Speer, George Bailey, J. Scott Russell (the eminent engineer, afterwards Secretary), John Bethell, Joseph Woods (architect, geologist, and botanist), and William Tooke, solicitor. Thomas Webster's second son, Richard, afterwards became Lord Alverstone, L.C.J., and he has followed his father's example by his devotion to the interests of the Society. 
funds of this Society, whose great object is the promotion of the useful arts rather than the personal gratification of its members."

"Another prominent cause has been the withdrawal of active members from the committees, the consequence of which has been a want of confidence in the decisions and a falling off in the number and value of the reports of the committees. These, and other causes combined, have led to a decline in the interest of the weekly meetings, the proceedings of which are now principally confined to discussions of rule and order, accounts and other matters, not tending to promote the interest of the Society."

After some very judicious remarks on the wide field open to the Society, notwithstanding the competition of newly-instituted societies with more specialised objects, in the application of science to the arts and manufactures, it goes on to suggest the formation of a governing body or council, to consist of the chairmen of the six principal committees, the president, two vice-presidents, and two treasurers. The three other committees would be abolished, their duties being transferred to the council.

Among the various other suggestions made in the report, certainly the most important are that the principal object of the Wednesday evening meetings should be the reading and discussion of communications on the arts and manufactures of the country, and that the exclusion of patented inventions from awards had been "extremely detrimental to the interests of the Society."

However, when this very judicious report was submitted to a general meeting of the Society in the following January (1842), it met with distinct opposition. Eventually most of its proposals were disapproved, and after a good deal of argument another committee was appointed, which in its turn reported advising a number of economies, the result of which must certainly have been the winding-up of the Society for good and all. One of these suggestions was that there should no longer be a salaried secretary, but that the office should be placed in commission, its duties being discharged by a committee of five members. 
Graham, the secretary, promptly resigned his office, and things appear to have got into a general muddle. Webster's committee was reappointed, and they prepared a report practically on the same lines as their previous one. This time they took the precaution of submitting it to the President, the Duke of Sussex, who cordially approved it, adopted it as his own, and sent it as such to the general body. It was, of course, accepted without much further demur, and in April i 843 it was finally adopted. In the following month a resolution of thanks to Webster was passed, which shows that, in spite of what seems to have been merely factious opposition, the Society appreciated his labours on their behalf. This was the last service rendered by the Duke to the Society, for he died in the same month, April i 843. It was, however, no trifling one, for it enabled the necessary reforms to be effected, and thus helped to start the Society on a new and prosperous career.

Part of the committee's work was to provide for the immediate carrying on of the regular work of the office. They therefore recommended that a temporary arrangement for filling the office of secretary should be made, and at their request Webster undertook to find a suitable person. He had but lately resigned the office of Secretary of the Institution of Civil Engineers, and was therefore thoroughly familiar with the ordinary routine of a society's work. At a meeting of the Miscellaneous Matters Committee, in January 1843, he produced a letter from Francis Whishaw, an engineer, who was then known principally as the author of a volume published in 1840 on The Railways of Great Britain and Ireland, in which Whishaw offered to act temporarily as secretary on the terms proposed-two guineas a week, together with the use of certain of the rooms in the secretary's house. This offer was accepted, and Whishaw was appointed. At the annual election, in April i 843, Whishaw's name was placed on the balloting list, and he was duly elected at a salary of $£$ i 50 a year and a house.

Among other recommendations of the committee was included one to the effect that it was not desirable to continue the office of assistant secretary, and notice was 
given to Woodfall, in March I 843 , that his services would be dispensed with, but that his salary would be paid until the end of the session, and that he would have an additional grant of $£ 100$. A very complimentary vote of thanks was also passed to him at the annual meeting, and he was presented with a set of Barry's etchings, a gift which at the time was made by the Society to various people to whom it was desired to pay a compliment. Woodfall at first protested, but eventually expressed himself as entirely satisfied, although he said that it was with very great regret that he gave up a post which he had held for thirty-seven years. He appears to have discharged all his duties efficiently. On several occasions additional grants were made in augmentation of his salary, which was always on a moderate scale.

For some months Whishaw carried on the work without assistance, but in October I 844 he was authorised to engage somebody to help him, and he engaged S. T. Davenport, then a young man of twenty-one. Davenport developed into a very valuable and trusted official, for he served the Society in various capacities for over thirty years till his death in 1876.1

Whishaw held the secretaryship for nearly two years, until November 1845 , when he wrote that he wished to resign, as he had accepted some other work which would prevent his giving proper attention to that of the Society. This work appears to have been an appointment in connection with Prosser's wooden railway. ${ }^{2}$ At the same time he stated that Mr. Scott Russell was willing to undertake the work of secretary, and proposed that he should be

1 See Chapter XVI, p. 366.

2 This was a scheme for the use of wooden rails, which it was thought would be cheaper than rails of iron. The inventor was William Prosser, the Secretary of the Metropolitan Railway Company, who took patents out for his invention in I 843 and I 844. An experimental line was laid down on Wimbledon Common. Although favourably reported on by Major-General Pasley, Inspector-General of Railways, the scheme never came into practical use. Prosser himself did well out of it, for his rights were purchased by the London and South-Western for $£ 20,000$. $\mathrm{He}$ also received $£ 32$, ,oo from an Irish line. A full account of the system will be found in the Engineer, $5^{\text {th }}$ January I900, p. 9. 
nominated jointly with himself. This offer was accepted, and Scott Russell was appointed. At the annual election in the following year, in April i 846, Scott Russell was elected secretary, Whishaw being elected corresponding secretary. In i 848 he was made auditor, and after this his official connection with the Society terminated; but he had been elected a life member on his resignation of the secretaryship, and he continued to take an interest in the Society's work. The chief thing for which he is to be remembered is that he originated the idea of holding exhibitions, first on a small scale in the Society's rooms, and afterwards in the form of a national exhibition of industries. A full account of this work will be found in the chapter dealing with the early history of the i 85 I Exhibition. ${ }^{1}$

Although, both before and after his connection with the Society, Whishaw appears to have been fully occupied in work associated with the construction of railways and of electric telegraphs, his career was, on the whole, not a fortunate one. In later life he seems to have suffered a good deal from illness, and eventually he died, in October I 856 , in Marylebone Workhouse. ${ }^{2}$

The most important reform, however, suggested by Webster's committee was that a Council or managing committee should be appointed, which should have full control of the Society's business, thus taking it out of the hands of the general body, and this was really the crux of the whole business. Though the change was greatly disliked by the excellent persons who had found amusement and occupation in the control of the Society's affairs, the reform had been passed, and, in order to carry it into

1 See Chapter XVII, p. 403.

${ }^{2}$ A full biography of Whishaw is given in the Proceedings of the Institution of Civil Engineers, vol. xvi. p. 143. The account of his connection with the Society requires a little modification, for it attributes to Whishaw's efforts rather more importance than is actually their due. It does not mention his unhappy end, about which, however, there is no doubt. It is recorded in Boase's Modern English Biography (I90r), vol. iii. p. I 306 , and in the Gentleman's Magazine (November r 856, p. 642). The facts have also been verified by the Clerk of the Marylebone Board of Guardians, who, at the request of the writer, very kindly made a search in the records of the Marylebone Workhouse. 
effect, a complete revision of the old rules and orders of the Society was necessary. Such a revision was made, and in December 1845 new rules and regulations were passed, establishing a managing committee or Council, and giving that body the necessary powers. It was to consist of the chairmen of committees, together with a certain number of elected members. The first meeting of the Council was held on 6th December I845, with Edward Speer in the chair. For the first few months of its existence the Council seems to have had no regular chairman, but after its election, at the annual meeting in March i 846, Edward Speer and George Bailey ${ }^{1}$ were elected chairmen, and this arrangement was repeated in 1847 and 1848 .

The Council very soon got into active work, and the wisdom of the change became evident. Its proceedings, however, and the many useful alterations it introduced into the work and the character of the Society, will be more fitly considered when we come to deal with the history of the Society after the grant of a Royal Charter, the obtainment of which was one of the first matters with which the new council dealt.

It is rather remarkable that no steps had ever before been taken towards making the Society a chartered body, although, as will be remembered, the suggestion that a charter should be applied for was one of the very earliest matters considered. Whether the original proposal contemplated a charter for the Society in its original form, or a charter for an academy of painting and sculpture, is not quite clear, but at all events it was in the latter form that the proposal was submitted to the Society in 1755 , and, as previously mentioned, a complete draft of a charter for a Royal Academy of Arts is preserved among Dr. Templeman's papers. It may have been intended that the Society

${ }^{1}$ George Bailey (1792-1860) was the first Curator of the Soane Museum, having been designated for the post by the founder. $\mathrm{He}$ was articled to Sir John Soane, and remained in his service first as architectural assistant, and afterwards as confidential clerk. He became a member of the Society of Arts in I82I, and continued until his death in I860. After serving, as above mentioned, as one of the two chairmen of Council for three years, he resigned membership of the Council in January I 849 . 
should be merged in such an academy. Probably this idea was not consonant with the notions of the original promoters of the Society, and it was for this reason that it was opposed and dropped, to be resuscitated later on by the committee of artists and successfully carried out in the foundation of the Royal Academy. ${ }^{1}$

The question does not appear to have been brought up again till i 843. In December of that year the secretary (Whishaw) reported to the Committee on Miscellaneous Matters, that " the subject of the Society obtaining a Royal Charter had lately been a matter of conversation by two or three members, who were willing to subscribe $£ 5,5 \mathrm{~s}$. each towards this desirable object." But nothing was done. In February 1845 the question of applying for a Royal Charter was raised at one of the meetings, and was referred to the Committee on Miscellaneous Matters, but again no result followed. At last, in February of the following year (1 846), the newly-formed council took the matter up seriously, and recommended that steps should be taken to make application for a Royal Charter. In December of the same year we find that a draft of the Charter was submitted by William Tooke, who was then acting as the Society's honorary solicitor. This being approved, in the following March (1847), Tooke brought up a draft of the Charter, together with a petition, which, after they had received the approval of H.R.H. the Prince Consort, as President of the Society, were lodged in the PrivyCouncil Office. In June, Tooke reported that the Charter had been passed, and that fees amounting to $£ 400$ in all were required-of these the official charges amounted to $£ 308$, 9s. 2 d., and there was about $£ 75$ for office expenses.

With the grant of a Royal Charter the first period of the Society's history may be held to have come to an end. After this it may be said to have entered on a new chapter of its existence. It found new aims and adopted novel methods; not only its constitution but its character was to a large extent altered, and with a reorganised system it may certainly be said to have started on a fresh career of usefulness.

${ }^{1}$ See Chapter X, p. 232, and Chapter XV, p. 328. 


\section{CHAPTER X V I}

\section{The Presidency of the Prince Consort}

$$
\text { ( I } \left.843^{-1} 861\right)
$$

The Council and its Work-Influence of the Prince Consort-Sir Henry Cole-The Chairmen of the Council, I 850 to I862-The Leading Members of the Society-The Officials, Scott Russell, Gcorge Grove, Fdward Solly, Peter Le Neve Foster, Samuel Davenport, James Forrest, Charles Critchett-The Work of the CouncilEducation-The Union of Institutions-Educational Exhibition - The Journal-South Kensington Museum and the Science and Art Department-Trade Museum-Lectures on I85 I ExhibitionAnnual Exhibitions of Inventions-Gallery of British Art-Minor Exhibitions-The Society's Collections-Patent Legislation, the Act of 1852-First Exhibition of Photographs-Fine Art Copyright-Nusical Pitch-Public Lavatories-Prizes for Industrial Art-Other Prizes-The Society's Microscope-Cheap Writing Case-Prizes for Essays-The Swiney Bequest-Industrial Pathology-Postal Reform-Paper Duty-Centenary of the Society-The Annual Dinner-Finances-Death of the President -The Prince's Services to the Society-The Albert Medal.

In the last chapter, which dealt with the internal organisation and constitution of the Society, we left off at the point when a Council had just been appointed, and a Charter obtained for the Society. The task before the new Council was no light one, and it started on its work of reform with many difficulties in the way. It had to rescue the Society from the condition of torpor and ineptitude into which it had fallen, to arrange its finances, and indeed to provide funds for its work. It had to justify its existence, to rouse public interest, and to find fresh directions for its efforts to carry out the objects for which the Society was originally founded. To do this it had first to organise itself, and to distribute the work between 


\section{PRESIDENCY OF THE PRINCE CONSORT}

itself and the various committees into whose hands the details might safely be entrusted. At first the original six "Premium" Committees were maintained, the committee on "Miscellaneous Matters" being merged in the Council. But it is hardly worth while to enter into an account of the various changes which were made in the number and duties of the committees. Sometimes the number was increased; sometimes it was diminished; at one time there were as many as thirty. But eventually the sensible system was adopted of appointing committees from time to time as questions arose for their consideration.

Inasmuch as all the business of the Society at once passed under the control of the new governing body, there was nothing of this nature left to occupy the attention of the ordinary meetings, which had hitherto been taken up in the award of the premiums, and in the continual discussion of the Society's rules and orders. This naturally led to an increased iniportance in the scope and character of the papers, the reading of which rapidly became, at first, the most important, and very soon the only function of these meetings. By the time we have now reached, the system started by Aikin had grown and dereloped until it became the recognised practice that every Wednesday evening during the session should be occupied, either by a paper, followed by a discussion, on some new invention or some novel industrial development, or else by a lecture (which was not discussed) on some branch of industry, some fresh application of science, or, less frequently, some application of artistic principles or methods.

The desire to encourage the reading of papers is shown by the fact that in 1845 it was determined to " prepare a form of Honorary Testimonial to be presented to persons making communications which may appear to the Society deserving of such notice." The Committee of Fine Arts, with the help of its chairman, Sir William Ross, decided on the design shown in the plate on the opposite page, ${ }^{1}$ in which the principal feature is Miss Denman's drawing of Flaxman's medal, ${ }^{2}$ with a wreath

1 This is reproduced from the original copper-plate.

2 See Chapter XIV, p. 3 I 8. 


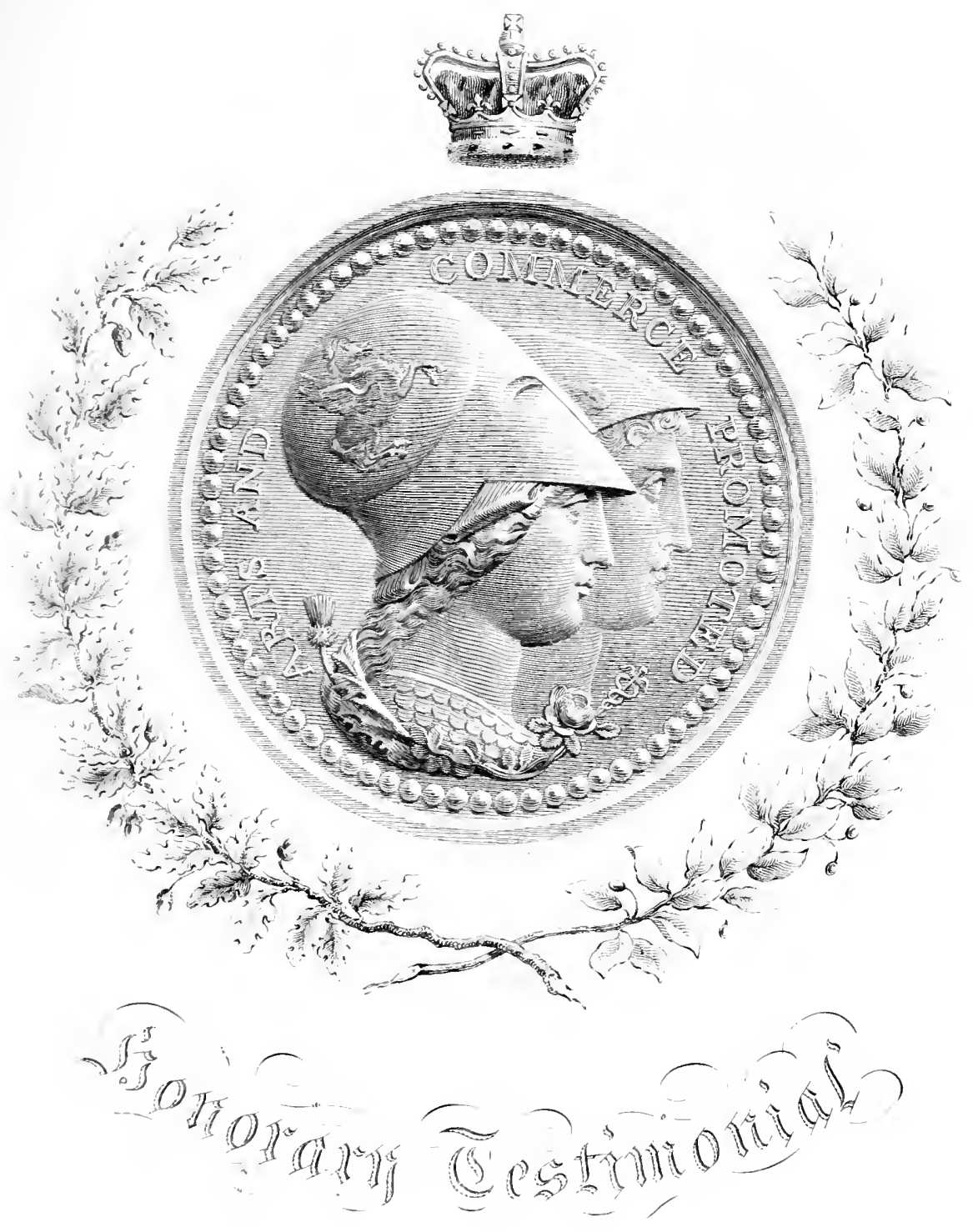



and a crown, executed after the Committee's instructions by $\mathrm{S}$. Davenport, the father of S. T. Davenport, a member of the Society's staff from i 844 to $1876 .^{i}$ This "Testimonial," besides being employed for the purpose for which it was designed, was also used to supplement the award of medals, as a sort of "Honourable Mention" for cases not quite deserving a medal. It was employed in this way up to 1850 .

Perhaps unfortunately, the series of lectures, for the introduction of which, as previously mentioned, Aikin was responsible, gradually died out. Aikin himself had no successor among the officials able and willing to devote himself to popular exposition, though Scott Russell had all the capacity for such work had he cared to undertake it. And so after Aikin's time the Society, less fortunate than the Royal Institution, found no Faraday to draw intelligent audiences to its meeting-room by brilliant expositions of the applications of science and art, and it really was not until the receipt of the Cantor bequest provided funds for the payment for lectures that this valuable means of diffusing knowledge on industrial subjects was utilised. There was, however, no very great difficulty in securing suitable topics or capable authors for filling up the programme for the Wednesday evening meetings, and this important portion of the Society's labours rapidly developed, and eventually became its principal duty.

But if the regular routine of the Society's work was thus provided for, there were many outside objects to which the Council now began to direct its attention. In this they were very greatly helped by the fact that they had as the Society's President the Prince Consort, who assisted them not only by his influence, which at the time was naturally much less powerful than it became in later years, but by the interest which he took in, and the attention which he devoted to, the Society's affairs during the first years of his Presidency. He realised-and he himself told the Society-that the main object of its existence was the application of science and of art to industrial purposes. These were matters in which he took a genuine

${ }^{1}$ See page 366 of this chapter. 


\section{PRESIDENCY OF THE PRINCE CONSORT}

personal interest, and so long as the Society was ready to promote the objects he had at heart, he was quite willing to assist it as far as the numerous other occupations of his exalted position allowed him sufficient leisure.

It has often been said that too much credit has been given to the Prince Consort for the Society's success about this time, especially for its success in starting the $185 \mathbf{I}$ Exhibition, but a careful study of the Society's records has satisfied the present writer that his influence was by no means exaggerated. It is quite clear that the Prince did not initiate the reforms-economic, social, and industrial-which started from the Society of Arts. But most new suggestions of any importance appear to have been submitted to him, and he discriminated with extreme shrewdness between those which were of value and those which it was not worth while to press. He evidently had an extremely quick and active mind. His judgment on the questions submitted to him seems generally to have been prompt and correct, and this is surely as much as can reasonably be looked for from one occupying a position such as he occupied. The period on which we are now engaged may justly be considered as the period of his Presidency, and there may be a little more to be said about the value of the services he rendered the Society when we come to deal with the termination of that Presidency by the Prince's death in 1861 .

During that period by far the most important of the public works carried out by the Society was the starting of the two great Exhibitions of $185 \mathrm{I}$ and 1862. The history of these two Exhibitions, so far as the Society was associated with them, is important enough to deserve separate treatment, and may be left alone for the present. ${ }^{1}$ The next most important piece of public work was the establishment and organisation of a system of examinations carried out simultaneously all over thekingdom, which had the very greatest influence on industrial, middle-class, and scientific education during the fifties and sixties. The history of the examinations also will be more conveniently dealt with by itself, and any further account

${ }^{1}$ See Chapter XVII, p. 40I, and Chapter XVIII, p. 416. 
of them is therefore deferred to a later chapter. ${ }^{1}$ The present chapter will therefore be devoted to the consideration of the various other matters which the Society had in hand during the period extending from the date of its charter (I847), or the assumption of the Presidency by Prince Albert (1843), down to the date of the Prince's death (1861) and the holding of the second great Exhibition in 1862 .

The subjects pursued by the Society during this period were so diverse and so numerous, that it is not at all easy to give any connected history of its proceedings. Perhaps, when those who had in hand the reconstitution of the Society realised that the purpose of its original institution had been served, and that some other methods must be devised for carrying out the objects of its foundation, they found it difficult to set a limit to the scope of its work, and the result was that they extended its operations a good deal beyond what was intended or contemplated by its original founders, somewhat, indeed, beyond what was intended by the framers of its charter.

The newly-constituted Council was a strong body, and the very fact that it was newly-constituted made it anxious to effect reforms, not only in the Society itself, but in all the departments of public life and administration with which the Society could, by any reasonable extension of its objects, claim association.

The Council, as a body, was quick to realise the value of the Society's organisation as an instrument for the promotion of many useful social and economic as well as industrial changes. Many of its members were activeminded, energetic men, keenly interested in the promotion of special reforms, full of enthusiasm for the causes they had espoused, and anxious to utilise the growing influence of the Society for the realisation of their own particular objects.

Prominent among these was Henry Cole, a man of inexhaustible energy and indomitable perseverance, full of enthusiasm for his own ideals and of confidence in their value. At the instance of Scott Russell he joined the

${ }^{1}$ See Chapter XIX, p. 425 . 
Society in 1846 , and at once became a member of the Committee of Fine Arts. In January of the following year we find him attending a meeting of the Council, to explain, as a representative of the Committee, the scheme he had laid before them for annual exhibitions of the works of British artists, and suggesting as a commencement an exhibition of the works of Landseer, then at the height of his popularity. In the same year (I 847) he was nominated for the Council, and from that time till the date of his death, in I 882 , he continued to exercise the strongest personal influence over the Society, influence which, for the first half or so of this period, really amounted to absolute control. A man of singularly active mind, he was perpetually conceiving fresh projects for the improvement of public welfare and the benefit of mankind. Some of these were eminently successful, such as the Victoria and Albert Museum, and, it may be said, the I85 I Exhibition, since, if he did not originate the idea of a great international exhibition, it was his capacity for organisation that rendered the scheme practicable. Others naturally enough were failures, but the bulk of his proposals were valuable, and of genuine public utility. With very nearly all of them the Society of Arts was associated. $\mathrm{He}$ utilised its influence and its organisation to the full, and he repaid its help by useful guidance and administrative direction.

He was not a skilful or a cautious financier. Certain of his schemes cost the Society dear, but if he wasted some of its funds, it was mainly due to him that the Society had any funds to waste. It is the matured opinion of the writer, who knew him well and admired his great qualities, without being in the least unaware of his faults, that Henry Cole ought to be looked on as the second founder of the Society, and that it was owing to his influence and authority that the Society was raised from a state of impotence and insignificance to a condition of prosperity and influence. This does not imply that he started the improvement. He did not. The Society had been rescued from dissolution before he became a member of it; but he infused fresh vigour into its growth, and in a few years from his 


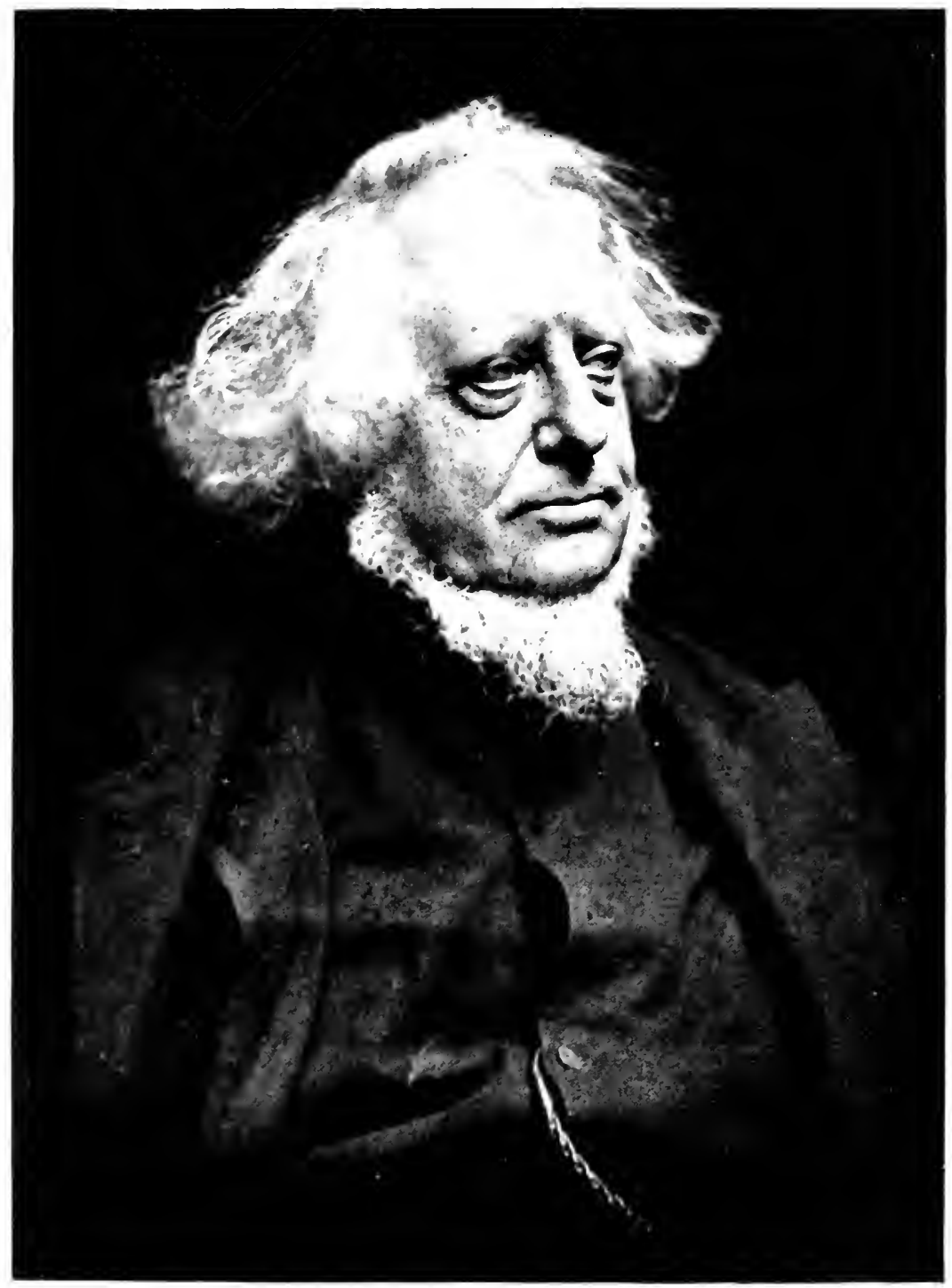

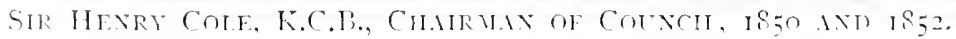

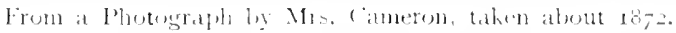



joining its governing body it had trebled the number of its members and quadrupled the amount of its funds.

It may be admitted that Cole had in full measure the defects of his qualities. He liked having his own way, and he generally got it. He disliked opposition, and was ruthless with his opponents. He was a born fighter, and his methods of fighting were often questioned and disliked. Naturally enough, this made him unpopular, while the objects he sought often laid him open to the ridicule which is generally the lot of those who first advocate schemes for the accomplishment of which others in a later age are hailed as the benefactors of their kind. However, he cared little for ridicule or for unpopularity, so long as he got what he wanted, as he usually did. His best friends and admirers must wish that he had had greater regard for the feelings of others, and that he had been content to attain his objects without thrusting aside and trampling down those who did not agree with him. But that was not his way, and perhaps gentler methods might have proved less successful. At all events, it is likely that they would have been slower, and of all things, delay was hateful to the impatient soul of Henry Cole.

Of course, he had a fight soon after he joined the Council, and, unhappily, it was with one of the best and staunchest friends of the Society, Thomas Webster. Webster, doubtless disapproving of Cole's arbitrary methods, and his somewhat reckless expenditure, opposed his proposals for annual exhibitions, industrial and pictorial. His criticisms were supported in the Council, and, in 1850 , Cole resigned. But he organised an opposition at the next annual meeting, and circularised the members, with the result that at a largely attended meeting, on 3rd April 1850, when 207 members voted, Cole and his friends were elected by a considerable majority, while Webster and his supporters were turned out. Inasmuch as it was Webster who, by the introduction of muchneeded reforms, had saved the Society from certain dissolution in $1842,{ }^{1}$ the vote of the electors appears

${ }^{2}$ Sce Chapter XV, p. 346. 


\section{PRESIDENCY OF THE PRINCE CONSORT}

ungracious, especially as bitter feeling was engendered by it. But, as above said, those who got in Henry Cole's way generally had to get out of it. His differences with Webster are the more to be regretted as Webster had the scientific knowledge to which Cole never made any pretensions, and his experience as a great patent lawyer might not improbably have led the Society to take a larger part in the guidance of industrial progress and the application of science to manufactures than it actually did take.

Cole was Chairman of the Council in 1850 , and again in 1852 . One of the most prominent of his successors was Wentworth Dilke, who was Chairman in 1857 and 1858. He took an active share in the arrangements for the two great Exhibitions of 185 I and 1862 , and a baronetcy was conferred upon him at the close of the latter Exhibition. He was so keen about the Society's welfare that he brought his relations into it. His father, the wellknown editor of the Athencum, became a member of the Society in I 849-Dilke himself having joined four years earlier-and he made his two sons, Charles and Ashton, life members when they were boys. Another very energetic and capable Chairman was Sir Thomas Phillips, who succeeded Dilke, and was found so useful in the post that the by-laws were altered so as to allow him to hold the Chairmanship for four consecutive years, is 859 to i 862 . Sir Thomas Phillips was a man of some character. He earned his knighthood by his action in quelling a Chartist riot in a mining district of South Wales, when he was wounded. He was a liberal and public-spirited man. Besides devoting himself strenuously to the Society's work, he took an active part in the work of King's College and of many metropolitan societies.

Another most useful member was Harry Chester, who was Chairman in 1853 . He was the originator of the Union of Mechanics' Institutions and of the Society's examinations, and continued an active worker on behalt of the Society until his death in 1868 . He held certain official appointments, including the Assistant Secretaryship of the Committee of Privy Council on Education. The public work he did, mainly through the Society of Arts, 
never received due recognition; he is even ignored by the Dictionary of National Biography. Lieut.-Colonel Owen was elected Chairman in I 853 , but was compelled by pressure of his official work to decline office before actually taking any active part in it. But he was in many respects a useful member of the Council, and took his full share of its work. He was a brother of Sir Philip Cunliffe-Owen, who in later years was closely associated with the Society. The Rev. James Booth became Chairman in 1855 . The work he did in suggesting the establishment of the Society's Journal, and in the development of its examinations, will be referred to later on.

Other Chairmen of Council during this time were Colonel W. H. Sykes, M.P., F.R.S. ( 1856 ), Chairman of the Board of Directors of the East India Company ; Lord Ebrington (1854), afterwards Earl Fortescue, who lived and preserved his interest in the Society until 1905; and William Saunders, F.R.S. ( 185 I), a naturalist of some note in his day, who wrote much on botany and entomology, and served as President of the Entomological and Horticultural Societies.

Amongst other members of the Council who took a prominent part in the Society's work, and attended most constantly at its meetings, the following should be mentioned : Dr. Lyon Playfair (afterwards Lord Playfair), the eminent chemist; Richard Redgrave, R.A., and his brother Samuel, the author of the useful Dictionary of Artists of the English School; Sir Joseph Paxton, who designed the 185 I Exhibition building; Robert Stephenson, the great engineer; Richard Dawes, the Dean of Hereford, who gave valuable help in organising the examinations ; J.C. Macdonald, the manager of the Times; Sir W. H. Bodkin, the eminent lawyer, who co-operated with Thomas Webster in the reform of the Society; Thomas Graham, Master of the Mint; William De la Rue, F.R.S. ; Sir John Pakington (afterwards Lord Hampton); Sir William Page Wood (afterwards Lord Chancellor Hatherley); J. J. Mechi, the enthusiastic agriculturist ; Sir William Fairbairn, the engineer, who was a commissioner for the $185 \mathrm{I}$ and 1862 Exhibitions, and took a 


\section{PRESIDENCY OF THE PRINCE CONSORT}

particularly active part in the organisation of the latter ; Thomas Winkworth, a man not much known outside the Society, but one who did much hard work within it for the Exhibitions, and other matters; Thomas Twining, the earnest advocate of many philanthropic schemes; Joseph Hume, the Radical M.P. and economical reformer ; Sir John Boileau, an archæologist of repute; and William Tooke, for many years a Vice-President, and the Society's honorary solicitor.

These were among the most active supporters of the Society. Something may now be said about the permanent officials. In the early part of the period with which we are now concerned, the office of secretary changed hands rather frequently. In the ten years, 1843-53, there were six occupants of the post. As previously mentioned, ${ }^{1}$ when Graham retired in 1843 (after holding office for two years only), Whishaw was appointed, and in I 845 he was succeeded by John Scott Russell. Scott Russell was a worthy successor to Templeman and Aikin, and, indeed, as a scientific man he was superior to either. Born in 1808 , he was thirty-six years of age when he came to London and became a member of the Society of Arts. He had already acted as Professor of Natural Philosophy at Edinburgh, and had acquired a reputation for his original researches on Wave Motion. He had also carried out, with much success, the construction of several large vessels in which his principles were embodied. These were all designed by him as manager of the shipbuilding establishment at Greenock, afterwards belonging to Messrs. Caird.

Before his election as secretary, he had taken an active part in the deliberations of the Committee on Miscellaneous Matters. Though he was too active-minded to confine his attention to the Society's work, he made a most efficient and energetic secretary, and took his full share in the work of reconstructing the Society, which may be said to have been completed during his term of office. The steady improvement in the character of the papers brought before the evening meetings was certainly to a large extent due to 1 See Chapter XV, p. 348. 
him. He seemed ever ready to place at the disposal of the Society not only his abilities, but what he had in much less abundance, the contents of his purse ; for he frequently took upon himself the provision of expenses which assuredly he was not called upon to meet, and which, indeed, he could not properly afford.

His energy in helping on the preparations for the $185 \mathrm{I}$ Exhibition led to his being appointed, jointly with Mr. Stafford Northcote (afterwards Earl of Iddesleigh), Secretary to the Royal Commission when it was appointed in January i 850 . After this he resigned the secretaryship of the Society, and, having been elected a life member, was placed on the Council. In later life he resumed the practice of his profession, with a result that cannot be better stated than in the words of the author ${ }^{1}$ of the account of his life in the Proceedings of the Institution of Civil Engineers :-

"In summing up Mr. Scott Russell's comnection with the profession of naval architecture, it may be said that on commencing his career he found it the most empirical of arts, and he left it one of the most exact of engineering sciences. To this great result many others contributed largely besides himself; but his personal investigations, and the theories he deduced from them, gave the first impeius to scientific naval architecture." 2

A man of real genius, he took high rank in his profession among a race of great engineers, and in his own particular branch of it he was far ahead of his contemporaries. But, spite of his great talents, his worldly success was never equal to his deserts, and when he died in 1882 he was in straitened circumstances.

Scott Russell's successor was George Grove, who was appointed jointly with Russell in February i $85^{\circ}$, and, after a month's trial, sole secretary in March. Grove, like his two predecessors, was an engineer, and he had practised his profession to some extent before his appointment, though never afterwards. His tenure of office was very

${ }^{1}$ Sir George Holmes, a pupil of Scott Russell's, and at one time Secretary of the Institution of Naval Architects.

${ }^{2}$ Obituary notice, Proceedings of the Institution of Civil Engineers, vol, lxxxvii. p. 435 . 


\section{PRESIDENCY OF THE PRINCE CONSORT}

short, for when the Crystal Palace was established at Sydenham he was (in May 1852) offered the appointment of secretary, and thereupon he gave up his post at the Society. He was a thoroughly capable official-in this respect supcrior to his immediate predecessors - and with a longer period of service he would doubtless have left his mark on the administration of the Society. As it was, his powers were devoted to other institutions-first the Crystal Palace, and afterwards the Royal College of Music -where they had full scope and were greatly appreciated. Grove was the last secretary to live on the Society's premises. When he quitted office the house in which all the secretaries since Templeman had lived, and in which one of them (More) had died, was added to the Society's offices.

When Grove retired, Edward Solly, long an active member of the Council, was appointed secretary, and held the office for a year-May I 852, to May I 853 . Solly was an old member of the Society. He had been elected in 1838 , and had served on the Council since I850. At the time of his appointment as secretary he was actually deputy-chairman. He was a chemist of some reputation. He became a Fellow of the Royal Society in 1843 , and in 1845 was appointed a Professor at the Addiscombe Military College. He resigned the secretaryship of the Society of Arts that he might devote himself to the organisation of the Trade Museum started by the Society, of which more hereafter. Though not a man of brilliant talent, he possessed considerable intellectual powers and some literary capacity, which he devoted in later life principally to antiquarian and bibliographical subjects. He died in 1886 .

Solly was succeeded in the secretaryship in 1853 by Peter Le Neve Foster, whose genial and kindly nature gained him the regard and esteem of all those with whom he worked. He is still remembered by many of the older members of the Society; by none outside those of his own family can his memory be more affectionately cherished than by the writer of this narrative. He, like his predecessor, had for some years been connected with 
the Society, which he joined in 1837 , at the instance of his grandfather, Abraham Osorio, who had become a member in $1800 .^{1}$ His father (also Peter Le Neve) joined the Society in $\mathrm{I} 807$, so that he had a long family connection with it. When the first Council was formed, he became an ex officio member of it, as he was at the time Chairman of the Committee of Accounts. He was at once elected treasurer, and this office he held till i 852 , when he became an ordinary member of the Council.

Foster took his degree in the Cambridge Mathematical Tripos of 1830 , and became a Fellow of his college (Trinity Hall). In 1836 he was called to the Bar at the Middle Temple, and he practised as a conveyancer until his election to the secretaryship, which he held for a period of not quite twenty-three years, till his death in 1879 . He had taken his full share in the reorganisation of the Society, and by the time that he became secretary its various difficulties had been surmounted, and its second era of prosperity had commenced. This prosperity continued unabated during his term of office, and much of the credit for this state of things may fairly be claimed for him.

If he did not originate any changes or introduce many fresh ideas, he carried out efficiently and well all the executive work of the Society, and it may fairly be said that its public reputation for practical work stood a good deal higher at his death than it did when he became secretary. Possessed of much sound scientific knowledge, of wide general reading, and endowed with considerable intellectual capacity, he was well qualified for the duties of his office, for which also he was equally well fitted by character and taste. Of a kindly genial nature, singularly patient and forbearing, tactful and full of common sense, he made an admirable secretary. If he was devoid of

1 Abraham Osorio's father, Jacob, was also a member, and of a very early date ( 1766 ). His brother Abraham, who died unmarried, joined the Society in 1761. Three sons of Mr. Peter Le Neve Foster and one of his grandsons are now (1913) members, so that six generations of the family have been associated with the Society during a period extending from $176 \mathrm{I}$, seven years after its foundation, down to the present time. 


\section{PRESIDENCY OF THE PRINCE CONSORT}

ambition and inclined to be somewhat "easy-going," this only made him more contented with his duties, and never induced him to neglect them, for he was a steady and regular worker, who took a pleasure in his work.

He had various interests outside the Society. Among the first to practise, as a scientific anateur, the art of photography, he was one of the founders of the Photographic Society, and for many years on its Council. $\mathrm{He}$ followed with interest the developments of the art during its most interesting period, from the first photographic application of collodion to the introduction of the gelatine dry plate, and wrote a good deal on the subject. At one time he served on the Council of the British Association, and was for thirteen years secretary of Section " $G$," Mechanical Science. ${ }^{1}$

Some reference is also due to certain of the other officials of the Society. Of these Samuel Thomas Davenport comes first, both from his seniority and because he devoted his whole life to the Society's service.

His appointment in I 844 as a sort of clerk or assistant to Whishaw has been mentioned, ${ }^{2}$ and from that date he served the Society faithfully and well in various capacities, being always ready to undertake any work that might be required of him. His pay was very moderate, and occasionally small grants were made to him, which were certainly well deserved. In April 1848 he was given the title of assistant secretary, and in January of 1849 his salary was made up to $£_{1} 00$ a year. Six months later W. Ellis was appointed assistant secretary, but he only held office for less than a year, as he resigned in March I 850 , when the post was left vacant. Davenport was then made "Curator and Collector," at a salary of $£_{150}$, and in 1853 his title was changed to that of "Finance Officer," afterwards modified to "Financial Officer," an appellation which he bore, with much personal pride and gratification, till his death in 1876 . It would not be easy

1 The fullest account of P. Le Neve Foster will be found in the notice published after his death in the Journal, vol. xxvii. p. 316. There is also a short life in the Dictionary of National Biography.

2See Chapter XV, p. 349. 
to overrate the value of Davenport's services to the Society, though they were in the earlier part of his life of an unpretending nature. Later on, his very considerable experience, and his minute knowledge of the Society's history, gave him much influence with the Council, and his opinion in matters connected with the internal administration of the Society carried great weight. He had had in youth some artistic training, and would have made a capable engraver had he followed the profession for which he was intended, but in other subjects he was mainly self-educated. He had acquired a curious and extensive knowledge of the contents of the Society's records, and this led him to produce, in the form of a paper read at one of the meetings in I 868, a short history of the Society, ${ }^{1}$ which has been more than once referred to before. Though it contains much information, it is badly put together, and shows a want of literary skill. The same criticism may be applied to his other communication to the Society, on "Prints and their Production," 2 though it has a distinct value as recording much which is not to be found elsewhere about the earlier attempts to produce printing surfaces by means of photography, since at the date of the paper many such attempts had been made, but none had yet succeeded.

His single-minded and whole-hearted devotion to the interests of the Society rendered him a zealous and valuable official. The present writer, who, of course, knew him intimately during the last eleven years of his life, and had for him a genuine liking and regard, can testify to the kindliness of his nature and to his popularity amongst those with whom he was associated. ${ }^{3}$

From the date of Ellis's resignation in 1850 to the middle of 1852 , the office of assistant secretary was left vacant. In June of that year James Forrest, who had

${ }^{1}$ Journal, vol. xvii. pp. I0, 127, 143, 160. He had previously (in I 864) read a paper on the Society's promotion of industrial education (Journal, vol. xiii. p. 88).

${ }^{2}$ Journal, vol. xviii. p. 62. The paper had been preceded by an article on the same subject in the Journal, vol. xiii. p. I 31 .

${ }^{3}$ A notice of Davenport will be found in the Journal, vol. xxiv. p. 139 . 
previously been assistant secretary to the Institution of Civil Engineers, was appointed. He held office till April 1856 , when he resigned in order that he might return to his old office at the Civil Engineers, with a view to his succeeding Charles Manby, who was about to give up the secretaryship of the Institution. This arrangement was duly carried out, and Mr. Forrest was appointed in 1860. All engineers know with what credit to himself, and with what benefit to the Institution, he filled his office, till he resigned in 1896 . His name will always be associated with the Institution by the Forrest Lectures, founded to commemorate his secretaryship. Mr. Forrest is still living in retirement at St. Leonards, now one of three surviving representatives of the Society of Arts of sixty years ago.

It was determined to fill up the vacancy caused by Forrest's retirement by an open competitive examination, the time being one when the value of test examinations ranked higher than it does now after half a century's experience. Accordingly, the appointment was advertised, and the candidates who applied were submitted to a regular examination, both viva voce and by papers. Charles Critchett, who had taken his degree at Cambridge (Trinity) in 1855 , was successful and he was duly appointed. It must be said that the experiment was quite successful. Critchett made a perfectly efficient assistant secretary for thirteen years. He resigned of his own accord in 1869 , though his connection with the Society was preserved by his appointment as educational officer, in which capacity he had a nominal responsibilty for the conduct of the examinations. He held this office till 1879 , and when he gave it up he was made a life member. As he was quite comfortably provided for there was no need for him to work, and he naturally enough preferred a life of leisure to a continuance of official routine. He was a man of artistic tastes, cultivated manners, fond of society, and popular in a large circle of friends. He died in 1906. ${ }^{1}$

Having dealt with the principal individuals who carried on the Society's work during the period which

1 A notice of his life will be found in the Journal, vol. liv. p. 528 . 
began with its incorporation and ended with the 1862 Exhibition, we may pass on to a consideration of the work itself. At the commencement of the period, the attention of the Council was chiefly occupied with the organisation of the first great exhibition, and during its last years with the preparations for the second ; but in spite of this, time was found for a great variety of other business, the chief items of which have now to be described.

Of these, the most important was education, industrial education as it was then termed, though by this was meant the general education of those engaged in industry, not what we now know as technical education, the training of industrial workers in the subject-matter of their trades.

The first efforts for the promotion of popular education in this country took the form of the establishment of Mechanics' Institutions. Their origin may be traced as far back as 1800 , when Dr. Birkbeck, who had succeeded Dr. Garnett as Professor of Natural Philosophy at the Andersonian University of Glasgow, established courses of lectures, to which working men were admitted at a low fee. The mechanics' classes thus established were for a long time a successful department of the University, and in I 823 this department became the Glasgow Mechanics' Institution, apparently the first genuine institution of the sort.

The establishment of this institution suggested the formation of a similar organisation in London, where $\mathrm{Dr}$. Birkbeck had been resident for about twenty years. $\mathrm{He}$ took the lead in the movement, and, with the assistance of Lord Brougham and others, established the London Mechanics' Institution, which later on became the wellknown Birkbeck Institution, the name being changed in honour of its founder and first president.

The London and Glasgow Societies had many imitators, and in 1848 the Society passed a resolution that any such institution established not less than fifteen miles from London might join the Society for the same subscription as an individual, so that its members might enjoy, under certain conditions, the advantages of membership of the 
Socicty. A few institutions availed themselves of the offer, and a little later, in $185 \mathrm{I}, \mathrm{Mr}$. Harry Chester addressed a letter to the Council, suggesting that "the Society should exert itself to increase the efficiency of the metropolitan and provincial mechanics' institutes." The result of this letter was that the Society called together a conference on the subject, which was held in May i 852, under the presidency of the Earl of Lansdowne. At this conference a union of institutions was suggested, and such a union was formed in the following July by a resolution of the Council. The object of the union was to enable the scattered institutions to co-operate, and thereby to strengthen their educational powers. The intention of the Society was to provide a central organisation, from which information could be distributed to the institutions, lists of lecturers provided, and other facilities for their development arranged.

In addition to holding this conference, the Society issued in 1853 a long report on Industrial Instruction, which had been prepared by a committee appointed for the purpose. This committee took a great deal of evidence from schoolmasters, manufacturers, representatives of mechanics' institutions, and others, and the information they supplied forms the principal and the most valuable part of the report.

It was determined to hold an annual conference for the discussion of subjects relating to the institutions and their organisation, and such a conference was held at the Mansion House in May 1853, by the then Lord Mayor, $\mathrm{Mr}$. Thomas Challis, at the request of the Society, by which time two hundred and seventy institutions had joined the union. In connection with this conference a small exhibition of educational appliances was held in the Guildhall, and this led to a proposal for a similar exhibition on a larger scale to be held in the following year, the centenary of the Society. The proposal was readily taken up. Prince Albert expressed his warm approval of it, and promised a subscription of $£ \mathrm{I}$ oo. The accommodation on the Society's premises being quite inadequate for an exhibition on the scale proposed, St. Martin's Hall-a large 
concert hall which had been built for John Hullah in Long Acre-was taken for the purpose. ${ }^{1}$

The exhibition proved to be a great success, and quite justified the very considerable amount of labour which was expended upon it by the Council. Contributions (through the assistance of the Foreign Office) were secured from France, Belgium, Holland, Sweden, Norway, Denmark, Austria, Prussia, Switzerland, Spain, and the United States. The exhibits included educational apparatus and appliances of all sorts, school buildings (shown in plans and models) and fittings, books, maps, etc., together with samples of work produced at schools. It was opened in July 1854 by Prince Albert, and remained open until September. Arrangements were made for the delivery of lectures by the most eminent authorities on Science and Education. The list of lecturers included Dr. Whewell, Professor De Morgan, Dr. W. B. Carpenter, Dean Trench, Cardinal Wiseman, Professor Alexander Williamson, Professor Huxley, Dr. Hullah, and many other names of almost equal renown. ${ }^{2}$

Including the donation from the Prince Consort, the subscriptions amounted to £IO79. This involved a pecuniary loss of $£ 363$, which was made good by the Society. The success of the exhibition led to the suggestion that it should be made permanent, and this view was impressed by the Council upon the Government, with the result of the foundation of the educational collection and library at South Kensington as part of the Museum, now the Victoria and Albert Museum. A great number of the exhibits were presented to the new Museum, and formed the nucleus of the educational collection, and also of the fine library now forming part of the Victoria and Albert Museum.

The conference of representatives of institutions became

1 St. Martin's Hall was built in $1847-50$; it was No. 89 Long Acre. It was burnt down in 1860 , and its destruction nearly ruined Hullah, who had invested most of his money in it. Later on, the Queen's Theatre was erected on the site, which is at present occupied by private premises.

2 Some of these lectures were published in a volume (Routledge, 1855). Others were reported, more or less fully, in the Journal. 


\section{PRESIDENCY OF THE PRINCE CONSORT}

an annual function, and was continued regularly on the same day as the annual dimer, so long as the dinner was held. It lasted for a little over twenty years, until i 875 , by which time its usefulness had quite passed away, In the following year it was changed into a special conference on Adult Education, at which Sir Henry Cole presided, and in 1877 its place was taken by a conference on Domestic Economy, held at Birmingham, at the suggestion of the same gentleman, who had by that time retired from the public service, and was then temporarily resident in Birmingham. After that the conference was allowed to lapse.

It would, indeed, have died out long before, but for the institution of the system of examinations, which has now for over fifty years been a very important part of the Society's work. It was in December 1853 that Mr. Harry Chester, the founder of the Union, suggested the establishment of a system of examinations for the benefit of members of the affiliated institutions. As above mentioned, a full account of the origin and growth of the Society's examinations will be found in a later chapter. ${ }^{1}$

Probably the real value of the Union of Institutions was that it encouraged the establishment and development in provincial towns of educational organisations, which a little later provided suitable centres for the local science and art schools, and thus served as a basis for the whole system of education, scientific, artistic, and technical, which has grown up around those schools.

When the Society took in hand the organisation of local institutions, some of them were flourishing and doing serious work, but many others were in a feeble condition. Such education as these latter afforded was of a trivial sort, and they were devoted rather to amusement than to instruction. The Society provided a standard to which all were expected to conform, and a central organisation from which all could get information and help.

After some twenty years or so the work of the Union was done, and there was no longer much need for its existence. When in I 882 the examination system was

${ }^{1}$ See Chapter XIX, p. 425. 
remodelled, and the examinations were thrown open to everybody, the last reason for its maintenance disappeared, and though there are still a few institutions which like to preserve their old association with the Society, it must be admitted that the practical advantages they derive from that association are now inconsiderable.

It was the existence of the Union of Institutions that led to the establishment of the Society's weekly Journal. The first suggestion of such a thing was made by the Rev. Dr. Booth in a letter which he addressed to the Council in June 1852 . In this letter he set out in considerable detail the scheme of a weekly newspaper which should record all the Society's proceedings, serve as a medium of communication between the Society and the allied institutions, and form a permanent record of the progress of science, art, and industry. The proposal had evidently been thoroughly well thought out, and was, indeed, eventually adopted without any considerable modifications. ${ }^{1}$

As mentioned in a previous chapter, ${ }^{2}$ the Transactions of the Society had stopped in I 844, and from that time there had been no regular record of the Society's proceedings. The occasional publication first known as the Abstract of Proceedings, and afterwards, when it got to be published with greater regularity during the session, entitled Weekly Proceedings, had increased slightly in size, and it, at all events, recorded in brief abstract the papers read before the Society, and gave some amount of information about its other proceedings. This from $\mathrm{I} 84.4$ to 1852 was the only publication regularly issued by the Society, for the odd volume of Transactions published in I 852 , and intended to form the first of a new series, had no successor, and can only be regarded as an unsuccessful

${ }^{1}$ The Rev. James Booth, LL.D., F.R.S., was at this time Vicar of Wandsworth. His suggestion led to his being elected on the Council (1852), and he afterwards ( 1855 ) became its chairman. He took a very active and useful part in the establishment of the examinations, but later on some friction arose between the Council and him, and after a quarrel, the details of which are certainly now not worth recording, he was called upon to resign his seat on the Council, and did so. He died in April 1878.

${ }^{2}$ See Chapter XV, p. 333. 


\section{PRESIDENCY OF THE PRINCE CONSORT}

experiment, as it proved too costly for repetition. A volume issued in $185 \mathrm{I}$, and entitled Vol. Lvir. of the Transactions, is really nothing more than the weekly proceedings for the year bound together. Even the meagre record preserved in the Weekly Proceedings would not now be available but for the care of Davenport, who in November 1852 presented to the Council a "volume containing a complete set of the papers published in the years I 844-9, during which time no regular transactions were published, and consequently no record of the Society's proceedings existed." 1 Davenport had no doubt carefully preserved a copy of each issue, which nobody else seems to have done, and his volume is the only set of them in the Society's possession.

Booth's suggestion commended itself to the Council, and after some discussion and consideration it was accepted, the form of the Joumal settled, and its regular publication commenced, the first number appearing on 26th November 1852. This number, after a preliminary notice dealing with the proposed scope and character of the new publication, contained the address of the chairman (Henry Cole) at the opening meeting of the session, an interesting account of the Industrial Societies of the United States, one of the replies (from British Guiana) to a circular asking for information about the productions and commerce of the Colonies ; reports of the proceedings of many of the affiliated institutions, and a list of applications for patents under the new Patent Law Amendment Act of 1852 . There are four pages of advertisements, but three of these are Society's notices. Succeeding numbers contain the papers read at the ordinary meetings-at first in abstract, and afterwards in full-with brief notes of the discussions, reports and notices dealing with the various matters on which the Council and the numerous committees were engaged, and much miscellaneous information on subjects connected with the objects of the Society. From the first the Joumal was a newspaper, and was stamped with the newspaper stamp required at the time. This duty on newspapers was originally ${ }^{2}$ Council Minutes, Ioth November I 852. 
imposed by the Stamp Act of 1712, and, after several reductions, was finally abolished in 1853 .

When the accounts of the 185 I Exhibition had been made up, it was found that there was a surplus profit of $£$ I 86,000 . Of this, however, $£ 67,896$ was the amount which had been subscribed before the Exhibition was started, and it was expected that this would be returned to the subscribers, or at all events given back to the various localities in which it had been subscribed. The Society, which had collected the money, also put in a claim for a share. However, it was decided that the money should be kept, and used for the foundation of a central institution "for the dissemination of a knowledge of science and art among all classes."

This caused a good deal of natural disappointment at the time, but, looking back at all the circumstances, it may fairly be admitted that the decision was a wise one, and that better results have been obtained than if the money had been frittered away by distributing it in comparatively small sums for provincial objects. Eventually, as is well known, the estate at Kensington Gore was purchased, and the $185 \mathrm{I}$ Commissioners were formed into a permanent body for its administration. Many schemes were proposed and discussed. Prince Albert had a large and comprehensive scheme of his own, which included the erection of suitable buildings, and the transplantation of the principal learned societies to South Kensington. The idea was a fine one, and if it could have been carried out we might perhaps have had, years ago, a single comprehensive board or institution for dealing with education, science, and art, instead of our present system, which, whatever its merits, cannot chaim to be a model of organisation, economy, or uniformity.

But there was much opposition, and there were many difficulties. The story is too long for repetition here. Those who care may find much of it in Sir Henry Cole's Life. ${ }^{1}$ It may be sufficient to say that the immediate outcome was the South Kensington Museum and the

${ }^{1}$ Fifty Ycars of Public Work. 


\section{PRESIDENCY OF THE PRINCE CONSORT}

Science and Art Department, with the foundation of both of which the Society had much to do.

The second report of the Commissioners of the $185 \mathrm{I}$ Exhibition, published at the end of 1852 , and reporting the purchase of the Kensington estate, referred, amongst other matters, to the formation of a trade museum, and invited the co-operation of the Society of Arts. The Council at once took the matter into consideration, and the result was that in May i 853 they offered to undertake the formation of a collection of animal products used in manufactures, and to devote to it a sum of $£ 400$, to be expended in the course of two years, if the Commissioners would provide a similar amount. This was at once agreed to, and the formation of such a collection was immediately put in hand. Professor Solly undertook the task, and for that purpose resigned the secretaryship of the Society. He devoted himself energetically during the following two years to the work, and the result was that in May I 855 a very complete collection was exhibited. in the model room, and was formally opened by the reading of a paper by Mr. Solly. The exhibits fully illustrated the utilisation of animal products for industrial purposes, and comprised textiles (wool and silk), leather and furs, horn and bone, bristles, feathers, hair and shell, also wax and lac, oils, and, finally, refuse materials.

The collection, after being for some time exhibited by the Society, was made over to the Science and Art Department, and was placed in the South Kensington Museum, which was opened, in the temporary buildings for long known as the "Brompton Boilers," in 1857 . As a matter of fact, the original intentions of the i 85 I Commissioners about the formation of a trade museum were never carried out. The collection of animal products was transferred to the Bethnal Green Museum, when, new buildings having been built for the South Kensington Museum, the old "boilers," with certain additions, were re-erected at Bethnal Green in 1872.1

The total amount expended by the Society, including

${ }^{1}$ The building was opened in March I 872 by the Prince of Wales. 
the $£ 400$ originally granted by the Commissioners, was $£ 976$. On the transfer of the collection, the Commissioners agreed to repay the Society's expenditure, and the balance $(£ 576)$ was accordingly repaid to the Society:

This collection and the educational collection previously mentioned were the chief contributions of the Society to the Museum. Both of them were valuable, not so much for themselves, but because they formed a nucleus about which, by continual accretions, the scientific and educational collections now forming part of the Victoria and Albert Museum have grown. It must, of course, be understood that this does not refer to the Art Museum, to the contents of which the Society was never in a position to make any but trifling contributions.

As regards the Science and Art Department, the Society can only claim the credit of having done a good deal of pioneer work, and of having prepared the way for its establishment. Though Schools of Design ${ }^{1}$ were started in 1839 or 1840 , they were, by all accounts, not very successful, and in $185 \mathrm{I}$ a vigorous attempt was made by the Society to encourage the formation of such schools on an independent basis. The proposal was well taken up in several provincial towns and in London, but in the following year the Department of Practical Art was formed by the Board of Trade, and this a year later became the Science and Art Department. It took over the existing Schools of Design, and there was no further need for the Society to persevere with its scheme, which was accordingly dropped.

Still more useful service was rendered to the new Department by the Society's development of Mechanics' Institutions and by its examinations. It was at these institutions that the Science Schools and Art Schools were first formed, and it was on the model of the Society's examinations that the much larger scheme of Government science examinations was carried out.

1 They were not really Schools of Design at all. They were called so because they were imitations of the French Ecoles de Dessin, and were simply, like the French originals, drawing-schools. 


\section{PRESIDENCY OF THE PRINCE CONSORT}

Before the opening of the 185 I Exhibition the Council announced the offer of prizes for essays or treatises on certain sections of the Exhibition. But before the time came for the award of these prizes, Prince Albert, in the autumn of $185 \mathrm{I}$, suggested that a series of lectures should be given at some of the Society's meetings, "on the probable bearing of the Exhibition on the various branches of Science, Art, and Industry." This proposal was at once adopted, and the offer of prizes withdrawn.

In all twenty-four lectures were delivered during the session $185 \mathrm{I}-52,{ }^{1}$ and these were afterwards published in two volumes, which attained a considerable amount of popularity. The first lecture was given by Dr. Whewell, at the opening meeting of the session in November $185 \mathrm{I}$, and dealt with the general bearing of the Exhibition on the progress of Art and Science. Among the other eminent lecturers were Sir Henry de la Beche, on Mining, etc. ; Professor Owen, on Raw Materials; Dr. Playfair, on Chemistry ; Dr. Lindley, on Food Substances ; Professor Willis, on Machines; Professor Royle, on the Arts and Manufactures of India; Sir Thomas Bazley, on Cotton; and Digby Wyatt and Owen Jones, on the Decorative Arts. The concluding lecture on the "International Relations of the Exhibition" was given by (Sir) Henry Cole.

After the great international exhibition of $185 \mathrm{I}$ the Society still went on holding exhibitions on its own account. In 1848 an exhibition of recent inventions had been held. This was composed partly of objects belonging to the Society's own collection, which had not then been finally disposed of, and partly of inventions recently patented or registered under the Designs Act of $185 \mathrm{I}$. This exhibition was a fairly good one. It contained 446 exhibits in all, of a rather miscellaneous character, some, however, of permanent interest and value. It remained open from 26 th December 1848 to 3oth January i 849 . It was the

\footnotetext{
${ }^{1}$ Sir H. Cole's leeture had to be postponed, and was delivered in December I 852 .
} 
first of an annual series continued regularly up to I86I. By that time the character of the Exhibitions had depreciated, and Sir Thomas Phillips, in the address which he delivered as Chairman of the Council in November i 862 , remarked that "the series have not kept pace with the progress of science, and have not been worthy of the present position of the Society." It was determined, in consequence of the I 862 Exhibition, not to hold an exhibition of inventions that year, and the opportunity was taken of letting the series 'come to an end.

Besides these exhibitions of an industrial character, the Society organised several exhibitions of pictures. As mentioned in a previous part of this chapter, the first action taken by Henry Cole in connection with the Society was the submission of a proposition for the holding of exhibitions of pictures by modern artists, the idea being that they would be a source of profit, from which funds might be provided for the establishment of a National Gallery of British Art. The proposal was that the profits from the exhibition of each artist's works should be expended in purchasing one or more of his pictures, and that these should be lent to the National Gallery, until enough had been collected to fill a special gallery. The idea was an admirable one. But the means proposed were quite inadequate, and, in spite of the enthusiasm which Cole devoted to the scheme, it proved financially an absolute failure. The proposed series was started with an exhibition in 1848 of Mulready's works, the original idea of beginning with a collection of Landseer's not having for some reason been carried out. The financial result of the Mulready Exhibition was a small surplus, which was later on expended in the purchase of two of the artist's studies, and these were presented to the National Gallery. In I 849 an exhibition of Etty's works was arranged. But this resulted in a loss, and the idea of making money for the proposed gallery was abandoned. In fact, the Society was a heavy loser, for the expenses were ultimately paid only by the diversion, with the donor's consent, of a gift of $£ 500$ from Mrs. Acton, the widow of a member, which 
had been intended for the general purposes of the Society. ${ }^{1}$ Some years later, in 1855 , an exhibition of the works of the two brothers John and Alfred Chalon (both R.A.'s) was held, but it does not appear that this had any connection with Cole's scheme. ${ }^{2}$ After the death of Sir William Ross, an exhibition of his miniatures was held in the Society's rooms in I860, which attracted a good deal of interest, but did not produce any profit. Ross, as may be seen by reference to the list of the Society's prize-winners, ${ }^{3}$ took many of the Society's prizes as a youth. He was long a member of the Society, was Chairman of the Committee of Fine Arts, and served as a member of the first Council.

In December I860 a proposal was made that an exhibition should be held in the following year of the works of C. R. Leslie, R.A., who had died in 1859. Although a number of owners of his pictures, including Queen Victoria, promised to contribute, it was found that a representative collection could not be brought together, and the proposal was consequently abandoned. ${ }^{4}$

It may be sufficient to mention that an exhibition of lithography was held in 1847 , one of bookbinding in the same year, and a second of lithography in 1853. The photographic exhibition of i 852 will be referred to later, and the educational exhibition of 1854 has already been described. In the year I 852 the idea was started of holding an exhibition of the products of India. The East India Company was approached, and promised assistance, and some steps were taken for organising such an exhibition in London. Eventually, however, there were difficulties in finding a suitable locality, and the collection was sent to the Dublin Exhibition of 1853 , of which it formed an important section.

${ }^{1}$ Mrs. Acton gave this money in 1837 o found prizes in memory of her husband, Samuel Acton, an architect, the prizes to be generally for subjects connected with architectural design or construction. She herself became a member after her husband's death.

2 It is stated that this exhibition did not attract much attention, the works of the Chalons never acquiring much popularity.

${ }^{3}$ See Chapter VIII, p. 200.

* Sec Council Ninutes, I860 and I 86 I. 
Since the first exhibition held by the Society in 1761 of agricultural and other machines for which the Society had offered prizes, ${ }^{1}$ it had always kept up a permanent collection of mechanical and other models. As these accumulated from time to time, their disposal was always a matter of difficulty, and every now and again we find notices of the older models, for which it was difficult to find room, being sold, or given away, or destroyed. Many of these one may legitimately regret. It would have been satisfactory if the original model of Sturgeon's electromagnet had been preserved, and we should certainly be glad to possess now the whole collection which was shown in $176 \mathrm{r}$.

But it must be remembered that such things accumulate rapidly, and that they soon become obsolete and uninteresting; while they have to be kept for a great many years before they acquire antiquarian interest-an interest, indeed, which only belongs to the survivals because nearly all the apparatus or models have been destroyed.

When the Society began to hold temporary exhibitions the space occupied by the old models was required, and they were finally disposed of in various ways. The bulk of them was presented in 1850 to Bennet Woodcroft, who was then Professor of Machinery at University College, London, the trustees of the College having undertaken to repair and preserve them. ${ }^{2}$ Some of these eventually found their way into the Patent Office Museum ${ }^{3}$ at South Kensington, which grew into the collection of engineering models now forming part of the Science Museum. Others were given to the South Kensington Museum at its foundation in 1857 , and no doubt a great deal of what was really rubbish was quietly disposed of.

1 See Chapter III, p. $5^{8}$.

2 Transactions, vol. Ivii. p. xvii.

${ }^{3}$ The contents of this museum were the property either of the Commissioners of Patents or of their clerk, Bennet Woodcroft. They were to have been placed in the principal museum building, but Woodcroft objected to the admission fee of sixpence on "Students' days." Cole insisted, and neither would give way. The result was that the models of inventions were crowded into an unsightly iron shed, which was always open free. So the authorities had their way, and nobody suffered except the public. 


\section{PRESIDENCY OF THE PRINCE CONSORT}

Reference has already been made to the injurious effects on the Society's Premium List of the exclusion of patented articles from its awards, and the alteration in the regulations by which in 1845 patented articles were made eligible for such awards has also been mentioned.1 Not very long after this date, the Society, taking a different view of the value of patents, turned its attention to the amendment of the patent law, and in 1849 the Council, at the instigation of Henry Cole, appointed a Committee on the Rights of Inventors. It cannot be said that Cole had any deep or accurate knowledge of patent law; but he had on this, as on most subjects which he took up, very clear and definite ideas, and he never hesitated as to their correctness. The committee, however, which was appointed by the Council, included many members who were quite competent to supply any deficiency in Cole's knowledge, and he provided the moving force, which eventually brought about the much-needed reform in the law of patents in this country.

About a year after the appointment of this committee, Charles Dickens published in Household Words his wellknown "Poor Man's Tale of a Patent "; ${ }^{2}$ this, by the public attention it attracted to a very dull and uninteresting branch of legislation, greatly aided in securing the required reform.

The committee published several reports-reports containing many suggestions of considerable practical value. The general tendency of the reports was rather in favour of the French system-simple registration, sans garantie du gouvernement-a principle which has commended itself to a great many authorities on Patent Law. As a matter of fact, this has always really been the English system, which, while professing to make a grant direct from the Crown of an important monopoly, gave, as has often been said, nothing but a licence to go to law, and a registration of the date on which the inventor might commence his action. The logical French mind naturally agreed to a simple statement of the facts as they were.

1 See Chapter XI, p. 243, and Chapter XV, p. 347.

${ }^{2}$ Household Words, 19th October I850. 
But the Englishman preferred something which appeared a great deal more important, although the imposing document, with the Great Seal attached to it, actually gave no more right than would have been conferred by a simple entry in a ledger. On the other hand, it has to be remembered that an invalid patent, which could not be maintained for a moment in any court of law, is often extremely valuable as a scarecrow, warning off trespassers from a territory to which the professed owner has no legal right, and this, perhaps, is after all the reason why the pretentious but illogical British system has so long been maintained.

In America and in Germany the opposite ideal has prevailed, and the attempt is made to provide a patentee with a genuine monopoly, by certifying to the originality of his ideas. The system in America used, if all tales be true, to be modified by the friendly relations existing between the patent agents and the officials, though no doubt this is no longer the case; while the German carried out his ideas to the utmost, and reduced them ad absurdum by such cases as refusing Siemens a patent for his regenerative furnace on the ground that it was anticipated by a mediæval oven, in which bread was baked after the material by which the oven had been heated was removed.

Whichever may be the better of these two opposite systems and ideals of patent law, it may suffice to say here that the view of the Society's committee was not adopted when the Bill, which in 1852 became an Act, for the reform of the Patent Law, was introduced into the House of Commons ; but many of the other provisions were, and many parts of the Act were founded on the Society's suggestions. This Act, which came into force on ist October 1852 , introduced many and great changes into the system for granting patents. It abolished the "hanapers" and " chaffwaxes," whom Dickens had held up to scorn ; it simplified procedure, and it reduced cost. It continued to be the law for many years, as it was not until i 883 that any important alterations were made, and in that later reform the Society, as will hereafter be recorded, had its due share, For the present, the work of the committee 


\section{PRESIDENCY OF THE PRINCE CONSORT}

having been more or less satisfactorily accomplished, no further action was taken, and it was not reappointed after the passing of the Act.

The natural result of the new Act was an enormous increase in the number of patents applied for, and a consequent considerable revenue to the Patent Office. In the course of a few years the amount of patent fees had totalled up to a large sum, and suggestions began to be made that money provided by inventors ought to be applied in some way for their benefit, instead of being added to the public revenue. Sir Joseph Paxton, in 1856 , addressed a letter to the Council on the subject, and the result was a committee, and a memorial to the Commissioners of Patents. Nothing, however, came of it, though the Commissioners seem to have been sympathetic enough, for they published year after year in their annual report a sort of mute appeal to the Treasury in the form of a statement of the accumulated surplus income they had earned. The last time this statement appeared was in I88I, in their report for the previous year. At that time the aggregate surplus income, from ist October 1852 to the end of 1880 , was stated (with a meticulous accuracy) as $£ 2,041,159,16 \mathrm{~s}$. Iod. The Treasury, however, were deaf to the appeal, and apparently saw no reason to abandon so convenient a source of revenue.

In December i 852 an Exhibition of Photographs was arranged by the Society. This was the first public exhibition of photographs which had ever been held, though a few specimens had been exhibited in the Philosophical Instrument Section of the i $8_{5}$ I Exhibition. One hundred and twenty-nine pictures were shown, nearly all of them by the paper processes, though there were some collodion positives. At that time collodion had not been applied to the production of negatives, though a few months later (July I 853) it was found that the picture on the collodion film on glass could be employed as a negative, and from that time forward it was so employed, to the ultimate cxclusion of the earlier methods, in which paper rendered transparent by wax or other means hạd been used. 
The formation of a Photographic Society was first proposed by Roger Fenton in April 1 852, and in the same month Robert Hunt applied to the Society, asking for the use of the meeting-room for an inaugural meeting to establish such a society. ${ }^{1}$ The request was granted, but the meeting was not held until January i 853 . At this meeting Le Neve Foster, who had previously obtained the sanction of the Council to his suggestion, brought forward a proposal that, instead of forming an independent society a special section of the Society of Arts should be established dealing with photography. This proposal, however, did not meet with the approval of the photographers present, who were strongly in favour of an independent organisation, and the Photographic Society of Great Britain was established on 2oth January I 853. Sir Charles Eastlake, then President of the Royal Academy, became the first president of the new society. This, the earliest of all photographic societies, became the parent of many other similar bodies in this country, and its example was also soon followed in other countries.

The question of copyright in works of Art was taken up in March I858, when a committee was appointed by the Council to inquire into this subject. Of this committee Sir Charles Eastlake, P.R.A., was appointed chairman, and he held the post until the termination of its work four years later. At that time there was almost no copyright in works of Art. The only Act in which any protection at all was given them was

1 Roger Fenton was one of the earliest photographers, and among the most successful of his time. He was one of the principal contributors in the Society's Photographic Exhibition of 1852 . He took a number of pictures in the Crimea during the war. He died in IS69. A short notice of him will be found in the Photographic Journal, I 5 th September I869. Robert Hunt, F.R.S., was a man of varied pursuits and attained reputation in more than one of them. His Researches on Light is believed to be the earliest book on photography. He was Keeper of Mining Records for over thirty years, and professor at the Scliool of Mines. He was a copious yet accurate writer. He was a candidate for the Secretaryship of the Society in 1853 when Le Neve Foster was elected. There is a life of him in the Dictionary of National Biography 


\section{PRESIDENCY OF THE PRINCE CONSORT}

that known as Hogarth's Act (8 George II. c. I 5 ), passed in 1735 . It was connected with the name of Hogarth because it was obtained by him, mainly at his own expense, in order to protect his engravings from the piracy by which he suffered considerable loss. It merely provided a copyright of fourteen years in original engravings. There had been several amending Acts, but none which gave the author of an original work of Art the power of preventing its being reproduced and copies being sold.

The committee drafted a Bill to establish copyright in works of Fine Art, and this was introduced in the Session of 1860 . In spite, however, of all the pressure that the Society could bring to bear, by deputations to the Government, petitions, and otherwise, the Bill was not passed until July I 862, and then only in an emasculated form, because the promoters were obliged to abandon its more important provisions in order to get the Act passed at all. Nevertheless, it was a very important reform, and it continued for many years to be the law on the subject. It established the existence of a copyright in works of Art, though, owing to the way in which one of the clauses was drafted, it left in uncertainty the question as to whom the copyright should belong in cases in which the artist had executed the work for a valuable consideration, or when he had disposed of the work itself without either retaining or transferring the copyright. In spite, however, of its admitted imperfections, it worked fairly satisfactorily, and though it has been adversely criticised, it was at the time a great and valuable advantage to artists. ${ }^{1}$

Its main provisions have been preserved in the most recent legislation on the subject, the Copyright Act ( I \& 2 Geo. v. c. 46) passed in the Session of I9I I, and in force since ist July i 9 I 2 .

In 1859 the Society, at the suggestion of Wentworth Dilke, who was then the Chairman of Council, took up the

${ }^{1}$ A few years later, on the receipt of an influentially signed memorial from artists and picture dealers, the Council drafted an amending Bill, and it was introduced into the House of Lords in I 868 by Lord Westbury, but nothing came of it (Joutrnal, vol. xiv. pp. 2 I 3 and 544, vol. xv. p. 526, vol. xvi. p. 580 ). 
question of musical pitch. The French standard pitch, then and since known as the Diapason Normal, became legal in France on 1st July I 859 ; and it was no doubt the fact of the French having adopted a musical standard that led to the endeavour in this country to follow their example. The proposal that an attempt should be made to standardise musical pitch here was referred to a meeting of musicians, and after this a committee was appointed, which produced a very comprehensive and valuable report drawn up by Dr. Hullah. ${ }^{1}$

On the recommendations of the committee, a standard was suggested of 528 vibrations for the middle $\mathrm{C}$ of the pianoforte. The French Diapason Normal was 435 for the corresponding note A. The Society's note A would naturally be 440 ; but instead of this, A was made 444 vibrations, on the equal temperament system.

It is certainly unfortunate that the Society's committee did not adopt the "just" A 440, which would have been near enough to the French pitch for the two to have been treated as practically identical, and the probable result would have been that the French pitch would have been adopted in this country, and we should have got a uniform musical pitch many years ago. The question was further complicated by the fact that Mr. Griesbach, a musician who had concerned himself with experimental acoustics, and who had been entrusted by the Society with the tuning of the standard forks, unfortunately was incorrect in his determination. His $\mathrm{C}$ fork was 534.5 , instead of 528 , and his A fork 445.7 , instead of $444 .^{2}$

The Society's well-intentioned efforts had no practical result, and the suggested pitch was never to any extent adopted here or elsewhere. Much later on its existence became one of the obstacles to the adoption in this country of a standard pitch, and in 1886 it was referred to a committee to consider whether it was still

${ }^{1}$ The report was printed in the Journal for Sth June I860, vol. viii. p. 572 .

${ }_{2}^{2}$ These particulars are taken from a most interesting paper by Mr. A. J. Hipkins, read before the Society in February 1896 , and published in the Journal, vol. xliv. p. 535 . 


\section{PRESIDENCY OF THE PRINCE CONSORT}

desirable for the Society to maintain its theoretical C 528 . On the advice of this committee, the Council, in February 1886, formally abaudoned the Society of Arts pitch, and published their reason for so doing. ${ }^{1}$

The committee further advised that the Society in abandoning its own pitch should use its influence in furthering the adoption of the French pitch, from which, as before said, the Society's pitch, when accurately measured, did not really differ very much.

One of the schemes taken up by the Council aroused a great deal of ridicule, although it provided for what has now got to be considered as one of the necessaries of civilization-that is, the supply of public water-closets and lavatories. Such conveniences had been provided in the $185 \mathrm{I}$ Exhibition, and the charges made for their use resulted in a considerable profit. ${ }^{2}$ It was thought, very properly, that similar conveniences ought to be available in all great cities, and (Sir) Samuel Morton Peto, the well-known contractor, offered to defray the cost of the experiment, if the Society of Arts would undertake to provide waiting-rooms with suitable accommodation in London. Arrangements were made for two such places-one for gentlemen in Fleet Street, and one for ladies in Bedford Street, Strand.

The experiment turned out a complete failure, as the cost of establishment and current expenses for a period of about six months amounted to $£ 492$, I $7 \mathrm{~s}$. $4 \mathrm{~d}$., whereas the total receipts were only $£ 15,135$. $11 \mathrm{~d}$. Mr. Peto (as he then was) paid up the balance of $£ 477,3 \mathrm{~s} .5 \mathrm{~d}$., and the experiment was brought to an end. It, however, served its purpose in drawing attention to the necessity for such places. Later on the matter was taken up by the City Corporation, mainly owing to the recommendations of William Haywood, the City engineer (1846-1894), who originated the system of underground lavatories; and now London, which fifty or sixty years ago was probably

1 Joumal for I 2 th February I 886, vol. xxxiv. p. 265.

2 The receipts were $£ 2470$, and the expenses about $£ 680$ (Transactions, vol. lvii. p. xvii). 
the worst supplied of any capital in Europe with sanitary conveniences, is certainly the best.

Although the Society had long since given up the practice of making the bestowal of premiums its chief object, it never wholly abandoned that practice. Reference has been made more than once to the special prizes which were given during the years which preceded the I 85 I Exhibition, and, indeed, gave the first stimulus to the idea of such an exhibition. The award of these special prizes was carried on from i 846 to 1850 , and during that period the following well-known firms, amongst others, received the Society's medals:-Minton \& Co. and Copeland (pottery) ; Osler \& Co. and Pellatt \& Co. (glass); Woollams \& Co. and W. B. Simpson (paperhangings) ; the Coalbrookdale Co. (iron castings) ; Hunt and Roskell (jewellery); Crossley (carpets); Chubb (safes); and Leighton (bookbinding). Mention should also be made of the gold medal awarded to W. C. Siemens in 1850 for his regenerative condenser. This was an early and not very successful application of the regenerative principle. It was included in the patent for a regenerative engine ( I 847), and was the subject of a later patent (i 849). The regenerative furnace was patented by Frederick Siemens in $1856 .^{1}$ Many years afterwards, when he occupied the post of Chairman of Council, Sir William Siemens said that this prize, the first he ever received, had been of the greatest encouragement to him. In the same year ( 1850 ) Henry Bessemer also had a gold medal for one of his minor inventions-a sugar-cane press. His improvements in steel manufacture were of a later date, his first patent connected with the "Bessemer process " having been taken out in I 855 .

Inasmuch as the Society never formally discontinued its practice of awarding medals for meritorious inventions, it was always open to anybody to submit anything which he considered worthy of award, and from time to time new inventions of various sorts were so submitted, were ct seq.

${ }^{1}$ Life of Sir William Siemens, by William Pole, 1888, p. 75 
referred to a small committee or to some individual expert, and received prizes.

During the period with which we are now engaged some special prizes of importance were offered. The Society's colour-box has already been mentioned. ' This was the most popular of all its awards. The most important was the prize offered for a microscope. In the summer of 1854 Dr. W. B. Carpenter suggested to the Council that a prize should be offered for a cheap microscope, the cost of such instruments being then such as to put them out of the reach of students and teachers of elementary science. The proposal was approved, and on the recommendation of a committee of microscopists, two medals were offered, one for a simple and one for a compound microscope, to be supplied at the price of $\mathrm{Ios}$. $6 \mathrm{~d}$. and $£ 3$, 3s. respectively. It was said that at such prices nothing of any practical use could be provided, but Messrs. Field, of Birmingham, produced two excellent instruments at the stipulated prices, and the prizes were awarded to them. In the simple microscope, a tubular stem, which screwed into the top of the box containing the instrument when not in use, carried an inner rod fitted with a rack and pinion, and on this rod the lenses were mounted. There were three lenses, giving separately or in combination a range of magnification from about five to forty diameters. The top of the stem carried a stage, to which could be fitted a condensing lens for illumination or a stage-forceps. The little instrument, which was sold for ros. 6d., was well suited for the examination of botanical and other natural history specimens. In construction and design it seems to have been quite novel at the time.

The compound microscope was a really excellent instrument. It had a cast-iron stand, very firm and steady, two eye-pieces, two objectives giving a range from 25 to 200 diameters, a stage with rotating diaphragm, coarse and fine adjustments, adjustable mirror with plane and concave sides, separate condenser, stage-forceps and live-box. It was not, of course, an instrument suited for scientific research, but it was a thoroughly serviceable

\footnotetext{
${ }^{1}$ See Chapter IX, p. 2 I4.
} 
one, and nothing like it had ever before been produced at such a price. Dr. Carpenter, in his well-known book on the microscope, speaks highly of it, and in his third edition, published in I872, he says that by the end of the year i 86 I , i 800 instruments had been sold.

The principal value of the award was that it proved that a serviceable microscope could be produced at a cost far lower than that of any previous instrument, and the natural result followed that it had many successors, some of them improvements on the original, though perhaps there were none which competed with it in lowness of price. Certainly more than twenty years after its introduction microscopes were being sold which professed to be the Society of Arts pattern, and resembled it more or less closely both in character and merits. Later still, of course, much greater improvements were made, especially in the optical part, and inexpensive microscopes can now be bought compared with which the original Society's microscope is but a very inefficient tool. But it remains the first of its sort, and its introduction was a great boon to the scientific student of fifty years ago.

In 1857 Mr. John MacGregor offered the sum of $£$ io for a prize for a cheap writing-case suitable for the use of soldiers and sailors. The donor was well known as "Rob Roy " MacGregor, from his having invented what he called the "Rob Roy" canoe. This was a canoe rather larger than the double-paddle canoes which were then coming into fashion, covered in fore and aft, and capable of standing heavier weather than the ordinary canoe. MacGregor made various voyages in his favourite craft, including one down the Jordan (1868), which he described in a book that attracted a good deal of attention at the time. MacGregor's offer being considered insufficient, it was supplemented by a donation of an equal amount from the Rev. T. Trench, and the full prize of $£ 20$ was awarded in 1859 to Messrs. Parkins and Gotto for a writing-case which was sold at the price of is. $6 \mathrm{~d}$. It achieved a considerable amount of popularity, for within a year 20,000 of them were sold; but its chief use was, like that of the colour-box and microscope, that it was 
succeeded by various forms of cheap desks and writingcases, which were improvements on the original, and were sold at an almost equally moderate cost.

The offer in 1848 of a Gold Medal or Thirty Guineas for a design for Labourers' Cottages attracted sixtyone competitors. In the result a prize of $£ I 5$ was awarded to $T$. C. Hine of Nottingham, and a prize of $£_{1} 0$ to S. J. Nicholl. Both these designs were for a double cottage. Under the terms of the offer, the cost of a double-cottage erected in Middlesex was not to exceed £300. There does not seem to be any evidence to show that there was much practical outcome of the competition. But it attracted a good deal of public attention, and both the prize-winners published a description of their designs, with working drawings and specifications. ${ }^{1}$

In addition to these there were several prizes for essays. In 1853 a prize of $£ 50$ was awarded to James Hole, of Leeds (Honorary Secretary to the Yorkshire Union of Mechanics' Institutions), for an essay on Mechanics' Institutes. To this reference has already been made.

In 1855 a prize of twenty-five guineas, offered by Benjamin Oliveira, M.P., was awarded to Charles Wye Williams ${ }^{2}$

${ }^{1}$ Reference to an earlier offer of similar prizes will be found in Chapter XIII, p. 3I2, and to a later one in Chapter XXI, p. 49 I.

${ }^{2}$ Charles Wye Williams was a man of a certain importance in his time. He founded the City of Dublin Steam Packet Company, which for long maintained the service between Holyhead and Kingstown. He was the Managing Director of this Company until the time of his death in 1866 . He also took an active part in the formation of the Peninsular and Oriental Steam Navigation Company, and is credited with having applied watertight bulkheads to divide a ship into separate compartments at an early date. He was the patentee of a steam boiler furnace, the principle of which is described in his Essay, and he wrote several books on coal combustion and the production of steam. The value of his work in this direction, however, is a little doubtful. His principal book has been described to the writer by a very competent authority as a "queer mixture of sense and nonsense." It was vigorously attacked by Armstrong and Bourne in their book on Boiler Engineering (1856), and also by Bourne in a review published in 1843 . He was for many years a member of the Society, and a long obituary notice of him appears in the Joumal, vol. xiv. p. 383 . 
for an essay on "The Prevention of the Smoke Nuisance," and two years later, in 1857 , a prize of $£ 200$, which had been offered by Henry Johnson for an essay "On the Present Financial Position of the Country" was awarded to Edward Capps.

It should be added that in I 850 Scott Russell made a suggestion that medals should be given to the readers of the best papers every year. The suggestion was adopted and at once acted upon. The practice has been continued from that date down to the present time.

As the first award of the Swiney Prize was made in I 849, this would seem to be the proper place to insert some account of this curious bequest.

At the meeting held on 7 th February i 844, Arthur Aikin reported that during his secretaryship thirteen years before, which would mean some time in I 83 I, " a stranger called at this office and put into my hand the will of Dr. Swiney, sealed up in an enclosure, and immediately left." Dr. Aikin endeavoured to find out the doctor's address, but without success. When he retired from the secretaryship (1839) he took legal advice as to what had better be done with the packet, and was advised to open it, when he found a note from Dr. Swiney addressed to himself, expressing a wish that he should take charge of the will. This note was dated from Sidmouth Street, Gray's Inn Road, but no trace of Dr. Swiney could then be found, though inquiries were at once made.

Aikin handed over the will to William Tooke, the Society's honorary solicitor, and it remained in his hands until January i 844, when Aikin was summoned to attend at Dr. Swiney's lodgings in Grove Street (now Arlington Road), Camden Town, where he had died on 2 Ist January.

On the will being read, it appeared that the deceased had bequeathed, amongst other legacies, $£ 5000$ Three per Cent. Consols to the Society of Arts, and a like amount to the British Museum, on the condition, so far as the Society of Arts was concerned, that a sum of $f_{\mathrm{I}}$ oo contained in a silver cup of the same value should be awarded on. 


\section{PRESIDENCY OF THE PRINCE CONSORT}

every fifth anniversary of Dr. Swiney's death as a prize to the author of the best published book on Jurisprudence.

Not a great deal has ever been found out about Dr. George Swiney. He was said to be a son of Admiral Swiney, and a relation of Sir Humphry Davy. He was about fifty when he died, and had resided in Grove Street for about fifteen years. He was an M.D. of Edinburgh, where he graduated in 1816 . He was certainly an eccentric character, and it was thought that some of his relationsfor he appears to have had some-would have disputed the will. Nothing of the sort was done, and in due course the Society received its bequest. His eccentricity was displayed in the provisions made in his will for his funeral. These were all duly carried out. His coffin was covered with a yellow velvet pall, and followed by three girls in gay dresses. So curious a procession naturally attracted a great deal of attention, and the crowd was so great that there was some difficulty in carrying out the funeral. $\mathrm{He}$ was buried in the burial-ground in Pratt Street, Camden Town. His tombstone having fallen into disrepair, it was twice repaired at the cost of the Society, the second time in I 899 , when the old stone was in so bad a condition that it was thought best to renew it entirely and re-cut the inscription, which runs as follows-

\section{Hic Jacet}

Georgius Swinaeus, Med. Doct.

Anglus, Scotus, et Hibernicus.

Vixit Simpliciter

LuBENS OBIIT

I 2 Kal. Feb. MDCCCXLIV.

Anno Aetatis Suae L. ${ }^{1}$

Although the bequest was made to the Society of Arts alone, the adjudicators were, by the terms of the will, to be the members of the Society and the members of the Royal College of Physicians, "with the wives of such of them as happen to be married." It may be supposed

${ }^{1}$ A few further details will be found in two articles in the Journal. vol. xlvii. p. 660 , and vol. lvii. p. 440 . 
that it was his connection with medicine which led him to drag in the College of Physicians; but it is only another proof of the man's eccentricity that on deciding to found an award connected with Jurisprudence he should select as adjudicators the members of two institutions neither of which has any connection with the law, or their members any special qualifications for the task. It, therefore, became desirable to consult with the College of Physicians as to the disposition of the prize, and before the time for the first award came round the Council communicated with the College, with the result that an arrangement was arrived at that the award should be given alternately for Medical and General Jurisprudence. This arrangement has been amicably adhered to up to the present date.

When the question of designing a cup arose, Daniel Maclise was invited to submit a design, which was approved and accepted by the Council in May 1849 , the execution of the design being entrusted to Messrs. Garrard, the silversmiths. On two occasions since-in 1856 and $1894-$ the question has arisen of substituting a new design for that of Maclise, and the Council on both occasions went so far as to offer prizes for such a new design. In neither case, however, was the result satisfactory, and the cup is now, with some trifling alterations, the same as that originally designed by Maclise.

Besides the various matters already mentioned to which the special attention of the Society and its Council was directed, there were many other topics of which little more than bare mention must suffice.

In I 854 a Committee on Industrial Pathology was appointed, of which the most important members were Dr. T. K. Chambers and Mr. (afterwards Sir John) Simon. This committee produced two reports. ${ }^{1}$ Dr. Chambers also read a paper on the subject in June 1854 . In this paper, ${ }^{2}$ and in the first report of the committee, the subject was dealt with in a general manner. The second report had special reference to trades which affected the

1 Journal, vol. ii. p. 364 , and vol. iii. p. I 19.

2 Ibid., vol, ii. p. 49 I. 


\section{PRESIDENCY OF THE PRINCE CONSORT}

eyes. Nothing very much seems to have come of the committee's efforts, and, indeed, this important subject hardly met with adequate treatment at the Society's hands.

The question of cheap international postage was taken up as early as $185 \mathrm{I}$, and in $\mathrm{I} 852$ the Council sent a deputation to Lord Granville, then Foreign Secretary, on the subject. In 1855 a parcel post was proposed for the first time. A committee reported on the proposal, and there was much discussion upon it, which bore fruit eventually, but not for many years.

The effects of the Paper Duty came under consideration from time to time, first in 1853 , when the Council undertook an elaborate investigation into the effect of the duties, and collected the opinions of those whose interests were affected by them, including paper-makers, stationers, publishers, newspaper proprietors and editors, authors and traders using paper for manufacturing and other purposes. A considerable amount of information collected from these various classes was published. In 1860 a petition against what was called "taxes on knowledge" was addressed to the House of Commons. The duties were abolished in I 86I, after a dispute between the two Houses of Parliament.

It is curious to note that when a proposal for national holidays was brought up before the Council in 1861, a resolution of disapproval was passed.

The centenary of the Society occurred in 1854 , and was duly celebrated by a dinner at the Crystal Palace, at which Earl Granville presided. The Society's annual dinner was continued regularly up to 1862 , when Mr. Gladstone was in the chair. This dinner was held in one of the refreshment rooms of the 1862 Exhibition building. Two years previously Mr. Disraeli presided. Other chairmen had been the Duke of Argyll, Lord Ashburton, Lord Stanley, the Earl of Carlisle, Lord Napier, and the Earl of Elgin. The numbers attending the dinner had gradually fallen off (there were 750 in 1854), and after 1862 it was not continued.

It is worth mentioning as a matter of record that the present Common Seal of the Society dates from i 856 . It 


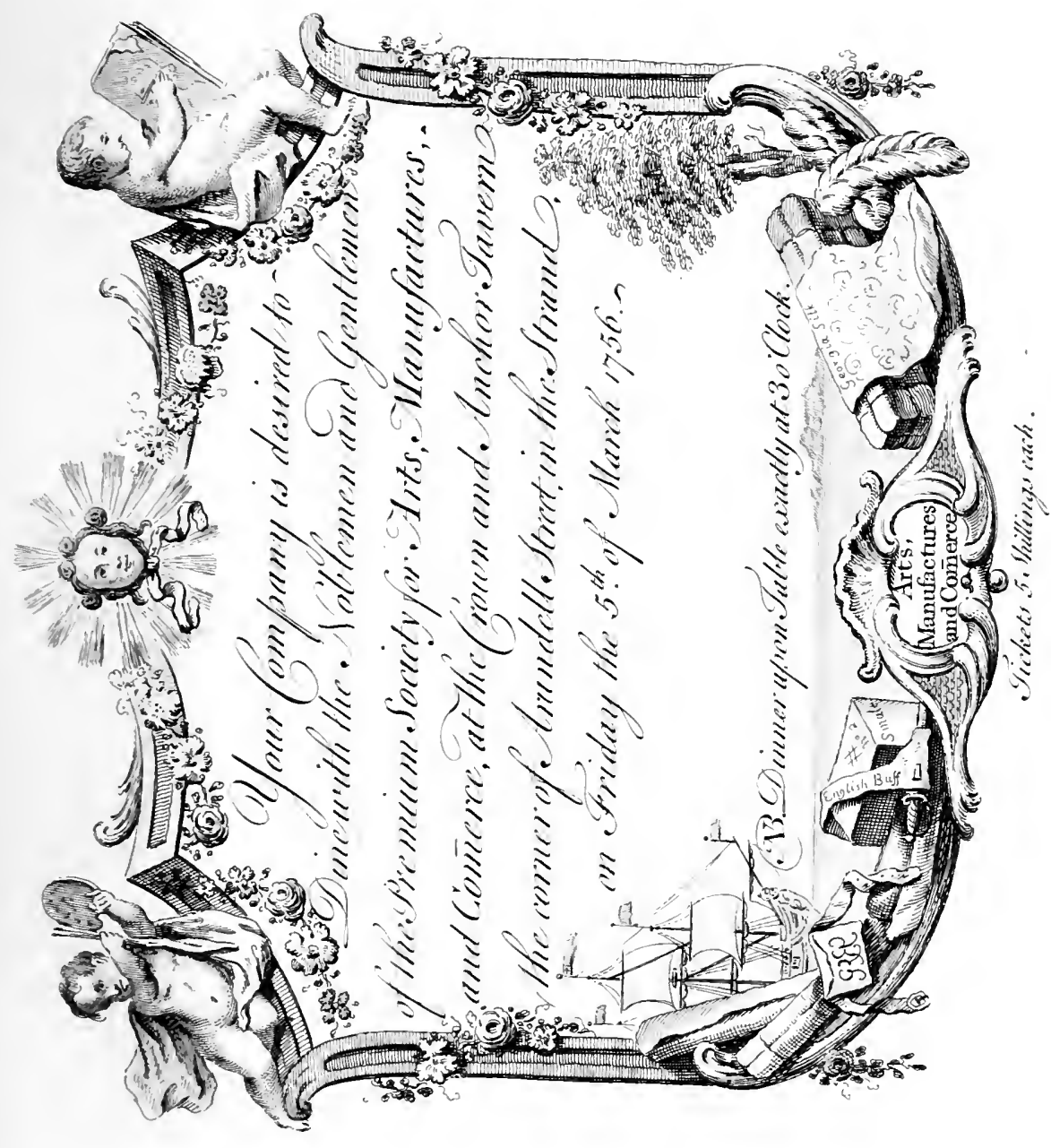



was adopted by a resolution of Council passed on 1 sth June in that year, and the old seal, with the design by Cipriani, which had been adopted in 1848 , was given up.

When the Council met for the first time in December I 845 , the Society was not far from being bankrupt. All the available stock had been sold, and only a few trust funds, amounting to just $£_{\mathrm{I}} \mathrm{OoO}$, were left. The receipts for the year were insufficient to meet the annual expenditure; there was just $£$ I 7 in the bank, and the Society was about fiooo or so in debt. The accounts are not very clear, but that seems to have been about the actual state of the finances. It was obvious that if the Society was to go on at all, money had to be provided. Various plans were considered. Among other expedients suggested was the raising of a loan fund amongst the members. Various liberal offers were made to contribute to such a fund without requiring any interest, and several hundred pounds were thus paid, or promised, by some of the members. 'These contributions kept things going for a year or two, and then the Council received an offer from one of the members, Mr. Henry Hobhouse, to lend the Society a sum of $£ 1000$ at $4 \frac{1}{2}$ per cent. interest, to be secured by a debenture on the Socicty's property. This offer was gratefully accepted in May i 848. It enabled temporary difficulties to be tided over, and in a year or so from this time the Society became practically solvent, the receipts from the increasing number of members and other sources being just about enough to balance the expenses. Still, when Mr. Hobhouse died in 1854 and his executors required the debenture to be taken up, the Council were not yet in a position to discharge the liability, but Mr. Thomas Twining, who was then a member of the Council, advanced $£_{1000}$ in the following year to pay Mr. Hobhouse's estate. This amount he was repaid in three instalments, the last in December 1857 .

The 1851 Exhibition and the growing reputation of the Society caused a large influx of members, and a similar result accrued from the Exhibition of 1862 , so that the balance-sheet for the year ending June 1862 showed a 
total of actual revenue of nearly $\$ 9000$, and a balance of income over expenditure of more than $£$ iooo. The moneys in hand, and the amounts actually due and recoverable, were much more than sufficient to balance the actual liabilities.

That the actual financial condition of the Society was not generally appreciated, or its independence of official support generally known, is shown by an order made by the House of Lords in 1856 for a return of the sums of money granted by Government to the Society during the five years ending April of that year. The officials of the House, unable to supply the information themselves, applied for help to the Society, whereupon the Council directed the Secretary to reply that the Society had existed for over a hundred years, and had never received any public money whatever, and that, therefore, the amount in question was " nil." There does not appear to have been any further correspondence. If the question were repeated at the present date, the same answer would serve.

When all the arrangements for the I 862 Exhibition had been successfully completed, and the Society, then in the full tide of prosperity and success, was looking forward to the realisation of a considerable financial endowment from the anticipated profits of the Exhibition, their hopes were suddenly destroyed by the sudden and unexpected death of their President. The Prince Consort died in December I86I. Though it was decided that the Exhibition should still be held, it was held during a period of national mourning, and without any of the pomp and circumstance which are essential to the success of such an undertaking. The result was a financial failure, which deprived the Society of any advantage whatever, though it did not involve it in any actual loss.

But the loss of prospective revenue was not the greatest of the Society's deprivations. For eighteen years Prince Albert had been the active and watchful President of the Society. He had taken office when its fortunes were at their lowest ebb, its members few and falling away, its resources exhausted. If he had not consented to accept the Presidency, a very few more years would have seen its 


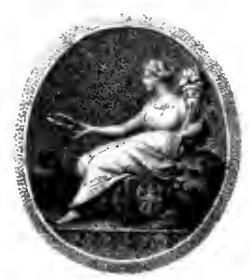

THE SOCWTY'S FIRST SEAL.

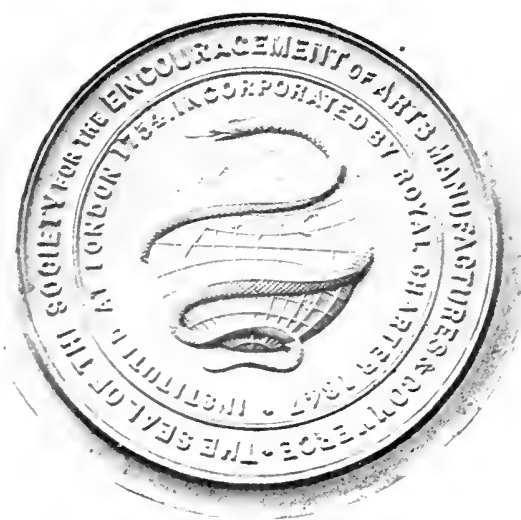

The SOCIETY's PRESENT SEAL. 

extinction. When he died it was flourishing and rich, the number of its supporters was just as many thousands as they had been hundreds, and it had accomplished an amount of public work of which any institution might have been proud. To attribute all this to the Prince Consort alone would be the merest sycophancy; but it is absolutely certain that but for his influence and his inspiring interest the work would never have been done. At his last appearance at the Society, when, in May 1861, he presided at one of its meetings, he expressed his regret that of late he had been unable to give to its work the attention and the care he had given in earlier years. The Society of Arts was one of the first public institutions in the country to which he lent his patronage and his help. It repaid his attention by being amongst the first public bodies in England to value him at his true worth. For years he was unappreciated, misunderstood, almost unpopular ; but by the members of the Society with whom he worked, in pursuance of aims and objects on which his heart was set, he was from the first appreciated, understood and esteemed. It is something to the credit of the band of workers who used the organisation of the Society for the promotion of much public good, that they estimated at its true value the character of a man who for long lacked fit recognition at the hands of his adopted countrymen, and whose genuine worth was only fully realised in the closing years of his life among them.

When the question of a national memorial to the Prince came under consideration, the Council at once voted what was-considering the Society's resources-the very large sum of $£ \mathrm{I} O 00$ towards it, and also took steps to collect subscriptions among the individual members. Yet to many outside the Council this seemed insufficient, and a proposal was put forward for a separate special memorial of the Society's own. This was at first opposed by the Council, who were aware of the Queen's desire that the monument to her late husband should be the result of a single united national effort. The feeling, however, was too powerful. An influentially-signed memorial was presented to the Council calling on them to summon a 
second general meeting-one had already been held to endorse the action of the Council in contributing from the Society's funds to the national memorial-and the Council, submitting to the evident wishes of the members, at once abandoned all opposition and took the lead in the proposed movement. The result was that a fund was subscribed by the members, out of which were provided the two portraits of the Queen and of the Prince now in the meeting-room, and the bust of the Prince now in the anteroom.

A still finer memorial of the Prince is the Albert Medal founded in I863, "for distinguished merit in promoting Arts, Manufactures, and Commerce," and awarded for the first time in 1864 . This was established by the Council in pursuance of a suggestion made at the general meeting above mentioned, and is, of course, provided at the cost of the Society.

It has been awarded annually since it was first founded. This year (1913) completes a half-century of awards, and the occasion has been emphasised by the presentation of the medal to his present Majesty, King George V. The list of its recipients forms a record of the greatest of those who during that period have laboured to apply the advances of science to the practical benefit of mankind. Their names are fitly associated with that of the earnest philosopher and philanthropist, to commemorate whose association with the Society the medal was established, and while the renown of the recipients adds a constantly increasing value to the honour of the award, the services recognised by the medal may fitly be held to lend some further lustre to the reputation of the sagacious and benevolent Prince in whose memory it was founded. 


\section{CHAPTER XVII}

\section{The 185 I Exhibition}

Origin of National and International Exhibitions-The First French Exhibition-The "National Repository," I 828-First Proposals for a National Exhibition of Industry-Attempts to carry out the Proposal-The Society's Exhibitions of Manufactures-Exhibition of Ancient and Mediæval Art-Proposal for a National Exhibition-Idea taken up by Prince Albert-International Exhibition decided upon-First Steps to carry out the SchemeAgreement with Contractors for a Building-Royal Commission appointed, and work handed over to it.

Probably the most important piece of work ever undertaken by the Society of Arts was the foundation of the Great Exhibition of 1851 , and through it of that long series of international exhibitions which have had such farreaching influences on the arts, as well as on industry and trade.

In the history, therefore, of the Society of Arts, the chapter dealing with its connection with exhibitions is a very important chapter, and so it becomes necessary to set forth in some detail an account of the steps which led to the successful inauguration of the Great Palace of Industry in Hyde Park. Now that so many exhibitions have been held, and that experience has established a system-even a routine--for their management, we may easily overlook the difficulties which surrounded the path of those who started-without example or experience to guide them-so novel an experiment, and who, indeed, realised a success not surpassed by any of their followers. Some of these men are now forgotten. Others never received their due share of credit. Perhaps, now that all 
of them have passed away, it may be possible to set out without invidious comparisons their various shares in the great enterprise, so far as the records of the Society enable it to be done.

As it was only with the initiation of the undertaking that the Society was concerned, it will be only the early steps of preparation that will be recorded here. As soon as success was assured, and national support was certain, it was decided that so important a movement should be under Government control. Probably in no other way than by means of a Royal Commission could the great enterprise have been so successfully accomplished. Still, the historian of the Society of Arts may be pardoned a regret that the Society should not have been able to carry out to the end the scheme it had brought so far, and to reap the full reward of its early and devoted labours.

The question of the origin of national and international exhibitions has often been discussed, and there seems no doubt that the earliest industrial exhibition of which there is any record was the Exhibition, held by the Society of Arts in 176I, of Agricultural and other Machines, for which the Society had offered prizes. Thus it may certainly be claimed for the Society that it initiated the idea of Industrial as well as of Fine Art exhibitions.

The idea was also independently originated in France. In 1797 , in the time of the Directory, an exhibition of French manufactures was organised in the then dismantled Chateau of St. Cloud. The execution of the scheme was, however, interrupted by the decree for the expulsion of the nobility, and the consequent enforced sudden flight of the originator-the Marquis d'Aveze, who was then commissioner for the State manufactures, Gobelins, Sèvres, etc., and had proposed the exhibition as a means of raising these works from the state of decay into which they had lapsed. ${ }^{1}$

In the following year the scheme was actually carried into effect in a temporary building on the Champ de Mars.

1 A full account of this first French exhibition, and of its successors, will be found in the Report on the 1849 Exhibition, prepared by Mr. Digby Wyatt for the Council of the Society. 
This was the first of a series of French national exhibitions, the last of which was held in I 849. The success of these national shows was avowedly one of the causes which led to the promotion of similar exhibitions in this country.

Such an attempt was made in 1828. An influential committee was formed, with the Hon. G. Agar Ellis as chairman, and King George the Fourth gave his patronage. The Committee proposed to hold a series of annual exhibitions "of new and improved productions of our artisans and manufacturers." The place fixed upon was the King's Mews, which stood on the site of the National Gallery, and were pulled down in 1833 . The scheme was well thought out, but seems to have been in advance of its time, for the manufacturers of the country did little to support it. The "National Repository," as it was termed, was continued for four years; in 1833 it was moved from the King's Mews to a house in Leicester Square, and after this it was discontinued. ${ }^{1}$

Mention should also be made of the triennial exhibitions of the Royal Dublin Society, held from i 827 to i 850 ; of an exhibition held in Covent Garden in 1845 , of which, however, no complete record appears to have been preserved; and also of attempts by Mr. S. Richards to get up an exhibition of industry, including foreign manufactures, in Birmingham, in $1836 .^{2}$

In November 1844, Francis Whishaw, the Secretary of the Society, started a scheme for an annual exhibition of the products of national industry, and inserted advertisements in the Times, Athenoum, and other papers, offering prizes to the amount of $£ 300$. In this scheme Whishaw had the assistance of Joseph Woods; it came to very little, for the public gave it but slight support. A small exhibition of works of art and mechanical inventions was, however, held in the Society's rooms on the

${ }^{1}$ A full account of this exhibition is given in Mr. Hollingshead's introduction to the official illustrated catalogue of the I862 Exhibition.

${ }^{2}$ Local exhibitions were held at Munich, 1818; Hanover, 1835; Brussels, 1835 ; Lausanne, I839; Vienna, 1839 ; Berlin, I844; and at many other places on the Continent. A list of these is given in the Introduction to the British Catalogue for the Philadelphia Exhibition, 1876 . 
6th December 1844 , and a similar one on the 28 th January I 845. So far as appears from any remaining records, these little exhibitions were held for a single evening each, but they deserve notice as being really the first sign of the movement which eventually led to the Great Exhibition. Whishaw states, in a memorandum he left on the subject, that, in I844, he had an interview with Mr. Anson, Prince Albert's private secretary, and that he had asked for the Prince's patronage, apparently without any result.

At a meeting of the Miscellaneous Matters Committee of the Society, held on the 2 ist of May I 845 , with Thomas Webster in the chair, William Fothergill Cooke, apparently at the instance of the Secretary, Whishaw, suggested that steps should be taken for the establishment of a national exhibition of the products of industry, and that efforts should be made to raise funds for the purpose, he himself offering to start a loan fund with the sum of $£_{5} 00$. The matter was brought under the notice of H.R.H. Prince Albert, the President of the Society, in the address read to him at the distribution of the Society's rewards on the 2nd June in that year; and it is stated that His Royal Highness then directed the matter to be brought again before him as soon as the plan for carrying the proposal into effect had attained a practical form. A Committee ${ }^{1}$ was appointed for the purpose, and succeeded in obtaining the promise of a certain amount of funds. Hyde Park was suggested as a suitable site, and other plans were proposed. The committee even entered into communication with the owner of Baker Street Bazaar. However, when they took steps to ascertain the views of manu-

${ }^{1}$ The Committee consisted of W. F. Cooke (well known in connection with the establishment of the electric telegraph; d. I879); Joseph Woods, G. T. Kemp, Alfred Ainger, J. Scott Russell (then a member of the Miscellaneous Matters Committee), Thomas Webster, Q.C. ; Thomas Winkworth (partner in the firm of Winkworth \& Proctor, silk brokers; an active member of the Society ; d. 1865), Francis Fuller, Bennet Woodcroft (F.R.S., Professor of Machinery at University College, London; clerk to the Commissioners of Patents; d. I879), Thomas Sopwith (F.R.S., Civil and Mining Engineer; d. 1879), and Francis Whishaw as Secretary. 
facturers generally on the subject, though many promised support, they did not meet with sufficient encouragement, and the proposal for a general national exhibition was for a time allowed to drop.

But the idea was not permitted entirely to perish. Steps were taken by those who directed the Society's action to prepare the public mind for a great national exhibition. The Prince Consort had, since his election as President, continuously impressed on the Society the necessity of its taking steps to improve the condition of the artistic industries of the country, then in a very backward condition, and had urged on the Society, as its proper work, the encouragement of the application of art to practical purposes. As a means to this end, the Council were induced-at the original suggestion, it is believed, of Scott Russell, who was then associated with Whishaw, as secretary, ${ }^{1}$ and succeeded him in the following March-to offer prizes for improved designs of " useful objects calculated to improve general taste." A fund for the purpose was subscribed, and a first offer of prizes was made in the year i 846. The response was meagre, but among the articles sent in was a tea-service designed by (Sir) Henry Cole (under his well-known pseudonym of Felix Summerly), and manufactured at his instance by Messrs. Minton. This service was simple in form, excellent in shape and thoroughly artistic in design. It afforded an admirable example of the true principles which should be followed in the manufacture of articles of common daily use, and, indeed, it effected a revolution in that manufacture. It is because this offer of prizes led to the first Exhibition of British Manufactures, and because this first Exhibition led to that of 1851 , that it has often been said that this tea-service was the origin of the Exhibition. There is perhaps just enough foundation in fact to justify the epigrammatic statement that "the Exhibition started from a tea-cup." It is, however, much more true to say that Felix Summerly's tea-

${ }^{2}$ At the first meeting of the Council, 6th December I845, a sum of 50 guineas was offered "through the Secretary," for prizes. It appears that the offer came from Scott Russell himself. 
cup originated that application of art to industry which has changed the whole character of those British manufactures to which artistic principles are applicable. It was, indeed, the commencement of the present school of art-workmanship in this country.

Although, as above stated, the response to the first offer of prizes was unsatisfactory, it was renewed in the following year (1847), and it was the prize articles of i 846 , together with the articles submitted in competition in 1847 , which formed the basis of the Society



The Felix Summerly Tea-service. ${ }^{1}$

of Arts' first exhibition of " select specimens of British Manufactures and Decorative Art," which was opened at the Society's house in March 1847. The exhibition itself would have been but a poor one had it not been supplemented by examples lent at the urgent solicitation of Henry Cole, Scott Russell, and another member of the Society. These three devoted men, as Russell himself afterwards said, spent three whole days travelling about London in four-wheel cabs calling on manufacturers and shopkeepers, till they had at last succeeded by personal

${ }^{1}$ Reproduced by permission of Messrs. Bell \& Sons from Sir Henry Cole's Fifty Years of Public Work. 
entreaty in inducing some of them to send sufficient goods to fill the exhibition room. The event more than justified the effort; the exhibition turned out a complete success, and it was visited by 20,000 people. Still greater success attended a repetition of the experiment in 1848 , for manufacturers began to realise the advantage of the cheap advertisement provided by exhibitions. This second exhibition was attended by over 73,000 visitors; and for the third, in 1849 , the accommodation on the Society's premises proved quite inadequate.

Even more successful was the exhibition held in $185^{\circ}$ "of works of Ancient and Mediæval Art." The success of this exhibition was due to a large extent to the exertions made by Mr. (afterwards Sir) Augustus Wollaston Franks, the eminent archæologist, who in later years was the head of the British Museum Department of British and Mediæval Antiquities. He acted as honorary secretary to the exhibition, and took infinite pains to ensure its success. This attracted even more public attention than the exhibitions of manufactures. Collectors, who had not then the numerous applications for loans to which they are now subjected, were liberal, and generously lent many objects of interest and value. The newspapers at the time were full of accounts of the exhibition and its contents.

The next definite step taken by the Council of the Society was to send, in March 1848 , a deputation to the President of the Board of Trade, Mr. Labouchere (afterwards Lord Taunton), suggesting that the articles shown at the Society of Arts annual exhibitions should be circulated amongst the provincial Schools of Design, then under the Board of Trade. ${ }^{1}$ The memorial presented by the deputation (which bears on the face of it evident signs that it was the work of Henry Cole) further proposed that

${ }^{1}$ The members of the deputation were:-Sir J. P. Boileau, Bart. (a well-known archæologist and an active Vice-President of the Society; he died I869), Mr. G. Bailey (Curator of the Soane Museum), Mr. Henry Cole (afterwards Sir H. Cole, K.C.B.), Mr. P. Le Neve Foster (at that time one of the Society's Treasurers), Mr. J. S. Lefevre, Assistant Secretary of the Board of Trade (afterwards Sir John Shaw Lefevre), and Mr. J. Scott Russell. 
every fourth year the Society should make a collected exhibition of the principal objects, and others specially prepared, in a suitable building in London; that the site for the building might be Trafalgar Square; that the Government should provide the building; and that the Society should have the management of the exhibition.

Mr. Labouchere approved of the proposal, and promised the assistance of the Schools of Design, but, on the question of site, referred the deputation to the Chairman of the Commission on Woods and Forests, ${ }^{1}$ Lord Morpeth (afterwards Lord Carlisle). The same deputation waited on Lord Morpeth two months later (in May I 848), and though he refused the use of Trafalgar Square, he offered the use of the quadrangle of Somerset House.

The progress which had been made was duly reported by the Council to the Society in an address read on the occasion of the opening of the third Exhibition of British Manufactures in March 1849 . This address definitely stated that the annual exhibitions were " only parts of a series of displays which it is proposed shall culminate every fifth year in a great national exhibition, embracing all manufactures," and it suggested i 85 I, the fifth year from the first of the Society's Exhibitions of Manufactures, for the first national one. The address then went on to state what had been done by the deputation above mentioned, claimed that the Society had " practically demonstrated the means of establishing such exhibitions, and educated most successfully a numerous public of all classes of society to appreciate them and crowd to see them," and concluded by urging on Government that it should "provide, once in every fifth year, a suitable building, in which national exhibitions, duly representing the best productions in all branches of manufactures, may be found."

A little later in the same year-in April I849-a petition from the Council, which had been drafted by $\mathrm{Mr}$.

${ }^{1}$ Trafalgar Square, which is now under the control of the Office of Works, was then (and until $\mathrm{x} 85 \mathrm{I}$ ) under the control of the Commissioners of Woods and Forests. It forms part of the hereditary possessions of the Crown. 
Henry Cole, was presented by Mr. Milner Gibson to the House of Commons. This petition was referred to the Select Committee on the Schools of Design, which reported on it favourably, thinking that there was " every reasonable probability that a National Exhibition of Decorative Manufactures, if properly organised, might be made to a considerable extent, if not wholly, to repay its expenses." The Committee also thought that the prayer of the petition was well worthy of the consideration of the Government.

In the previous year, I $848, \mathrm{Mr}$. Cole had submitted to Prince Albert, through his secretary, Colonel Phipps, the memorial afterwards presented to the Board of Trade, but its reception was not encouraging. Colonel Phipps stated that the Prince's opinion was not favourable to the plan, and that " no reasonable hope could be entertained of any co-operation or assistance, at any rate at present, from the Government." The time, however, had now arrived when the Prince was induced to take a different view of the proposal, and, by lending it the support of his great influence, to carry it to the success it eventually attained. ${ }^{1}$

Careful study of the original records only serves to confirm the popular idea that the success of the Great Exhibition of $185 \mathrm{I}$ was due to the wisdom and energy of the Prince Consort. Had he given but a nominal support it would doubtless indeed have been carried to a successful issue, but it would have been on a much smaller scale; probablyitwould have been confined to national products alone;

1 The early history of the Exhibition is contained in a report prepared by Mr. Scott Russell, and read to a general meeting of the Society held on the 8 th February I 850 . A great deal of information about these preliminary steps is given in Sir Henry Cole's Fifty Years of Public Life. The introduction to the official illustrated catalogue of the 1862 Exhibition, prepared by Mr. John Hollingshead, contains an account of the origin of the Exhibition, mainly founded on Mr. Scott Russell's report. Mr. Scott Russell also made an interesting collection of documents on the subject, which, after his death, was purchased by the Society, and is now in its possession. The First Report of the I 85 I Commissioners gives only a very summary account of these early proceedings. 
and, while it would certainly have had useful and important results, it could never have had the effect it certainly did exercise on the arts, industries, and commerce of the world.

As previously mentioned, an exhibition of French Industry was being held in 1849 in Paris. This was visited by Henry Cole in company with Digby Wyatt, who had been commissioned by the Society to prepare a report on the exhibition, ${ }^{1}$ and also by Francis Fuller, ${ }^{2}$ a member of the Council of the Society. Mr. Fuller, on his return, wrote to $\mathrm{Mr}$. Scott Russell that, in his opinion, it would be possible to get up in London a much better exhibition than the one in Paris. On his way back to London, as Mr. Fuller stated at a later period, he accidentally met at Southampton Mr. Thomas Cubitt, ${ }^{3}$ who was then engaged in building the Royal Residence at Osborne House, in the Isle of Wight. A few days later, when Mr. Cubitt returned to Osborne, he mentioned the idea to the Prince, who is said to have expressed sympathy with the project. The matter, however, was more formally brought to His Royal Highness's notice, first privately, by Mr. Scott Russell, and then publicly, in the report of the Council, read at the annual presentation of the prizes on the 14 th June in that year.

From the minutes of the meeting, which are somewhat meagre, it does not appear that Prince Albert expressed any views of his own on that occasion, but he shortly afterwards sent for Mr. Scott Russell, and obtained from him full information as to the scheme. He also sent for Mr. Cole, on the occasion of a visit paid by him to Colonel Phipps, and questioned him about the arrangements for the proposed exhibition. It was evident that His Royal Highness's interest had been thoroughly aroused, for on both occasions he went fully into the matter, and gave

${ }^{1}$ Published the same year for the Society. A copy is in the Society's library. Sir Matthew Digby Wyatt died in 1877 .

2 Francis Fuller was a member of the Society from 1843 till his death in 1887 . He, as will be seen, took a very energetic part in the preparations for the Exhibition. For some time he was managing director of the Sydenham Crystal Palace.

${ }^{3}$ The founder of the great firm of builders of which he and his brother William were partners. He died in 1855 . 
his own opinions as to the best means of success. He suggested Leicester Square as a suitable site, and, in answer to a question from $\mathrm{Mr}$. Cole as to whether the exhibition should be national or international, he decided that it ought to embrace foreign productions, and must certainly be international. On Mr. Cole suggesting that, in that case, Leicester Square might not be large enough, and proposing, in reply to a further question, a site in Hyde Park, he was directed by the Prince to visit the park, and to consider whether a suitable site could be found there.

These informal discussions were preliminary to a more formal meeting, when the Prince summoned Scott Russell, Francis Fuller, Henry Cole, and Thomas Cubitt to attend at Buckingham Palace. A formal minute of the proceedings of this meeting was prepared, at the Prince's desire, by Mr. Scott Russell, and the original MS. of this minute, with the Prince's own corrections, is amongst the documents before referred to as having been collected by $\mathrm{Mr}$. Scott Russell. Sir Henry Cole reproduced in facsimile in his autobiography the passage in which it was laid down that the exhibition was to be international. In the Prince's own words, it was considered "that whilst it appears an error to fix any limitation to the productions of machinery, science, and taste, which are of no country, but belong as a whole to the civilised world, particular advantage to British industry might be derived from placing it in fair competition with that of other nations." At this meeting, also, Prince Albert suggested that the exhibition should include the four following divisions: Raw materials, machinery and mechanical inventions, manufactures, sculpture and plastic art. It will be seen, therefore, that it was at this meeting that the various proposals for the holding of the Great Exhibition in $185 \mathrm{I}$ at last took definite form, and here, it may be said, that the Exhibition really originated.

A second similar meeting was held at Osborne, which was attended by Scott Russell, Henry Cole, and Francis Fuller, Mr. Labouchere, President of the Board of Trade, being also present, by desire of the Prince. At this meeting it was decided that the best means of carrying 
out the proposed scheme would be by the appointment of a Royal Commission.

At this meeting a definite plan for the exhibition was decided upon. It was settled that an exhibition should be held in London in $185 \mathrm{I}$, under the presidency of Prince Albert, of works of art and industry of all nations; that there should be a Royal Commission to control and regulate the exhibition, and to deal with the question of prizes; that the Society of Arts should undertake to collect funds for prizes and all the other expenses, and should provide for the holding of similar exhibitions quinquennially.

It was also decided that steps should be taken to ascertain the feelings of manufacturers, and to obtain their support. ${ }^{1}$

In order to carry these suggestions into effect, the Prince authorised Mr. Cole and Mr. Fuller to visit the principal provincial centres of industry, and to hold public meetings for the purpose of awakening interest and obtaining promises of support for the proposed exhibition. The costs of these journeys were, at all events in the first instance, defrayed by Mr. Fuller. The work of these gentlemen was supplemented by similar efforts by several other members of the Society, and the result was that a little later on in the year a report was presented to the Prince, showing that the proposal had met with warm support in all parts of the country.

In the meantime the matter had been brought before the Council of the Society, which was summoned on the 26 th July i $849^{2}$ to hear a report from the secretary of the meeting at Buckingham Palace on the zoth June, and to consider what the action of the Society should be. The

${ }^{1} \mathrm{Mr}$. Fuller, in an account of the meeting, published at a later date, states that Sir Robert Peel was also present, and that he expressed the opinion that the project was good and deserved support, but that until a sufficient majority of the manufacturers of the United Kingdom should declare in favour of it, he strongly advised His Royal Highness to have nothing to do with it.

2 At this meeting Mr. Thonas Winkworth was in the chair, and there were present Miessrs. Le Neve Foster, S. Hickson (d. 1870), S. Redgrave (d. I876), F. Whishaw, and J. Scott Russell (secretary). 
conclusion arrived at was that the resources of the Society were not such as to justify the Council in guaranteeing the necessary preliminary outlay, but that it might be possible to find some capitalists who would provide the necessary funds, provided they were allowed to make the exhibition, to some extent, a source of pecuniary profit.

The total probable cost of the exhibition was naturally a subject of considerable discussion. It was estimated by Mr. Cubitt that the cost of the building would not be much less than $£ 50$,000; $£ 20$,000 was proposed for prizes, and thus, with preliminary expenses, it was considered that $£ 75$,0oo would be required to ensure success. To recoup this expenditure the following sources were relied uponreceipts at the doors, payments from exhibitors for their stalls, and various other miscellaneous sources of revenue.

For a long time great difficulty was experienced in finding anybody who would undertake the speculation. The matter was laid before numerous contractors, but without success, until at last Mr. Fuller, through the agency of his father-in-law, Mr. George Drew, of Guildford, succeeded in inducing Messrs. J. \& G. Munday to undertake the risk. Messrs. Munday agreed to advance the sum suggested for a prize fund- $£ 20,000$ - to the Treasurer of the Society, to be placed in the name of Prince Albert or of trustees appointed by him. They also undertook the whole cost of erecting the necessary buildings, and to provide the money for preliminary expenses. From the exhibition receipts they were to receive 5 per cent. interest on money advanced, and of the surplus profits one-third was to be paid to the Society of Arts to form a fund available for future exhibitions, while the remaining two-thirds were to go to the contractors, after payment of all costs of the exhibition.

To carry on the work the Council appointed an executive committee and three treasurers. ${ }^{1}$ When the deeds of

1 The Executive Committee consisted of Henry Cole, C. Wentworth Dilke (afterwards Sir C. Wentworth Dilke, Bart.; he died i869), George Drew, Francis Fuller, Rober Stephenson (the distinguished engineer; he died I859), and M. Digby Wyatt (secretary). The treasurers were-P. Le Neve Foster, Joseph Payne, and Thomas Winkworth. 
contract came up for approval, some of the members of the Council were of opinion that provision ought to be made in case the Government eventually consented to take over the management of the exhibition, and by agreement with the contractors a clause was inserted, empowering the Society, in the case of the above contingency arising, to annul the contract on terms to be settled by arbitration.

In the meantime steps had been taken for the appointment of the Royal Commission, which had been decided upon as necessary at Osborne on the 14th July. At the end of that same month the Prince had written to Sir George Grey, the Home Secretary, asking, as President of the Society, for the appointment of a Royal Commission, and had received from him an encouraging reply. The Commission was published in the Gazette for the $3 \mathrm{rd}$ January I 850.1 Besides the Commissioners, it appointed four treasurers for the receipts. The three gentlemen who had been appointed treasurers by the Society of Arts, were named as treasurers for the payment of the executive expenses, and the same executive committee was nominated as had been appointed by the Council of the Society of Arts. ${ }^{2}$ Mr. John Scott Russell and Mr. Stafford Henry Northcote (afterwards Sir Stafford Northcote, and later Earl of Iddesleigh) were appointed secretaries to the Commission.

The first step taken by the Commission on the IIth June I 850 , was to terminate the contract which had been made with Messrs. Munday. It was thought, as the experiment was of a national character, it ought to rely upon voluntary subscriptions, and should not be made a question of profit and loss. The proposal was met in the most liberal spirit by the Messrs. Munday, who accepted

${ }^{1}$ Mr. W. E. Gladstone was the last survivor of the original Commission.

${ }^{2}$ The constitution of this committee was afterwards modified. Mr. Stephenson retired, and his place was taken by Lieut.-Colonel (afterwards Sir W.) Reid, who became chairman. Mr. Drew and Mr. Fuller took no part in the proceedings of the committee, though their names werc kept on it. 
an award made by Mr. Robert Stephenson, of $£ 5$ I 20, with costs of $€ 587^{1}$

On the 8th February i 850 a special general meeting of the Society of Arts was held to hear a report by Mr. Scott Russell on the preliminary steps which had been taken. A resolution approving the proceedings was passed, and the Society pledged itself to support its President by every means in its power. It was also resolved that a subscription list should be opened, and a sum of $£ 7888$, out of a total of $£ 67,896$, was eventually contributed by the members.

The management of the exhibition was now, therefore, taken out of the hands of the Society, and the undertaking placed on an independent basis. The success achieved is matter of history, but it is outside the history of the Society of Arts. ${ }^{2}$

1 A few months later (I5th August I 850 ) the Commission was granted a Charter of Incorporation, by which it was created a corporate body, with executive powers. Under this authority it still exists.

2 The official history of the Exhibition is given in the first three reports of H.M. Commission for the Exhibition of 1851 , published in I 852 and 1856 . A good account of it is also given in the introduction to the I 862 Exhibition Catalogue, previously referred to.

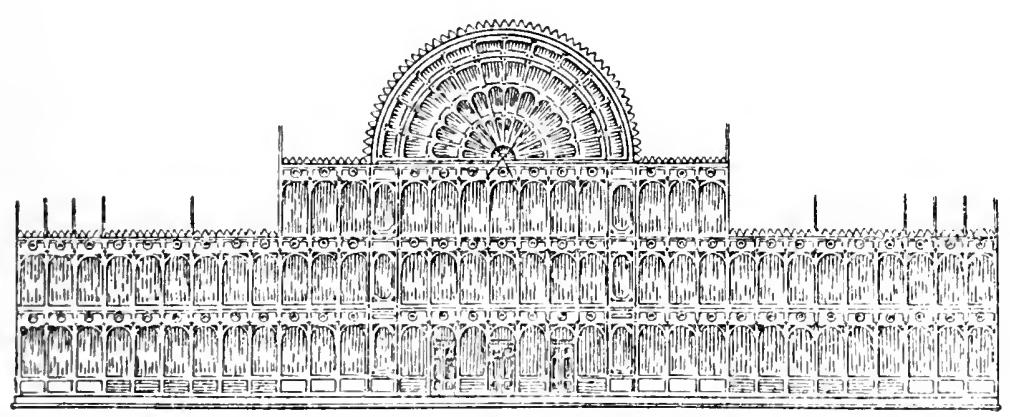

I85 I Exhibition (Front Elevation). 


\section{H A P TER X VIII}

\section{The I 862 Exhibition}

Proposal for Exhibition in $186 \mathrm{I}$-Various Plans suggested-Date deferred in consequence of Franco-Austrian War-Decision to hold Exhibition in I 862-Guarantee Fund-Agreement with I 85 I Commissioners-The Society's Trustees incorporated as Commission for I862-Financial Failure of the Exhibition-The Jury Reports published by th : Society.

WHEN the proposal for the $185 \mathrm{I}$ Exhibition first took shape, it was intended that it should be the first of a quinquennial series of such exhibitions The importance, however, and the magnitude of the enterprise quite precluded any idea of repeating so great an undertaking every fifth year, but as the ten-year period from i 85 I approached, suggestions began to be made for holding a second exhibition. Sir Henry Cole tells us in his autobiography that he and Mr. Wentworth Dilke had discussed the matter in the early part of 1858 , and in February of that year Mr. Dilke, who was then Chairman of the Council of the Society, submitted to the Council a memorandum from Mr. J. C. Deane proposing that there should be held in London in 1861 a Great International Exhibition of Arts. Mr. Deane had been associated with the Art Treasures Exhibition held at Manchester in 1857 , and the memorandum was the outcome of a conversation which he and Mr. Dilke had had at Manchester. According to Mr. Deane's proposal, the exhibition was to consist of two divisions, Ancient Art and Modern Art. The matter was discussed at numerous meetings of the Council and various suggestions were made. Eventually it was determined, on the 28th March I 858 , that a series of decennial exhibitions was desirable 
that an International Exhibition should be held in I86I, and that steps should be taken for the formation of a guarantee fund. The exhibition was to deal with Art and Industry (Fine Art had been excluded in $185 \mathrm{I}$ ) and was to include Music ; it was to be mainly an exhibition of progress. As soon as the guarantee reached a certain sum, $£ 100,000$ or $£ 150,000$, an Executive Committee of three was to be nominated. Eventually in May a series of resolutions was finally agreed to which practically embodied these proposals. ${ }^{1}$

On the 5 th May a committee was appointed to wait upon H.R.H. Prince Albert and to submit the scheme to him. This Committee consisted of Harry Chester, Henry Cole, Thomas Winkworth, J. Scott Russell, Sir Thomas Phillips, Peter Graham, and the Chairman, Wentworth Dilke. The Prince, however, was away and could not receive the deputation at the time, so beyond the publication of the resolutions of the Council no further step was then taken.

The announcement, however, of the Society's proposals naturally attracted public attention, and considerable discussion took place both inside and outside the Society as to the best site for the exhibition. The sites which found most public favour were Battersea Park and the estate at South Kensington, which had been purchased by the 185 I Commissioners with the surplus of the $185 \mathrm{I}$ Exhibition. This estate at the time consisted of the block of ground now occupied by the Natural History Museum, the Imperial Institute, the Albert Hall, and other buildings, and the site proposed for the exhibition was the southern extremity of this plot, where the Natural History Museum now stands. Those who were moving in the business on behalf of the Society were strongly of opinion that the proper site was at South Kensington, and indeed it was a question whether it was not the duty of the 1851 Commissioners to take entire charge of the proposed exhibition.

It was early in December 1858 that the Society brought the matter officially under the notice of the Com-

1 The resolutions agreed to were published in the Journal of the I6th April 1858 ; vol. vi. p. 333. 
missioners, and asked them whether they were willing to undertake the management of the exhibition. They were the trustees of the surplus of the $185 \mathrm{I}$ Exhibition, and in that surplus was included the amount of the subscriptions $(f 67,896)$ which had been originally given to start the exhibition. It was urged in many quarters that the funds thus provided should be available for exhibition purposes, and that if a second exhibition was wanted the Commissioners of 1851 were the proper persons to carry it out. The Commissioners did not meet until the 19th February in the following year, when they replied asking for further information as to the prospects of the scheme, and the support it was likely to receive from manufacturers, and from the public. They stated that they had no funds to meet the expenses, but that if the report was favourable they were willing to consider how they could effectively help the undertaking. To this communication the Council replied on the I th March 1859, promising that they would endeavour to collect information, and would try to obtain subscriptions to a guarantee fund of $£ 250,000$ on the understanding that the Commissioners would initiate it by a contribution of $£ 50,000$. It does not appear that any definite steps were taken to form such a fund, but informal promises were received from a number of the members of the Council and their friends of sums amounting in the aggregate to over $£ 70,000$.

In the midst of the negotiations the Franco-Austrian war broke out (on the 26th April 1859), and after very careful consideration it was determined by the Council that it would be wiser to postpone the holding of an exhibition. This conclusion was not arrived at without much discussion, for the opinion was warmly urged that a state of war on the Continent ought not to be allowed to interfere with an industrial and peaceful enterprise like an exhibition, and it was further argued that even if no foreign nations co-operated, a sufficient exhibition could be formed of British productions alone. However, the more cautious counsels prevailed, so a formal resolution of postponement was adopted, and was publicly 
notified at the annual general meeting of the Society, held on the 29 th Junc i $859 .{ }^{1}$

The war, however, was brought to a conclusion much more rapidly than had been expected, and peace was concluded in July. On the and November I 859 , the Council passed a resolution to resume proceedings, postponing, however, the date of the exhibition till i 862 , and resolved to take steps to obtain a guarantee fund of $£ 250,000$. They also appointed a committee to prepare a form of guarantee and to deal with exhibition matters generally. This committee consisted of Mr. Cole, Mr. Uzielli, and the Chairman of the Council, Sir Thomas Phillips. The committee reported on the 22 nd February i 860 , and in pursuance of their report a form of guarantee was adopted and five trustees were nominated-Earl Granville, the Marquis of Chandos (afterwards Duke of Buckingham), Mr. Thomas Baring, M.P., Mr. C. Wentworth Dilke, and Mr. Thomas Fairbairn, who had been chairman of the Art Treasures Exhibition at Manchester in I857. These proceedings were reported to Prince Albert by a deputation from the Council on the 28th February.

The guarantee form adopted took the shape of "an agreement for holding an international exhibition in i 862." This was signed by the intending guarantors, and afterwards, when it became necessary to raise money for the purpose of the exhibition, a formal deed was executed, and it was signed by the guarantors. Under the provisions of this agreement it was resolved that no subscriber should be liable until $£ 250,000$ at least was guaranteed : that the undertaking was to be under the management of the five trustees above named, who were to have full control of the exhibition; that the trustees should apply to the Commissioners for the i 85 I Exhibition for the grant of a portion of their estate at South Kensington as a site for the intended exhibition, but that they should have power, if they could not obtain such site on favourable

${ }^{1}$ The report of the Council, presented at this meeting, gives a full account of the correspondence between the Council and the Commissioners, and of the proce dings previous to the decision of postponement. See Journal, vol. vii. p. 557. 
terms, to adopt any other suitable site; that one-third at least of the sum expended on buildings should be employed on erections of a permanent character, to be used by the Society for holding decennial or other periodical exhibitions, and for other purposes tending to the encouragement of arts, manufactures, and commerce; that at the close of the exhibition the temporary buildings should be sold. If there should be a deficit, which the Society of Arts declined to liquidate, then the permanent buildings were to be sold; and after such sale, if there was still a deficit, the ultimate loss was to be paid by the subscribers pro rata. If there was a surplus it was to be applied in a manner to be determined by the guarantors themselves to the encouragement of arts, manufactures, and commerce.

In deciding on the terms of this agreement the Council were evidently inspired by two ideas-first, to secure for the Society some tangible results from the success of the project, if success there should be; and secondly, to make provision for the regular holding of exhibitions at stated intervals in the future.

It is noticeable that a financial success was looked upon as assured. The large profits from the first exhibition made it but reasonable to expect that a second, managed with all the benefit of the former experience, would produce even larger gains, and doubtless it seemed but prudent to avoid the discussions and controversies which had arisen about the disposal of the first surplus.

With management as skilful as that of 1851 , and conditions as favourable, it seems probable that i 862 might have been made a source of profit, as an exhibition on a similar scale might be at any time, but this is only a speculation, and experience has long since taught the lesson that international exhibitions on the scale on which they are now held, cannot possibly prove remunerative, but must always involve a heavy expenditure.

On the 8th March i 860 a copy of the guarantee agreement was sent to the Commissioners of 1851 , and an application was made on behalf of the Society for the grant of a suitable site. The Commission being in 
doubt as to the means at the disposal of the Society for carrying out their proposal, delayed response; but on a further letter being addressed to them in June I 860, containing the information that the guarantee fund had been subscribed to the amount of $£ 308,350$, the Commissioners expressed their readiness to appropriate a portion of their estate, rent free, for the exhibition; and to vest in the Society of Arts, at a moderate rent, the site of the permanent buildings proposed to be erected, provided that the sum of $£ 50$,000 was expended on their erection. They, moreover, undertook to reserve the remainder of the ground for an International Exhibition, to be held in 1872 , provided $£ \mathrm{IO}$, Ooo were paid to them out of the proceeds of the I 862 Exhibition.

There was a good deal of further correspondence between the Society of Arts, the Trustees, and the Commissioners, ${ }^{1}$ and amongst other suggestions it was proposed, at the instance of Lord Granville, and with the concurrence of the other trustees, that the management of the exhibition should be handed over to the $185 \mathrm{I}$ Commission. This proposal, however, was not accepted by the Commission for various reasons, one of them being that, as the guarantee agreement entrusted the control of the exhibition to a body of trustees specifically named, the agreement would fall to the ground if the management was transferred from the trustees to the Commission. The Commission, however, undertook to assist the trustees, and on that understanding the trustees agreed, in November i 860, to accept the trust on the condition that a charter of incorporation was obtained for them by the Society of Arts.

A charter accordingly was applied for by the Council of the Society on behalf of the trustees, and was granted under date of the I 4 th February i $861 .{ }^{2}$ This charter incorporated the trustees under the name of the "Commissioners for the Exhibition of I 862," and gave them full power to take all necessary steps for the management of the exhibition, including the power of borrowing

${ }^{1}$ The whole of the correspondence is printed in the Fourth Report of the 185 I Commissioners.

"See Journal, vol. ix. p. 205. 
money for the purpose. It stipulated that a sum not exceeding $£ 50$,ooo was to be expended on buildings of a permanent character adapted for the purposes to which the Society of Arts might put them, as previously agreed, the conditions for the ultimate disposal of these buildings being the same as those set forth in the guarantee agreement. If there was a loss, the Society of Arts was to have the option of making it good, and taking over the permanent buildings. If there was a surplus, $£ \mathrm{I} O, 000$ was to be paid to the 185 I Commissioners for the use of a site of sixteen acres for an exhibition in 1872 ; the balance, as above stated, was to be employed as the guarantors might decide.

The trustees did not wait for the formal issue of the charter, but took some provisional action before they commenced their labours, and they soon came to the conclusion that it would be impossible for them to carry out the condition of spending not less than $£ 50$, ooo on permanent buildings. They therefore proposed that the sum to be spent on permanent buildings should be reduced from $£ 50,000$ to $£ 20,000$, with the understanding that if at the close of the exhibition the necessary funds were available, the difference should be made up. This was agreed to by the Society of Arts and by the i 85 I Commission, and these conditions were substituted for the conditions described as having been stated in the charter.

The full control of the exhibition was now vested in the Commissioners appointed for the purpose, and passed out of the hands of the Society of Arts, which however was still occupied with its duty of increasing the guarantee fund. This was eventually raised to $£ 451,070$, contributed by 1 I 57 subscribers.

It will therefore be seen that the Society had a more intimate connection with the management of the 1862 Exhibition than with that of 1851 . In both cases the preliminary organisation was due to the Society, and in both cases the early preparations were made by, and at the risk of, the Society, but the exhibition of 1862 was managed by a Commission appointed by the Society, whereas the Commission of $185 \mathrm{I}$ was an entirely inde- 
pendent body, the Society having had no roice in the selection of its members. ${ }^{1}$

At the conclusion of the exhibition it was found, as is well known, that the receipts had been insufficient to defray the expenses. This unfortunate result was no doubt largely due to the death of the Prince Consort in I 86r. Not only did the exhibition lose the benefit of his personal interest and sympathy, but it was held during a period of national mourning, and was of course therefore deprived of the patronage of the court, and of the pomp and ceremonial essential to the success of such an undertaking as an International Exhibition.

Eventually it was agreed that the contractors-Messrs. Lucas \& Kelk-should take over the whole of the buildings, alike the temporary erections and those which had been intended to be permanent, in discharge of their claims against the Commissioners of 1862 ; and in addition to this, one of the members of the firm-Sir John Kelkpersonally gave the sum of $£ \mathrm{i}, 000$ to the Commissioners to enable them to balance their accounts without making any call upon the guarantors. The anticipation of the Society, therefore, that it would enter into possession of buildings at South Kensington suitable for the holding of exhibitions, and for other purposes, was not realised, and, as in $185 \mathrm{I}$, it derived no profits from the undertaking.

Later on an important service was rendered to the exhibition by the Society of Arts by the publication of the Jury Reports. After the conclusion of the 185 I Exhibition the Commissioners published a very valuable volume of Reports of the Juries, containing not only particulars of all the awards but a great mass of valuable information on industrial history, much of which is not to be found elsewhere.

The financial failure of the 1862 Exhibition prevented the Commissioners for that Exhibition from undertaking

1 For detailed information as to the management of the exhibition, construction of buildings, financial results, etc., referencc may be madc to the report of the I862 Commission published in 1863 ; to the fourth and fifth reports of the 1851 Commission, and to the introduction to the Official Illustrated Catalogue, 1862. 
a similar task. Thereupon the Council of the Society, anxious, as they said, that a record of the industrial progress of the previous ten years should be preserved, undertook the duty of issuing a similar volume to that of 1851. There was some little delay in the publication of the work, as it was not completed and issued until January 1864. It appeared under the editorship of Dr. Lyon Playfair, afterwards Lord Playfair, and was of the same form as its predecessor. It also is a work of considerable value to the student of industrial history, though, dealing as it does for the most part only with the ten years from I 851 to 1862 , it is not quite so useful as the earlier volume. Unfortunately, the cost of its production proved to be very heavy; the original estimate of $£$ I 806 was exceeded by over $£ 45^{\circ}$, and the total cost amounted to $£ 2343$; of this $£$ I 3 I O was recovered by sales, leaving a total loss to the Society of $£ 1033$.

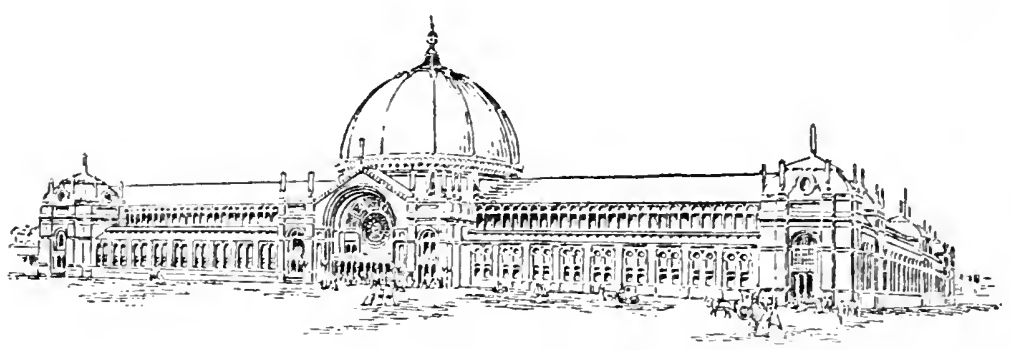

The 1862 Exhibition Building. 


\section{CHAPTER XIX}

\section{The Society's Examinations}

Origin of the System-First Examination of I 856 - The College of Preceptors-Qualifying and Competitive Examinations for the Government Service-Value of Examinations generally-Prof. Huxley's Views-The Society's Board of Examiners-Changes in the System-The Existing System-Value of the CertificatesSpecial Examinations for Soldiers-Technological Examinations, their Origin and their Transference to City Guilds InstituteExaminations in Practical Commercial Knowledge-Viva Voce Examinations in Modern Languages-Music Examinations.

THE examination system of the Society, which has now attained such large proportions, was, as previously mentioned, ${ }^{1}$ started as an adjunct to the " Union of Institutions," established in 1852 . Though it was many years before the examinations attained their present dimensions, they were popular from the first, and much appreciated. There is this special interest associated with them, that the system they started was afterwards adopted by the Universities, the Science and Art Department, the City Guilds Institute, and many other bodies. There seems no good reason to claim any direct connection between the Society's examinations and the local examinations of the two Universities, though W. Hawes, in his chairman's address in November I $863,,^{2}$ says that they originated from " a suggestion of one of our examiners that the Universities should do for the class immediately above those for whom our examinations were intended," what the Society had done for its own candidates, but the Government system certainly grew out of that started by

${ }^{1}$ See Chapter XVI, p. 372.

${ }^{2}$ Journal, vol. xii. p. 5 . 
the Society, and the Guilds Institute took over and developed the technological examinations founded by the Society.

It was in November $185 \mathrm{I}$ that Harry Chester submitted to the Council his scheme for the formation of a union of mechanics' institutions, the principal object of which was to encourage the founding of such institutions, and to develop the educational facilities which they provided. As they were meant to help the education of artisans, it was considered that their promotion came legitimately within the scope of the Society of Arts.

Among the early suggestions for the utilisation and development of these institutions was a proposal for a general system of examinations among their members. In December $1853, \mathrm{Mr}$. Chester definitely proposed the establishment of such a system, and in the spring of 1854 a scheme of examinations was published. The scheme was of a very comprehensive character, and included the following subjects: (I) Mathematical Sciences; (2) Experimental Sciences ; (3) Sciences of Observation; (4) Mechanical Sciences ; (5) Social Sciences ; (6) Fine Arts ; (7) Moral and Metaphysical Sciences; (8) Literature. This very elaborate programme proved a little impracticable, and it is not to be wondered at that only a single candidate offered himself for examination in March 1854. The promoters of the movement were not, however, discouraged ; the scheme was remodelled, principally by Dr. Booth, and in 1856 an examination of 62 candidates was held at the Society's house. The subjects of this first examination were: (I) Book-keeping; (2) Arithmetic ; (3) Algebra ; (4) Mensuration; (5) Geometry ; (6) Mechanics; (7) Chemistry ; (8) Animal Physiology ; (9) Botany ; ( I0) Agriculture ; (I I) Geography ; (1 2) Physical Geography; (13) English History ; (14) English Literature ; ( 5 ) Latin and Roman History ; (16) French ; (17) German; (18) Freehand Drawing.

In the following year, 1857 , the first attempt at provincial examinations was made, and an examination was held at Huddersfield, as well as in London, the examiners of the Society going down for the purpose. The 
desire of increasing the number of examination centres and the obvious impossibility of sending examiners simultaneously all over the country, led in 1858 to the elaboration of the system of local committees to supervise examinations worked from a single centre.

The system thus started has been developed and modified in the course of the sixty years which have passed since it was first devised, but in principle it remains unaltered. The numbers examined are now (1913) nearly 30,000 , the character of the examination has changed, the subjects have been altered from time to time, but in the method and general system there has really been no change whatever. Of this system, it may suffice to say that the examinations are conducted simultaneously at a number of different centres throughout the kingdom, through the agency of local examination committees established for the purpose by the Society. The papers in each subject are sent down in separate envelopes to the secretary of the committee immediately before the day of examination. The envelopes are opened in the presence of the candidates, and the papers distributed. The worked papers are sealed up at once and dispatched to the office of the Society. They are then distributed among the various examiners, who report upon them, and the results are published.

It is, however, proper to say that the Society of Arts cannot claim the sole credit of the invention of the system of local examinations. In 1850 the College of Preceptors (established in 1846) was considering the best means of examining the schools of its members. It commenced by sending down examiners, its first school examination having been held in December 1850 at Nottingham, but in 1853 the experiment was tried of collecting pupils to a centre and examining them by means of papers sent down from London. The experiment proving successful, the system was regularly organised in the following year, I 854 , and has been continued ever since.

It will be seen that the College of Preceptors' examinations preceded those of the Society of Arts by two years, but the objects, the conditions, and the methods of the 
two systems have been so different that there has never been any but the most friendly rivalry between them. The College examinations were school examinations, whereas those of the Society were intended for students of all ages, but especially for those beyond school age, and a special organisation had to be devised for carrying them on. In 1856 a conference was held at the Society's house between representatives of the two bodies, the College being rather afraid that the Society's examinations would interfere with their own. It was soon apparent that the two systems were intended to occupy different ground, and were not likely to affect one another. In practice this has proved to be the result, and it has never been found that they have interfered in the least with one another.

The Society's methods had many imitations. The University local examinations were established in 1858 . They deal with a class quite different from the classes for whose benefit the Society's examinations were intended, and have always been of a distinctly higher standard. The beginning of elementary drawing examinations by the Department of Science and Art was about contemporaneous with the Society's examinations, and when those examinations were regularly established, drawing was struck off the Society's list in 1860 . The Science examinations began in I 859 , and as these developed it was found that the Society's examinations were in many respects competing with those of the Department. The same candidates were being examined in the same subjects, and there was an evident waste of power. In 1870 this led to the abandonment by the Society of seventeen out of the thirty-six subjects then included in its programme.

At the time when the Socicty's examinations were started, there was no doubt as to the value of examinations as a means of education, or as a test of fitness for any employment, especially employment by the State. In I 854 a stringent qualifying examination was introduced for the Home Civil Service, and in the following year (1 855 ) the first competitive examination was held for appointments in the Civil Service of India. Such examinations were 
regarded as the only alternative to patronage and jobbery on the one hand, and as providing the only opening for deserving merit on the other. After half a century the pendulum has swung back, and we have now arrived at the stage of reaction against over-examination, although it is quite certain that no other remedy against the evils of patronage in the disposal of minor Government appointments has yet been discovered. Perhaps it may come to be recognised that examinations answer well enough as a rough test or for sorting men into classes. If thirty or forty clerks are wanted for a Government office and there are 100 or 150 applicants, it is certain that the men at the top of the list will, on the whole, be the best, though one or two who might have special qualifications will be rejected.

When it comes to selecting men for special posts, examinations are not very satisfactory, and this has got by now to be generally admitted. Such, however, was not the case in 1853 . The evils of the old system were evident and obvious; the drawbacks to the new had yet to be discovered, and so it was naturally regarded as a panacea for all existing ills.

Apart from their value as an impartial method of distributing State patronage, there are two points in which examinations have, or may have, a value-first, as a test of knowledge; and, secondly, as an incentive to the acquisition of knowledge. As to their value as a genuine test of knowledge, it is rather difficult to form an opinion. They can only test the information there is in the candidate's head at the moment, and in too many cases that information has acquired but a temporary resting-place there. An examination is, probably, a better test of a candidate's power of acquiring knowledge than it is of the amount he possesses, and perhaps that may be considered as an argument in its favour. As a matter of fact, the question cannot be answered in general terms. Perhaps no better test need be desired of a man's mathematical knowledge than the mathematical tripos at Cambridge. On the other hand, an elementary examination in physics or chemistry, or indeed in most other subjects, offers but 
a poor means of estimating the real amount of knowledge possessed by a candidate. But it must always be remembered that on the whole a student who has passed an examination is probably a little better informed and a little better instructed than one who has failed, and if the possession of an elementary certificate does not amount to a great deal, at all events it means something.

As an incentive to the acquisition of knowledge, it is evident that the present system of examination has its value; its enormous extent alone is sufficient to show that. There are very few such earnest students as to be satisfied with the acquisition of knowledge for its own sake, and in the case of most people, especially of young people, an artificial stimulus is required. This stimulus, it is found, can very satisfactorily be provided by hallmarking those who have passed an examination, and allowing them to bear some special title-as "Dr." or the like-or permitting them to attach certain initials to their names.

There is, therefore, a good deal to be said in favour of general examinations, although there is also a good deal to be said against them on the score of the superficiality of the knowledge that they tend to produce, and on account of the very erroneous idea that has been disseminated that the fact of a student having passed an examination affords much proof of his possessing a knowledge of the subject in which he has been examined.

It was not very long before the general system of the Society's examinations took definite. shape, and they assumed the commercial character they have ever since maintained. The institutions through whose agency the examinations were held, were originally intended for the benefit of the artisan class, but as they developed they drew their members more and more from middle-class folk, and adapted whatever education they provided to the needs of clerks and professional people rather than to those of work-people. Naturally the examinations were affected by the same influences, and their character was modified accordingly. The non-commercial subjects were gradu- 
ally dropped out, and subjects which were considered to have a distinct commercial value were introduced. ${ }^{1}$

It has always been a question whether the system adopted from the beginning by the Society, of holding separate examinations in separate subjects, is the best, or whether it might not be better to classify the subjects, and only issue certificates on the result of an examination held in a number of specified subjects. The experience of the Society certainly shows that the system of separate examinations is the more popular, and there is much to be said as to its actual merits. The arguments in its favour were very strongly put by Professor Huxley many years ago in an address which he delivered on the occasion of the opening of the Johns Hopkins University at Baltimore. He said : "It [the system of separate subject examinations] allows the student to concentrate his mind upon what he is about for the time being, and then to dismiss it. Those who are occupied in intellectual work will, I think, agree with me that it is important, not so much to know a thing, as to have known it, and known it thoroughly. If you have once known a thing in this way, it is easy to renew your knowledge when you have forgotten it; and when you begin to take the subject up again, it slides back upon the familiar grooves with great facility." 2

When the scheme was first started, a very strong Board of Examiners was formed, including amongst others such names as the following: Sir George Airy, the Astronomer Royal; Dr. Temple, then Headmaster of Rugby, and afterwards Archbishop of Canterbury; Dr. Vaughan, Headmaster of Harrow, and afterwards Dean of Llandaff and Master of the Temple; Dr. Liddell, Headmaster of Westminster, and afterwards Dean of Christchurch; Dr. William Sharpey, for long Secretary of the Royal Society ; William Spottiswoode, afterwards President of the Royal Society; Canon Moseley, one of the first Inspectors of Schools; Richard Dawes, Dean of Hereford; Harvey

${ }^{1}$ Book-keeping first appears as a separate subject in 1859 . Before that date it was included in arithmetic. Shorthand was introduced in 1876 , and typewriting in $\mathrm{I} 89 \mathrm{I}$.

${ }^{2}$ Huxley's American Addresses (1877), p. I 16. 
Goodwin, Dean of Ely, and afterwards Bishop of Carlisle ; Charles Neate, the well-known economist and political writer; Robert Hunt, the Keeper of Mining Records; (Sir) E. G. Creasy, the historian, author of the Fifteen Decisive Battles of the World; and Professors W. B. Carpenter, A. W. Williamson, Bartholomew Price, Baden Powell, and T. M. Goodeve.

At first the control of the examinations was left entirely in the hands of this Board; but the arrangement was not found a wholly satisfactory one, and it was thought better that the Council should take over the direct management. Accordingly the Board was superseded in 1857 , after which date the examiners were paid a fee. Previously their services had been honorary.

Until the introduction of a competitive examination for posts in the Civil Service it was a not uncommon practice for Ministers to place at the disposal of the Society a few appointments in their Departments, and from their first establishment down to the year 1864 a good many clerkships in Government offices were thus obtained by candidates in the Society's examinations.

To the examinations in 1858 fifty-eight institutions sent up 288 candidates; in the following year there were 480 ; in 1860,586 . The numbers increased steadily till 1865 , when there were 1899 ; the next year showed a slight diminution, and then there was a further increase, till the number of 2160 was reached in 1869 . This was the largest number examined under the original system.

In 187 I, when the Council was considering the establishment of a system of technological examinations, of which an account is given below, they passed a resolution to discontinue the general examinations, but on the application of some of the more important of the Institutions in Union, they rescinded the resolution and determined to continue the examinations for a further period. This was done, on the same system as before, till i 876 , when the programme was revised, and the plan on which certificates were granted was somewhat modified. Previously certificates had been granted for single subjects, but in 
that year a "Commercial Certificate" was established in addition, to take which it was necessary to pass in at least three subjects. Very few of these certificates were ever taken, the system of single certificates for single subjects being more popular and better suited to the needs of the class of students who take up the Society's examinations.

Before his death in I86I, Prince Albert offered a prize of twenty-five guineas to the candidate who obtained the largest number of first-class certificates in four consecutive years (including the year of the award). This was first awarded in 1862 , and after his death the prize was continued by Queen Victoria. It was awarded annually under the title of the "Prince Consort's Prize" up to I 879, when the proposed abandonment of the examinations referred to below unfortunately led to its discontinuance.

In 1879 the question of abandoning the examinations again arose, it being thought that the ground was covered by other agencies. To quote from the report of the Examination Committee in 1879 :-

"The Committee feel that the time has now come when the Society should cease to compete with other educational agencies more influential in the work of examination. With the Education Department examining millions of children in elementary schools, and thousands of young persons in night classes; with the Universities holding their local examinations throughout the country for young persons of a higher class; with the Science and Art Department examining students in every branch of science and art ; with the new City Institute developing yet further the technological examinations just handed over to them by the Society; with other agencies, such as the College of Preceptors, doing kindred work, the Society of Arts may well retire from the field, having in all these various directions acted as pioneer. It held science examinations before the Science Department, examinations in literature before the Universities went afield to meet the classes who could not go to Oxford or to Cambridge. It has seen the system it established develop, with the aid of Government funds, as it could never have grown without such help, and the time has now arrived 
when it may cease to compete with the agencies it has done so much to foster."

In pursuance of the course recommended in this report no examination was held in $188 \mathrm{I}$, but again some of the institutions where the examinations were held protested, and on further consideration it was determined to continue the examinations, but to try whether they could not be made self-supporting. Hitherto they had been free. In 1882 a fee of $2 \mathrm{~s}$. $6 \mathrm{~d}$. was charged to each candidate, and this charge has since been continued. The "Commercial Certificate" was abandoned and the old system was resumed of giving a separate certificate for each subject. The natural result of fees being charged was a considerable falling off in the numbers examined. In I 882 only 695 papers were worked as compared with 2325 in 1880 . The numbers, however, soon began to increase again. In 1890 there were 2474 ; in 1895,5108 ; and in 1900,9808 . This very considerable increase was doubtless to a great extent due to the facts that the County Councils had, by the Technical Instruction Act, I 889, been placed in possession of large funds available for the promotion of technical education; and that certain commercial subjects were scheduled by the Science and Art Department as subjects coming within the scope of the Act. The commercial subjects so scheduled were precisely those in which the Society of Arts examined.

In addition to its Commercial Knowledge Examinations, the Society conducted, from 1856 to I 894 , Elementary Examinations. These were of the same character as the general examinations, but much simpler. They were really carried on by the district unions and local boards in connection with the Society. All the Society did was to supply identical examination papers, the results being examined and certificates awarded by examiners appointed by the local boards. The Society supplied the certificates, but accepted no responsibility as to their award. The system, though useful at its first establishment, was never found to work in a very satisfactory manner, and in 1895 it was abandoned. 
There was, however, always a demand for examinations of a more elementary character than the general examinations, and in consequence elementary examinations in modern languages (French, German, and Spanish) were established in i897. These were fully appreciated, and eventually, in I90I, an elementary or preliminary grade was added, with two classes only, passes and failures. The subjects selected for this grade included Handwriting and Correspondence, Shorthand, Book-keeping, Arithmetic, Typewriting, Commercial Geography, French, and German,-Spanish and Italian were added a year or two later. In the first year in which these Elementary Examinations were held (190I), there were 4458 papers worked in the different subjects, of which 2494 passed and 1964 failed. The percentage of successes and of failures was, therefore, 56 and 44 . There has since been a continuous growth, till in 19 I 2 the numbers reached $\mathrm{I}$ I 448 , with a percentage of $64^{\circ} 99$ successes and $35^{\circ}$ Io failures. It may, therefore, fairly be concluded that the increased numbers have been accompanied by a perceptible improvement in quality.

In 1905 some considerable modifications were made in the general programme. ${ }^{1}$ In the system existing in 1904 there were two grades-Senior and Junior. In the Senior there were three classes, and in the Junior, or Elementary, there was one. For some years past suggestions had been made from various quarters to the Council that it would be desirable to establish a higher grade of examination, which might be taken by more advanced students than those entering for the examinations as they then were. After very careful consideration, and a good deal of correspondence with the local committees, it was determined that the examinations should be arranged under three stages. Stage I. was to be elementary; Stage II., intermediate; and Stage III., advanced. The elementary was to be, as before, a pass examination, and in each of the two upper stages there were to be two classes. It was proposed that the advanced

1 During the preceding ten years, no changes of importance were made. Domestic Economy, which had been in the programme almost from the beginning, was dropped in 1901 . 
stage (No. III.) should practically correspond with the first class of the old Grade II. and the upper part of the second class, while the idea was put forward that the standard should be very gradually advanced. The intermediate stage was made up of the third class and the lower part of the old second class of Grade II.

This system has since been carried on without any alteration, and it has been found to work very well. The advance in the standard has been but trifling, as it was found from the general character of the papers sent in that any considerable elevation of the standard would involve an undue amount of rejections - that is to say, more than a third of the candidates entering. Some new subjects were also added to the advanced stage, the principal of which were commercial law and accounting and banking. A slight change was also made in the fees, those for the advanced and intermediate being left as before at 2s. $6 \mathrm{~d}$., and for the elementary stage the fee was fixed at $2 s$., with a reduction of is. for every subject after the first subject taken up.

The new system resulted in a very large increase of candidates, from $17,77 \mathrm{I}$ in 1904 , to 21,253 in $1905,22,597$ in 1908 , and 28,644 in 1911 . This is the highest number yet reached.

In 1912 the Education Committee of the London County Council took over thesuperintendence of the London examinations, and thus provided an independent local authority responsible for the work previously carried out by voluntary committees. The example is being followed in nearly all the large Provincial centres, and much is hoped from this most recent development. It is, however, at the present time too novel for much to be said about it here.

As regards the practical value of the three sets of certificates, it may safely be said that a certificate of the advanced grade (especially of the first class) may be taken to afford an employer a reasonable assurance of a competent knowledge of the subject (so far as it can be tested by examination) on the part of a candidate for employment who presents it. A certificate of the intermediate grade may be taken as evidence that the person presenting 
it has made a study of the subject and has made some progress in that study. An elementary certificate in the hands of a young person shows that special study of the subject has been attempted, and its successful pursuit looked forward to in the future. It must be remembered that this grade is only intended for young persons of, or just over, school age.

In 1907, at the request of the Army Council, it was arranged that a special annual examination in Shorthand should be held for soldiers at any centre fixed by the Army Council at any place in the Empire. Such an examination has been held every year since. The number of centres has generally been about twenty-five; they have been situated in the United Kingdom, India, South Africa, Egypt, and Malta. The average number of candidates is between sixty-three and sixty-four, of whom 75 per cent. pass. This is much above the average of shorthand examinations. There are also a good many soldier shorthand writers who hold certificates obtained at the Society's ordinary examinations.

In 1908 and 1909, also at the request of the Army Council, a similar examination for soldiers in Typewriting was carried out. All the work was good, but the entries were not sufficiently numerous to justify the expenditure, the cost of printing the necessary papers for such a subject for a few candidates being relatively considerable, and so the examination was discontinued.

The Technological Examinations, referred to on page 432 , were instituted in 1873 at the suggestion of Sir John Donnelly. Some account of their origin will be found in Chapter XX. ${ }^{1}$ These examinations were intended to test the knowledge possessed by artisans of the subjectmatter of their respective industries. It was arranged that they should be held in connection with the May examinations of the Science and Art Department, the technological papers being given out with those of the Department. Before a candidate could obtain a certificate, he was required to pass the Department's examination in certain specified science subjects, these varying according 
to the technological subject taken up. Certificates of three grades were given-elementary, advanced, and honours-corresponding with those of the Department examination. No attempt was made to test practical skill, but each candidate was required to produce a certificate from his employer in which his competence was stated. The number of candidates was never great. In the first year ( 1873 ) only six entered, and the numbers gradually increased to 68 in 1870 , and 184 in 1878.1

In 1879 , on the foundation of the City and Guilds of London Institute, the Technological Examinations were handed over to that body. From the funds placed at its disposal by the City Companies the Institute was able to offer to teachers payments on the results of the examinations like the grants of the Science and Art Department. Teachers were thus enabled to form classes and to send pupils in for the examinations, and a large increase in the number of candidates took place. These examinations now form an important part of the Institute's work, and attract annually a very large number of candidates. In I 9 Io the number examined was 24,508 . Large additions have also been made to the list of subjects, which now numberseventy-five. Nogreatchangehas been made in the general character or system, which remains much the same as that proposed by Sir John Donnelly, but the details have been considerably modified, and, in some cases, a practical examination, to test handicraft skill, has been provided.

In I 889 an attempt was made to establish a system of examinations in "Practical Commercial Knowledge." Syllabuses for two subjects, "The Commerce of Food" and "The Commerce of Clothing," were issued, but no candidates came forward, and after a second year's trial, the proposition was dropped.

A question which had been for a long time before the Council was the holding of viva voce examinations in

${ }^{1}$ The following were the subjects included in the 1878 examinations: Cotton Manufacture, Paper, Silk, Steel, Carriage-building, Manufacture of Pottery and Porcelain, Gas Manufacture, Glass, Cloth, Silk-dyeing, Wool-dyeing, Calico Bleaching Dyeing and Printing, Alkali Manufacture, Blow-pipe Analysis. 
Modern Languages, and as far back as 1870 suggestions made by Mr. Hyde Clarke for holding such examinations locally, were included in the programme. No definite arrangements were made for holding the examinations ; it was merely announced that if any local board could find a suitable examiner in any modern language, the Society would grant a certificate to any candidate certified by him as proficient. The experiment was tried on a small scale in London, Birmingham, Manchester, Lichfield, and Penzance for six years, 1870 to 1875 , and in that time only fifteen candidates qualified. The languages taken up were French, German, and Spanish. After 1875 the experiment was dropped. ${ }^{1}$

It is quite obvious that no paper examination can be an adequate test of knowledge of a spoken language ; but the difficulties connected with the holding of colloquial examinations simultaneously at a number of different centres for a long time proved insuperable. In 1902 the idea of holding such examinations at the same time as the other examinations was abandoned, and it was announced that examinations in French, German, and Spanish would be held at any date at any of the Society's examination centres where proper arrangements could be made. Portuguese and Italian were afterwards added to the list of subjects. The experiment proved quite successful. In the first year 280 candidates were examined. The numbers rose to $68 \mathrm{I}$ in 1905 , and this has been the highest number reached up to the present time. About 75 per cent. of the candidates are successful, and it has been found on the whole that nearly all the candidates who enter have a very fair colloquial knowledge of the language, while certificates of distinction have been granted to a great many who showed thorough proficiency. No difficulty has been experienced in conducting the examinations satisfactorily.

Although Music was hardly considered as coming properly within the range of the Society's work, it was included almost from the first in the list of examination

1 Journal, vol. xviii. p. 654 ; vol. xix. p. 576 ; vol. xx. p. 604 ; also the examination programmes and lists of results for the years $1870-75$. 
subjects. The Theory of Music first appears in the 1859 programme, the examiner being John Hullah. In that year twelve candidates entered, and the numbers slowly grew to 324 in 1880 . Hullah continued to conduct the examination till his death in 1884 . He was succeeded in the following year by W. A. Barrett, who for some time previously had acted as his assistant. Mr. Barrett carried on the work till his death in 1891 . Sir John Stainer acted for one year (1 892), and in I 893 Sir Joseph Barnby took it on. He acted for three years, and in I $\$ 96$ Dr. W. G. McNaught undertook the work, which he has since carried on. In I 893 a change in the form of the examination was introduced, the subject being divided into two, "Harmony" and "Rudiments of Music." About 700 papers are now worked in the two subjects, a certain number of candidates taking both.

In I 879, at the suggestion of Dr. Hullah, examinations in Practical Music were established-that is to say, examinations at which the actual capacity of students to play an instrument, or to sing, could be tested. For many years these have been held in London only, at a certain specified date, though at one time there were also a few provincial centres. It was intended that these examinations should apply to a less advanced class of candidate than those who entered for the well-known examinations of the Royal Academy of Music, at the time when the Society's system was started, or who now enter for those of the Associated Board of the Royal Academy and the Royal College of Music. It is believed that the Society's examinations have fulfilled their purpose, and have proved a useful means of encouragement to many musical students. Dr. Hullah acted as examiner from i 879 till I 884, and was succeeded by Mr. W. A. Barrett. The work was continued by Sir John Stainer, Sir Joseph Barnby, and Mr. W. G. McNaught. In i 895, Mr. John Farmer was appointed, and he continued to act till I 899, when he was obliged to give up the work in consequence of illness, which, at a later date, terminated fatally. Since his death the examinations have been conducted by Dr. Ernest Walker and Mr. Burnham 
W. Horner, who served as Assistant Examiners to Mr. Farmer.

The numbers examined have never varied within very wide limits. In the first year there were i 7 candidates; the numbers increased gradually to 276 in 1891 , and to 393 in 1895 . The largest number yet examined was 566 in 1900. During the last few years there has been a small but steady diminution. The standard has not varied greatly, but is now (1913) a little higher than it was. The general level of attainment is reported by the examiners to be slightly higher of recent years.

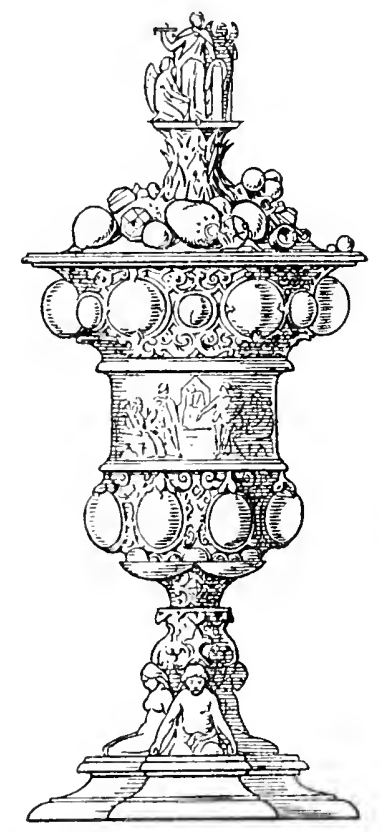

The Swiney Cup (see p. 395). 


\title{
CHAPTER XX
}

\section{The Presidency of King Edward VII.}

\author{
$(1862-1880)$
}

History not carried beyond I 880 -Value of the Society's PublicationsElection of Albert Edward, Prince of Wales, as President-His relations with the Society and his interest in it-His accession to the Throne as King Edward vir.-Presidency filled by Sir Frederick Bramwell-Election of George, Prince of Wales, as PresidentHis accession to the Throne as King George v.--Presidency filled by Lord Alverstone, C. J.-Election of Duke of Connaught as President - Chairmen of Council, I86I-90-Principal Members of CouncilThe Cantor Bequest-Allowance to Dr. Cantor's Mother and Sister-in-Law - The Cantor Lectures-The Society and the Colonies-First Suggestion of a Colonial Section-Formation of Indian Section-African Section, afterwards the Colonial Section, established-Chemical Section-Art Workmanship Prizes-Food Committee-Trevelyan Prize for Food Preservation-Value of the Food Committee's Work-First Applications of RefrigerationFailure to award the Prize-Its ultimate disposal-Technical Education Question raised by Dr. Playfair-Conference and Report of Committee-Technolo ical Examinations-Other Educational Work of Society-Sciool Drill-Memorial Tablets; Suggestions by G. C. T. Bartley; The Society's Tablets; Work taken over by London County Council.

THE final chapters of this book are intended to bring the history of the Society as far as it has seemed desirable to carry it, viz. to the year i 880 or thereabouts, the time when the writer succeeded Mr. Le Neve Foster as secretary. There are obvious reasons for this course, one of them being that it avoids the need for reference to persons still alive. It has not seemed necessary to draw a hard-andfast line, and in a few cases it has been more convenient to carry the history of a subject down to the end of the 
century, or even later. In many others it has appeared better to stop at an carlier date. At all events, it may be taken that this and the next chapter are intended to deal with the Society's principal work in the period of fifteen or twenty years after Prince Albert's death in I86I .

Whether I should apologise for the brevity with which I have treated the various portions of my subject-matter, or for the length to which the whole narrative has extended, I am not certain. It is difficult to realise that I may have erred in both directions.

One portion of my subject I know I have dealt with most inadequately, and that is the vast mass of literature which the Society has published in the form of papers read at its meetings. This publication is the Society's principal duty. Its execution of it is its chief claim to public support, and yet in a history of the Society's labours this department is almost ignored, or left with only occasional reference. But how could it be properly treated ? The first thirty volumes of the Journal, recording the proceedings from i 852 to i 882 , contain the reports of about twenty-four meetings in each year, 720 in all. The 720 odd papers are on the most diverse topics-industrial, economic, social, artistic, scientific, educational, mechanical, fiscal, commercial, hygienic, and who shall say how many other divisions of human polity.

The Society might take for its motto the old Terentian tag, Humani nithil a me alienum puto. It never refused a hearing to anybody who had fresh information to give on any subject likely to be beneficial to human progress or human welfare. The mere list of the titles of the papers occupies nearly fifteen pages (large pages and small type) of the amalgamated indexes to the Journal. A summary of their contents would easily fill a volume, and, as any reasonable summary is hopeless, it has seemed better to be content with a general reference to the vast mass of information available in the Journal ${ }^{1}$ for the

${ }^{1}$ In the first address which, as Chairman of the Council, he delivered to the Society in I 890 , the present Lord Chief Justice, I.ord Alverstone, referred to "the mine of wealth as to the history of invention and scientific research which lay stored up . . . in the pages of the Journal." 
student of recent social and economic history, and not to attempt any account of it.

As mentioned before, Prince Albert died in December I 861, and at first the Council considered that the office of President ought not to be left vacant, for at their meeting of I 5 th January they decided that a letter should be sent to General Grey, the Queen's private secretary, " requesting him to ascertain any wishes which Her Majesty may have on the election of a President to succeed the late deeply-lamented Prince Consort."

It was, however, soon realised that there was no need for immediate action, as the letter apparently was not sent to General Grey, and the matter was allowed to rest until near the time of the annual meeting, when, in answer to a letter from the Secretary, General Grey wrote :-

"Her Majesty now commands me to say that, as His Royal Highness the Prince of Wales is not yet of age, and would himself be indisposed, young and inexperienced as he is, to be placed in any office in immediate succession to his great and beloved father, it would not be desirable that he should now be chosen. The best arrangement would probably be to fill up the office for the present in such a manner, should that be possible, as to admit of a reconsideration of the subject on a future occasion."

General Grey's letter was read at the meeting of 12 th June 1862, and the Council accordingly, at their next meeting ( 18 th June), invited William Tooke, the senior VicePresident, to accept the office, and his name was accordingly placed on the balloting paper for the general meeting.

Mr. Tooke was a very old member of the Society, which he joined in 1802 , and he had for many years taken an active part in its administration. He was a solicitor of some eminence, and his firm (Tooke, Hallowes, \& Price) had for long acted as the Society's honorary solicitors. They had carried through all the legal work connected with the grant of the Charter in 1847 . At the time of his election he was in failing health, and he only held office for little more than a year, for he died in September 1863 , two months after his second election to the Presidency. $\mathrm{He}$ was in his eighty-sixth year at the time of his death. 
The Presidency being again vacant, a second application was made to General Grey, who intimated in reply that the Prince would now be willing to receive a formal deputation from the Council. A deputation was accordingly appointed to wait on His Royal Highness with an address from the Council, asking him to accept the Presidency. The Prince consented, saying, in his reply to the deputation, that he accepted the office in the hope "that he might be better able to promote the great and beneficent objects which his dear father had so much at heart, and in which he was so zealously supported by the Society."

It only remained to complete the formalities of election, and for this purpose an extraordinary general meeting of the Society was held at Burlington House on 22nd October I 863, the Society's house in the Adelphi being then under repair. On the motion of Mr. William Hawes, the Chairman of the Council, it was proposed "that His Royal Highness the Prince of Wales be elected a member of this Society," and, this resolution having been unanimously passed, it was further resolved "that His Royal Highness the Prince of Wales be elected President of this Society."

The office to which he was thus elected in 1863 the Prince held for thirty-eight years, until his accession to the throne in r9or. If the aims and objects of the Society did not appeal to his personal tastes in the same way as they did to those of his father, yet he was led, at first by filial affection, and afterwards by his natural capacity for organisation, to pay all necessary attention to the Society's doings, and to devote to its interests as much time and thought as could reasonably be expected from the heir to the throne.

From the earliest years of his Presidency he made it clearly understood that he did not choose to be a President in name alone, but that he expected to be consulted in all matters of importance sufficient to justify their submission to him. This, indeed, was characteristic of him, not only in his relations with the Society, but in regard to the numerous other bodies with which, as time went on, he became associated as President or Patron.

In later years, when his time was more occupied by 
the numerous demands upon it, he was not able to give so much attention to the institutions with which he was associated; but from the time he assumed the Presidency until the date of his accession, it may safely be said that no new action of any importance was ever undertaken by the Council without its being submitted to the Prince for his consideration and approval. Furthermore, it may be added that such advice as he cared to give was generally well worth taking, for he was gifted with great natural shrewdness and sense, as his subjects fully realised when he became King in after years.

The Albert Medal of the Society was never awarded without the names being submitted to him, and his final choice of the selected candidate was always more than a nominal one. The Medal was regularly presented by him personally in the presence of the members of the Council, who attended for the purpose at Marlborough House.

In 1887 , when the Albert Medal was awarded to Queen Victoria "In commemoration of the progress of Arts, Manufactures, and Commerce throughout the Empire during the fifty years of her reign," the presentation was made to the Queen by the Prince at Buckingham Palace, in the presence of the Council, on the 8th March 1888 .

After his accession, the Medal was awarded to King Edward, " in recognition of the aid rendered by His Majesty to Arts, Manufactures, and Commerce during thirty-eight years' Presidency of the Society of Arts, by undertaking the direction of important exhibitions in this country, and the executive control of British representation at international exhibitions abroad, and also by many other services to the cause of British industry." In accepting the medal he expressed the gratification which the award gave him, and it was clear that he was genuinely pleased.

When, on his accession in $190 \mathrm{I}$, he, of necessity, vacated the Presidency, he became the Society's Patron, and, indeed, he was the first Patron of the Society ; for though it appears from the old Minutes that on her accession a suggestion was made that Queen Victoria should be invited to become Patron of the Society, that suggestion 
was not acted upon at the time, and, so far as can be ascertained, no application was ever made to Her Majesty that she should accept the position.

It was in his capacity of Patron that in 1908, King Edward granted the Society permission to prefix to its title the term Royal. ${ }^{1}$

After King Edward's accession in I90I, when the date for the election of a President came round, H.R.H. the Duke of Cornwall (afterwards Prince of Wales, and now King George v.) was absent on a journey round the world, so the precedent of 1862 was followed and a temporary President was elected, Sir Frederick Bramwell, the eminent engineer, being selected for the vacant office. Sir Frederick had served every office on the Council, having been Vice-President, Treasurer, and Chairman. On the return of His Royal Highness in the autumn of I90I, Sir Frederick Bramwell resigned, and the Council, on behalf of the Society, invited the Prince to accept the office of President. From that date he continued to act as President till his accession to the throne in 1910 necessitated his abandonment of the office, and he then became Patron.

At the annual meeting of 1910 , Lord Alverstone, C.J., was elected President. He held the office till February I9I I, when he was succeeded by His Royal Highness the Duke of Connaught.

The first Chairman of Council elected after the death of Prince Albert was William Hawes, and, as previously mentioned, he was in office when the Prince of Wales was elected President. Hawes was a capable man of business, and had great experience in the work of society administration, as he was for many years treasurer of the Royal Humane Society, of which his grandfather had been the founder. He was succeeded by Sir Thomas Phillips, and when Sir Thomas died in his first year of office Hawes was again elected, and served for a year. After him came Lord Henry Lennox. He accepted office at the desire of the Prince of Wales, who wished

${ }^{1}$ The first number of the Journal with the new title was that of 3ist January 1908. 
that the chairmanship should be held by a personal friend of his own, so that he might be kept in touch with the Society's proceedings. Lord Henry was a son of the fifth Duke of Richmond, and for long sat in the House of Commons. He held various official posts, including that of Under-Secretary of State for War. His official position often rendered him specially serviceable to the Society, and he became a very popular and useful Chairman. He was thrice re-elected, and so held office for four years. His successor was Major-General Eardley-Wilmot, an officer of singularly high character and of considerable reputation. The next Chairman was Lord Alfred Churchill, the second son of the sixth Duke of Marlborough, who served for two terms-i 875-6 and i878-9. Lord Alfred was devoted to the Society, and gave unremitting attention to its concerns, both during his tenure of the chair and afterwards till his death in 1893. Without any pretence to brilliance, he was a man of much common sense and infinite tact, to whom his colleagues were much attached. The interval between his two terms of office was filled by the election of Major-General Cotton, who was prevented by illness from taking up any of the work of his office, and Mr. Hawes, as deputy-chairman, delivered the opening address of the Session 1877-8. Lord Alfred Churchill was followed by Sir Frederick Bramwell, whose record of service to the Society is certainly second to that of none of his predecessors or successors. He read several papers, and delivered a course of Cantor Lectures before the Society. He constantly occupied the chair at its meetings, and still more frequently took part in its discussions. He served in every capacity on its Council from 1875 to 1893 , and the list of the offices he filled was (as mentioned above) completed by his election to the post of President in 1901, in the interval between the accession of King Edward Vir. and the acceptance of the Presidency by the Prince of Wales (King George v.).

In succession to him (in I 882) came Sir William Siemens, the illustrious inventor, who eight years before (1874) had received the Society's Albert Medal, and thirty-two years before (1850) had been awarded a Society's gold 
medal. ${ }^{1}$ His term of office was cut short by his sudden death, and his place was taken by Sir Frederick Abel, another recipient of the Albert Medal, and a chemist of European fame. Abel's successor was Sir Douglas Galton, who held office for the two years i 886-88. Like his two predecessors, Bramwell and Abel, Galton was a copious contributor to the Society's proceedings. The list may close with the name of the Duke of Abercorn, who was chairman in $1888-90$, and whose death occurred this year (1913).

Many of the members of Council mentioned in Chapter XVI. still took a leading part in the direction of the Society. Amongst others whose work should be recorded are the following: (Sir) Edwin Chadwick was a member of long standing; he was elected in 1847, and served on the Society's Committee of Agriculture before the incorporation, but he did not join the Council till 1868 . From that date till his death in 1890 he exercised considerable influence. As a young man he had been secretary to Jeremy Bentham, and he was saturated with the ideas of that philosopher. His persistent advocacy of sanitation left its mark on his generation, which owed much to his energy, though his methods did not meet with the universal approval of his contemporaries. The valuable service, rendered the Society by Hyde Clarke in the formation of the Indian Section will be referred to later. He also made his influence felt in the conduct of the examinations ${ }^{2}$ and in other matters. Sir Antonio Brady, an active member of the Society for more than thirty years, was the founder of the Bethnal Green Museum. J. Bailey Denton, the wellknown engineer, and a great authority on matters connected with sanitation and water-supply, gave a prize for improved workmen's dwellings. The Rev. William Rogers ("Hang Theology" Rogers), the wise educational reformer and genial humorist, took an active part in the Society's educational work; as also did Sir J. Kay Shuttleworth. Sir Daniel Cooper, well

1 See Chapter XVI, p. 389.

${ }^{2}$ See Chapter XIX, p. 439. 
known first as an Australian statesman and then as representative in this country of New South Wales, took great interest in all the Society's Colonial work. Thomas Sopwith, mining engineer and geologist, was a member of the Society from 1843 to 1879 , and of the Council from 1858 to 1864 . Sir Charles Trevelyan, the distinguished Indian administrator, took an active part in the work of the Indian Section. All the above were working members of the Council between 1862 and 1870 . Later on there were others who became more prominent ; Captain (later General) Sir John Donnelly, Sir Henry Cole's successor at South Kensington, devised the system of technological examinations, since widely developed by the City Guilds Institute. He became Chairman of the Council in I 894. (Sir) George Bartley, Sir Henry Cole's son-in-law, afterwards M.P. for Islington, first suggested the erection in London of memorial tablets to distinguished men, and helped to carry the proposal into effect. Andrew Cassels, a member of the India Council, gave great help towards the establishment of the Indian Section. (Sir) Robert Rawlinson, the eminent sanitarian, read his first paper to the Society in 1858 and his last in 1889. Colonel Strange was the constant and trusted adviser of the Council in all scientific matters. Admiral Ryder was responsible for the valuable report on lifesaving appliances issued in I 879. ${ }^{1}$ (Sir) Benjamin Richardson gave the Society several of his brilliant addresses on hygienic subjects. Sir Philip Cunliffe-Owen, the popular organiser of international exhibitions, joined the Council in 1879 , but his work upon it was of later date. Francis Cobb, if he was not well known oustide the Society, was highly esteemed within it for his constant and ungrudging service. These-though many others might be mentioned-were the principal organisers of the Society's multifarious work during the period under review.

The first intimation of the Cantor bequest was made known to the Society in November i 860 , when a letter was received from James Welch, the Administrator-General of

${ }^{1}$ See Chapter XXI, p. 494. 
Fort William, Bengal, who in that capacity had been named executor of the testator's will, stating that Dr. Edward Theodore Cantor, who had died a few months before, ${ }^{1}$ had bequeathed his property in equal shares to the Society and to Wellington College, declaring it to be his desire that the moneys so given should be applied by the President of the Society and the Governors of the College respectively, in such manner as they should deem most conducive to promote the objects of the Society and of the College.

Dr. Cantor was a surgeon in the Indian Medical Service and was Superintendent of the lunatic asylums at Bhowanerpore and Dallunda of Fort William, Bengal. It does not appear that he was ever a member of the Society.

The bequest was not paid over until i 862. A technical difficulty arose because the money was left to the President, and in January of that year the Society was without a President. This, however, was settled by the agents of the administrator of the will consenting to accept the acknowledgment of the treasurers pending the election of a President, and in February the amount of $£ 5042$ was paid over, and was invested in India 5 per cent. stock. In the meantime, in November I86I, an appeal was made to the two legatees by Mrs. Cantor, the mother of the testator, who had been greatly dependent on her son, and was at his death left very badly off. The Governors of Wellington College gave her $£ 50$; but the Council of the Society replied that, as the estate had not been distributed, they could not make any promise for the time. It appeared that Mrs. Cantor was a Danish lady, living in her own country, and that her son had allowed her $£ 35$ a year. Inquiries were made at the Danish Legation, and her appeal was supported by the Minister. The matter was discussed with the authorities of Wellington College, and it being ascertained that she would be well satisfied with an allowance of $£ 50$, it was agreed that this amount should be given her, the College and the Society each paying half. The allowance was continued until the lady's death in 1867 . Nine years after this, in 1876 , an application was made to the

${ }^{1}$ The date of the will was 3 rd March 1859, that of probate 3 Ist May 1680.-Council Minutes, 7 th November 1860. 
Society by the widow of Dr. Cantor's brother, who was in reduced circumstances, and a grant was made to her of $£ 25$ a year. This was continued until she died in 1883 .

Some consideration was given as to the best way of disposing of the money, and eventually it was determined to expend it upon courses of lectures on industrial technology. Thus the Cantor Lectures were started, very much to the advantage of the Society and the promotion of the interests it was founded to assist. These courses of lectures have been delivered regularly from i 864 down to the present date, the greatest number of lectures in any one session having been eighteen. With a very few exceptions, all the lectures have been published in the Journal, and afterwards in separate form. Many of them have besides been developed into standard works on the subjects with which they dealt. The whole series may be said to form an encyclopædia of information on matters of industrial technology, since there are very few important industries which have not at one time or another formed the subject of a course.

The first series delivered was one on "The Operation of the Present Laws of Naval Warfare on International Commerce," by Dr. G. W. Hastings. It must be admitted that the subject does not appear to be a particularly suitable one. But it is to be remembered that at the time (i 864) the American War was being carried on, and the various points of international law raised by a maritime war were then of pressing urgency. The two other courses given in the same session, on "Fine Arts Applied to Industry," by Mr. W. Burges, the well-known architect, and on "Chemistry Applied to the Arts," by Dr. F. Crace Calvert, were certainly very much more suitable, and, as a matter of fact, it is stated that they attracted very much larger audiences.

It may be worth while to mention a few of the more important courses which were delivered before the end of the period with which this chapter deals. Besides his first course, Dr. Crace Calvert gave three others, all dealing with practical applications of Chemistry. The applications of Geology formed the subject of a course by Professor 
Ansted in 1865 . In the following year Professor Fleeming Jenkin lectured on Submarine Telegraphy. In i 867, Dr. John Hullah gave a course on Music and Musical Instruments, and Richard Vestmacott, R.A., one upon Sculpture. In the following year Dr. (afterwards Sir) W. H. Perkin lectured on Aniline and Coal-Tar Colours. In 1869, and in 1874 there were courses on Spectrum Analysis by (Sir) Norman Lockyer. Professor A. W. Williamson lectured on Fermentation in 1870 , and in the same year Professor Barff gave a course on Artists' Colours and Pigments, the first of many courses which he delivered here. Special interest attaches to this series, because it led to the appointment of a Professor of Chemistry by the Royal Academy, Professor Barff himself being the first holder of the post. In I 874, Dr. Charles Graham gave a long course on the Chemistry of Brewing-these lectures have become a classic on the subject. Other courses deserving mention are those by (Sir) Frederick Bramwell on the Steam Engine in 1875 ; by (Sir) William Preece on recent advances in Telegraphy in 1877 (the first of many lectures given to the Society by Sir William); by A. Vernon Harcourt, on the Chemistry of Gas Manufacture in 1877 ; by (Sir) Benjamin Ward Richardson on Alcohol in 1875 ; and by Dr. W. H. Corfield, on the Sanitary Construction of Dwelling-houses in 1879 .

The history of the early association of the Society with the Colonies was given in an earlier chapter. ${ }^{1}$ After the incorporation of the Society, the new Council, when it was first formed, was perhaps too much occupied with its own domestic matters to pay much attention to Colonial business. So it was not until the $185 \mathrm{I}$ Exhibition attracted to London a large number of Colonial visitors-amongst them many Colonial Governors, some of whom were made honorary members of the Society-and thus once more brought Colonial affairs to the front, that the Society again began to devote special attention to the Colonies.

At the instance of the Society, the Secretary of State, in April 1852, sent out a dispatch in which the British Colonies were invited to form Associations in connection

${ }^{1}$ See Chapter IV, p. 83. 
with the Society ; and, in response to this appeal, a certain number of such Associations were formed, some of which are even now in existence. But the dispatch does not seem to have had a very great effect.

A little later on, the Society endeavoured to include Colonial Institutions in the Union of Institutions, which was then being formed, and the Journal for 2 ist December I 855 contains a notification that the Council desired to include such institutions, and states the terms on which they could be admitted. In return for the usual subscription of two guineas, the Council offered to represent Colonial Institutions in London in business matters, to receive any of their members who were visiting London, and to give such visitors the privilege of temporary membership, to purchase books for their libraries at reduced rates, and to establish centres for the examinations in the Colonies. A certain number of Colonial Institutions joined the Union on these terms, but the response was not very great, and the number of such Institutions does not appear at any time to have exceeded sixteen. In i 860 there were fifteen Colonial Institutions on the list, and from this date the numbers fell away.

In I857, however, a proposition, which had much greater effects in the future, was made by Mr. Hyde Clarke, who wrote to the Council suggesting that "a special section be formed for India, another for Australia, one for English America, and so on." It was suggested that the Indian Section should meet once a fortnight, and the Australian once a month, for the reading of papers. The subjects suggested were " railway extensions, irrigation, canals, European colonisation, tea cultivation, fibre products, the iron manufactures, and the copper mines." Mr. Hyde Clarke also laid considerable stress on the "non-existence of a Colonial centre in London."

The letter was published in the Journal of i 5 th May I 857, and a committee was appointed to consider the matter. Nothing, however, was really done. This was no doubt due to the fact that Mr. Hyde Clarke shortly afterwards left this country for Smyrna, where he resided 
for some time. Ten years later he returned to England, and in 1868 he renewed his proposal, but only proposing the formation of a committee which should organise conferences on Indian subjects. This time the suggestion was taken up more warmly. Hyde Clarke himself was placed on the Council, and the Indian Conferences, which soon developed into the Indian Section, were started. Previous to this date there had been occasional papers read on Indian matters; but from I 869 onwards, when the Indian meetings began with a paper on Indian tea by Mr. C. H. Fielder, read on 12 th March in that year, the Indian Section has continued its regular work. There were eight meetings in 1869 and four in 1870 . The number of meetings held each year from that date down to the present time have varied a little, but there have never been less than five or more than seven.

The Indian Section thus established became a most important department of the Society. It lias had great results in India by spreading information in that country as to the directions which the development of Indian manufactures and Indian products could most usefully take, and in this country by giving similar information as to the industrial resources and progress of India itself. The Section has received great help from the Indian press and it has in return been of service to the Indian press in supplying useful information to it. It has been of great value to the Society itself as the means by which many members have been added to its list, so that in fact, thanks to a very large extent to the work of the Indian Section and of the allied section for the Colonies, a large proportion of the present number of members come from the dependencies of the Empire abroad.

The continued success of the Indian Section led to the establishment in 1874 of the African Section, and this also was due to a very large extent to the efforts of Mr. Hyde Clarke. Five years later, in 1879 , it was enlarged and became the Foreign and Colonial Section; and in r 1901 it was altered into the Colonial Section, under which title it has been continued to the present time.

It will be seen, therefore, that Hyde Clarke's original 
suggestion of more than fifty years ago has eventually been carried out, and with remarkable success. Something might be said on behalf of the scheme in its original form, in which separate sections for the various portions of the Empire were proposed. But it is to be remembered that soon after this idea was put forward, the Royal Colonial Institute was established, and since its foundation, in 1868 , it has carried out to the full the work which it was suggested in 1857 that the Society of Arts might do, especially the formation of a Colonial centre in London. There was no question that a separate Institution, devoting itself entirely to such work, could carry it out more effectually than the Society of Arts with all its different aims and objects could hope to do, and this has in practice proved to be the case. Still it has been found that there was an abundance of opportunity for the two institutions, both of which have, it is to be hoped, carried on work which has been useful to the Colonies.

The growing importance of industrial chemistry led to the establishment in 1874 of a special Chemical Section for the discussion of subjects connected with practical chemistry, and its application to the arts and manufactures. The Section was opened with an introductory address from Dr. Odling, then President of the Chemical Society, who dwelt not only on the industrial importance of applications of chemistry, but on the assistance which those applications had rendered to the growth of chemical knowledge. It was arranged that six papers should be read every session, and among the list of contributors are to be found not only men of considerable reputation at the time, but also many who have since made a reputation for themselves. ${ }^{1}$

In 1879 the scope of the Section was enlarged so that it might include matters connected with applications of physical science to the Arts. It continued its successful work for twelve years, until i 886, when its success led to its own extinction, for it had resulted in the formation of

${ }_{1}$ The first Secretary of the Section was Thomas Wills, a promising young chemist who died in 1878 in his twenty-eighth year. 
the Society of Chemical Industry, founded in $188 \mathbf{1}$, the Institute of Chemistry having also been established in I 877, a few years after the Section was started. The Council came to the decision to discontinue the work of the Section, the reason for this action being given in the following extract from the annual report of i 887 :-

"Since its establishment, the Section has fully carried out the intentions of those who advised its formation, for it has been the means of bringing before the Society, and, through the Society, before the scientific public, many very valuable applications of science to practical purposes. Looking back at the list of papers which have been read before it, it will be seen that many of the most important of the communications to the Society during the time found a place in this Section. Since its formation, however, two independent societies-namely, the Institute of Chemistry and the Society of Chemical Industry-have been specially established for the purpose of carrying on the work to which the Section was originally devoted; and it appeared to the Council that the Society of Arts having, as in so many other cases, originated a movement of considerable public importance, might, as the work grew, leave it in the efficient hands of the above-mentioned Societies." 1

In the early part of i 863 the Society of Wood-Carvers ${ }^{2}$ applied to the Society of Arts to assist them in holding an exhibition of wood-carving, in connection with which prizes were proposed to be offered. The Council agreed to allow the use of the Society's rooms for the exhibition, and also offered a silver medal and a grant of $£ 30$. This amount, with a contribution of $£ I 5$ from the Wood-Carvers, was distributed in prizes to workmen, and the exhibition was duly held.

Its success led to a proposal for a series of Art workmanship prizes, and later in the same year the Council

1 Journal, vol. xxxv. p. 775.

2 This was a small society of working wood-carvers that was carried on successfully for a good many years in rooms in Bloomsbury. It came to an end about the beginning of the present century. 
offered prizes, amounting altogether to $£_{1} 62$, for modelling, repoussé work, hammered work, carving, chasing, enamel painting, painting on porcelain, and other subjects. In the following year the scheme was a good deal developed, and prizes amounting to $£ 623$ were offered in a larger number of subjects for productions from prescribed designs. A list of subjects for competition was drawn up with considerable care. It included carving in various materials, metalwork, etching and engraving, enamel painting, painting on porcelain, decorative painting, inlaying, cameo-cutting, engraving on glass, wall mosaics, gem engraving, die-sinking, glass-blowing, book-binding and leather work, and embroidery. The examples selected were mostly in the South Kensington Museum, but some were in private possession. Reproductions of them in the form of lithographs, photographs, or casts were provided at prices in most instances not exceeding a shilling. There was also a division for works to be executed without prescribed designs.

The offer was continued annually up to the year 1870. The total annual amount offered in prizes varied up to $£ 666$, but the money awarded never in any one year reached $£ 300$, and was in several years under $£$ ioo. Although this seems a sufficiently good result, the Council at the time appear to have been disappointed. The prizes certainly were popular, as is shown by the fact that when a surplus was obtained by the North London Exhibition in 1864 , an amount of $£ 157$ was handed over to the Society to be added to the prize fund.

In the Council Report of i 870 an announcement was made that these prizes would be discontinued "for the present," and that special prizes would be offered for objects of art workmanship to be exhibited at the International Exhibition of 1871 , then being organised by the I 85 I Commissioners at South Kensington. Such special prizes were accordingly offered in the form of medals for manufacturers and designers, and money prizes to the workmen employed. The articles which received prizes were to be shown in the exhibition, and it was a condition of exhibiting that the names of all engaged in 
the production of the works should be sent in. Seventyfive such articles were submitted, and silver medals and money prizes to the amount of $£ 200$ were awarded. ${ }^{1}$

In announcing the discontinuance of the ordinary Art workmanship prizes, the Council expressed their regret that, in spite of the large amount of prizes offered, there was still wanting anything like an adequate response on the part of manufacturers, designers, or workmen, the result being that though the articles rewarded were of a very satisfactory character, and showed great skill and taste, yet the competition was small, and the amount of money awarded far less than the offered total. The hope was also expressed that the annual exhibitions of industry would sufficiently encourage Art workmanship, and would, therefore, take the place of the Society's prizes. It is hardly necessary to say that these expectations were not realised.

On the whole, it seems certain that these prizes, with the accompanying small exhibitions, served a useful purpose, and helped to encourage the workers in artistic industries. Some disappointment was expressed in various quarters at their discontinuance, and if at the time they were not popular with employers, they were certainly appreciated by the workmen themselves. It is quite possible that the real cause of their discontinuance was a desire on the part of the Council to concentrate the Society's efforts on the projected series of exhibitions.

The problem of food supply seemed to be specially urgent in the middle of the last century, or at all events its urgency was very generally realised. The population had increased, and was increasing, at a rate far outstripping the growth of the national resources of the kingdom, and the means of supply from foreign countries had not yet been developed. Of actual food-stuffs it may be said that only cereals were imported. Dead meat could not be conveyed for any distance, while the trade in cattle was limited, and confined to European countries. The importation of canned meat had been introduced, but as yet

1 See Chapter XXI, p. 486. 


\section{0}

only on a small scale. Imported fresh fruit was practically represented by a single sort-the orange. Salted and dried fish were regular articles of trade, as they long had been, and so were salt beef and pork; but even of these the bulk was supplied from domestic sources.

It was a realisation of this state of things that, in 1866 , led the Council to appoint a committee "to inquire and report respecting the food of the people," with special instructions to investigate methods for "the production, importation, and preservation of substances suitable for food." In the words of the authors of the most recent book on the subject, ${ }^{1}$ the appointment of this committee was the "most practical step in the direction of providing a more ample food supply" which had yet been taken, and the committee did much useful work, though its labours were not quite so successful as they might have been.

A proximate cause for the nomination of the committee was the offer by Sir Walter Trevelyan of a sum of $£ 70$ to form a prize for the discovery of a process for preserving fresh meat, the prize being specially intended to encourage the preservation of meat "in countries where it is now almost valueless." Later on, in 1872, Sir Walter added another $£ 30$ to his offer, making the total sum available for the prize $£ 100$.

Some years before, in 1856 , the same gentleman had given $£ 100$ for a prize for an essay on the utilisation of seaweed ; but, though the prize was offered, the response was unsatisfactory, and no award was made. The money was then applied to the more practical object of encouraging the preservation of meat.

The committee met for the first time in December I 866, and it continued its useful labours for fifteen years. Though one of its duties was to award Sir Walter Trevelyan's prize, this was only a part of its work, its main object being to accumulate and disseminate information on the best means of increasing the available food supplies of the country. Its members took a wide view of their duties

${ }^{1}$ History of the Frozen Meat Trade, by J. T. Critchell and J. Raymond. I9I2. 
and worked at them conscientiously, and if they failed in the first-mentioned object of their efforts, they certainly succeeded in the second and more important part.

The committee collected an enormous amount of information, which was published in successive reports in the Society's Journal. These reports were of great value at the time in directing attention to what was being done for the preservation of food, and they are now of considerable historical interest as a record, which appears to be fairly complete, of the various methods, more or less successful, which were proposed for the preservation and supply of meat before the introduction of cold storage and the importation of refrigerated meat. The committee took a large amount of evidence from experts, inventors, and others, and their reports dealt with almost every variety of food. At that time canned meats were a novelty, and the manufacturers who produced them gave evidence before the committee. All sorts of processes were described, and the results tested. Many of these processes were quite useless, but among the samples shown were some which have since been developed into valuable commercial products. Samples of meat from Australia and South America, preserved in various ways, were examined and reported on, but none proved satisfactory. The importation of live-stock was also considered. The supply of milk and that of fish were among the subjects dealt with by the committee, and they devoted one meeting to the examination of a witness on salmon preservation. In one of their reports in 1867 they suggested a Fishery Exhibition, a proposal which, some years later, was carried into effect with great success, not only in London but in several Continental towns.

In 1868 prizes were offered for railway vans for meat conveyance, and for milk-cans. None of the suggestions for improved vans were thought worthy of reward, but a silver medal was given to the Aylesbury Dairy Company for the best milk-can sent in.

The problem of meat-supply may be said to have been solved in 1879-80, when a cargo of frozen meat was brought to London by the Strathleven, which sailed 
from Sydney on 29th November 1879 , and arrived in London on 2nd February 1880 ; but the results of this experiment were either not brought before the notice of the committee, or were not appreciated as they deserved. It is certainly a matter of regret that this successful experiment met with no award at the hands of the committee-which for so long had done really excellent work in publishing information on the food supplies of the people. However, the value of the discovery was not realised at the time, and the view taken of it is shown by the rather desponding report of $\mathrm{I} 88 \mathrm{I}$, the last issued by the committee, which summed up the situation as follows: "Though numerous methods, more or less successful, for treating meat have been before the committee, the committee have never felt themselves able to select any one as being so far superior to the rest as to deserve the award of the prize; neither have they had from any of those persons who are now engaged in the importation of meat preserved by means of cold from America or Australia, any such precise claim to the credit of the invention as would warrant the committee in thus awarding the prize. The prize, therefore, still remains in the charge of the Society, and the Council would gladly welcome the advent of any process which would justify them in presenting it."

That the committee did not promptly recognise the value of the new experiment is perhaps not remarkable. They had been at work for fifteen years, the personnel of the committee had changed, and probably the interest of the early investigations had flagged. But failure is the more to be regretted since at various times they had before them, and had carefully considered, the question of the preservation of meat by the application of cold. As far back as 1869 they had under consideration Reece's freezing machine, ${ }^{1}$ one of the earliest of the ammonia machines,

1 Reece's machine was the subject of a report by a special committee (Journal, vol. xvii. p. 829). The report, though commendatory, is not wholly favourable. It was also described by Dr. B. H. Paul in his paper on "Refrigeration," read in December 1868 (Journal, vol. xvii. p. 67). 
while throughout their reports references are constantly made to the use of low temperatures for meat preservation. In $1868^{1}$ they "look with interest at the scheme, proposed by influential persons at Sydney, to resort . . . to cold." They say that " the promoters of this plan are understood not to have decided in what form they can most economically provide the refrigeration, which must, of course, be kept up during the voyage by some artificial means." In the following year " they " still look with much hope to the process of preserving meat in cold temperatures," and they mention some experiments "by which they hope to be able to determine the conditions most favourable for the practical appliance to animal and vegetable substances of this mode of preservation."

In the Journal for 24th April i 868, a full report is given of the meeting above referred to, which was held at Sydney in February of the same year. At it Mr. T. S. Mort described the results of his experiments in freezing meat for exportation, experiments which were certainly the foundation of the whole frozen meat trade of the present day. It is probable that this report was supplied by Mr. John Alger, who was present at the meeting, and took an active part in the movement. He had been treasurer of the Society of Arts in 1862, and had gone out to Australia. It is now generally admitted that Mort was beyond doubt the pioneer of cold storage, and if he had lived a few years later (he died in i 878) he certainly ought to have had awarded to him the Trevelyan prize.

After the publication of their rather despondent report in $188 \mathrm{I}$ the committee abandoned any further attempts to discover a suitable candidate for the prize, and the money was eventually awarded in five prizes of $£ 20$ each at the Health Exhibition of I 884. One of these was given to Messrs. J. \& E. Hall for their " cold dry-air machines and cold storage chamber." Their machine was a carbonic acid compression refrigerating machine of the type invented by Giffard, and afterwards supplied by the firm for use on board ship, and for the preservation of imported meat in cold storage establishments.

I Journal, vol. xvi. p. $5^{83}$.

${ }^{2}$ Ibid. vol. xvii. p. 642. 
Still, if they missed the opportunity of awarding the $£ 100$ prize-and after Mort's death it would have been very difficult to name an individual who deserved it - the committee, as was said above, did a great deal of really useful work which might have been carried to an even more successful conclusion but for the sudden death in I 877 of its energetic and devoted chairman, Benjamin Shaw.

On his return from a visit to the Paris Exhibition of 1867, where he had been acting as one of the jurors, Dr. Lyon Playfair addressed a letter to Lord Granville commenting on the industrial progress which had been made by other countries as compared with that of Great Britain. ${ }^{1}$ In Dr.Playfair's opinion, England compared very unfavourably with some of the other principal European countries who exhibited in Paris, and this state of things he attributed mainly to the advance which had been made on the Continent in technical or industrial education. As far back as 1853 Dr. Playfair had published a work on industrial education on the Continent, and had prophesied that the result of the attention given to such education abroad, and its neglect in England, would lead to a much more rapid industrial advance on the Continent than in England. He considered that the views he had stated in I 853 were confirmed in 1867 .

The result of the attention thus drawn to the subject was that the Council, in the latter part of the year, appointed a committee on the subject, and by this committee a conference was organised, which met in the Society's Room in January 1868 . The list given in the Journal of the persons attending the conference is a very remarkable one. It is too long for quotation at length, and the list of names is too distinguished to justify a selection from them. ${ }^{2}$

After the conference, at which the subject was fully discussed, a committee was appointed by the Council,

${ }^{1}$ Dr. Playfair's letter, prefaced by one from Lord Granville, is reprinted in the Journal, vol. xv. p. 477.

2 Journal, vol. xvi. p. 184 . 
which, after a number of meetings, published an exhaustive report ${ }^{1}$ - a report that may with advantage be consulted at the present date. In it for the first time technical education was defined as meaning "general instruction in those sciences the principles of which are applicable to various employments of life," and it was also resolved that, for the purposes of discussion, technical education "should be deemed to exclude the manual instruction in Arts and Manufactures which is given in the workshop."

Throughout the report the committee had mainly in view the education, not so much of the operatives as of managers and superintendents of works-a wise view which was afterwards lost sight of, when the subject of technical education became popular, and the training of the artisan was advocated as the one remedy for all industrial shortcomings. At the end of their report they added an appendix suggesting courses of study for such persons, and it is evident that these courses were intended for students having already a certain amount of general and scientific education, and not for artisans. It may be mentioned that at the end of the list was included a syllabus of higher commercial education, intended for the use of merchants and commercial men generally. After the issue of this report, the Council did little more for a time to promote technical education, though in May I 869 they presented a petition to the House of Commons urging its necessity, and asking for legislation such as would encourage scientific training in secondary schools.

The next step was the proposal for the introduction of technological examinations, which was brought before the Council in November 1871, by Captain (afterwards General Sir John) Donnelly. The first draft scheme prepared by him was afterwards considerably elaborated, and was submitted to a conference held in July I 872 , at which H.R.H. Prince Arthur (now the Duke of Connaught) presided. ${ }^{2}$ The result of this conference was the establishment of the technological examinations, described in a previous chapter. ${ }^{3}$

1 Journal, vol. xvi. p. 627.

${ }^{3}$ See Chapter XIX, p. 437.

${ }^{2}$ Ibid., vol. Ivii. p. 434 . 


\section{PRESIDENCY OF KING EDWARD VII}

Ever since its foundation the Society had been earnest in promoting industrial education, but for the most part this was considered to mean merely general education of the artisan class, not the provision of scientific or technical training.

The proper educational work of the Society had always been for the most part the furtherance of industrial and technical instruction, though the foundation of the system of examinations had been an important contribution to the cause of secondary education in England. The movement, however, for the improvement of elementary education, which led to the passing of Mr. Forster's Elementary Education Act in 1870 , drew the Society into its influence, and in the years I 869 and 1870 it was busy with the subject of national education generally. By means of specially-appointed committees, it collected information about the educational needs and facilities in several districts in and near London, and published reports upon them. Of those reports the most remarkable was the one prepared by G. C. T. Bartley, on "The Educational Condition and Requirements of one Square Mile in the East End of London." This was published as a supplement to the Joumal for 25th March i870, and, as it well deserved to do, attracted a great deal of attention. It was a document of considerable value, prepared with great care, and at the cost of much labour and minute inquiry.

Before the Elementary Education Bill was introduced into the House of Commons, a conference was held (February I 870) ${ }^{1}$ at which the various proposals already formulated were discussed, and the opinions upon them of leading educationalists were elicited. After the introduction of the Bill, a petition, embodying the views of the Council, was presented to the House, and a little later a full memorandum suggesting various amendments and improvements was submitted to the Prime Minister (Mr. Gladstone) by the chairman (Lord Henry Lennox) on behalf of the Council. The principal demand of the Council, the appointment of a Minister of Education, was not suc-

1 Jourinal, vol. xviii. p. 23s, 
cessful, but some of the other suggestions were not without effect.

Special attention was drawn to the question of female education by the paper read by Mrs. Grey on "The Education of Women," in June I 872. In consequence of this paper, a committce was, a little later, appointed by the Council "to promote the better education of girls of all classes." It was at first proposed to form a " National Union for the Improvement of the Education of Girls," but the actual result was the much more practical proceeding of the establishment of the Girls' Public Day School Company, which has been in successful operation ever since.

At the end of I 868 the Council took up the idea of encouraging drill in schools. The reasons for their action are well set out in a paper read in March 187 I by MajorGeneral Eardley-Wilmot, who laid stress on the value of drill as a means of physical and also of mental education. It was, indeed, as a means of improving the national intelligence, rather than as a preparation for the national army, that the encouragement of drill in schools was first taken up by the Society, and it was on such grounds that its extension was always advocated.

The efforts of the Society met with a good deal of success. The first result of the movement was the holding, in June 1870 , of a drill review of 3000 boys from metropolitan schools at the Crystal Palace, in the presence of the Prince of Teck. A similar review was held in the following year, in the presence of the Duke of Connaught, at the Horticultural Gardens, when banners provided by the Society were presented to the schools which were most successful in a test competition. In I 872 the Prince of Wales patronised the review, which was again held in the Horticultural Gardens. He afterwards presented the Society's prize-banners in the Albert Hall. Over 4000 boys attended. Other reviews were held in 1873 and 1875 ; and in 1876 the London School Board undertook to arrange a public review of the boys in their schools. This review was duly held in Regent's Park, when over I0,000 boys are reported to have gone through various 
manœuvres. On this occasion an elaborate challenge banner, provided by the Society, was competed for. This banner was embroidered by the School of Art Needlework, and cost nearly $£ 100$.

For some time the School Board continued these drill reviews. But there was a good deal of opposition to them from a certain party, who were afraid they would encourage " militarism," by which it was presumably meant that children who had been drilled in early youth might thereby acquire a pernicious desire to become soldiers in after life. The total cost of the movement to the Society, from the start in 1870 down to the time when the drill reviews passed over to the School Board, was $£ 944$, but of this $£ 400$ was recouped to the Society by the sale of tickets, subscriptions towards the expenses, etc.

In the year 1864 an anonymous letter was printed in the Journal, which suggested that the Society might offer a prize for a design for memorial tablets to be affixed to houses in which celebrated persons had been born or lived. In the same year also some suggestions appeared in the Builder newspaper, to the effect that some sort of memorial might be set up on certain houses and churches in London to commemorate their association with eminent men. Probably in consequence of these suggestions, the Council appointed a committee to consider the " erection of statues or other memorials to persons eminent in arts, manufactures, and commerce."

This committee does not seem to have done anything for some time. But in May I 866 (Sir) George Bartley submitted to the committee a proposal for affixing memorial tablets to houses in London which were known to have been inhabited by famous men. In his letter ${ }^{1} \mathrm{Mr}$. Bartley quotes a reference by Samuel Rogers to the fact that in various towns in France and Germany such memorials were in existence, and he added a list of houses in London which at one time were associated with celebrated persons. Many of these, as well as many of those suggested by the 1 Published in the Journal, vol. xiv. p. 438. 
writer in the Builder, have since had tablets attached to them. Mr. Bartley concluded his proposal by suggesting that the best kind of indicating label might be some form of mosaic or marble slab.

The committee at once approved the idea, and $\mathrm{Mr}$. Bartley's proposals as they stood were practically adopted and carried out. A list was at once prepared of suitable houses, and in 1867 the first memorial tablet was affixed to the house in Holles Street, Cavendish Square, where Byron was born. The work was continued year by year for a considerable time, although there were certain difficulties in carrying it out. It was not always easy to indentify with absolute certainty the house in which it was recorded that some eminent person had dwelt. Before the latter part of the eighteenth century the houses in London streets were not numbered, and since that date many alterations have been made at different times in the numbering. Then the owners of houses were often reluctant to give permission for the attachment of the tablets to their premises, especially in the earlier years of the movement. Even so enlightened a body as the Benchers of the Middle Temple refused to allow the erection of a tablet in Brick Court, where Goldsmith lived and died, though later a more reasonable view was taken, and permission was given for the erection of a bronze memorial. But, on the whole, the work was carried out with a considerable amount of success, and it attracted a great deal of public interest and approval. In the year 1872 a sum of $£ 50$ was presented to the Council by Mr. Benjamin Whitworth and Mr. H. D. Pochin, to be devoted to the erection of tablets, but the rest of the cost, never very considerable, was provided by the Society.

When the idea was first taken up, the offer of a $£$ io prize for a suitable design was made, but nothing seems to have come of this. Later on Mr. Bartley undertook to obtain a design, and with the assistance of (Sir) Henry Cole, who took a great interest in the matter, various designs were prepared in the offices of the Science and Art Department, South Kensington, under the superin- 
tendence of Godfrey Sykes ${ }^{1}$ and his assistant. Eventually the matter was placed in the hands of Messrs. Minton, Hollins, \& Co., of Stoke-on-Trent, who appear to have worked on the suggestions submitted to them, and produced the tablet which was approved and adopted by the Council of the Society. One of the main objects in the design was that the Society of Arts' name should be given, but that it should not be made too prominent, and this object was effectively attained by the ingenious border, in which the name of the Society is introduced. The same design has, in all cases, been used by the Society,

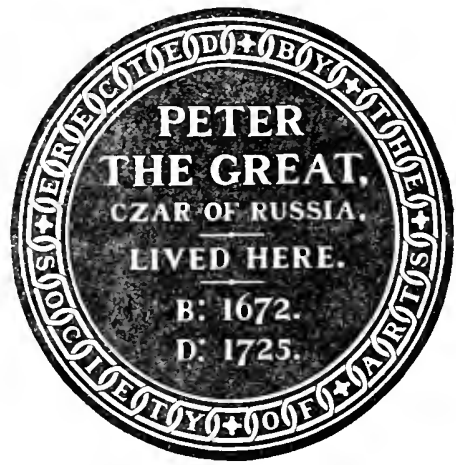

Tablet formerly on No. I5 Buckingham Street. ${ }^{2}$

with the solitary exception of the tablet to Milton in Bunhill Row. The architecture of the building there did not admit of the convenient erection of a circular tablet, and consequently the oblong slab which is now in position was specially designed and erected.

The work was carried on by the Society until igor, by which time thirty-five tablets had been set up. The houses on which four of these were erected have since been demolished.

${ }^{1}$ Godfrey Sykes (I $825-66$ ) was the talented designer of much of the terra-cotta and other decoration of the old buildings of the South Kensington Museum. One piece of his work is very familiar, the design on the cover of the Cornhill Magazine.

2 The house was pulled down about 1906. It was the last remaining part of the Duke of Buckingham's house. 
The house in Holles Street on which Lord Byron's tablet had been affixed, was pulled down in 1889. In May 1900, Messrs. John Lewis \& Co. erected on the front of the new house, which was in their occupation, a fresh memorial consisting of a bronze relief bust of Byron placed in an architectural frame of Portland stone. When Furnival's Inn was pulled down in I 898 , the tablet which had been set up to Charles Dickens disappeared, but two other residences of the great novelist have since been marked by the London County Council. About 1906 the house at the bottom of Buckingham Street, Strand, which carried a tablet to commemorate the fact that Peter the Great of Russia had lived there during his stay in London, was pulled down, and a block of chambers erected on the site. Mrs. Siddons' house in Upper Baker Street was demolished in 1904, but the original tablet was re-fixed by the London County Council on the new premises.

It is always a difficult question whether these tablets should only be placed on the actual house in which the person to be commemorated had lived. In some cases the house had disappeared, and the tablet was set up on the building which had taken the place of the old house. Whether this was worth doing must remain a moot question, and, on the whole, perhaps it is really not worth while, for instance, to have a tablet on Archbishop Tenison's Grammar School in Leicester Square, now occupying the site of Hogarth's old house; on the other hand, something might be urged on behalf of the tablet on a warehouse in Bunhill Row, built on the spot where Milton's house once stood, because it at all events suggests to the passer-by the original suburban character of the locality.

In 190 I the Historical Records and Buildings Committee of the London County Council proposed to advise the County Council that it should undertake the work of indicating houses and localities of interest in London; but, before taking any action in the matter, the Committee very courteously applied to the Society to know what its views on the matter were. The Council of the Society readily agreed to hand over the work to the County Council, 
and offered at the same time to render any assistance in the Society's power. The London County Council thereupon formally resolved to take upon itself the duty in future, and since that date they have certainly carried it out in a most able and efficient manner. Up to the present time (1913) the Council have set up seventy-six tablets. They have, probably wisely, in almost every case refused to indicate merely sites, and have confined themselves to indicating actual houses. It may be added that their work in this respect is a little easier, because nearly all the houses with which they have had to deal are comparatively modern. Looking at the list of persons commemorated, it appears that, leaving out of consideration a few tablets which bear more than a single name, only ten of the seventy-six tablets refer to persons who might not certainly be classed as belonging to the nineteenth century; that is to say, their reputations were made since the beginning of that century; while there are only two-Sir Isaac Newton and General Wolfe-who had died before the last quarter of the eighteenth century. About two-thirds of the names commemorated are of persons who have died since the work began in $1864 .^{1}$

The ancient sites are doubtless the more attractive; but with the constant changes which have been made in London streets, especially during the last half-century or so, innumerable houses of historical interest have of necessity disappeared. An enormous hotel, or shop, or block of flats, may now cover ground once occupied by

1 A complete list of the tablets erected up to that date, which include all except Milton's, will be found in the Journal of 5 th October 1900 (vol. xlviii. p. 827). A similar list, which is quite complete, is in the Directory of the Society, published in 1909, p. 53. An account of many of the houses bearing tablets is given in two articles by Mr. Henry $\mathrm{B}$. Wheatley (then Assistant Secretary of the Society), which appeared in the Journal (vol. xxix. p. \$23, and vol. xxx. p. I066). The London County Council have published three volumes of Ancient Houses of Historical Interest in London, the latest of which is dated 1909. Several parts, which no doubt will form a fourth volume, have since been issued in pamphlet form. There is also a companion volume, edited by Sir Laurence Gomme, Return of Outdoor Memorials in London (I910). This gives a list of all such memorials erected by the L.C.C., the Society of Arts, and private individuals. 
a dozen houses, in some of which painters or poets, or writers, or scientific men or statesmen of the eighteenth and earlier centuries may have been born, or lived, or died. The obliteration is complete, and there is nothing left to commemorate. On the other hand, during the past century and a half very many fresh sites of interest have been created in the birthplaces and residences in London of some of the men who have been occupied in making history since the nineteenth century began, and so fresh work is ever being provided for the Historical Committee of the London County Council.

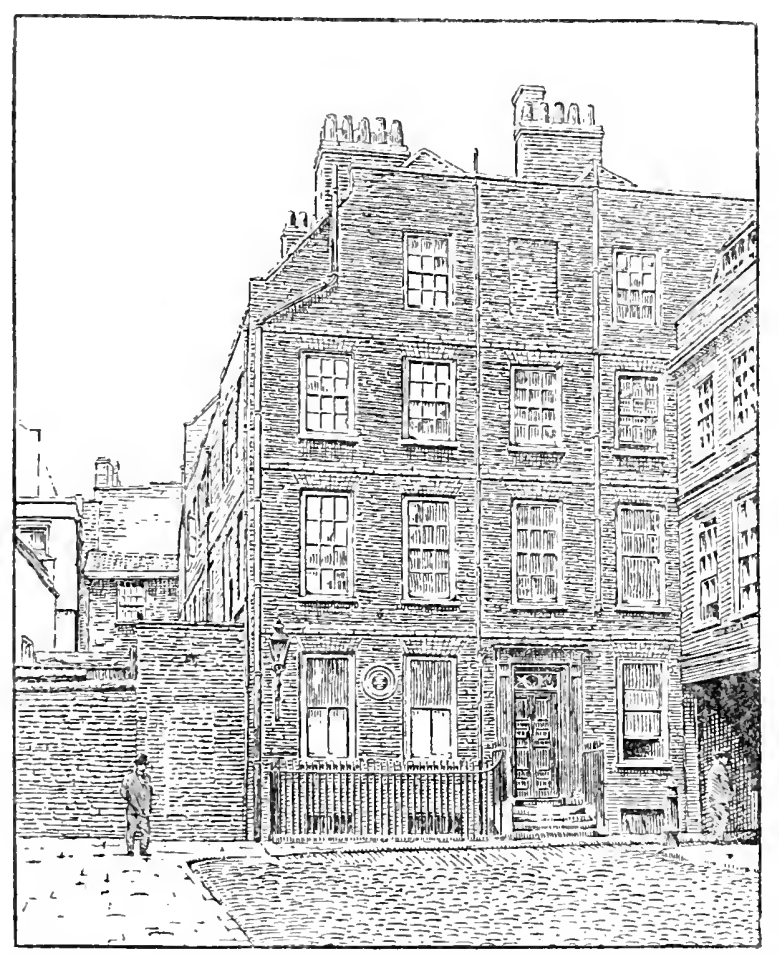

Dr. Johnson's House in Bolt Court, with Memorial Tablet. 


\section{H A P T E R X X I}

\section{The Presidency of King Edward Vil. (Continued)- Conclusion}

(1862-1880)

Patent Law Amendment-The Government Bills, I875-9 The Society's Bill, I88I-2-The Patents Act, I 883-Postal ReformMusical Education-The Royal Academy of Music and the Society -National Training School of Music-Its Successful Establishment by the Society-The Society's Expenditure-School of Art Wood-Carving-Its foundation by the Society-Subsequent History-Paris Exhibition, I 867-Artisan Reports, I867 and I878The Annual Exhibitions, I871-4-The Society's connection with them-Memorial Window in St. Paul's after Prince of Wales's illness-Sanitary Conferences, i 876-84-Prizes-Issue of Premium Lists-Special Prizes-Domestic Stoves-Labourers' CottagesChannel 'Traffic-Ships' Life-boats and Life-Saving AppliancesBlow-pipe Apparatus-Essay on Thrift-Mechanical Road Traction-London Cabs-Railway Lamp-Steel-Revolution Indicator-Harvesting Crops in Wet-Rating of Societies-FinanceConcluding Remarks.

After the passing of the Patent Law Amendment Act of $\mathrm{I} 852$, a measure which, as mentioned previously, owed a great deal to the Society of Arts, the question of Patent Law reform was for a long time allowed to slumber, so far as the Society was concerned. The Act was working extremely well, and the criticisms of objectors were mainly directed to matters of detail, which might perfectly well have been dealt with by administrative rather than legislative reform. In some quarters a feeling of opposition to the granting of patents at all had gathered a certain amount of strength. But the case of the objectors-if, indeed, they had any case-was demolished by a brilliant paper read before the Society in December I 874 by Mr. 


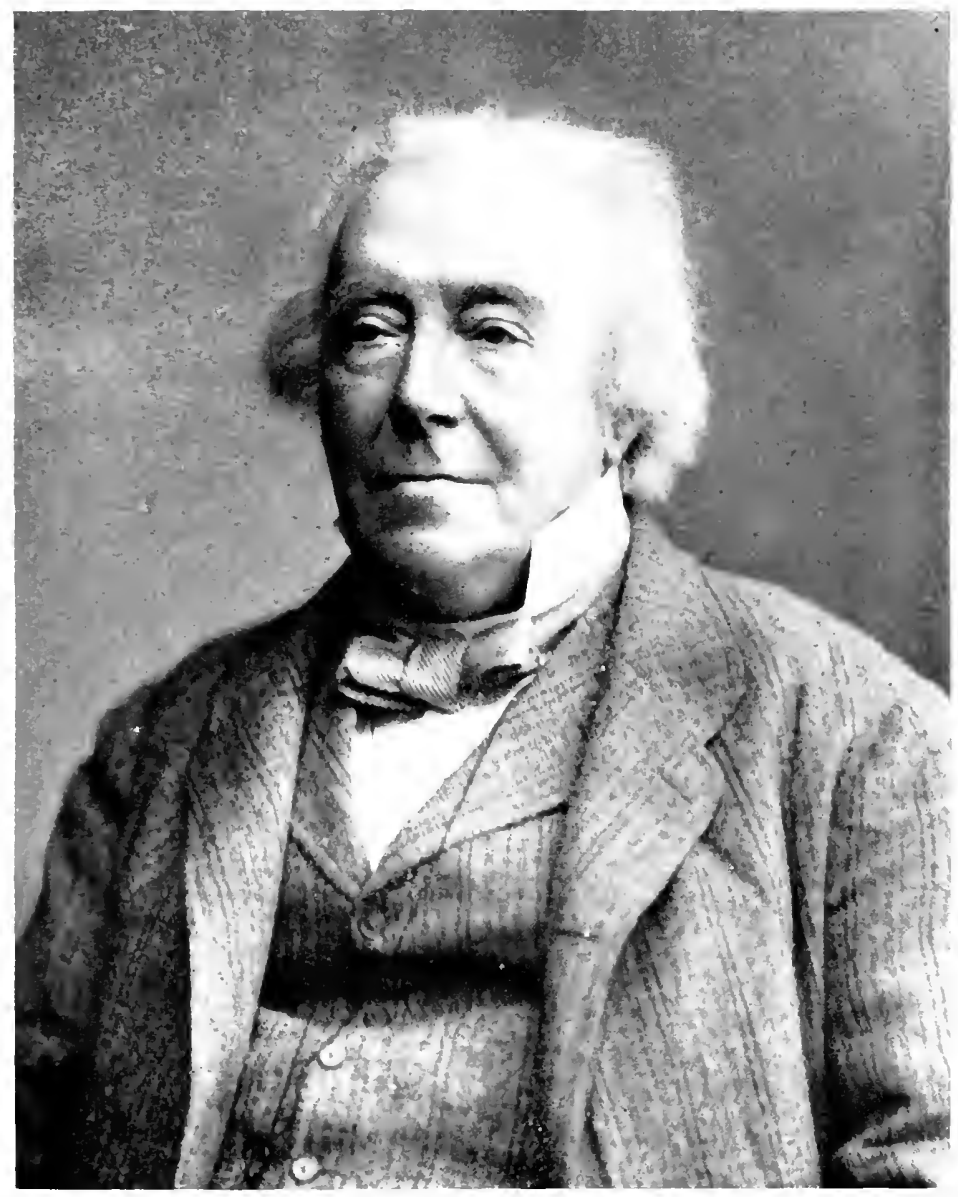

SIR FRIIERICK BRAMWELL. B.IKT.

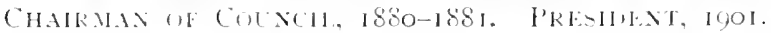

fiome it Photegriph. 

(afterwards Sir) F. J. Bramwell, on "The Expediency of Protection for Inventions."

In 1875 the Government, urged on by admirers of the American patent system, brought forward a Bill for the reform of the Patent Law, in which it was proposed to introduce into this country a system of examination similar to that which has always been favoured in the United States. It was not indeed quite clear whether the examination proposed by the Bill really extended to points of novelty ; but there is not much doubt that an examination for novelty was well within the scope of the Bill, and it would probably have been introduced. The Bill raised a good deal of opposition amongst those who were most competent to form an opinion on Patent Law and administration, prominent amongst whom was Sir Frederick Bramwell. The Council of the Society took an active part in opposing it. The Bill, with various modifications, was before Parliament for three consecutive years, and it was persistently opposed during the whole time. Petitions against it were presented by the Council, on behalf of the Society, to the House of Lords-in which the Bill was introduced in 1875 -and in the following year, when it was brought into the House of Commons, to that House.

A special meeting was held in March 1877 , for the discussion of the Bill, the meeting being opened by the reading of a paper which the present writer, who was then the Assistant Secretary of the Society, had, at the wish of the Council, prepared. The general feeling of the meeting was strongly adverse to the proposed measure; and eventually it was so evident that public opinion was against it, that it was dropped.

In 1879 a different Bill was brought in by the Government, but this, like its predecessors, met with a good deal of adverse criticism, and nothing came of it.

When Sir Frederick Bramwell became Chairman of the Council in 1880 , he drew attention, in the address which he delivered before the Society at the opening meeting of the Session I 880-8 I, to the desirability of certain modifications which experience had proved to be desirable in the 
Act of 1852, and eventually it was determined that the best way of bringing the Society's views definitely forward would be to draft a Bill embodying the amendments which experience had shown to be necessary, and to get this Bill introduced in the House of Commons. A committee, appointed for the purpose, considered very carefully the main alterations which seemed imperative, and, under the instructions of this committee, a Bill was drafted by a Parliamentary draftsman. It seems hardly needful to mention that the leading spirit of the committee was Sir F. Bramwell, who read two papers on the Bill-one before the British Association at York, in September I88I, ${ }^{1}$ and one before the Society in February i $883 .{ }^{2}$ The Bill, after being submitted to, and considered by, a meeting of the Society specially held for the purpose in the autumn of I 88I, was introduced into the House of Commons by Sir John Lubbock, Mr. W. H. Smith, and Mr. J. Compton Lawrance, ${ }^{3}$ in March 1882 , and again in the Session of I883. It received a good deal of attention, and it had the effect of inducing the Government to bring in a fresh Bill in I 883, which embodied many of its main provisions, and was, in the opinion of all competent judges, a very great improvement on the Bill of 1879 . A comparison of the Society's Bill with that which eventually passed into law ${ }^{4}$ will show to what a large extent the Act was founded upon the Society's Bill, although certain of the provisions which the Society's committee considered of first-rate importance, especially that of the appointment of paid commissioners, were not adopted. The Society's Bill only dealt with Patents, while the i $88_{3}$ Act included also Designs and Trade Marks. As is well known, the 1883 Act abolished the old Commissioners for Patents (the Lord Chancellor, the Master of the Rolls, and the Law Officers, Irish and Scotch as well as English), and trans-

1 Journal, vol. xxix. p. 8o9.

2 Ibid. vol. xxxi. p. 285.

${ }^{3}$ Sir John Lubbock became Baron Avebury in 1900 and died in May of the present year (1913). Mr. W. H. Smith, the distinguished statesman, served in Lord Salisbury's Government of I886, and died in I89I. Mr. Lawrance became a judge in I900, and died last December (I912).

${ }_{4}^{4}$ As the Patents, Designs, and Trade Marks Act, 1883. 
ferred the Patent Office from their authority to the Board of Trade, appointing a Comptroller of Patents instead of the Commissioners.

Mention has already been made of the fact that a parcel post had been suggested as far back as $185 \mathrm{I}$. This was no doubt due to the suggestion of (Sir) Henry Cole, who made his first mark in public life by his advocation of the introduction of penny postage, and ever afterwards took a great interest in the development of the Post Office. ${ }^{1}$ In the period which we now have under consideration, the Society was specially active in postal reform, and this time the protagonist was (Sir) Edwin Chadwick, who in 1857 read a paper urging the purchase of the telegraphs by the State. The proposal had been made some time before, and was then under consideration; but, in the opinion of Sir John Cameron Lamb, ${ }^{2}$ a most competent authority, Chadwick's paper " had a powerful effect on public opinion, and helped materially to pave the way for the telegraph legislation of i 868," by which provision was made for the purchase.

It was largely owing to the exertions of Cole and Chadwick that the Society was so earnest at this time in promoting postal reform. The object was sought by every possible means; conferences were held, deputations were sent to successive Postmasters-General and to the Treasury; petitions were presented to the House of Commons, and in every way an agitation was kept up in favour of cheaper postal charges, the development of a parcel and sample post, the reduction of telegraph rates, the development of savings banks, the improvement of colonial and foreign postal communications and other changes-many of which have since been introduced, thanks to a large extent to the persistent recommendations of the Society. Amongst other matters may be mentioned the provision of facilities for the purchase of small amounts of Consols, which, at the suggestion of (Sir) George Bartley, was submitted to the Chancellor of the Exchequer (Sir Stafford Northcote)

${ }^{1}$ Sir H. Cole, Fifty Years of Public Work, vol. i. p. 34.

'Journal, vol. lix. p. 12,' 
by a deputation in 1874 , though the idea was not adopted by the Post Office until i 888.

In the Address which Sir John Cameron Lamb delivered when he was Chairman of the Council in 1910, ${ }^{1}$ he described very fully, and with special knowledge, the aid which the Society had rendered in the development of the electric telegraph, first by encouraging inventors and giving publicity to their work, and, secondly, by bringing pressure to bear upon the Government Department for the improvement and development of telegraphy after it had passed into the hands of the Government. Sir John Lamb's experience, as a Secretary of the Post Office for many years, lent great force to what he said, and it is satisfactory to be able to record that in the opinion of a leading official of a Department which had been for years worried by the Society, the efforts of the Society had been judicious and useful, and that, on the whole, they had secured the friendly appreciation of the Post Office.

The Art of Music had never been considered to be one of the arts which it was the duty of the Society to promote, and, indeed, this view had been definitely stated on one or two occasions. But in the period with which we are now concerned this opinion was changed, a larger interpretation was given to the Society's title, and a very considerable addition was made, through its agency, to the existing provisions for musical education in England.

In 1854 or 1856 the Directors of the Royal Academy of Music asked the 185 I Commissioners for the grant of a site on the Kensington Estate. ${ }^{2}$ Nothing, however, came of the proposal, and the Academy, which was at the time in a state very far from prosperous, seems to have gone from bad to worse, for in June i 860 an application was made by its directors to the Society, asking for suggestions for the improvement and extension of its system of management.

${ }^{1}$ Journal, vol. lix. p. 7 .

2 Sir Henry Cole's Fifty Years of Public Work, vol. i. p. 365 ; Journal, vol. xiii. p. 593. The former reference gives the date as I 854 , the latter as 1856 . The date is not very important. 
The Council thereupon appointed a committee, which reported in May 1861, and suggested rather sweeping alterations in the constitution and management of the Academy-alterations which, in fact, amounted to the creation of a new institution. It appears that these suggestions did not commend themselves to the management of the Royal Academy, for nothing came of them. But three years later the Council appointed a committee on musical education. This was done at the instance of (Sir) Henry Cole, who became chairman of the committee, and directed, or rather dictated, all its proceedings.

The first work of the committee was to collect, through the help of the Foreign Office, and by independent inquiries, a great deal of information about foreign musical education, and full reports were obtained of the working of the musical academies or conservatoires of Paris, Munich, Vienna, Prague, Leipsic, Milan, Naples, Berlin, Brussels, and Liége. Much of this information was published in the Journal, and was embodied in a long report issued in 1866.

While this committee was at work, Cole conceived the idea of forming a number of scholarships by public subscription to be tenable either at the Royal Academy of Music or elsewhere. Negotiations were for a long time carried on with the Academy. But the conditions suggested were not appreciated by that body, and eventually the committee, at the instigation of its chairman, proposed the establishment of a separate institution, which should have for its main object the training of teachers, and the students at which should all be holders of scholarships to be obtained by competitive examination, the funds being supplied by public subscription. The idea once formulated, energetic measures were taken to carry it into effect. Meetings were held at the Mansion House in 1875 and 1876 , under the presidency of the Lord Mayor (Alderman Stone in 1875 and Alderman Cotton in 1876), at Marlborough House, under the presidency of the Prince of Wales, at Manchester, Liverpool, Bristol, Birmingham, Dover, Hastings, Rhyl, and elsewhere. At all of the provincial meetings deputations from the Society attended. 
Sufficient promises of support having been secured, it was determined that an attempt should be made to provide a building for a National Training School for Music at South Kensington. An application was made to the $185 \mathrm{I}$ Commissioners, who agreed to grant a site for the purpose, and steps had been taken to collect money for building the school, when (Sir) C. J. Freake liberally undertook to provide the necessary building at his own charge. A design was prepared by Lieutenant $\mathrm{H}$. H. Cole, R.E., and the first stone of the building was laid by the Duke of Edinburgh, who had joined the committee in 1872 , on I 8 th December 1873. The building was completed and opened at Easter 1876 , when the Council were able to announce that a sufficient number of scholarships of $£ 40$ each had been promised, and that sixty-seven scholars had already been appointed. The number of scholarships was soon raised to eighty-two. The Queen, the Prince of Wales, and the Duke of Edinburgh each provided one, the Society of Arts founded four, the Corporation of London ten, the City Guilds fourteen, Mr. Freake five, and thirty-three were provided by various provincial towns.

These scholarships were to be of $£ 40$ each, tenable for five years, the hope of the founders being that by that time the institution would be taken over by the State, and placed on a permanent basis.

The school carried on a very successful career until 1882, when it was reconstituted, and became the Royal College of Music, the College taking over all the property of the school, including the house and a balance of $f_{11} 100$.

When the five years for which the school had been established expired in I88I, steps were taken to carry it on for another year until the arrangements for the new foundation could be completed. Many of the subscribers renewed their payments for a year. The Society of Arts voted $£ 160$ for its four scholarships.

The final report of the school was issued in June 1882 , and an abstract of it appears in the Society's Journal for the 9 th of that month. From this it appears that since the opening of the school 180 students had been admitted. 
Of these 152 held free scholarships, and twenty-eight were private students who paid their own fees, a modification having been made in the regulations, which at first did not contemplate such students. These private students, like the free scholars, were only admitted after passing a test examination. The report states that i io of the students were either earning their own living or largely contributing thereto, by the profession for which they had been prepared, thirty of them being said to be artists of recognised merit.

After the establishment of the Royal College of Music, further negotiations were carried on with the Royal Academy of Music, in the hope of some amalgamation between the two bodies being effected. These, however, were unsuccessful, though in I 889 the two institutions agreed to form an associated board for their examinations.

The total amount expended upon this object by the Society of Arts from 1861 to 1882 was $£ 2035$. In 187 I six concerts were arranged at the Royal Albert Hall, in the hope of obtaining funds for the foundation of the school, but they resulted in a loss of over $£ 87$, which fell upon the Society, and is included in the above total.

It may be said that the establishment of the School of Music was the principal object to which the energies of the Society were devoted for a period of twelve yearsfrom I86I to I873. It expended a considerable amount of money, an expenditure justified by the hope expressed in 1874 that it, or the greater part of it, would be refunded. ${ }^{1}$ Many of the Society's members devoted much time and thought to its organisation, and others, like Sir Charles Freake and Sir Titus Salt, contributed munificently to its funds. It cannot be said that sufficient credit has ever been given to the Society for its efforts. When the school, already an acknowledged success, became the Royal College of Music, even the trivial compliment of retaining a representative of the Society on its governing body was unpaid, and, as a matter of fact, the work of the original founders was absolutely ignored.

${ }^{1}$ Council Minutes, I9th May I 874. 
Another educational institution established by the Society was the School of Art Wood-Carving, which has now been doing useful work for more than thirty years. In 1878 the Drapers' Company offered the Society a sum of money to be applied in the promotion of some branch of technical education, and the Council, at the suggestion of (Sir) John Donnelly, determined to devote it to the encouragement of wood-carving, an art which had long prospered in this country, but was then languishing. The Council secured the services of a Florentine wood-carver of considerable merit, named Antonio Bulletti, and established a small school in Somerset Street, Oxford Street, under the direction of a committee, of which Colonel Donnelly was the chairman. Nine free students were nominated, and a few paying students were also admitted.

After being carried on for some time in Somerset Street, the school migrated in 1879 to the Royal Albert Hall, where convenient rooms were placed at its disposal free of rent. In I 880 the City Guilds' Institute took the school under its protection, and in $\mathrm{I} \delta 85$ it was provided with accommodation at the Guilds' College in Exhibition Road. Here it remained until I 898 , when, the rooms it occupied being required for the purposes of the Technical College itself, it was transferred to the Imperial Institute, funds for its support being still provided through both the Drapers' Company and the City Guilds' Institute. In I900 the grant from the City Guilds' Institute was withdrawn, but the loss was temporarily made up by a special grant from the Clothworkers' Company of $£ 50$. 'Two years later, in 1902, the school had again to move, and this time it hired premises from the Royal School of Art Needlework. In I90 I the then newly-formed Technical Education Committee of the London County Council made the school an annual grant of $£ 250$, increased to $£ 400$ in 1903. In 1908 the school moved to premises of its own in Thurloe Place, and there it has since been carried on.

In I9I 2 the grant from the London County Council committee was further increased to enable the school to add to its staff of teachers. Since 1905 the school has been recognised by the Board of Education, and it has earned a 
gradually increasing amount each fyear, thus proving that the efficiency of its teaching has been well maintained.

Numerous prizes and medals have been taken by the school and its members at various exhibitions and at the national competition held under the Board of Education. It has also trained many teachers, and produced a number of highly-trained carvers of wood who are now at work in the trade. ${ }^{1}$

The connection of the Society with the Paris Exhibition of 1867 was not very close, though a visit of the members was organised, and it was really the holding of the Exhibition which led to the presentation of the Albert Medal to the Emperor Napoleon in 1865. The most important movement initiated by the Society in connection with the exhibition was the organisation of a body of artisan reporters, who, in accordance with a resolution passed by the Council-at the instance of Sir William Page Wood-in November I 866, were sent to the Exhibition to report upon it for the Society. The British Commissioners for the Exhibition placed a sum of $£ 500$ at the disposal of the Society, and rather more than the same amount was obtained by subscriptions. By means of the funds thus obtained, supplemented by a sum of $£ 350$ from the Society, eighty artisans, representing various industries, were selected from different parts of the country, and arrangements were made for their visiting Paris, where full opportunities were given them, not only for examining the contents of the Exhibition, but also for inspecting French factories and workshops. The result was the production of an extremely interesting volume of reports, which was published by the Society in 1867 . The reports are naturally of varying interest and value, but all of them are useful and interesting. ${ }^{2}$

${ }^{1}$ Notes on the History of the School of Art Wood-Carving, by Thomas Armstrong, C.B., I9I0. Mr. Armstrong succeeded Sir John Donnelly as Chairman of the Committee of the School in 1902, and devoted himself earnestly to its interests until his death in I9I I.

${ }^{2}$ In 1855 the Society had organised facilities for artisans visiting the Paris Exhibition. A reduction in the railway fares was ubtained, 
The same idea was carried out at the next great French Exhibition in 1878 , when a greater number of artisans were sent over and a larger number of reports were printed. But, on the whole, this second volume is inferior in interest and value to the one issued in 1867 .

As the date approached, various proposals were put forward for holding an exhibition in $187 \mathrm{I}$, the idea being that such exhibitions should be held every ten years. The suggestion, however, met with but scant support, the financial result of the i 862 Exhibition not having been such as to encourage a repetition of the experiment. A scheme, however, which did not involve so heavy an expenditure met with greater approval ; and when (Sir) Henry Cole, in I 868, brought before the Commissioners of the I85I Exhibition a proposal for holding a series of annual exhibitions, it was, after some consideration, adopted. The original scheme was modified in some details, and in July I 869 , Cole was ready with his completed programme, which was approved by the Commissioners, and announced in the Society's Journal of 6th August I 869. The idea was to hold a series of annual international exhibitions of " selected works of fine and industrial art," to last over a period of ten years, from i 87 I to i 880 . A careful classification was prepared, allotting to the exhibition of each year certain specified industries, while the fine arts were to form a section of each exhibition. The i 85 I Commissioners guaranteed a sum of $£ 100,000$, and gave the use of a portion of their land at South Kensington. This land consisted of the area extending from the Royal Albert Hall on the north to the site of the I 862 Exhibition, where the Natural History Museum now stands. The central portion of the ground was in the occupation of the Royal Horticultural Society, and had been laid out as a garden. The part intended for the Exhibitions was a space on the south side of the gardens, and the strips bounding the gardens on the east and west. Certain buildings existed upon it, including the long gallery now (1913) containing the lodgings were provided, and other privileges arranged, but no reports were expected from the visitors. 
engineering collection, which was originally part of the I 862 Exhibition, and to these considerable additions were made, forming a quadrangle which enclosed the gardens.

In accordance with the programme, the first exhibition was opened in 1871 . It was quite successful, and attracted more than a million visitors, the total receipts being over $£ 75$,ooo. Had a similar amount been earned by the other exhibitions, the series would have been at least self-supporting. Its successors, however, were less fortunate, for the attendances gradually dropped off, and the receipts got less and less satisfactory, until the series was brought to an end in i874. The total amount expended by the I 85 I Commissioners on the four exhibitions was $£ 303,364$, while the total receipts only amounted to $£ \mathrm{I} 59,725$, thus involving a loss of $£_{1} 143,639 .^{1}$

The cause of this financial failure was certainly that the exhibitions, though of great technical excellence, were not of a sufficiently popular character, as is proved by the fact that ten years later a very similar series of exhibitions-the Fisheries, Health, Inventions, and Colonialheld on the same site, were made so attractive that they not only paid their way, but produced a handsome surplus. If, since then, the popular side of exhibitions has been given undue prominence, it has at all events been clearly shown that without large concessions to popularity, the heavy expenditure necessitated by the extent of our modern shows cannot possibly be met.

But the non-popularity of the older series is without doubt to be attributed mainly to the dissensions which arose between the Council of the Royal Horticultural Society and the exhibition authorities. In the first year (1871) the gardens of the Society formed part of the exhibition. But in the three later exhibitions difficulties were raised, and the use of the gardens was refused, except under harassing and inconvenient conditions. This not only deprived the exhibition of its most attractive and popular feature, but seriously affected the use of the

1 These figures are taken from the 6th Report of the Commissioners of 1851 , published 1879 . 
buildings for exhibition purposes, because easy communication between different parts of the buildings was prevented. Although the picture galleries were excellent, the rest of the buildings were really not very well adlapted for exhibitions, and after the whole central area was taken away they became very unsuitable. It may be added that the action of the Royal Horticultural Society not only wrecked the exhibition scheme, but went far to ruin the Society itself. A few years later it was removed from South Kensington, and in new quarters, and under better management, it became the prosperous institution which it now is.

The connection of the Society with these exhibitions was very close. In December 1869 the Commissioners applied formally for the co-operation of the Society, basing their request on the ground that the projected scheme was really carrying out an idea formulated by a Committee of the Society in 1858. The proposal was at once accepted, and the Council undertook to co-operate with the Commissioners, and to assist the series of exhibitions to the best of their ability. To all four of them it lent a very active support. As has already been mentioned, the scheme of art-workmanship prizes was modified, with a view of providing a typical collection for the $187 \mathrm{I}$ Exhibition, ${ }^{1}$ and at all the exhibitions gold and silver medals were offered under various conditions. The Journal was made the official organ of the exhibitions, and its volumes for the years 1870 to 1874 are full of information about them. Certain of the sections were also placed under the special charge of the Society, which appointed committees for their organisation. The Executive Committee of the Exhibition published reports on the first of the series, but for the other three the Society undertook this duty. The reports on the three later exhibitions were published in the Journal, and those for 1872 and 1873 were reprinted separately. Although the assistance thus rendered by the Society to the scheme was very considerable, the actual cost was not very great, as the total amount which is charged to the International

${ }^{1}$ See Chapter XX, p. 459. 
Exhibitions for the four years only amounts to a little over $£ 300 .{ }^{1}$

After the service held in St. Paul's Cathedral in thanksgiving for the recovery of the Prince of Wales from his serious illness in 1872 , it was suggested that a permanent memorial in St. Paul's should be provided by members of the Society, and that that memorial should take the form of a stained-glass window. At the time the question of the decoration of St. Paul's was under consideration, and the offer of the Society to contribute a window was gratefully accepted by the Dean and Chapter. A subscription list was accordingly opened, and a sum of $£ 343$ was collected among the members. But it was a long time before the scheme of decoration could be settled, and there was consequently considerable delay in carrying the proposal into effect, the Dean not feeling himself justified in accepting the design for the window, which had been prepared by F. W. Moody, ${ }^{2}$ until some decision had been arrived at upon the whole character of the decorations. So the matter was hung up for the time, and the amount which had been subscribed was placed on deposit with the Society's bankers. In this state the matter remained for ten years, when the Council renewed negotiations with the Dean and Chapter, and, as there were still

1 A very full account of the series, with minute details, will be found in the report presented by Sir Henry Cole to the Commissioners for I 851 , and published as a Parliamentary Paper in 1879 . The exhibitions are also dealt with in the Sixth Report of the 1851 Commissioners, issucd in 1879. A brief account of them is to be found in Sir Henry Cole's Fifty Years of Public Work, vol. i. p. 269, and there is of course a very large amount of information contained in the Society's Journal for the period.

${ }^{2}$ Instructor in Decorative Art at the National Art Training School. $\mathrm{He}$ was a designer of considerable merit, and was responsible for a good deal of the decorative work in the Museum, the Royal College of Science, and the old National Training School for Music. In the Museum his staircase and the decorations (largely Majolica and Mosaic) of the Lecture Theatre Gallery are remarkable. His work on the last-named building was mainly sgraffito. His Lectures and Lessons on $A r t$ (1870) was for long a text-book for art students. He died before I 890 . 
difficulties in coming to any definite agreement, it was finally resolved that the amount subscribed should be placed at the disposal of the Dean and Chapter to be expended upon a stained-glass window in such a manner as they should decide. The money was accordingly handed over to the Dean in 1882 .

Although numerous papers had previously been read before the Society on subjects relating to sewage treatment and utilisation, the first definite attempt made by the Society for the promotion of sanitation may be said to have been the conference on Rivers Pollution, held in the December of 1874 , with Sir Lyon Playfair in the chair. At this conference a number of papers were read, referring not only to the actual pollution of rivers, but to methods of dealing with sewage which would prevent such pollution. Indeed, the conference was really one on sewage treatment, the question of the pollution of rivers by manufacturing refuse receiving but a small amount of attention.

The success of this meeting led to the organisation o a conference in 1876 , under the presidency of Mr. James Stansfeld, ${ }^{1}$ which dealt with the whole subject of the health and sewage of towns. This was the first of the important series of sanitary conferences which was continued for five years, and included a second meeting on the " Health and Sewage of Towns" (1877) ; a congress on " National Water-Supply" (I878); a conference on "National Water-Supply, Sewage, and Health" (I879); and a conference on the "Progress of Public Health" (I880). A second congress on "National Water-Supply" was also held in 1884 . Reports of the proceedings of all these meetings were duly published, and also a useful compilation, "Notes on Previous Inquiries," which was issued before the Water-Supply Conference of 1878 .

There is no doubt that this series of health conferences was mainly instrumental in directing public attention to

${ }^{1}$ Rt Hon. Sir James Stansfeld, M.P. (1820-98). Radical politician Held various offices under Palmerston and Gladstone. President of Local Government Board, I87I-t. 
sanitary questions. If they did not start the movement in favour of improved sanitation-and this would be no unreasonable claim-they undeniably popularised it, and the ultimate result of this rousing of popular feeling was certainly the great improvement in domestic and municipal sanitation, which may be dated from the time when these conferences were held.

As has been previously pointed out, ${ }^{1}$ systematic prizegiving practically came to an end with the change in the Society's character which followed on its incorporation. But prizes were still offered. A list of subjects for premiums was published for the Sessions I863-4 and 1864-5, and another similar list for the Sessions $1873-4-5$. This is the last of the series of premium lists commenced in 1756 . Both of these were rather miscellaneous lists. Many of the desiderata are now commonplace products, others are as far from realisation as ever. Probably not very much trouble was spent on the preparation of the lists, and they do not look like the production of expert authorities. That they do not to any extent foreshadow the lines along which industrial and scientific progress has since advanced, is not, perhaps, to be wondered at. It would have been a very remarkable feat to forecast in 1863 or 1873 the advances even of the remainder of the century. Occasionally a few applications were made for the offered awards, and still more rarely medals were awarded.

Yet a good many prizes were actually given as the result of special offers, generally made by the aid of liberal donors who provided the necessary funds. The more important of these deserve record.

A generous donation of $£ 500$ from an anonymous friend of Sir William Bodkin (there can now be no objection to its being stated that it was Mr. John Noble, a member of the Society, who died in I890), enabled the Society to carry out in 1873 and 1874 some very interesting experiments on the economical use of coal in domestic stoves. The money was placed at the disposal of the Society in July 1872 , and the intention of the donor was, in his own

' See Chapter XV, p. 336, and Chapter XVI, p. 389. 
words, to encourage the development of improved means for the economical use of fuel in private dwellings. The manner in which it was to be utilised was left to the discretion of the Council, and they determined to offer five prizes of $£ 50$ each, together with a gold medal, under certain specified categories, for stoves or grates for warming and cooking, whether by coal or gas. The competing apparatus were to be exhibited in the 1874 Exhibition at South Kensington, and it was expected that the awards would be made at the conclusion of that Exhibition.

Two hundred and four competitors replied to the invitation, and from the various apparatus sent in 107 were selected for testing. To carry out the tests a series of rooms was erected on ground lent for the purpose by the I 85 I Commission. Six rooms, fifteen feet cube, were erected in concrete, and facilities were provided in each room for fitting the stoves to be tested. A committee was appointed, and a very elaborate series of tests was devised; indeed, the committee were a little too ambitious in their efforts, for the tests were so elaborate that it would hardly have been possible to have carried them to a successful conclusion with the funds provided. They included careful temperature tests of the air in different parts of the room and chimney, measurement of the chimney-draught, and of the air coming into the room, and hygroscopic tests for the amount of moisture in the air at different stages of the experiments. It is probable that the value of these last-mentioned tests was at all events diminished by the character of the buildings, which were new and possibly not quite dry even by the time the experiments were finished. However, a great deal of time and trouble was taken, one member of the committee-the Rev. Arthur Rigg ${ }^{1-d e v o t i n g}$ himself constantly to the work from February i 874 until

1 The Rev. Arthur Rigg was the first Principal of the Diocesan Training College at Chester, which he converted into a really excellent technical school, the first of its sort in England (see obituary notice, Journal, vol. xxviii. p. 820). He gave the Society some valuable courses of Cantor Lectures, the first of them being the one on "Mechanism," delivered in 1872. Mr. Rigg was an extremely skilful amateur mechanic, and a man of considerable scientific knowledge. 
the latter part of the summer of that year. No actual cooking tests were made, but the time required to raise a measured quantity of water to boiling-point was taken with all the cooking-stoves, and careful thermometer tests of the temperature of the ovens were also carried out.

The committee eventually acquired a great mass of information, but the results were hardly sufficiently conclusive to justify their publication. A number of the stoves tested were of considerable merit, certainly the best that were constructed at that date; but amongst these the committee did not feel justified in making any selection for the prizes, and consequently in December I 874 they published a report giving the conclusion, which they said they had arrived at with very considerable regret, that they were unable to award any prizes. The grant of $£ 500$ was all expended, and about $£ 75$ in addition was paid by the Society.

Whether the committee might not fairly have awarded medals to a certain number of the competitors is a matter upon which it is not now possible to express any opinion. But it is quite certain that they could not fairly have discriminated amongst the different stoves submitted by selecting any particular one for the first prize.

The competition is specially interesting in being probably the first attempt to apply an elaborate series of scientific tests for the purpose of exhibition awards, and it affords certain testimony as to the inevitable difficulties in carrying out such tests, which, it may be added, have often been demanded by exhibitors, and without which, it must be confessed, exhibition medals lose a great part of their value.

The efforts made by the Society in previous years to secure suitable houses for the labouring classes have been recorded in previous chapters. ${ }^{1}$ The matter was again taken up in 1863, when Mr. J. Bailey Denton provided two prizes of $£ 25$ each for approved designs for cottages,

${ }^{1}$ See Chapter XIII, p. 31 2, and Chapter XVI, p. 392. 
to be built singly or in pairs, at a cost not exceeding $£_{100}$ each. One hundred and seven competitors sent in I 34 designs, and in the following year one of the prizes, with a medal, was awarded to Mr. John Birch, on the recommendation of the committee that, although the conditions were not strictly complied with, the design contained so much merit that it richly deserved an award. The report of the committee, with a plan and elevation of Mr. Birch's design, will be found in the Journal (vol. xii. p. $40 \mathrm{I})$.

The offer of these prizes, and some discussion which took place on a paper read by Mr. J.C. Morton, in the autumn of i 863 , on agricultural progress, together with some statistics collected by a committee on model dwellings appointed by the Society, under the chairmanship of $\mathrm{Mr}$. Thomas Twining, led to the holding of a conference in May 1864, at which the subject was fully discussed and a good many useful suggestions were made. Two years later, in I866, a Bill drafted on the lines suggested by the conference was introduced by Charles Buxton into the House of Commons. Neither the proposals of this conference, nor the various offers of prizes through the Society, successful as they were in obtaining excellent designs, have done very much to assist the provision of labourers' dwellings in rural districts, though they certainly have had their effect by influencing public opinion in the promotion of the provision of industrial dwellings in London and other cities. So far as rural districts go, notwithstanding the constant attention which has been paid to the subject, the great Royal Commission of 1880 , of which King Edward vir. (then Prince of Wales) was a member, and the recent special efforts which have been made to encourage the erection of labourers' cottages, it cannot be said that much progress has been made since the Society first offered a prize in 1799 , inasmuch as a writer on the subject was able to say at the present time, and with perfect truth, that "the deficiency of good cottages in rural districts is one of the most notorious evils from which the English countryside suffers." 1

${ }^{1}$ Daily Graphic, 3rd December I9r 2. 
Those who are old enough to remember the conditions of the traffic between England and France in the sixties and seventies of the last century, can realise that the Council of the Society were well justified in offering, in I869, gold and silver medals for improved Channel steamers. The vessels used were small. They were heavily engined and fine sea-boats, but extremely lively, while the passenger accommodation was limited, and in bad weather they were very uncomfortable. For many years there had been little improvement, and there seemed small prospect of any. The offer of the prizes cannot be said to have had much effect, although it produced the double-hull steamer of Captain Dicey and Mr. Sedley, on the lines of which the Castalia was afterwards constructed. This vessel, as many will remember, ran successfully between Dover and Calais for some years. But the report of the committee appointed by the Council, and the evidence they collected, together with the admirable paper read a few years later, in I 873, by Colonel Strange on "Ships for the Channel Passage," had a great deal to do with helping forward the formation of public opinion, so that eventually sufficient pressure was brought to bear upon the railway authorities, who were responsible for the trans-Channel traffic, to induce them to improve the accommodation as it was improved in the later years of the nineteenth century.

About the same time as these prizes for Channel steamers were offered, a prize was offered for improved ships' life-boats. Although a good many models and drawings were sent in, none of these were considered worthy of an award. Later on again the subject was taken up, attention having been drawn to it by the sudden sinking of H.M.S. Eurydice, a training-ship which had capsized in a sudden squall off Ventnor in March 1878, and a prize was offered for a ready means for saving life where any apparatus to be of any service at all has to be available within a very short period, possibly not exceeding five minutes. It was found possible to award this prize (a gold medal), and it was given to Messrs. J. \& A. W. Birt, for a collection of buoyant articles sent in by 
them, while several other exhibitors received honourable mention. The most useful work, however, done by the committee was the production of an exceedingly valuable report, due mainly to the excrtions of Admiral A. P. Ryder, which appeared in the Joumal, ${ }^{1}$ and was afterwards published as a Parliamentary paper.

Among the subjects included in the list of the Society's technological examinations was the use of the blow-pipe. This addition was made at the suggestion of !(Sir) Clement Le Neve Foster, one of the inspectors of metalliferous mines, who was himself a skilful user of the implement, and was a great believer in the value of blow-pipe analysis. The examination was a practical one. Test specimens were circulated among the candidates, which they were expected to analyse.

Some difficulty was found by the students who came up for examination in obtaining a good set of blow-pipe apparatus at a moderate price, and in 1877 a prize of $6_{10}$, which was provided by Colonel Angus Croll, a member of the Society, was offered for the best blow-pipe apparatus which could be sold retail for a guinea. Several sets were sent in, including one by Messrs. Letcher, of St. Day, Cornwall, and to this the prize was awarded.

After the Technological Examinations were handed over to the City Guilds' Institute, the committee of that institute, or its technical advisers, took a different view of the value of blow-pipe analysis, and the examination was discontinued.

A sum of $£ 100$ was offered to the Council by Sir Joseph Whitworth in 1873 , for the purpose of providing prizes for Essays on Thrift, the subject to be dealt with being defined as "The advantages which would be likely to arise if railway companies and limited companies generally were each to establish a savings bank for the workingclasses in their employ."

Fifty-three essays were sent in, but the judges reported, in July 1874 , that none of them were of sufficient merit 1 Vol. xxvii. (1 879) p. 298. 
to be entitled to the full prize. They, however, recommended that $£ 50$ should be awarded for an essay sent in by Joseph Mason, and this was done. The essay was afterwards printed, and a small edition issued by the Society.

An attempt by the Society to encourage mechanical road traction is worth mention. In the premium list issued in 1873 a gold medal had been offered under the Howard Trust, for " a traction-engine of moderate power capable of being employed as a substitute for horse-power on tramways, and in the streets of cities and towns." The engine was to form one structure in combination with the carriage. The power might be generated by any means, provided that "noise, noxious fumes, or the discharge of refuse into the air or on to the road surfaces "was avoided. John Grantham, an engineer, who died in 1874 , had built an engine purposely to compete for this prize, and after his death his widow put in a claim for it. (Sir) F. J. Bramwell, with whom the development of steam traction on common roads had been since the days of his apprenticeship-when he was associated with Hancock, the pioneer of mechanical road traction-a subject of special interest and study, sent in a report strongly recommending Grantham's engine and car, and on that report the medal was awarded. The report, which was published in the Journal, ${ }^{1}$ is interesting reading at the present time. It not only gives a clear account of the particular invention described, but contains a good deal of information on the early history of mechanical road locomotion, and a lucid exposition of the principles which should guide the construction of road-cars, now common knowledge, but little appreciated in 1875 .

Grantham's car was soon after set to work on the Wantage tramways, and ten years later it was stated in the discussion of a paper on Steam Tramways, read before the Institution of Civil Engineers by the Hon. R. C. Parsons, that it was still working on them. Speaking in the same discussion, Mr. Edward Woods, the well-known engineer and a Past-President of the Institution, referred to $\mathrm{Mr}$.

${ }^{2}$ Journal, vol. xxiii. (I875) p. 728. 
Grantham as the "pioneer in the introduction of steam tramway cars for traffic." 1 From Sir Frederick Bramwell's description of it, it is clear that the car was equally suitable for work on common roads, and doubtless, but for the legislative restrictions on mechanical traction, it would have been so applied. But Grantham, like Loftus Perkins and many another inventor of steam carriages about this time, was prevented from carrying out his ideas, and it was not till the advent of the petrol engine and the success of the automobile in France compelled the rescission of obstructive laws that English inventors were given fair-play in their attempts to develop what has since proved to be a great and lucrative industry.

In the middle of the last century the cab system of the metropolis was in a by no means satisfactory condition. In a paper on the subject, read at a meeting of the Society in 1867 , (Sir) Henry Cole expressed the opinion that, " on the whole, we had in London the meanest cabs in the world." The system of cab fares was also a constant cause of complaint. At that time the rate was $6 \mathrm{~d}$. a mile within the four-mile radius, without the shilling minimum afterwards introduced. Two years after the reading of Henry Cole's paper, the Council took up the subject, and began by organising a conference upon it, which was held in June $\mathrm{I} 869$, and in this a good many cab proprietors and others interested in the question took part. A deputation also waited on the Home Secretary asking for legislation, and this may have had its effect in hastening on the Act of 1869.

In order to encourage the production of a better class of vehicles, in the same year gold and silver medals were offered for open and closed hackney carriages constructed to carry two or four persons. At the same time a silver medal was offered for an instrument which should indicate the fare, either by registering the distance or otherwise. The offer was not successful in the production either of improved vehicles or of a practical taximeter. Although a number of instruments were sent in, none of them were

${ }^{1}$ Proceedings, Inst. C.E., vol. lxxix. (1884) p. 129. 
approved by the committee, and, indeed, it is probable that if at the time a good instrument had been constructed, it would not have been adopted by the trade.

In 1872 the question was again taken up, and this time with more success. One of the sections of the Exhibition of 1873 was devoted to carriages, and the Council determined to offer money prizes, amounting altogether to $£ 120$, for improved cabs, which were to be shown in the exhibition, and were also to have been regularly used in London for three months. For this competition a considerable number of cabs were sent in, showing a great variety of construction and a good deal of novelty. From them a committee appointed by the Council selected four as worthy of favourable notice and specially deserving reward, and they recommended the Council to divide the total amount offered equally among these four. The Council, therefore, awarded prizes of $£ 30$ each for hansoms to Mr. C. Thorn, of Norwich, and to Messrs. Forder \& Co., of Wolverhampton ; and for four-wheelers to Mr. Lambert, of Great Queen Street, W.C., and Messrs. Quick \& Norminton, of Kilburn. Both four-wheelers were capable of being used either open or closed. As regards the hansoms, the result of the offer was considerable, as from that time forward the character of the London hansom was greatly improved. The prize also seems to have exerted some influence in improving the character of the four-wheeler, but it had no effect whatever in promoting the production of a four-wheeler capable of being used as an open carriage.

In March 1874 the Council determined to offer a gold medal for an improved railway lamp, and an announcement to that effect was made in the Journal for 29th May of that year. In response to the announcement, twelve competitors sent in lamps, some for mineral oil, some for vegetable oil, and some for gas. A selected number of these were tested for the light afforded, and the best of these were subjected to a practical trial on the St. John's Wood Railway. At that time the Metropolitan Railway did not extend farther than Swiss Cottage, and there 
was an unused length of tunnel beyond this which was available for the purpose. The company lent a railway carriage and afforded all necessary facilities for the experiments. The lamp which came out the best from all these trials was Pintsch's Compressed Gas Lamp, and this was subjected to a further practical trial by the Metropolitan Railway Company. The trial, which extended over about three weeks, being reported upon as favourable, the medal was awarded to Messrs. Pintsch for their lamp. This lamp afterwards came into extensive use, and the award of the Society was fully justified.

A gold medal was offered for the best collection of specimens of steel suitable for general engineering purposes sent to the International Exhibition of 1873. But the committee appointed to make the award reported that none of the collections sent in fulfilled the conditions laid down, and therefore they could not recommend any award.

In November 1873 a letter was addressed by Admiral Ryder to the Council, pointing out the need which existed for the provision of an accurate revolution indicator for use on board ship, since at the time, although various plans for indicating the number of revolutions made by the screw-shaft had been proposed, none had as yet been successful. In accordance with Admiral Ryder's suggestion, a gold medal was offered in the following January for the best revolution indicator "which shall accurately inform the officer on deck and the engineer in charge of the engine what are the number of revolutions of the paddles or screw per minute, without the necessity of counting them." Eighty-four competitors sent in apparatus or descriptions, and of these nine were selected by the committee for trial on board ship. The Admiralty lent H.M. gunboat Arrow for the purpose, and five of the selected candidates fitted their instruments on board, where they were duly tested. As the result of the trials, the prize was awarded in May i 876 to Mr. T. A. Hearson, whose strophometer was found to work with complete 
satisfaction. The apparatus was afterwards brought into practical use, and was found of considerable value.

The wet weather of the summer of 1867 , and the consequent injury to the harvest of that year, induced the Council to offer a prize of fifty guineas and the Society's gold medal for an essay on harvesting corn in wet seasons, in the hope that some practical suggestions for drying crops of all sorts might be forthcoming. Twenty essays were sent in, and the prize was awarded to $\mathrm{Mr}$. W. A. Gibbs, of Gillwell Park, Essex, for an essay which appeared in three numbers of the Journal. ${ }^{1}$ This essay gives a very full account of the various methods proposed for the artificial drying of crops, including hay as well as corn, and described at considerable length the devices proposed by the author, which were the result of long-continued experiments upon his own farm.

Mr. Gibbs' proposal was to utilise a hot-air blast, driven through a chamber of suitable construction, and provided with various devices according to the character of the crop to be treated. In the case of hay, it was proposed to carry the wet grass through the chamber on a travelling apron. With corn it was preferred to place each sheaf on a vertical support, consisting of a pipe, by which the hot air was delivered into the centre of the sheaf. The sheaf, when dried, was removed by hand. Mr. Gibbs' arrangements met with a good deal of approval by agricultural authorities, but they do not appear ever to have come into actual use.

Something must now be said about the finances of the Society in the period after the great Exhibitions, but before this it may be worth while to find room for a paragraph about a financial question which at one time exercised the minds of the Council, though it is really rather curious than important. The question of the liability of societies to parochial rates has always been rather a difficult one since the passing of the Act in 1843 (6 \& 7 Vict. c. 36), which exempted societiesinstituted "for purposes of science,

${ }^{1}$ Vol. xvi. pp. 781, 793, and 804. 
literature, or the fine arts exclusively" from "county, borough, parochial, and other local rates." To enable it to claim exemption the society must be "supported, wholly or in part, by annual voluntary contributions," and there are certain other conditions. Immediately the Act was passed the Society of Arts took advantage of it, and, in accordance with its provisions, applied to Mr. Tidd Pratt, the Registrar of Friendly Societies, for his certificate. Mr. Pratt was of opinion that the Society " could avail itself of the provisions of the Act," and from that time forward it paid no rates. In i 869, however, the parochial authorities declined to admit the exemption, and rated the Society in full. The matter duly came before the Petty Sessions, and the magistrates decided against the Society, but granted a case for appeal to the Queen's Bench. Mr. (now Sir) H. B. Poland was instructed to state a case, and did so, but he added the opinion that the Society was rateable, inasmuch as it had been established for the promotion of commerce, whereas the Act applied exclusively to societies for the promotion of science, literature, and the fine arts.

The Council at the time were inclined to drop the proceedings, but eventually decided that the case should be proceeded with. It was accordingly sent by the Society's solicitors to the solicitors for the parish, who allowed the matter for a long time to stand over. But in 1872 the application was suddenly renewed, and the Society then took the opinion of Mr. Hardinge Giffard (now Lord Halsbury), which was to the effect that the proposition contended for by the Society was hardly arguable. He therefore advised the Council not to proceed further with the case. Under these circumstances the Council abandoned further opposition to the claim of the parish, and in February 1873 they paid the amount of $£ 246,19 s$. , being the rates due from Michaelmas i $\$ 69$ to Lady Day I 873 .

The Act itself was intended for the benefit of the various local institutions which at the time were being founded in different parts of the country- "Athenæums," as they were commonly called-and it was certainly 


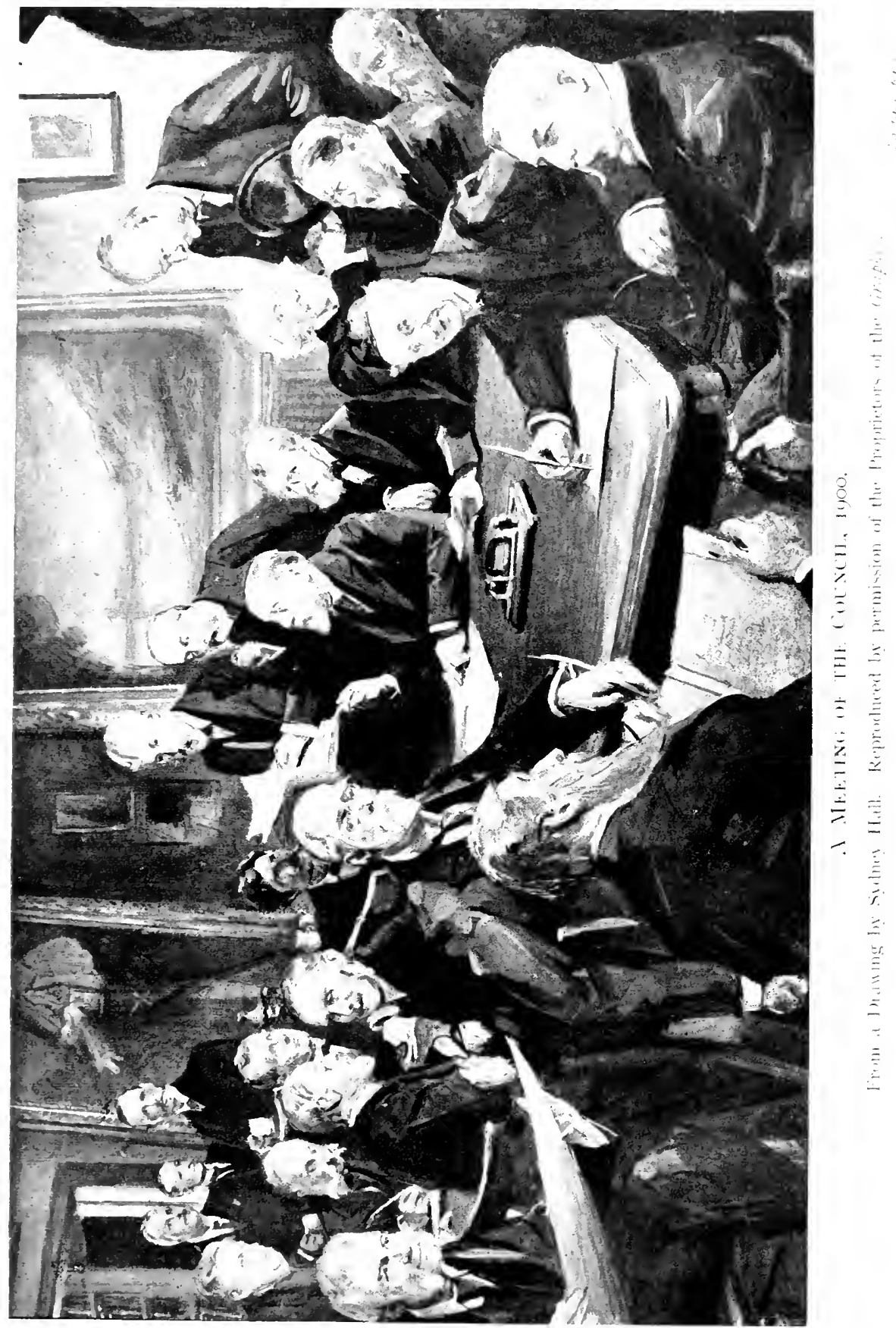



meant to be of much wider application than it has proved to be under the interpretation of necessity placed upon it by the Courts of law. There have been various cases under it, some of which are reported in a treatise on the Act published in $185 \mathrm{I}$ by George Taylor, a barrister, and others in the principal modern authority on the subject, "The Law and Practice of Rating," by W. C. Ryde (1912).

In 1878 the liability of the Institution of Civil Engineers to pay rates was raised, and a special case was argued before Justices Field and Manisty, who confirmed the rate, with costs against the Institution, on the ground that a society the primary object of which is the acquisition of scientific knowledge for the purposes and in the interests of a particular profession is not a society instituted for purposes of science exclusively. Some doubt has, however, been thrown on this decision by a more recent decision of the House of Lords in I890, when the Commissioners of Inland Revenue appealed against a decision of the Court of Appeal that the Institution was not liable to Corporation Duty under the Customs and Inland Revenue Act, I 885 ( 48 \& 49 Vict. c. 51). In that case it was held by Lords Watson and Macnaghten (Lord Halsbury dissenting) that the property of the Institution was entitled to exemption, because it was in fact legally appropriated and applied substantially for the promotion of mechanical and engineering science, and not for the promotion of the professional interest or advantage of its members.

In the case of the Zoological Society, tried in 1854 , it was held that the Society could not be considered either as a society for the purpose of science exclusively or as supported by voluntary contributions.

In 1895 the Imperial Institute appealed to the County of London Sessions against the assessment of the Institute and claimed exemption. The Bench (Sir Peter Edlin being the chairman) decided that the Institute was liable, but reduced the rateable value from $£$ I5,400 to $£$ I I,700. The United Service Institution, the Working Men's Education Union, the Art Union, and the British and Foreign School Society are also among the institutions which have been held not to be exempt. 
On the other hand, the Linnæan Society and the Royal College of Music have been held to be exempt.

It appears to have been held, in one case, that by "voluntary contributions" are meant free gifts which the society could not recover by process of law or enforce in any way, and in return for which the donors received no benefit. The donor must give "from disinterested motives, not looking for any return in the shape of direct personal advantage." Whether under this ruling any society publishing Transactions, or providing its members with an annual conversazione, could maintain its right to exemption, may perhaps be an open question. If so, on a strict interpretation of the wording of the statute, there must be few institutions which could take advantage of its provisions.

Whether it is reasonable that certain parishes should be called upon to contribute to the funds of institutions, however meritorious, from which they derive no special advantage-for, however beneficial to the world in general may be the work (say) of the Society of Arts, it cannot be said to profit the parish of St. Martin's more than the parish of Paddington or of Bethnal Green-is a matter of opinion. It might be held that such aid might more properly come from Imperial than from local sources, while it is hardly disputable that the statute of $6 \& 7$ Vict. c. 36 badly needs revision, so that the benefits it is intended to provide might be distributed with greater impartiality amongst those morally, if not legally, entitled to them. Whether any modern Chancellor of the Exchequer would approve of such a modification of the law is another question.

During the period of the Society's history with which we are dealing (i 860 to i 880), its resources were sufficient and its financial position was sound. Looking back to the period of its greatest depression, before its incorporation, we see that its membership had been reduced to something like 300 , and its resources were nil. In December i 843, six months after the Prince Consort had become President, there were 685 members. In I 850 the numbers were a little under 2000. In 1856 they were reported as being about 
1700. After this we get a constant and regular increase. The numbers in November I 86 I were 2263 , and by the same date in 1866 they had grown to $303 \mathrm{I}$, an increment due mainly to the i 862 Exhibition. In the next ten years the increase was steady, but less rapid-3200 in 1870 , and 3800 in 1875 . The numbers fell to 3300 in 1881 , and rose again to 3656 in 1885 .

The Society's income of necessity fluctuated with the number of its members, since their contributions form its sole source of revenue. Taking round figures, its income in I 86I was over $£ 5000$, and in 1862 over $£ 6000$. In these two years also a sum of over $£ 2000$ was repaid by the Commission of the 1862 Exhibition, but this amount was absorbed by the expenditure on the new lease of the premises, $£ 2361$. In addition to the renewal fine and the charges on the new lease, the Society spent a sum of $£ 2800$ on the premises during the four years i 863-6.

The income was practically stationary for some years, but by 1880 it had grown to more than $£ 8000$, the increase being mainly due to the dividends from invested benefactions, increased revenue from the advertisements in the Journal, and other minor receipts.

During this period the Society was singularly fortunate in the benefactions it received. The Swiney and Cantor bequests, already recorded, were of an earlier date, but in the eight years 1868 to 1876 it came in for a considerable amount. It received a legacy of $€ 100$ in 1868 from Dr. Aldred, one of $£ 2000$ in 1870 from Alfred Davis, and another of $£ 200$ in the same year from Alexander Robb. In 1872 , Thomas Howard bequeathed to it $£ 500$ to found prizes for treatises on motive-power and for other purposes; while in 1875 and 1876 respectively, the Mulready and Owen Jones Prize Trusts were made over to the Society. In i 876 also Benjamin Shaw presented the Society with $£^{1} 33$ to found a prize for industrial hygiene. These last-named donations or trusts, though of no pecuniary benefit to the Society, yet are valuable as aiding it to carry out certain portions of its proper work.

With such abundant resources it might have been 
expected that the Society at the end of this period would have been in a stronger financial position than it really was. But it must be admitted that its expenditure was somewhat lavish, and not controlled with sufficient care or strictness. Large sums were expended upon objects no doubt desirable but rather costly, and much money was spent which could easily have been saved by a more judicious administration of the funds. The publication of the Jury Reports of the 1862 Exhibition ${ }^{1}$ was a creditable piece of work, and the book produced was of considerable value, but the expenditure upon it of over $£$ iooo seriously hampered the Society at a time when it had to provide a sum of $£ 5000$ for lease renewal and repairs. If, as was indeed the case, the 1862 Commissioners had no available surplus for publication purposes, they might reasonably have called upon their more fortunate predecessors of 1851 for the needed help.

A few years later the National Training School for Music was successfully endowed with large funds collected entirely by a committee of the Society, and started in a building provided by one of its members. Surely this was sufficient without the Society being called upon to contribute over $£ 2000$ in cash. The Society's efforts to encourage drill in schools cost $£ 540$. The efforts were quite successful, but rather expensive. The contribution of $£$ iooo to the Prince Consort's Memorial in 1862 is in a very different category. No money gift could represent the value of the Prince's services to the Society. Yet is it unreasonable or ungrateful to feel a wish that the evidence of appreciation had been shown in some other form? That while it was liberal, it was yet felt at the time to be inadequate, is shown by the spontaneous decision of the members ${ }^{2}$ to establish by voluntary subscriptions a special memorial of their own.

The Society was always solvent, but expenditure of this liberal character was just a little more than it could stand. and consequently the annual revenue did not always meet he annual outlay, and the balance had to be temporarily made good by applications to the bankers. Whether

\footnotetext{
1 See Chapter XVIII, p. 423.

${ }^{2}$ See Chapter XVI, p. 399.
} 
an institution like the Society ought to make provision in prosperous years for possible future needs may be a matter of opinion. It is certainly not called upon to accumulate large funds, but all experience goes to show that it is wise in times of prosperity to use a judicious economy, and to keep, as long as possible, a sufficient margin of surplus, so as to provide for the bad times which are certain some day or other to overtake institutions as well as individuals.

The writer has now brought to an end the task he started upon about three years ago-the preparation of a History of the Royal Society of Arts. He has striven to give some account of the objects for which it was established, of the work it endeavoured to accomplish, and of the individuals of whom it was composed. The work has not been without its special difficulties, the chief of which has been that of correlating and bringing into some sort of ordered sequence the multifarious and miscellaneous subjects to which in the course of its long career the energies of the Society, corporate and individual, have been devoted. He doubts whether he could have persevered with the task but for the kind encouragement he received from many members of the Council and of the Society while the articles of which this volume is composed were appearing in the Society's weekly Journal.

At all events, he is satisfied that the work of the Society deserves record, and he is not without hope that the narrative which he has prepared may add to the Society's credit and promote its future welfare. Naturally, such an account must record much wasted energy, but it also records much strenuous hard work, done by individuals for what they considered the public service, and without any personal interest beyond the natural and human desire to obtain credit and appreciation from their fellows. The results of the associated efforts of such a combination of individuals as this Society will be appreciated at different values according to the point of view of the observer. The standpoint of one who has served the 
Society for a little over forty years cannot be that of an impartial critic, but the writer can honestly say that the fairly minute study of the Society's records to which he has devoted the leisure of the past three years (added to a certain familiarity with them acquired during the work of the past forty) has resulted in a genuine admiration of the unselfish labours of its dead-and-gone constituents, and in a sincere conviction that, on the whole, their labours have been of constant and real service to the State.

Many of their objects were trivial, many of their efforts were futile, but when all allowance is made, the net result is an enormous mass of useful work, beneficial to the country and serviceable to mankind. Certainly no society has had objects so many or so multifarious. Few can have endured such vicissitudes. It has earned much popularity, it has incurred its fair share of ridicule. It has been often praised and often blamed, generally with equal lack of reason. It has endured for a period of more than a century and a half, and is certainly as prosperous now as it has ever been. There is no reason why that prosperity should not continue. In the future, as in the past, it will doubtless find fresh fields of activity, and, as it has ever done, change with the changing years, and adapt itself to the fresh conditions of the coming time.

For all institutions depending on voluntary subscriptions the times grow harder. They are in the position of people with fixed incomes and growing expenses. In our own case the scale of contribution was fixed i 50 years ago, and it cannot well be altered now ; but it is far less profitable, while nearly all the items of expenditure are of necessity far more costly. It is difficult to discern a source from which the Society's revenue can be supplemented. It is unlikely that the subsidies given by the State to certain institutions will be increased. That the bounty might be more fairly distributed there cannot be much doubt. Few would question the propriety of State aid being liberally given to the two great institutions which are respectively at the head of Science and of Art in this country. The method of distribution of State support to other institutions is open to criticism. It seems 
accidental and casual, governed by no particular principle. At all events, the Secretary of a Society which has always been left out in the cold when there was any benefit going, may be forgiven if he does not fully appreciate the manner in which State patronage has been bestowed elsewhere.

Perhaps, in default of State aid, the private benefactor may supply the needed help. Many of the best institutions of the country-Universities, Schools, Hospitals-owe their existence to the surplus wealth of the pious founder of ancient days. Numerous modern charities have been founded, and are still supported, by philanthropic benefactors. Education and science have had their full share of generous gifts. Perhaps in the future it may occur to some liberal possessor of millions, accumulated from industrial sources, that an endowment might well be bestowed on an institution which for the best part of two centuries has really done not a little to carry out the objects of its foundation-the promotion of "Arts, Manufactures, and Commerce." 



\title{
APPENDIX I
}

\section{THE SOCIETY'S OFFICIALS}

\author{
I754-I9I3
}

\section{Presidents}

Viscount Folkestone

Lord Romney

The Duke of Norfolk, E.M.

H.R.H. the Duke of Sussex, K.G.

H.R.H. Albert Prince Consort, K.G. . I843-I86I

William Tooke, F.R.S. . . . . . 1862

H.R.H. the Prince of Wales, K.G. (King Edward VII.) I863-IgoI Sir Frederick Bramwell, Bart., F.R.S. •

H.R.H. the Prince of Wales, K.G. (King George V.) · Igor-I9Io

Lord Alverstone, L.C.J., G.C.M.G., F.R.S. IgIo

H.R.H. the Duke of Connaught, K.G. . IgII

\section{Chairmen of Council}

Edward Speer

George Bailey $\}$ Joint Chairmen

Edward Speer

Francis Fuller

Henry Cole

W. W. Saunders, F.R.S. .

Henry Cole, C.B.

Captain Owen, R.E.

Harry Chester

Viscount Ebrington, M.P.

Rev. James Booth, LL.D., F.R.S.

Colonel W. H. Sykes, M.P., F.R.S.

C. Wentworth Dilke

Sir Thomas Phillips

William Hawes, F.G.S.

Sir Thomas Phillips

William Hawes, F.G.S.

I846-I848

. I848-I849

- 1850

- 1850

- 1851

. 1852

- 1853

. 1853

. 1854

. $\quad$ 855

. 1856

- $1857-1858$

- $\quad \mathrm{I} 859-\mathrm{I} 862$

. I863-I865

. $\quad$ I866

. 1867 
Lord Henry G. Lennox, M.P. I868-I87I

Major-Gen. F. Eardley-Wilmot, R.A., F.R.S. . $1872-1874$

Lord Alfred Spencer Churchill . . . . $1875-1876$

Major-Gen. F. C. Cotton, C.S.I. . . . . $\quad 1877$

Lord Alfred Spencer Churchill . . . . . I878-I879

Sir Frederick Bramwell, Bart., F.R.S. . I880-I88I

Sir William Siemens, D.C.L., LL.D., F.R.S. $1882-1883$

Sir Frederick Abel, G.C.V.O., K.C.B., D.C.L., D.Sc., F.R.S.

Sir Douglas Galton, K.C.B., F.R.S. $8886-1887$

The Duke of Abercorn, C.B. . . . . I888-1889

Sir Richard Webster, Q.C., M.P. I890-I893

Major-Gen. Sir John Donnelly, K.C.B. . . I894-I895

Major-Gen. Sir Owen Tudor Burne, G.C.I.E., K.C.S.I. I896-I897

Sir John Wolfe-Barry, K.C.B., F.R.S. I898-I899

Sir John Evans, K.C.B., F.R.S. 1900

Sir William H. Preece, K.C.B., F.R.S. . I90I-I902

Sir William Abney, K.C.B., D.C.L., F.R.S. . . I903-1904

Sir Owen Roberts, D.C.L., F.S.A. . . . . I905

Sir Steuart Colvin Bayley, K.C.S.I., C.I.E. I906-1907

Sir William H. White, K.C.B., F.R.S. . · 1908-I909

Sir John Cameron Lamb, C.B., C.M.G. . I9Io

Lord Sanderson, G.C.B., K.C.M.G., I.S.O. I9II-I9I2

\section{SeCretaries}

William Shipley . . . . . . I754-I757

George Box . . . . . . . $1757-1760$

Peter Templeman, M.D. ․ . $\quad$. $\quad$. I760-I769

Samuel More $\quad . \quad$. $\quad$. $\quad$. $\quad$. . . 1769-I799

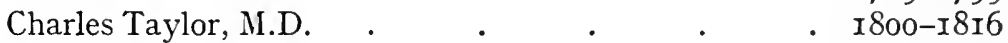

Arthur Aikin $\quad . \quad$. $\quad . \quad$. $\quad . \quad$. I8I7-I839

W. A. Graham . . . . . . . I839-I842

Francis Whishaw $\quad . \quad$. $\quad . \quad$. $\quad$ I $1843-1845$

J. Scott Russell, F.R.S. . . . . . . $1845-1850$

George Grove . . . . . . . $1850-1852$

Edward Solly, F.R.S. . . . . . . $1852-I 853$

Peter Le Neve Foster, M.A. I853-I879

Sir Henry Trueman Wood, M.A. 1879

\section{Assistant-Secretaries}

George Box

- $1756-1757$

Richard "Samuel .

- I760-I779

- I779-I787 
John Samuel

Thomas Taylor

Charles Combe

Thomas Woodfall

S. T. Davenport .

W. Ellis .

James Forrest .

Charles Critchett, B.A.

H. Trueman Wood, B.A.

Henry B. Wheatley, F.S.A.

G. K. Menzies, M.A.

- ${ }^{17} 8_{7}-1798$

- I799-I805

- 1806

- $\mathrm{I} 807-\mathrm{I} 842$

. $1848-I 849$

. $I 849-1850$

. $\quad 1852-1856$

. $\quad$ I856-I 869

. $1876-1879$

- $1879-1908$

- 1908

\section{REgISTRARS, ETC.}

William Shipley .

Edward Grant Tuckwel

William Bailey

Alexander Mabyn Bailey

George Cockings (Porter, Collector, and Registrar)

- $\mathrm{I} 757-\mathrm{I} 760$

- $1760-1766$

. $1766-1773$

. $1773-1779$

Miss Ann Birch Cockings (Housekeeper and Registrar) . I802-I844

S. T. Davenport (Financial Officer) . . . $1853-1876$

H. Trueman Wood (Editor of Journal) . . . $1872-1876$

Colonel E. A. Hardy (Secretary of the Indian Section) I873-I884 Howard H. Room (Accountant). . . . I876-I900 George Davenport (Chief Clerk) . I879

Professor J. M. Thomson, F.R.S. (Secretary of the Chemical Section). . . . . . I879-I886

S. Digby, C.I.E. (Secretary of Indian and Colonial Sections) . . . . . . . 1890

J. H. Buchanan (Accountant) • . . . $\quad$ • 1900 


\section{APPENDIX II}

\section{THE ALBERT MEDAL}

\section{LIST OF RECIPIENTS}

I864-I9I3

THE Medal was instituted in I862 as a memorial of the Prince Consort, and is awarded annually for "Distinguished Merit in promoting Arts, Manufactures, or Commerce." It may be given to persons of any nation.

I864.- Sir Rowland Hil.L, K.C.B., F.R.S., " for his great services to Arts, Manufactures, and Commerce, in the creation of the penny postage, and for his other reforms in the postal system of this country, the benefits of which have, however, not been confined to this country, but have extended over the civilised world."

I865.-His Imperial Majesty NAPoleon III., " for distinguished merit in promoting, in many ways, by his personal exertions, the international progress of Arts, Manufactures, and Commerce, the proofs of which are afforded by his judicious patronage of Art, his enlightened commercial policy, and especially by the abolition of passports in favour of British subjects."

I866.- MichaEL FARADAY, D.C.L., F.R.S., " for discoveries in electricity, magnetism, and chemistry, which in their relation to the industries of the world have so largely promoted Arts, Manufactures, and Commerce."

i 867.- Sir W. Fothergill Cooke and Sir Charles Wheatstone, F.R.S., " in recognition of their joint labours in establishing the first electric telegraph."

I868.- Sir JOSEPH WhITwORTH, LL.D., F.R.S., " for the invention and manufacture of instruments of measurement and uniform standards by which the production of machinery has been brought to a state of perfection hitherto unapproached, to the great advancement of Arts, Manufactures, and Commerce."

I869.-Baron Justus von LIEBIG, Associate of the Institute of France, For. Memb. R.S., Chevalier of the Legion of Honour, etc., " for his numerous valuable researches and writings, which 
have contributed most importantly to the development of food economy and agriculture, to the advancement of chemical science, and to the benefits derived from that science by Arts, Manufactures, and Commerce."

I870.-Vicomte Ferdinand DE Lesseps, Member of the Institute of France, Hon. G.C.S.I., " for services rendered to Arts, Manufactures, and Commerce, by the realisation of the Suez Canal."

I87I.- Sir Henry Cole, K.C.B., " for his important services in promoting Arts, Manufactures, and Commerce, especially in aiding the establishment and development of International Exhibitions, the Department of Science and Art, and the South Kensington Museum."

I872.- Sir Henry Bessemer, F.R.S., " for the eminent services rendered by him to Arts, Manufactures, and Commerce, in developing the manufacture of steel."

I873.-Michel Eugìne Chevreul, For. Memb. R.S., Member of the Institute of France, "for his chemical researches, especially in reference to saponification, dyeing, agriculture, and natural history, which for more than half a century have exercised a wide influence on the industrial arts of the world."

I874.--Sir William Siemens, D.C.L., F.R.S., " for his researches in connection with the laws of heat, and the practical applications of them to furnaces used in the Arts; and for his improvements in the manufacture of iron ; and generally for the services rendered by him in connection with economisation of fuel in its various applications to Manufactures and the Arts."

I875.-Michel Chevalier, " the distinguished French statesman, who, by his writings and persistent exertions, extending over many years, has rendered essential services in promoting Arts, Manufactures, and Commerce."

I876.-Sir George B. Airy, K.C.B., F.R.S., Astronomer Royal, " for eminent services rendered to Commerce by his researches in nautical astronomy and in magnetism, and by his improvements in the application of the mariner's compass to the navigation of iron ships."

I877.-Jean Baptiste Dunias, For. Memb. R.S., Member of the Institute of France, "the distinguished chemist, whose researches have exercised a very material influence on the advancement of the Industrial Arts."

I878.--Lord ARMStrong, C.B., D.C.L., F.R.S., " because of his distinction as an engineer and as a scientific man, and because by the development of the transmission of power-hydraulically -due to his constant efforts, extending over many years, the manufactures of this country have been greatly aided, and mechanical power benefically substituted for most laborious and injurious manual labour."

I879.-Lord Kelvin, O.M., LL.D., D.C.L., F.R.S., “ on account of the signal service rendered to Arts, Manufactures, and Commerce. by his electrical researches, especially with refer- 
ence to the transmission of telegraphic messages over ocean cables."

I880.-JAMES Prescotr Joule, LL.D., D.C.L., F.R.S., " for having established, after most laborious research, the true relation between heat, electricity, and mechanical work, thus affording to the engineer a sure guide in the application of science to industrial pursuits."

I88I.-August Wilhelm Hofmann, M.D., LL.D., F.R.S., Professor of Chemistry in the University of Berlin, " for eminent services rendered to the Industrial Arts by his investigations in organic chemistry, and for his successful labour in promoting the cultivation of chemical education and research in England."

I882.-LLuis Pasteur, Member of the Institute of France, For. Memb. R.S., " for his researches in connection with fermentation, the preservation of wines, and the propagation of zymotic diseases in silkworms and domestic animals, whereby the arts of wine-making, silk production, and agriculture have been greatly benefited."

I883.- Sir Joseph Dalton Hooker, K.C.S.I., C.B., M.D., D.C.L., LL.D., F.R.S., " for the eminent services which, as a botanist and scientific traveller, and as Director of the National Botanical Department, he has rendered to the Arts, Manufactures, and Commerce by promoting an accurate knowledge of the floras and economic vegetable products of our several colonies and dependencies of the Empire."

I884.-Captain JAMES BUCHANAN EADS, "the distinguished American engineer, whose works have been of such great service in improving the water communications of North America, and have thereby rendered valuable aid to the commerce of the world."

I885.-Sir HENRY DOULTON, " in recognition of the impulse given by him to the production of artistic pottery in this country."

I886. -Lord MASHAM, "for the services he has rendered to the textile industries, especially by the substitution of mechanical wool combing for hand combing, and by the introduction and development of a new industry - the utilisation of waste silk."

I887.- HER MAJESTY QUEEN VICTORIA, " in commemoration of the progress of Arts, Manufactures, and Commerce throughout the Empire during the fifty years of her reign."

I888.-Professor Herinann Louis Helmholtz, For. Memb. R.S., " in recognition of the value of his researches in various branches of science and of their practical results upon music, painting, and the useful arts."

I889.-JOHN PERCY, LL.D., F.R.S., " for his achievements in promoting the Arts, Manufactures, and Commerce, through the world-wide influence which his researches and writings have had upon the progress of the science and practice of metallurgy."

I890.-Sir William HENRY PERKIN, F.R.S., " for his discovery 
of the method of obtaining colouring matter from coal tar, a discovery which led to the establishment of a new and important industry, and to the utilisation of large quantities of a previously worthless material."

I89I.-Sir FREDERICK ABEL, Bart., G.C.V.O., K.C.B., D.C.L., D.Sc., F.R.S., " in recognition of the manner in which he has promoted several important classes of the Arts and Manufactures, by the application of Chemical Science, and especially by his researches in the manufacture of iron and of steel; and also in acknowledgment of the great services he has rendered to the State in the provision of improved war material, and as Chemist to the War Department."

I892.-Thomas Alva EdISON, "in recognition of the merits of his numerous and valuable inventions, especially his improvements in telegraphy, in telephony, and in electric lighting, and for his discovery of a means of reproducing vocal sounds by the phonograph."

I893.- Sir John Bennet Lawes, Bart., F.R.S., and Sir Henry GILBERT, Ph.D., F.R.S., " for their joint services to scientific agriculture, and notably for the researches which, throughout a period of fifty years, have been carried on by them at the Experimental Farm, Rothamsted."

I894.- - Lord Lister, F.R.S., " for the discovery and establishment of the antiseptic method of treating wounds and injuries, by which not only has the art of surgery been greatly promoted, and human life saved in all parts of the world, but extensive industries have been created for the supply of materials required for carrying the treatment into effect."

I895.- Sir ISAaC LowTHIAN BELL, Bart., F.R.S., " in recognition of the services he has rendered to Arts, Manufactures, and Commerce, by his metallurgical researches and the resulting development of the iron and steel industries."

I896.-Professor David Edward Hughes, F.R.S., "in recognition of the services he has rendered to Arts, Manufactures, and Commerce, by his numerous inventions in electricity and magnetism, especially the printing telegraph and the microphone."

I897.-GEORGE JAMES SyMONS, F.R.S., " for the services he has rendered to the United Kingdom by affording to engineers engaged in the water supply and the sewage of towns, a trustworthy basis for their work, by establishing and carrying on during nearly forty years systematic observations (now at over 3000 stations) of the rainfall of the British Isles, and by recording, tabulating, and graphically indicating the results of these observations in the annual volumes published by himself."

I898.-Professor Robert Wilhelm Bunsex, M.D., For. Memb. R.S., "in recognition of his numerous and most valuable applications of Chemistry and Physics to the Arts and to Manufactures." 
I899.-Sir Willian Crookes, F.R.S., "for his extensive and laborious researches in chemistry and in physics, researches which have in many instances developed into useful practical applications in the Arts and Manufactures."

IgOo.-HEXRY WILDE, F.R.S., "for the discovery and practical demonstration of the indefinite increase of the magnetic and electric forces from quantities indefinitely small, a discovery now used in all dynamo machines; and for its application to the production of the electric search-light, and to the electro-deposition of metals from their solutions."

Igor.-His HAJEsty King Edward VII., " in recognition of the aid rendered by His Majesty to Arts, Nanufactures, and Commerce during thirty-eight years' Presidency of the Society of Arts, by undertaking the direction of important exhibitions in this country and the executive control of British representation at International Exhibitions abroad, and also by many other services to the cause of British Industry."

I902.-Professor Alexander Grahair Bell, "for his invention of the Telephone."

I903.- - Sir Charles Augustus Hartley, K.C.M.G., " in recognition of his services, extending over forty-four years, as Engineer to the International Commission of the Danube, which have resulted in the opening up of the navigation of that river to ships of all nations, and of his similar services, extending over twenty years, as British Commissioner on the International Technical Commission of the Suez Canal."

I904.-W WaLter CRANe, " in recognition of the services he has rendered to Art and Industry by awakening popular interest in Decorative Art and Craftsmanship, and by promoting the recognition of English Art in the form most material to the commercial prosperity of the country."

I905.-Lord RaYleigh, O.MI., D.C.L., Sc.D., F.R.S., “ in recognition of the influence which his researches, directed to the increase of scientific knowledge, have had upon industrial progress, by facilitating, amongst other scientific applications, the provision of accurate electrical standards, the production of improved lenses, and the development of apparatus for Sound Signalling at Sea."

Ig06.--Sir JOSEPh IVILSON Swax, MI.A., D.Sc., F.R.S., " for the important part he took in the invention of the incandescent electric lamp, and for his invention of the carbon process of photographic printing."

Ig07.- The Earl of Cromer, O.MI., G.C.B., G.C.M.G., K.C.S.I., C.I.E., " in recognition of his pre-eminent public services in Egypt, where he has imparted security to the relations of this country with the East, has established justice, restored order and prosperity, and, by the initiation of great works, has opened up new fields for enterprise."

Igo8.-Sir Janes Dewar, M.A., D.Sc., LL.D., F.R.S., " for his 
investigations into the liquefaction of gases and the properties of matter at low temperatures, investigations which have resulted in the production of the lowest temperatures yet reached, the use of vacumm vessels for thermal isolation, and the application of cooled charcoal to the separation of gaseous mixtures and to the production of high vacua."

I909.- Sir ANDREw Noble, K.C.B., D.Sc., D.C.L., F.R.S., “ in recognition of his long-continued and valuable researches into the nature and action of explosives, which have resulted in the great development and improvement of modem ordnance." I9I0.-Madame Curie, " for the discovery of Radium."

igi i. -The Hon. Sir Charles Algernon Parsons, K.C.B., LL.D., D.Sc., F.R.S., " for his experimental researches into the laws governing the efficient action of steam in engines of the turbine type, and for his invention of the reaction type of steam turbine, and its practical application to the generation of electricity and other purposes."

I9I2.-Lord Strathcona and Mount Royal, G.C.M.G., G.C.V.O., LL.D., D.C.L., F.R.S., " for his services in improving the railway communications, developing the resources, and promoting the commerce and inciustry of Canada and other parts of the British Empire."

I9I3.- - His Majesty King George V., " for nine years President, and now Patron of the Society, in respectful recognition of His Majesty's untiring efforts to make himself personally acquainted with the social and economic condition of the various parts of his Dominions, and to promote the progre:s of Arts, Manufactures, and Commerce in the United Kingdom and throughout the British Empire." 


\section{APPENDIX III}

\section{PORTRAITS IN THE SOCIETY'S POSSESSION}

Portrait group of QueEN Victoria with the Prince of Wales, the Princess Royal, and other members of the Royal Family. Painted by J. C. Horsley, R.A., I864.

Portrait of H.R.H. the PrINCE Consort, president of the Society I843 to I86I. Painted by C. W. Cope, R.A., I864.

These two portraits, together with the bust of Prince Albert, form the memorial provided by subscriptions of members of the Society in 1863 in memory of the Prince.

Portrait of Jaсов, Viscount Folizestone, first president of the Society of Arts. Painted by Thomas Gainsborough, R.A., I776. It was a copy of a three-quarter portrait by Hudson (I749); enlarged to full length by Gainsborough to match the portrait of Lord Romney. The fee paid to the artist was a hundred guineas. Dance had previously been asked to do the work, and had undertaken to do so, but eventually was unable to carry out the commission.

Portrait of ROBERT, LORD ROMNEY, second president of the Society of Arts. Painted by Sir Joshua Reynolds, P.R.A., I770. The price paid to Sir Joshua Reynolds was I5o guineas.

Portrait of William Shipley, "whose public spirit gave rise to this Society." Painted by Richard Cosway, R.A., and presented by him to the Society in 1785 , through the intervention of Caleb Whitefoord, V.P.

Portrait of Peter Templeman, M.D., secretary of the Society from I760 to I769. Painted by R. Cosway, R.A., and presented by Caleb Whitefoord, V.P.

Portrait of Sanuel MoRe, secretary of the Society from $I 769$ to I799. Painted by Benjamin West, P.R.A., I796. The amount paid the artist was $f 66,8 \mathrm{~s}$.

Portrait of JAMEs BARRY, painted by himself. Presented to the Society by IV. Moffatt. 
Portrait, said to be JAMES BARRY's mother, and to have been painted by him. Of uncertain history and doubtful authenticity.

Portraits of CALEB WhiteFoord and of his wife. The painter is not known. Whitefoord was a member of the Society from I 762 to I8Io.

Portrait of Sir John Gladstone, father of the Rt. Hon. IV. E. Gladstone. Presented by Thomas Murray Gladstone in 1847 . T. M. Gladstone, who was a member of the Society, was a son of James, a younger brother of Sir John. He was engaged in the iron trade, and was a pioneer in the art of galvanising. The portrait is almost certainly the work of Thomas Gladstone (a son of Thomas, another brother of Sir John). He is said to have been an artist of promise, but died early.

Portrait of Sir FREDERICK BRAMwELL, Bart., president of the Society in I9or. Painted after Sir F. Bramwell's death by Seymour Lucas, R.A., and presented to the Society by H. Graham Harris, V.P., in I904.

Portrait of Sir Henry Trueman Wood, secretary of the Society from 1879. Painted by Sir Hubert von Herkomer, R.A., and presented by the members of the Council in 1902.

Portrait of Dr. Frederick Crace Calvert, F.R.S. Presented by Mrs. Calvert (I876). He delivered several courses of Cantor Lectures-the first in I864.

Portrait of Miss ANn BiRcH Cockings, housekeeper and registrar of the Society (I802-I844). Painted and presented to the Society by Miss E. A. Drummond (I822). This was in all probability the portrait for which Miss Drummond was awarded a gold medal in that year.

Bust of the Prince Consort by William Theed. Purchased by subscription from the members as part of the Prince Consort Memorial.

The Statue at the foot of the staircase is of Joshua WARD, a wellknown character in his time (I685-I76I). Ward, known as "Spot" Ward from a mark on his face, was a quack doctor who amassed a large fortune by the sale of his remedies. In his later life he was very popular, and had many patrons, including George II. In $\mathrm{I} 74^{\circ}$ he introduced into England an improved method of manufacturing sulphuric acid, already practised on the Continent, and set up works for the purpose at Twicken- 
ham and Richmond. The process was afterwards perfected by Roebuck. The statue is by Agostino Carlini, and was presented to the Society in I792 by Ralph Ward, Ward's grandnephew, and one of his heirs.

The Society also possesses a bronze Bust of Sir George Birdwood by Alfred Gilbert, R.A., a replica of one presented in $I 900$ to the University of Bombay by some Indian friends of Sir George ; and a terra-cotta Bust of Sir EDwix CHADwICk, the well-known sanitary reformer (I800-I890), by George Tinworth. It was presented to the Society by Sir Edwin's daughter in I905. 


\section{NDEX}

Abel, Sir Frederick, on methods for rendering fabrics wininflammatble, 310; Chairman of Council, 4.49; Albert medallist, 5 I 5 .

Abercorn, Duke of, Chairman of Council, $4+9$.

Abercorn, Earl of, 29.

Abraham, J. H., prize for apparatus to prevent injury from dust in grinding, 273.

Absolon, J., 162 .

Abstract of Proceedings, $333,373$.

Academy of Arts, draft charter for an, 328, 35I

Academy of Arts, Royal, first proposals for, 232 ; foundation of, I 54 , 233 ; grew out of Society's Picture Exhibitions, 226 ; effect of its establishment on Society's prizes, I 55, I 57 ; Professor of Clemistry at, 453.

Academy, Maiden Lane (Burgess's), I 68.

Academy of Misic, Royal, 478 .

Academy, St. Martin's Lane, 8, I 52, 227.

Academy, Shipley's, 7, 8, 9, 10, I6, $53,57,195$.

Academy, Sir IV. Thornhill's, S

Acierage, introduction of, 2 I 7 .

Acton, Mrs., donation to Society, $379,380 \mathrm{n}$. ; used to defray deficiency on Etty exhibition, 379.

Adam Brothers, design for the Adelphi, 6o; offer to build a house for the Society, 59.

Adam, J., 35.

Adam, R., 35 .

Adam, IV., 35 .

Adams, F., I62.

Addington, Dr. A., 35.

Adelpli, account of the, 59; history of site, 59; Adam's design, 60; completion of scheme, $63 ;$ Acts for building, 63 ; lottery for, 63 ; house in, offered to the Society by the Bros. Adam, 59 ; its construction, 63 ; foundation-stone laid, 64 ; conditions of tenure,
67, alterations, etc., in, 65 ; renewal of lease, $65 ; 503$.

African colonies, 84 , I 12,113 .

African section, 455 .

Agar, J. S., I62.

Aglio, A., I62.

Agrarian Revolution, I 4 .

Agricultural implements, I 24 .

Agricultural Societies, Highland, 3 ; Bath and IVest of England, 3; Scotch improvers in knowledge of agriculture, 3 ; connty, 6.

Agricultural Society, Royal, $1+2$.

Agriculture, Board of, II8. I4I ; account of, by Sir E. Clarke in Jourmal of the Royal Agricultural Society, I 4 I $n$.; statistical surveys by, I 4I, 302 .

Igriculture, condition of, in I754, 114 ; first connection of Society with, I I 5 ; offer of premiums, I 16 ; Society's lessened interest in, $\mathbf{I} 4 \mathbf{I}$.

Aikin, Arthur, account of method of making awards, $238 n$.; elccted Secretary, 335 ; his life and character, 335 ; his death, 336 ; suggests courses of lectures, 336 ; portrait, 336 ; organises and delivers lectures, 337 ; offer of gold medal declined, 337; medal awarded, 337; testimonial to, 337 ; originates regular reading of papers and discussions, 337 ; elected life member, 337 ; resigns sccretaryship, 338 ; his character, 343 ; system of lectures abandoned, 355 ; relates circumstances connected with Dr. Swiney's will, 393 .

Ainger, A., on first exhibition committee, $404 n$.

Ainslie, Dr. H., medals for planting trees, 149.

Airy, Sir George, acts as examiner, 43I ; Albert medallist, 513.

Albert, H.R.H. The Prince Consort, portrait in Great Room, 8o, $17 \mathrm{I}$, 400,518 ; bust, 80, 400, 5I9; on industrial applications of art, $\mathrm{I} 5.1$; his head placed on Society's meilal, 
319; clected a member, 325; address on his marriage, 326 ; elected President, 326; approves draft of charter, 352; influcnce of, on Society's work, 355; approves scheme of Educational Exhibition, 370; opens the Exhibition, 37I; proposal for Institute of Scicnce and Art at South Kensington, 375; suggests lectures on I 85 I Exluibition, 37S; services to Suciety, 399; subscription of fiooo to National Memorial, 399, 504; Society's memorial to, 400 ; the Albert medal, 320, 400; list of medallists, 5 I2 (App.); informed of Whishaw's Exhibition proposals, 40.4; has proposal for Exlubition formally submitted to him, 4o4; urges importance of application of art to industry, 405; receives proposals for Exhibition from $H$. Cole, 409 ; success of Exhibition due to him, 409 ; interest aroused in proposals for Exhibition, 4 Io; receives suggestions about Exlibition from $T$. Cubitt, tIo; decides that Exhibition is to be international, 4II; scheme for Exhibition in I $86 I^{\prime}$ submitted to him, 4I7; arrangements for organising $\mathrm{IS6} 2$ Exhibition reported to him, 4I9; founds Prince Consort's prize, 433; death of, 395,444 .

Albert Edward, H.R.H. The Prince of Wales, see Edward vir.

Albert medal, the, 320,400 ; list of recipients, 512 ( $A P p$.$) ; considera-$ tion of award by King Edward, 446 , 516 ; presented to Queen Victoria, $4+6,514$; presented to King Edward VII., 446; presented to King George V., 517 .

Alcock, Sir J. R., medals for anatomical models, I62.

Aldini, Giovanni, prize for firemen's mash, 272.

Aldred bequest, 503.

Aldridge, J., prize for ship model, 255.

Alger, J., on frozen meat, 163 .

Aliamet, F. G., I62.

Alkali from India, $88,27 \mathrm{~S}$.

Alkali from salt, offer of prize for, 86.

Alliali manufacture in America, 86.

Alkali, supply of, 278 .

Allason, T., I 63 .

Allen, R., 35.

Allom, Mrs., medal for introducing bees into New Zealand, I I 2.
Almack, W., 35 .

Almond, J., prize for hand-loom, 263.

Almonds in West Indies, 96.

Alocs from America, 92; from West Indies, 93.

Alverstone, Lord, on Society's proceclings, 443; President, 447.

Antrica, early societies in, 3 .

Anerican wine, 85 ; silk, 85, 265 ; potash, 85 ; saltpetre, 87 ; iron, 88 ; timber, 89 ; lemp, S9; sturgeon, 90 ; isinglass, 90 ; myrtleberry wax, $9 \mathrm{I}$; olives, raisins, logwood, cochincal, scammony, opium, safflower, persimmon, aloes, and sarsaparilla, 92 ; cotton, 98 ; tobacco, IoI ; sawmills in, 92, 247.

Ancaster, Duke of, 28 .

Ancient and Mediæval Art Exhibition, 407.

Anderson, Dr. Alexander, on breadfruit, 96 ; superintendent of St. Vincent Botanic Gardens, 99 ; medal for report, 99; medal for cultivating cloves and cinnamon, 99 ; letter by, IоI.

Anderson's History of Commerce, reference to Society, 52 .

Andras, Catherine, awards for wax modelling, I63, 224 .

Angerstein, J. J., 35; promotes suppression of climbing boys, 277 .

Anglesey, Earl of, 29.

Animal products, collection of, 376 ; made over to science and art department, 376 ; transferred to Bethnal Green, 376 ; cost of formation paid by 1851 Commission, 377 .

Annatto, West Indian, 93.

Annual dinner, $324,396$.

Annual distribution of prizes, $15 S$, $319,324$.

Anson, Baron, 33.

Ansted, Prof., Cantor Lectures, 453.

Anstey, Mrs., medal for growing cinnamon in India, Io2.

Anti-Gallican Society, 4.

Antill, E., premium for wine from New Brunswick, S6.

Aquatint, improvements in, 2rs.

Argyll, Duke of, 2s; presides at annual dinner, 396 .

Argyll Rooms, distribution of premiums in, 325 .

Armstrong, Lieut., prize for map of Northumberland, 300.

Armstrong, Lord, Albert medallist, 513 .

Armstrong, T., History of the School of Art Wood-Carving, ${ }_{4} 8_{3} n$.

Arne, T., 35 . 
Arnold, F., medal for Canadian hemp, ros.

Arsenic, prize for test of, $28 z$.

Art workmanship, offer of prizes for, 457 ; conditions, $45 \mathrm{~s}$; amounts offered, 458 ; discontinued, $45^{8}$; donation from North London Exhibition, 458 ; prizes offered at 1871 Exhibition, 458 .

Artand, W., I 63

Arthur, li., 35.

Artisan reports on Paris Exhibitions, $4^{8}, 4^{8} 4$.

Artists, list of those who received Society's awards, I62; materials and appliances, prizes awarded for, 213 ; committee of proposed exhibition of pictures, 227 ; Society of, of Great Britain, 229; Free Society of, 230; Incorporated Society of, 232 .

Ashburnham, Farl of, 29.

Ashburton, Lord, presides at annual dinner, 396.

Assam, wild tea in, Io6 ; tea plantations in, Io6.

Assèzat, Euvres de Diderot, 227.

Associations, Colonial, connected with Society, 453 .

Astle, T., 35 .

Astley, J., 35.

Austin, J., power loom, 246 ; medals for looms, $26_{3}$.

Austin, R., awards for wood engraving, 163 ; engraves frontispiece for premium list, I 56, I 63 .

Australia, first offer of prizes, I 10 ; olives in, I I I ; tanning materials from, III; wool from, I IO; wine from, III; sand for glass-making in, I 4 ; meat from, $46 \mathrm{r}$.

Awards, method of making, 237; annual distribution of, 158,324 ; see also Preminms.

Aylesbury Dairy Co., prize awarded to, $46 \mathrm{I}$.

Bacon, J., awards for sculpture, I 63.

Bahamas, proposal for botanic garden in, 100 .

Bailey, A. M., appointed Registrar, $34 \mathrm{I}$; resigns, $34 \mathrm{I}$; his edition of his father's book, 34 I.

Bailey, G., on committee for reorganising Society, 346 ; Chairman of Council, 35I ; on deputation to Board of 'Trade, $407 n$.

Bailey, IV., prize for chaff-cutter, I 34 ; prize for turnip-cutter, I 36.

Bailey, IV., appointed Registrar, 34I; his death, 34I; his book,
Mechanical Machines, etc., I34, $239,248,249,329$.

Baillie, E., I 64 .

Baily, E. H., I fif.

Baker, Capt. H. C., presents collection of woods, 107 .

Baker, David Erskine, 35.

Baker, Henry, attends first meetin 3 , 12 ; his work, $12 \%$; elected " perpetual member," I 7 ; in list of members, 35; suggests prizes for tree planting, I 45 ; on committee of first picture exhibition, 228 ; proposes institution of medals, 3 I 2 .

Baker, Samuel, 36 .

Baker Street Bazaar suggested for National Exhibition, 404.

Baker, Wynn, his agricultural work in Ireland, i 8.

Bakewell, stock-raising, 1 I 5, I 39.

Ball, J., prize for growing opium, 28.4 .

Ballantyne, J., I 64 .

Baltimore, Baron, 33.

Bamboo, introduction into West Indies, 94 .

Banca tin, I 02.

Banknotes, Perkins' method of printing, 215,303 .

Banks, C., I64.

Banks, Sir Josepl,, 36, 95, 99 ; suggests cultivation of tea-plant in India, 105 .

Banks, T., I 64 .

Barbados Society of Arts, 97 ; mango in, 97.

Barff, Prof., Cantor Lectures, 453; appointed Professor of Chemistry at Royal Academy, 453.

Barilla, 87 ; prize offered for British, 278 ; Indian, 278 .

Baring, Sir Francis, 36.

Baring, T., nominated trustec for I 862 Exhibition, 4 I9.

Barker, Robert, 36 .

Barnby, Sir J., examiner in music, 4.10 .

Barnett, Miss, presents plates of Barry's etchings, $8 \mathrm{I}$.

Barney, J., I64.

Barralet, J. J., 164 .

Barret, G., I64.

Barret, J., I 64 .

Barrett, IV. A., examiner in music, $44^{\circ}$.

Barrington, Hon. Daines, on Englishgrown silk, 266 ; papers on silk and tobaceo, 338 .

Barrington, Viscount, 32 .

Barron, H., I 64.

Barron, W. A., 165 . 
Barrow, Sir J., and the electric telegraph, 252.

Barry, Sir Edward, 36.

Barry, James, invited to paint picture for Great Room, 70 ; offers to paint pictures for the Great Room, 7I ; his character, 71 ; his history, 72 ; his death, 72 ; his other works, 73 ; his execution of the work, 73 ; his influence upon art, 73 ; exhibition of his pictures, 73 ; hit: relations with the Society, 74 ; his account of the pictures, $7 \mathrm{I}, 74$; his portrait by himself, 82 ; his proposal to paint portraits of King George III. and Queen Charlotte, 79, 323; his "Adam and Eve," 73, 8I ; his etchings, $8 \mathrm{I}$; his pictures, - the "Orpheus," 75; "A Arecian Harvest Home,", 75 ; "The Victors at Olympia," 75; "The Thames," 76; "The Society," 76; "Elysium," 77 ; later history of the pictures, So; award for the pictures, 165 ; his portrait of S. More, 77,327 ; early lithographs by, 305; suggested design for Society's medal, 316 .

Bartley, Sir George, member of Council, 450: reports on Education, etc., in East End of London, 466 ; his scheme for memorial tablets, 468 ; proposes purchase of small amounts of Consols, 477 .

Baskerville, John, 36 .

Basket-makers, scarcity of osiers for, 305.

Bassett, H., I65.

Bath and TVest of England Agricultural Society, 3 .

Battersea Park, suggested site for proposed I S6I Exhibition, 47 .

Bazley, Sir T., lectures on I 851 Exhibition, 378 .

Beans for cattle-food, I2o.

Beauclerk, Topham, $3^{\text {f }}$.

Beaufort Buildings, Shipley's Academy in, 9, 57 ; demolition of, 58 .

Beaufort, Duke of, medal for planting trees, I 45 .

Beauvais, I., ro5.

Beckford, William, 36 ; medal for planting trees, I 47 .

Bedford, Duke of, 28 ; medals for planting trees, $1+5$.

Bee culture, I 40 .

Bees, introduction of, into New Zealand, II 2 .

Beet for cattle food, I2O.

Behnes, IV., I65.
Bell, Professor Alexander Graham, Albert medallist, $5 \mathbf{I} 6$.

Bell, Sir Isaac Lowthian, Albert medallist, 5 I 5 .

Bell, J., prize for methorl of communicating with stranded ship, 297.

Bell, Rev. P., lis reaping machine, I 30.

Belleisle, medal to commemorate naval action off, $22 c$.

Bellingham, J., I 65 .

isenefactions to Society, Stock, 43, 161. 319 ; Earle, 221; Swiney, 343; Acton, 379, 380 n.; Cantor, 54I ; Aldred, 503; Davis, 503; Robb, 503; Howard, 503; Mulready, 503; Owen Jones, 503 ; Shaw, 503 .

Bengal tanie, I03.

Bennet, A., medal for growing cotton in Tobaso, 98 .

Bentham, Jeremiah, 36 .

Bentinck, Lord William, appoints committee on Indian tea, Io6.

Bentley, C., 165.

Penwell, Saral, I 65.

Berg. Sir J. C., carly threshing machine, I $3 \mathbf{I}$.

Berney, J., medal for tree-planting, 147 .

Berridge, J., 165 .

Bessborough, Earl of, 29.

Bessemer, Sir Henry, medal for sugar-cane press, 389 ; Albert medallist, 5I 3 .

Bethell, J., on committee for reorganising Society, 346 .

Bethnal Green Museum, coilection of animal products transferred to, 376.

Bewick, T., prize for wood-engraving, I 53,165 .

Bhaugulpore cotton, I02.

Biffin, Sarah, I 66.

Billings, R. IV., I 66.

Birch, J., prize for labourer's cottages, 492.

Birch, IV., I 66.

Birdwood, Sir G., bust of, 520.

Birkbeck, Dr., founder of Mechanics' Institutes, 369.

Birmingham, conference on Domestic Economy held at, 372 ; attempted exhibition in, 403; mecting for Training School for Music, 479.

Birt, J. \& A., prize for life-saving apparatus, 493.

Bisnuth, offer of prize for, 278 .

Blackman, G., prize for oil colours, $2 \mathrm{I} 3$.

Blackmore, J., I 66. 
Blake, J., prize for improving fish supply, 3 Iо.

Blaxland, G., medal for Australian wine, I I I.

Bligh, Captain, motal for introduction of bread-fruit into West Indies, 95 .

Blore, E., I 66.

Blow-pipe apparatus, 1rizo for, 494 .

Board of Agriculture, see Agricalture.

Bodkin, Sir IV. H., nember of Council, 36I ; obtains funds for prizes for stove competition, 489 .

Boileau, Sir J., member of Council, 362 ; on deputation to Board of Trade, $407 n$.

Bolingbroke, Viscount, 32.

Bond, J. D., I 06 .

Bond, WV., medal for paper on Canadian industries, 109.

Bonner, T., I 60 .

Bonomi, J., medal for sculpture, I 60.

Bookbinding, exhibitions of, 3 So.

Book-plate, Societr's, I6I, 316; for books purchased under Earle bequest, $22 \mathrm{I}$.

Booth, Rev. J., Chairman of Council, 36I ; suggests weekly Journal for Societr, 373; his connection with the Society, $373 \mathrm{n}$; his death, $373 n$.

Borax, offer of prize for, 278 .

Borecole, I 20.

Boswell, -, award for nct-making machine, 269.

Boswell, James, $3^{6}$.

Botanic garders in Wost Indies suggested by Society, 98; St. Vincent, 99 ; Hintol East's, in Jamaica, 97, 99 ; Jamaica, 97,99; Trinidad, Ioo; proposed in Bahamas, 100 ; Calcutta, I02, roj, I 06 .

Soucliette, Col. J., medal for survey of Canada, $\mathbf{1} 09$.

Bouvier, A. J., I67.

Bowman, collector and temporary assistant secretary, 339 .

Box, George, appointed assistant secretary, 22 ; appointed secretary, 22 ; re-appointed assistant secrtary, 23, 25; collector, 339; retires. 339 ; lease of Little D nmark Court premises in his nam , 5.5.

Boydell, J., 36; medal for encouraging engraving, 167 .

Brady, Sir Antonio, member of Council, 449.

Bramwell, Sir Frederick, President, 447 ; Chairman of Council, 4,8 ; Cantor Lectures, 453 ; paper on protection for inventions, 474 ; suggested clanges in I aw of Patents, 475 ; promotes Socicly's Patents 13ill, $47^{6}$; papers on the I3ill, 476 ; reports on Grantham's steam car, 495; portrait, 5 I 9.

Brandenburgh, Anspach, and Bareith, etc., The Margravine of, medal for portrait model, I 67 .

Brander, Gustavus, one of the founders, I 2, 36 .

Branston, A. R., 167 .

Branwhite, C., I67.

Breadalbane, Earl of, medal for planting trees, 146 .

Bread-fruit, introduction of, into Vest Indies, 93, 95 .

Brereton, A., Literary History of the Adelphi, $59 \mathrm{n}$.

Brereton, O.S., 36 ; portrait in Barry's picture, 77 .

Bridge, first iron, 254.

Bridgen, R., prize for device for avoiding noxious fumes, 27 I.

Bridgewater, Duke of, medal for canal development, 254 .

Brigstocke, T., I 67 .

Bristol, meeting to promote Training School for Music, 479 .

Brocade-weaving, nedal for, 268 .

Brockedon, IV., medal for artist's rest, I 67, 214; Chairman of Committee of Polite Arts, I 67, $2 I_{4}$.

Brockelbank, A., appointed collector, 339 ; his deatl, $34 \mathrm{I}$.

Bromley, J., 167.

Bromley, J. C., 167.

Bromley, VW., I67.

Brougham, Lord, on Society's administration, 315 .

Prown, S., meclal for information abont Grorgia, 93.

Iirowne, H. K., medals for drawing and etching, $I 68$.

Browne, J., I 68 .

Brownlow, Lord, medal for planting osiers, $\mathrm{I}_{4} 6,300$.

Bruce, C. A., superintendent of tea plantations in Assam, awarded inclal for services, Iob.

Bruce, Major, discovers tea plant in Assam, I06.

Brunswick, New, wine from, 86 .

Bryan, Dictionary of Artists, I 60.

Bryant, Jacob, 36.

Bryer, H., I 68 .

Buck-wheat, 120

Buff leather, prize for, 308 .

Bunning, J. B., 168.

Bunsen, Professor Robert Wilhelm, Albert medallist, 5I 5 . 
Burch, E., prizes for gem-engraving, 168, 222, 223; his remarks on Society's prizes, 223 ; his Catalogue of ... Gems, ctc., $223 n$.

Burdett, P. P., prize for map of Derbyshire, 300.

Burges, W., Cantor Lectures, 452.

Burgess, T., I 68 .

Burgess, IV., I 08.

Burke, Edmund, 77 .

Burnet, I 20.

Burney, Dr. Charles, 36 ; his portrait in Barry's picture, 76 .

Burt, A. R., I 69.

Buss, R. IV., I 69 .

Bute, Earl of, life nember, 20, 29.

Buxton C., introduces Bill for improved labourers' cottages, 492.

Byrne, IV., I 69.

Cabbages for cattle food, I 20 .

Cabs, distance indicator for, 496 ; conference on London, 496 ; prizes offered for improved, 496 ; offer renewed, 497 ; competing cabs to be shown in ${ }^{872} \mathrm{Ex}-$ hibition, 497 ; prizes awarded, 497.

Cadogan, Baron, 33.

Cadogan, Dr. IV., 36 .

Calcutta Botanic Gardens, I02, I03, I 6 6.

Callaghan, J., prize for workman's mask, 272 .

Callendar, Mr., medal for growing rhubarb, 284 .

Calooee hemp, Io3.

Calvert, F., I69.

Calvert, F. C., Cantor Lectures, 452 ; his portrait, 5 I9.

Cameo-cutting, I 57.

Cameos, pastes for, 224 .

Campeachy logwood, 98.

Camphor, West Indian, 93; in Jamaica, I oo.

Canada, first association of Society with, I07; hemp, Io8; industries in ISo7, I09; survey of, I09; explorations in North-VVest, ro9: pigments from, rog; medals in celebration of conquest of, 220 .

Canal locks, awards for, 255.

Cantor, Dr. E. T., leaves his property to the Society and to Wellington College, $45 \mathrm{r}$; terms of bequest, $45 \mathrm{I}$; grant to Mrs. Cantor (his mother), 45I ; grant to his sisterin-law, 452; application of bequest, $45^{2}$; the Cantor Lectures, 452 .

Caoutchouc, see Rubber.

Cape, tea from, I 55 ; wine from, I 12.
Cardigan, Agricultural Socicty in, 6 .

Cardigan, Earl of, 29.

Cardiganshire, map of, 300.

Carlini, A., contributes to first art exhibition, 229.

Carlisle, Earl of, presides at annual dinner, 396.

Carmarthen, Agricultural Society in, 6.

Carnarvon, Marquis of, 29.

Carolina, wine from, 86 ; tea in, $93 \boldsymbol{n}$.

Carpenter, Dr. IV. B., lectures at Educational Exhibition, 37I ; suggests prize for cheap microscope, 390 ; acts as examiner, 432.

Carpets, awards for, 207.

Carr, J., I69.

Carriages, awards for construction of, 255 .

Carrots for cattle food, I 20.

Carter, C., prize for Virginian wine, $\mathrm{S}_{5}$.

Carter, E., awards for artificial cameos, 224.

Carter, J., 169.

Cartwright, Rev. E., power loom, 246 ; candidate for secretaryship, 334; medals for agricultural implements and experiments, 335 .

Cary, J., medal for map of Cardiganshire, 30o; publishes IVilliam Smith's geological map, 301 .

Carysfort, Baron, 33.

Casali, A., I 69.

Caslon, IVilliam, 36.

Caslon, $\mathrm{IV}^{\top}$., medal for telescopic gas lamp, 296.

Cassels, Andrew, member of Council, 450.

Castle Conrt, Society's offices in, 53 .

Catharine, Empress of Russia, founds Economical Society of St. Petersburg, 6 .

Catherlough, Earl of, 29.

Cattle food, I 8 , I 20.

Cavendish, Hon. H., 36.

Cayenne, coffee introduced into, 94.

Centenary dinner, 396.

Centenary of Society, educational exhibition held to celebrate, $37^{\circ}$.

Ceres medal, 2 I 2, 3 I 8 .

Ceylon, coco-nut oil from, Io7; rice in, I07.

Chadwick, Sir Edwin, member of Council, 449 ; paper on purchase of telegraphs, 477 ; promotes postal reform, 477 ; his bust, 520 .

Chaff-cutters, I 33 .

Chalon, J. and A., exhibition of pictures by, 380 .

Chalon, Maria A., I 70 . 
Chamber of Arts proposed, 6, 328.

Chamberlin, M., I 70 .

Chambers, Sir Robert, 36 .

Chambers, T. I., on industrial pathology, 395 .

Chambers, Sir William, 36 ; acts as Society's architect, 54; on committee of first picture exhibition, 228.

Chandelicr, gas, 296.

Chandler, Dr. S., 37.

Chandos, Marquis of, nominated trustce for 1862 Exhibition, 4 I9.

Chaney, Weights and Meastres, $290 n$.

Channcl passage, prizes for improved steamers for, 493 .

Chappe introduces mechanical telegraph, $25 \mathrm{I}$.

Charlemont, Viscount, 32.

Charlotte, Qucen, proposal by Barry to paint her portrait, 79,323 .

Charlton, Capt., finds tea-plant in Assam, 106.

Charter, early proposals for, 35I ; first steps for obtaining, $35^{I}$; proposal discussed, 352 ; draft considered, 352 ; grant of, 352 .

Chauncey, C., 37.

Cheere, Sir Henry, 37 ; advocates an Academy of Fine Arts, 232, 234; member of committee on medals, 315.

Cheesman, T., I 70.

Chelsea Physic Garden, rhubarb grown in, $283 n$.

Chemical Industry, Society of, 457 .

Chemical section established, $45^{6}$; discontinued, 457 .

Chemistry, agricultural, I39; industrial, awards for, 277.

Chemistry, Institute of, 457.

Chester, Harry, Chairman of Council, 360 ; originates Union of Institutions, 360 ; suggests examinations, 372 ; on committee for proposed I 86I Exhibition, 4I7.

Chesterfield, Earl of, 29.

Chevalier, Michel, Albert mcdallist, 5. 3 .

Chevreul, Michel Eugene, Albert medallist, 5 I 3 .

Chimneys, sweeping, 275 .

China, tea imported into Assam from, 106 .

Chintz, designs for, I 54 .

Chip hats, prizes offered for, 306.

Chippendale, T., 37.

Chiswell, R. Ml. T., medals for planting trees, 147 .

Chou-rave, I2 I, $123 n$.

Chubb, Messrs., prize for safes, $3^{89}$.
Chucks, awards for lathe, 256 .

Churchill, Lord Alfred, Chairman of Council, 4.48 .

Cinnamon, from Sumatra, $8_{4}$; West Indian, 93; introduced into Jamaica, 97 ; in Guadaloupe, 97 ; in St. Vincent, 99; in India, I02.

Cipriani, Giovanni, 37; invited to paint picture for Great Room,7o.

City and Guilds Institute take over technological examinations, 438 ; assists school of wood-carving, 482.

Clack, R. A., I 7 o.

Clanny, Dr., medals for safetylamps, 253.

Clanricarde, Earl of, 29.

Clarke, Hyde, proposes Colonial sections, 454; proposes Indian section, 455 ; promotes formation of African section, 455; suggests viva voce examinations in Modern Languages, 439; member of Council, 449.

Clarke, Dr. T., superintendent of Jamaica Botanic Garden, Ioo.

Clegg, medal for making and using coal gas, 295.

Clement's ellipsograph, 294.

Clennell, L., I 7 O.

Clevely, J., I 7 o.

Climbing boys, abolition of, 275 .

Clint, G., I 70 .

Clint, R., I 70 .

Clint, S., awards for medal dies, I 7o, 222.

Clive of Plassy, Baron, 33 .

Clocks, a ward̆s for, 255 .

Clothmakers' Company subscribes to School of Wood-Carving, 482 .

Clover, I20.

Cloves, West Indian, 93; in St. Vincent, 99 ; in Trinidad, Ior.

Coach-maling, prizes for designs for, I 53 .

Coalbrookdale Co., prize for iron castings, 389 .

Coal-gas manufacture, 294.

Cobalt, offer of prizes for British, I 5 , 279.

Cobb, Francis, paper on silkworm "grain," 266; member of Council, 450.

Cobbett, IV., medal for encouraging straw-plait industry, 307 .

Cochineal, East Indian, 84 ; from A merica, 92; from West Indies, 95.

Cockburne, Captain, rewarded by Anti-Gallican Society, 4.

Cockings, Ann Birch, 69; appointed housekeeper, 342 ; appointed regis- 
trar and librarian, 343; her character, 343 ; her death, 342 ; her portrait, 343,5 I 8 .

Cockings, George, appointed porter, collector, and registrar, 34I ; his poems, 342 ; his character, 342 .

Coco-nut in West Indies, 96.

Coco-nut oil from Ceylon, Io7 ; from Mauritius, I I 2.

Coffee, introduction of, into West Indies, 94 ; in Vest Indies, 96.

Colbert and picture exhibitions, 226 ; silk manufacture in France, 264.

Cole, Alan, on carly carpet-making in England, $267 n$.

Cole, Sir Henry, the Felix Summerly tea-service, I 54. 405 ; suggests prize for shilling colour-box, $2 \mathrm{I}_{4}$; suggests president's head for medal, 319; influence on Society, 357; member of Committee of Fine Arts, $35^{8}$; proposes exhibitions of works of British artists, 358; his character, $35^{8}$; elected on Council, 358 ; share in organising I 85 I Exhibition, $35^{8}$; dispute with T. Webster, 359 ; resigns seat on Council, 359; re-clected, 359; Chairman of Council, 360; presides at conference on adult education, 372 ; suggests conference on domestic cconomy, 372 ; Chairman's address in first number of Journal, 374; account of foundation of South Kensington Museum, $375 n$.; lectures on I $85 \mathrm{I}$ Exhibition, 378 ; National Gallery of British Artists, 379; promotion of Patent Reform, $3 \delta_{2}$; drafts memorial on circulating objects from Society's exhibitions among Schools of Design, 407 ; on deputation to Board of Trade, $407 n$; submits scheme of exhibition to Prince Albert, 409; drafts petition to House of Commons about National Exhibition, 409; account of carly history of $I S_{5 \mathrm{I}}$ Exhibition in lis Life, $409 n$. ; visits Paris Exhibition of 1849,410 ; suggests Hyde Park as site for exhibition, 4II; visits provincial cities on behalf of $185 \mathrm{I}$ Exhibition, 4I2; member of Society's Executive Committee for is5 I Exhibition, 4 3 3 ; proposals for I 862 Exhibition, 416; on Committee for proposed I86I Exhibition, 4I7; on Committee for I 862 Exhibition, 4I9; Postal reform, 477; National Training School for Music, 479; series of Annual International Exhibitions, 484 ; paper on London cabs, 496; Albert medallist, 5I 3.

Cole, Lieut. H. H., designs building of National Training School for Music, 480 .

Coleman, W., I 7 I.

Coleraine, Baron, 33.

Collison, F., medal for Cape wine, I 3 .

Collyer, J., I 7 I.

Colman, G., 37 .

Colonial Institute, Royal, 456.

Colonial Manufactures Prohibition Act, 89 ; premiums, amount of, IOI $n$.; section suggested by Hyde Clarlie, 454; section established, 455 .

Colonies and Society, $\delta_{3}$; later association of Society with, 453 .

Colour-box, the Society's shilling, 2 I $4,390$.

Colour printing, mezzotints, 218 ; wood block, 2 I9.

Colouring matters, prizes for, 279.

Colours, artists', prizes for, 2 I 3,279 , $28 I$.

Combe, C., appointed assistant secretary, 340.

Comber, T., chaff-cutter, I 33 .

Commemorative medals rewarded by the Society, 220.

Commerell, Abbé, Account of MangelWurzel, I 24.

Commission of 1851 proposed, 412 ; appointed, $4 \mathrm{I} 4$; made permanent, 375 ; reports of, $409 n ., 485 n ., 487 n$.

Committees appointed by first Council, 354 .

Committees, the Society's, 236.

Common, J., his reaping machine, I 28 ; medals for drill, etc., 130 .

Conference of Institutions, see Institutions.

Conferences, on industrial education, 370 ; on adult education, 372 ; on domestic economy, 372 ; on technical education, 464 ; on technological examinations, 465 ; on elementary education, 466 ; on postal reform, 477 ; on rivers pollution, 488 ; on sanitation, 488 ; on water supply, 488 ; on housing of the people, 492 ; on London cabs, 496.

Connaught, H.R.H. the Duke of, President, 447 ; presides at conference on technological examinations, 465 ; reviews drill of school children, $46 \%$.

Consols, purchase of, in small amounts, 477 . 
Constitution of Society, I8; alterations in, $34^{6}, 350,35^{2}$.

Conyngham, Viscount, 32 .

Cook, B., medal for distillation of gas-tar, 295.

Cook, J., chaff-cutter, I 35 .

Cook, R., I 7 I.

Cook, T., I 7 I.

Cooke, Sir W. Fothergill, proposes holding national exhibition, 404; on first Exhibition Committee, 404 n.; Albert medallist, 512.

Cooke's patent drill, I27.

Cooley, T., I $7 \mathbf{r}$.

Cooper, Sir Daniel, submits samples of British-grown silk, 266; member of Council, 449 .

Coote, Sir E., 37.

Cope, C. W., medals for drawing and painting, I $7 \mathbf{I}$; portrait of Prince Consort, 80, I 7 I, $400,518$.

Copeland \& Co., prize for pottery, 386 .

Copper-plate, steeling, 2 I 7.

Copyright, Committee on Fine Art, 385 ; Hogarth's Act, 386; Act passed, 386 .

Corbaux, Fanny, I 7 I.

Corbaux, Louisa, $\mathbf{I} 7$.

Corbould, G., I 7 I.

Corbould, H., r7 r.

Corfield, Dr. W. H., Cantor Lectures, 453.

Corn, prizes for harvesting in wet weather, I 40, 499.

Corn-mills, awards for, 255.

Cornwall, Duke of, see George v., King.

Cornwall, J., medal for Canadian hemp, Io8.

Corston, W., medal for straw-plait, 306.

Cosway, Richard, his portrait of Shipley, IO, 5 I 8 ; one of first prizewinners, I6, I5I; his portrait of Templeman, 25, 5I8; in list of members, 37 ; list of his awards, I72; reports on sample of oil paints, 2I3; contributes to first exhibition of pictures, 229.

Cotman, J. S., I 72 .

Cottages for labourers, conference on, 492 ; prizes for improved, 3 r 2 , $392,49 \mathrm{I}$.

Cotton from Africa, medal offered for, 84 ; West Indian, 93; American, 98 ; in Tobago, 98 ; from India, I02.

Cotton, Capt., medal for growing ramie, IO3.

Cotton, General, Chairman of Council, $44^{8}$.
Council first proposed, 347 ; formation of, 35I ; organisation of, 353, 357.

Counting machine, medal for, 292.

County histories, offer of prizes for, 302 .

County maps, 298.

Courtenay, Viscount, 32 .

Cousins, S., I 72 .

Coutts, J., 37.

Coutts, P., 37.

Coutts, T., 37.

Coutts's Bank, 59.

Crace, Messrs., decorations by, in Great Room, 66.

Craig's Court, Society's offices in, $8,9,53$.

Craik, medal for agricultural drill, I 27 .

Crane Court, Society's meetings in, I6.

Crane, Walter, Albert medallist, 5 r 6 .

Cranes, awards for, 255.

Crayon drawings, prize for treatment of, 2 r 3.

Crayons, prize for making, 213.

Creasy, Sir E., acts as examiner, 432 .

Crellin, H. N., I 72 .

Crellin, H. P., I72.

Crisp, Nicholas, one of the founders, I2; member of committee on medals, 315 ; prize for zaffre and smalt, 279.

Critchell and Raymond, History of the Frozen Meat Trade, $460 n$.

Critchett C., assistant secretary, 368 ; resigns, 368 ; made lifemember, 368 ; appointed educational officer, 368 ; his death, 368 .

Croll, Col. A., offers prize for blowpipe apparatus, 494.

Cromer, the Earl of, Albert medallist, $5 \mathrm{r} 6$.

Cronmire, J. and $H$., prize for set of drawing instruments, 215.

Crookes, Sir William, Albert medallist, 5 I 6.

Crops, rotation of, 140; prizes for apparatus for drying, I 40, 499 .

Cross, R., I 72.

"Crossing " made in Strand opposite Society's offices, 58 .

Crossley, Messrs., prize for carpets, 389.

Crowther's English Pattern Coins, 327.

Cuba, coffee in, 94 .

Cubitt, T., speaks to Prince Albert about proposed exhibition, 4IO; submits estimate of cost of $185 \mathrm{I}$ Exhibition to the Council, 4 I 3 . 
Cubitt's ellipsograph, 294.

Cuisset, F. F., medals for intaglios, 225.

Cultivators, 128.

Cundall's Biographia Jamaicensis, 6.

Cunliffe-Owen, Sir P., member of Council, 36I, 450.

Cunningham, English Industry and Commerce, 5, I 43.

Curie, Madame, Albert medallist, 517.

Curwen, J. C., medals for planting trees, I 48.

Cust, Sir J., 37.

Dall, N. T., 172.

D'Almeida, Dr. José, presents samples of gutta-percha to Asiatic Society, 104.

Dance, G., 37 .

Dance, Sir Nathaniel, invited to paint picture for Great Room, 70.

Dancer, Dr., on bread-fruit, 96 ; on cinnamon, 97 ; in charge of Jamaica Gardens, Ioo; medal, Ioo.

Daniell, T., I 72.

Darby, Abraham, makes iron with coal, I44; medal for first iron bridge, 254 .

Dartmouth, Earl of, 29.

Darwin, Erasmus, 246, 247.

Dashwood, Sir F., 37.

Davenport, S., design for Society's Honorary Testimonial, 35.5.

Davenport, S. T., his life of Barry, $73 n$.; on the origin of steelengraving, 215; engaged as clerk, 349 ; his life, 366 ; assistant secretary, 366 ; curator and collector, 366; financial officer, 366 ; his death, 366 ; his services to the Society, 367 ; his history of the Society, 367 ; paper on prints, etc., 367 ; presents volume of weekly proceedings, 374 .

Davies, Martha, mother of William Shipley, 9.

Davies, T., Life of Garrick, 24.

Davis bequest, 503 .

Davis, J., prize for fire-escape, 309.

Davis, J., medal for mechanical telegraph, 252.

Davis, J. S., I 73 .

Davy, Sir Humphry, I 39 ; chemical professor to Board of Agriculture, I $_{4} \mathrm{I}$; his safety lamp, 244, 254.

Dawes, R. (Dean of Hereford), member of Council, 36I; acts as examiner, $43 \mathrm{I}$.

Dean, H. P., I 73 .
Deane, J. C., proposes Art Exhibition for I 862, 4 I 6 .

Deare, J., I 73 .

Decadence of Society and attempts at reform (184I), 345 .

De Chayal, medal for conveying silk-worms' eggs into Mauritius, I 2.

Decorticating rice, machine for, 107.

De la Beche, Sir H., lectures on I 85 I Exhibition, 378.

Delamare, J., submits English-grown silk to Society, 265 .

De la Motte, W., I 73.

De Morgan, Professor, lectures at Educational Exhibition, 37I.

Denbigh, Countess of, $5 \mathrm{I}$.

Denman, J. F., I 73.

Denman, Maria, prizes for modelling, I 73; draws reproduction of Flaxman's medal, 3 I 8 ; design used for Honorary Testimonial, 354.

Denman, T., I 73 .

Denmark Court, Little, Society's house in, 55 .

Denovan, J. F., prizes for curing herrings, 3 II.

Dental instruments, prizes for, 294.

Denton, J. Bailey, member of Council, 449 ; offers prize for labourers' cottages, $49 \mathrm{I}$.

Derby, Louisa, I 73.

Derbyshire, map of, 300 .

De Re Rustica, 329.

Desaguliers, Captain T., 37.

Devis, A., 173 .

Devonshire, Duchess of, 77.

Devonshire, Duke of, 28 ; medal for planting trees, $\mathbf{I}_{4} 6$.

Dewar, Sir James, Albert medallist, 5 I6.

Dick, Sir Alexander, and Scotch Society of Arts, 4; in list of members, 37 ; medal for introduction of rhubarb, 283 .

Dickens, Charles, Poor Man's Tale of a Patent. 382.

Dickinson, IV., I 74 .

Dictionary of National Biography, 7 , $25,34,160,301,340,341,361,366$, 382 .

Diderot on Salons des Beaux Arts, 227.

Die sinking, prizes for, I 57, 2 I9.

Dighton, D., I 74 .

Dighton, R., I 74 .

Dilke, Sir Wentworth, Chairman of Council, 360 ; connection with I 85 I and 1862 Exhibitions, 360; member of Society's Executive Committee for 185 I Exhibition, 4I3 $n$.; 
proposals for I 862 Exhibition, 416 ; on Committee for proposed I 86I Exhibition, 4I7; nominated trustee for I 862 Exhibition, 4 I 9 .

Dingley, C., medal for saw-mill, 247.

Dinner, annual, 324, 396.

Disraeli, I., presides at annual dinner, 396.

Distribution of premiums, annual meeting for, $158,319,324$.

Dobson, A., Life of Hogarth, 227.

Dobson, W. C. T., I 74 .

Docking ships, Seppings' method of, 255.

Dodsley, J., 37.

Dodsley, R., 37.

Dollond, J., 37 ; achromatic telescope, 286.

Domestic Economy, conference on, 372 ; examinations in, $435 n$.

Donaldson, J., I 74 .

Donaldson, T. L., I 74 .

Donaldson's Agricultural Biographies, 331 .

Donegal, Earl of, medal for planting trees, I46.

Donkin, B., medals for tachometer and counter, $29 \mathrm{I}$.

Donn, B., prize for map of Devon, 299.

Donnelly, Sir John, suggests Technological Examinations, 437 ; member of Council, 450; founds School of Wood-Carving, 482; Chairman of Committee of School, $483 n$.

Dorset, map of, 299, 300 .

Dossie, Robert, Memoirs of Agriculture, etc., 4 n., 330 ; candidate for the secretaryship, 24, 331; in list of members, 38 ; medal for aiding to establish manufacture of potash in N. America, 87,331 ; opinions about spinning machines, 258; prize for method of purifying oil, 282,331 ; contributions to Museum Rusticum, $329 n$. ; his life and character, 33I; Dr. Johnson's opinion of him, $33 \mathrm{r}$.

Doulton, Sir Henry, Albert medallist, 514.

Dover, meeting to promote Training School for Music, 479 .

Downe, Viscount, 32.

Downman, J., I 74 .

Draining land, I4O.

Drapers' Company, subscribes to School of Wood-Carving, 482 .

Drawboy, invention of, 264 .

Drawboy, prize for improved, 264.

Drawing, technical need of, I 5, I 5 I.

Drawing instruments, set of, prize, 2 I5; awards for, 294.
Drawings, first offer of prizes for, I 5 ; list of awards for, 162 .

Dredgers, awards for, 255 .

Drew, George, introduces Messrs. Munday as contractors for $185 \mathrm{I}$ Exhibition, 4I3; member of Society's Executive Committee for I 85 I Exhibition, 4 I $3 n$.

Drew, T., medal for tree-planting, I 47 .

Drill and broadcast husbandry, I 21 , I 26.

Drill in schools, 467 ; General Eardley Wilmot on, 467 ; reviews, 467 ; review by London School Board, 467 ; challenge banner, 468 .

Drills, agricultural, I26, I 27.

"Drop-box" for weaving, Robert Kay's, 262.

Drugget, prizes offered for manufacture of, 268.

Drummond, Eliza A., medals for portrait, etc., I74; portrait of Miss Cockings, 343,518 .

Drummond, George, owner of the Adelphi estate, 6o, 64 .

Drummond, John, the banker, 38 .

Drummond, Robert, the banker, 38 .

Drummond, R., Archbishop of York, patron of Whitehall School, $8 \boldsymbol{n}$.

Drury Lane Theatre, distribution of premiums in, 325 .

Drying crops in wet weather, prizes offered for apparatus for, I 40, 499.

Dublin Exhibition, collection of Indian products sent to, 380 .

Dublin, Royal Society of, 2, I 8 ; exhibitions of, 403 .

Dubourg, R., I 74 .

Dudley, Viscount, 32 .

Duff, A., prize for improved drawboy, 264 .

Dumas, Jean Baptiste, Albert medallist, $5 \mathrm{I} 3$.

Dunkarton, R., I75.

Durand, Mr., medal for Canadian hemp, 108.

Durant, Susan, I 75 .

Dürer, Albert, use of steel plates, 2 I 5.

Durham, Bishops of, 59, 60 .

Durham, C., medal for an intaglio, 225.

Durham House, 56.

Durnford, E., I 75 .

Durno, J., I75.

Dusty trades, preventing injury in, 272.

Dyeing, prizes for, 279.

Eads, Captain James Buchanan, Albert medallist, 5 I 4 .

Eardley-Wilmot, General, Chairman of Council, 448 ; paper on school drill, $4^{6} 7$. 
Earle, W. B., bequest for purchases of books, $22 \mathrm{I}$.

Earlom, R., premiums for drawing and etching, I75.

Earthenware, innocuous glaze for, 273.

East, Hinton, 95, 97, 99.

East India Company, ?discourages offer of prizes in East Indies, 84; consults Society, I02 ; discourages growth of tea in India, 105; sends samples of Indian tea, 106; forwards collection of woods, 107; promises to assist exhibition of Indian products, 380 .

Eastlake, Sir C. L., medal for drawing, I75; becomes President of the Photographic Society. 375; serves as Chairman of Copyright Committee, 385 .

Ebrington, Lord, Chairman of Council, 36r.

Eckstein, J., 176.

Edelcrantz, Chevalier, medal for mechanical telegraph, 252.

Eddis, E. U., I 76 .

Edgcumbe, Lord, 33.

Edgeworth, R., medal for " early mechanical genius," 249.

Edgeworth, R. L., turnip-cutter, I37, 248 ; Memoirs, 137 n., $246 n ., 251$; medal for various inventions, 247 ; medal for a "Perambulator" for measuring land, 248 ; portable railway, $248 n$.; mechanical telegraph, 251.

Edgill, J., prize for chaff-cutter, I34; prize for turnip-cutter, 136.

Edinburgh, Duke of, lays first stone of National Training School for Music, 480; provides scholarship for National Training School for Music, 480 .

Edinburgh Society for encouraging Arts, etc., of Scotland, 3; Society for Promotion of Natural Knowledge, 4; Philosophical Society, 4 ; Society for Improvement of British Wool, 6.

Edison, Thomas Alva, Albert medallist, 515 .

Education, conference on Adult, 372.

Education, elementary, efforts for improvement of, 466; Act of I 870,466 ; reports on condition of, in London, 466 ; Bartley's report, 466 ; conference on, 466 .

Education, Mrs. Grey on female, 467 .

Education, industrial, promotion of, by Society, 369, 466; report on, 37 .
Educational appliances, exhibition of at Guildhall, 370 ; at St. Martin's Hall, 370 .

Educational collection at South Kensington founded on exhibits from Educational Exhibition, 371.

Edward vir., King, suggestion about presidency, 444; consents, 445 ; deputation to, 445 ; elected President, 445 ; his head on Society's medal, 319, 320; his services to Society, 445; presents Albert Medal to Queen Victoria, 446; receives Albert Medal, 446, 516 ; becomes Patron on his accession, 320,446 ; grants Society use of term "Royal," 447 ; reviews drill of school children, 467; provides scholarship at National Training School for Music, 480 ; memorial window in St. Paul's on recovery from illness, 487 .

Edwards, B., History of the British West Indies, 97, $99 \mathrm{n}$.

Edwards, E., I 76.

Edwards, J., I76.

Egan, Dr., medal for teaching Latin, 312.

Eggbrecht, J. E., 176

Egmont, Earl of, 29.

Egremont, Earl of, 30.

Electric lighting of Society's house, 70.

Electro-deposition, use of plumbago in, 293.

Electro-magnet, Sturgeon's first, 292.

Elgin, Earl of, presides at annual dinner, 396.

Ellipsographs, prizes for, 294 .

Ellis, IV., assistant secretary, 366.

Elton's Origins of English History, I $38 \mathrm{n}$.

Employment of women, prizes offered for encouragement of, 3 I 2 .

Engineering, awards in, 254.

Engleheart, T., 176 .

Engleheart, T. S., I 76 .

Engleheart, W. F., I 76 .

Engraving, first offer of prizes for, I 53 ; conditions of offer, I 57 .

Engraving on steel, 215.

Engraving on steel, Perkins' process of, 2 I $5,303$.

Ensom, W., I 77.

Esparto, first use of, for paper making, 305.

Essays, prizes for, 392.

Etching, first offer of prizes for, I 53 ; conditions of offer, I 57.

Etching fluid for steel, 2 I 8.

Etching on steel, 216.

Etty, exhibition of pictures by, 379 . 
Evelyn, John, his Sylva, ${ }_{44}$.

Examinations in Domestic Economy, $435 n$.

Examinations, Elementary, 434.

Examinations, importance of, 356 , $368,428$.

Examinations in Modern Languages, viva voce, $3 \mathrm{r} 2,439$.

Examinations in Music, 439.

Examinations in Practical Commercial Knowledge, 438 .

Examinations of Society, suggested by $\mathrm{H}$. Chester, 372,425 ; system followed by other institutions, 425,428 ; their origin, 426 ; their original character, 426 ; date of first examination, 426 ; system adopted, 427 ; negotiations with College of Preceptors, 427; gradual development of system, $43^{\circ}$; advantages of system, 43I; Board of Examiners, 43I; civil service appointments given to candidates, 432 ; number of candidates, 432 ; programme revised, 432 ; "Commercial Certificate," 433; Prince Consort's prize, 433; proposed abandonment, 433 ; system remodelled, 434 ; fee charged, 434 ; increase in numbers, 434 ; effect of Technical Instruction Act, 434 ; further modifications, 435 ; increase in numbers, 436 ; co-operation of London County Council, 436 ; value of certificates, 436 .

Examinations for soldiers, 437.

Examinations, suggestions for Colonial, 454.

Examinations, Technological, 437, 465 .

Examinations, value of, $35^{6}, 368$, 428.

Exeter Change, proposal to acquire, for Society's offices, 54 ; demolition of, 58 .

Exeter, Earl of, 30.

Exeter Hall, distribution of premiums in, 325 .

Exeter Street, covers part of site of Society's offices, 55 .

Exhibition of 1851 , the Summerly tea-service, I 54, 405; importance of, 356 ; early history of, 4 or ; committee formed to consider, 404 ; r $85 \mathrm{r}$ suggested as suitable date, 408 ; petition to House of Commons, 409; committee reports favourably, 409 ; report by Scott Russell on early history of, $409 n$.; discussions at Buckingham Palace, and decision of Prince Albert to make exhibition international, 4II ; Royal Commission proposed, $4 \mathrm{r} 2$; organisation of exhibition settled, 4I2; Executive Committee appointed by Society, 413 ; Royal Commission appointed, $4^{\mathrm{I}} 4$; resolution of Council as to preliminary outlay, 4I3; estimate of cost by Cubitt, 4I3; arrangements with Messrs. Munday, $4^{\mathrm{I}} 3$; report by Scott Russell, 4r 5 ; subscription list opened, 415; Charter of Incorporation granted to Commission, $415 n$.; references for official history, $4^{\mathrm{r}} 5 n$.; Colonial visitors, 453; Commission made permanent, 375 ; offer of prizes for essays on, 378 ; lectures substituted, 378 ; financial results, 375 ; disposal of surplus, 375 .

Exhibition of $x 862$, importance of, 356 ; first proposals for, 416 ; decision to hold exhibition in $\mathrm{r} 86 \mathrm{r}, 4^{\mathrm{I}} 7$; guarantee fund to be opened, 41 7 ; committee appointed, 417; South Kensington site proposed, 417; proposals submitted to Commission of $185 \mathrm{r}, 4^{\mathrm{I}} 7$; proposed application of surplus from 1851,418 ; date postponed, 418 ; date fixed as 1862 , 419; guarantee fund started and committee appointed, 4 I9; trustees nominated, 419 ; application made to $185 \mathrm{I}$ Commission for site, 420 ; application granted, 42x; Commission decline to manage exhibition, 421; charter obtained for r 862 Trustees, 42I; financial failure of exhibition, 423 ; deficiency made good by contractors, Kelk \& Lucas, 423 ; Jury Reports published by Society,423; Reports of Commission, $423 n$.; loss of anticipated profits, 398 .

Exhibition of $x 871-2-3-4$, see Exhibitions, Annual, etc.

Exhibition of ancient and mediæval art, 407.

Exhibition of art-workmanship, 457 .

Exhibition of bookbinding, 380 .

Exhibition of British manufactures, $405,406,408$.

Exhibition in Covent Garden ( 1845 ), 403.

Exhibition, Dublin, of $\mathrm{r} 853$, collection of Indian products sent to, 380.

Exhibition, early, in London, 403.

Exhibition, Educational, 370 .

Exhibition, Health, award of Trevelyan prize at, 463 . 
Exhibition of Indian products proposed, 380 ; collection sent to Dublin Exhibition, 380.

Exhibition of inventions, 378 .

Exhibition of lithographs, 305 n., 380 .

Exhibition of models, etc., 58, 66, I I 8 , $239,381,402$.

Exhibition of photography, 380,384 .

Exhibition of pictures, first, 58,226 .

Exhibition of pictures by modern artists, proposed, 358,379 ; of Mulready's pictures, 379; of Etty's pictures, 379 ; of John and Alfred Chalon's pictures, 380 ; of miniatures by Sir W. Ross, 380; of Leslie's pictures proposed, but abandoned, 380.

Exhibition proposed in Birmingham, 403.

Exhibition, suggested Fishery, 46I.

Exhibition, surplus from North London, given to Society, 458 .

Exhibition of wood-carving, 457 .

Exhibitions, Annual International, 1871-4, 484; grant of land at South Kensington, 484 ; financial results, 485 ; connection with Horticultural Society, 485 ; causes of failure, 485 ; connection of Society with, 486 ; prizes offered, $45^{8}, 486,490,497,498$; Reports on, 486 ; official records, $487 n$.

Exhibitions of Free Society of Artists, 230.

Exhibitions, French, 226, 402, 410, 483,484 .

Exhibitions of Incorporated Society of Artists, 230.

Exhibitions, increase in number of members due to, 397 .

Exhibitions, Munich, Hanover, Brussels, Lausanne, Vienna, Berlin, 403.

Exhibitions, origin of International, 402.

Exhibitions of Paris, $1849,403,410$; I 867 , artisan reporters at, 483 ; I 878 , artisan reporters at, 484 .

Exhibitions of Royal Dublin Society, 403.

Exhibitions in Society's rooms organised by Whishaw, 404 .

Faden, W., prizes for maps of Hampshire and Sussex, 300.

Fahie, History of Electric Telegraphy, $252 n$.

Fairbairn, Sir W., member of Council, $36 r$.

Fairbairn, T., nominated trustee for I 862 Exhibition, 419.

Fairland, T., 177 .
Falconet, P., I 77 .

Falkland, Viscount, 32.

Falmouth, Viscountess, $5 \mathrm{I}$.

Faraday, Michael, Albert medallist, 512.

Farey, John, supplies illustrations to Transactions, I77; his ellipsograph, 294.

Farey, Joseph, awards for mechanical drawing, I 77 .

Farington, G., I 77 .

Farington, J., I 77 .

Farnham, Earl of, 30.

Faulkner, B., I 77 .

Feary, J., I 78.

"Felix Summerly" tea-service, I 54, 405.

Felkin, W., submits samples of British-grown silk, 266; his History of Lace Manufacture, 269.

Felspathic glaze, 274.

Female education, Mrs. Grey on, 467 .

Female employment, prizes offered for encouraging, $3 \mathrm{I} 2$.

Fennell, J. G., I 78 .

Fenton, Roger, promotes formation of Photographic Society, 385 .

Fenwick, R., medals for planting trees, 147.

Ferrers, Earl, 30.

Field, Messrs., prize for cheap microscopes, 390 .

Fielder, C. H., paper on Indian tea, 455.

Fielding, Sir J., 38 .

Fielding, John, Society's landlord, 53 .

Fife, Earl of, medals for planting trees, 146.

Finances of Society (I 755-64), 21 ; $(\mathrm{I} 776), 22 ; \quad(\mathrm{I} 840), 344,345$; (I845), 397; (I860-80), 502, 506.

Finden, E., award for drawing, I 78 .

Finden, W., award for drawing, 178 .

Fine art prizes of the Society, I5I, $2 \mathrm{I} 3$; list of recipients, I62; remarks on character of the list, 159.

Finlayson, J., premium for mezzotint of Lord Romney's portrait, I 78 .

Fire-escapes, prizes for, 309.

Fires, means for extinguishing, 309.

Fish supply, improvement of, 3 Io.

Fishery Exhibition, suggested, 461 .

Fishing-nets, machines for making, 269.

Fitzgerald, Keane, 77 .

Fitzgerald, P., Picturesque London, $59 n$.

Fitzwilliam, Viscount, 32.

Flag, medal for weaving, as sample of brocade, 268. 
Flaxman, J., premiums for modelling and for designing Society's medal, 178; designs Society's medal, 316 ; design used for Honorary Testimonial, 354 .

Florida, indigo in, 98 .

Fludyer, Sir S., 38 .

Fly-shuttle, Kay's, 26o, 262.

Foley, Baron, 33 .

Folkestone, Viscount, co-operates with Shipley in formation of Society, I I ; attends first meeting, I2; contributes to first prize fund, I5; elected President, I $_{7}$; in list of members, 32 ; portrait by Gainsborough, 7I, 79, 518 ; portrait in Barry's picture, 77 ; death of, $32 \mathrm{r}$.

Food Committee appointed, 460; reports, $46 \mathrm{r}$; meat preservation, $46 \mathrm{x}$; canned meat, 461 ; milk, $46 \mathrm{r}$; fish, $46 \mathrm{x}$; food transport, $46 \mathrm{I}$; prize for railway van, $46 \mathrm{I}$; prize for milk-can, $46 \mathrm{r}$; first cargo of frozen meat, 461 ; final report, 462 ; use of low temperatures, 463 ; Australian frozen meat, 463.

Food supply, conditions of, in 1866 , 459.

Foord, Capt., uses gun-harpoon, 250.

Forder \& Co., prize for hansom cab, 497.

Fordham, Sir G., on county maps, 298 ; his pamphlet on John Cary, Engraver and Map-seller, $300 n$.

Foreign and Colonial Section, 455.

Forestry and the Society, 143.

Forestry, number of awards in, 149.

Forrer's Dictionary of Medallists, $160,318 n$., 327.

Forrest J., assistant secretary, 368 .

Forster, John, Life of Goldsmith, 24.

Fortescue, Earl, see Ebrington.

Foster, P. Le Neve, appointed Secretary, 364; his life and character, 365 ; Chairman of Committee of Accounts, 365 ; member of first Council, $365 ;$ his death, 365 ; family connections with Society, $365 \mathrm{n}$.; on strawplait industry, $307 n$.; takes part in formation of Photographic Society, 385 ; on deputation to Board of Trade, $407 \mathrm{n}$.; treasurer for $185 \mathrm{I}$ Exhibition, 4 I $3 n$.

Foster, Sir C. Le Neve, suggests prize for blow-pipe apparatus, 494.

Fothergill, Dr. J., 38.
Foundling Hospital, exhibition of pictures at, 227.

Fox, C., 178 .

France, exhibitions of pictures originated in, 226; Early Industrial Exhibitions in, 402; 1849 Exhibition, 403, 4ro; 1867 Exhibition, $483 ;$ I 878 Exhibition, 484 .

Franklin, Benjamin, originates American Philosophical Society, 3; life member, 38 ; Chairman of Committee on Colonies, 38 ; encourages American silk industry, 85 ; proposes Whitefoord as member, 322 .

Franks, Sir A. W., Hon. Sec. for Exhibition of Ancient and Mediæval Art, 407.

Fraunhofer's achromatic objective, 287.

Freake, Sir C. J., provides scholarship at National Training School for Music, 480 ; provides building for National Training School for Music, $4^{80 .}$

Freebairn, A. R., I 78 .

Freemason's Hall, distribution of premiums in, 325 .

Fresnau, describes caoutchouc, 103.

Frith, W. P., medals for drawings, I 79 .

Frost, W. E., 179.

Fruin, J., prizes for gem-engraving, 223.

Fruin, R., award for artificial cameos, 224.

"Fryers' Pyes," 57.

Fuchs, E., engraves Society's medal, with head of Albert Edward, Prince of Wales, 320.

Fuel, prizes for economical use of, 489.

Fuller, F., on first exhibition committee, $404 n$.; reports on French Exhibition of 1849,4 ro ; becomes managing director of Crystal Palace, 4Io n.; attends meetings at Buckingham Palace and at Osborne, when $185 \mathrm{r}$ Exhibition is decided on, 4II : visits provincial cities on behalf of Exhibition, 4I2; introduces Messrs. Munday as contractors for Exhibition, 4I3; member of Society's Executive Committee for 1851 Exhibition, 4I3 $n$.

Furniture, prizes for designs for, I 52 . Fuseli, early lithographs by, 305 .

Gahagan, S., I 79.

Gainsborough, Rev. H., prize for drill-plough, I27; prize for a tidemill, 246. 
Gainsborough, T., portrait of Viscount Folkestone, 7I, 79, 518.

Gale, medal for agricultural drill, $127 n$.

Galloway, Earl of, 30.

Galloway's History of Coal Mining, $253 n$.

Galton, Sir Douglas, Chairman of Council, 449.

Galvanic battery, Smee's, 293.

Gandon, J., I 79 .

Gardens, Botanic, see Botanic Gardens.

Gardner, Rev. J., I79.

Gardner's turnip-cutter, 137.

Garnier, H., invents method of " acierage," 218.

Garrick, David, in list of members, 38 ; refuses to recommend Goldsmith for the secretaryship, 24; epigram on Hill, 46 .

Garvey, E., I 79.

Gas, first used in Society's house, 69.

Gas-holder, Clegg's, 295.

Gas lamp, telescopic, medal for, 296.

Gas manufacture, prizes for, 294.

Gas manufacture, utilisation of byproducts, 295.

Gas-meter, invention of, 295.

Geddes, Margaret, I 79.

Gem-engraving, prizes for, I 57, 222.

George IIr., King, proposal by Barry to paint the King's portrait, 79 .

George v., King, becomes President, 447 ; becomes Patron on his accession to throne, 447 ; his head on Society's medal, 320; receives Albert Medal, 5I 7 .

Georgia, "observations on," 93; silk from, 84 ; filature in, 85 .

Germain, Lady Betty, $5 \mathrm{r}$.

Gibbon, Edward, 38 .

Gibbs, W. A., prize for harvesting crops in wet weather, 499 .

Gibson, Milner, presents Society's petition to House of Commons, 409.

Gilbert, Sir H., Albert medallist, 515 .

Gilding, prizes for improved methods of mercurial, $270,27 \mathrm{I}$.

Girls' Public Day School Co., 467.

Gisborne, Dr. T., 38.

Gladstone, Sir J., portrait, 519.

Gladstone, W. E., presides at annual dinner, 396.

Glaze for pottery, innocuous, 273.

Goadby, prize for improvements in the microscope, 288.

Godby, J., I 79 .

Godfrey, A., prize for fire-extinguishing apparatus, 309.
Goldicutt, J., I8o.

Goldsmith, Oliver, 39; canvasses for the post of secretary, 24.

Gomme, Sir Laurence, supplies information about Rawthmell's Coffee-House, 12 ; about Society's Strand offices, 57 ; lists of London memorials, $472 n$.

Gooch, T., I 80 .

Goodall, E., medal for water-colour, 180 .

Goodall, F., medals for drawing and painting, 180 .

Goodchild, John, attends first meeting, I 2 ; first treasurer, I7.

Goodchild, John, the younger, succeeds his father as treasurer, 21 ; account of his treasurership, 21 .

Goodeve, Prof., acts as examiner, 432.

Goodwin, Dean, acts as examiner, 432.

Goree, medal in celebration of capture of, 220.

Gott, J., 180 .

Gough, British Topography, 298, 299. 300.

Government assistance, absence of, $21,398$.

Grafton, Duke of, 28.

Graham, Dr. Charles, Cantor Lectures, 453.

Graham, G., I8o.

Graham, Thomas, member of Council, 361 .

Graham, W. A., elected Secretary, 338 ; resigns, $33^{8}, 34^{8}$.

Grant, W., I 80 .

Grantham, J., prize for steam-car, 495.

Granville, Earl, presides at Centenary Dinner, 396 ; nominated Trustee for 1862 Exhibition, 419; on Technical Education, 464 .

Grass-seed, prizes for, I I9.

Gray, J. M., James and William Tassie, $224 n$.

Great Room (in Little Denmark Court), 54, 57; size of, 58 ; first London exhibition of pictures held in, 228.

Great Room (in the Adelphi), decorations of, 65,66 ; alterations in, 65; warming arrangements, 66 ; lighting, 69 ; Barry's pictures in, 70 .

Greathead, H., medal for invention of lifeboat, 296.

Grece, C. F., medal for Canadian hemp, 108.

Green, B. R., I 80.

Green, Valentine, negotiates with Royal Academicians about pictures for Great Room, 70; reports 
Barry's willingness to provide the pictures, 71 ; suggestions for publication of Transactions, 332 ; candidate for secretaryship, 334; his work for the Society, $334 n$.; gold medal for services, $334 n$.

Green, W., medal for Canadian pigments, rog.

Gresse, J. A., one of first prizewinners, 17, I 52 ; prizes for drawing and painting, 180.

Greville, Lady Augusta, first award of medal for a drawing, I60; medals for drawing and etching, I 8o.

Grey, Earl, 30.

Grey, Mrs., on Education of Women, 467.

Griesbach, constructs forks for Society's standard of musical pitch, 387.

Griffin, Admiral T., 39.

Griffin, Sir J., 39.

Grignion, C., prizes for drawing, I 8r.

Grignion, Thomas, presents clock to Society, 39.

Grignion, Thomas, jun., prize for drawing, I 8 I

Grinding mills, awards for, 255.

Grinding, preventing injury from dust in, 272.

Grose, F., 39.

Grove, Sir George, appointed Secretary, 363 ; becomes secretary to Crystal Palace, and resigns, 364.

Guadaloupe cinnamon, 97.

Guarantee Fund for I 862 Exhibition, conditions of, $4 \mathrm{I} 9$.

Guilding, L., account of St. Vincent Botanic Garden, $99 n$.

Guimand, P. L., optical glass, 287 .

Gun-harpoon, awards for, $249,250$.

Gutta-percha, introduction of, $\mathrm{IO}_{4}$; Obach's lectures on, I05.

Gwilt, G., I 8I.

Gwynn, J., contributes to first exhibition of pictures, 229 .

Habershon, M., I 8 I .

Hakewill, J., I 81 .

Hales, Dr. Stephen, one of the founders, I 2, 39, 77 .

Halifax, Earl of, 30 .

Hall, J., r 8 I.

Hall, J. and E., prize for refrigerating apparatus, 463 .

Hall, M., achromatic telescope, 286 .

Hamilton, Duchess of, 3 .

Hamilton, H. D., I 81.

Hampshire, map of, 300 .

Handasyde, C., I 82 .

Hand-signalling, awards for, 252.
Hanover Square Rooms, distribution of premiums in, 325 .

Hanway, Jonas, in list of members, 39; subscribes to exhibition of Barry's pictures, 74 ; procures Act for suppressing use of climbing boys, 276 .

Harcourt, A. V., Cantor Lectures, 453.

Harcourt, Earl, 30.

Harding, J. D., I 82 .

Hardwick, P., I 82 .

Hardwicke, Earl of, 30.

Hardy, Sir C., 39.

Harley, Hon. T., 39.

Harris, James, 77.

Harris, J., syringe for oil-paints, 2 I 4. Harrows, I 24 , I 28.

Hart, Solomon, medal for drawing, I 82 .

Hartley, Sir Charles Augustus, Albcrt medallist, 5 I 6 .

Harvesters, see Reaping Machines.

Harvesting crops in wet weather, $1_{4}{ }^{\circ}$, 499.

Harvey, Mr., prize for threshingmachine, 133 .

Hassell, E., I 82 .

Hassell, J., medal for improvements in aquatint process, I 82, 218 .

Haste's Essays on Husbandyy, $12 \mathrm{I}$.

Hastings, G. W., Cantor Lectures, 452.

Hastings, meeting at, to promote Training School for Music, 479.

Hatton, prize for standard of length, 289.

Hauling devices for mines, 253

Hawes, W., Chairman of Council, 447 ; proposes election of H.R.H. the Prince of Wales as member and as President, 445 ; DeputyChairman, $44^{8}$.

Hawke, Sir E., 39.

Hawkesworth, Dr. J., 39.

Hawkins, E., Medallic Illustrations, etc., $220 n$.

Hawkins, Sir C., 39.

Hay, D. R., Decorations in Great Room, 65.

Hay, Sir G., 39.

Hay, prizes for harvesting in wet weather, I $40,499$.

Hayman, Francis, 39 ; suggests exhibition of pictures, 228 ; contributes to first exhibition of pictures, 229.

Hayter, Sir G., medal for painting, I 82.

Hayward, W., medal for growing rhubarb, 284 .

Head, G., I 82 . 
Health, conferences on, 488 .

Health Exhibition, award of Trevelyan prize at, 463 .

Hearne, T., I 82 .

Hearson, T. A., prize for revolution indicator, 498 .

Heberden, W., 39.

Hebert, W., 183 .

Helmholtz, Professor Hermann Louis, Albert medallist, 5I 4.

Hemp in America, 89; in Canada, 108.

Henderson, J., 183.

Henning, J., 183.

Herrings, prizes for curing, $3 \mathrm{I} I$.

Hewett, Rev. J. M., medal for horsehoe, 128.

Hicks's ellipsograph, 294.

Hickson, S., attends meeting about 185 I Exhibition, 412.

Highland and Agricultural Society of Scotland, 3 .

Highmore, N., contributes to first exhibition of pictures, 229 ; member of committee on medals, 3 I 5 .

Hilditch, G., I 83.

Hill, Sir Rowland, Albert medallist, 512.

Hills, J., prize for means of obviating risks of mercurial gilding, 270.

Hillsborough, Earl of, 30 .

Hincks, W., his portrait of Shipley, ro.

Hine, T. C., prize for design for labourer's cottage, 392 .

Hipkins, A. J., on musical pitch, $387 n$.

Hispaniola, bamboo in, 94 .

Hoare, P., I 83 .

Hoare, W., 39 .

Hobhouse, H., lends the Society £1000, 397 .

Hoblyn, T., medals for coco-nut oil from Ceylon, and for machine for decorticating rice, 107.

Hodges, W., I 83 .

Hodgson, T., 183.

Hodgson and Eaton, History of the Royal Academy, 233.

Hofmann, August Wilhelm, Albert medallist, $5 I_{4}$.

Hogarth, William, founds St. Martin's Lane Academy, 8; in list of members, 39 ; member of committee on medals, 315 ; and the Society of Artists, 23I ; Copyright Act, 386.

Hogg, J., The Microscope, $288 n$.

Holdernesse, Earl of, 30 .

Hole, H., 183 .

Hole, J. C., prize for essay on Mechanics' Institutes, 392.
Holidays, proposal for national, condemned, 396.

Hollingshead, J., Introduction to I 862 Exhibition Catalogue, 403 n., $409 n$.

Hollis, Thomas, 40 ; promotes prizes for die-sinking, 220 ; on committee of first picture exhibition, 228.

Hollis, T., medal for water-colour, 183 .

Holt, Dorothy, prize for lace, 266.

Holtzapffel, Mechanical Manipulation, $273 n$.

Honduras logwood, 98.

Hone's Everyday Book, $276 n$.

Honorary Testimonial proposed for readers of papers, 354 .

Hook, J. C., medals for drawing, 183.

Hooke, R., method of signalling, $25 \mathrm{I}$.

Hooker, Sir Joseph Dalton, Albert medallist, $5 \mathrm{I} 4$.

Hooper, Edward, 77.

Hooper, L., Cantor Lectures on Weaving, $263 n$.

Hope, Dr., on Jamaica Botanic Garden, 99 ; grows rhubarb plants, 283.

Hopwood, J., I 83 .

Horner, B. W., examiner in music, 441 .

Horse-hoes, 124, 127.

Horsley, J. C., medals for drawing, 184 ; his portrait of Queen Victoria, 8o, 5 I 8 .

Horton, R. W., presents collection of Australian articles, II2.

Hortus Jamaicensis, $94 \boldsymbol{n}$.

Horwell, C., 184 .

Horwood, R., prize for map of London, 302.

Houses, memorial tablets on, see Memorial Tablets.

Housing labourers, prizes for, 312, 392,491 .

Howard, F., I 84.

Howard, J., 40.

Howard Trust founded, 503; prize for traction engine, 495 .

Howe, Viscount, 32.

Huck, Dr. R., 40.

Hughes, Professor David Edward, Albert medallist, 5 I 5 .

Hughes, E., 184 .

Hullah, John, St. Martin's Hall built for, $37 \mathrm{I}$; lectures at Educational Exhibition, 37I ; examiner in music, 440 ; Cantor Lectures, 453.

Hullmandel, C. J., medal for lithography, 184,305 . 
Hume, Joseph, member of Council, 362.

Humphreys, W., I84.

Hunt, Robert, promotes formation of Photographic Society, 385; candidate for secretaryship of Society, $385 n$.; acts as examiner, 432.

Hunt and Roskell, prize for jewellery, 389.

Hunter, Dr. A., on Society's promotion of tree-planting, I 50.

Hunter, Dr. W., 40, 77.

Huntingdon, Earl of, 30.

Hurd, Dr., 77.

Hurlstone, F. Y., I 84.

Hurlstone, R., I 85 .

Hussey's reaping machine, I3I.

Huxley, Prof., lectures at Educational Exhibition, 37I; on the use and value of examinations, 43 I.

Hyde Park first suggested 'for I85I Exhibition, 404; recommended, 4 II.

Hydrometer, prizes for, $29 \mathrm{r}$.

Implements, agricultural, I 24.

Incorporated Society of Artists, 232.

Incorporation of Society, see Charter.

Indian alkali, 88, I02; cotton, I02; cinnamon, I02; tea, 105, I06; collections of woods, 107 ; barilla, 278.

Indian products, collection sent to Dublin Exhibition, 380.

Indian Section established, 455 ; its work and value, 455 .

India-rubber, see Rubber.

Indigo, West Indian, 93; Mexican, 98; Guatemalan, 98 ; in Tobago, 98; in Jamaica, 98; in East Florida, 98 ; prize offered for British, 280.

Industrial art, early prizes for, I 52 .

Industrial hygiene, 269.

Industrial instruction, Report on, 370 ; conference on, $37^{\circ}$.

Industrial pathology, Committee on, 395.

Inglish, J., medal for growing rhubarb, 283.

Insect pests, I 40 .

Institutions, origin of mechanics, 369 ; those near London affiliated to Society, 369; H. Chester suggests their development, 370 ; conference on, 370 ; Union founded, 370 ; annual conference started, 370 ; organisation of Union of,
370 ; discontinuance of conference, 372 ; examinations in connection with, 372,425 ; use as centres for Science Examinations, 377; prize for essay on, 392; Colonial, 454.

Inventions, exhibitions of, 378 .

Inventors, difficulties of, 240 ; opposition to, 241,242 .

Inwood, H. W., I 85 .

Ireland, S., I 85.

Iron bridge, first, 254.

Iron manufacture in America, 88.

Iron shipbuilding, award for, 255 .

Iron, wood only fuel for making, I 43,144 .

Irrigation, I 40.

Irvine, Viscount, 32.

Isinglass from America, 90.

Isis Medal, 318, 319.

Isle of France, see Mauritius.

Jacquard apparatus, prizes for improved, 264.

Jacquin, E. A., patentee of Garnier's method of "acierage," 218.

Jamaica, sugar cane first cultivated in, $94 ;$ coffee in, 94 ; bamboo in, 94; cotton in, $94 ;$ Handbook, $94 n$.; cochineal, 95 ; bread-fruit in, 95,96 ; Botanic Garden, 99 ; cinnamon, 97 , Ioo; cargo of captured plants carried to, 97 ; indigo, 98 ; logwood, 98 ; camphor, I0о ; sago, I00 ; tea, I05;

James I., efforts to improve British manufactures, 265.

James, Dr. R., 40.

Jamison, Sir John, medal for method of extracting tree stumps, I I 2 .

Jebb, Sir Richard, 40 ; obtains seeds of mangel-wurzel, I23.

Jeffer, prize for carpets, 268.

Jeffereys, J., 185 .

Jefferys, $\ddot{T}_{\text {., }}$ map by, showing Society's offices in Little Denmark Court, 57 ; map of Yorkshire, 299; map of Devon, 299.

Jenkin, Prof. F., Cantor Lectures, 453.

Jenkins, A., Life of George Borrow, $306 n$.

Jenkins, Capt., finds tea-plant in Assam, 106.

Jennings, W., prize for improvements in Jacquard loom, 264.

Jenyns, Soame, 40, 77 .

Johnes, Colonel Thomas, medals for planting trees, $\mathrm{I}_{4} 8$.

Johnson, Dr. Samuel, 40 ; his portrait in Barry's picture, 77; 
writes to Baretti about the Picture Exhibitions, 230; his Preface to Catalogue of Exhibition of Society of Artists, 23I.

Jones, G., I 85 .

Jones, Owen, lecture on $185 \mathrm{I}$ Exhibition, $37^{8}$; prize in memory of, 503 .

Jones, T., 185 .

Jones, T., prize for growing opium, 284.

Joubert, F., describes method of "acierage," 2 r8.

Joule, Dr. James Prescott on Sturgeon's electro-magnet, 292 ; Albert medallist, 5 I 4 .

Journal of the Society first published, 334; suggested by Dr. Booth, 373 ; character of, 374 ; contents of first number, 374 ; value as record of history of invention, 443.

Jukes, F., 185.

Jurisprudence, Swiney prize for book on, 394 .

Jury Reports of 1862 Exhibition published by Society, 423; loss on publication, 424,504 .

Kauffmann, Angelica, invited to paint picture for Great Room, 70.

Kay, John, share in invention of power loom, 246 ; his relations with the Society, 259; his wirecard apparatus, 26I; his flyshuttle never submitted to Society, 260,262 ; fresh information about him in Society's records, 260.

Kay, Robert, submits his "dropbox" for weaving coloured fabrics, 262 .

Kay, William, submits his father's wire-card machine to Society, 26I premium awarded, $26 \mathrm{r}$.

Kay-Shuttleworth, Sir J., member of Council, 449.

Keith, Elizabeth, I 85 .

Kelly, H., 40.

Kelp, prize offered for, 278 .

Kelsey, C. S., 185 .

Kelsey, R., I 85 .

Kelvin, Lord, Albert medallist, 5 I 3 .

Femp, G. T., on first exhibition committee, $404 n$.

Kendrick, Emma E., I 86.

Fendrick, J., I86.

Kenmare, Viscount, 32.

Kent, T., medal for tanning material, III.

Keppel, Admiral A., 40.
Keyse, T., prize for fixing crayon drawings, I 86, 213.

King, J., medal for Australian wine, I I I.

King's Theatre, distribution of premiums in, 325 .

Kingston, Duke of, 28 .

Kirby, Sarah, I 86.

Kirby, W., I 86.

Kirk, John, prizes for medal designing, I86, 220, 221 ; cuts die for Society's seal, 221 .

Kirk, Thomas, I 86.

Kitchingman, J., 186.

Knight, Dr. G., 40 ; on committee of first picture exhibition, 228 .

Knight's London, references to Society in, $66 n$.

Knowles, Admiral Sir C., 40.

Kohl-rabi, 121, 123n.

Labouchere, Mr., deputation to, 407 ; attends meeting about $185 \mathrm{I}$ Exhibition, 4 II.

Labourers' cottages, prizes for, 3I2, $392,49 \mathrm{I}$.

Lace, encouragement of English, 266.

La Condamine, describes caoutchouc, ro3.

Lady members, $5 \mathrm{I}$.

Lamb, Charles, on climbing boys, 275 .

Lamb, Sir J. C., on the invention of the lifeboat, 296; on Society's labours for postal reform, $477,4,78$.

Lambert, J., I 86.

Lambert, Mr., prize for four-wheeled cab, 497.

Lamp, prize for railway, 497.

Lancashire, map of, 300.

Land reclamation, $\mathrm{4} 40$; cultivation of waste, I 40.

Landseer, C., prize for drawing, I 87 .

Landseer, Sir E., medals for drawing and painting, 187 .

Landseer, G., medals for painting, I 87.

Landseer, Miss, prize for painting, I 87.

Landseer, T., medals for etching and painting, I 87 .

Lane, J. B., I 87.

Langford, A., 40.

Lansdowne, Earl of, presides at conference on Mechanics' Institutions, 370 .

Larousse, Dictionnaive Universel, $227 n$.

Latin, prizes awarded for colloquial, 3 II.

Lavatories, scheme for establishing public, 388 . 
Law, W., History of Coffee, $94 n$.

Law, submits sample of glazing material for pottery, 274 .

Lawes, Sir John Bennet, Albert medallist, 5 I 5 .

Lawrance, J. C., introduces Society's Patents Bill, 476.

Lawranson, W., 188 .

Lawrence, Charles, one of the founders, I 2.

Lawrence, Coloncl S., 40.

Lawrence, T., 40.

Lawrence, Sir Thomas, prize for drawing, I 88 ; on method of preserving oil colours, $2 \mathrm{I}_{4}$.

Lawrie, R., prizes for drawing, etc., I 88 ; prize for method of printing mezzotints in colour, 218.

Lawson, Sir Wilfrid, 40.

Leadless glaze, 273, 274 .

Leake, H., i 88 .

Lease of Adelphi premises, terms of, 64.

Lease renewal, expenditure on, 65 , 503.

Leather, prize for dyeing, 308; prizes for, 308 .

Leblanc's process for making soda carbonate, 277.

Lecky, England in the 18 th Century, 3 n., 21 .

Lectures, Cantor, see Cantor Lectures.

Lectures, system started by Aikin, 336,337 ; decadence of this system, 353.

Lee, H. P., prize for threshing machine, I33.

Lefevre, Sir J. S., on deputation to Board of Trade, $407 n$.

Legard, Sir D., medal for observations on drill and broad-cast husbandry, I26.

Legge, H. Bilson, 4I.

Legrew, J., I 88.

Le Hardy, Major, medal for mechanical telegraph, 252.

Leicestershire, map of, 300.

Leighton, Messrs., prize for bookbinding, 389 .

Le Jeune, H., I 88.

Lennox, Lord Henry, Chairman of Council, 447; presents memorandum on education to Mr. Gladstone, 466.

Lesseps, Vicomte Ferdinand dc, Albert medallist, $5 \mathrm{I} 3$.

Lester, W., medal for cultivator, I 28.

Letcher, Messrs., prize for blow-pipe apparatus, 494 .

Lettsom, J. C., on introduction of mangel-wurzel, I23.
Liart, M., I 88.

Library Catalogue, $333 n$.

Lichfield, Earl, 30.

Liddell, Dr., acts as examiner, $43 \mathrm{I}$.

Liebig, Baron Justus von, Albert medallist, 512 .

Lifeboat, invention of, 296.

Lifeboats, prize for improved ships', 493.

Life-saving apparatus, prizes for, 297. 493; report on, 494.

Ligonier, Field-Marshal Earl, 30.

Lincoln, Earl of, 30 .

Lincoln, local society in, 5 .

Lindley, Dr., lectures on $185 \mathrm{I} \mathrm{Ex}$ hibition, 378 .

Lindsey, local society in, 5 .

Lines, S., I 89.

Linwood, Mary, medal for needlework, I 89.

List of members, 26,27 .

Lister, Lord, Albert medallist, 515.

Lists of premiums, $116,141,152,236$, $238,240,489$.

Lithography, prize for invention of, by Senefelder, 21 4, 305; medal to Hullmandel for, 184,305 ; prize to Netherclift for transfer paper for, 193, 305; exhibitions of, $305 \mathrm{n}$,, 380.

Liverpool, Earl of, candidate for presidency, 324.

Liverpool, meeting to promote Training School for Music, 479.

Llandaff, Bishop of (R. Watson), medals for planting trees, 147.

Lloyd, J., prize for threshingmachine, 132 .

Loat, S., I 89 .

Lochée, J. C., prizes for sculpture, I 89.

Locke, William, 77.

Lockhart, D., medal for culture of nutmegs and mace in Trinidad, IoO.

Locks, awards for, 255.

Lockyer, Sir N., Cantor Lectures, 453.

Logographic Press, vol. iii. of Transactions printed at, $333 n$.

Logwood from America, 92 ; in West Indies, 98 ; Campeachy, 98 ; Honduras, 98 .

London County Council and the Society's examinations, 436 ; and school drill, 467 ; undertakes erection of memorial tablets, 47I; subscribes to School of WoodCarving, 482 .

London, prize for map of, 302.

Long, J. St. J., I89. 
Long, History of Jamaica, 94, $98 n$.

Looms, awards for, 263.

Louisburg, medal in celebration of capture of, 220.

Lowther, Rev. Mr., medal for observations on drill and broadcast husbandry, 126.

Lubbock, Sir John, introduces Society's Patents Bill, 476.

Lucerne, 120.

Lucy, C., 189.

Lukin, L., inventor of a lifeboat, 296.

Lupton, T. G., medal for mezzotint engraving on steel, I89, 216.

Lyttelton, Baron, 34 .

M'Ardell, J., 4 I ; contributes to first exhibition of pictures, 229.

M'Arthur, H., medal for Australian wool, I Io.

M'Arthur, John, vineyard in N.S. Wales, I I I ; medals for Australian wool, IIO.

Macclesfield, Countess of, 5I.

Macclesfield, Earl of, 30.

McCormick's reaping machine, 129.

Macdonald, J. C., member of Council, 361 .

Mace, West Indian, 93 ; in Trinidad, Ioo.

Macgregor, J., offers prize for cheap writing-case, $39 \mathrm{I}$.

Machinery, opposition to introduction of, $24 \mathrm{I}$.

Machines, etc., exhibition of, by Society, 58,66 , I I $8,239,402$; disposal of collection of, $38 \mathrm{i}$.

Mackennal, B., designs the Society's medal, 320 .

Mackenzie, Alexander, medal for explorations in North-West Canada, 109.

Mackreth, Sir R., 4I.

Maclise, D., design for Swiney Cup, 395, 44I.

McNaught, Dr., cxaminer in music, 440.

Macquarrie, Governor, memorial about Australian wine, II I.

Madden, Dr., and the Dublin Society, 2.

Madder, offer of prize for, I5; amount expended in prizes for, 28 o.

Maidstone, Shipley died in, 5 ; local Society in, 5 .

Majendie, L., medals for planting trees, 148 .

Malam, J., medal for improved gas-meter, 295.
Malta silk, I I 2.

Malton, T., 190.

Malton, W., I9o.

Manby, Capt., medal for means of communication with stranded ship. 297.

Manchester, Duke of, 29.

Manchester, meeting to promote Training School for Music, 479.

Mangel-wurzel, introduction of, I2 $\mathrm{I}$, 123.

Mango, West Indian, 93; first introduced into Brazil and thence to West Indies, 94,97 ; offer of medal for introduction to West Indies, 96 ; introduced into St. Vincent, 96 ; first introduction of, in West Indies, 97 ; in Martinique, 97.

Manipur, tea in, Io6.

Manning, S., I9o.

Manningham, Sir R., 4 I.

Mansfield, Earl of, medal for plant. ing trees, 146.

Manures, $137, x_{3} 8$.

Map of Canada, Io9.

Maps, county, prizes for, 298; offer of prizes for mineralogical, 30r ; Smith's geological, 301.

Marchant, N., prizes for gem-engraving, 190, 222, 223; asked to design Society's medal, 3 I 7 .

Markham, Dr. WV., 4I.

Marl, revived use of, $\mathrm{I} 38$; ancient use of, ${ }_{3} 8 n$.

Marlborough, Duke of, 29.

Marsden, Barbara, one of first prizewinners, I 7,152 ; prizes for drawings and designs, 190.

Marsh, J., medal for test for arsenic, 282 ; medal for electrical apparatus, 293.

Marshall, Captain, captures French ship with plants for Hispaniola, 97.

Marsham, Hon. Charles, 77.

Martin, D., I9I.

Martin, W., I 9 .

Martin's hydrometer, 290.

Martinique, coffee introduced into, 94; mango introduced into, by French, 97.

Masham, Lord, Albert medallist, 514.

Mask for use in noxious vapours, $271,272$.

Mason, J., prize for essay on Thrift, 495.

Mason, W., I9I.

Masquerier, J. J., I9I.

Maty, Dr. M., $4 \mathrm{I}$; candidate for the secretaryship, 24. 
Mauduit, I., $4 \mathrm{r}$.

Mauritius, silk in, II2 ; coco-nut oil from, II 2 ; tea in, I05.

Mayhew's London Labour, etc., $276 n$.

Mayor, B., I9r.

Mead, Captain, rewarded by AntiGallican Society, 4.

Mead, Dr., I4.

Measures, standard of, $28 \mathrm{~g}$.

Meat preservation, see Food Committee.

Mechanical movements, awards for, 255.

Mechanics' Institutions, see Institutions.

Mechi, J. J., member of Council, 36r.

Medals, first offer of, I 56 ; first award of, I6o; selected list of those given for Fine Arts, I62; awards for dies for, 219 ; Society's dies for first medal cut by Thomas Pingo, 220 ; account of Society's, 3 I 4 ; awarded for papers read,393.

Medicinal plants, prizes for, 283 .

Medland, T., I 9 I.

Meigh, J., prize for leadless glaze, 274.

Meikle's threshing-machine, I32.

Mellish, W., medals for planting trees, 147 .

Melville, General, reports on breadfruit in St. Vincent, 96 ; establishes botanic garden in St. Vincent, 99.

Members, list of, 26, 27 ; numbers of, $26,27,344,397,502$.

Memorial tablets first proposed, 468 ; committee appointed, 468 ; scheme prepared by G. Bartley, 468 ; first tablet erected, 469 ; subscriptions towards expenses, 469 ; design of tablet, 470 ; number of tablets set up, 470 ; houses pulled down, $47^{\circ}$; work taken over by London County Council, $47 \mathrm{I}$; references to lists, etc., of memorials, $472 n$.

Memorial Window in St. Paul's after Prince of Wales's illness, 487 .

Menzies' threshing-machine, I32.

Mercurial gilding, prize for improved methods of, $270,27 \mathrm{I}$.

Messiter, Husband, friend of Shipley, 8 ; attends first meeting, I2.

Metal-working, prizes for designs for, I 53 , I 57 .

Metz, C. M., I9I.

Meyer, J., medal for design for a die, I9I.

Mezzotint, first offer of prizes for, I 53 ; conditions of offer, I57; use of steel for, I90 n., 216 ; tool for laying grounds, 218 ; printing in colours, 2 I 8 .

Michelsen, Prof., method of obtaining standard measure in terms of wave-lengths of light, 290.

Microcosm of London, references to Society, 65 .

Microscope, prizes for improvements in, 288; prize for cheap, 390.

Midleton, Viscount, 32 ; on committee of first picture cxhibition, 228.

Milbourn, J., r9r.

Milk-cans, prize for, $46 \mathrm{r}$.

Milk supply, see Food Committee.

Millais, Sir J. E., medals for painting, I9I.

Miller, J., r92.

Mills, G., medals for die-engraving, I92; medal for medal designing. 222 ; awards for die for Vulcan Medal, 222 ; designs Vulcan Medal, 318.

Milnes, R. S., medals for planting trees, $I_{4} 8$.

Mimosa, tanning material from Australia, I I I.

Minden, medal in commemoration of battle of, 221 .

Mineralogical maps, offer of prizes for, 30I.

Mining, awards for, 253.

Minorca silk, II2.

Minton, Messrs., present mosaic pavement, 66 ; prize for pottery, 389 ; manufacture the Felix Summerly tea-service, 405 ; manufacture memorial tablets, 470 .

Mitchell, Dr., candidate for the secretaryship, 24.

Mitchell, J., 4 I.

Mitchell, T., I92.

Models, exhibition of, $58,66,118,239$, 402 ; disposal of collection of, $38 \mathrm{r}$.

Moffat, W., presents Barry's portrait, 82 .

Monpesson, Sir Thomas, purchases Adelphi Estate, 60.

Montagu, Mrs., 51; portrait in Barry's picture, 77 ; dinner to climbing boys, 275 .

Montagu's Copper Coinage, 327.

Montfort, Baron, 34.

Montgomerie, Dr. William, sends first samples of gutta-percha, IO4; medals for discovery of guttapercha, and for cultivation of nutmegs, $\mathrm{IO}_{4}$.

Montrath, Earl of, 30.

Moody, F. W., designs memorial window for St. Paul's, 487 . 
Moore, prize for carpets, 268.

Moore, F. J., 192.

Moore, Sir H., 4I.

Moray, Earl of, 30 ; medal for planting trees, ${ }_{4} 6$.

More, R., 4I.

More, Samuel, portrait in Barry's picture, 77,327 ; awards for artificial cameos, I92, 224, 327; papcr on standards, 289 ; elected Secretary, 326 ; his life and character, 327 ; his portrait by West, 327; his design for a coin, 327 ; his death, 334 .

Moring $T$., medal for intaglio, 192, 225.

Morland, G. H., contributes to first exhibition of pictures, 229.

Morpeth, Lord, deputation to, 408.

Morris, Sir D., Lectures on Commercial Fibres, $108 n$.

Morris, Valentine, suggests introduction of bread-fruit into West Indies, 95.

Mort, T. S., experiments on preserving meat by cold, 463 .

Mortimer, J. H., invited to paint picture for Great Room, 70; prizes for painting, I92.

Morton, Dr. C., 4 I.

Morton, J. C., Cyclopadia of Agriculture, $13 \mathrm{r}$; paper on agricultural progress, 492.

Mosaic pavement in hall and staircase, 66.

Moseley, Canon, acts as examiner, 431.

Moser, G. M., $4 \mathrm{I}$; prize for design for medal, I92; award for his design of a medal for the Society, 22I ; contributes to first exhibition of pictures, 229.

Moser, Joseph, awards for medal designing, r $93,22 \mathrm{I}$.

Moser, Mary, medals for drawing, etc., 193 .

Moses, H., 193.

Motive power, premiums for, 245 .

Mounsey, Dr., medal for introduction of rhubarb, 283 .

Mulberry trees, plantation of, in St. James's Park, 265; at Chelsea, 265; encouragement of growth of, 266 .

Mulready, W., reports on Barry's pictures, 80; prize for drawing, 193; exhibition of pictures by, 379 .

Mulready prize, 503 .

Munday, Messrs. J. \& G., undertake contract for I 85I Exhibition, 4I3 ; contract terminated, $4^{1} 4$.
Mure, S., medal for growing breadfruit in Jamaica, 96.

Murray, Lieut.-General Lord John, $4 \mathrm{r}$.

Murray, R., medal for using plumbago to obtain conducting surface for electro-deposition, 293.

Murray's English Dictionary, 87, 92, $128,249$.

Museum Rusticum, II 8, 329.

Museum, Victoria and Albert, see South Kensington Museum.

Music, examinations in, 439.

Music, National Training School for, first suggested, 479 ; meetings in support of, 479 ; scholarships at, 479, 480; building for, 480 ; reconstituted as Royal College of Music, 480 ; final report, I882, 480 ; amount expended by Society, $48 \mathrm{r}, 504$.

Musical Education, Society's attention directed to, 478 ; negotiations with Royal Academy, 478 ; committee appointed, 479 ; reports on musical education abroad, 479; proposals for scholarships, 479 .

Musical Pitch, Committee on, 387 ; report by Hullah, 387 ; standard pitch adopted, 387 ; abandoned, 388 ; $\mathrm{A}$. J. Hipkin's paper on, $387 n$.

Mylne, R., 4I.

Myrtleberry wax from America, 9I.

Napier, Lord, presides at annual dinner, 396.

Napoleon III., Albert medallist, 5 I2.

National Gallery of British Art, proposals for, 379 .

"National Repository" the, 403.

Natron, 87, 102 ; natron pits of Sind, 88.

Naval construction, prizes for, 255 .

Navy Office and timber supplies, 144.

Neate, C., acts as examiner, 432 .

Needles, preventing injury from dust in grinding, 272.

Neil, J. W., medal for paper on varnish-making, $28 \mathrm{r}$.

Nesbitt, C., 193.

Netherclift, J., prize for lithographic transfer process, 193, 305.

Net-making machines, awards for, 269.

New Brunswick, hemp in, 108.:

New South Wales, tea from, 105; wool from, I Io; wine from, I I I.

New York, Society of, 3 .

New Zealand, introduction of bees into, II2; Phormium tenax from, I 08 . 
Newark, Viscount, medal for planting trees, ${ }_{4} 6$.

Newbery, J., 4I.

Newborough, Lord, medal for planting trees, ${ }_{4} 6$.

Nicholl, S. J., prize for design for labourer's cottage, 392.

Nicholls, Dr. F., 4I.

Nichols' Literary Anecdotes, $12 n$. ; Literary Illustrations, I 4 .

Nitrates from America, 87.

Noble, Sir Andrew, Albert medallist, 517 .

Noble, John, gives prizes for stove competition, 489 .

Nollekens, J., student at Shipley's Academy, 17 n.; prizes for drawing and sculpture, 193.

Nootka Sound, ro8.

Norfolk, Agricultural Society in, 6.

Norfolk, Duke of, elected President, 322 ; his character, 323 ; objects to Barry's proposal to paint portraits for Great Room, 323; his death, 323 .

North London Exhibition, surplus from, given to Society, 458 .

North, Lord, 34.

Northampton, Earl of ( $7 \mathrm{th}), 3 \mathrm{I}$.

Northampton, Earl of (8th), $3 I$.

Northcote, Sir Stafford, Secretary to I 851 Commission, 363,4 I 4 .

Northumberland, Countess of, $5 \mathrm{I}$.

Northumberland, Duchess of, 77 .

Northumberland, Duke of, 77 ; seconds proposal for election of Prince Albert as member, 325.

Northumberland, Earl of, 3I.

Northumberland, map of, 300.

North-West Passage by land, prize for, ro8.

Norton, C., I94.

Nova Scotia, hemp in, ro8.

Noxious vapours, preventing injury from, 270, $27 \mathrm{I}$.

Nutmegs, West Indian, 93; in Trinidad, roo.

Oaks, planting, see Trees.

Obach, Dr. E., on gutta-percha, I05.

Odling, Prof., address on formation of Chemical Section, 456.

Offices of Socicty, 53.

Officials, list of, $509(A p p$.$) ; duties of,$ 25.

Ogle, co-operates with Common in invention of reaping machine, I29, I 30.

Oglethorpe, Lieut.-General, $4 \mathrm{I}$.

Oil, prize for purifying, 282, 331.

$$
3^{6}
$$

Oil-cake, first use of, as cattle food, 1 I 9.

Oil-colours, prize for, 213 .

Okey, S., I94.

Olives in America, 92 ; West Indian, 93 ; in N.S. Wales, III.

Open-field system of farming, I 15.

Opium in America, 92; West Indian, 93; prizes for growing British, 284 . Optical glass, prizes for, 286 .

Orange, introduction of, into West Indies, 94 .

Orchella, prize offered for British, 28 o.

Origin of Society, $\mathbf{I}$.

Orwell, Baron, 34.

Osiers, offer of prizes for growing, 306.

Osler \& Co., prize for glass, 389 .

Oxfordshire, map of, 300 .

Owen, Col., Chairman of Council, 36r.

Owen Jones prize, 503.

Owen, Prof., lecture on 1851 Exhibition, 378 .

Owen, Sir P. Cunliffe, member of Council, 36r, 450.

Packe, J., prize for crayons, 213.

Packing press, award for, 255.

Paget, Lord, medal for planting trees, $1_{4} 6$.

Pain, G. R., I94.

Paine, J., $4 \mathrm{I}$.

Paints and colouring matters, prizes for, 21 3, 279, 28r.

Pakington, Sir J., member of Council, 36r.

Palette, the Society's, I6o, 318.

Palk, Sir R., 42.

Palmer, C. F., medals for planting trees, I 49.

Palmerston, Viscount, 32.

Paper and paper-manufacture, prizes offered for improvements in, 303.

Paper duty, report on, 396.

Paper for copper-plate printing, prize offered for, $2 \mathrm{I}_{4}, 304$.

Papers, regular reading of, suggested by Aikin, 337; definite arrangements made by Council for reading, 354 ; number and subjects of, 443 .

Papworth, E. G., I 94 .

Papworth, J. W., I 94.

Papworth, W., I 94.

Para rubber, I03.

Parcel post, 396, 477.

Paris Exhibition, 1849, 410; 1867, artisan reporters at, $483 ; 1878$, artisan reporters at, 484 .

Paris, picture exhibitions first started in, 226. 
Parke, H., I94.

Parker, J., I94.

Parkins \& Gotto, prize for cheap writing-case, $39 \mathrm{I}$.

Parry, J., medal for straw-plait, 306.

Parry, WV., I95.

Pars, Albert, prizes for modelling, etc., I95.

Pars, Anne, prizes for drawing, 195.

Pars, Henry, carries on Shipley's Academy in Beaufort Buildings, 9.

Pars, William, 9 ; prizes for painting, drawing, etc., 195 .

Parsnips for cattle food, I 20.

Parsons, The Hon. Sir Charles Algernon, Albert medallist, 5 I 7.

Parsons, Dr. J., 42 .

Parsons, W., 195.

Passavent, prize for carpets, 268.

Pastes for cameos, 224.

Pasteur, Louis, Albert medallist, 5 I 4.

Patent fees, proposals for disposal of surplus, 384 .

Patent Law Reform promoted by Society, 382 ; Act of 1852,383 ; Sir F. Bramwell on 474; Bill of I 875 opposed by Society, 475 ; discussed at special meeting, 475 ; Bill of 1879,475 ; Sir F. Bramwell's proposals, 475 ; Bill embodying them, drafted, 476 ; brought in $I 882$ and 1883,476 ; Government Bill of 1883,476 ; becomes law as Patents Designs and Trade Marks Act, I 883, 476 .

Patent Office Museum, $38 \mathrm{I}$.

Patented inventions ineligible for awards, 243,382 ; rule rescinded, 243 ; detrimental effect of rule, 347.

Patents, early objection to, 243; advantages of, 244 .

Paterson, net-making machine, 269.

Pathology, Committee on Industrial, 395.

Patmore, Coventry, prize for drawing, 195.

Patron, King Edward viı., the first, 320,446 ; King George v. succeeds his father, 320, 447 ; proposal that the Prince of IVales (King George IV.) should be elected, 322 ; suggestion that Queen Victoria should be invited, 446 .

Patten, G., 195 .

Paul \& Wyatt's spining machinery, 258.

Paxton, Sir J., member of Council, $36 \mathrm{I}$; on disposal of surplus patent fees, 384 .
Payne, J., treasurer for 185 I Exhibition, 4 I $3 n$.

Peace, prize offered for treatise on Arts of, 3I2.

Pearlash from America, 86.

Pearson, Mrs. C., I95.

Peart, C., I95.

Peele's Coffee-house, Society's meetings at, 16, 53 .

Peers, special offer of prizes for children of, I 56 .

Pellatt \& Co., prize for glass, 389 .

Pelling, A., prize for optical glass, 287.

Pembroke, Agricultural Society in, 6.

Pembroke, Earl of, 3I; owns the Adelphi Estate, 60.

Penny, E., invited to paint picture for Great Room, 70.

Pepper, West Indian, 93.

Pepys, Sir L., 42.

"Perambulator" for measuring land, 248.

Percy, Earl, 77.

Percy, Dr. John, Albert medallist, 5 i4.

Perkin, Sir IVilliam Henry, Cantor Lectures, 453; Albert medallist, 5 I 4.

Perkins, Jacob, his "Siderographic" process, 2 I 5,303 .

Perkins, Loftus, inventor of steam carriage, 496.

Persimmon from America, 92.

"Perspectographs," 294.

Petchey \& Wood, medal for Tasmanian tanning materials, II I.

Peters, M. W., I96.

Pether, W., 196.

Petit, Dr. L. P., 42.

Peto, Sir S. M., defrays cost of experimental establishment of public lavatories, 388 .

Phillippo, prize for information about dyeing leather, 308, 330.

Phillips, J. S., medal for cameo, 225.

Phillips, L., medal for growth of mangel-wurzel, I 24.

Phillips, Sir T., Chairman of Council, 360,447 ; on Committee for proposed I86I Exhibition, 4I7; on Committee for I 862 Exhibition, 419.

Phipps, C. J., 42.

Phormium tenax, prizes for, 108 ; importation of, Io8.

Photographic exhibition, 380,384 .

Photographic Society, formation of, 385 .

Physicians, College of, joint adjudicators of Swiney Cup, 394.

Physick, E. G., I96. 
Physick, E. J., I96.

Pictures, exhibitions of, see Exhibitions.

Pidgeon, G. F., engraves die from Flaxman's design for Society's medal, 3 I 8 .

Pigments, Canadian, 109 ; prizes for, 2 I $3,279,28$ I.

Pike, J., prize for chaff-cutter, I 34.

Pile-drivers, awards for, 255.

Pinchbeck, C., 42.

Pinches, T. R., medals for dieengraving, 196, 222.

Pine, R. E., prizes for painting, 196; on committee of first picture exhibition, 228 ; contributes to first exhibition of pictures, 229.

Pinfold, C., 42.

Pingo, B., prizes for drawings, 196.

Pingo, H., prizes for designs, 196.

Pingo, John, prizes for die-engraving, 196; prizes for medal-designing, $220,221$.

Pingo, Lewis, prizes for die-sinking, gem-engraving, etc., I96; prizes for medal designing, $220,22 \mathrm{I}$; prize for gem-engraving, 223.

Pingo, Mary, prizes for drawing, etc., 197.

Pingo, Thomas, 42 ; award for die of Society's medal, 197; prizes for dies of his designing, 219; cuts dies for Society's first medal, 220, 316 ; contributes to first art exhibition, 229.

Pintsch, Messrs., prize for railway lamp, 498.

Pitcairn, Dr. W., 42.

Pitt, George, 42.

Pitt, William (Earl of Chatham), 42.

Pitts, W., I97.

Planer, medal for, 254.

Plantain in West Indies, 96.

Plassy, medal in commemoration of battle of, 221 .

Playfair, Lord, member of Council 361 ; lectures on 1851 Exhibition, 378 ; edits Jury Reports on 1862 Exhibition, 424 ; letter on technical education, 464 ; presides at conference on pollution of rivers, 488 .

Ploughs, I 24, I 25.

Plumbago for electro-deposition, 293.

Plymouth, Earl of, 31.

Pochin, H. D., subscribes towards cost of memorial tablets, 469 .

Pocock, Admiral Sir G., 42.

Pocock, W. F., I97.

Pollington, Baron, 34.

Pomegranate in West Indies, 96.

Pomfret, Earl of, 3I.
Poplram, Sir H., medal for meclianical telegraph, 252.

Portable railway, Edgeworth's, $248 n$.

Porter, J. A., I97.

Porter, Sir J., 42.

Porter, Sir R. K., 197.

Porter's Silk Manufacture, 85 n., $263 n$., $264 n$.

Portland, Duke of, 29.

Portsmouth, Earl of, medal for planting trees, 146 .

Post office, premium lists distributed by, 240 .

Postage, international, 396.

Postal parcels, 396, 477.

Postal reform advocated, 396, 477.

Potash from America, 86.

Potato, introduction of, $120 \mathrm{n}$; " clustered," I 20.

Potatoes for cattle food, I 20.

Pottery, innocuous glaze for, 273 .

Powell, prizes for improvements in the microscope, 288.

Powell, Prof. Baden, acts as examiner, 432.

Power-looms, 246, 263.

Powerscourt, Viscount, 32 .

Powis, Earl of, $3 \mathrm{I}$.

Pownall, Governor, 42.

Poynter, Ambrose, I97.

Practical Art, Department of, 377.

Practical commercial knowledge, examination in, 438 .

Pratt, Sir C., 42.

Preceptors, negotiations with College of, 4 I 7.

Preece, Sir W., Cantor Lectures, 453.

Premium Lists, I 16, I41, 1 52, 236 , 238,240 ; last issue of, 489 .

Premium Society, title used by Society, I 8.

Premiums, annual distribution of, 158, 319, 324; method of awarding, 237 ; decadence of system of awarding, 345 .

Premiums, Fine Arts, I51, 162, 213 ; Colonial, 83 ; agricultural, I 14 ; in forestry, 143; industrial, etc., 235.

Preservation of food, see Food Committee.

Presidents of Society, Viscount Folkestone, I7; Lord Romney, 32I; Duke of Norfolk, 322 ; Duke of Sussex, 324 ; Prince Albert, 326 ; William Tooke, 444 ; Albert Edward, Prince of Wales (King Edward vir.), 445; Sir Frederick Bramwell, 447 ; George, Prince of Wales (King George v.), 447 ; Lord Alverstone, 447 ; Duke of Connaught, 447 ; list of, $509(A P p$.). 
Price, Prof. Bartholomew, acts as examiner, 432 .

Priestley, first mention of indiarubber, I03.

Printing, awards for, 305.

Printing bank-notes and stamps, Perkins' process for, 2 I 5, 303.

Prior, Rev. J., map of Derbyshire, 300 ; prize for map of Leicestershire, 300.

Prize Lists, see Premium Lists.

Proceedings i of Society, see Transactions, Journal, Abstract of Proceedings, and Weekly Proceedings.

Proctor, T., 197.

Prussian blue for dyeing purposes, $28 \mathrm{I}$.

Pugh, H., Igs.

Pulteney, Viscount, 42 .

Pumping engine, 253.

Pusey, P., experiments on draught of ploughs, I25; on use of drills, 127.

Pye, Admiral Sir T., 42.

Pye, C., Ig8.

Quebec, medal in celebration of capture of, 220.

Queensberry, Duke of, 29.

Quick \& Norminton, prize for fourwheeled cab, 497.

Quilting in the loom, prizes for, 267.

Quin, M., medals for hydrometer, 291.

Quinine, West Indian, 93.

Racine de disette, 123.

Radclyffe, G. E., 198 .

Radnor, Earl of, 77 ; seconds proposal for election of Prince Albert as member, 325 .

Railway, Edgeworth's portable, $248 n$.

Railway lamp, prize offered for, 497 ; lamps tested, 497 ; award made, 498.

Railway vans, prize for, $46 \mathrm{r}$.

Raimbach, A., I98; his experiments in engraving on steel, 216.

Raine, John, medal for Tasmanian wool, i 10.

Raisins from America, 92.

Ramie, introduced by Roxburgh, ro3; Sumatra, ro3; from Bengal, Io3.

Ramsay, A., 43.

Ranson, T. F., ros.

Rates, liability of Society to parochial, 499; Act of I 843, 499; action taken by Society, 500; authorities on, 50I; cases tried, 501 .
Ravenet, F. S., I98.

Rawlinson, Sir R., member of Council, 450 .

Rawthmell's Coffee-house, first meeting of Society held at, II ; position of the house, etc., I2.

Rayleigh, Lord, Albert medallist, 516.

Read, N., I 98 .

Read, R., I 98 .

Reaping machines, I 28.

Reclamation of land, I40.

Redgrave, R., member of Council, $36 \mathrm{r}$.

Redgrave, S., member of Council, 361 ; attends meeting about $185 \mathrm{I}$ Exhibition, 4I2; his Dictionary of Artists, $7 n ., 73 n$., I60, 36I.

Reece's refrigerating machine, 4002.

Reeves, T. \& W., prize for watercolours, 2 I 3.

Refrigeration processes, see Food Committee.

Register of Premiums, I 45 n., 239 n., 267.

Register, Templeman's Historical, 328.

Registrars of Society, Shipley, ro ; Tuckwell, 34I ; W. Bailey, 34I ; A. M. Bailey, 34 I ; G. Cockings, 342 ; A. B. Cockings, 342.

Reid, Sir W., Chairman of Executive Committee of I85 I Exhibition, 4 I $4 n$.

Reinagle, P., I98.

" Repository," the National, 403.

"Repository of Inventions," the Society's, 58, 66, I I 8, 239, 381, 402.

Respirators for workmen's use, 27 , 272,273 .

Revel, R., I9s.

Revolution indicator for ships, prize for, 498; instruments tested on H.MI.S. Arrow, 498 ; prize awarded, 498.

Reynolds, John, prize for introduction of Swede turnip, 122.

Reynolds, Sir Joshua, 43; invited to paint picture for Great Room, 70 ; his portrait of Lord Romney, 7I, 5 I 8 ; contributes to first exhibition of pictures, 229.

Rhubarb, prizes for British, 283.

Rhyl, meeting to promote Training School for Music, 479 .

Rhys Jenkins on paper-making, 304 .

Rice in Ceylon, I07; machine for decorticating, 107.

Rich, General R., 43.

Richards, S., attempts to organise exhibition in Birmingham, 403 . 
Richardson, Sir B., member of Council, 450; Cantor Lectures, 453.

Richardson, G., 199.

Richardson, S., 43.

Richardson's saccharometer, 290.

Richmond, Duke of, 29, 77 ; establishes school in Whitehall, 8, 152.

Rigaud, S. F., 199.

Rigg, Rev. A., superintends tests of heating and cooking apparatus, 490 .

Rimbault's Soho, 233.

Ripon, Marquis of, his subscription, 20.

Rivers' pollution, conference on, 488 .

Roads, mechanical traction on, 495 .

Robb bequest, 503 .

Roberts, J., 199.

Roberts, J., prize for device for breathing in smoke, etc., 271 .

Roberts, T., medal for use of iron in shipbuilding, 255.

Robertson, G., 199.

Robertson, -, award for net-making machinery. 269.

Robinson, Sir John, reports on Barry's pictures, $8 \mathrm{I}$.

Robinson, Sir T., 43 ; on committee of first picture exhibition, 228.

Robinson, W., The Vegetable Garden, $123 n$.

Robison, J., 43.

Robley, John, medal for growing indigo in Tobago, 98.

Robley, Joseph, medal for growing bread-fruit in Tobago, 96.

Rochard, F., 199.

Rockingham, Marquis of, 29.

Rodney, Admiral Lord, 34, 97.

Roebuck, attempts to manufacture alkali from common salt, 278 .

Rogers, E., medal for planting trees, 149.

Rogers, J., prize for shilling colourbox, 214.

Rogers, P. H., 199.

Rogers, Rev. W., member of Council, 449.

Rolle, Dennis, medals for planting trees, 147.

Rollers, agricultural, 128.

Rolls, C., 199.

Romney, Lord, attends first meeting, I2: contributes to first prize fund, I 5 ; first vice-president, 17 ; his portrait by Sir J. Reynolds, 34, 7 I, 79,518 ; his portrait by Barry, 77 ; on silk from Georgia, 84; presents Society with some swede turnip seed, $123 n$. ; elected President, 34, 32I; death of, 32 I.

Romney, George, invited to paint picture for Great Room, 70; prizes for paintings, 199.

Romney, J., 199.

Ronald's electric telegraph, 252.

Rooker, M. A., prizes for drawings, 199 ; contributes to first exhibition of pictures, 229.

Root-cutters, see Turnip-cutters.

Rose, J., medal for leadless glaze, 274.

Rosebery, Earl of, 3I.

Ross, A., prize for improvements in the microscope. 288; prize for spherometer, 294.

Ross, Sir William, awards for drawings, paintings, and miniatures, 200 ; approves design for Society's Honorary Testimonial, 354: exhibition of miniatures by, 380 ; Chairman of Committee of Fine Arts, 380 ; member of Council, 380.

Rossi, C., 200.

Rossi, H., 200.

Roubiliac, F. L., 43; contributes to first Art Exhibition, 229.

Roxburgh, Dr. William, superintendent of Calcutta Botanic Gardens, ro2; sends specimen of Malay rubber, I03; introduces ramie, ro3; gold medals for his communications, ro4; his memoir and portrait, 104; on Indian barilla, 278.

Royal Academy, see Academy.

Royal Society, the, I, 27.

"Royal," Society granted permission to use the term, by King Edward viI., 18, 447 .

Royle, Prof., lectures on 185 r Exhibition, 378 .

Rubber, introduction of, $\mathrm{IO}_{3}$; Malayan, 103: Para, 103.

Rules and orders of the Society, 18 , $25,243,345,351,354$.

Russell, J., 200.

Russell, J. Scott, on Committee for reorganising Society, 346 n.; his capacity as a lecturer, 355 ; appointed Secretary, 362 ; his life and character, 362 ; appointed Secretary to 1851 Commission, 363 , 414; his death, 363 ; elected life member, 363 ; suggests award of medals for paper read, 393; on first exhibition committee, $4^{\text {o } 4} n$.; on deputations to Board of Trade, $407 n$.; report on preliminary stages of $\mathrm{r} 85 \mathrm{I}$ Exhibition, $409 n$. ; supplies information to Prince Albert about proposed exhibition, 4IO ; reports to special general meeting on preliminary arrangements for 
I85 Exhibition, 4I5; on committec for proposed IS6x Exhibition, 4I 7 .

Russell R., prize for optical glass, 287 .

Rutland, Duchess of, 77 ; medal for method of growing oaks, I 46.

Rntlandshire, local Society in, 6 .

Ryan, J., medal for mine ventilation, 253.

Ryder, Admiral A. P., member of Council, $45^{\circ}$; report on life-saving apparatus, 494 ; suggests offer of prize for revolution indicator, 498.

Ryder, T., 200.

Ryley, C. R., 200.

Saccharometer, 290.

Sackville, Lord George, 43, 51 .

Safety lamps, Clanny, 253; Davy, 254; Stephenson, 254.

Safflower in America, 92; in West Indies, 93.

Sago in Jamaica, roo.

Sail-cloth, cotton, 90 .

Sainfoin, I 20.

St. Albans, Duke of, owner of the Adelphi Estate, 6o.

St. Aubyn, Sir J., 43.

St. John of Bletsoe, Baron, 34.

St. Martin's Hall, Educational Exhibition at, 370 .

St. Martin's Lane Academy, S, I52, 227.

St. Vincent, bread-fruit in, 95, 96 ; Botanic Gardens, 96, 99 ; cloves in, 99 ; cinnamon in, 99.

Sal-ammoniac, offer of prize for, 278 .

Salmon, Robert, chaff-cutter, I 35 ; other inventions, I $35 \%$; medal for paper on pruning trees, 149.

Salon des Beaux Arts, first of exhibitions of pictures, 226 .

Salt, Sir Titus, subscribes to National Training School for Music, $48 \mathrm{I}$.

Saltpetre in America, 87; offer of prizes for British, 278.

Salvesen, T. E., paper on whale fishery, 25 I $n$.

Samuel, G., 200 .

Samuel, John, appointed assistant secretary, 339.

Samuel, Richard, appointed assistant secretary, 339.

Samuel, R., prize for mezzotint tool, $200,218$.

San Domingo, introduction of sugarcane into, 93.

Sandby, P., 43, contributes to first exhibition of pictures, 229.

Sandwich, Earl of, $3 I$.

Sanitary Conferences, 488 .
Sarsaparilla from America, 92 ; West Indian, 93.

Sass, H., 200.

Saunders, Admiral Sir C., 43.

Saunders, W., chairman of Council, $36 \mathrm{r}$.

Savage, IV., medal for printing in colours from wood blocks, 201, 219; Thoughts on Decorative Printing, $219 n$.

Savile, Sir George, 43, 77; on committee of first picture exhibition, 228.

Saw-mills for America, 92, 247.

Saw-mills, introduction of, 247 .

Say, F. R., 20 .

Say, William, first mezzotint on steel, $190 n ., 216$.

Scammony from America, 92.

"Scandiscope," the, 276 .

Scarsdale, Baron, 34.

Scarsdale, Viscount, medal for planting trees, $\mathbf{I} 46$.

Scharf, Sir George, awards for drawings, 201.

Scheemakers, T., 201.

Schiavonetti, L., 201.

Schools of design, 377 ; proposal to circulate objects from Society's exhibitions among, 407 .

Science and Art Department, assistance rendered by Society to, 377 ; relation of its examinations with those of Societv, 425 .

Scoresby, IV., on Society's prizes for gun-harpoon, 250; his Arctic Regions, $250 n$.

Scotland, Society for encouraging arts and manufactures of, 3; Highland and Agricultural Society of, 3 ; see also Edinburgh.

Scott, H., medal for sample of Indian alkali, 88 .

Scott, J., 201.

Scott, Mr., discovers tea-plant in Manipur, 106.

Scoular, J., 201 .

Scoular, IV., $20 \mathrm{r}$.

Screw, originating, 256.

Screw-jack, medal for, 249; early references to, 249; mentioned by Defoe, 249.

Scriven, E., 201.

Scrivenor's History of the Iron Trade, $89 n$.

Sea-coal for fuel, I44.

Seal-engraving, prizes for, 222.

Seal of the Society, engraved by Kirk from design by Cipriani, 22 I ; adopted as corporate seal, 221; disused, 397 ; present, 397 . 
Secretaries of Society, Shipley, 10, I7, 22 ; Box, 22; Templeman, 24; More, 326; Taylor, 334; Aikin, 335; Graham, 338; Whishaw, 348; Scott Russell, 350 ; Grove, 363 ; Solly, 364; Le Neve Foster, 364.

Sections of Society, see Indian, Colonial, African, Foreign, Chemical.

Seddon, T., 202.

Senefelder, Alois, medal for invention of lithography, 202, $214,305$.

Seppings, Sir R., medal for method of docking ships, 255 ; his application of iron in shipbuilding, 255.

Setchel, Sarah, 202.

Shaftesbury, Earl of, contributes to first prize fund, 15 ; in list of members, 31 .

Sharp, W., prizes for drawings, etc., 202 ; engraves More's portrait, 327.

Sharpe, Granville, on introduction of mangel-wurzel, 123.

Sharpe, Dr. Gregory, 43.

Sharpey, Dr. W., acts as examiner, $43 \mathrm{I}$.

Shaw, B., prize for industrial hygiene, 270, 503; chairman of Food Committee, 464 .

Shaw, P., 43.

Sheep, marking, I 40.

Shelburne, Earl of, 3 I.

Shelley, S., 202.

Shenton, H. C., 202.

Sherb, premium for cultivating vines in S. Carolina, 86.

Sheridan, T., 43.

Sherlock, W., 202.

Sherwin, J. K., awards for engraving, etc., 202.

Shilling colour-box, the, 2 I $4,390$.

Ships' models, prizes for, 255 .

Shipley, Jonathan, father of William Shipley, 9.

Shipley, Jonathan, Bishop of St. Asaph, brother of William Shipley, 9.

Shipley, William, founds local Society at Maidstone, $5 ;$ proposes formation of Society, 7; his life, 7,9 ; his academy, $7,8,9,10,16$, $53,57,195$; his portrait by Cosway. 10, 518 ; by Hincks, 10 ; at tends first meeting, 12; elected Secretary. IO, 17, 22; elected " perpetual member," I7 ; registrar, 22, 23 ; resigns post of registrar, 25; portrait in Barry's picture, 77 ; opposes inclusion of agriculture among Society's objects, I I 5 ; object in establishing the Society, I5I; his portrait shown at first exhibition of pictures, 229 ; medal for lifesaving apparatus, 298; his death, II.

Shipwreck, saving lives from, 297,493.

Sholl, J., prize for improvements in the draw-boy, 264.

Sholl, S., organises weaving an claborate flag as sample of brocade, 268; his Account of the Silk Manufacture, 268.

Short, James, one of the founders, I2.

Shropshire, map of, 300 .

Shut leworth, Sir J. Kay, member of Council, 449.

Siemens, Werner, receives sample of gutta-percha from his brother, 104.

Siemens, Sir William, obtains sample of gutta-percha, IO4; medal for regenerative condenser, 389,448 ; chairman of Council, 389, 448 ; Albert medallist, 448, 5 I3.

Sievier, R. W., 203.

Signalling, methods of, $25 \mathrm{I}$.

Signature Book of the Society, 26.

Silk in America, 85,265 ; from Georgia, 84,85 ; in Malta, I I 2 ; in Mauritius, I I 2 ; in Minorca, I I 2.

Silk manufacture in England, 264.

Silk, mills for throwing, 264 .

Silk produced in England, prize offered for, 265; samples submitted to Society, 265 ; paper by Hon. Daines Barrington on, 266, 338 ; company started for production of, 266 ; samples submitted by W. Felkin and by Sir D. Cooper, 266; paper by F. Cobb, 266.

Silk-weaving, improvements induced by Society, 263 .

Silkworm, attempts by James I. to acclimatise, 265 .

Simmons, W. H., 203.

Simon, Sir J., on industrial pathology, 395.

Simpson, P., 203.

Simpson, W. B., prize for paperhangings, 389 .

Sinclair, Sir John, President of the Board of Agriculture, 6, I 4 I .

Sind natron, 87, 88, 102 .

Singapore, gutta-percha from, IO4; nutmegs in, IO4.

Skeat's Etymological Dictionary, $\delta_{7} n$.

Skelton, W., 203.

Slate, prize for transparent, 294.

Smalt, see Cobalt.

Smart, G. M., prize for chimneysweeping apparatus, 276 .

Smart, John, one of first prize-winners, I $7,152,203$. 
Smeaton, John, medal for account of hydraulic engine, 253.

Smee, A., medal for galvanic battery, 293.

Smirke, Sir R., prize for architectural drawing, 203.

Smith, Anker, engraves Flaxman's design for Socicty's medal, 3 I 8 .

Smith, E., Life of Sir Joseph Banks, $95^{n}, 99 n$.

Smith, Emma, 203.

Smith, G., 203.

Smith, J. T., Life of Nollekens, I 6.

Smith, Joachim, 204.

Smith, John, 204.

Smith, J. Catterson, 204.

Smith, N., 204.

Smith, T., prize for gem-engraving, $204,222$.

Smith, William, medal for draining Prisley Bog, 30I ; grant for geological map, 30r.

Smith, W. H., introduces Society's Patents Bill, 476 .

Smoke, devices for breathing in, 27I, 272.

Smoke nuisance, prize for essay on prevention of, 393 .

Smollett, his opinion of the Society (in Humphrey Clinker), I $8 n$. (in his History), 52.

Societies:-Royal, 1, 27 ; Royal Dublin, 2; Philosophical of Dublin, 2 ; Highland and Agricultural of Scotland, 3; Bath and West of England Agricultural, 3; American Philosophical, 3; New York, 3; Improvers in the Knowledge of Agriculture in Scotland, 3, 132 ; Select Society of Edinburgh, 3; Anti-Gallican, 4; Edinburgh, for Promotion of Natural Knowledge, 4 ; Edinburgh Philosophical, 4; in Breconshire, 5 ; in Maidstone, 5 ; in Lindsey, 5 ; in Rutlandshire, 6 ; in Norfolk, 6; in Pembroke, 6; in Carmarthen, 6; in Cardigan, 6 ; Edinburgh for Improvement of British Wool, !6 ; in Barbados, 6 ; Economical, of St. Petersburg, 6; Royal Agricultural, I 42, 344; Chemical, 336, 344; Photographic, 385; Linnean, 344; Geological, 344 ; Royal Geographical, 344 ; Institution of Civil Engineers, 344, 501 ; Royal Institution, 344 ; London Institution, 344 ; Royal Institute of British Architects, 344; Chemical Industry, 457; Institute of Chemistry, 457; Wood-Carvers, 457; Zoological, 5 or.
Societies, rating of, 499.

Soils, analysis of, r 99.

Soldiers, special examinations for, 437.

Solly, E., obtains conducting surface for electro-deposition by use of nitrate of silver, 294; appointed Secretary, 364; deputy-chairman, 364 ; resigns, 364 ; undertakes to arrange collection of animal products, 364,376 .

Solly, R. H., presents Barry's “'Adam and Eve," 82 ; promotes offer of prizes for microscopes, 288 .

Solomon, A., 204.

Somerset House Quadrangle offered for National Exhibition, 408.

Somerset, map of, 300 .

Sopwith, Thomas, member of Council, 450 ; on first exhibition committee, $404 n$.

South Kensington estate purchased, 375.

South Kensington Museum, transference of educational collections to, 37I ; establishment of, 375 ; animal products collection formed for, 376 ; contributions by Society to, 377 ; models presented to, $38 \mathrm{r}$.

Southwell, Baron, 34 .

Southwell, Viscount, 32.

Spalatro, Diocletian's Palace at, suggests the idea of the Adelphi, 59.

Spang, M. H., 204.

Speer, Edward, on committee for reorganising Society, 346; chairman of Council, 35r.

Spencer, K., award for method of signalling, 252.

Spencer, Viscount, 32.

Spherometer, prize for, 294.

Spicer, N., prizes for gem-engraving, $204,223$.

Spiller, J., 204.

Spilsbury, J., 205.

Spinning machinery, invention of, $25^{8}$.

Spottiswoode, W., acts as examiner, 43 r.

Sprague, J. T., Electricity, $293 n$.

Spratt, Lieut. J., award for method of signalling, 252 .

Staghold, A., medal for screw-jack, 249 ; medal for gun-harpoon, 249.

Stainer, Sir J., examiner in music, 440.

Stamford, Earl of, 3 I.

Stamps, Perkins' process for printing, 215,303 .

Standard of weights and measures, offer of prize for, 289. 
Stanhope, Earl, 3 I.

Stanley, Lord, presides at annual dinner, 396.

Stannard, Mrs. J., 205.

Stansfeld, J., presides at sanitary conference, 488 .

Stansfield, J., premium for saw-mill, 247 ; model of his mill sent to America, 92.

Staples, R., prizes for gem-engraving, 205, 223.

Starkey \& Co., medal for cloth from Australian wool, I Io.

Statistical surveys of Board of Agriculture, I41, 302 .

Staves for casks, importation of, from America, 92.

Steam car for common roads, Grantham's, 495.

Steam-carriage, proposal for, 247.

Steam-engine, offer of prize for improvements in, 247 ; application to drive textile machinery, 246.

Steel-engraving, introduction of, 215 .

Steel in Exhibition of 1873, prize offered for, 498.

Steel, fluid for etching, 2 I 8 .

Steele, Joshua, 77, 97.

Steeling copper-plates, 217.

Stephenson, Robert, member of Council, 361; member of Society's Executive Committee for 1851 Exhibition, $413 n$. ; arbitrates on rescission of contract with Messrs. Munday for 1852 Exhibition, 415.

Sterne, Laurence, 43.

Stevens, E., 205.

Stirling, Earl of, 31 ; premium for planting vines in N. America, 86.

Stock, John, 43 ; his bequest, 161 ; medallion, $161,319 n$.

Stocking-frame, prizes for, 263.

Stothard, T., reports on sample of oilpaints, 213.

Stoves, prizes for heating and cooking. 489 ; report of committee, 491 .

Strand buildings, demolition of, in $1830,58 n$.

Strand, Society occupies No. 380 or $381,54$.

Strange, Colonel, member of Council, 450; paper on "Ships for the Channel Passage," 493.

Strange, E. F., on invention of lithography, $305 n$.

Strange, Mary B., 205.

Strange, Sir Robert, 43 ; contributes to first exhibition of pictures, 229.

Strathcona and Mount Royal, Lord, Albert medallist, 517 .
Straw-plait industry, prizes offered for, 306.

Strode, General W., 43.

Stuart, J., 44 ; designs Society's first medal, 316.

Stubbs, G., 44.

Stubbs, J. H. P., 205.

Sturgeon in America, 90.

Sturgeon, W., medal for electromagnet, 292.

Subscription, amount of, 20.

Suffolk, map of, 300 .

Sugar in West Indies, ror.

Sugar-cane first cultivated in Jamaica, 94; in San Domingo, 93.

Sumatra, cinnamon in, 84 ; tin, 102 ; ramie, 103.

Summerly, Felix, 1 54, 406.

Surgical instruments, prizes for, 294.

Surveying instruments, prizes for, 248, 294.

Sussex, Duke of, elected President, 324 ; his character, 324 ; proposes Prince Albert as a member, 325 ; death of, 326,348 ; adopts committee report advocating reforms, 348.

Sussex, map of, 300 .

Sutherland, Earl of, 3 I.

Swaine, F., 205.

Swaine, J. B., 205.

Swan, Sir Joseph Wilson, Albert medallist, 5 I 6.

Swede, introduction of, 121, I 22.

Sweeping chimneys, 275.

Sweetness, offer of prize for measuring, 290.

Swiney, Dr., his will given to Aikin, 393; his death ; 393, his bequest, 393; his character, 394; his funeral, 394 .

Swiney prize, method of adjudicating, 395 ; cup for, 395,44 I.

Sykes, Col., Chairman of Council, 361 . Sylva, John Evelyn's book on trees, etc., I 44.

Symons, George James, Albert medallist, 515 .

Tablets, memorial, see Memorial Tablets.

Tachometer, prize for, 291.

Tallmache, W., 205.

Tanning materials from Australia, III.

Tanning, prizes for improvements in, 308.

Tansley, A. J., paper on straw-plait industry, $307 n$.

Tar, prize for substitute for, 294; from gas-making, 295. 
Tasmania, wool from, I Io; tanning materials from, I I I.

Tassie, James, medallion of Robert Adam, 59; award for his paste for artificial cameos, 206, 224.

Taximeter, prize offered for, 496.

Taylor, C., elected Secretary, 334; his life and character, 335; his death, 335 .

Taylor, I., 206.

Taylor, I., map of Dorset, 299.

Taylor, John, 206.

Taylor, John (of Bath), awards for medal designing, 206, 221.

Taylor, Dr. R., 44.

Taylor, S., 206.

Taylor, T., appointed assistant secretary, 339; his life and character, 339 ; his writings, $34^{\circ}$; resigns, 340; his death, 340 .

Tea in South Carolina, 93 2 . : Indian, 105, 106; in West Indies, 105; in the Cape, 105 ; in Mauritius, 105 ; in New South Wales, 105.

Tea-service, the Summerly, I 54, 406.

Technical education, early association of Society with, Is; proposals by Dr. Playfair, 464; conference on, 464; definition of, 465.

Technological examinations, 437; proposed by Capt. Donnelly, 465 ; conference on, 465 ; establishment of, 465 .

Teck, Prince of, at school drill review, 467 .

Telegraphs, mechanical, $25 \mathrm{I}$.

Telegraphs, paper by E. Chadwick on purchase of, 477 .

Temple, Dr., acts as examiner, 431 .

Temple, Earl, 3 I.

Templeman, Dr., appointed Secretary, 24; account of him, 25; his portrait by Cosway, 25, 518; his death, 25, 326; his house in Little Denmark Court, 55 ; his Historical Register, 328.

Textiles, prizes for designs for, I 52, I 54; premiums connected with, 257.

Thackeray, Dr. W. M., medals for planting trees, I 49.

Theed, W., awards for sculpture, 206.

Theobald, James, one of first vicepresidents, 17,44 .

Thomas, C., on gem-engraving, 222.

Thomas, Sir N., 44.

Thomond, Earl of, $3 \mathbf{I}$.

Thompson, Prof. S., on Sturgeon's electro-magnet, 292.
Thorn, C., prize for hansom cab, 497.

Thornhill, Sir WVilliam, his academy in Covent Garden, 8.

Thornton, B., 44 .

Thornton, J., 44.

Thorpe, Sir E., Humphry Davy, 139 n.; History of Chemistry, $277 n$.

Thrale, H., 44.

Tlireshing machines, 131 .

Thrift, prize for essay on, 494.

Thurston's History of the Steam Engine, 247.

Tide-mills, prizes for, 246 .

Timber, in America, 89 ; lack of, 143 ; statutes for preventing waste of, 143, 308; Evelyn's Sylva, I44: for naval use, Society consulted for advice on, 254 .

Timber trade, first application of motive power in, 247 .

Tin from Banca, 102.

Titchfield, Marquis of, medal for planting trees, I 46.

Title of Society, 17, 447 .

Tobacco, American, IOI.

Tobacco, paper by Hon. Daines Barrington on, 338 .

Tobago, bread-fruit in, 96 ; cotton in, 98 ; indigo in, 98 .

Tomkins, C., 206.

Tomkins, P. W., 206.

Tomkins, W., 207.

Tonson, J., 44 .

Tooke, William, promotes suppression of climbing-boys, 276 ; on committee for re-organising Society, 346; submits draft of charter, 352 ; vice-president, 362 ; elected President, 444; his death, 444.

Tools, awards for mechanical, 255.

Toussaint, A., 207.

Towne, F., 207.

Towne, J., medals for anatomical models, 207.

Townley, Rev. J., 44 .

Townshend, C., 44.

Townshend, Viscount, 33 .

Trade Museum, proposal for, 364,376 ; its formation undertaken, 376 .

Trafalgar Square proposed as site for National Exhibition, 408.

Transactions, account of, 328 ; interval between their publication and the Journal, 373 .

Transit instrument, offer of prize for, 288.

Tree-stumps, method of extirpating. I I 2 . 
Trees, planting, prizes for, 145 .

Trench, Dean, lectures at Educational Exhibition, 371.

Trench, Rev. T., provides prize for cheap writing-case, 391.

Trevelyan, Sir Charles, nember of Council, 450.

Trevelyan, Sir W., prize for utilisation of sea-weed, 460 ; for food preservation, 460; prizes awarded, 463.

Trinidad, Botanic Garden in, Ioo; mace, 100; nutmegs in, 100; cloves, 101.

Tuckwell, E. C., appointed registrar, 34 I.

Tull, Jethro, II5; incorrectly credited with introduction of turnip, I20; his Horse-hoeing Husbandry, 126; on the horsehoe, 127.

Tulley's achromatic objective, 288 .

Turner, W., 207.

Turnerelli, E. T., 207.

Turning-lathes, awards for, 256 .

Turnip cabbage, see Kohl-rabi.

Turnip-cutters, 136; Edgeworth's, $137,248$.

Turnip-rooted cabbage, see Swede.

Turnip, swede, see Swede.

Turnips, I I9, I 20, I 2 I.

Turnour, Viscount, medal for planting trees, 146.

Turrell, E., medal for etching fluid for steel, 2 I8.

Twining, Elizabeth, 207.

Twining, T., member of Council, 362 ; pays off loan owing by Society, 397 chairman of committee on model dwellings, 492.

Tyers, J., 44.

Tylney, Earl, 31 .

Tytler, G., 208.

Ultramarine, prize offered for artificial, 279; its manufacture abroad, 279.

Underwood, T., 208.

Uninflammable fabrics, prizes for, 309.

Union of Institutions, see Institutions.

Unwin, G., medal for reviving tin trade with the East, 102.

Unwin, S., prize for stocking-frame, 263.

Upper Ossory, Earl of, medal for planting trees, 146.

Uzielli, T., on Committee for 1862 Exhibition, 419.
Vacher, C., 208.

Van Diemen's Land, see Tasmania.

Van Rymsdyk, A., 208.

Vanilla, West Indian, 93.

Vansittart, R., 44 .

Varley, C., prize for improvenents in the microscope, 288; paper on the microscope, $288 n$.

Varnish, medal for account of manufacture of, 28I; offer of prizes for, $28 \mathrm{I}$.

Vaughan, Dr. C. J., acts as examiner, $43 \mathrm{I}$.

Vehicles, awards for construction of, $255,495,496,497$.

Vendramini, Caroline, 208.

Vendramini, G., 208.

Vendramini, Miss R., 208.

Ventilation of mines, Ryan's system of, 253.

Verdigris, prizes for British, 278.

Verney, Earl, 32.

Vetches, 120.

Vice-Presidents, number and duties of, 326 .

Vickers, A. G., 208.

Victoria, Queen, her portrait in Great Room, 80, 400, 518; address on her marriage, 326 ; continues Prince Consort's prize for examinations, 433; suggestion that she should be asked to become Patron, 446 ; provides scholarhip at $\mathrm{Na}$ tional Training School for Music, 480; Albert Medal presented to, 514.

Victoria and Albert Museum, see South Kensington Museum.

Virginian vineyards, 85 .

Vivares, Mary, 208.

Vivares, T., 208.

Vulcan Medal, 192, 222, 318.

Vulliamy, B., prize for drawing, 208.

Vulliamy, L., medal for Architectural Design, 209.

Wade, E., pamphlet on planting trees, 145 .

Waldegrave, Earl, 32.

Wales, map of North, 300.

Wales, Prince Albert Edward of, see Edward vir.

Wales, Prince George of, see George v.

Wales, Prince of (King George IV.), his portrait, 77; proposal that he should be elected Patron, 322.

Walker, Dr. E., examiner in music, 440.

Wallich, Dr. N., superintendent of Calcutta Botanic Gardens, secretary to committee on Indian tea, 
I06; medal for presenting collection of Indian woods, 107.

Walpole, Horace, 44.

Walter, John, prints vol. iii. of Transactions, $333 n$.

Waltham, Baron, 34 .

Ward, Baron, 34.

Ward, E. M., prize for drawing, 209.

Ward, F. S., 209.

Ward, G., prize for Canadian hemp, I08.

Ward, J., 45; his statue, 519.

Ward, J. R., 209.

Ward, Lord, on committee of first picture exhibition, 228 .

Ward, W., 209.

Ward, W. J., 209.

Waring, J. B., 209.

Warner, W., medal for intaglio, 210 , 225.

Warren, C., medal for engraving on steel, 210,216 ; his etching fluid, 218.

Warren, Dr. R., 45.

Warwick, Earl of, 32.

Watches, awards for, 255.

Water-colours, prize for, 213.

Water-supply, conferences on, 488 .

Watson, Dr. Forbes, on ramie fibre, IO3.

Watson, J. B., 210.

Watson, Sir W., 45 .

Wax portraits, award for, 224.

Wax, vegetable, from America, 9I.

Webb. P. C., 45; medal for planting trees, $147 ;$ on committee of first picture exhibition, 228 .

Webber, H., 210.

Webster, Thomas, chairman of committee on accounts, 346 ; his efforts to reform constitution of Society, 346; proposes Whishaw as secretary, 348 ; dispute with H. Cole, 359 ; not re-elected on Council, 359 ; in chair of committee when exhibition is first proposed, 404; on first exhibition committee, $404 n$.

Wedderburn, A., 45.

Wedgwood, T., reports on pottery glaze, 274; reproduces Lochée's medallions, $\mathrm{r} 89$.

Weekly Proceedings, 333, 373 .

Weight, standard of, 289 .

Weight and value of Society's medals, 318.

Welch, S., 45.

Weldon, G., medal for machine for planing cast-iron, 254.

Wellington College, share of Cantor bequest, 451 .
Wentworth, Baron, 34 .

Wentworth, Viscount, 33 .

Werden, Sir John, his trustees purchase Adelphi Estate, 60.

West, Benjamin, $45 ;$ invited to paint picture for Great Room, 70; reports on Barry's pictures, 80: lithographic reproduction of drawing by him, 305; portrait of $\mathrm{S}$. More, 327.

West Indies, prizes offered in, 93, 105; introduction of economic plants by Bligh, 96. See also Cuba, Guadaloupe, Jamaica, Martinique, St. Vincent, San Domingo, Tobago, Trinidad.

Westall, W., 2 10.

Westgarth, WV., medal for hydraulic engine, 253.

Westmacott, R., Cantor Lectures, 453.

Westmorland, Earl of, 32.

Weymouth, Viscount, 33 .

Whale-fishery, prizes for use of gun harpoon in, 250; Scoresby on, 250; recent account of, $25 \mathrm{I} n$.

Wheatley, F., prizes for drawing, etc., 210.

Wheatley, H. B., on the Society's origin, 27; his listory of the Adelphi, 59; Life of Sir Humphry Davy, I 39 n.; on Society's first exhibition of pictures, $228 \mathrm{n}$.

Wheatstone, Sir Charles, Albert medallist, $5 \mathrm{I} 2$.

Whewell, Dr., lectures at Educational Exhibition, 371; lectures on I 851 Exhibition, 378 .

Whishaw, Francis, describes specimens of gutta-percha, IO4; elected Secretary, 348 ; his book on Railways, 348 ; resigns, 349 ; elected corresponding secretary, 350 ; appointed auditor, 350 ; suggests holding of exhibitions, 350 ; elected life-member, 350 ; his death, 350 ; proposes annual industrial exhibitions, 403; secretary to first exhibition committee, $404 n$.

Whitbread, S., 45.

White, Thomas, medals for planting trees, I 47.

White lead, substitute for, $28 \mathrm{I}$.

Whitefoord, Caleb, 45; proposes Prince of Wales (George IV.), as patron, 322 ; his life and character, $322 n$.; obtains Shipley's portrait, and presents Templeman's, 518 .

Whitehall, Duke of Richmond's school in, 8, 152 .

Whitty, prize for carpets, 268. 
Whitworth, B., subscribes towards cost of memorial tablets, 469 .

Whitworth, Sir Charles, one of first vice-presidents, 17,45 .

Whitworth, Sir Joseph, prize for essay on Thrift, 494; Albert medallist, 512.

Whyman, J., prize for stockingframe, 263 .

Whyman, J., map of Leicester, 300.

Wickstead, P., 2 Io.

Wilde, Henry, Albert medallist, 516.

Wiles, J., superintendent of East's Botanic Garden in Jamaica, 99.

Wilkes, Israel, 45 ; on committee of first picture exhibition, 228 .

Wilkes, John, 45.

Wilkins, R., 2 10.

Williams, C. W., prize for essay on prevention of smoke, 392.

Williams, P., 2 Io.

Williams, W., 2 Io.

Williams and Woodin, Society's landlords, 54.

Williamson, Prof. A., lectures at Educational Exhibition, 371 ; acts as examiner, 432 ; Cantor Lectures, 453.

Willis, Prof., lectures on 185 I Exhibition, 378 .

Willoughby de Broke, Baron, 34.

Willoughby de Parham, Baron, 34.

Wills, T., first secretary of Chemical Section, 456 .

Wilmot, Sir E., 45.

Wilmot, Sir John Eardley, 45.

Wilmot, General Eardley, chairman of Council, 448; paper on school drill, 467.

Wilson, A., 2 Io.

Wilson, R., contributes to first exhibition of pictures, 229.

Wilton, Joseph, 45; contributes to first exhibition of pictures, etc., 229.

Wind-mills, prizes for, 247.

Wine from America, 85 ; Australian, I I ; Cape, I 2.

Winkles, H., 211.

Vinkworth, T., member of Council, 362 ; on first exhibition committee, $404 n$. ; in chair of meeting about I 85 I Exhibition, $412 n$.; treasurer for $185 \mathrm{I}$ Exhibition, 4I3 $n$.; on committee for proposed $186 \mathrm{I} \mathrm{Ex}$ hibition, 417.

Winsor utilises by-products from gas-making, 295.

Winter food for cattle, I I 8, I 20.

Winterton, Baron, 34 .
Winterton, Earl, medals for sowing acorns, etc., 146 .

Wiseman, Cardinal, lecturesat Educa. tional Exhibition, $37 \mathrm{I}$.

Wollaston, Dr., on the compound microscope, 288.

Wood, Sir WV. P., member of Council, 361 ; proposes scheme for sending artisan reporters to Paris Exhibition, 1867,483 .

Wood-carvers, exhibition by Society of, 457 .

Wood-carving, School of, founded, 482 ; moved to South Kensington, 482 ; supported by city companies and London County Council, 482 .

Woodcroft, B., Appendix to Reaping Machines, I 3 I $n$.; models presented to, $38 \mathrm{I}$; on first exhibition committee, $404 n$.

Wood-engraving, first offer of prizes for, 153; conditions of award, 157.

Woodfall, H. S., 46

Woodfall, T., appointed assistant secretary, 340 ; his office abolished, 349 .

Woodhouse, Miss S., medal for grass for straw-plait, 307 .

Woodin, Society's landlord, 54 .

Woods, E., on Grantham's steam car, 495 .

Woods, Joseph, on committee for reorganising Society, 346 ; assists Whishaw's exhibition scheme, 403 ; on first exhibition committee, $404 n$.

Woods, collection of, presented to Society by Wallich and Baker, I07.

TVool, Society for Improvement of, 6 ; Tasmanian, I Io; from New South Wales, i io.

Woollams \& Co., prize for paper hangings, 389 .

Woollett, W., 211 ; contributes to first exhibition of pictures, 229.

Woolner, Thomas, $21 \mathrm{I}$.

Wouldhave, W., inventor of a lifeboat, 296.

Wright, P., medal for Canadian hemp, 108.

Wright, R., prizes for paintings, 211 ; invited to paint picture for Great Room, 70 .

Wright, R. P., Cyclopadia of Agriculture, I $37 n$.

Writing-case, prize for cheap, 39 I.

Wyatt, Sir Matthew Digby, lectures on I85I Exhibition, 378; reports on French Exhibition, 402 n., 4 Io; 
Secretary of Society's Executive Committee for 185 I Exhibition, 4I $3 n$.

Wyatt, H., 2 II.

Wyatt and Paul's spinning machinery, 258.

Wyon, Allan, engraves die for Society's medal, 320 .

Wyon, Anne, medal for wax flowers, 2 II.

Wyon, Benjamin, medals for die-engraving, 211 .

Wyon, James, medal for miniature, 2 II.

Wyon, Leonard, engraves Society's medal with head of Albert Edward, Prince of Wales, 320.

Wyon, Thomas, medals for die-engraving, 2 I I; designs Isis Medal, 3 I8.

Wyon, William, medals for dieengraving, $2 \mathrm{II}$; designs Ceres Medal, 318; designs Society's medals, 319.

Yonge, Sir G., 46.

Yorkshire, map of, 298.

Young, Arthur, refers to Rutlandshire Society, 6; elected member of Economical Society of St. Petersburg, 6; portrait by Barry, 77 ; on introduction of turnips, 120 ; medals awarded, I2O, I40; comments on the work of the Society, I I 7; chairman of committee on agriculture, I I 7,332 ; Farmer's Letters, II 7,136 n., 144, 332; Annals of Agriculture, I I 7 n., I 32 n., 332 ; use of oil-cake as cattle food, I I9; on threshing machines, 132 ; on turnip-cutters, I 36 ; on marl, 138 ; Secretary to Board of Agriculture, I4I ; on timber supplies, I44: account of Society's examinations in Latin, 3I 2 .; on Society's transactions, 329 ; contributions to Museum Rusticum, 329 n. ; suggested publication of Transactions, 332 ; au tobiography, 332.

Young, Dr. George, on mango, 96 : on cinnamon, 97 ; superintendent of St. Vincent Botanic Gardens, 99; medal for report, 99.

Young, J., prize for growing opium, 284.

Zaffre, see Cobalt.

Zincke, C. F., 46. 





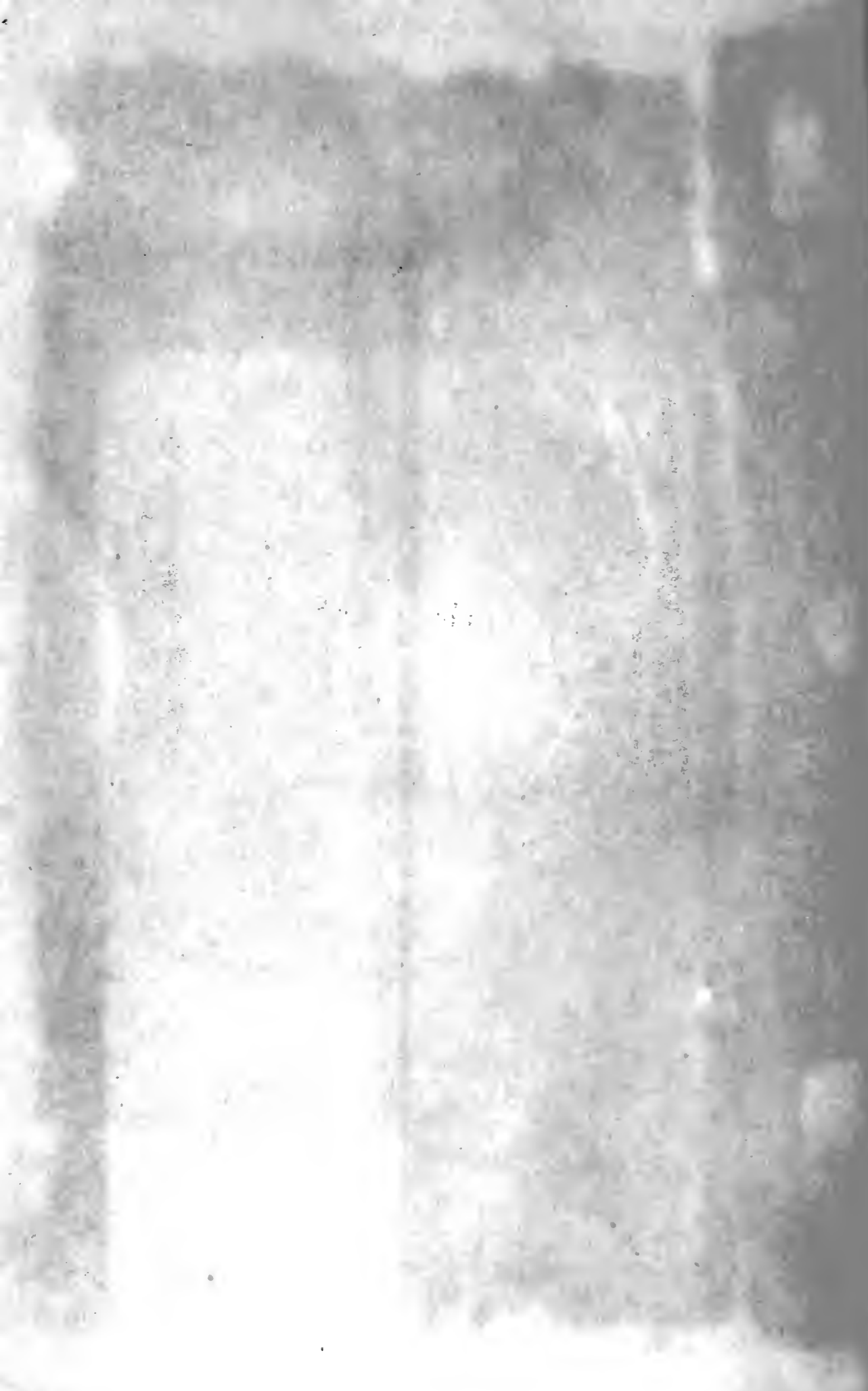


$\mathrm{T}$

1

R79N6

Wood, (Sir) Henry Trueman Wright

Enoin."

A history of the

Royal Society of Arts

PLEASE DO NOT REMOVE CARDS OR SLIPS FROM THIS POCKET

\section{UNIVERSITY OF TORONTO LIBRARY}




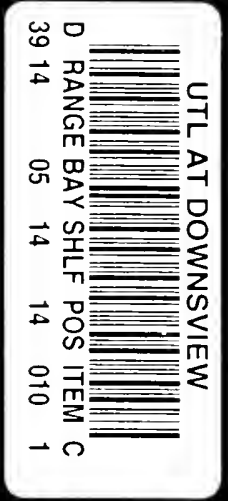

